Prepared for the U.S. Department of Energy under Contract DE-AC05-76RL01830

\title{
Characterization of Vadose Zone Sediment: Borehole 299-E33-46 Near B 110 in the B BX-BY Waste Management Area
}

\begin{tabular}{|c|c|c|}
\hline $\begin{array}{l}\text { RJ Serne } \\
\text { BN Bjornstad } \\
\text { GW Gee } \\
\text { HT Schaef } \\
\text { DC Lanigan } \\
\text { RG McCain }\end{array}$ & $\begin{array}{l}\text { CW Lindenmeier } \\
\text { RD Orr } \\
\text { VL LeGore } \\
\text { RE Clayton } \\
\text { MJ Lindberg } \\
\text { IV Kutnyakov }\end{array}$ & $\begin{array}{l}\text { SR Baum } \\
\text { KN Geiszler } \\
\text { MM Valenta } \\
\text { TS Vickerman } \\
\text { LJ Royack }\end{array}$ \\
\hline
\end{tabular}

(a) S.M. Stoller, Richland, WA.

September 2008 


\title{
DISCLAIMER
}

This report was prepared as an account of work sponsored by an agency of the United States Government. Neither the United States Government nor any agency thereof, nor Battelle Memorial Institute, nor any of their employees, makes any warranty, express or implied, or assumes any legal liability or responsibility for the accuracy, completeness, or usefulness of any information, apparatus, product, or process disclosed, or represents that its use would not infringe privately owned rights. Reference herein to any specific commercial product, process, or service by trade name, trademark, manufacturer, or otherwise does not necessarily constitute or imply its endorsement, recommendation, or favoring by the United States Government or any agency thereof, or Battelle Memorial Institute. The views and opinions of authors expressed herein do not necessarily state or reflect those of the United States Government or any agency thereof.

\author{
PACIFIC NORTHWEST NATIONAL LABORATORY \\ operated by \\ BATTELLE \\ for the \\ UNITED STATES DEPARTMENT OF ENERGY \\ under Contract DE-AC06-76RL01830
}

Printed in the United States of America

Available to DOE and DOE contractors from the

Office of Scientific and Technical Information,

P.O. Box 62, Oak Ridge, TN 37831-0062;

ph: (865) 576-8401

fax: $(865) 576-5728$

email: reports@adonis.osti.gov

\footnotetext{
Available to the public from the National Technical Information Service, U.S. Department of Commerce, 5285 Port Royal Rd., Springfield, VA 22161 ph: (800) 553-6847 fax: (703) 605-6900

email: orders@ntis.fedworld.gov

online ordering: http://www.ntis.gov/ordering.htm
}

This document was printed on recycled paper. 


\section{Characterization of Vadose Zone Sediment: Borehole 299-E33-46 Near B-110 in the B-BX-BY Waste Management Area}
R. J. Serne
C. W. Lindenmeier
S. R. Baum
B. N. Bjornstad
R. D. Orr
K. N. Geiszler
G. W. Gee
V. L. LeGore
H. T. Schaef
R. E. Clayton
M. M. Valenta
D. C. Lanigan
M. J. Lindberg
T. S. Vickerman
R. G. McCain ${ }^{(2)}$
I. V. Kutnyakov
L. J. Royack

(a) S. M. Stoller, Richland, WA.

September 2008

Prepared for CH2M HILL Hanford Group, Inc., and the U.S. Department of Energy

under Contract DE-AC06-76RL01830 


\section{Executive Summary}

This report was revised in September 2008 to remove acid-ectractable sodium data from Table 4.17. The sodium data was removed due to potential contamination introduced during the acid extraction process. The rest of the text remains unchanged from the original report issued in December 2002.

The overall goal of the of the Tank Farm Vadose Zone Project, led by CH2M HILL Hanford Group, Inc., is to define risks from past and future single-shell tank farm activities. To meet this goal, $\mathrm{CH} 2 \mathrm{M}$ HILL Hanford Group, Inc., asked scientists from Pacific Northwest National Laboratory to perform detailed analyses on vadose zone sediment from within the B-BX-BY Waste Management Area. This report is the third in a series of three reports to present the results of these analyses. Specifically, this report contains all the geologic, geochemical, and selected physical characterization data collected on

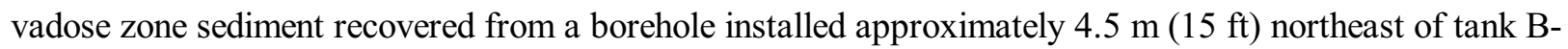
110 (borehole 299-E33-46).

This report also presents our interpretation of the data in the context of the sediment lithologies, the vertical extent of contamination, the migration potential of the contaminants, and the likely source of the contamination in the vadose zone and groundwater east of the B Tank Farm. The information presented in this report supports the B-BX-BY field investigation report prepared by CH2M HILL Hanford Group, Inc. ${ }^{(a)}$

Overall, our analyses identified common ion exchange and heterogeneous (solid phase-liquid solute) precipitation reactions as two mechanisms that influence the distribution of contaminants within that portion of the vadose zone affected by tank liquor. We did not observe significant indications of caustic alteration of the sediment mineralogy or porosity, but we did observe slightly elevated $\mathrm{pH}$ values between the depths of 15 and $25 \mathrm{~m}$ (52 and $83 \mathrm{ft}$ ) bgs. X-ray diffraction measurements indicate no evidence of mineral alteration or precipitation resulting from the interaction of the tank liquor with the sediment. However, no scans of samples by scanning electron microscopy were performed that might suggest that there is faint evidence of caustic attack.

Our analyses do not firmly suggest that the source of the contamination in the groundwater below and to the east of B Tank Farm is the 1971 transfer line leak at B-110. However, we are firmly convinced that the fluids from the transfer line leak event are present in the vadose zone sediments at borehole 299-E33-46 to a depth of $52 \mathrm{~m}(170 \mathrm{ft}) \mathrm{bgs}$, within the Hanford $\mathrm{H} 2$ sand unit. Below this depth the concentration of nitrate still appears to be slightly elevated above natural background levels. There is also elevated technetium-99 between 68 and $69 \mathrm{~m}$ (222 and $226 \mathrm{ft})$ bgs in the Plio-pleistocene mud layer but we can't show that this contamination traveled through the entire vadose zone and in fact may have migrated horizontally from other sources.

(a) Draft Field Investigation Report for Waste Management Area B-BX-BY. RPP-10098, Draft, Volume 2, Appendix D, CH2M HILL Hanford Group, Inc., Richland, Washington. 
The near horizontally bedded, northeasterly dipping sediment likely caused horizontal flow of the migrating contaminants. At borehole 299-E33-46, there are several fine-grained lens within the H2 unit at 26, 41, and $57 \mathrm{~m}(85,168$, and $186 \mathrm{ft})$ bgs that likely cause some horizontally spreading of percolating fluids. The 12.7-ft thick Plio-pleistocene fine-grained silt/clay unit is also an important horizontal flow conduit between 66 to $69.4 \mathrm{~m}$ (215 to $227.7 \mathrm{ft})$ bgs.

The porewater electrical shows a two-lobed elevated plume. The shallower but more concentrated lobe, between 15.42 and $25.91 \mathrm{~m}(50.6$ and $85 \mathrm{ft}) \mathrm{bgs}$, resides within the middle sand sequence in Hanford $\mathrm{H} 2$ unit. The shallow lobe appears to pond on top of the fine-grained lens at $85 \mathrm{ft}$ bgs. The slightly less concentrated lobe resides between 27.61 and $42.67 \mathrm{~m}$ (90.6 to $140 \mathrm{ft})$ bgs within the Hanford $\mathrm{H} 2$ unit. Thus, the leading edge of the transfer line leak plume appears to reside well above the water table at $78.0 \mathrm{~m}$ $(255.8 \mathrm{ft})$ bgs.

Elevated nitrate concentrations in 299-E33-46 borehole sediment start at 50.6 feet bgs but the more concentrated zone resides between 26.8 and $51 \mathrm{~m}(87.8$ and $168 \mathrm{ft})$ bgs within the Hanford $\mathrm{H} 2$ unit. This more concentrated nitrate plume appears to stop at the fine-grained thin lens at $51 \mathrm{~m}(168 \mathrm{ft})$ bgs. The peak vadose zone porewater nitrate concentration is $1.5 \mathrm{~g} / \mathrm{L}$ at $41 \mathrm{~m}(134 \mathrm{ft})$ bgs. The deeper units, $\mathrm{H} 3$ and PPlz, have porewaters that contain 100 to 200 and $130 \mathrm{mg} / \mathrm{L}$ nitrate, respectively. These values appear to be slightly elevated above natural background values. Even the coarse-grained PPlg unit that includes the water table has porewater nitrate concentrations that hover near $50 \mathrm{mg} / \mathrm{L}$ suggesting slightly elevated nitrate concentrations penetrate the entire vadose zone at this borehole. However, an alternate source of nitrate within and below the PPlz could be the nearby cribs and trenches with horizontal transport within the very moist fine-grained sediments.

Within the Hanford $\mathrm{H} 2$ unit the porewater fluoride and bicarbonate concentrations are also elevated above natural background levels down to a depth of about $37 \mathrm{~m} \mathrm{(120} \mathrm{ft)} \mathrm{bgs.} \mathrm{The} \mathrm{porewater} \mathrm{cation}$ distributions show the ion exchange front wherein the sodium in the tank fluids pushes the naturally occurring divalent cations (calcium, magnesium and strontium) deeper into the sediments and out in front of the plume. The most concentrated portion of the vadose zone plume has a porewater chemical composition that is $0.15 \mathrm{M}$ sodium and $0.13 \mathrm{M}$ bicarbonate, $0.01 \mathrm{M}$ fluoride, $0.007 \mathrm{M}$ sulfate, and $0.003 \mathrm{M}$ nitrate. This composition is not as saline as contaminated porewaters below the BX-102 tank or under the S-SX tank farm.

The only detectable radionuclides in the vadose zone sediments from borehole 299-E33-46 are strontium-90, technetium-99 and a faint trace of water leachable uranium, which suggests non-natural uranium at very low concentrations. Strontium-90 is considered to be the primary radionuclide released from tank B-110 transfer line and is concentrated in the sediment between 19 and $28 \mathrm{~m}$ (62 and $83 \mathrm{ft})$ bgs at concentrations between 1,000 and $11,250 \mathrm{pCi} / \mathrm{g}$. Strontium- 90 in the sediments is not readily water leachable yielding an insitu desorption $\mathrm{K}_{\mathrm{d}}$ value of $>100 \mathrm{ml} / \mathrm{g}$. All technetium- 99 concentrations in the shallow depths is at or below the detection limit thus it is difficult to determine if the technetium profile at 299-E33-46 can be traced from below the tank all the way to the groundwater. The two more concentrated 
peaks of technetium-99 are found in the deep H3 unit and in the PPlz unit and it is more likely that the technetium found at the deeper depths is from some horizontal migration of fluids containing technetium-99 from other sources that was carried to depth by active disposal of large quantities of contaminated water or some other driving force such as domestic water line leaks, recharge from topographic lows for snow melt etc.

In summary, the moisture content, $\mathrm{pH}$, electrical conductivity, sodium, and strontium-90 profiles do not suggest that the leading edge of the plume has penetrated below $52 \mathrm{~m}(170 \mathrm{ft}) \mathrm{bgs}$. The profiles of two mobile constituents, technetium-99 and nitrate, suggest that the leading edge of the plume may have penetrated all the way to groundwater. But there may be other sources of these two mobile contaminants in the deep vadose zone. The very moist PPlz sediments, which contain a perched water table at several nearby wells, is a likely driving force to move fluids from other sources into the borehole environs. 


\section{Acknowledgments}

This work was conducted as part of the Tank Farm Vadose Zone Project led by CH2M HILL Hanford Group, Inc., in support of the U.S. Department of Energy's Office of River Protection. The authors wish to thank Anthony J. Knepp, Fredrick M. Mann, David A. Myers, Thomas E. Jones, and Harold A. Sydnor with CH2M HILL Hanford Group, Inc., and Marc I. Wood with Fluor Hanford for their support of this work. We would also like to express our gratitude to Robert Yasek with DOE's Office of River Protection.

We would especially like to thank Kent D. Reynolds (Duratek Federal Services, Inc.) for his efforts in design and construction of the core extruder, and Victoria Johnston and Kevin A. Lindsey (Kennedy Jencks Consultants, Inc.) for their insights on the geologic nature of the materials penetrated by this borehole.

Dr. Karl Koizumi (MACTEC-ERS ) was a co-author of Appendix C.

Finally, we would like to thank George Last, Bill Deustch, Ken Krupka, and Duane G. Horton for their technical review of this document, Karrol Lehman (Jacobs Engineering) for editorial and document production support and Shanna Muns (CH2M HILL Hanford Group, Inc.) for final word processing and formatting. 


\section{Acronyms and Abbreviations}

\begin{tabular}{|c|c|}
\hline ASA & American Society of Agronomy \\
\hline ASTM & American Society for Testing and Materials \\
\hline bgs & below ground surface \\
\hline DFS & Duratek Federal Services, Inc. \\
\hline EPA & U.S. Environmental Protection Agency \\
\hline FIR & Field Investigation Report \\
\hline g's & gravitational forces \\
\hline GEA & gamma energy analysis \\
\hline $\mathrm{Hf} / \mathrm{PPu}(?)$ & Hanford formation/Plio-Pleistocene unit(?) \\
\hline HPGe & high purity germanium \\
\hline $\mathrm{IC}$ & ion chromatography \\
\hline $\mathrm{ICP}$ & inductively coupled plasma \\
\hline ICP-MS & inductively coupled plasma mass spectrometer \\
\hline ICP-OES & inductively coupled plasma - optical emission spectroscopy \\
\hline ID & inside diameter \\
\hline NTA & nitrilo triacetic acid \\
\hline OD & outside diameter \\
\hline PNNL & Pacific Northwest National Laboratory \\
\hline PPlc & Plio-Pleistocene calcic \\
\hline PPlg & Plio-Pleistocene gravelly sand or sandy gravel \\
\hline $\mathrm{PPlz}$ & Plio-Pleistocene mud \\
\hline RCRA & Resource Conservation and Recovery Act \\
\hline REDOX & Reduction Oxidation Plant \\
\hline SEM & scanning electron microscope \\
\hline TEM & transmission electron microscopy \\
\hline UFA & unsaturated flow apparatus (ultracentrifuge for squeezing porewater out of sediment) \\
\hline VZMS & vadose zone monitoring system \\
\hline vol\% & volumetric water content \\
\hline XRD & $\mathrm{x}$-ray diffraction \\
\hline $\mathrm{XRF}$ & $\mathrm{x}$-ray fluorescene \\
\hline WMA & Waste Management Area \\
\hline $\mathrm{wt} \%$ & gravimetric moisture content \\
\hline
\end{tabular}




\section{Contents}

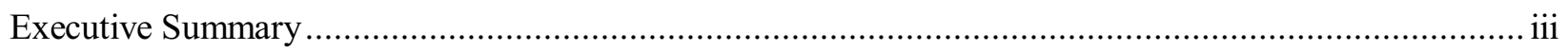

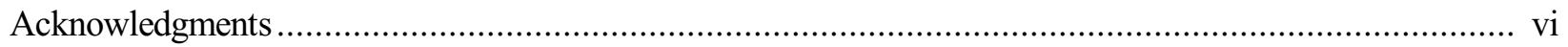

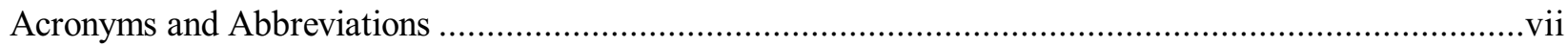

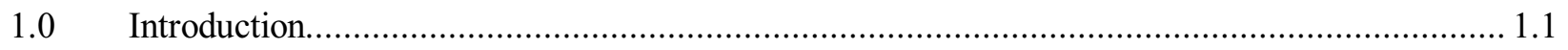

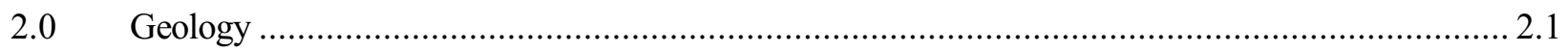

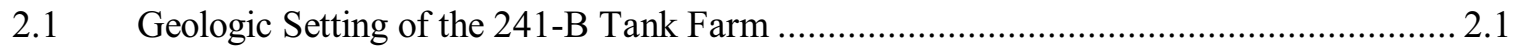

2.2 Drilling and Sampling Of Borehole 299-E33-46 (C3360)........................................... 2.3

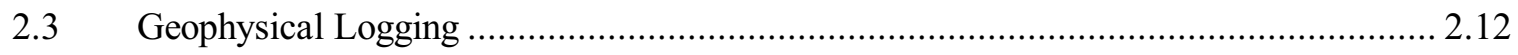

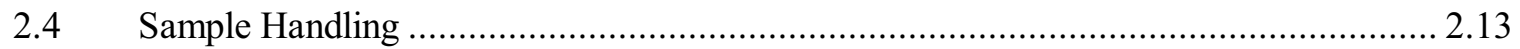

2.5 Sub-Sampling and Geologic Description............................................................... 2.14

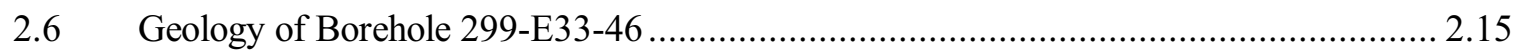

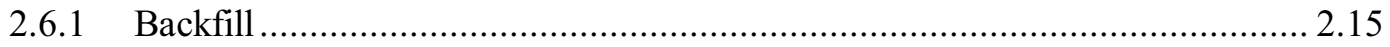

2.6.2 Hanford Formation......................................................................... 2.15

2.6.3 Hanford Formation H3 Unit..................................................................... 2.17

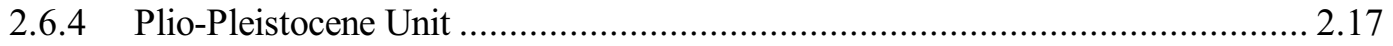

$2.7 \quad$ Discussion On Increased-Moisture Zones ............................................................... 2.21

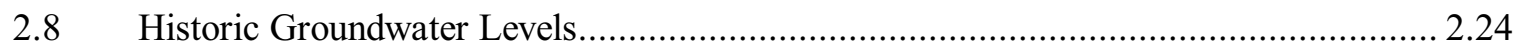

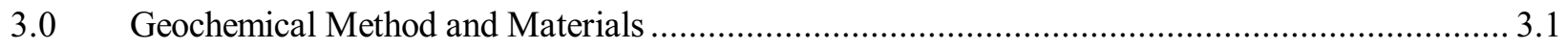

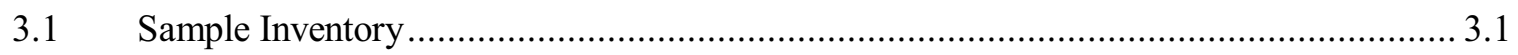

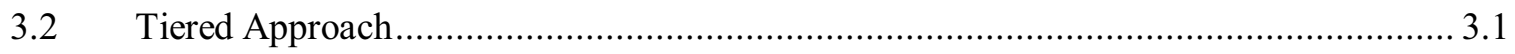

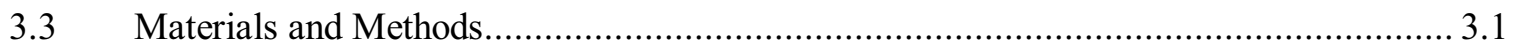

3.3.1 Moisture Content...................................................................................... 3.2

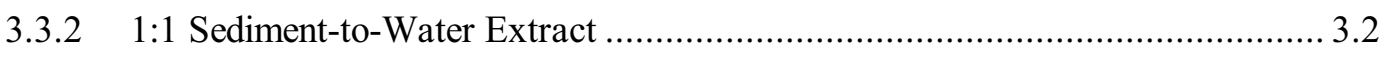

3.3.3 Porewater, Suction Candle, and Groundwater Composition .............................. 3.4

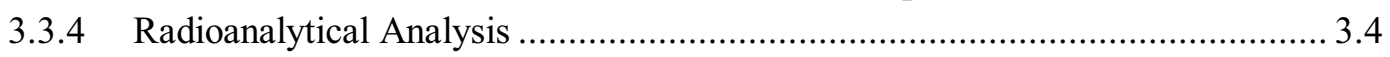

3.3.5 Carbon Content of Sediment ........................................................................ 3.4

3.3.6 8 M Nitric Acid Extract............................................................................... 3.5

3.3.7 Elemental Analysis ................................................................................. 3.5

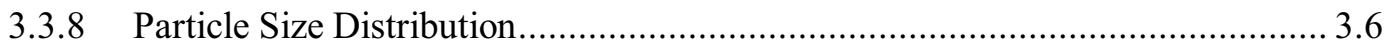

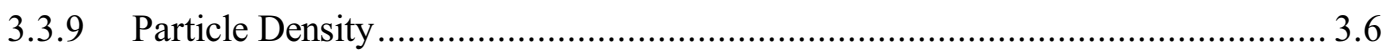

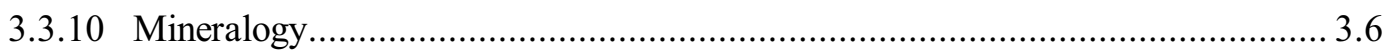

3.3.11 Water Potential (Suction) Measurements ............................................. 3.8

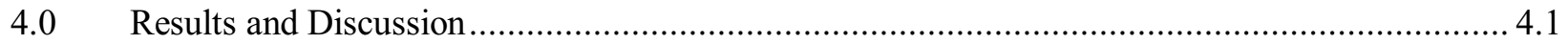

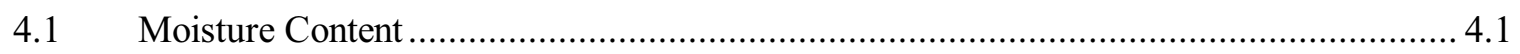

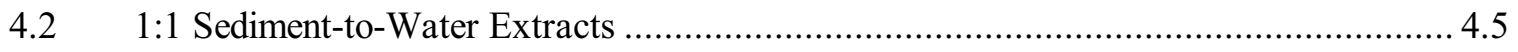




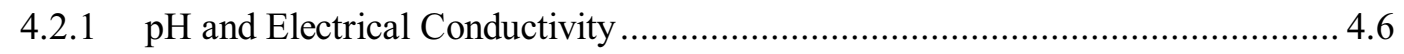

4.2.2 Porewater Anion Composition .................................................................. 4.11

4.2.3 Porewater Cation Composition ................................................................. 4.12

4.2.4 Porewater Trace Constituent Composition .................................................. 4.27

4.2.5 Porewater Solute Ratios ...................................................................... 4.31

4.3 Radionuclide Content In Vadose Zone Sediment .........................................................4. 4.46

4.3.1 Gamma Energy Analysis ........................................................................... 4.46

4.3.2 Strontium-90 Content of Sediment from 299-E33-46.................................. 4.46

4.3.3 Uranium Content in Sediment .......................................................................... 4.56

4.3.4 Technetium-99 Content in the Vadose Zone Sediments ................................ 4.63

4.3.5 Recharge Estimates Based on Technetium-99 Distribution in Sediments from Borehole 299-E33-46 ..................................................................... 4.65

4.3.6 Tritium Content in Vadose Zone Sediments.................................................. 4.67

4.4 Total Carbon, Calcium Carbonate, and Organic Carbon Content of Vadose

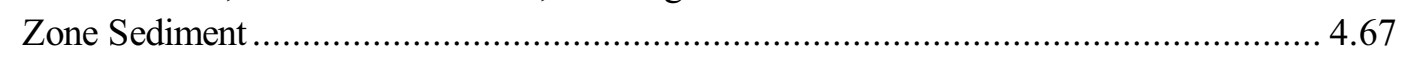

4.5 $8 \mathrm{M}$ Nitric Acid Extractable Amounts of Selected Elements....................................... 4.71

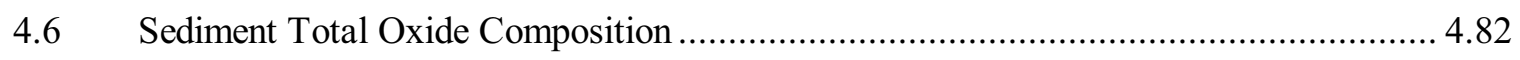

4.7 Particle Size Measurements On Vadose Zone Sediment ............................................. 4.87

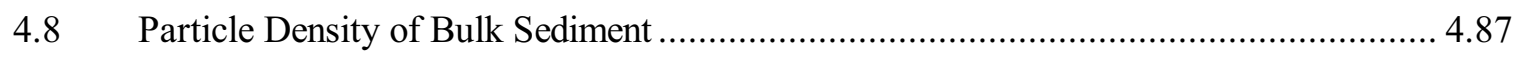

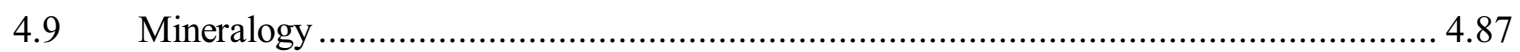

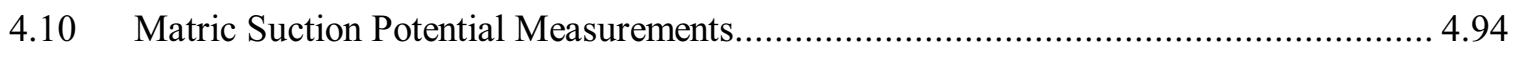

4.11 Vadose Zone Monitoring System................................................................................ 4.98

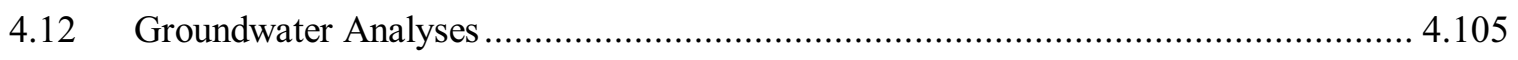

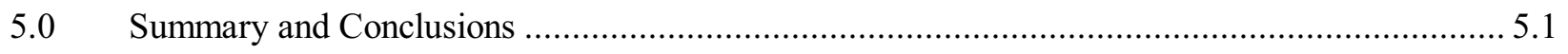

5.1 Conceptual Model of the Geology At 299-E33-46 ................................................... 5.1

$5.2 \quad$ Vertical Extent Of Contamination ...................................................................... 5.3

5.3 Detailed Characterization To Elucidate Controlling Geochemical Processes .................. 5.7

$5.4 \quad$ Estimates of Sorption-Desorption Values ................................................................ 5.8

5.5 Other Characterization Observations ............................................................... 5.9

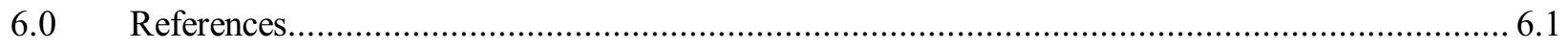

Appendix A - 299-E33-46 Geologic Descriptions of Split-Spoon And Grab Samples Performed During Core/Sample Opening In Pnnl Laboratory................................ A.1

Appendix B-1 - 299-E33-46 Splitspoon Core Sample Photographs ............................................... B.1

Appendix B-2 - 299-E33-46 Composite Grab and Splitspoon Shoe Sample Photographs ....................55

Appendix C - Correlation of Spectral Gamma Log Response Through Borehole Casing With 90sr Concentration In Sediments ...................................................................... C.1

Appendix D - X-Ray Diffractograms For Bulk And Clay Sized Sediments From

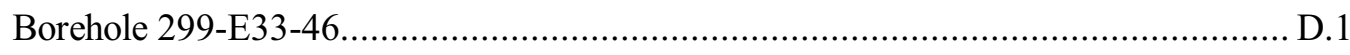




\section{Figures}

2.1 Generalized, Composite Stratigraphy for the Late Cenozoic Sediments Overlying the Columbia River Basalt Group at the B Tank Farm............................................................ 2.2

2.2 Location of Borehole 299-E33-46 Within the B Tank Farm.................................................2.4

2.3 Summary Geologic Log for Borehole 299-E33-46.............................................................. 2.5

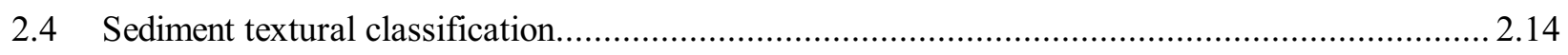

2.5 Medium to coarse sand recovered from the Hanford Formation H2 Unit in Borehole 299-E33-46.

2.6 Gravelly sand recovered from the Hanford formation H3 Unit in Borehole 299-E33-46.

2.7 Calcareous, quartzo-feldspathic fine sand recovered from the upper portion of the PPlz unit in borehole 299-E33-46.

2.8 Well-laminated silt to silty fine sand recovered from the lower portion of the PPlz unit in borehole 299-E33-46.

2.9. Sandy gravel recovered from the PPlg subunit in borehole 299-E33-46

4.1 Moisture Content, Water Extract $\mathrm{pH}$, Calculated Porewater, UFA and Suction Candle Porewater and Groundwater Electrical Conductivity for Borehole 299-E33-46

4.2 Major Anions Calculated (from sediment-to-water extracts), UFA and Suction Candle Porewaters and Groundwater from Borehole 299-E33-46.

4.3 Cations Calculated (from sediment-to-water extracts), UFA, and Suction Candle Porewaters and Groundwater for Borehole 299-E33-46 Sediment.

4.4 Pore Fluid Concentrations of Aluminum, Iron, Silicon, and Manganese (calculated from sediment-to-water extracts), UFA and Suction Candle Porewaters and Groundwater for 299-E33-46 Borehole Sediment

4.5 Radionuclide Pore Water (calculated from sediment-to-water extracts), UFA and Suction Candle Porewaters and Groundwater for 299-E33-46 Borehole Sediment

4.6 Porewater Ratios for Constituents versus Fluoride for 299-E33-46 Sediments. 
4.7 Porewater Ratios for Uranium and Sodium to Other Species.

4.8 Porewater Ratios for Key Constituents versus Each Other

4.9 Porewater Ratios for Key Constituents versus Chloride

4.10 Uranium-238 and Potassium-40 Content in Sediment from Borehole 299-E33-46.

4.11 Strontium-90 Content of Borehole 299-E33-46 Vadose Zone Sediments.

4.12 Correlation Between Bremsstrahlung Signal (count rate between 60 and $350 \mathrm{kev}$ ) and Actual Strontium-90 Concentration in Vadose Zone Sediments from Borehole 299-E33-46.

4.13 Total Uranium in Sediment Based on Three Techniques

4.14 Technetium-99 and Uranium Concentrations in Acid and Water Extracts

4.15 Comparison Between Acid and Water Extractable Concentrations of Major Cations

4.16 Comparison Between Acid and Water Extractable Concentrations of $\mathrm{Ba}, \mathrm{Al}, \mathrm{Si}$, and $\mathrm{Fe}$

4.17 XRD Tracing of sample 110A along with the standard reference pattern for quartz.

4.18 XRD tracings of preferentially oriented clay slides taken from Borehole 299-E33-46 sample $110 \mathrm{~A}$

4.19 Matric Water Potential Measured by Filter Paper Technique on Core Samples from Borehole 299-E33-46

4.20 Matric Water Potential Measured by Filter Paper Technique on Core Samples from Borehole 299-E33-338 Located Outside the SE Perimeter of the B Tank Farm.

4.21 Vadose-Zone Monitoring System (without water-flux meter and temperature sensor) Before Deployment in B Tank Farm. Sensors from left to right are the Modified CSI Water Content Sensor, Advanced Tensiometer, Suction Candle, and Heat-Dissipation Unit 4.98 


\section{Tables}

2.1 Stratigraphic Terminology Used in this Report for the Vadose Zone Beneath the B Tank

Farm.

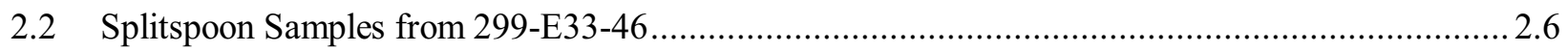

2.3 Composite Grab and Split-Spoon Shoe Samples from 299-E33-46 ....................................... 2.7

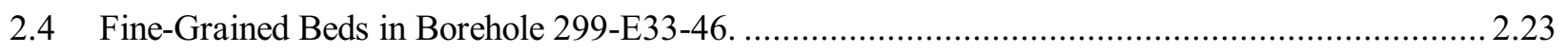

4.1 Moisture Content of Sediment from Borehole 299-E33-46. (4 pages)..................................... 4.2

4.2 Water Extract $\mathrm{pH}$ and Electrical Conductivity Values .................................................... 4.7

4.3 Anion Content of Water Extracts of Borehole 299-E33-46 (B-110 Sediment). (4 pages) ........... 4.14

4.4 Calculated Porewater Cation Composition from Water Extracts of Vadose Zone Sediment from 299-E33-46.

4.5 Calculated and Actual Porewater Radionuclide Composition for Water Extracts of Sediment

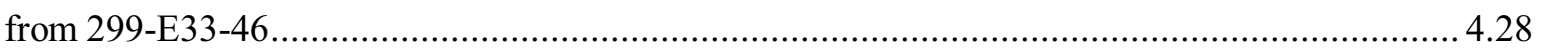

4.6 Strontium-90 Recovery Waste Streams from Zirconium-Clad Fuel ${ }^{(a)}$.................................... 4.32

4.7 Ratio of Major Strontium Recovery Waste to Fluoride Found in Dilution Corrected 1:1 Water to Sediment Extracts ..................................................................................... 4.34

4.8 Ratio of Constituents in Dilution Corrected 1:1 Water Extracts Versus Each Other .................. 4.38

4.9 Gamma Energy Analysis of Vadose Zone Sediment from Borehole 299-E33-46...................... 4.47

4.10 Total Radionuclide Content of Vadose Zone Sediments from Borehole 299-E33-46 ................. 4.50

4.11 NTA Analyses for Selected 1:1 Sediment to Water Extracts From Strontium-90

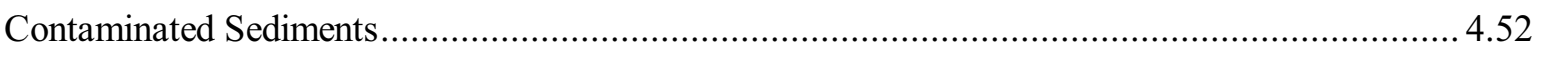

4.12 Total Uranium Content in Vadose Zone Sediments Determined by Three Methods ..................... 4.57

4.13 Calculated In Situ Desorption $K_{d}$ Values for Uranium in Vadose Sediments at 299-E33-46 ....... 4.61

4.14 Estimated recharge rates based on Tc-99 plume depth beneath B-110 …............................. 4.66 
4.15 Tritium Content in Vadose Zone Sediments Based on Water Extracts (pCi/g) ......................... 4.68

4.16 Carbon Content in Vadose Sediment from 299-E33-46....................................................... 4.69

4.17 Acid-Extractable Major Element Content of the Vadose Sediment from 299-E33-46

Borehole......

4.18 Acid-Extractable RCRA Metal Content of the Vadose Sediment from 299-E33-46 Borehole....... 4.77

4.19 Total Composition of the Vadose Zone Sediment from 299-E33-46 Percent Weight as Oxides.

4.20 Total Trace Constituents in Vadose Zone Sediment from 299-E33-46 in $\mu \mathrm{g} / \mathrm{g}(\mathrm{ppm})$.

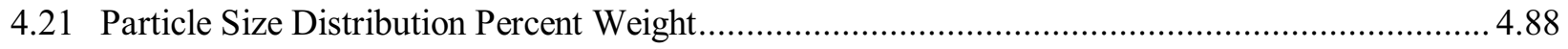

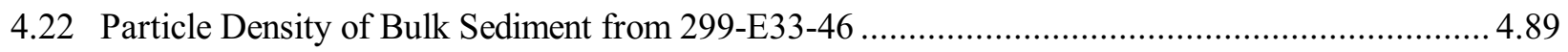

4.23 Semi-quantitative XRD Results of Minerals from the S01052 Borehole................................. 4.91

4.24 Semi-quantitative XRD Results of Clay Minerals Separated from the Sediment Collected from Borehole 299-E33-46

4.25 Matric Potential Measurements on Core and Grab Samples from Borehole 299-E33-46.

4.26 VZMS Sensor Placement in Borehole 299-E33-46 near Tank B110 in B Tank Farm .....

4.27 pH, Electrical Conductivity and Anion Composition of Suction Candle Derived Porewaters vs. Time

4.28 Major Cations and Selected Trace Metals Composition of Suction Candle Derived Porewaters vs. Time

4.29 Selected Trace Metals Composition of Suction Candle Derived Porewaters vs. Time 4.103

4.30 Composition of Groundwater Taken from Borehole 299-E33-46 at $255.8 \mathrm{ft}$ bgs 4.106 


\subsection{Introduction}

The overall goals of the of the Tank Farm Vadose Zone Project, led by CH2M HILL Hanford Group, Inc., are 1) to define risks from past and future single-shell tank farm activities, 2) to identify and evaluate the efficacy of interim measures, and 3) to aid via collection of geotechnical information and data, the future decisions that must be made by the Department of Energy (DOE) regarding the near-term operations, future waste retrieval, and final closure activities for the single-shell tank Waste Management Areas. For a more complete discussion of the goals of the Tank Farm Vadose Zone Project, see the overall work plan, Phase 1 RCRA Facility Investigation/Corrective Measures Study Work Plan for the Single-Shell Tank Waste Management Areas (DOE 1999). Specific details on the rationale for activities performed at the B-BX-BY Tank Farm waste management area (WMA) are found in CH2M HILL (2000).

To meet these goals, CH2M HILL Hanford Group, Inc., asked scientists from Pacific Northwest National Laboratory (PNNL) to perform detailed analyses of vadose zone sediment, both uncontaminated and contaminated, from within the B-BX-BY WMA.

Specifically, this report contains all the geologic, geochemical, and selected physical characterization data collected on vadose zone sediment recovered from borehole 299-E33-46 that is near tank B-110. We also provide our interpretation of the data in the context of determining the appropriate lithologic model, the vertical extent of contamination, the migration potential of the contaminants that still reside in the vadose zone, and the correspondence of the contaminant distribution in the borehole sediment to groundwater plumes in the aquifer proximate and down gradient from the B Tank Farm.

This report is one in a series of three reports to present recent data collected on vadose zone sediment, both uncontaminated and contaminated, from within the B-BX-BY WMA. Two other PNNL reports discuss the characterization of 1) uncontaminated sediment from a Resource Conservation and Recovery Act (RCRA) borehole [299-E33-338], to provide a baseline against information from contaminated sediment (see Lindenmeier et al. 2002); 2) contaminated sediment obtained from the 299E33-45 northeast of tank BX-102 (see Serne et. al. 2002e), which has been decommissioned. This document describes all the characterization data collected and interpretations assembled by the Applied Geology and Geochemistry Group within PNNL's Environmental Technology Division. The main objective for placing the 299-E33-46 borehole at the location $\sim 15 \mathrm{ft}$ northeast from the B-110 tank wall was to investigate the vertical extent of strontium-90, uranium, technetium-99, and other mobile contaminants at a spot known to contain high strontium-90 contents based on bremmstrahlung signal in the spectral gamma logging. The borehole was extended to groundwater in order to track other mobile contaminants that can't be tracked with gamma logging such as technetium-99 and nitrate. 
The documents contain preliminary interpretations to identify the distribution of key contaminants within the vadose zone and to determine what their future migration potential could be. The information will be incorporated in the B-BX-BY field investigation report. ${ }^{(a)}$

This report is divided into sections that describe the geology, the geochemical characterization methods employed, the geochemical results that emphasize determination of the vertical extent of tank fluid migration and contaminant migration potential, as well as summary and conclusions, references cited, and four appendixes with additional details and sediment photographs.

( $\left.{ }^{\mathrm{a}}\right) \quad$ Draft Field Investigation Report for Waste Management Area B-BX-BY. RPP-10098, Draft, Volume 2, Appendix D, CH2M HILL Hanford Group, Inc., Richland, Washington. 


\subsection{Geology}

The geology of the vadose zone underlying the 241-B Tank Farm forms the framework through which the contaminants move, and provides the basis with which to interpret and extrapolate the physical and geochemical properties that control the migration and distribution of contaminants. Of particular interest are the interrelationships between the coarser and finer-grained facies, and the degree of contrast in their physical and geochemical properties.

This section presents a brief discussion on the geologic setting of the 241-B Tank Farm followed by a discussion on the drilling, sampling, and geophysical logging of borehole 299-E33-46 as well as a description and interpretation of the geologic materials penetrated by this borehole.

\subsection{Geologic Setting of the 241-B Tank Farm}

The 241-B Tank Farm was constructed in 1943 and 1944 to store high-level radioactive waste generated by chemical processing of irradiated uranium fuel at the chemical separation plants (DOE-GJPO 1999a). The tank farm was excavated into the Pleistocene-age Hanford formation and Holocene eolian deposits that mantle a portion of the northern flank of the Cold Creek flood bar (Wood et al. 2000). The geology beneath the B Tank Farm has been described in numerous reports (Price and Fecht 1976; Caggiano and Goodwin 1991; Caggiano 1996; Narbutovskih 1998; DOE-GJPO 1999a; Wood et al. 2000; and Lindsey et al. 2001). The major stratigraphic units beneath the tank farm include (in descending order); the Hanford formation, a unit described as Hanford formation/Plio-Pleistocene unit (?) $[\mathrm{Hf} / \mathrm{PPu}($ ?)], and the Columbia River Basalt Group (Figure 2.1). The uppermost $10.7 \mathrm{~m}$ (35 ft) of the Hanford formation was removed during construction of the tank farm and the stockpiled sediments were later used as backfill, placed around and over the underground storage tanks.

The stratigraphic nomenclature used in this report is summarized in Table 2.1. Stratigraphic terminology used in this report is consistent with that presented in Wood et al. (2000) and Lindsey et al. (2001) for the Hanford formation. However, the interpretation of stratigraphic units underlying the Hanford formation differs for these two reports. Wood et al. (2000) interpret the gravel sequence under a

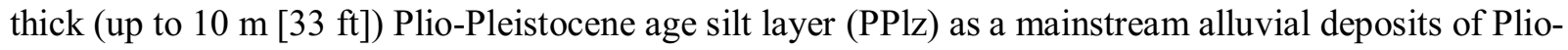
Pleistocene age, while Lindsey et al. (2001) interpret this gravel sequence as older Ringold Formation. The mafic content in these sandy gravels appears unlike that for the mostly quartzo-feldspathic Ringold Formation. Furthermore, numerous past studies (Tallman et al 1979; Last et al. 1989; Connelly et al. 1992; Williams et al. 2001) have never identified the Ringold Formation this far north within the 200 East Area. Therefore, we prefer the interpretation of Wood et al. (2000) that this gravel sequence is part of the Plio-Pleistocene unit, and thus it is designated as Plio-Pleistocene gravel (PPlg) in this report. 


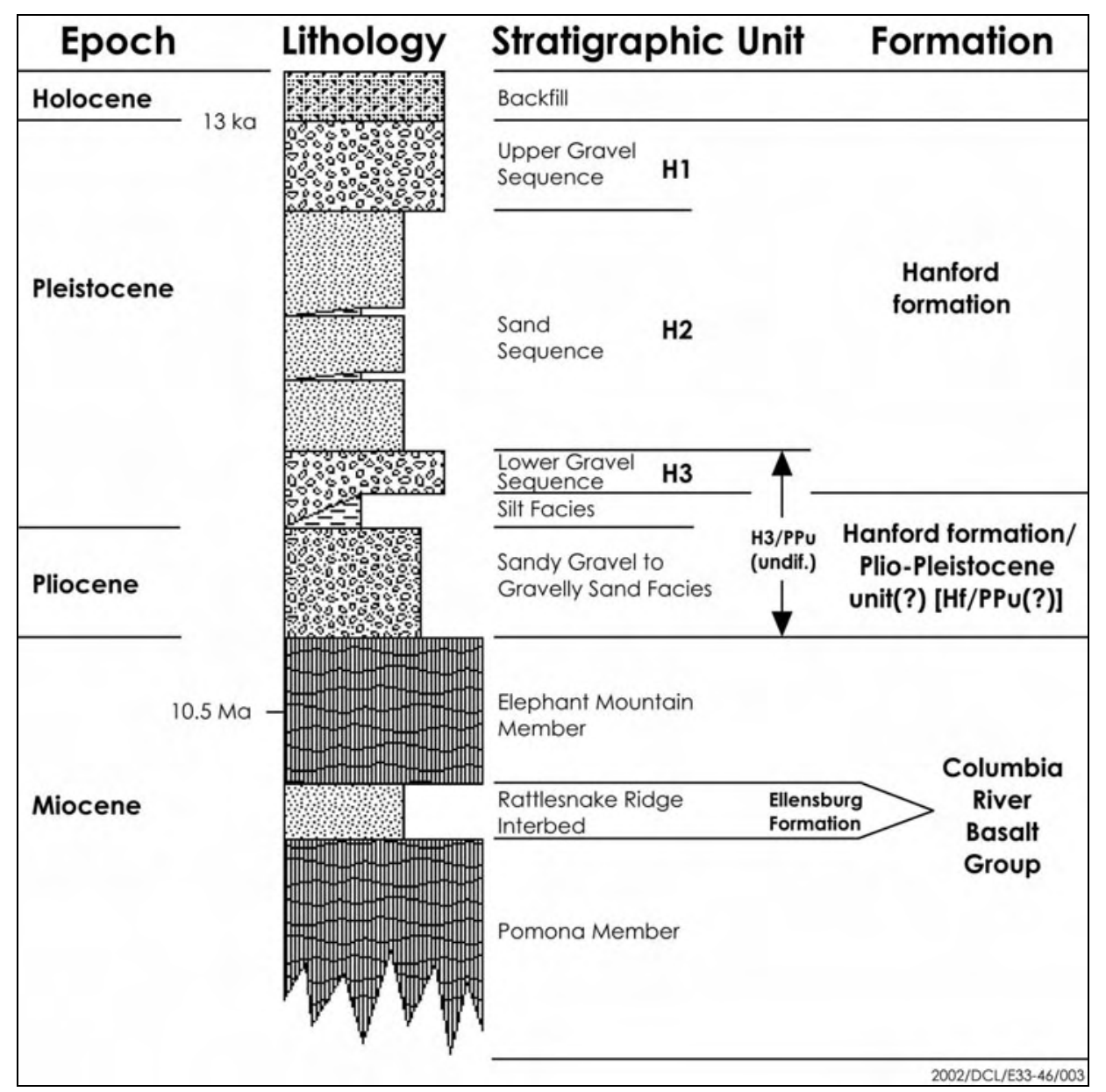

Figure 2.1. Generalized, Composite Stratigraphy for the Late Cenozoic Sediments Overlying the Columbia River Basalt Group at the B Tank Farm (Modified After Wood et al. 2000)

Table 2.1. Stratigraphic Terminology Used in this Report for the Vadose Zone Beneath the B Tank Farm. (2 Pages)

\begin{tabular}{|c|c|c|l|l|}
\hline $\begin{array}{c}\text { Stratigraphic } \\
\text { Symbol }\end{array}$ & Formation & Facies / Subunit & \multicolumn{1}{|c|}{ Description } & Genesis \\
\hline Backfill & NA & Backfill & $\begin{array}{l}\text { Poorly to moderately sorted cobbles, pebbles, } \\
\text { and coarse to medium sand with some silt } \\
\text { derived from coarse-grained Hanford formation } \\
\text { (H1 Unit) excavated around tanks (Price and } \\
\text { Fecht 1976) }\end{array}$ & Anthropogenic \\
\hline H1 & $\begin{array}{c}\text { Hanford } \\
\text { formation }\end{array}$ & Unit H1 & $\begin{array}{l}\text { Upper sandy gravel to gravelly sand sequence. } \\
\text { Equivalent to the H1 unit discussed by Lindsey et } \\
\text { al. (1994, 2001) the upper gravel sequence } \\
\text { discussed by Last et al. (1989) and Lindsey et al. } \\
\text { (1992), and the Qfg documented by Reidel and } \\
\text { Fecht (1994). Excavated out and missing from } \\
\text { most of B Tank Farm. }\end{array}$ & $\begin{array}{l}\text { Cataclysmic Flood } \\
\text { Deposits }\end{array}$ \\
\hline
\end{tabular}


Table 2.1. Stratigraphic Terminology Used in this Report for the Vadose Zone Beneath the B Tank Farm. (2 Pages)

\begin{tabular}{|c|c|c|c|c|}
\hline $\begin{array}{c}\text { Stratigraphic } \\
\text { Symbol }\end{array}$ & Formation & Facies / Subunit & Description & Genesis \\
\hline $\mathrm{H} 2$ & & Unit $\mathrm{H} 2$ & $\begin{array}{l}\text { Sand sequence consisting predominantly of } \\
\text { sand-dominated facies, with multiple graded beds } \\
\text { of horizontal to tabular cross-bedded sand to } \\
\text { slightly gravelly sand. Graded beds sometimes } \\
\text { capped with thin layers of silty sand to silt. } \\
\text { Equivalent to H2 unit of Wood et al. (2000) and } \\
\text { Lindsey et al. (1994, 2001), the sandy sequence } \\
\text { of Last et al. (1989) and Lindsey et al. (1992), } \\
\text { and to Qfs documented by Reidel and Fecht } \\
\text { (1994). }\end{array}$ & \\
\hline $\mathrm{H} 3$ & & Unit $\mathrm{H} 3$ & $\begin{array}{l}\text { Lower gravelly sand to slightly gravelly sand } \\
\text { sequence. Equivalent to the H3 unit of Lindsey et } \\
\text { al. (1994, 2001) lower gravel sequence discussed } \\
\text { by Last et al. (1989) and Lindsey et al. (1992), } \\
\text { and the Qfg documented by Reidel and Fecht } \\
\text { (1994). }\end{array}$ & \\
\hline $\begin{array}{l}\mathrm{Hf} / \mathrm{PPu} \text { and/or } \\
\text { PPlz }\end{array}$ & \multirow{2}{*}{$\begin{array}{l}\text { Hanford } \\
\text { Formation/ } \\
\text { Plio- } \\
\text { Pleistocene } \\
\text { Unit (?) }\end{array}$} & $\begin{array}{l}\text { Silt-Dominated } \\
\text { Facies }\end{array}$ & $\begin{array}{l}\text { Silty sequence consisting of interstratified well } \\
\text { sorted calcareous silt and fine sand. Equivalent } \\
\text { to the Silt facies of the Hanford Formation/Plio- } \\
\text { Pleistocene Unit(?) of Wood et al. (2000). } \\
\text { Perhaps equivalent to the "early Palouse soil" } \\
\text { originally described by Tallman et al. (1979) and } \\
\text { DOE (1988). Also equivalent to the upper } \\
\text { portion of the Hanford/Plio- } \\
\text { Pleistocene/Ringold(?) of Lindsey et al. (2001) }\end{array}$ & $\begin{array}{l}\text { Fluvial overbank } \\
\text { and/or eolian } \\
\text { deposits (with some } \\
\text { weakly developed } \\
\text { paleosols) }\end{array}$ \\
\hline $\begin{array}{l}\mathrm{Hf} / \mathrm{PPu} \text { and/or } \\
\text { PPlg }\end{array}$ & & $\begin{array}{l}\text { Sandy Gravel to } \\
\text { Gravelly Sand } \\
\text { Dominated Facies }\end{array}$ & $\begin{array}{l}\text { Sandy gravel to gravelly sand sequence } \\
\text { consisting predominantly of unconsolidated } \\
\text { basaltic sands and gravels. Actual origin of this } \\
\text { unit is still uncertain. Without intervening silt } \\
\text { facies (PPlz subunit) this unit cannot be } \\
\text { differentiated from the Hanford formation H3 } \\
\text { unit (Wood et al. 2000). Lindsey et al. (2001) } \\
\text { suggested this unit may be part of the Ringold } \\
\text { Formation. }\end{array}$ & $\begin{array}{l}\text { Plio-Pleistocene } \\
\text { age mainstream } \\
\text { alluvium (Wood et } \\
\text { al. 2000) or } \\
\text { possibly Ringold } \\
\text { Formation (Lindsey } \\
\text { et al. 2001) }\end{array}$ \\
\hline
\end{tabular}

\subsection{Drilling and Sampling of Borehole 299-E33-46 (C3360)}

Borehole 299-E33-46 was drilled using the cable-tool technique between May 8 and June 26, 2001.

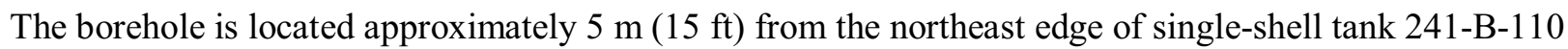
(Figure 2.2), which was first recognized as a suspected leaker in 1973 later becoming an assumed leaker in 1984 (DOE-GJPO 1999b). Total depth of the borehole was $80.6 \mathrm{~m}$ (264.4 ft) below ground surface (bgs); the groundwater table was encountered at $78.0 \mathrm{~m}(255.8 \mathrm{ft}) \mathrm{bgs}$. The borehole was later completed as a well for the installation of down-hole hydrologic sensors (Reynolds 2001). The surveyed well 
elevation is $200.3 \mathrm{~m}(657.3 \mathrm{ft})$ above mean sea level; geographic coordinates are N13728.365 and E573792.553.

During drilling, a total of 33 two-ft long, 4-inch diameter split-spoon core samples were collected starting at a depth of about $3 \mathrm{~m}(10 \mathrm{ft})$ bgs (Table 2.2, Figure 2.3). Four $0.5 \mathrm{ft}$ long stainless-steel core liners were used in each 2-ft split spoon. A geologic log was compiled in the field by a Duratek Federal Services, Inc. (DFS) subcontract geologist (KR Simpson), based on observations made on cuttings retrieved from the core barrel between core runs as well as the exposed ends of contained split-spoon samples (Reynolds 2001). Core extraction was performed later in a radiologically controlled PNNL laboratory between July 10th and 18th, 2001. At this time a second geologic log, which describes the character of the core interiors, was prepared by a PNNL geologist (BN Bjornstad). Geologic logging occurred after each core segment was emptied into an open plastic container, followed by photographing and sub-sampling for physical and chemical characterization. Material from each $0.5 \mathrm{ft}$ liner was placed into a separate plastic container and after geologic logging, photographing and sub-sampling, the plastic containers were sealed shut and placed into cold storage. Selected composite grab samples were also examined in the laboratory.

Geologic description on the opened cores and composite grab samples was performed according to the procedure outlined in PNNL (1999). Both of the Duratek and PNNL geologic core logs from borehole 299-E33-46 are presented in Appendix B of Lindsey et al. (2001). A one-page summary log of borehole 299-E33-46, compiled from the geologic logs, is presented in Figure 2.3. Penetration resistance (i.e., blowcounts) and percent core recovered from each $2 \mathrm{ft}$ core run are also plotted in Figure 2.3, based on data presented in Appendix D of Reynolds (2001).

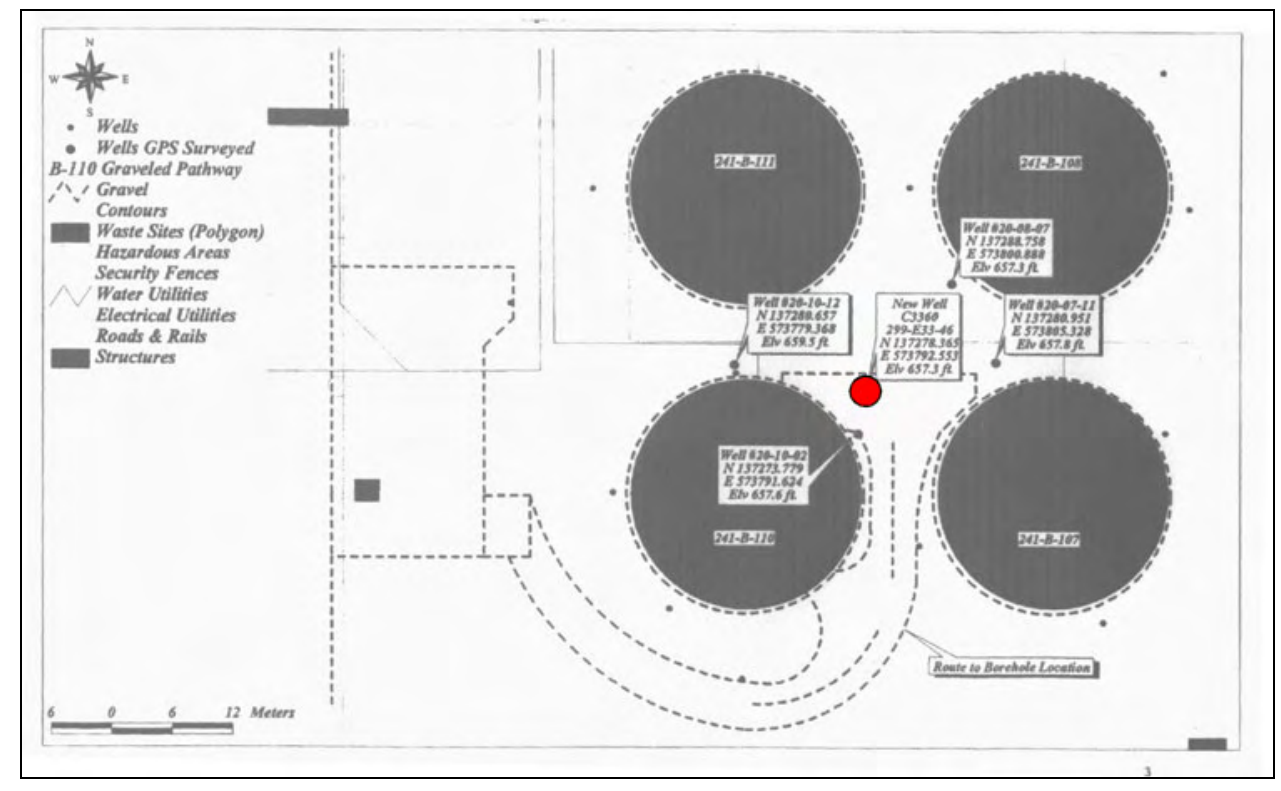

Figure 2.2. Location of Borehole 299-E33-46 Within the B Tank Farm. Modified after Reynolds (2001). 


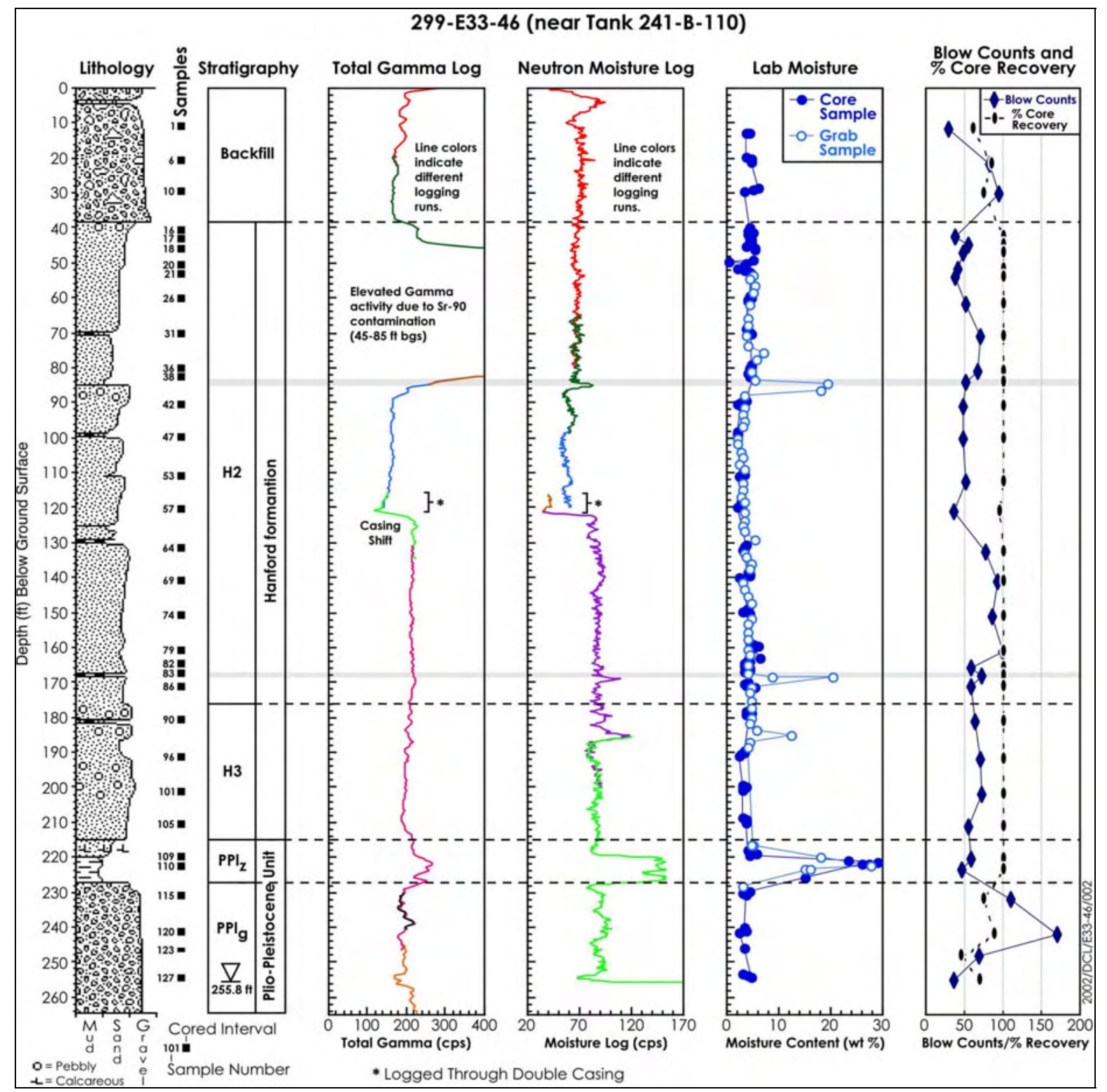

Figure 2.3. Summary Geologic Log for Borehole 299-E33-46.

Two sets of temporary casing were used to control the borehole during drilling and sampling (Reynolds 2001). Surface casing (13 3/8 in. outside diameter [OD]) was set to $37.0 \mathrm{~m}$ (121.3 $\mathrm{ft}$ ) bgs; the

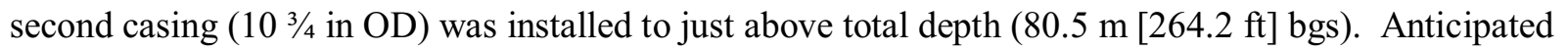
perched-water conditions were not encountered atop a fine-grained silt layer at $67 \mathrm{~m}(220 \mathrm{ft}) \mathrm{bgs}$, thus it was not necessary to telescope down to a smaller-diameter casing within this fine-grained zone. Eight vadose zone porewater sensor arrays were installed in the borehole prior to decommissioning and removal of temporary casing (Reynolds 2001).

Thirty-three split-spoon core samples were collected between 3 and $77 \mathrm{~m}$ (10 and $254 \mathrm{ft})$ bgs - an average of every $2.3 \mathrm{~m}(7.5 \mathrm{ft})$. Grab samples were collected between these core sample intervals to yield near continuous samples to a depth of $78.3 \mathrm{~m}(257 \mathrm{ft})$. The split-spoon samples were taken ahead of the 
casing by driving a split-spoon sampler into the undisturbed formations below the casing. The complete list of split-spoon cores collected, depth interval, sediment description, and percent core recovery is listed in Table 2.2. The relative location of each 2-ft split-spoon core is shown graphically in Figure 2.3. Core recovery was excellent (95-100\%) in the finer grained sediments, decreasing significantly in the coarser materials (Table 2.2, Figure 2.3).

Table 2.2. Splitspoon Samples from 299-E33-46. (2 pages)

\begin{tabular}{|c|c|c|c|c|c|c|}
\hline $\begin{array}{c}\text { Field Sample } \\
\text { No. }\end{array}$ & $\begin{array}{l}\text { Top Depth } \\
{\text { (ft })^{(1)}}^{(1)}\end{array}$ & $\begin{array}{c}\text { Bottom Depth } \\
(\mathbf{f t})^{(1)}\end{array}$ & $\begin{array}{c}\text { Sampled } \\
\text { Interval } \\
\text { Thickness } \\
\text { (ft) }^{(1)}\end{array}$ & $\begin{array}{c}\text { Sediment } \\
\text { Description }\end{array}$ & $\begin{array}{c}\text { Stratigraphic } \\
\text { Unit }\end{array}$ & $\begin{array}{l}\% \text { Core } \\
\text { Recovery }\end{array}$ \\
\hline S01052-1 & 9.5 & 11.7 & 2.0 & Sandy gravel & Backfill & 60 \\
\hline S01052-6 & 19.3 & 21.6 & 2.0 & $\begin{array}{l}\text { Sandy to pebbly } \\
\text { gravel }\end{array}$ & Backfill & 85 \\
\hline S01052-10 & 27.7 & 30.0 & 2.0 & Sand and cobbles & Backfill & 75 \\
\hline S01052-16 & 40.0 & 42.3 & 2.0 & Sand & $\mathrm{H} 2$ & 100 \\
\hline S01052-17 & 42.3 & 44.6 & 2.0 & Sand & $\mathrm{H} 2$ & 100 \\
\hline S01052-18 & 44.7 & 47.0 & 2.0 & Sand & $\mathrm{H} 2$ & 100 \\
\hline S01052-20 & 48.9 & 51.2 & 2.0 & Coarse sand & $\mathrm{H} 2$ & 100 \\
\hline S01052-21 & 51.3 & 53.6 & 2.0 & Sand & $\mathrm{H} 2$ & 100 \\
\hline S01052-26 & 59.0 & 61.3 & 2.0 & Sand & $\mathrm{H} 2$ & 100 \\
\hline S01052-31 & 68.7 & 71.0 & 2.0 & Sand & $\mathrm{H} 2$ & 100 \\
\hline S01052-36 & 78.2 & 80.5 & 2.0 & Sand & $\mathrm{H} 2$ & 100 \\
\hline S01052-38 & 81.3 & 83.6 & 2.0 & Sand & $\mathrm{H} 2$ & 100 \\
\hline S01052-42 & 88.6 & 90.9 & 2.0 & Sand & $\mathrm{H} 2$ & 100 \\
\hline S01052-47 & 97.9 & 100.2 & 2.0 & Sand & $\mathrm{H} 2$ & 100 \\
\hline S01052-53 & 109.7 & 112.0 & 2.0 & Sand & $\mathrm{H} 2$ & 100 \\
\hline S01052-57 & 118.2 & 120.5 & 2.0 & Sand & $\mathrm{H} 2$ & 95 \\
\hline S01052-64 & 130.1 & 132.4 & 2.0 & $\begin{array}{l}\text { Sand, salt and } \\
\text { pepper }\end{array}$ & $\mathrm{H} 2$ & 100 \\
\hline S01052-69 & 138.3 & 140.6 & 2.0 & Sand & $\mathrm{H} 2$ & 100 \\
\hline S01052-74 & 148.4 & 150.7 & 2.0 & Sand & $\mathrm{H} 2$ & 100 \\
\hline S01052-79 & 158.4 & 160.7 & 2.0 & Sand & $\mathrm{H} 2$ & 100 \\
\hline S01052-82 & 162.8 & 165.1 & 2.0 & Sand & $\mathrm{H} 2$ & 100 \\
\hline S01052-83 & 165.1 & 167.4 & 2.0 & Sand & $\mathrm{H} 2$ & 100 \\
\hline S01052-86 & 169.4 & 171.7 & 2.0 & Sand & $\mathrm{H} 2$ & 100 \\
\hline S01052-90 & 178.1 & 180.4 & 2.0 & Sand & $\mathrm{H} 3$ & 100 \\
\hline S01052-96 & 189.1 & 191.4 & 2.0 & Coarse sand & $\mathrm{H} 3$ & 100 \\
\hline S01052-101 & 199.2 & 201.5 & 2.0 & Sand & $\mathrm{H} 3$ & 100 \\
\hline S01052-105 & 208.4 & 210.7 & 2.0 & Sand & $\mathrm{H} 3$ & 100 \\
\hline
\end{tabular}


Table 2.2. Splitspoon Samples from 299-E33-46. (2 pages)

\begin{tabular}{|c|c|c|c|c|c|c|}
\hline $\begin{array}{c}\text { Field Sample } \\
\text { No. }\end{array}$ & $\begin{array}{c}\text { Top Depth } \\
\text { (ft) }^{(\mathbf{1})}\end{array}$ & $\begin{array}{c}\text { Bottom Depth } \\
\text { (ft) }^{(\mathbf{1})}\end{array}$ & $\begin{array}{c}\text { Sampled } \\
\text { Interval } \\
\text { Thickness } \\
\text { (ft) }^{(\mathbf{1})}\end{array}$ & $\begin{array}{c}\text { Sediment } \\
\text { Description }\end{array}$ & $\begin{array}{c}\text { Stratigraphic } \\
\text { Unit }\end{array}$ & $\begin{array}{c}\text { \% Core } \\
\text { Recovery }\end{array}$ \\
\hline S01052-109 & 217.7 & 220.0 & 2.0 & Sand/silt & $\mathrm{PPlz}$ & 100 \\
\hline S01052-110 & 220.4 & 222.7 & 2.0 & Silt/clay & $\mathrm{PPlz}$ & 100 \\
\hline S01052-115 & 229.4 & 231.7 & 2.0 & Gravel/sand & PPlg & 75 \\
\hline S01052-120 & 239.4 & 241.7 & 2.0 & Gravel/sand & PPlg & 87.5 \\
\hline S01052-123 & 245.5 & 246.0 & 0.5 & Gravel & PPlg & 44 \\
\hline S01052-127 & 252.4 & 254.7 & 2.0 & Gravel/sand & PPlg & 69 \\
\hline
\end{tabular}

(1) to convert to meters multiply by 0.3048

$\mathrm{H} 2=$ Hanford H2 Sand Sequence (see Table 2.1)

H3 = Hanford H3 Lower Sand Sequence (see Table 2.1)

PPlz = Plio-Pleistocene slit (see Table 2.1)

PPlg = Plio-Pleistocene gravel (see Table 2.1)

Table 2.3. Composite Grab and Split-Spoon Shoe Samples from 299-E33-46. (6 pages)

\begin{tabular}{|c|c|c|c|c|c|c|}
\hline $\begin{array}{c}\text { Sample } \\
\text { No. }\end{array}$ & $\begin{array}{c}\text { Top Depth } \\
\text { (ft) }^{(\mathbf{1})}\end{array}$ & $\begin{array}{c}\text { Bottom } \\
\text { Depth } \\
\text { (ft) }^{(\mathbf{1})}\end{array}$ & $\begin{array}{c}\text { Sampled } \\
\text { Interval } \\
\text { Thickness } \\
\text { (ft) }^{(\mathbf{1})}\end{array}$ & Sample Type & $\begin{array}{c}\text { Sample } \\
\text { Description }\end{array}$ & $\begin{array}{c}\text { Stratigraphic } \\
\text { Unit }\end{array}$ \\
\hline S01052-03 & 11.80 & 14.07 & 2.27 & Composite Grab & $*$ & $*$ \\
\hline S01052-04 & 14.07 & 15.90 & 1.83 & Composite Grab & $*$ & $*$ \\
\hline S01052-05 & 15.90 & 18.00 & 2.10 & Composite Grab & $*$ & $*$ \\
\hline S01052-06 & 21.37 & 21.60 & 0.23 & Splitspoon Shoe & $*$ & $*$ \\
\hline S01052-07 & 21.60 & 24.10 & 2.50 & Composite Grab & $*$ & $*$ \\
\hline S01052-08 & 24.10 & 26.00 & 1.90 & Composite Grab & $*$ & $*$ \\
\hline S01052-09 & 26.00 & 27.70 & 1.70 & Composite Grab & $*$ & $*$ \\
\hline S01052-10 & 29.67 & 30.00 & 0.33 & Splitspoon Shoe & $*$ & $*$ \\
\hline S01052-11 & 30.00 & 31.70 & 1.70 & Composite Grab & $*$ & $*$ \\
\hline S01052-12 & 31.70 & 33.30 & 1.60 & Composite Grab & $*$ & $*$ \\
\hline S01052-13 & 33.30 & 35.40 & 2.10 & Composite Grab & $*$ & $*$ \\
\hline S01052-14 & 35.40 & 37.80 & 2.40 & Composite Grab & $*$ & $*$ \\
\hline S01052-15 & 37.80 & 40.00 & 2.20 & Composite Grab & $*$ & $*$ \\
\hline S01052-16 & 41.97 & 42.30 & 0.33 & Splitspoon Shoe & $*$ & $*$ \\
\hline S01052-17 & 44.27 & 44.60 & 0.33 & Splitspoon Shoe & $*$ & $*$ \\
\hline S01052-18 & 46.67 & 47.00 & 0.33 & Splitspoon Shoe & $*$ & $*$ \\
\hline S01052-19 & 47.00 & 48.90 & 1.90 & Composite Grab & $*$ & $*$ \\
\hline
\end{tabular}


Table 2.3. Composite Grab and Split-Spoon Shoe Samples from 299-E33-46. (6 pages)

\begin{tabular}{|c|c|c|c|c|c|c|}
\hline $\begin{array}{l}\text { Sample } \\
\text { No. }\end{array}$ & $\begin{array}{l}\text { Top Depth } \\
\text { (ft) }^{(1)}\end{array}$ & $\begin{array}{c}\text { Bottom } \\
\text { Depth } \\
(\text { ft })^{(1)}\end{array}$ & $\begin{array}{c}\text { Sampled } \\
\text { Interval } \\
\text { Thickness } \\
\text { (ft) }^{(1)}\end{array}$ & Sample Type & $\begin{array}{c}\text { Sample } \\
\text { Description }\end{array}$ & $\begin{array}{c}\text { Stratigraphic } \\
\text { Unit }\end{array}$ \\
\hline S01052-20 & 50.87 & 51.20 & 0.33 & Splitspoon Shoe & * & $*$ \\
\hline S01052-21 & 53.27 & 53.60 & 0.33 & Splitspoon Shoe & $*$ & $*$ \\
\hline S01052-22 & 53.60 & 55.60 & 2.00 & Composite Grab & * & * \\
\hline S01052-23 & 53.60 & 55.60 & 2.00 & Composite Grab & $*$ & $*$ \\
\hline S01052-24 & 55.60 & 57.80 & 2.20 & Composite Grab & $*$ & $*$ \\
\hline S01052-25 & 57.80 & 59.00 & 1.20 & Composite Grab & $*$ & * \\
\hline S01052-26 & 60.97 & 61.30 & 0.33 & Splitspoon Shoe & * & * \\
\hline S01052-27 & 61.30 & 62.90 & 1.60 & Composite Grab & * & $*$ \\
\hline S01052-28 & 62.90 & 64.90 & 2.00 & Composite Grab & $*$ & $*$ \\
\hline S01052-29 & 64.90 & 67.20 & 2.30 & Composite Grab & $*$ & $*$ \\
\hline S01052-30 & 67.20 & 68.70 & 1.50 & Composite Grab & * & $*$ \\
\hline S01052-31 & 70.70 & 71.00 & 0.30 & Splitspoon Shoe & $*$ & $*$ \\
\hline S01052-32 & 71.00 & 72.70 & 1.70 & Composite Grab & $*$ & * \\
\hline S01052-33 & 72.70 & 74.30 & 1.60 & Composite Grab & $*$ & $*$ \\
\hline S01052-34 & 74.30 & 76.50 & 2.20 & Composite Grab & Medium sand & $\mathrm{H} 2$ \\
\hline S01052-35 & 76.50 & 78.20 & 1.70 & Composite Grab & $*$ & $*$ \\
\hline S01052-36 & 80.50 & 80.50 & 0.00 & Splitspoon Shoe & $*$ & $*$ \\
\hline S01052-37 & 80.50 & 81.30 & 0.80 & Composite Grab & $*$ & $*$ \\
\hline S01052-38 & 83.30 & 83.60 & 0.30 & Splitspoon Shoe & Medium sand & $\mathrm{H} 2$ \\
\hline S01052-39 & 83.60 & 85.50 & 1.90 & Composite Grab & Medium sand & $\mathrm{H} 2$ \\
\hline S01052-40 & 85.50 & 87.10 & 1.60 & Composite Grab & $*$ & $*$ \\
\hline S01052-41 & 87.10 & 88.60 & 1.50 & Composite Grab & $*$ & $*$ \\
\hline S01052-42 & 90.87 & 90.90 & 0.03 & Splitspoon Shoe & $*$ & $*$ \\
\hline S01052-43 & 90.90 & 92.00 & 1.10 & Composite Grab & $\begin{array}{c}\text { Slightly } \\
\text { pebbly coarse } \\
\text { sand }\end{array}$ & $\mathrm{H} 2$ \\
\hline S01052-44 & 92.00 & 94.30 & 2.30 & Composite Grab & Medium sand & $\mathrm{H} 2$ \\
\hline S01052-45 & 94.30 & 96.00 & 1.70 & Composite Grab & Medium sand & $\mathrm{H} 2$ \\
\hline S01052-46 & 96.00 & 97.90 & 1.90 & Composite Grab & $*$ & $*$ \\
\hline S01052-47 & 99.87 & 100.20 & 0.33 & Splitspoon Shoe & $\begin{array}{l}\text { Medium to } \\
\text { coarse sand }\end{array}$ & $\mathrm{H} 2$ \\
\hline S01052-48 & 100.20 & 102.90 & 2.70 & Composite Grab & Coarse sand & $\mathrm{H} 2$ \\
\hline S01052-49 & 102.90 & 104.80 & 1.90 & Composite Grab & $\begin{array}{l}\text { Medium to } \\
\text { coarse sand }\end{array}$ & $\mathrm{H} 2$ \\
\hline
\end{tabular}


Table 2.3. Composite Grab and Split-Spoon Shoe Samples from 299-E33-46. (6 pages)

\begin{tabular}{|c|c|c|c|c|c|c|}
\hline $\begin{array}{c}\text { Sample } \\
\text { No. }\end{array}$ & $\begin{array}{l}\text { Top Depth } \\
\text { (ft) }^{(1)}\end{array}$ & $\begin{array}{c}\text { Bottom } \\
\text { Depth } \\
(\text { ft })^{(1)}\end{array}$ & $\begin{array}{c}\text { Sampled } \\
\text { Interval } \\
\text { Thickness } \\
\text { (ft) }^{(1)}\end{array}$ & Sample Type & $\begin{array}{c}\text { Sample } \\
\text { Description }\end{array}$ & $\begin{array}{c}\text { Stratigraphic } \\
\text { Unit }\end{array}$ \\
\hline S01052-50 & 104.80 & 106.60 & 1.80 & Composite Grab & $\begin{array}{l}\text { Medium to } \\
\text { coarse sand }\end{array}$ & $\mathrm{H} 2$ \\
\hline S01052-51 & 106.60 & 108.30 & 1.70 & Composite Grab & $\begin{array}{l}\text { Medium to } \\
\text { coarse sand }\end{array}$ & $\mathrm{H} 2$ \\
\hline S01052-52 & 108.30 & 109.70 & 1.40 & Composite Grab & $*$ & $*$ \\
\hline S01052-53 & 111.67 & 112.00 & 0.33 & Splitspoon Shoe & $*$ & $*$ \\
\hline S01052-54 & 112.00 & 114.00 & 2.00 & Composite Grab & Coarse sand & $\mathrm{H} 2$ \\
\hline S01052-55 & 114.00 & 115.80 & 1.80 & Composite Grab & $\begin{array}{l}\text { Medium to } \\
\text { coarse sand }\end{array}$ & $\mathrm{H} 2$ \\
\hline S01052-56 & 115.80 & 118.20 & 2.40 & Composite Grab & $\begin{array}{l}\text { Medium to } \\
\text { coarse sand }\end{array}$ & $\mathrm{H} 2$ \\
\hline S01052-58 & 120.70 & 122.30 & 1.60 & Composite Grab & $\begin{array}{l}\text { Medium to } \\
\text { coarse sand }\end{array}$ & $\mathrm{H} 2$ \\
\hline S01052-59 & 122.70 & 124.30 & 1.60 & Composite Grab & Medium sand & $\mathrm{H} 2$ \\
\hline S01052-60 & 122.70 & 124.30 & 1.60 & Composite Grab & Medium sand & $\mathrm{H} 2$ \\
\hline S01052-61 & 124.30 & 125.80 & 1.50 & Composite Grab & $\begin{array}{l}\text { Medium to } \\
\text { coarse sand }\end{array}$ & $\mathrm{H} 2$ \\
\hline S01052-62 & 125.80 & 127.70 & 1.90 & Composite Grab & $\begin{array}{l}\text { Medium to } \\
\text { coarse sand }\end{array}$ & $\mathrm{H} 2$ \\
\hline S01052-63 & 127.70 & 130.10 & 2.40 & Composite Grab & $\begin{array}{l}\text { Medium to } \\
\text { coarse sand } \\
\text { with silt lens }\end{array}$ & $\mathrm{H} 2$ \\
\hline S01052-64 & 132.10 & 132.40 & 0.30 & Splitspoon Shoe & $*$ & $*$ \\
\hline S01052-65 & 132.40 & 133.30 & 0.90 & Composite Grab & Coarse sand & $\mathrm{H} 2$ \\
\hline S01052-66 & 133.30 & 135.10 & 1.80 & Composite Grab & Coarse sand & $\mathrm{H} 2$ \\
\hline S01052-67 & 135.10 & 136.90 & 1.80 & Composite Grab & $\begin{array}{l}\text { Medium to } \\
\text { coarse sand }\end{array}$ & $\mathrm{H} 2$ \\
\hline S01052-68 & 136.90 & 138.30 & 1.40 & Composite Grab & Coarse sand & $\mathrm{H} 2$ \\
\hline S01052-69 & 140.30 & 140.60 & 0.30 & Splitspoon Shoe & & \\
\hline S01052-70 & 140.60 & 142.20 & 1.60 & Composite Grab & $\begin{array}{l}\text { Medium to } \\
\text { coarse sand }\end{array}$ & $\mathrm{H} 2$ \\
\hline S01052-71 & 142.20 & 144.50 & 2.30 & Composite Grab & $\begin{array}{l}\text { Medium to } \\
\text { coarse sand }\end{array}$ & $\mathrm{H} 2$ \\
\hline S01052-72 & 144.50 & 146.50 & 2.00 & Composite Grab & $\begin{array}{l}\text { Medium to } \\
\text { coarse sand }\end{array}$ & $\mathrm{H} 2$ \\
\hline
\end{tabular}


Table 2.3. Composite Grab and Split-Spoon Shoe Samples from 299-E33-46. (6 pages)

\begin{tabular}{|c|c|c|c|c|c|c|}
\hline $\begin{array}{c}\text { Sample } \\
\text { No. }\end{array}$ & $\begin{array}{l}\text { Top Depth } \\
\text { (ft) }^{(1)}\end{array}$ & $\begin{array}{c}\text { Bottom } \\
\text { Depth } \\
(\text { ft })^{(1)}\end{array}$ & $\begin{array}{c}\text { Sampled } \\
\text { Interval } \\
\text { Thickness } \\
\text { (ft) }^{(1)}\end{array}$ & Sample Type & $\begin{array}{c}\text { Sample } \\
\text { Description }\end{array}$ & $\begin{array}{c}\text { Stratigraphic } \\
\text { Unit }\end{array}$ \\
\hline S01052-73 & 146.50 & 148.40 & 1.90 & Composite Grab & $\begin{array}{l}\text { Medium to } \\
\text { coarse sand }\end{array}$ & $\mathrm{H} 2$ \\
\hline S01052-74 & 150.40 & 150.70 & 0.30 & Splitspoon Shoe & $*$ & $*$ \\
\hline S01052-75 & 150.70 & 152.20 & 1.50 & Composite Grab & $\begin{array}{l}\text { Medium to } \\
\text { coarse sand }\end{array}$ & $\mathrm{H} 2$ \\
\hline S01052-76 & 152.20 & 154.40 & 2.20 & Composite Grab & $\begin{array}{l}\text { Medium to } \\
\text { coarse sand }\end{array}$ & $\mathrm{H} 2$ \\
\hline S01052-77 & 154.40 & 156.60 & 2.20 & Composite Grab & $\begin{array}{l}\text { Medium to } \\
\text { coarse sand }\end{array}$ & $\mathrm{H} 2$ \\
\hline S01052-78 & 156.60 & 158.60 & 2.00 & Composite Grab & $\begin{array}{l}\text { Medium to } \\
\text { coarse sand }\end{array}$ & $\mathrm{H} 2$ \\
\hline S01052-79 & 160.40 & 160.70 & 0.30 & Composite Grab & $\begin{array}{l}\text { Medium to } \\
\text { coarse sand }\end{array}$ & $\mathrm{H} 2$ \\
\hline S01052-80 & 160.70 & 162.80 & 2.10 & Composite Grab & Medium sand & $\mathrm{H} 2$ \\
\hline S01052-81 & 160.70 & 162.80 & 2.10 & Composite Grab & Medium sand & $\mathrm{H} 2$ \\
\hline S01052-82 & 164.80 & 165.10 & 0.30 & Composite Grab & $\begin{array}{l}\text { Medium to } \\
\text { coarse sand }\end{array}$ & $\mathrm{H} 2$ \\
\hline S01052-83 & 167.10 & 167.40 & 0.30 & Composite Grab & $\begin{array}{l}\text { Medium to } \\
\text { coarse sand }\end{array}$ & $\mathrm{H} 2$ \\
\hline S01052-84 & 167.50 & 169.40 & 1.90 & Composite Grab & $*$ & $*$ \\
\hline S01052-85 & 168.10 & 168.40 & 0.30 & Composite Grab & $\begin{array}{l}\text { Fine sandy } \\
\text { silt }\end{array}$ & $\mathrm{H} 2$ \\
\hline S01052-86 & 171.40 & 171.70 & 0.30 & Composite Grab & Coarse sand & $\mathrm{H} 2$ \\
\hline S01052-87 & 171.70 & 174.10 & 2.40 & Composite Grab & $\begin{array}{l}\text { Medium to } \\
\text { coarse sand }\end{array}$ & $\mathrm{H} 2$ \\
\hline S01052-88 & 174.10 & 176.10 & 2.00 & Composite Grab & $\begin{array}{l}\text { Medium to } \\
\text { coarse sand }\end{array}$ & $\mathrm{H} 2$ \\
\hline S01052-89 & 176.10 & 178.10 & 2.00 & Composite Grab & Pebbly sand & $\mathrm{H} 3$ \\
\hline S01052-90 & 180.10 & 180.40 & 0.30 & Composite Grab & Pebbly sand & $\mathrm{H} 3$ \\
\hline S01052-91 & 180.40 & 183.10 & 2.70 & Composite Grab & $\begin{array}{c}\text { Fine to } \\
\text { medium sand } \\
\text { with silty fine } \\
\text { sand lens }\end{array}$ & $\mathrm{H} 3$ \\
\hline S01052-92 & 183.10 & 184.30 & 1.20 & Composite Grab & Pebbly sand & $\mathrm{H} 3$ \\
\hline S01052-93 & 184.30 & 185.90 & 1.60 & Composite Grab & Pebbly sand & $\mathrm{H} 3$ \\
\hline S01052-94 & 185.90 & 187.80 & 1.90 & Composite Grab & Medium sand & $\mathrm{H} 3$ \\
\hline
\end{tabular}


Table 2.3. Composite Grab and Split-Spoon Shoe Samples from 299-E33-46. (6 pages)

\begin{tabular}{|c|c|c|c|c|c|c|}
\hline $\begin{array}{c}\text { Sample } \\
\text { No. }\end{array}$ & $\begin{array}{l}\text { Top Depth } \\
\text { (ft) }^{(1)}\end{array}$ & $\begin{array}{c}\text { Bottom } \\
\text { Depth } \\
\text { (ft) }^{(1)}\end{array}$ & $\begin{array}{c}\text { Sampled } \\
\text { Interval } \\
\text { Thickness } \\
\text { (ft) }^{(1)}\end{array}$ & Sample Type & $\begin{array}{c}\text { Sample } \\
\text { Description }\end{array}$ & $\begin{array}{c}\text { Stratigraphic } \\
\text { Unit }\end{array}$ \\
\hline S01052-95 & 187.80 & 189.10 & 1.30 & Composite Grab & Medium sand & $\mathrm{H} 3$ \\
\hline S01052-97 & 191.40 & 193.50 & 2.10 & Composite Grab & $*$ & $*$ \\
\hline S01052-98 & 193.50 & 195.10 & 1.60 & Composite Grab & $*$ & $*$ \\
\hline S01052-99 & 195.10 & 197.50 & 2.40 & Composite Grab & $*$ & $*$ \\
\hline $\begin{array}{c}\text { S01052- } \\
100\end{array}$ & 197.50 & 199.20 & 1.70 & Composite Grab & $*$ & $*$ \\
\hline $\begin{array}{c}\text { S01052- } \\
102\end{array}$ & 201.50 & 203.30 & 1.80 & Composite Grab & $*$ & $*$ \\
\hline $\begin{array}{c}\text { S01052- } \\
103\end{array}$ & 203.30 & 205.80 & 2.50 & Composite Grab & $*$ & $*$ \\
\hline $\begin{array}{c}\text { S01052- } \\
104\end{array}$ & 201.50 & 203.30 & 1.80 & Composite Grab & $*$ & $*$ \\
\hline $\begin{array}{c}\text { S01052- } \\
105\end{array}$ & 210.20 & 210.70 & 0.50 & Composite Grab & $*$ & $*$ \\
\hline $\begin{array}{c}\text { S01052- } \\
106\end{array}$ & 210.70 & 213.70 & 3.00 & Composite Grab & $*$ & $*$ \\
\hline $\begin{array}{c}\text { S01052- } \\
107\end{array}$ & 213.70 & 215.70 & 2.00 & Composite Grab & $*$ & $*$ \\
\hline $\begin{array}{c}\text { S01052- } \\
108\end{array}$ & 215.70 & 217.70 & 2.00 & Composite Grab & Fine sand & $\mathrm{PPlz}$ \\
\hline $\begin{array}{c}\text { S01052- } \\
109\end{array}$ & 219.90 & 220.00 & 0.10 & Composite Grab & $\begin{array}{l}\text { Fine sand } \\
\text { over silt }\end{array}$ & $\mathrm{PPlz}$ \\
\hline $\begin{array}{c}\text { S01052- } \\
110\end{array}$ & 222.40 & 222.70 & 0.30 & Composite Grab & $\begin{array}{c}\text { Fine sandy } \\
\text { silt }\end{array}$ & $\mathrm{PPlz}$ \\
\hline $\begin{array}{c}\text { S01052- } \\
111\end{array}$ & 222.70 & 224.30 & 1.60 & Composite Grab & $\begin{array}{l}\text { Silty fine } \\
\text { sand }\end{array}$ & $\mathrm{PPlz}$ \\
\hline $\begin{array}{c}\text { S01052- } \\
112\end{array}$ & 222.70 & 224.30 & 1.60 & Composite Grab & $\begin{array}{l}\text { Silty fine } \\
\text { sand }\end{array}$ & $\mathrm{PPlz}$ \\
\hline $\begin{array}{c}\text { S01052- } \\
113\end{array}$ & 224.30 & 227.50 & 3.20 & Composite Grab & $*$ & $*$ \\
\hline $\begin{array}{c}\text { S01052- } \\
114\end{array}$ & 227.70 & 229.20 & 1.50 & Composite Grab & Sandy gravel & PPlg \\
\hline $\begin{array}{c}\text { S01052- } \\
116\end{array}$ & 231.70 & 233.70 & 2.00 & Composite Grab & $*$ & * \\
\hline $\begin{array}{c}\text { S01052- } \\
117\end{array}$ & 233.70 & 235.70 & 2.00 & Composite Grab & $*$ & $*$ \\
\hline
\end{tabular}


Table 2.3. Composite Grab and Split-Spoon Shoe Samples from 299-E33-46. (6 pages)

\begin{tabular}{|c|c|c|c|c|c|c|}
\hline $\begin{array}{c}\text { Sample } \\
\text { No. }\end{array}$ & $\begin{array}{c}\text { Top Depth } \\
\mathbf{( f t )}^{(\mathbf{1})}\end{array}$ & $\begin{array}{c}\text { Bottom } \\
\text { Depth } \\
\text { (ft) }^{(\mathbf{1})}\end{array}$ & $\begin{array}{c}\text { Sampled } \\
\text { Interval } \\
\text { Thickness } \\
\text { (ft) }^{(\mathbf{1})}\end{array}$ & Sample Type & $\begin{array}{c}\text { Sample } \\
\text { Description }\end{array}$ & $\begin{array}{c}\text { Stratigraphic } \\
\text { Unit }\end{array}$ \\
\hline $\begin{array}{c}\text { S01052- } \\
118\end{array}$ & 235.70 & 238.00 & 2.30 & Composite Grab & $*$ & $*$ \\
\hline $\begin{array}{c}\text { S01052- } \\
119\end{array}$ & 238.00 & 239.40 & 1.40 & Composite Grab & $*$ & $*$ \\
\hline $\begin{array}{c}\text { S01052- } \\
121\end{array}$ & 241.70 & 243.80 & 2.10 & Composite Grab & $*$ & $*$ \\
\hline $\begin{array}{c}\text { S01052- } \\
122\end{array}$ & 243.80 & 245.20 & 1.40 & Composite Grab & $*$ & $*$ \\
\hline $\begin{array}{c}\text { S01052- } \\
124\end{array}$ & 246.00 & 247.50 & 1.50 & Composite Grab & $*$ & $*$ \\
\hline $\begin{array}{c}\text { S01052- } \\
125\end{array}$ & 247.50 & 249.50 & 2.00 & Composite Grab & $*$ & $*$ \\
\hline $\begin{array}{c}\text { S01052- } \\
126\end{array}$ & 249.50 & 252.40 & 2.90 & Composite Grab & $*$ & $*$ \\
\hline $\begin{array}{c}\text { S01052- } \\
128\end{array}$ & 254.70 & 255.10 & 0.40 & Composite Grab & $*$ & $*$ \\
\hline $\begin{array}{c}\text { S01052- } \\
129\end{array}$ & 254.70 & 255.10 & 0.40 & Composite Grab & $*$ & $*$ \\
\hline
\end{tabular}

\footnotetext{
(1) to convert to meters multiply by 0.3048

H2 = Hanford H2 Sand Sequence (see Table 2.1)

H3 = Hanford H3 Lower Sand Sequence (see Table 2.1)

$\mathrm{PPlz}=$ Plio-Pleistocene slit (see Table 2.1)

PPlg $=$ Plio-Pleistocene gravel (see Table 2.1)

* Not examined
}

Each of the 33 split-spoon core runs were disassembled in the field and the set of four, half-foot sample liners recovered. The lower most sample liner was labeled "A" and the upper most liner labeled "D". Each liner was individually capped and packaged for transport to the PNNL's radioactive sample handling laboratory at the 3720 Building, located within the 300 Area. All split-spoon liners and composite grab samples were surrounded by blue ice to maintain sample temperature between 2 to $4^{\circ} \mathrm{C}$ during transport. The shipping containers were sealed with custody tape and maintained under chain-ofcustody protocols. Upon arriving at the 3720 Building, samples were placed into cold storage until such a time that liners could be opened and sub-sampled.

\subsection{Geophysical Logging}

Geophysical logging (total gamma, spectral gamma, and neutron moisture) in borehole 299-E33-46 was performed twice by Duratek Federal Services, Inc., once before downsizing to the smaller-diameter casing to a depth of $37.0 \mathrm{~m}$ (121.3 ft) bgs, and again upon reaching total depth (80.6 m [264.4 ft] bgs). Detailed descriptions of the logging tools and data analysis can be found in reports by Reynolds (2001) 
and Lindsey et al. (2001). Composites of the neutron-moisture and total gamma logs are illustrated in Figure 2.3.

The neutron-moisture log is generally used to depict the relative moisture content within a 20 to $30 \mathrm{~cm}$ ( 8 to $12 \mathrm{in}$ ) radius around the borehole. However, the neutron-moisture logging tool was not calibrated for the casing conditions, therefore absolute moisture values cannot be obtained directly from the neutron-moisture log.

Two different high-purity germanium (HPGe) spectral-gamma logging events were conducted to identify the specific gamma-emitting radionuclides in the formation surrounding the borehole (Reynolds 2001). A different logging event was conducted at the end of each drilling phase, through a single thickness of casing (with the exception of short overlaps between successive events) (Lindsey et. al. 2001).

A sharp prolonged increase in total gamma activity between 14 to $26 \mathrm{~m}$ (45 to $85 \mathrm{ft}$ ) bgs (Figure 2.3) is apparently associated with a zone of strontium-90 contamination in the subsurface (DOE-GJPO 1999b). The silt-dominated unit between 67 to $69.5 \mathrm{~m}$ (220 to $228 \mathrm{ft})$ bgs is also well defined on the total gamma $\log$, coincident with a high-moisture zone on the neutron-moisture log (Figure 2.3).

\subsection{Sample Handling}

Once received by the laboratory the sample liners and grab samples were stored in a refrigerator to maintain the sample temperatures between 2 and $4^{\circ} \mathrm{C}$. All the split-spoon sample liners were opened, sub-sampled, and geologically described. In addition, 54 out of a total of 120 composite grab samples listed in Table 2.3 were opened, sub-sampled, logged, and photographed.

Processing of the split-spoon cores (Table 2.2) was as follows. Each split-spoon sampler was taken to a fume hood, unpackaged and the lower two (i.e. deeper two designated A and B) of the four liners were opened. A small portion of the sample (approximately $1 \mathrm{~cm}$ ) was scraped away and a sandwich of three filter papers (for matric potential measurements) was inserted into the sample. The scraped materials were then placed back over the filter paper sandwich such that the filter paper sandwich was surrounded by, and in intimate contact with, the soil matrix. The end cap was replaced, sealed with tape, and the sample returned to the refrigerated storage.

About three weeks later, all split-spoon liners were sequentially taken to a fume hood for sample processing. Initially, the liner end caps were removed and an estimate of the approximate amount of sample material retained in the liner (\% recovery) was noted on the geologic log. Then all the material within a liner was placed in a plastic tray (one plastic tray per liner). Material within the plastic tray was then sub-sampled for physical and geochemical analysis, photographed, and described geologically.

Sediment within the sample liners was extracted using a hammer to tap on the stainless-steel liner to get the materials to fall out into the plastic sample tray. Efforts were made to keep the sample materials as intact as possible. However, the unconsolidated friable nature of these coarse-grained materials generally made it impossible to preserve the internal sedimentary structures in these materials. 


\subsection{Sub-sampling and Geologic Description}

Immediately, upon extracting material from the core liner or grab sample container, moisture samples were collected. An attempt was made to sample the finer grained and/or wetter materials as well as distinct hydrogeologic units, while at the same time trying to avoid slough and/or other unrepresentative portions. The remaining portions of the samples were then used for a brief visual geologic evaluation.

The visual geologic evaluation was conducted in accordance with procedures American Society for Testing and Materials (ASTM) D2488 (ASTM 1993) and PNL-DO-1 (PNL 1990). Throughout the subsampling and geologic evaluation activities, the laboratory geologist made continual visual observations regarding the mineralogy, structure, grain-size distribution (and sorting), grain-shape (e.g. roundness), color, moisture, consolidation, and reaction to dilute hydrochloric acid ( $\mathrm{HCl})$ (used to test for the presence of calcium carbonate). Copies of the geologist's logs are found in Appendix A. Particular attention was given to visually estimate the percentage (by weight) of gravel, sand, and mud (silt + clay), and to visually classify the samples based on the modified Folk (1968) and/or Wentworth (1922) classification scheme historically used at the Hanford Site. This sediment classification scheme uses a ternary diagram to categorize the sediment into one of 19 textural classes based on the relative proportions of gravel, sand, and mud (silt + clay) (Figure 2.4). Geologic logs recording the visual observations made while opening, sub-sampling and characterizing and these materials, are presented in Lindsey et al. (2001, Appendix B). Photographs were also taken of each of over 100 core liners after extrusion into their respective plastic trays. A few of these photographs appear in subsequent sections of this report and most of them are in Appendix B. A portion of the grab samples (Table 2.3) were also examined and photographed in the laboratory. These photographs, along with core photos are available online to PNNL staff at IIWd26776\AGGPublic \B-110 Final Report|E33-46 Photos.

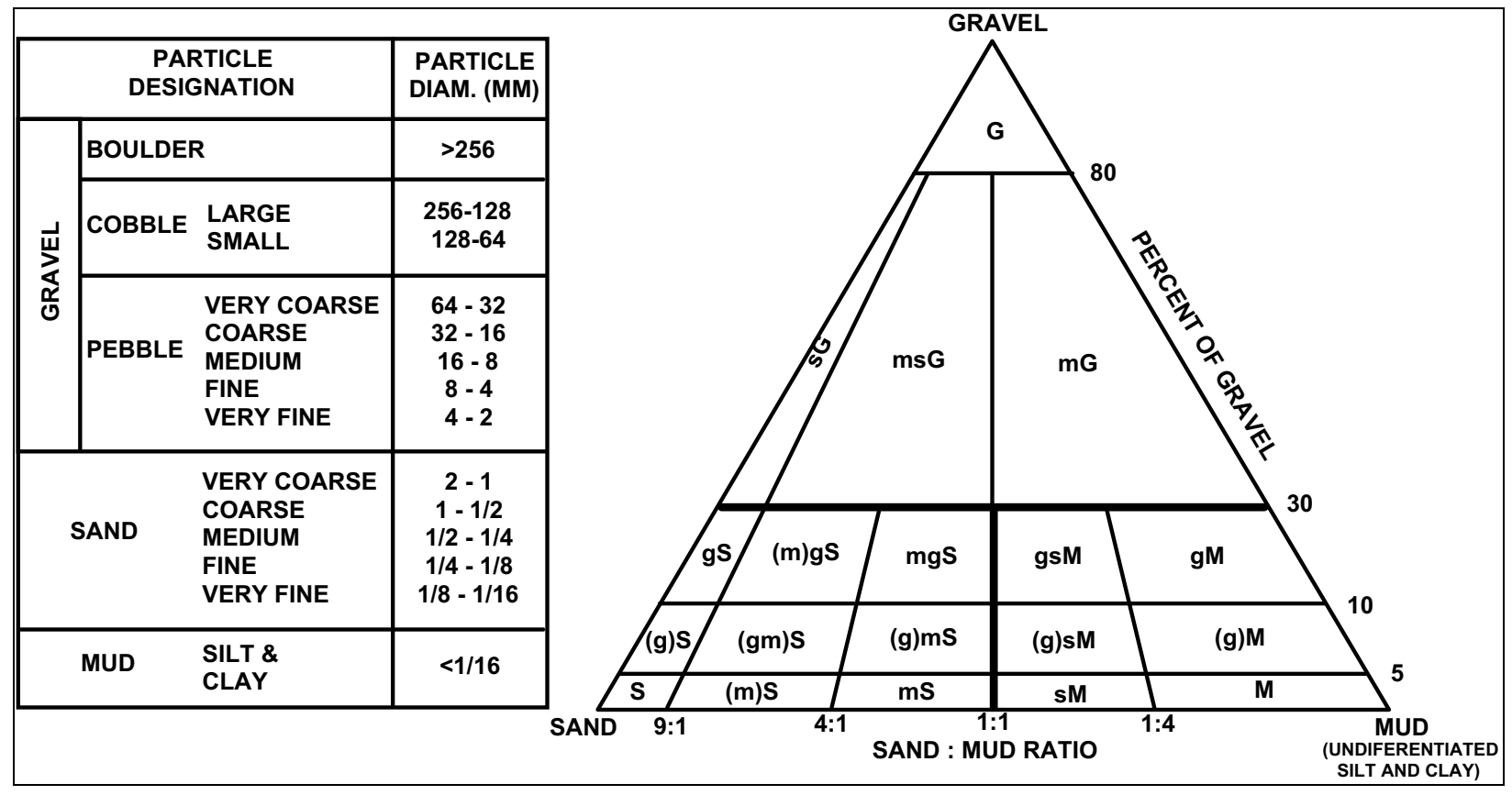

Figure 2.4. Sediment textural classification (modified after Folk 1968 and Wentworth 1922) 


\subsection{Geology of Borehole 299-E33-46}

Figure 2.3 presents a summary log of borehole 299-E33-46 based on the field geologists logs, geologic descriptions of the split-spoon and composite grab sample materials, laboratory analyses, and geophysical logs. Three primary stratigraphic units were encountered by this borehole: 1) backfill materials, 2) the Hanford formation, and 3) the Plio-Pleistocene unit. A brief description of the sampled materials from each of these major stratigraphic units is presented below.

\subsubsection{Backfill}

The backfill extends from the ground surface to a depth of $11.7 \mathrm{~m}(38.5 \mathrm{ft})$ where it lies in contact with the Hanford formation (Figure 2.3). Three split-spoon samples were collected from the backfill. The backfill material consists of predominantly dark to olive gray, moderately sorted, silty sandy gravel to gravelly sand, which is unconsolidated and weakly to strongly calcareous. An unusual pink coating was noted on cobbles recovered from about $6.4 \mathrm{~m}(21 \mathrm{ft}) \mathrm{bgs}$. The neutron-moisture log shows higher moisture just below the surface, probably associated with near-surface natural recharge. A greater penetration resistance (i.e., blowcounts) and poorer core recovery in the backfill are consistent with the relatively high percentage of gravel compared to the underlying sands of the Hanford formation.

\subsubsection{Hanford Formation}

Recent geologic reports (Wood et al. 2000, Lindsey et al. 2001), divide cataclysmic flood deposits of the Hanford formation beneath the 241-B Tank Farm into three informal units (H1, H2, and H3). However, it appears that the H1 unit was completely removed during excavation in the vicinity of borehole 299-E33-46, and then later used as backfill around the tanks. Based on the lithologies observed during drilling and in core samples, the Hanford formation beneath the backfill consists of mostly sand separated by several distinctly finer (fine sand to silt) strata. A total of three moisture spikes occur within the Hanford formation associated with these fine-grained intervals and/or other interfaces between strata with contrasting grain sizes (Figure 2.3).

The sands are associated with moderate to high energy deposition during flooding, while relatively thin fine sand to silt layers represent remnants of slack-water sedimentation deposited towards the end of ice-age flood episodes (Baker et al. 1991). According to Lindsey et al. (2001), the H2 unit, which consists of predominantly sand, occurs to a depth of $56.7 \mathrm{~m}(186 \mathrm{ft}) \mathrm{bgs}$ in 299-E33-46. However, the uppermost gravelly interval, used to define the boundary between $\mathrm{H} 2$ and $\mathrm{H} 3$, was observed $3 \mathrm{~m}(10 \mathrm{ft})$ higher in cores to a depth of $54 \mathrm{~m}(176 \mathrm{ft})$ bgs. Below this depth lies the $\mathrm{H} 3$ unit, a predominantly coarser-grained gravelly sand sequence that extends to base of the Hanford formation at $65.5 \mathrm{~m}$ $(215 \mathrm{ft})$ bgs.

A significant zone, approximately12 m (40 ft) thick, of radionuclide contamination (strontium-90) occurs at the top of the Hanford formation starting at the interface with the overlying coarse-grained backfill (Figure 2.3). The base of the strontium-90 contamination as defined by bremmstrahlung radiation in the spectral gamma log is well defined and occurs just above a $0.5 \mathrm{~m}(1.5 \mathrm{ft})$ thick very fine sand layer, which may have acted as a localized perched zone or capillary boundary. 


\subsubsection{Hanford Formation H2 Unit}

The Hanford formation $\mathrm{H} 2$ unit is present between 12 to $54 \mathrm{~m}(38.5$ to $176 \mathrm{ft})$ bgs. A total of $202-\mathrm{ft}$ split-spoon cores were collected from this unit, which consists of mostly olive gray, moderately to well sorted, fine- to coarse-grained sand beds. These beds show occasional weak horizontal laminations and are generally noncalcareous to weakly calcareous. Within this sequence also lies several feet of loose, gravelly sand around $26 \mathrm{~m}$ (86 ft) bgs. Dispersed within the Hanford formation $\mathrm{H} 2$ unit are four separate,

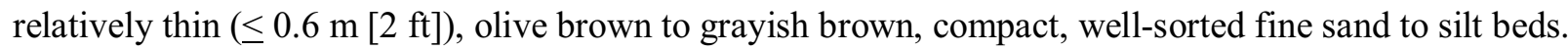
These occur at depths of about 21.2, 30.0, 37.5, and $51.2 \mathrm{~m}(69.7,98.5,123.0$, and $168.0 \mathrm{ft}) \mathrm{bgs}$ (Figure 2.3).

The most common sediment type within the $\mathrm{H} 2$ unit, a medium-to coarse grained sand, is represented in Figure 2.5. The term "salt and pepper" is often used to describe sands of the H2 unit on geologic logs due to the roughly equal amounts of dark- (basaltic) and light-colored (quartz and feldspar) grains. While this unit appears to be unconsolidated the penetration resistance (i.e., blow counts) increases slightly for the middle portion between 40 to $47 \mathrm{~m}$ (130 to $155 \mathrm{ft}$ ) bgs (Figure 2.3), which might reflect a greater degree of compaction within this interval. Core recovery was consistently $100 \%$ within the $\mathrm{H} 2$ unit.

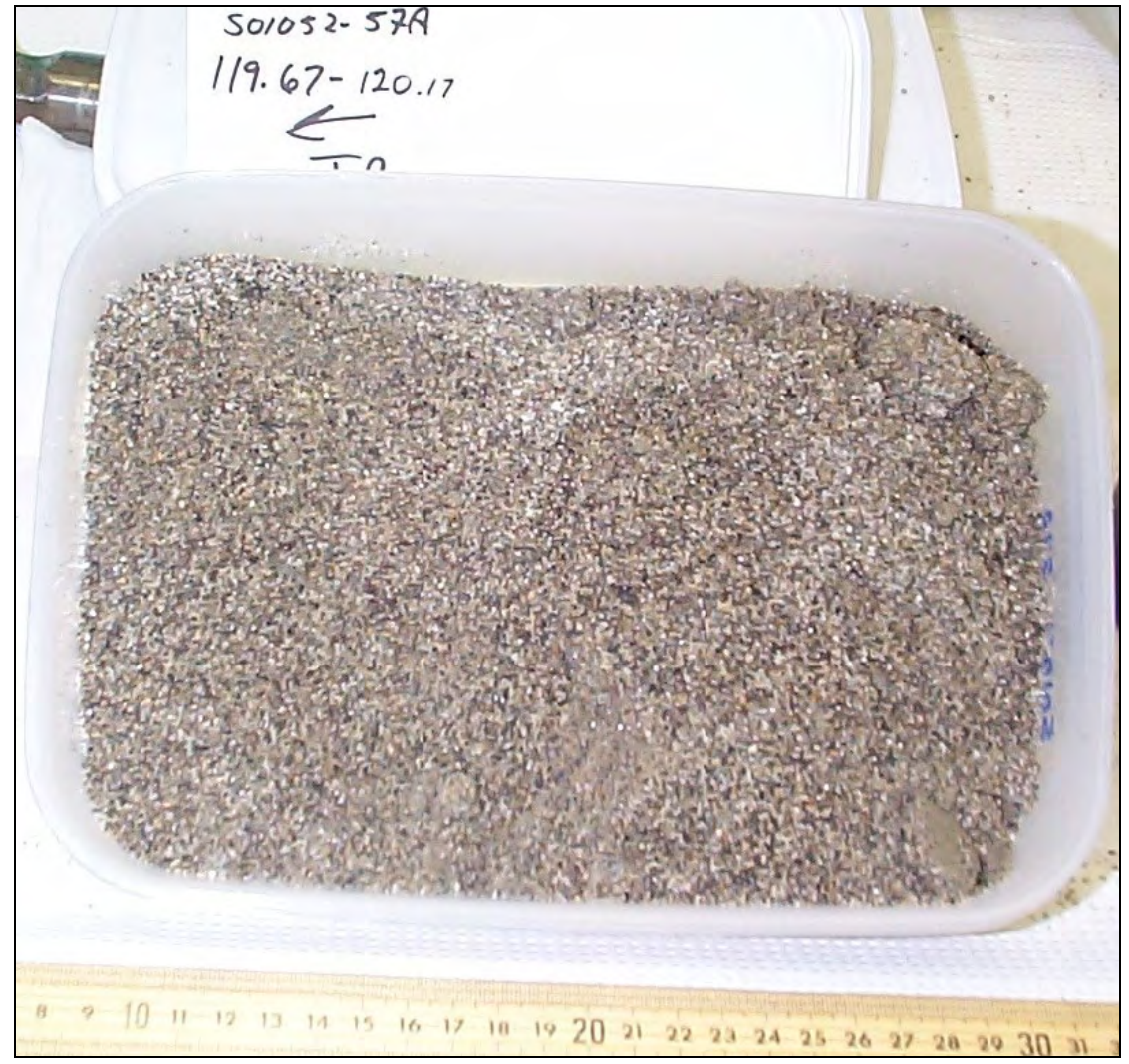

Figure 2.5. Medium to coarse sand recovered from the Hanford Formation H2 Unit in Borehole 299-E33-46. 


\subsubsection{Hanford Formation H3 Unit}

The top of the Hanford formation H3 unit is defined by a transition from predominantly sand to slightly gravelly sand at $53.6 \mathrm{~m}(176 \mathrm{ft}$ ) bgs (Figure 2.3). The Hanford formation $\mathrm{H} 3$ unit is about $11.9 \mathrm{~m}$ $(39 \mathrm{ft})$ thick, the base of which is defined by the top of the Plio-Pleistocene unit silty facies (PPlz) at $65.5 \mathrm{~m}(215 \mathrm{ft})$ bgs. A total of four, two-foot split-spoon cores were collected from the Hanford formation $\mathrm{H} 3$ unit. Like the $\mathrm{H} 2$ unit, core recovery within the $\mathrm{H} 3$ unit was consistently $100 \%$. This matrix-supported, gravelly sand sequence consists predominantly of gray to olive gray, "salt and pepper", unconsolidated, moderately to well sorted, medium- to coarse-grained sand with pebbles up to $3 \mathrm{~cm}$ in intermediate diameter (Figure 2.6). The unit is unconsolidated and non-calcareous to weakly calcareous. The H3 unit in 299-E33-46 grades downward into medium to coarse sand with depth, identical to sands described for the overlying $\mathrm{H} 2$ unit (see section 2.6.2). Paleomagnetic results from a nearby borehole (299-E33-335) suggest ice-age flood deposits at roughly the same stratigraphic position as the H3 unit were deposited during the early Pleistocene Epoch, during very old flood events that occurred at least 780,000 years ago and perhaps as early as 2 million years ago (Bjornstad et al. 2001).

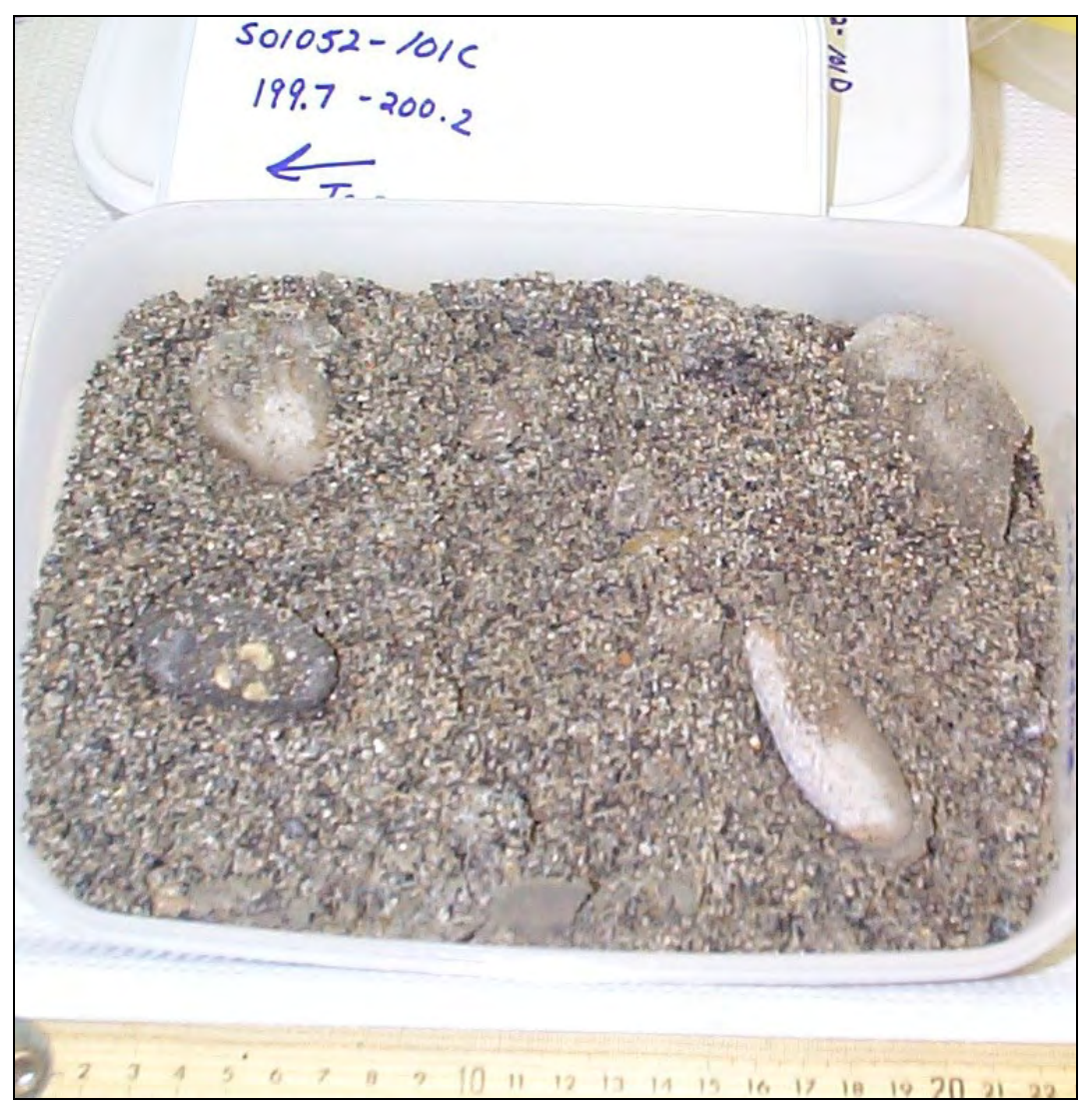

Figure 2.6. Gravelly sand recovered from the Hanford formation H3 Unit in borehole 299-E33-46.

\subsubsection{Plio-Pleistocene Unit}

The exact origin of the sedimentary deposits underlying the Hanford formation H3 unit is uncertain and still open to interpretation (Table 2.1). Recent reports have designated deposits beneath the Hanford formation $\mathrm{H3}$ unit as the Hf/Ppu(?) (Wood et al. 2000) and Hanford/Plio-Pleistocene/Ringold(?) unit (Lindsey et al. 2001). Wood et al. (2000) recognized two facies of the Hf/PPu(?) beneath the 241-B, BX, 
and BY Tank Farms; a fine-grained eolian/overbank silt (silt facies), up to $10 \mathrm{~m}$ (33 ft) thick, and a sandy gravel to gravelly sand facies. The thick silt-rich interval is believed to be a pre-ice-age flood deposit, since silty layers associated with ice-age flood deposits of the Hanford formation in this area are generally much thinner (few centimeters or less) (Wood et al. 2000). The texture, structure, and color of the thick silt layer are all identical to that of the early "Palouse" soil (Tallman et. al., 1979; DOE 1988), more recently referred to as the PPlz or upper Plio-Pleistocene unit, which is widely distributed beneath the 200 West Area (Wood et al. 2000, Serne et al. 2002a).

Where the PPlz unit is absent beneath the B-BX-BY Tank Farms, the gravel sequence below the silt unit is indistinguishable from similar-appearing facies of the Hanford formation H3 unit, which overlies the PPlz unit (Wood et al. 2000). In fact, prior to the discovery of the thick silt layer, reported in Wood et al. (2000), gravels overlying basalt bedrock were always included in with the Hanford formation (Tallman et al. 1979; Last et al. 1989; Connelly et al. 1992; Lindsey et al. 1992). If the thick silt layer predates the Hanford formation, however, then the underlying gravels must also predate the Hanford formation. Thus, the gravel sequence beneath the silt layer must belong to either a mainstream alluvial facies of the Plio-Pleistocene unit or the Ringold Formation.

Lindsey et al. (2001) assigned the gravel sequence underlying the PPlz unit to the Ringold Formation based on:

- Iron oxide stains on clasts

- Brown, gray and olive colors

- Abundance of basalt clasts, but with numerous other lithologies

- Sand matrix ranging from basalt to quartz rich

- Reports of "hard" drilling on some borehole logs

However, none of the characteristics above are diagnostic of the Ringold Formation, exclusively, and in certain cases could be used to describe other stratigraphic units, including the Plio-Pleistocene alluvium and flood gravels. Lindsey et al. (2001) argued against a Plio-Pleistocene age for this gravel sequence, since Plio-Pleistocene-age gravels (informally named pre-Missoula gravels by PSPL [1982]) have previously been reported as "bleached" on the Hanford Site (Lindsey et al. 1994). However, unbleached alluvial gravels of Plio-Pleistocene age are reported for the 200 East Area (Williams et al. 2000) as well as south of the Hanford Site at Yakima Bluffs (Lindsey et al. 1994). Furthermore, gravelly deposits recovered from beneath the PPlz unit in 299-E33-46 did not display all the characteristics listed above. For example, iron oxide stains on clasts were not observed on either of the geologic logs prepared for borehole 299-E33-46 and the mafic content in these sandy gravels appears unlike that for the mostly quartzo-feldspathic Ringold Formation. Furthermore, this interval, described as "hard" to drill on the field-geologist's log, not because it consists of cemented Ringold Formation, but because drillers were trying to recover intact split-spoon cores, which is a very difficult thing to do in any clast-supported gravel unit. Finally, past studies (Tallman et al.1979; Last et al. 1989; Lindsey et al. 1992; Connelly et al. 1992; Williams et al. 2001) have all shown the limit of the Ringold Formation as being much farther south than the B-BX-BY Tank Farms within the 200 East Area. 
In summary, we believe insufficient evidence exists at this time to establish the presence of the Ringold Formation beneath B-BX-BY Tank Farms. Instead, we favor an interpretation that the gravel sequence beneath the PPlz unit belongs to a mainstream alluvial facies of the Plio-Pleistocene unit as previously defined by Wood et al. (2000). Thus, we designate this gravel-dominated facies as PPlg in this report (Table 2.1).

\subsubsection{Silt-Dominated Facies (PPlz)}

A fine-grained PPlz unit, $3.9 \mathrm{~m}(12.7 \mathrm{ft})$ thick, underlies the basalt-rich sands of the Hanford formation in borehole 299-E33-46 between $65.5 \mathrm{~m}(215 \mathrm{ft})$ and $69.4 \mathrm{~m}(227.7 \mathrm{ft})$ bgs. This unit can be subdivided into two facies types in borehole 299-E33-46. The upper part of the PPlz unit consists of a pale olive, loose, laminated, very well sorted, calcareous, fine- to medium-grained, quartzo-feldspathic sand (Figure 2.7). The lower part of the PPlz unit consists of a grayish brown, laminated to massive, compacted and very well sorted, moderately calcareous, silt to silty fine sand. One split-spoon core was collected from each of these facies types. The upper facies type, which begins at $65.5 \mathrm{~m}(215 \mathrm{ft})$ bgs was not recognized by the geologist in the field or by Lindsey et al. (2001), who picked the base of the Hanford formation $1.5 \mathrm{~m}(5 \mathrm{ft})$ deeper at $67 \mathrm{~m}(220 \mathrm{ft})$ at a sharp increase in the total gamma log. However, a distinct lithologic contrast exists between Hanford formation sands (above) and PlioPleistocene unit silt (below) in grab sample \#108 (215.7 to $217.7 \mathrm{ft}$ depth, Table 2.3) and the split-spoon core from the 217.7 to $220 \mathrm{ft}$ depth. The characteristics of the sediment from this unit, including its relatively high calcium carbonate content, uniform texture, and predominantly quartzo-feldspathic mineralogy, suggest it is lithologically different from the Hanford formation. Thus, this subunit is interpreted as a slightly coarser-grained overbank and/or eolian facies of the Plio-Pleistocene unit.

Relatively high neutron moisture and gamma activity on geophysical logs (Figure 2.3), in addition to several core and grab samples corroborate that the lower part of the PPlz unit in this borehole is finegrained (mostly silt). The contact between the silt and overlying fine sand exists within the 219.7 to $220.0 \mathrm{ft}$ grab sample (\#109, Table 2.3). The lower portion of the Plio-Pleistocene unit has characteristics similar to the PPlz unit which overlies an extensive Plio-Pleistocene calcic paleosol sequence (PPlc unit) beneath 200 West Area (Lindsey et al. 2000; Serne et al. 2002a). 


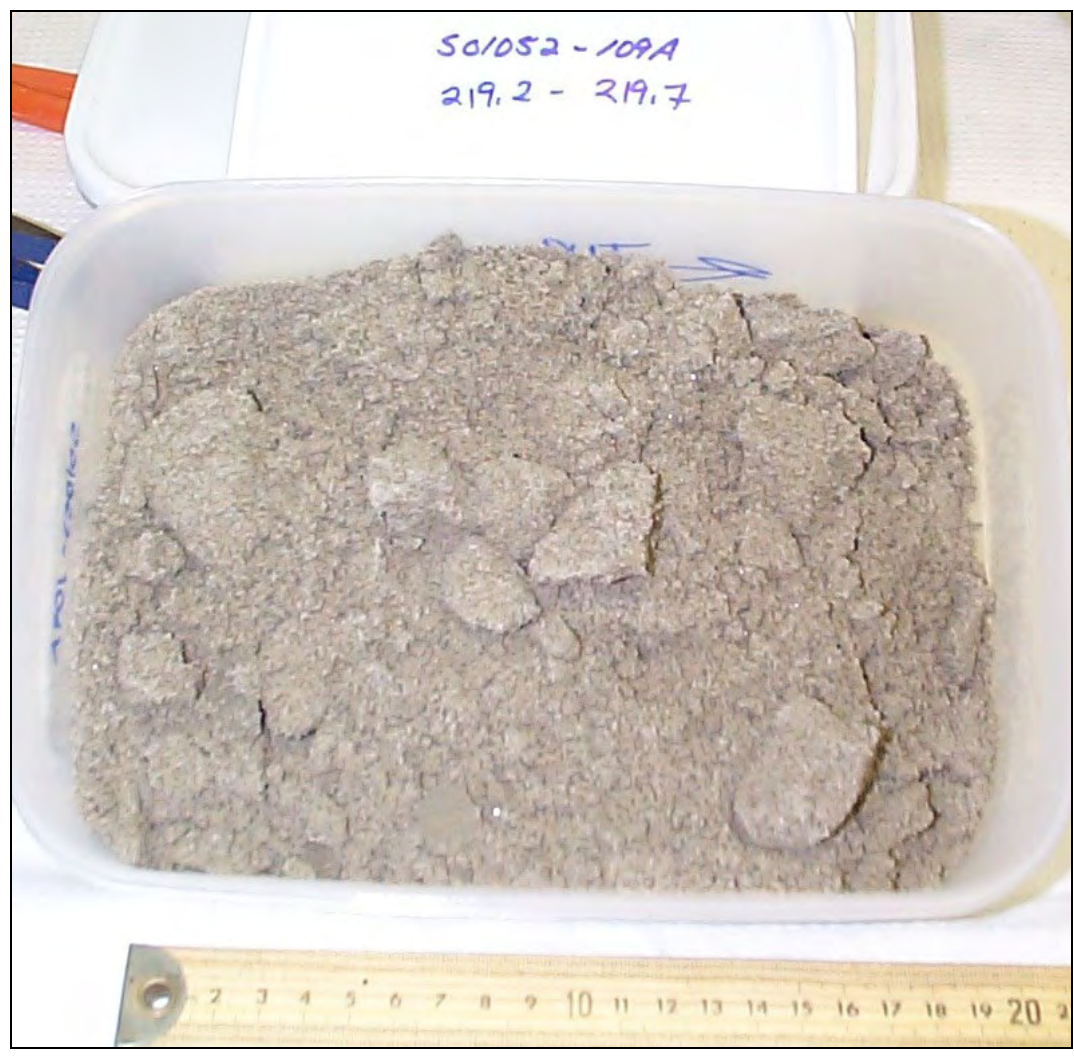

Figure 2.7. Calcareous, quartzo-feldspathic fine sand recovered from the upper portion of the PPlz unit in borehole 299-E33-46.

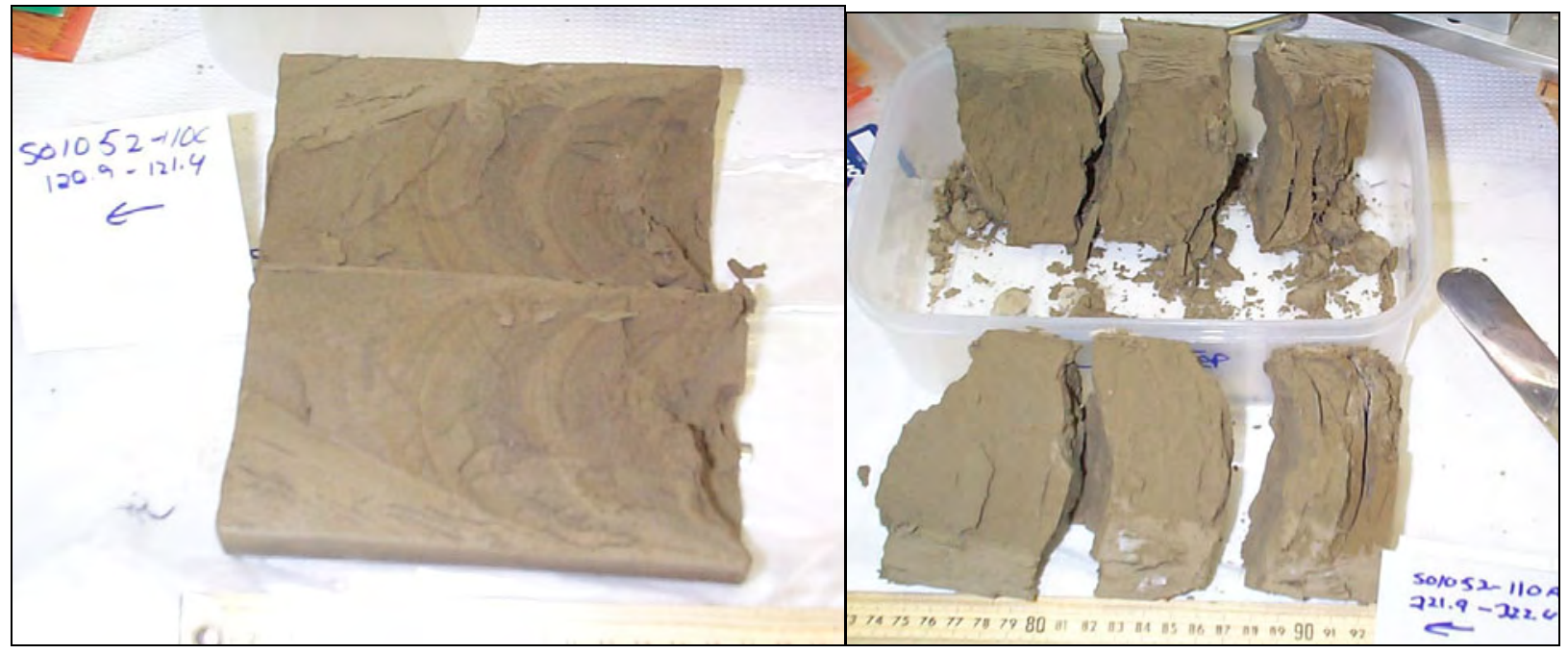

Figure 2.8. Well-laminated silt to silty fine sand recovered from the lower portion of the PPlz unit in borehole 299-E33-46. 


\subsubsection{Sandy Gravel to Gravelly Sand Dominated Facies (PPIg)}

A sequence of sandy gravel to gravelly sand was encountered starting at a depth of $69.4 \mathrm{~m}$ $(227.7 \mathrm{ft})$ bgs. Four split-spoon cores were collected within this unit. It consists of mostly olive gray, loose, clast-supported, moderately to poorly sorted mixtures of gravel and sand (Figure 2.9). This unit contains a moderate amount (approximately30-50\%) of basalt and is noncalcareous. Poor core recovery (Figure 2.3) and considerable pulverization of the sample resulted from trying to drive a narrow-diameter (4 inch ID) split spoon through the clast-supported pebbles and cobbles. Surfaces of individual gravel clasts are relatively unweathered and lack surface staining.

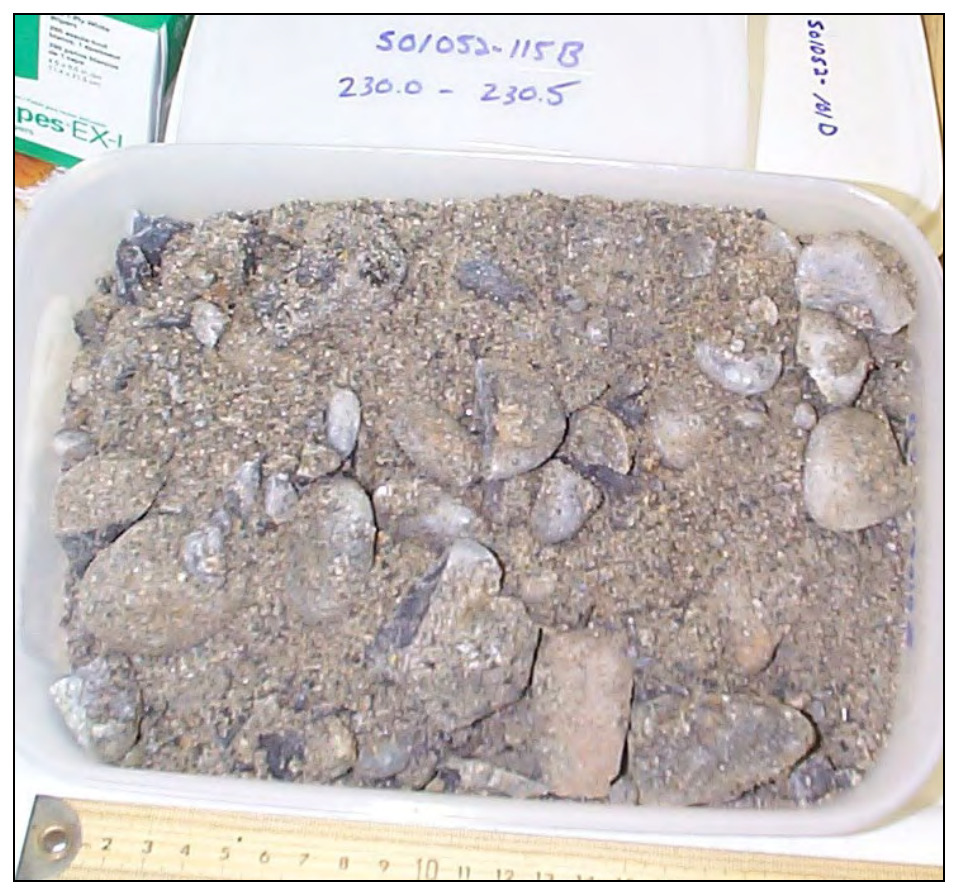

Figure 2.9.. Sandy gravel recovered from the PPlg subunit in borehole 299-E33-46 .

\subsection{Discussion on Increased-Moisture Zones}

Absolute moisture values (in wt\%) are available for a number of core and composite-grab samples analyzed in the laboratory; these data appear in Figure 2.3. There is general agreement between the neutron moisture log and moisture measured in the laboratory. In other words, spikes on the neutron moisture log coincide with zones of increased moisture measured in the laboratory. Increased moisture appears to be associated with the capillary boundary between sudden, large contrasts in grain size. Commonly, a lower-permeability fine-grained silty layer may be present along the boundary, but is not required for a high-moisture zone to develop. High-moisture zones may also develop along sharp lithologic boundaries where no silt is present.

Several notable increases in moisture content within the vadose zone occur in 299-E33-46. Only fine-grained beds about $\geq 0.3 \mathrm{ft}$ thick show up as elevated-moisture zones on the neutron-moisture log and laboratory analysis (Table 2.4). Starting from the surface, a zone of increased moisture appears to 
conform with a $0.5 \mathrm{~m}(1.5 \mathrm{ft})$ thick layer of fine sand sandwiched between layers of coarse sand at 25.6 to $26.1 \mathrm{~m}(84.0-85.5 \mathrm{ft})$ bgs (Table 2.4). A similar spike in neutron-moisture logs occurs in several nearby vadose zone boreholes (20-10-02, 20-07-11, and 20-08-07).

Another high-moisture zone is associated with a thin $9.1 \mathrm{~cm}(3.6 \mathrm{inch})$ silt layer at 51.2 to $51.3 \mathrm{~m}$ (168.1 to $168.4 \mathrm{ft}$ ) bgs; a core sample obtained from this zone yielded almost $20 \mathrm{wt} \%$ water in the laboratory. A zone of increased moisture occurs at about the same depth in two nearby coreholes (299-E33-45 and -338). A third increase in moisture lies near a sand-gravelly sand interface, perhaps associated with some fine and organic(?)-rich layers (between 56.4 to $57.9 \mathrm{~m}$ [185 to $190 \mathrm{ft}$ ] bgs). A final sharp increase in neutron moisture occurs at a depth between 67.1 to $69.5 \mathrm{~m}(220-228 \mathrm{ft})$ bgs associated with the silt-dominated facies (PPLz) of the Plio-Pleistocene unit.

A few other fine grained beds are present (i.e., 21.2, 30.0 and $39.3 \mathrm{~m}[69.7,98.5$, and $129 \mathrm{ft}]$ depths), however these do not show up as increased-moisture zones on either the neutron-moisture log or in the laboratory analyses, probably because they are thin $(0.5$ to $1.0 \mathrm{~cm}[0.2$ to $0.4 \mathrm{inch}])$. A critical thickness of at least $9 \mathrm{~cm}$ (3.5 inch) appears to be required for an elevated-moisture zone to appear on the neutron-moisture log for this borehole. These thin fine-grained beds also probably escaped sub-sampling for moisture in the laboratory, as suggested by Table 2.4 . 


\begin{tabular}{|c|c|c|c|c|c|c|c|c|}
\hline 总 总 & $\begin{array}{l}2 \\
\infty\end{array}$ & $\begin{array}{l}\stackrel{2}{2} \\
\frac{\hat{\sigma}}{b} \\
\frac{0}{0}\end{array}$ & $\begin{array}{l}0 \\
i \\
i\end{array}$ & $\begin{array}{l}\stackrel{q}{+} \\
\text { ir }\end{array}$ & $\overrightarrow{\tilde{i}}$ & $\tilde{m}$ & 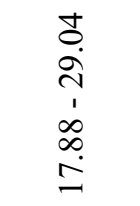 & \\
\hline 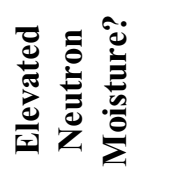 & $\stackrel{\circ}{z}$ & $\stackrel{\infty}{\nu}$ & $\stackrel{\circ}{z}$ & z & $\stackrel{\infty}{\infty}$ & a. & $\stackrel{\infty}{\infty}$ & \\
\hline 章 & $\stackrel{\mathscr{\Xi}}{\Omega}$ & is & $\stackrel{\mathscr{\Omega}}{\Xi}$ & $\sum_{i}$ & $\sum_{i=1}$ & 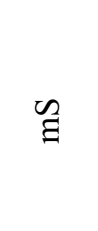 & $\underset{\Xi}{\sum_{\infty}^{n}}$ & \\
\hline 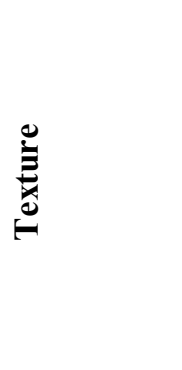 & 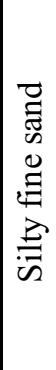 & 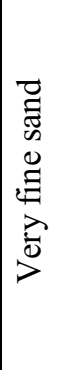 & 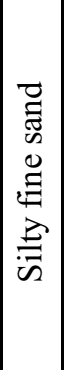 & 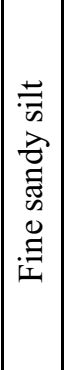 & 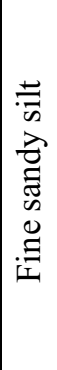 & 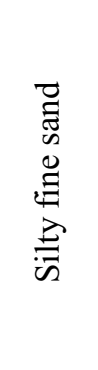 & 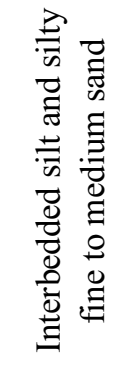 & \\
\hline 莺 & نั & हैं & $\begin{array}{ll}0 \\
0 \\
0\end{array}$ & 芴 & 芴 & हैं艹 & 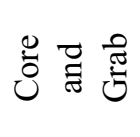 & \\
\hline 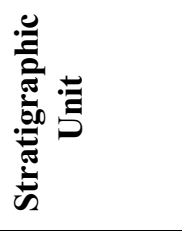 & Iี & $\underline{I}$ & 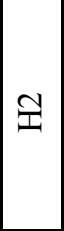 & $\because \exists$ & I & 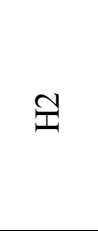 & $\frac{N}{a}$ & \\
\hline 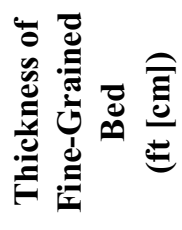 & $\begin{array}{l}n \\
\tilde{e} \\
0 \\
0 \\
\vdots \\
0 \\
0\end{array}$ & 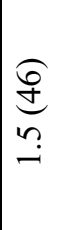 & 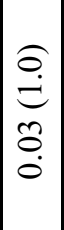 & 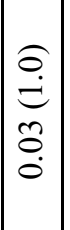 & $\underset{\mathfrak{a}}{\mathfrak{a}}$ & $\begin{array}{ll}0 & \\
i & 0 \\
0 & 0 \\
0 & 0 \\
0 & 0\end{array}$ & $\begin{array}{l}\underset{d}{d} \\
\stackrel{a}{r}\end{array}$ & 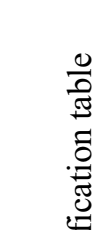 \\
\hline 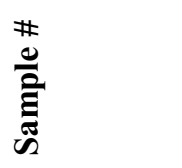 & $\frac{U}{m}$ & $\begin{array}{l}\text { ㅇ } \\
\text { à } \\
\text { mे }\end{array}$ & $\stackrel{\circlearrowright}{\stackrel{\vartheta}{+}}$ & $\theta$ & $\mathscr{\infty}$ & $\bar{a}$ & $\begin{array}{l}0 \\
= \\
g \\
g\end{array}$ & 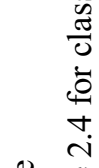 \\
\hline$\frac{1}{\overline{0}}$ & $\hat{g}$ & $\begin{array}{l}n \\
n \\
\infty \\
0 \\
\dot{j} \\
\infty\end{array}$ & $\begin{array}{l}n \\
\infty \\
\infty\end{array}$ & $\stackrel{\circ}{\stackrel{0}{\beth}}$ & $\begin{array}{l}+ \\
\dot{0} \\
0 \\
\stackrel{1}{1} \\
\dot{\infty} \\
0 \\
0\end{array}$ & $\frac{\infty}{2}$ & 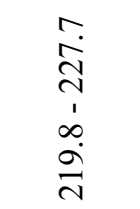 & 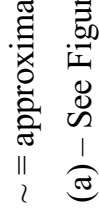 \\
\hline
\end{tabular}




\subsection{Historic Groundwater Levels}

Wood et al. (2000) reported that the discharge of large volumes of waste water in the early 1950s, raised the water table in the vicinity of the B Tank Farm to over $4.9 \mathrm{~m}(16 \mathrm{ft})$ above pre-Hanford conditions. They indicated that the groundwater reached a maximum elevation of approximate $124 \mathrm{~m}$ (407 ft) mean sea level in the 1967 to 1968 time frame, with a secondary maximum, just below this in the 1986 to 1989 time frame. Water levels have declined approximately 2.1 to $2.4 \mathrm{~m}$ ( 7 to $8 \mathrm{ft}$ ) since 1989 at a rate of approximately $20 \mathrm{~cm} / \mathrm{yr}(0.7 \mathrm{ft} / \mathrm{yr})$.

Given a surface elevation about $200 \mathrm{~m}(657.3 \mathrm{ft})$ mean sea level, the maximum water table is estimated to have reached a depth of about $76.2 \mathrm{~m}(250 \mathrm{ft}) \mathrm{bgs}$. The geologists logs made during the drilling of 299-E33-46 indicate that the groundwater table was encountered at a depth of $77.9 \mathrm{~m}$ $(255.8 \mathrm{ft})$ bgs. This suggests that the groundwater level has dropped almost $2 \mathrm{~m}(6 \mathrm{ft})$ in the vicinity of borehole 299-E33-46 since the late 1980s. 


\subsection{Geochemical Method and Materials}

This chapter discusses the methods and philosophy used to determine which samples would be characterized and parameters that would be measured.

\subsection{Sample Inventory}

Samples were identified using a project-specific prefix, in this case S01052 followed by a specific sample identification suffix such as -01 , for each split spoon. As noted in Section 2.0, the cores contained four sleeves identified by the letters A, B, C, and D, where the A sleeve was always in the position closest to the drive shoe (deepest in the formation at the time of sampling).

\subsection{Tiered Approach}

During the investigations at SX WMA, significant changes in sediment type and contaminant concentrations were noted within a distance of a few inches within a given sleeve. It was concluded that a more methodical scoping approach would be necessary to provide the technical justification for selecting samples for detailed characterization as defined in the data quality objectives process. Subsequently, a tiered method was developed that considered depth, geology (e.g., lithology, grain-size composition, carbonate content, etc.), individual sleeve contaminant concentration (e.g., radionuclides, nitrate, etc.), moisture content, and overall sample quality. Inexpensive analyses and certain key parameters (i.e., moisture content, gamma energy analysis) were performed on sediment from each sleeve.

The objective of the tier 1 characterization was to quantify the extent of penetration of mobile contaminants into the vadose zone sediment. We analyzed only the sediment from the A sleeve for most constituents except moisture and gamma energy. At borehole 299-E33-46 we did not notice measurable or significant drag-down effects for contaminants perhaps because the sediment was not highly contaminated with nuclides such as cesium-137 that are highly associated with fine-grained particles. Because drag down is dominated by highly contaminated sediment particles, the contaminants in this borehole had less chance of concentrating on particles.

Immediately following the geologic examination, the sleeve contents were sub-sampled for moisture content, gamma-emission radiocounting (for these samples, effectively natural potassium-40, uranium-238, and natural thorium-232 were found; although the strontium-90 bremmstrahlung emissions were evident over the depth interval ( 14 to $26 \mathrm{~m}$ [45 to $85 \mathrm{ft}$ ] bgs), one-to-one water extracts (which provide soil $\mathrm{pH}$, electrical conductivity, cation, and anion data), total carbon and inorganic carbon content, and $8 \mathrm{M}$ nitric acid extracts (which provide a measure of the total leachable sediment content of contaminants). The remaining sediment from each sleeve was then sealed and placed in cold storage. Later, additional aliquots of selected sleeves or grab samples were removed to measure particle size distribution and mineralogy and to squeeze porewater.

\subsection{Materials and Methods}

During sub-sampling of the selected core liner and grab samples, every effort was made to minimize moisture loss and prevent cross contamination between samples. Depending on the sample matrix, very 
coarse pebble and larger material (>32 mm [1.26 inch]) was avoided during sub-sampling. Larger substrate was excluded to provide moisture contents representative of counting and 1:1 sediment-to-water extract samples. Results from sub-sample measurements should then take into consideration a possible bias toward higher concentrations for some analytes that would be considered associated with smaller sized sediment fractions. The sediment in the Plio-Pleistocene mud facies contained no large pebbles or cobbles.

Procedures ASTM D2488-93 (ASTM1993) and PNL-MA-567-DO-1 (PNL 1990a) were followed for visual descriptions and geologic description of all split-spoon and grab samples. The sediment classification scheme used for geologic identification of the sediment types is based on the modified Folk/Wentworth classification scheme described earlier (see Figure 2.4). However, the mineralogic and geochemical characterization relied on further separation of the mud into discrete silt and clay sizes.

At 299-E33-46 borehole, one groundwater sample was taken during the drilling process. This water sample along with the cores and grab samples and ultracentrifuged porewaters (from the sediments) constitute the scope of our characterization activity.

\subsubsection{Moisture Content}

Gravimetric water contents of the sediment samples from each sleeve and selected grab samples were determined using PNNL procedure PNL-MA-567-DO-1 (PNL 1990). This procedure is based on the ASTM procedure Test Method for Laboratory Determination of Water (Moisture) Content of Soil and Rock (ASTM D2216-98; ASTM 1998). One representative sub-sample of at least 15 to 70 grams was taken from each sleeve and selected grab samples. Sediment samples were placed in tared containers, weighed, and dried in an oven at $105^{\circ} \mathrm{C}$ until constant weight was achieved, which took at least 24 hours. The containers then were removed from the oven, sealed, cooled, and weighed. At least two weighings, after 24-hour heatings, were performed to ensure that all moisture was removed. All weighings were performed using a calibrated balance. A calibrated weight set was used to verify balance performance before weighing samples. The gravimetric water content was computed as percentage change in soil weight before and after oven drying.

\subsubsection{1:1 Sediment-to-Water Extract}

The water-soluble inorganic constituents were determined using a 1:1 sediment-to-deionized-water extract method. This method was chosen because most of the sediment was too dry to easily extract vadose zone porewater. The extracts were prepared by adding an exact weight of deionized water to approximately 60 to 80 grams of sediment sub-sampled from each sleeve and selected grab samples. The weight of deionized water needed was calculated based on the weight of the field-moist samples and their previously determined moisture contents. The sum of the existing moisture (porewater) and the deionized water was fixed at the mass of the dry sediment. The appropriate amount of deionized water was added to screw cap jars containing the sediment samples. The jars were sealed and briefly shaken by hand, then

placed on a mechanical orbital shaker for 1 hour. The samples were allowed to settle until the supernatant liquid was fairly clear. The supernatant was carefully decanted and separated into unfiltered aliquots for conductivity and $\mathrm{pH}$ determinations, and filtered aliquots (passed through $0.45 \mu \mathrm{m}$ membranes) for anion, 
cation, carbon, and radionuclide analyses. More details can be found in Rhoades (1996) within Methods of Soils Analysis Part 3 (ASA 1996).

\subsubsection{1 pH and Conductivity}

Two approximately 3-mm aliquots of the unfiltered 1:1 sediment-to-water extract supernatant were used for $\mathrm{pH}$ and conductivity measurements. The $\mathrm{pHs}$ for the extracts were measured with a solid-state $\mathrm{pH}$ electrode and a $\mathrm{pH}$ meter calibrated with buffers 4, 7, and 10. Conductivity was measured and compared to potassium chloride standards with a range of $0.001 \mathrm{M}$ to $1.0 \mathrm{M}$.

\subsubsection{Anions}

The 1:1 sediment-to-water extracts were analyzed for anions using an ion chromatograph. Fluoride, acetate, formate, chloride, nitrite, bromide, nitrate, carbonate, phosphate, sulfate, and oxalate were separated on a Dionex ${ }^{\circledR}$ AS17 column with a gradient elution of $1 \mathrm{mM}$ to $35 \mathrm{mM}$ sodium hydroxide and measured using a conductivity detector. This methodology is based on U.S. Environmental Protection Agency (EPA) Method 300.0A (EPA 1984) with the exception of using the gradient elution of sodium hydroxide.

\subsubsection{Cations and Trace Metals}

Major cation analysis was performed using an inductively coupled plasma (ICP) unit using highpurity calibration standards to generate calibration curves and verify continuing calibration during the analysis run. Dilutions of 100x, 50x, 10x, and 5x were made of each sample for analysis to investigate and correct for matrix interferences. Details are found in EPA Method 6010B (EPA 2000b). The second instrument used to analyze trace metals, including technetium-99 and uranium-238, was an inductively coupled plasma mass spectrometer (ICP-MS) using the PNNL-AGG-415 method (PNNL 1998). This method is quite similar to EPA Method 6020 (EPA 2000c).

\subsubsection{Alkalinity and Carbon}

The alkalinity and inorganic/organic carbon content of several of the 1:1 sediment-to-water extracts were measured using standard titration with acid and a carbon analyzer respectively. The alkalinity procedure is equivalent to the U.S. Geological Survey Method Field Manual (USGS 2001) http://water.usgs.gov/owq. Inorganic and organic carbon in the water extracts were determined using a carbon analyzer and ASTM Method D4129-88 (1988) "Standard Test Method for Total and Organic Carbon in Water by High Temperature Oxidation and by Coulometric Detection."

\subsubsection{NTA}

Analysis for NitriloTriacetic Acid (NTA) was performed using a 1 to $35 \mathrm{mM}$ Gradient elution on a Dionex AS17 column for 20 minutes. The 1:1 extracts were spiked with 16 ppm NTA. The peak areas of the spiked extracts were then compared to the 1:1 extracts with no NTA added and the peak areas of a known 16 ppm NTA standard.

\footnotetext{
${ }^{\circledR}$ Dionex is a registered trademark of Dionex Corporation, Sunnyvale, California.
} 


\subsubsection{Porewater, Suction Candle, and Groundwater Composition}

Eleven samples (2B, 6B, 20B, 21A, 36A, 38A, 84, 105C, 110B, 110A, and 113) were packed in drainable cells that were inserted into an ultracentrifuge. The samples were centrifuged for up to 8 hours at several thousand gravitational forces (g's) to squeeze the porewater out of the sediment. Further, sampling of suction candles that were emplaced in the borehole at strategic depths as the borehole was decommissioned was performed periodically for all the suction candles on the following dates: February 12, 2002, May 17, 2002, July 2, 2002, July 30, 2002, and September 24, 2002. Chemical composition results are compared with both the ultracentrifuged porewaters and the calculated porewaters from the 1:1 sediment to water extracts. The one groundwater sample was also characterized. All these solutions were for $\mathrm{pH}$, electrical conductivity, cation, trace metals, and anions using the same techniques as used for the 1:1 sediment-to-water extracts.

\subsubsection{Radioanalytical Analysis}

\subsubsection{Gamma Energy Analysis}

Gamma energy analysis (GEA) was performed on sediment from all core " $\mathrm{A}$ " and selected " $\mathrm{B}, \mathrm{C}$, and D" sleeves and some of the grab samples. All samples for gamma energy analysis were analyzed using 60\%-efficient intrinsic germanium gamma detectors. All germanium counters were efficiency calibrated for distinct geometries using mixed gamma standards traceable to the National Institute of Standards and Technology. In the first GEA counting campaign field moist samples were placed in 150$\mathrm{cm}^{3}$ counting containers and analyzed for 100 minutes in a fixed geometry. All spectra were background subtracted. Spectral analysis was conducted using libraries containing most mixed fission products, activation products, and natural decay products. Control samples were run throughout the analysis to ensure correct operation of the detectors. The controls contained isotopes with photo peaks spanning the full detector range and were monitored for peak position, counting rate, and full-width half-maximum. Details are found in Gamma Energy Analysis, Operation, and Instrument Verification using Genie2000 Support Software (PNNL 1997).

\subsubsection{Tritium Content in 1:1 Sediment to Water Extracts, Perched, and Groundwater}

The tritium content of selected sediment samples was determined directly on the water extracts by liquid scintillation using PNNL-AGG-002 (PNNL 2000).

\subsubsection{Carbon Content of Sediment}

The carbon content of borehole sediment samples was determined using ASTM Method D4129-88, (ASTM 1988). Total carbon in all samples was determined using an UIC Coulometrics Inc. Model 5051 Carbon Dioxide Coulometer ${ }^{\mathrm{TM}}$ with combustion at approximately $980^{\circ} \mathrm{C}$. Ultrapure oxygen was used to sweep the combustion products through a barium chromate catalyst tube for conversion to carbon dioxide. Evolved carbon dioxide was quantified through coulometric titration following absorption in a solution containing ethanolamine. Equipment output reported carbon content values in micrograms per sample. Soil samples for determining total carbon content were placed into pre-combusted, tared platinum

\footnotetext{
${ }^{\text {тм }}$ Model 5051 Carbon Dioxide Coulometer is a trademark of UIC Coulometrics, Inc., Joliet, Illinois.
} 
combustion boats and weighed on a four-place analytical balance. After the combustion boats were placed into the furnace introduction tube, a 1-minute waiting period was allowed so that the ultrapure oxygen carrier gas could remove any carbon dioxide introduced to the system from the atmosphere during sample placement. After this system sparge, the sample was moved into the combustion furnace and titration begun. Sample titration readings were performed at 3 minutes after combustion began and again once stability was reached, usually within the next 2 minutes. The system background was determined by performing the entire process using an empty, pre-combusted platinum boat. Adequate system performance was confirmed by analyzing for known quantities of a calcium carbonate standard.

Inorganic carbon contents for borehole sediment samples were determined using a UIC Coulometrics, Inc. Model 5051 Carbon Dioxide Coulometer ${ }^{\mathrm{TM}}$. Soil samples were weighed on a fourplace analytical balance, then placed into acid-treated glass tubes. Following placement of sample tubes into the system, a 1-minute waiting period allowed the ultrapure oxygen carrier gas to remove any carbon dioxide introduced to the system from the atmosphere. Inorganic carbon was released through acidassisted evolution ( $50 \%$ hydrochloric acid) with heating to $200^{\circ} \mathrm{C}$. Samples were completely covered by the acid to allow full reaction to occur. Ultrapure oxygen gas swept the resultant carbon dioxide through the equipment to determine inorganic carbon content by coulometric titration. Sample titration readings were performed 5 minutes following acid addition and again once stability was reached, usually within 10 minutes. Known quantities of calcium carbonate standards were analyzed to verify that the equipment was operating properly. Background values were determined. Inorganic carbon content was determined through calculations performed using the microgram-per-sample output data and sample weights. Organic carbon was calculated by subtracting inorganic carbon from total carbon and using the remainder.

\subsubsection{M Nitric Acid Extract}

Approximately 20 grams of oven-dried sediment was contacted with $8 \mathrm{M}$ nitric acid at a ratio of approximately 5 parts acid to 1 part sediment. The slurries were heated to approximately $80^{\circ} \mathrm{C}$ for several hours and then the fluid was separated by centrifugation and filtration through $0.2 \mu \mathrm{m}$ membranes. The acid extracts were analyzed for major cations and trace metals using ICP and ICP-MS techniques, respectively. The acid digestion procedure is based on EPA SW-846 Method 3050B (EPA 2000a) that can be accessed on-line at http://www.epa.gov/epaoswer/hazwaste/test/sw846.htm.

\subsubsection{Elemental Analysis}

The elemental composition of the bulk sediment and clay fractions was determined by a combination of energy and wavelength dispersive $x$-ray fluorescence using methods developed at PNNL. Samples analyzed by energy dispersive $\mathrm{x}$-ray fluorescence method utilizing a KEVEX ${ }^{\odot} 0810 \mathrm{~A}$ commercial x-ray fluorescence excitation and detection subsystem. Sample preparation involved mixing the sample in a Coors high-density alumina $\left(\mathrm{Al}_{2} \mathrm{O}_{3}\right)$ mortar and pestle. Six hundred milligrams of the mixed sample were removed and further ground to approximately 300 mesh size, placed between two sheets of stretched para-film, and loaded into the $0810 \mathrm{~A} x$-ray fluorescence unit. Acquisition times ranged between 600 and

\footnotetext{
${ }^{\odot}$ KEVEX is a copyright trademark of Thermo Kevex X-Ray, Scotts Valley, California.
} 
3,000 seconds, depending on the targets (iron, gadolinium, silver, zirconium). Forty-one elements (aluminum, antimony, arsenic, barium, bromine, cadmium, calcium, cerium, cesium, chlorine, chromium, copper, gallium, indium, iodine, iron, lanthanum, lead, manganese, molybdenum, nickel, niobium, palladium, phosphorous, potassium, rhodium, rubidium, ruthenium, selenium, silicon, silver, strontium, sulfur, tellurium, thorium, tin, titanium, uranium, vanadium, yttrium, and zinc) were analyzed on each sample and the spectrum interpretation was by the backscatter fundamental parameter approach. Sample analysis by the wavelength method was accomplished using a Siemens Spectra 3000 instrument, equipped with both a flow counter detector to detect soft radiation of the low $\mathrm{Z}$ elements and a scintillation counter detector for the harder radiation of the higher $Z$ elements. Bulk solid samples were prepared by taking 180 to 1,500 milligrams of approximately 300 mesh ground sample and pressing it into a 3.2-cm diameter pellet, using a 27,000-kilogram laboratory press. Standard addition and similar matrix methods were used to generate calibration curves for sodium and magnesium, which were then used to process the data. Additional discussion of $\mathrm{x}$-ray fluorescence techniques for quantitative analysis of sediment are found in Chapter 7 "Elemental Analysis by X-Ray Fluorescence Spectroscopy" of ASA (1996), part 3, pages 161 to 223 and in the Siemens Spectra $3000^{\mathrm{TM}}$ Reference Manual.

\subsubsection{Particle Size Distribution}

The wet sieving/hydrometer method was used to determine the particle size distribution. The technique is described in (ASA [1986a], part 1; method 15-5 Hydrometer Method [pages 404 to 408]) and concentrated on quantifying the silt and clay distribution. The silt and clay separates were saved for mineralogical analyses. Samples from the borehole that were used for the hydrometer method were never air or oven dried to minimize the effects of particle aggregation that can affect the separation of clay grains from the coarser material.

\subsubsection{Particle Density}

The particle density of bulk grains was determined using pychnometers (see ASA 1986b, part 1; method 14-3 Pychnometer Method [pages 378 to 379]) and oven-dried material. The particle density is needed to determine the particle size when using the hydrometer method.

\subsubsection{Mineralogy}

The mineralogy of the whole rock and clay size fractions of the selected sediment samples was determined by x-ray diffraction (XRD) techniques. Each bulk sample was prepared for XRD analysis by placing two grams of sample into a tungsten carbide ball mill grinder for 10 minutes. The resultant powders were side packed into aluminum sample holders prior to being analyzed. Preparation of the clay fraction for XRD analysis began by dispersing the whole rock sediment using the following technique. Approximately $100 \mathrm{~g}$ of sediment was transferred into a $1.0 \mathrm{~L}$ bottle and mixed with $1.0 \mathrm{~L}$ of $0.001 \mathrm{M}$ solution of sodium hexametaphosphate. The suspensions were allowed to shake over night to ensure complete dispersion. The sand and silt fractions were separated from the clay fractions by repetitively using Stoke's settling law described in Jackson (1969). The lower limit of the silt fraction was taken at approximately 2 microns. The dispersed slurry was allowed to settle for approximately 24 hours and the

\footnotetext{
${ }^{\text {тм }}$ Spectra 3000 is a trademark of Siemens AG, Erlangen, Germany.
} 
unsettled slurry decanted. The settled solids were then re-suspended in approximately 1 liter of the sodium hexametaphosphate solution and the settling repeated several more times. All batches of settled solution containing the suspended clays for each sample depth were composited. Once the supernatant solution appeared to be clear, the clay separation was complete.

Each composited clay suspension was concentrated to an approximate volume of $30 \mathrm{mls}$ by adding a few drops of $10 \mathrm{~N}$ magnesium chloride to the dispersing solution. Concentrations of clay in the concentrated suspensions were determined by drying known volumes of the suspension and weighing the dried sediment. The density of the slurry was calculated from the volume pipetted and the final weight of dried sediment. Volumes of slurry equaling $250 \mathrm{mg}$ of clay were transferred into centrifuge tubes and saturated with either $\mathrm{Mg}^{2+}$ or $\mathrm{K}^{+}$cations. Clay samples were prepared using the Drever (1973) method and placed onto an aluminum slide for XRD analysis. Due to the tendency of the clay film to peel and curl, the $\mathrm{Mg}^{2+}$ saturated specimens were immediately solvated with a few drops of a $10 \%$ solution of ethylene glycol in ethanol and placed into a dessiccator containing excess ethylene glycol for a minimum of 24 hours. Potassium saturated slides were air dried and analyzed, then heated to $550^{\circ} \mathrm{C}$ for one hour and reanalyzed.

All bulk and clay-sized samples were analyzed on a Scintag XRD unit equipped with a Pelter thermoelectrically cooled detector and a copper x-ray tube. Randomly oriented whole sediment samples were scanned from 2 to $65^{\circ} 2 \theta$ with a dwell time of 14 seconds. Slides of preferentially oriented clay were scanned from 2 to $45^{\circ} 2 \theta$ with a dwell time of 2 seconds. Scans were collected electronically and processed using the $\mathrm{JADE}^{\circledR \circledast} \mathrm{XRD}$ pattern processing software. Some patterns were corrected for minor angular deviation using the quartz reflection. Identification of the mineral phases was based on mineral powder diffraction files published by the JCPDS International Centre for Diffraction Data ${ }^{1}$.

Semi quantification of mineral phases in the whole rock sediment samples were determined by the whole pattern fitting technique provided by $\mathrm{JADE}^{\circledR} \mathrm{XRD}$ pattern processing software. The software allows the whole pattern fitting of the observed data and Reitveld refinement of crystal structures. A diffraction model is fit by non-linear least-square optimization in which certain parameters are varied to improve the fit between the two patterns. Success of the refinement process is measured by a ratio of the weighted and calculated errors. This value, referred to as "goodness of fit", is expected to be close to one in an ideal refinement.

Clay mineral abundances in the less than 2 micron fraction were calculated using the method outlined by Brindley and Brown (1980), which relies on external standards. The relationship of intensity and mass absorption to the weight fraction of an unknown phase is expressed as:

$$
\mathrm{I} / \mathrm{I}_{\mathrm{p}}=\mu_{\mathrm{p}} / \mu(\mathrm{wf})
$$

\footnotetext{
${ }^{\circledR} \mathrm{JADE}$ is a registered trademark of Rigaku Corporation, Tokyo, Japan.

${ }^{1}$ JCPDS International Centre for Diffraction Data, Newton Square, Pennsylvania.
} 
Where:

I is the intensity of the unknown phase,

$I_{p}$ is the intensity of the pure phase,

$\mu_{\mathrm{p}}$ is the mass absorption of the pure phase,

$\mu$ is the average mass absorption of the unknown mixture, and

wf is the weight fraction of the unknown.

Pure mineral phases of illite, smectite, kaolinite, and chlorite were obtained from the Clay Mineral Society's source clays repository, (operated from the University of Missouri in Columbia, MO), and analyzed under the same conditions as the sediment samples. Quartz, feldspars, and calcite standards were purchased from the Excalibur Mineral Company (Peekskill, New York), ground and analyzed on the diffractometer to obtain intensities for pure non-clay phases. Based on previous data collected from Hanford sediments, an average mass absorption of $55 \mathrm{~cm}^{2} \mathrm{~g}^{-1}$ was assumed for the clay samples. Mass absorption values for standard reference minerals were calculated from published chemical data.

Furthermore, the copper x-ray tube used on the Scintag diffractometer generated a minor amount of tungsten $\mathrm{K} \alpha$ radiation, which produced peaks in the XRD. These extra peaks were identified and did not compromise the quality of the XRD data.

\subsubsection{Water Potential (Suction) Measurements}

Suction measurements were made on the two lower core liners in each split-spoon sampler from the borehole using the filter paper method PNL-MA-567-SFA-2 (PNL 1990b). This method relies on the use of a sandwich of three filter papers that rapidly equilibrates with the sediment sample. The middle filter paper does not contact sediment that might stick to the paper and bias the mass measurements. At equilibrium, the matric suction in the filter paper is the same as the matric suction of the sediment sample. The dry filter paper sandwiches were placed in the airtight liners while still filled with the sediment for three weeks to allow sufficient time for the matric suction in the sediment to equilibrate with the matric suction in the filter paper. The mass of the wetted middle filter paper that has had no direct contact with the sediment is subsequently determined, and the suction of the sediment is determined from a calibration relationship between filter paper water content and matric suction.

The relationships used for converting the water content of filter paper to matric suction for Whatman \#42 filter paper have been determined by Deka et al. (1995) and can be expressed as:

$$
\begin{aligned}
& \mathrm{Sm}=10^{(5.144-6.699 \mathrm{w})} / 10 \text { for } \mathrm{w}<0.5 \\
& \mathrm{Sm}=10^{(2.383-1.309 \mathrm{w})} / 10 \text { for } \mathrm{w}>0.5
\end{aligned}
$$

where: $\mathrm{Sm}=$ the matric suction $(\mathrm{m})$ and

$\mathrm{W}=$ the gravimetric water content $(\mathrm{g} / \mathrm{g})$ 
Two hundred forty-five core liner and grab samples from borehole 299-E33-46 were analyzed for water content and 60 of the core liners were analyzed for soil matric suction. The matric potential samples covered the entire borehole profile from 11.8 to $253.4 \mathrm{ft} \mathrm{bgs} \mathrm{(3.6} \mathrm{to} 77.3 \mathrm{~m}$ ). 


\subsection{Results and Discussion}

This section presents the geochemical and physical characterization data collected on sediment from borehole 299-E33-46. The tier 1 phase emphasized tests that were inexpensive or that were key to determining the vertical distribution of contaminants. Information on the borehole sediment presented in sections 4.1 and 4.2 includes moisture content, $\mathrm{pH}$ and electrical conductivity of 1:1 sediment to water extracts, and measurements of major cations, anions, trace metals, and radionuclides in 1:1 sediment water extracts. A gamma energy analysis on the sediments was performed to look for gamma emitting isotopes and to define the extent of the strontium- 90 bremsmstrahlung penetration. In addition tritium, strontium-90, technetium-99, and uranium-238 concentrations in the sediment are discussed in Section 4.3. The particle size, mineralogy, and tritium content of selected sediment samples were measured in tier 2 phase to aid in selecting contacts between major geologic units and to attempt to better define the vertical extent of the tank B-110 loss event. We also were looking for geochemical and mineralogic changes caused by interaction with the caustic fluids leaking from piping infrastructure associated with tank B-110. Selected sediment samples were also placed in the UFA to squeeze out vadose zone porewater to check the accuracy of using the 1:1 sediment to water extracts to calculate porewater compositions. Finally, the results of sampling suction candles that were emplaced in the borehole at strategic depths as the borehole was decommissioned are compared with both the squeezed porewaters and the calculated porewaters from the 1:1 sediment to water extracts.

\subsection{Moisture Content}

The moisture content of the sediment from the sleeves and grab samples is listed in Table 4.1 and graphed in Figure 2.3. Figure 2.3 shows both the field volumetric moisture obtained via neutron logging and the gravimetric moisture content of small aliquots of sediment taken during the geologic description activities. The moisture content profiles correlate with the lithology described in Section 2.5 and shown in Figure 2.3. The first region with elevated moisture is the $0.5 \mathrm{~m}(1.5 \mathrm{ft})$ thick mud lens at $22.86 \mathrm{~m}$ ( 84 to $85.5 \mathrm{ft}$ ) bgs within the Hanford $\mathrm{H} 2$ sand unit. Near the bottom of the Hanford $\mathrm{H} 2$ unit at $51.21 \mathrm{~m}$ $(168 \mathrm{ft}) \mathrm{bgs}$ is a moist approximate $9.1 \mathrm{~cm}$ (3.6 inch) thick lens of fine-grained material with moisture contents of $20.2 \%$ by weight. Within the Hanford $\mathrm{H} 3$ unit there is a slightly moist lens at $56.39 \mathrm{~m}$ (185 ft) bgs with a moisture content of $12.3 \mathrm{wt}$ \% compared to values of 3 to $4 \mathrm{wt} \%$ nearby. The PPlz lithology between 67.06 and $68.88 \mathrm{~m}(220$ and $226 \mathrm{ft}) \mathrm{bgs}$ is the wettest material in the borehole with moisture contents ranging from 15 to $29 \mathrm{wt} \%$. The gravels below this PPlz silt are relatively dry down to the water table that currently is found at $77.97 \mathrm{~m}(255.8 \mathrm{ft}) \mathrm{bgs}$.

The laboratory-generated data show gravimetric moisture content (wt $\%)$ and the field data are related to volumetric water content (vol\%). If the field tool had been calibrated and the vadose zone bulk density profiles were known, one could convert the field data to gravimetric data by dividing by the bulk density. For our needs, we merely compare the two logs qualitatively to see if the moisture peaks correspond depthwise. 
Table 4.1. Moisture Content of Sediment from Borehole 299-E33-46. (4 pages)

\begin{tabular}{|c|c|c|c|c|c|c|c|}
\hline $\begin{array}{c}\text { Lithologic } \\
\text { Unit }\end{array}$ & $\begin{array}{c}\text { Sample } \\
\text { No. }\end{array}$ & $\begin{array}{c}\text { Mid Depth } \\
{\text { (Vertical ft })^{(1)}}^{\text {(Ver }}\end{array}$ & $\begin{array}{c}\% \\
\text { Moisture }\end{array}$ & $\begin{array}{c}\text { Lithologic } \\
\text { Unit }\end{array}$ & $\begin{array}{c}\text { Sample } \\
\text { No. }\end{array}$ & $\begin{array}{c}\text { Mid Depth } \\
{\text { (Vertical ft })^{(1)}}^{\text {(Vertict }}\end{array}$ & $\begin{array}{c}\% \\
\text { Moisture }\end{array}$ \\
\hline Bckfl & $02 \mathrm{C}$ & 12.94 & $3.89 \%$ & $\mathrm{H} 2$ & 64B & 131.35 & $3.27 \%$ \\
\hline Bckfl & 02B & 12.94 & $4.48 \%$ & $\mathrm{H} 2$ & $64 \mathrm{~A}$ & 131.85 & $3.11 \%$ \\
\hline Bckfl & $02 \mathrm{~A}$ & 12.94 & $3.60 \%$ & $\mathrm{H} 2$ & 65 & 132.85 & $3.36 \%$ \\
\hline Bckfl & 06D & 19.62 & $3.71 \%$ & $\mathrm{H} 2$ & 66 & 134.2 & $3.66 \%$ \\
\hline Bckfl & $06 \mathrm{C}$ & 20.12 & $4.66 \%$ & $\mathrm{H} 2$ & 67 & 136 & $4.56 \%$ \\
\hline Bckfl & 06B & 20.62 & $4.78 \%$ & $\mathrm{H} 2$ & 68 & 137.6 & $4.29 \%$ \\
\hline Bckfl & $06 \mathrm{~A}$ & 21.12 & $4.84 \%$ & $\mathrm{H} 2$ & $69 \mathrm{D}$ & 138.55 & $3.87 \%$ \\
\hline Bckfl & $10 \mathrm{C}$ & 28.42 & $5.94 \%$ & $\mathrm{H} 2$ & $69 \mathrm{C}$ & 139.05 & $4.32 \%$ \\
\hline Bckfl & $10 \mathrm{~B}$ & 28.92 & $4.94 \%$ & $\mathrm{H} 2$ & $69 \mathrm{~B}$ & 139.55 & $4.35 \%$ \\
\hline Bckfl & $10 \mathrm{~A}$ & 29.42 & $3.30 \%$ & $\mathrm{H} 2$ & $69 \mathrm{~A}$ & 140.05 & $2.52 \%$ \\
\hline $\mathrm{H} 2$ & $16 \mathrm{D}$ & 39.97 & $4.31 \%$ & $\mathrm{H} 2$ & 70 & 141.4 & $3.20 \%$ \\
\hline $\mathrm{H} 2$ & $16 \mathrm{C}$ & 40.72 & $4.15 \%$ & $\mathrm{H} 2$ & 71 & 143.35 & $3.44 \%$ \\
\hline $\mathrm{H} 2$ & $16 \mathrm{~B}$ & 41.22 & $5.10 \%$ & $\mathrm{H} 2$ & 72 & 145.5 & $3.91 \%$ \\
\hline $\mathrm{H} 2$ & $16 \mathrm{~A}$ & 41.72 & $3.97 \%$ & $\mathrm{H} 2$ & 73 & 147.45 & $4.66 \%$ \\
\hline $\mathrm{H} 2$ & 17D & 42.52 & $4.31 \%$ & $\mathrm{H} 2$ & $74 \mathrm{D}$ & 148.65 & $4.16 \%$ \\
\hline $\mathrm{H} 2$ & $17 \mathrm{C}$ & 43.02 & $4.55 \%$ & $\mathrm{H} 2$ & $74 \mathrm{C}$ & 149.15 & $3.83 \%$ \\
\hline $\mathrm{H} 2$ & 17B & 43.52 & $4.42 \%$ & $\mathrm{H} 2$ & $74 \mathrm{~B}$ & 149.65 & $3.03 \%$ \\
\hline $\mathrm{H} 2$ & $17 \mathrm{~A}$ & 44.02 & $4.70 \%$ & $\mathrm{H} 2$ & $74 \mathrm{~A}$ & 150.15 & $4.27 \%$ \\
\hline $\mathrm{H} 2$ & $18 \mathrm{D}$ & 44.92 & $4.46 \%$ & $\mathrm{H} 2$ & 75 & 151.45 & $4.72 \%$ \\
\hline $\mathrm{H} 2$ & $18 \mathrm{C}$ & 45.42 & $3.72 \%$ & $\mathrm{H} 2$ & 76 & 153.3 & $3.87 \%$ \\
\hline $\mathrm{H} 2$ & $18 \mathrm{~B}$ & 45.92 & $5.32 \%$ & $\mathrm{H} 2$ & 77 & 155.5 & $4.04 \%$ \\
\hline $\mathrm{H} 2$ & $18 \mathrm{~A}$ & 46.42 & $5.33 \%$ & $\mathrm{H} 2$ & 78 & 157.6 & $4.05 \%$ \\
\hline $\mathrm{H} 2$ & $20 \mathrm{D}$ & 49.12 & $4.87 \%$ & $\mathrm{H} 2$ & $79 \mathrm{D}$ & 158.65 & $4.43 \%$ \\
\hline $\mathrm{H} 2$ & $20 \mathrm{C}$ & 49.62 & $0.29 \%$ & $\mathrm{H} 2$ & $79 \mathrm{C}$ & 159.15 & $5.03 \%$ \\
\hline $\mathrm{H} 2$ & $20 \mathrm{~B}$ & 50.12 & $3.67 \%$ & $\mathrm{H} 2$ & $79 B$ & 159.65 & $6.14 \%$ \\
\hline $\mathrm{H} 2$ & $20 \mathrm{~A}$ & 50.62 & $3.40 \%$ & $\mathrm{H} 2$ & $79 \mathrm{~A}$ & 160.15 & $5.12 \%$ \\
\hline $\mathrm{H} 2$ & $21 \mathrm{D}$ & 51.52 & $1.91 \%$ & $\mathrm{H} 2$ & 79 & 160.55 & $4.00 \%$ \\
\hline $\mathrm{H} 2$ & $21 \mathrm{C}$ & 52.02 & $3.29 \%$ & $\mathrm{H} 2$ & 80 & 161.75 & $4.36 \%$ \\
\hline $\mathrm{H} 2$ & 21B & 52.52 & $4.30 \%$ & $\mathrm{H} 2$ & 81 & 161.75 & $4.21 \%$ \\
\hline
\end{tabular}


Table 4.1. Moisture Content of Sediment from Borehole 299-E33-46. (4 pages)

\begin{tabular}{|c|c|c|c|c|c|c|c|}
\hline $\begin{array}{l}\text { Lithologic } \\
\text { Unit }\end{array}$ & $\begin{array}{l}\text { Sample } \\
\text { No. }\end{array}$ & $\begin{array}{c}\text { Mid Depth } \\
{\text { (Vertical ft })^{(1)}}^{(1)}\end{array}$ & $\begin{array}{c}\% \\
\text { Moisture }\end{array}$ & $\begin{array}{c}\text { Lithologic } \\
\text { Unit }\end{array}$ & $\begin{array}{c}\text { Sample } \\
\text { No. }\end{array}$ & $\begin{array}{c}\text { Mid Depth } \\
{\text { (Vertical ft })^{(1)}}^{\text {(Vea }}\end{array}$ & $\begin{array}{c}\% \\
\text { Moisture }\end{array}$ \\
\hline $\mathrm{H} 2$ & $21 \mathrm{~A}$ & 53.02 & $4.82 \%$ & $\mathrm{H} 2$ & $82 \mathrm{D}$ & 163.05 & $6.22 \%$ \\
\hline $\mathrm{H} 2$ & 21(shoe) & 53.44 & $5.15 \%$ & $\mathrm{H} 2$ & $82 \mathrm{C}$ & 163.55 & $3.98 \%$ \\
\hline $\mathrm{H} 2$ & 22 & 54.6 & $4.40 \%$ & $\mathrm{H} 2$ & $82 \mathrm{~B}$ & 164.05 & $4.32 \%$ \\
\hline $\mathrm{H} 2$ & 24 & 56.7 & $5.25 \%$ & $\mathrm{H} 2$ & $82 \mathrm{~A}$ & 164.55 & $3.42 \%$ \\
\hline $\mathrm{H} 2$ & 25 & 58.4 & $5.03 \%$ & $\mathrm{H} 2$ & 82 & 164.95 & $3.93 \%$ \\
\hline $\mathrm{H} 2$ & $26 \mathrm{D}$ & 59.22 & $4.24 \%$ & $\mathrm{H} 2$ & 82 Dup & 164.95 & $4.14 \%$ \\
\hline $\mathrm{H} 2$ & $26 \mathrm{C}$ & 59.72 & $4.58 \%$ & $\mathrm{H} 2$ & $83 \mathrm{D}$ & 165.35 & $3.29 \%$ \\
\hline $\mathrm{H} 2$ & 26C-DUP & 59.72 & $4.40 \%$ & $\mathrm{H} 2$ & $83 \mathrm{C}$ & 165.85 & $4.33 \%$ \\
\hline $\mathrm{H} 2$ & $26 \mathrm{~B}$ & 60.22 & $4.16 \%$ & $\mathrm{H} 2$ & $83 \mathrm{~B}$ & 166.35 & $4.23 \%$ \\
\hline $\mathrm{H} 2$ & $26-\mathrm{A}$ & 60.72 & $4.08 \%$ & $\mathrm{H} 2$ & $83 \mathrm{~A}$ & 166.85 & $3.34 \%$ \\
\hline $\mathrm{H} 2$ & 27 & 62.1 & $4.21 \%$ & $\mathrm{H} 2$ & 83 & 167.25 & $4.07 \%$ \\
\hline $\mathrm{H} 2$ & 29 & 66.05 & $4.04 \%$ & $* *$ & 84 & 168.45 & $8.77 \%$ \\
\hline $\mathrm{H} 2$ & 30 & 67.95 & $4.18 \%$ & $* *$ & 85 & 168.25 & $20.21 \% \%^{a}$ \\
\hline $\mathrm{H} 2$ & $31 \mathrm{D}$ & 68.95 & $3.69 \%$ & $\mathrm{H} 2$ & $86 \mathrm{D}$ & 169.65 & $3.87 \%$ \\
\hline $\mathrm{H} 2$ & $31 \mathrm{C}$ & 69.45 & $3.89 \%$ & $\mathrm{H} 2$ & $86 \mathrm{C}$ & 170.15 & $3.43 \%$ \\
\hline $\mathrm{H} 2$ & $31 \mathrm{~B}$ & 69.95 & $4.36 \%$ & $\mathrm{H} 2$ & $86 \mathrm{~B}$ & 170.65 & $3.82 \%$ \\
\hline $\mathrm{H} 2$ & $31 \mathrm{~A}$ & 70.45 & $4.81 \%$ & $\mathrm{H} 2$ & $86 \mathrm{~A}$ & 171.15 & $5.31 \%$ \\
\hline $\mathrm{H} 2$ & 31 (shoe) & 70.85 & $3.70 \%$ & $\mathrm{H} 2$ & 86 & 171.55 & $4.64 \%$ \\
\hline $\mathrm{H} 2$ & 33 & 73.5 & $4.15 \%$ & $\mathrm{H} 2$ & 87 & 172.9 & $4.36 \%$ \\
\hline $\mathrm{H} 2$ & 34 & 75.4 & $7.15 \%$ & $\mathrm{H} 2$ & 88 & 175.1 & $4.61 \%$ \\
\hline $\mathrm{H} 2$ & 35 & 77.35 & $5.63 \%$ & $\mathrm{H} 3$ & 89 & 177.1 & $4.70 \%$ \\
\hline $\mathrm{H} 2$ & $36 \mathrm{D}$ & 78.95 & $4.78 \%$ & $\mathrm{H} 3$ & $90 \mathrm{D}$ & 178.35 & $3.63 \%$ \\
\hline $\mathrm{H} 2$ & $36 \mathrm{C}$ & 79.45 & $4.79 \%$ & $\mathrm{H} 3$ & $90 \mathrm{C}$ & 178.85 & $4.70 \%$ \\
\hline $\mathrm{H} 2$ & $36 \mathrm{~B}$ & 79.95 & $4.36 \%$ & $\mathrm{H} 3$ & $90 \mathrm{~B}$ & 179.35 & $3.78 \%$ \\
\hline $\mathrm{H} 2$ & $36 \mathrm{~A}$ & 80.35 & $4.38 \%$ & $\mathrm{H} 3$ & $90 \mathrm{~A}$ & 179.85 & $4.37 \%$ \\
\hline $\mathrm{H} 2$ & 37 & 80.9 & $4.62 \%$ & $\mathrm{H} 3$ & 90 & 180.25 & $4.66 \%$ \\
\hline $\mathrm{H} 2$ & $38 \mathrm{D}$ & 81.55 & $3.98 \%$ & $\mathrm{H} 3$ & 91 & 181.75 & $4.37 \%$ \\
\hline $\mathrm{H} 2$ & $38 \mathrm{C}$ & 82.05 & $4.49 \%$ & $\mathrm{H} 3$ & 92 & 183.7 & $5.66 \%$ \\
\hline $\mathrm{H} 2$ & $38 \mathrm{~B}$ & 82.55 & $4.35 \%$ & $* * *$ & 93 & 185.1 & $12.33 \% \%^{a}$ \\
\hline $\mathrm{H} 2$ & $38 \mathrm{~A}$ & 83.05 & $5.09 \%$ & $\mathrm{H} 3$ & 94 & 186.85 & $4.38 \%$ \\
\hline
\end{tabular}


Table 4.1. Moisture Content of Sediment from Borehole 299-E33-46. (4 pages)

\begin{tabular}{|c|c|c|c|c|c|c|c|}
\hline $\begin{array}{l}\text { Lithologic } \\
\text { Unit }\end{array}$ & $\begin{array}{c}\text { Sample } \\
\text { No. }\end{array}$ & $\begin{array}{c}\text { Mid Depth } \\
{\text { (Vertical ft })^{(1)}}^{\text {(Vection }}\end{array}$ & $\begin{array}{c}\% \\
\text { Moisture }\end{array}$ & $\begin{array}{c}\text { Lithologic } \\
\text { Unit }\end{array}$ & $\begin{array}{c}\text { Sample } \\
\text { No. }\end{array}$ & $\begin{array}{c}\text { Mid Depth } \\
\text { (Vertical ft) }^{(1)}\end{array}$ & $\begin{array}{c}\% \\
\text { Moisture }\end{array}$ \\
\hline $\mathrm{H} 2$ & 38(shoe) & 83.45 & $5.23 \%$ & $\mathrm{H} 3$ & 95 & 188.45 & $4.07 \%$ \\
\hline$*$ & 39 & 84.55 & $19.39 \% \%^{a}$ & $\mathrm{H} 3$ & $96 \mathrm{D}$ & 189.35 & $3.37 \%$ \\
\hline$*$ & 40 & 86.3 & $18.16 \%^{a}$ & $\mathrm{H} 3$ & $96 \mathrm{C}$ & 189.85 & $3.41 \%$ \\
\hline $\mathrm{H} 2$ & 41 & 87.85 & $3.49 \%$ & $\mathrm{H} 3$ & $96 \mathrm{~B}$ & 190.35 & $2.77 \%$ \\
\hline $\mathrm{H} 2$ & $42 \mathrm{D}$ & 89.12 & $3.74 \%$ & $\mathrm{H} 3$ & $96 \mathrm{~A}$ & 190.8 & $2.42 \%$ \\
\hline $\mathrm{H} 2$ & $42 \mathrm{C}$ & 89.62 & $2.67 \%$ & H3 & 101D & 199.45 & $3.00 \%$ \\
\hline $\mathrm{H} 2$ & $42 \mathrm{~B}$ & 90.12 & $2.12 \%$ & $\mathrm{H} 3$ & $101 \mathrm{C}$ & 199.85 & $3.65 \%$ \\
\hline $\mathrm{H} 2$ & $42 \mathrm{~A}$ & 90.62 & $2.83 \%$ & $\mathrm{H} 3$ & 101B & 200.45 & $2.91 \%$ \\
\hline $\mathrm{H} 2$ & 43 & 91.45 & $3.26 \%$ & $\mathrm{H} 3$ & $101 \mathrm{~A}$ & 200.95 & $2.94 \%$ \\
\hline $\mathrm{H} 2$ & 44 & 93.15 & $3.00 \%$ & $\mathrm{H} 3$ & $105 \mathrm{D}$ & 208.55 & $2.91 \%$ \\
\hline $\mathrm{H} 2$ & 45 & 95.15 & $3.37 \%$ & $\mathrm{H} 3$ & $105 \mathrm{C}$ & 208.95 & $3.83 \%$ \\
\hline $\mathrm{H} 2$ & 46 & 96.8 & $3.16 \%$ & $\mathrm{H} 3$ & $105 \mathrm{~B}$ & 209.45 & $3.71 \%$ \\
\hline $\mathrm{H} 2$ & $47 \mathrm{D}$ & 98.12 & $2.03 \%$ & $\mathrm{H} 3$ & $105 \mathrm{~A}$ & 209.95 & $3.73 \%$ \\
\hline $\mathrm{H} 2$ & $47 \mathrm{C}$ & 98.62 & $2.10 \%$ & $\mathrm{PPlz}$ & 108 & 216.7 & $5.06 \%$ \\
\hline $\mathrm{H} 2$ & 47B & 99.12 & $2.02 \%$ & $\mathrm{PPlz}$ & 108 Dup & 216.7 & $4.72 \%$ \\
\hline $\mathrm{H} 2$ & $47 \mathrm{~A}$ & 98.62 & $2.18 \%$ & $\mathrm{PPlz}$ & 109D & 217.95 & $4.17 \%$ \\
\hline $\mathrm{H} 2$ & 47(shoe) & 100.04 & $2.09 \%$ & PPlz & $109 \mathrm{C}$ & 218.45 & $4.58 \%$ \\
\hline $\mathrm{H} 2$ & 48 & 101.55 & $2.13 \%$ & $\mathrm{PPlz}$ & 109B & 218.95 & $5.75 \%$ \\
\hline $\mathrm{H} 2$ & 49 & 103.85 & $2.75 \%$ & $\mathrm{PPlz}$ & $109 \mathrm{~A}$ & 219.45 & $4.35 \%$ \\
\hline $\mathrm{H} 2$ & 50 & 105.7 & $2.96 \%$ & $\mathrm{PPlz}$ & 109 & 219.95 & $17.88 \%^{\mathrm{a}}$ \\
\hline $\mathrm{H} 2$ & 51 & 107.45 & $2.53 \%$ & $\mathrm{PPlz}$ & $110 \mathrm{D}$ & 220.65 & $23.33 \%^{\mathrm{a}}$ \\
\hline $\mathrm{H} 2$ & 52 & 109 & $3.52 \%$ & PPlz & $110 \mathrm{C}$ & 221.15 & $29.04 \%^{a}$ \\
\hline $\mathrm{H} 2$ & $53 \mathrm{D}$ & 109.92 & $2.98 \%$ & $\mathrm{PPlz}$ & 110B & 221.65 & $27.24 \%^{\mathrm{a}}$ \\
\hline $\mathrm{H} 2$ & $53 \mathrm{C}$ & 110.42 & $3.21 \%$ & $\mathrm{PPlz}$ & 110BDup & 221.65 & $27.55 \%^{\mathrm{a}}$ \\
\hline $\mathrm{H} 2$ & $53 \mathrm{~B}$ & 110.92 & $2.51 \%$ & $\mathrm{PPlz}$ & $110 \mathrm{~A}$ & 222.05 & $25.94 \%^{\mathrm{a}}$ \\
\hline $\mathrm{H} 2$ & $53 \mathrm{~A}$ & 111.42 & $2.58 \%$ & PPlz & 111 & 223.5 & $14.98 \%{ }^{\mathrm{a}}$ \\
\hline $\mathrm{H} 2$ & 54 & 113 & $2.90 \%$ & PPlz & 112 & 223.5 & $15.91 \%^{\mathrm{a}}$ \\
\hline $\mathrm{H} 2$ & 55 & 114.9 & $2.97 \%$ & $\mathrm{PPlz}$ & 113 & 225.9 & $14.99 \%{ }^{\mathrm{a}}$ \\
\hline $\mathrm{H} 2$ & 56 & 117 & $2.82 \%$ & PPlg & 114 & 228.45 & $3.10 \%$ \\
\hline $\mathrm{H} 2$ & $57 \mathrm{D}$ & 118.42 & $2.80 \%$ & PPlg & $115 \mathrm{C}$ & 229.75 & $4.21 \%$ \\
\hline
\end{tabular}


Table 4.1. Moisture Content of Sediment from Borehole 299-E33-46. (4 pages)

\begin{tabular}{|c|c|c|c|c|c|c|c|}
\hline $\begin{array}{c}\text { Lithologic } \\
\text { Unit }\end{array}$ & $\begin{array}{c}\text { Sample } \\
\text { No. }\end{array}$ & $\begin{array}{c}\text { Mid Depth } \\
{\text { (Vertical ft })^{(1)}}^{\text {(Ver }}\end{array}$ & $\begin{array}{c}\% \\
\text { Moisture }\end{array}$ & $\begin{array}{c}\text { Lithologic } \\
\text { Unit }\end{array}$ & $\begin{array}{l}\text { Sample } \\
\text { No. }\end{array}$ & $\begin{array}{c}\text { Mid Depth } \\
{\text { (Vertical ft })^{(1)}}^{\text {(Vertict }}\end{array}$ & $\begin{array}{c}\% \\
\text { Moisture }\end{array}$ \\
\hline $\mathrm{H} 2$ & $57 \mathrm{C}$ & 118.92 & $2.98 \%$ & PPlg & 115B & 230.25 & $3.04 \%$ \\
\hline $\mathrm{H} 2$ & $57 \mathrm{~B}$ & 119.42 & $2.72 \%$ & PPlg & $115 \mathrm{~A}$ & 230.75 & $3.71 \%$ \\
\hline $\mathrm{H} 2$ & $57 \mathrm{~A}$ & 119.92 & $2.09 \%$ & PPlg & $120 \mathrm{D}$ & 239.95 & $3.32 \%$ \\
\hline $\mathrm{H} 2$ & 58 & 121.5 & $3.31 \%$ & PPlg & $120 \mathrm{C}$ & 240.45 & $3.46 \%$ \\
\hline $\mathrm{H} 2$ & 59 & 123.5 & $3.21 \%$ & PPlg & $120 \mathrm{~B}$ & 240.95 & $3.71 \%$ \\
\hline $\mathrm{H} 2$ & 60 & 118.5 & $3.48 \%$ & PPlg & $120 \mathrm{~A}$ & 241.45 & $2.50 \%$ \\
\hline $\mathrm{H} 2$ & 61 & 125.05 & $3.17 \%$ & PPlg & $123 \mathrm{~A}$ & 245.75 & $3.33 \%$ \\
\hline $\mathrm{H} 2$ & 62 & 126.75 & $3.38 \%$ & PPlg & $127 \mathrm{C}$ & 254.15 & $4.57 \%$ \\
\hline $\mathrm{H} 2$ & 63 & 128.9 & $5.49 \%$ & PPlg & $127 \mathrm{~B}$ & 253.65 & $4.06 \%$ \\
\hline $\mathrm{H} 2$ & $64 \mathrm{D}$ & 130.35 & $3.63 \%$ & PPlg & $127 \mathrm{~A}$ & 253.15 & $3.17 \%$ \\
\hline $\mathrm{H} 2$ & $64 \mathrm{C}$ & 130.85 & $3.21 \%$ & & & & \\
\hline $\begin{array}{l}{ }^{(1)} \text { to conv } \\
\mathrm{H} 2=\mathrm{Han} \\
\mathrm{H} 3=\mathrm{Han} \\
\mathrm{PPlz}=\mathrm{Pli} \\
\mathrm{PPlg}=\mathrm{Pl} \\
\mathrm{Bckfl}=\mathrm{b} \\
*, * *, * * * \\
\text { a denotes }\end{array}$ & $\begin{array}{l}\text { to } \mathrm{m} \text { multi } \\
\text { rd H2 sand } \\
\text { rd H3 unit- } \\
\text { pleistocenc } \\
\text { pleistocene } \\
\text { kfill }\end{array}$ & $\begin{array}{l}\text { ly by } 0.3048 \\
\text { equence } \\
\text { mud unit } \\
\text { gravelly unit }\end{array}$ & n the Han & sand units. & & & \\
\hline
\end{tabular}

No perched water was observed in the PPlz unit as was found between 69 to $71 \mathrm{~m}$ (227 to $233 \mathrm{ft}) \mathrm{bgs}$ during the drilling of borehole 299-E33-45 at the BX Tank Farm (see Serne et al. 2002e for details). A water sample was taken at the bottom of the 299-E33-46 borehole prior to its being decommissioned. The chemical composition for the groundwater is described along with the UFA porewaters, suction candle derived porewaters, and dilution corrected 1:1 sediment to water extracts in the sections that follow.

\subsection{1:1 Sediment-to-Water Extracts}

The main objective for placing the 299-E33-46 borehole at the location approximately $4.6 \mathrm{~m}$ (15 ft) from the tank wall was to investigate whether the field gamma log anomaly (bremsstrahlung radiation) truly could be correlated with strontium- 90 in the vadose zone sediments and to investigate whether other non-gamma emitting radionuclides were present. Details on the drivers for installing this borehole are discussed in Section 3.2.2 in the B-BX-BY Field Investigation Report [FIR]. The borehole was extended to groundwater in order to track other mobile contaminants that can't be tracked with gamma logging such as technetium-99 and nitrate. The most economical method for determining the distribution of the mobile contaminants in the vadose zone sediment is to use water extracts of the sediments because most of the sediment is too dry to readily extract native porewater. The following sections discuss the results 
of the analysis done on the water extracts and the few selected porewaters that were obtained by ultracentrifugation in the unsaturated flow apparatus (UFA).

\subsection{1 pH and Electrical Conductivity}

The $\mathrm{pH}$ and electrical conductivity for the water extracts and UFA squeezed porewaters are shown in Table 4.2 and Figure 4.1. The electrical conductivity for the 1:1 sediment-water extracts has been corrected for dilution with deionized water, but the $\mathrm{pH}$ is plotted as measured in the 1:1 sediment to water extracts. Note that Figures 4.1 through 4.5 also show data for porewaters obtained after the borehole was decommissioned through the use of suction candles. A discussion of the suction candles and data obtained over time from the candles will be discussed in Section 4.11.

The $\mathrm{pH}$ profile shows that between 30.48 and $45.72 \mathrm{~m}$ (52 and $83 \mathrm{ft}$ ) bgs (in the Hanford formation $\mathrm{H} 2$ middle sand sequence), there are elevated values (8.5 to 9.5) suggesting the presence of caustic waste interaction with the sediment. Below the fine-grained lens at approximately 25.6 to $25.9 \mathrm{~m}$ ( 84 to $85 \mathrm{ft}$ ) bgs is another lobe of slightly elevated $\mathrm{pH}$ with values between 8.8 and 9.1. This deeper zone with elevated $\mathrm{pH}$ extends from 29.3 to $36.6 \mathrm{~m}$ (96 to $120 \mathrm{ft}$ ) bgs and is also within the Hanford formation $\mathrm{H} 2$ unit. The thin fine-grained lens at approximately $25.9 \mathrm{~m}(85 \mathrm{ft})$ bgs does not show elevated $\mathrm{pH}$ or elevated electrical conductivity and thus appears to be acting as a partial barrier to tank related fluid migration. The electrical conductivity profile is similar to the elevated $\mathrm{pH}$ profile in that it shows two regions with high values. The shallower region starts at $15.4 \mathrm{~m}(50.6 \mathrm{ft}) \mathrm{bgs}$, a bit shallower than the elevated $\mathrm{pH}$ zone, and extends down to the thin fine-grained lens at 25.6 to $25.9 \mathrm{~m}$ (84 to $85 \mathrm{ft}) \mathrm{bgs}$. The dilution corrected (calculated) porewater electrical conductivity ranges from 6.5 to $15 \mathrm{mS} / \mathrm{cm}$ in this region. The deeper elevated EC zone extends from 27.6 to $42.7 \mathrm{~m}$ (90.6 to $140 \mathrm{ft}$ ) bgs with calculated porewater conductivities ranging from 5.7 to $12.75 \mathrm{mS} / \mathrm{cm}$. This deeper zone of elevated electrical conductivity is less concentrated than the shallow zone and resides within the lower portion of the Hanford formation $\mathrm{H} 2$ unit. It is possible that small portions of tank related fluids have mixed with the natural sediment moisture all the way down to the thin fine-grained lens at approximately $51 \mathrm{~m}$ (168 ft) bgs but below $51 \mathrm{~m}(168 \mathrm{ft})$ bgs the electrical conductivity values are not significantly elevated compared to values calculated in this zone in an uncontaminated borehole, 299-E33-338 as discussed in Lindenmeier et al. 2002. The porewaters that were extracted from selected samples using the ultracentrifuge (UFA) show slightly lower $\mathrm{pH}$ values than the 1:1 sediment to water extracts and the actual porewater electrical conductivity values are often significantly lower than calculated porewater conductivities obtained by making dilution corrections on the $1: 1$ sediment to water extracts. This discrepancy was also found at borehole 299-E33-45 east of the BX-102 tank. Unlike the contaminated sediments around REDOX tanks in the SX tank farm, the more dilute wastes in the sediments that surround the two tanks studied in the B-BX-BY WMA appear to have more of the wastes in a form that is not present in the actual porewater but readily re-dissolves upon addition of de-ionized water. At the SX tank farm the actual porewater electrical conductivities and the calculated values from dilution correcting the 1:1 water extracts agreed reasonably well; however the absolute values at SX were much larger because of the very high sodium nitrate concentrations that were present. 
Table 4.2. Water Extract pH and Electrical Conductivity Values

\begin{tabular}{|c|c|c|c|c|c|}
\hline Sample ID & $\begin{array}{l}\text { Mid Depth } \\
\text { (ft) }^{(1)}\end{array}$ & $\begin{array}{c}\text { Dilution } \\
\text { Factor }\end{array}$ & 1:1 pH & $\begin{array}{c}1: 1 \mathrm{EC} \\
(\mathrm{mS} / \mathrm{cm})\end{array}$ & $\begin{array}{l}\text { Pore EC } \\
(\mathrm{mS} / \mathrm{cm})\end{array}$ \\
\hline \multicolumn{6}{|l|}{ Backfill } \\
\hline 2B-UFA & 12.94 & 1 & 7.89 & & $6.35^{\mathrm{a}}$ \\
\hline $02 \mathrm{~A}$ & 13.7 & 27.8 & 7.89 & 0.154 & $4.28^{\mathrm{a}}$ \\
\hline 06B-UFA & 20.62 & 1 & 7.90 & & $7.54^{\mathrm{a}}$ \\
\hline $06 \mathrm{~A}$ & 21.12 & 20.66 & 7.48 & 0.133 & $2.75^{\mathrm{a}}$ \\
\hline $10 \mathrm{~A}$ & 29.42 & 30.33 & 7.83 & 0.139 & 4.22 \\
\hline \multicolumn{6}{|c|}{ Hanford H2 Sand (upper sequence) Unit } \\
\hline $16 \mathrm{~A}$ & 41.72 & 25.18 & 7.39 & 0.139 & 3.5 \\
\hline $17 \mathrm{~A}$ & 44.02 & 21.29 & 7.78 & 0.137 & 2.92 \\
\hline $18 \mathrm{~A}$ & 46.42 & 18.75 & 8.10 & 0.142 & 2.66 \\
\hline 20B-UFA & 50.12 & 1 & 8.23 & & $0.85^{\mathrm{a}}$ \\
\hline $20 \mathrm{~A}$ & 50.62 & 29.43 & 8.11 & 0.276 & $8.12^{\mathrm{ab}}$ \\
\hline $21 \mathrm{C}$ & 52.02 & 29.45 & $9.09^{b}$ & 0.317 & $9.34^{b}$ \\
\hline 21A-UFA & 53.02 & 1 & $8.69^{b}$ & & $\mathrm{NA}^{\mathrm{b}}$ \\
\hline $21 \mathrm{~A}$ & 53.02 & 20.75 & $9.18^{b}$ & 0.42 & $8.71^{b}$ \\
\hline 21A-dup & 53.44 & 19.42 & 8.48 & 0.413 & $8.02^{b}$ \\
\hline 22 & 54.6 & 22.75 & $9.27^{b}$ & 0.544 & $12.38^{\mathrm{b}}$ \\
\hline 24 & 56.7 & 19.05 & $9.47^{b}$ & 0.778 & $14.82^{b}$ \\
\hline 25 & 58.4 & 19.92 & $9.51^{b}$ & 0.583 & $11.61^{b}$ \\
\hline $26 \mathrm{C}$ & 59.72 & 19.45 & $9.49^{b}$ & 0.549 & $10.68^{b}$ \\
\hline 26C-dup & 59.72 & 22.74 & $9.54^{b}$ & 0.567 & $12.89^{b}$ \\
\hline $26-\mathrm{A}$ & 60.72 & 24.5 & $9.49^{b}$ & 0.615 & $15.07^{b}$ \\
\hline 27 & 62.1 & 23.78 & $9.52^{b}$ & 0.586 & $13.94^{b}$ \\
\hline 29 & 66.05 & 24.84 & 9.18 & 0.367 & $9.12^{b}$ \\
\hline $31 \mathrm{C}$ & 69.45 & 28.74 & 9.13 & 0.362 & $10.4^{b}$ \\
\hline $31 \mathrm{~B}$ & 69.95 & 23.92 & 8.89 & 0.367 & $8.78^{b}$ \\
\hline $31 \mathrm{~A}$ & 70.45 & 20.8 & 8.18 & 0.328 & $6.82^{b}$ \\
\hline 31A-dup & 70.45 & 27.03 & 8.10 & 0.366 & $9.89^{b}$ \\
\hline 33 & 73.5 & 25.04 & $9.08^{b}$ & 0.345 & $8.64^{\mathrm{b}}$ \\
\hline 35 & 77.35 & 15.03 & 8.8 & 0.367 & $5.51^{b}$ \\
\hline $36 \mathrm{C}$ & 79.45 & 21.67 & 8.84 & 0.346 & $7.5^{b}$ \\
\hline
\end{tabular}


Table 4.2. Water Extract pH and Electrical Conductivity Values

\begin{tabular}{|c|c|c|c|c|c|}
\hline Sample ID & $\begin{array}{l}\text { Mid Depth } \\
\text { (ft) }^{(1)}\end{array}$ & $\begin{array}{c}\text { Dilution } \\
\text { Factor }\end{array}$ & 1:1 pH & $\begin{array}{c}1: 1 \mathrm{EC} \\
(\mathrm{mS} / \mathrm{cm})\end{array}$ & $\begin{array}{l}\text { Pore EC } \\
(\mathrm{mS} / \mathrm{cm})\end{array}$ \\
\hline 36A-UFA & 79.95 & 1 & 8.39 & & $1.03^{\mathrm{ab}}$ \\
\hline $36 \mathrm{~A}$ & 79.95 & 22.85 & 8.44 & 0.354 & $8.09^{\mathrm{ab}}$ \\
\hline $38 \mathrm{C}$ & 82.05 & 24.7 & $9.00^{\mathrm{b}}$ & 0.345 & $8.52^{b}$ \\
\hline 38A-UFA & 83.05 & 1 & 8.45 & & $3.98^{\mathrm{ab}}$ \\
\hline $38 \mathrm{~A}$ & 83.05 & 19.64 & 8.76 & 0.331 & $6.5^{\mathrm{ab}}$ \\
\hline \multicolumn{3}{|c|}{ Natural Background Sediments } & 7.1 to 7.5 & & 1.4 to 4.0 \\
\hline \multicolumn{6}{|c|}{ Thin Fine Grained Lens } \\
\hline 39 & 84.55 & 5.17 & 8.26 & 0.345 & 1.78 \\
\hline 39-dup & 84.55 & 5.41 & 8.18 & 0.342 & 1.85 \\
\hline \multicolumn{6}{|c|}{ Hanford H2 Sand (middle sequence) Unit } \\
\hline 41 & 87.85 & 27.98 & 7.84 & 0.165 & 4.62 \\
\hline $42 \mathrm{~A}$ & 90.62 & 35.28 & 7.74 & 0.163 & 5.75 \\
\hline 46 & 96.8 & 31.85 & $8.90^{b}$ & 0.276 & $8.79^{b}$ \\
\hline $47 \mathrm{~A}$ & 98.62 & 45.97 & $8.84^{b}$ & 0.237 & $10.89^{b}$ \\
\hline 52 & 109 & 28.4 & $8.75^{b}$ & 0.292 & $8.29^{b}$ \\
\hline $53 \mathrm{~A}$ & 111.42 & 38.76 & $9.09^{b}$ & 0.329 & $12.75^{b}$ \\
\hline $57 \mathrm{~A}$ & 119.92 & 47.96 & $8.84^{b}$ & 0.232 & $11.13^{b}$ \\
\hline $64 \mathrm{~A}$ & 131.85 & 32.15 & 8.19 & 0.257 & $8.26^{b}$ \\
\hline $69 \mathrm{~A}$ & 140.05 & 39.7 & 8.20 & 0.177 & 7.03 \\
\hline $74 \mathrm{~A}$ & 150.15 & 23.41 & 7.67 & 0.189 & 4.42 \\
\hline $79 \mathrm{~A}$ & 160.15 & 19.54 & 7.52 & 0.181 & 3.54 \\
\hline $82 \mathrm{~A}$ & 164.55 & 29.22 & 8.28 & 0.178 & 5.2 \\
\hline $83 \mathrm{~A}$ & 166.85 & 29.95 & 8.07 & 0.181 & 5.42 \\
\hline \multicolumn{3}{|c|}{ Natural Background Sediments } & 7.1 to 7.5 & & 1.4 to 4.0 \\
\hline \multicolumn{6}{|c|}{ Fine Grained Lens } \\
\hline 84-UFA & 168.45 & 1 & 8.02 & & 1.52 \\
\hline 84 & 168.45 & 11.44 & 7.64 & 0.217 & 2.48 \\
\hline \multicolumn{6}{|c|}{ Hanford H2 Sand Unit } \\
\hline $86 \mathrm{~A}$ & 171.15 & 18.85 & 7.90 & 0.204 & 3.84 \\
\hline \multicolumn{6}{|c|}{ Hanford H3 Sand Unit } \\
\hline $90 \mathrm{~A}$ & 179.85 & 22.89 & 7.60 & 0.154 & 3.52 \\
\hline $96 \mathrm{~A}$ & 190.8 & 41.31 & 7.97 & 0.136 & 5.62 \\
\hline
\end{tabular}


Table 4.2. Water Extract pH and Electrical Conductivity Values

\begin{tabular}{|c|c|c|c|c|c|}
\hline Sample ID & 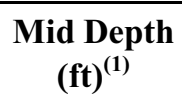 & $\begin{array}{c}\text { Dilution } \\
\text { Factor }\end{array}$ & $1: 1 \mathrm{pH}$ & $\begin{array}{c}1: 1 \mathrm{EC} \\
(\mathrm{mS} / \mathrm{cm})\end{array}$ & $\begin{array}{l}\text { Pore EC } \\
(\mathrm{mS} / \mathrm{cm})\end{array}$ \\
\hline $101 \mathrm{~A}$ & 200.95 & 34.06 & 7.57 & 0.139 & 4.73 \\
\hline 105C-UFA & 208.95 & 1 & 7.16 & & 1.70 \\
\hline $105 \mathrm{~A}$ & 209.95 & 26.84 & 7.55 & 0.142 & 3.81 \\
\hline \multicolumn{3}{|c|}{ Natural Background Sediments } & 7.3 to 7.4 & & 1.9 to 3.3 \\
\hline \multicolumn{6}{|c|}{ Plio-pliestocene Mud Unit } \\
\hline $109 \mathrm{~A}$ & 219.45 & 23.01 & 7.30 & 0.169 & 3.89 \\
\hline 110B-UFA & 221.65 & 1 & 7.42 & & 1.41 \\
\hline 110A-UFA & 222.05 & 1 & 7.49 & & $0.71^{\mathrm{a}}$ \\
\hline $110 \mathrm{~A}$ & 222.05 & 3.85 & 7.88 & 0.351 & $1.35^{\mathrm{a}}$ \\
\hline 110A-dup & 222.05 & 3.85 & 7.81 & 0.319 & 1.23 \\
\hline 113-UFA & 225.9 & 1 & 7.47 & & $0.752^{\mathrm{a}}$ \\
\hline 113 & 225.9 & 6.67 & 7.68 & 0.217 & $1.45^{\mathrm{a}}$ \\
\hline \multicolumn{3}{|c|}{ Natural Background Sediments } & 7.3 to 7.7 & & 0.9 to 3.1 \\
\hline \multicolumn{6}{|c|}{ Plio-pliestocene Gravel Unit } \\
\hline $115 \mathrm{~A}$ & 230.75 & 27.17 & 7.38 & 0.153 & 4.16 \\
\hline $120 \mathrm{~B}$ & 240.95 & 28.68 & 7.61 & 0.159 & 4.56 \\
\hline $120 \mathrm{~A}$ & 241.45 & 39.95 & 7.56 & 0.161 & 6.43 \\
\hline $123 \mathrm{~A}$ & 245.75 & 30.01 & 7.57 & 0.156 & 4.68 \\
\hline $127 \mathrm{~A}$ & 253.15 & 31.57 & 7.62 & 0.174 & 5.49 \\
\hline \multicolumn{3}{|c|}{ Natural Background Sediments } & 7.4 to 7.6 & & 4.0 to 5.0 \\
\hline
\end{tabular}

(1) to convert to meters multiply by 0.3048

${ }^{a}$ allows easy comparison of true porewater EC with calculated porewater EC.

$\mathrm{b}$ elevated values from caustic tank liquor.

Bold type $=$ maximum values in profile .

$\mathrm{EC}=$ Electrical conductivity.

$\mathrm{NA}=$ not analyzed for lack of sample volume. 
299-E33-46 (near Tank 241-B-110)

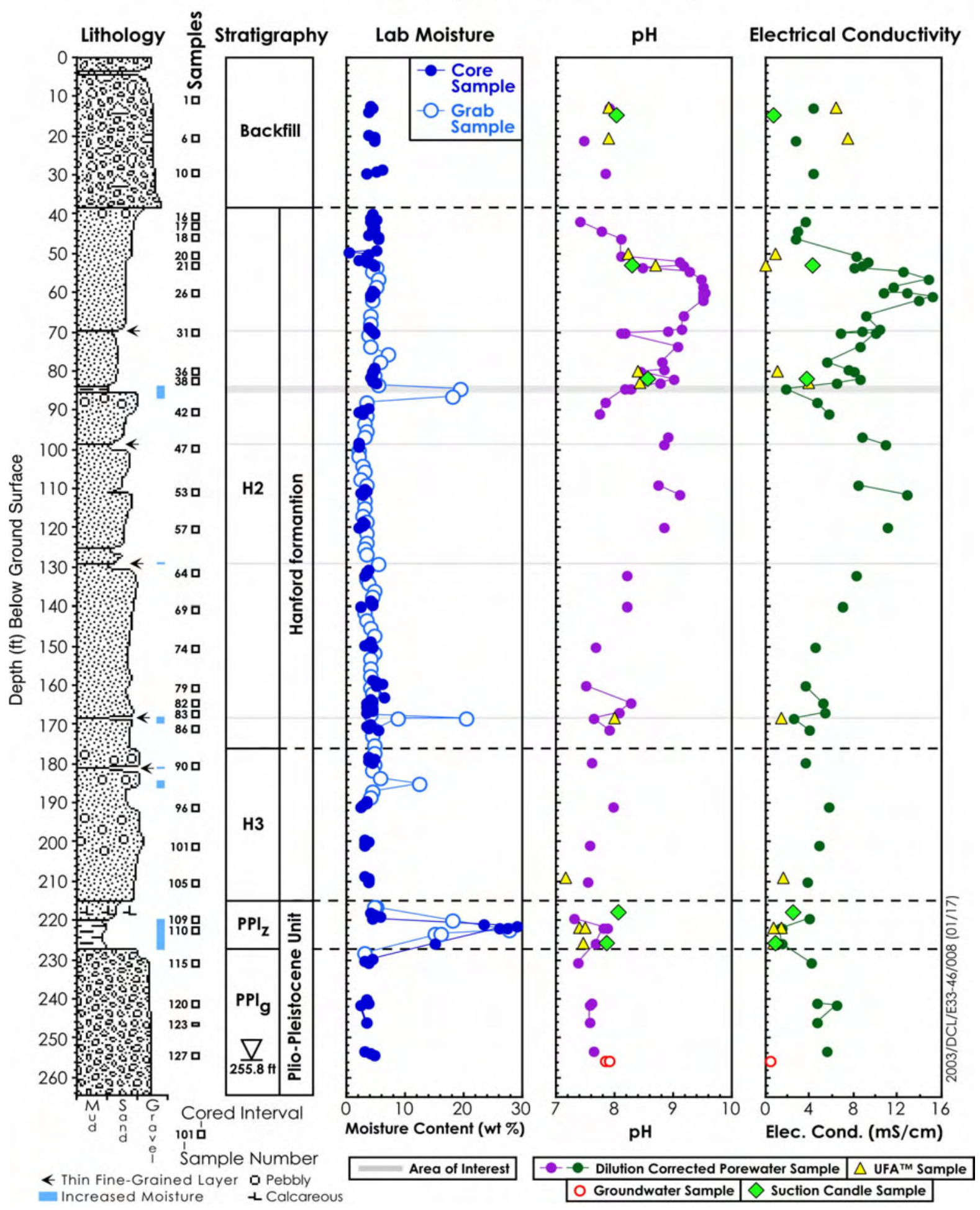

Figure 4.1 Moisture Content, Water Extract pH, Calculated Porewater, UFA and Suction Candle Porewater and Groundwater Electrical Conductivity for Borehole 299-E33-46 
Because so many chemical reactions can affect the $\mathrm{pH}$, it is not possible to determine whether the fluid lost from the B-110 piping traveled mainly in a vertical direction or spread horizontally resulting in a complicated vertical profile at this borehole.

\subsubsection{Porewater Anion Composition}

The 1:1 sediment-to-water extracts and the calculated porewater anion composition are shown in Table 4.3 and Figure 4.2, respectively. When compared to the uncontaminated "baseline" vadose zone sediments from borehole 299-E33-338 near the eastern fence line of the B tank farm, there are obvious signs of elevated porewater concentrations of nitrate, fluoride, and bicarbonate. There are some indications that phosphate and sulfate may be elevated in certain depth zones compared to the uncontaminated sediments nearby. There is shallow nitrate contamination starting at about $15.4 \mathrm{~m}$ $(50.6 \mathrm{ft})$ bgs that extends to $23.6 \mathrm{~m}(77.4 \mathrm{ft}) \mathrm{bgs}$, perhaps reaching the thin fine-grained lens at $25.8 \mathrm{~m}$ $(84.5 \mathrm{ft})$ bgs. Still within the Hanford formation $\mathrm{H} 2$ unit between the depths of 26.8 and $51.2 \mathrm{~m}(87.8$ and $168 \mathrm{ft}) \mathrm{bgs}$ is a more concentrated nitrate plume. At $40.2 \mathrm{~m}(132 \mathrm{ft})$ bgs the highest nitrate calculated porewater concentration is found (approximately $1500 \mathrm{mg} / \mathrm{L}$ ). The $\mathrm{H} 2$ sediment porewater between 50.1 and $51.4 \mathrm{~m}$ (164.5 and $168.5 \mathrm{ft}) \mathrm{bgs}$ contains approximately $500 \mathrm{mg} / \mathrm{L}$ nitrate. The Hanford formation $\mathrm{H} 3$ sediment also appears to contain elevated nitrate porewater concentrations that vary between 100 to $200 \mathrm{mg} / \mathrm{L}$ compared to the uncontaminated H3 sediment porewater concentration of 4 to $17 \mathrm{mg} / \mathrm{L}$. The $\mathrm{PPlz}$ unit also appears to contain slightly elevated nitrate porewater concentrations at approximately $130 \mathrm{mg} / \mathrm{L}$ compared to uncontaminated sediment porewater values that range from 2 to $14 \mathrm{mg} / \mathrm{L}$. The 299-E33-46 borehole sediments in the PPlg coarse-grained unit may also contain elevated nitrate porewater concentrations of approximately $50 \mathrm{mg} / \mathrm{L}$ compared to a natural background value of $10 \mathrm{mg} / \mathrm{L}$. Thus the sediment water extracts from this borehole appear to show elevated nitrate is present all the way to the groundwater; however the bulk of the nitrate is found in the sediment between the depth of 33.5 to $51.4 \mathrm{~m}$ (110 to $168.5 \mathrm{ft}$ ) bgs in the Hanford $\mathrm{H} 2$ sand sequence with values reaching as high as $1.5 \mathrm{~g} / \mathrm{L}$ or approximately $0.025 \mathrm{M}$ at $40.19 \mathrm{~m}(131.85 \mathrm{ft}) \mathrm{bgs}$. The bulk of the water- extractable nitrate is bounded between two thin fine-grained lenses in the $\mathrm{H} 2$ middle sequence sand unit. The upper bound is the finegrained lens at $37 \mathrm{~m} \mathrm{(120} \mathrm{ft)} \mathrm{bgs} \mathrm{and} \mathrm{lower} \mathrm{boundary} \mathrm{is} \mathrm{the} \mathrm{fine-grained} \mathrm{2.5-ft} \mathrm{thick} \mathrm{lens} \mathrm{that} \mathrm{forms} \mathrm{the}$ bottom of the $\mathrm{H} 2$ unit at 51 to $52 \mathrm{~m}$ (167 to $170 \mathrm{ft})$ bgs.

The porewater fluoride concentrations are elevated above the uncontaminated sediment baseline range of 0.4 to $23 \mathrm{mg} / \mathrm{L}$ over a depth region from 15.4 to $33.9 \mathrm{~m}(50.6$ to $111.4 \mathrm{ft}) \mathrm{bgs}$. The highest fluoride porewater concentrations are found between 18.6 and $25.3 \mathrm{~m}(61$ and $83 \mathrm{ft})$ bgs within the Hanford formation $\mathrm{H} 2$ unit at values that range from 110 to $210 \mathrm{mg} / \mathrm{L}$.

The bicarbonate concentration in the porewaters also is elevated in the $\mathrm{H} 2$ middle sand sequence between 22.9 and $50.9 \mathrm{~m}$ ( 75 and $167 \mathrm{ft}$ ) bgs; both above and within in the same zone with the largest nitrate concentrations. Interestingly, the bicarbonate distribution in the sediment water extracts mimics the elevated $\mathrm{pH}$ profile suggesting that either dissolution of natural carbonate minerals or capture of vadose zone carbon dioxide during tank waste fluid neutralization might be the cause for the elevated bicarbonate. The largest calculated porewater bicarbonate concentration occurs in the suspected paleosol at $36.6 \mathrm{~m} \mathrm{(120} \mathrm{ft)} \mathrm{bgs.} \mathrm{However,} \mathrm{based} \mathrm{on} \mathrm{the} \mathrm{UFA} \mathrm{squeezings} \mathrm{the} \mathrm{dilution-corrected} \mathrm{1:1} \mathrm{sediment} \mathrm{to}$ water extract bicarbonate values are biased high because of dissolution of carbonate bearing salts. The 
porewater bicarbonate maximum concentration varies between 0.1 and $0.21 \mathrm{M}$ between 33.5 to $39.6 \mathrm{~m}$ (110 to $130 \mathrm{ft})$ bgs around this potential paleosol at $36.6 \mathrm{~m}(120 \mathrm{ft}) \mathrm{bgs}$.

The porewater sulfate concentrations appear to be slightly elevated in the deeper depths of the borehole, rather than within the Hanford $\mathrm{H} 2$ unit where tank related fluids are generally found. The most significant concentrations of sulfate in the shallow vadose zone are found in a narrow zone within the middle sand sequence of the $\mathrm{H} 2$ unit between 42.7 and $50.6 \mathrm{~m}$ (140 and $166 \mathrm{ft})$ bgs. No UFA squeezings were obtained from sediments from this narrow zone and the natural background sediments in the borehole to the east, 299-E33-338, are also elevated. More puzzling are the elevated sulfate concentrations in the PPlg lithology at the bottom of the borehole. The dilution corrected porewater concentrations reach values approximately $500 \mathrm{mg} / \mathrm{L}$ compared to natural background values of approximately $40 \mathrm{mg} / \mathrm{L}$.

The porewater chloride concentrations do not appear to be significantly elevated compared to the nearby natural sediments from borehole 299-E33-338. Thus the observed chloride profile likely reflects natural conditions. The phosphate porewater distribution in the vadose zone sediment at borehole 299-E33-46 shows elevated concentrations between approximately 16.6 and $25 \mathrm{~m}$ (54.6 and $82 \mathrm{ft})$ bgs within the $\mathrm{H} 2$ upper sand sequence, the maximum concentrations are found in a thin zone at approximately $18 \mathrm{~m}(60 \mathrm{ft}) \mathrm{bgs}$ with a dilution corrected value of $108 \mathrm{mg} / \mathrm{L}(0.0011 \mathrm{M})$. Generally, soluble phosphate levels in natural sediments at Hanford are quite low because of precipitation of highly insoluble apatite minerals. Based on the measured 1:1 sediment to water extracts, the tank waste is not dominated by bismuth phosphate waste as was found at borehole 299-E33-45 northeast of tank BX-102. The nitrite porewater distribution in borehole 299-E33-46 shows no noteworthy elevated values throughout the profile.

The actual porewater concentrations (UFA squeezings) are plotted with the dilution corrected 1:1 water extracts in the tables and figures shown in this section. In the tables green shading is used to show the comparison. There are plausible explanations for the dilution-corrected water extracts (i.e., calculated porewaters) having larger concentrations, such as dissolution of material during the extraction process but we cannot offer a geochemical explanation for the observed opposite trend found for a few of the comparisons. The most likely explanation is analytical errors. In general, the comparison between actual porewater and calculated porewater concentrations for nitrate and chloride values is good. For bicarbonate, the dilution corrected extracts (calculated porewaters) show significantly larger values and for some of the fluoride comparisons the same trend is seen wherein actual porewater concentrations are lower than calculated concentrations.

\subsubsection{Porewater Cation Composition}

Table 4.4 shows the calculated concentrations of cations in the porewater from the vadose zone sediment at 299-E33-46 borehole obtained by dilution correction of the 1:1 sediment-to-water extracts and the selected actual porewaters obtained by ultracentrifugation. The distributions of several of the major cations and minor cations are shown in Figures 4.3 and 4.4. The depth profiles for the divalent alkaline earth cations calcium, magnesium, and strontium show remarkable similarities. All show depleted concentrations over the depth range from between 15.4 or $16 \mathrm{~m}(50.6$ or $52 \mathrm{ft})$ bgs down to $37 \mathrm{~m}$ $(120 \mathrm{ft}) \mathrm{bgs}$ where the concentrations return to values similar to those found in uncontaminated sediments. 
Conversely, the porewater sodium concentration is elevated from $15.4 \mathrm{~m}(50.6 \mathrm{ft})$ bgs down to $37 \mathrm{~m}$ (201 ft) bgs in the $\mathrm{H} 3$ sand sequence. There is also elevated porewater potassium in the shallow vadose zone from 50.6 to approximately $24 \mathrm{~m}(80 \mathrm{ft})$ bgs. The cation profiles for the divalent cations (calcium, magnesium, and strontium) and the mono-valent cations (potassium and sodium) are related through ion exchange reactions wherein the divalent cations that dominate the exchange sites in the natural sediments are stripped off and replaced by the sodium and potassium (perhaps an impurity in the sodium hydroxide used at Hanford to neutralize acidic waste streams). Barium differs from the other divalent cations and is present at low concentrations perhaps reflecting only natural amounts are present that are not impacted by

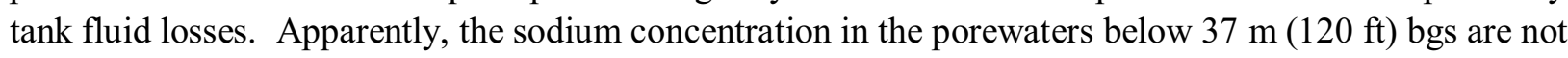
high enough to have stripped significant concentrations of the natural divalent cations from the sediments despite the sodium being elevated in comparison to uncontaminated sediment extracts.

There also appears to be elevated concentrations of soluble aluminum and iron in the shallow profile between 16 and 21 and 16 and $24 \mathrm{~m}$ (52 and 70 and 52 and $80 \mathrm{ft}$ ) bgs, respectively (see Figure 4.4). Soluble silicon also appears elevated in discontinuous zones between 16 and $37 \mathrm{~m} \mathrm{(52} \mathrm{and} 120 \mathrm{ft}$ ) bgs and perhaps in a thin zone at 58 to $61 \mathrm{~m}$ (190 to $200 \mathrm{ft}$ ) bgs. These zones of high water soluble aluminum, iron, and silicon may represent reaction and the presence of amorphous (more soluble) weathering products from tank waste interactions with the vadose zone sediments. 


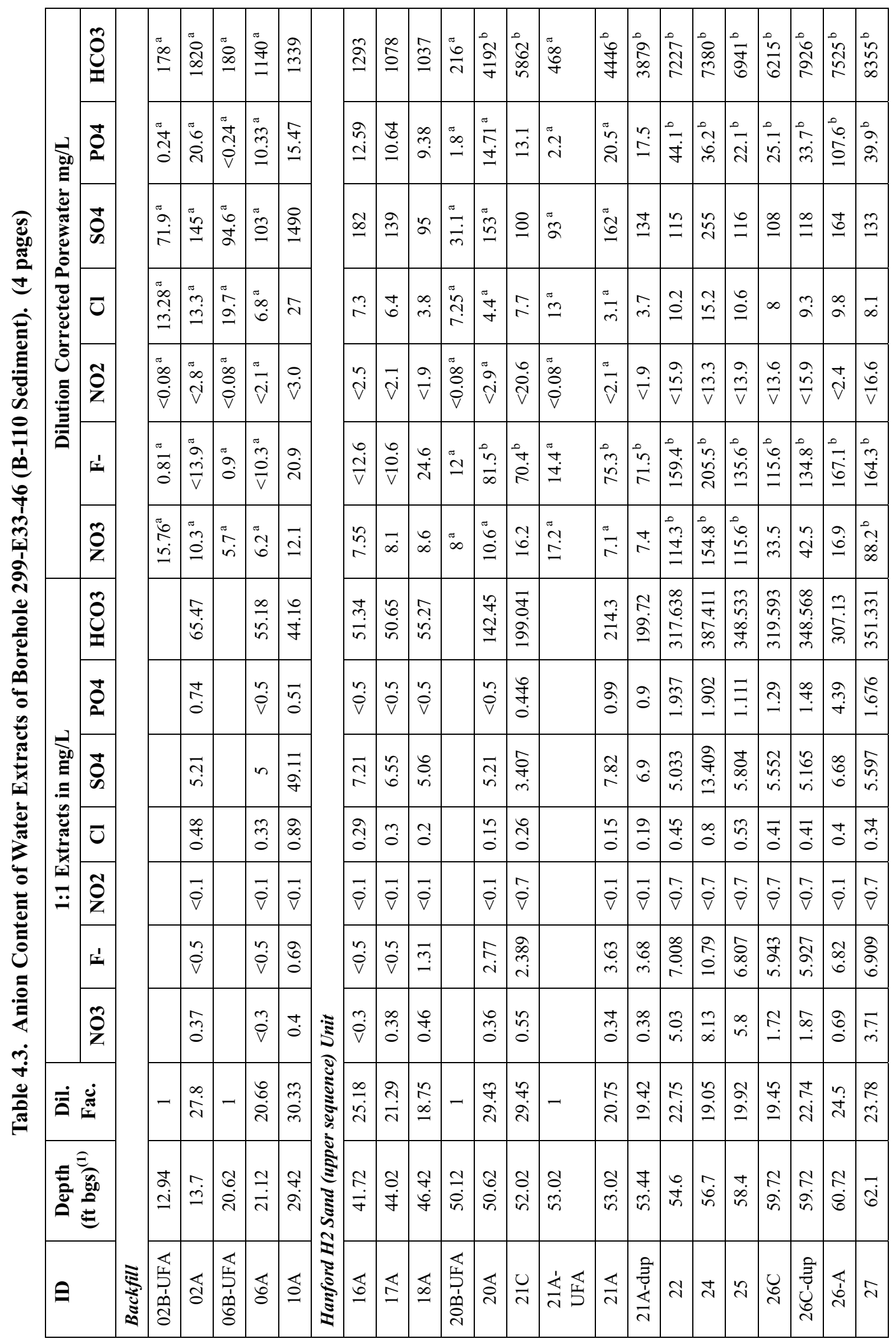




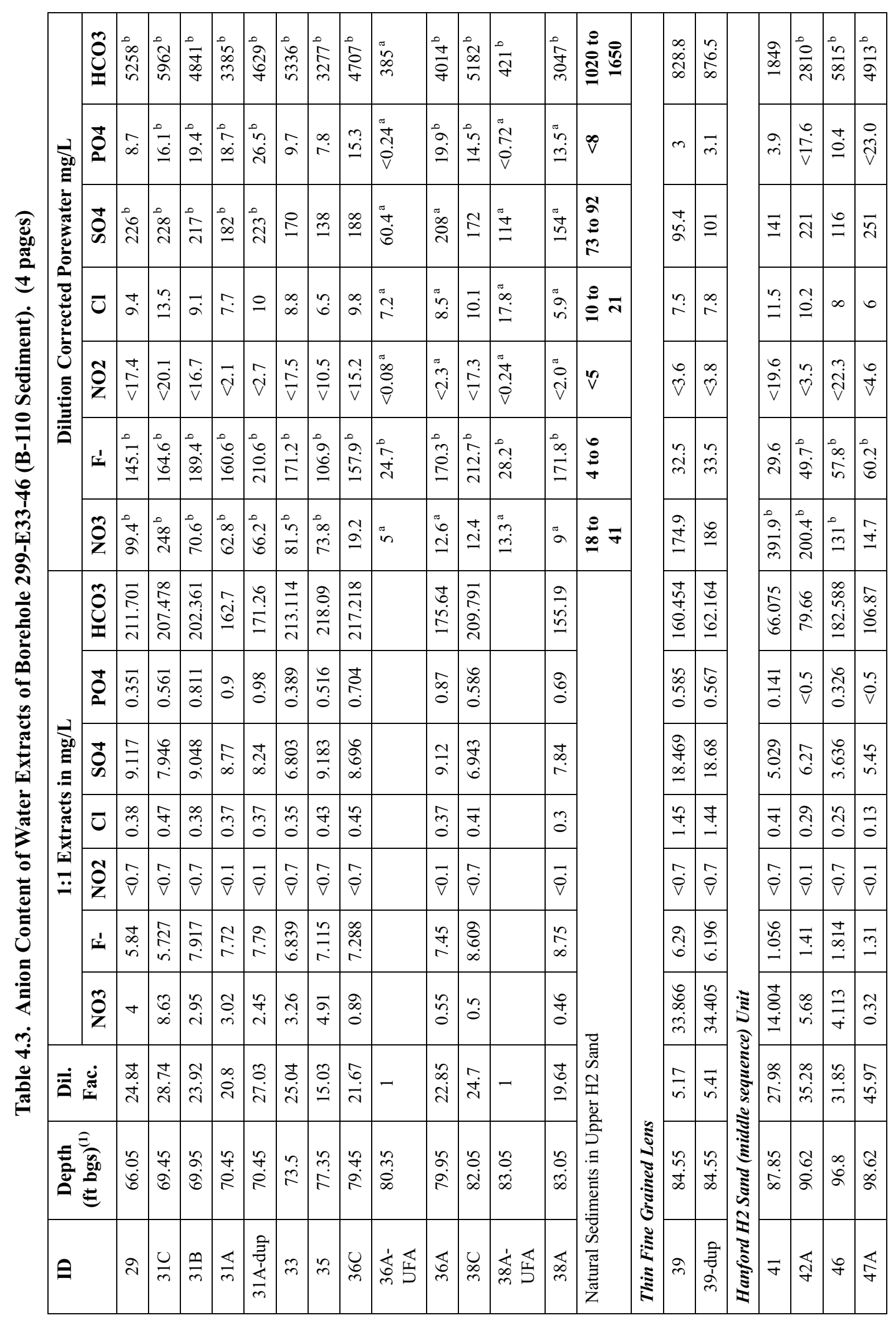




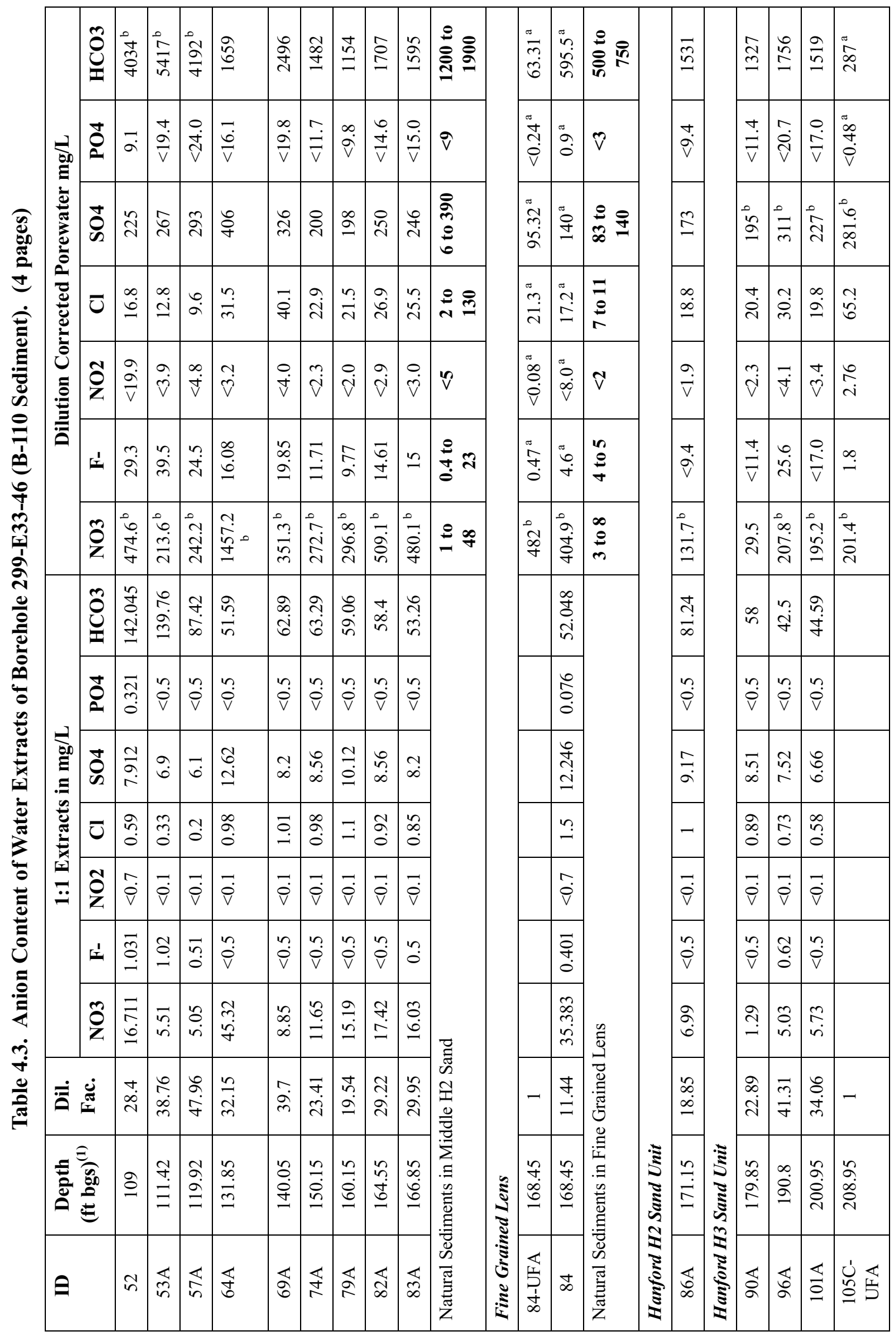




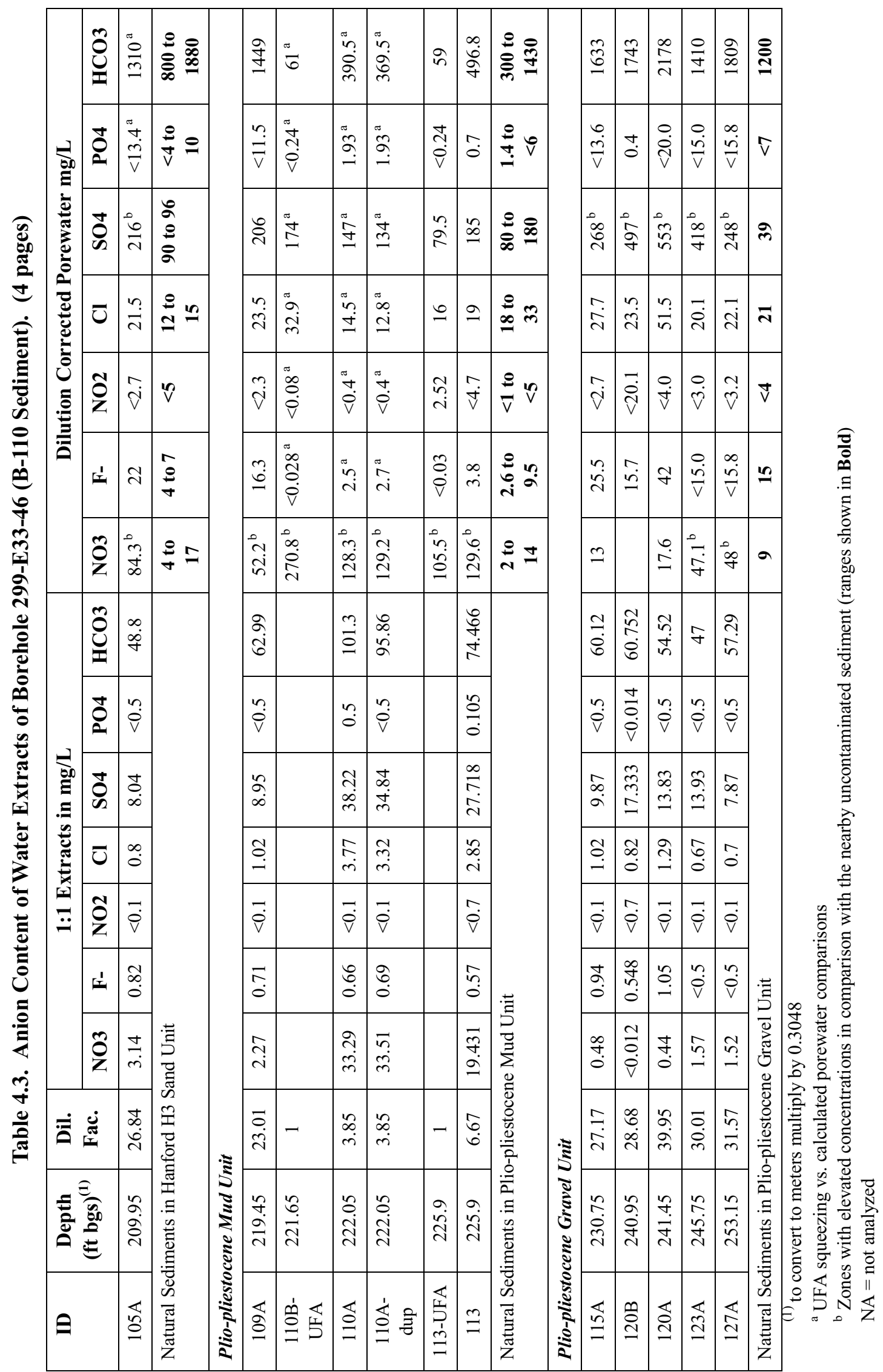




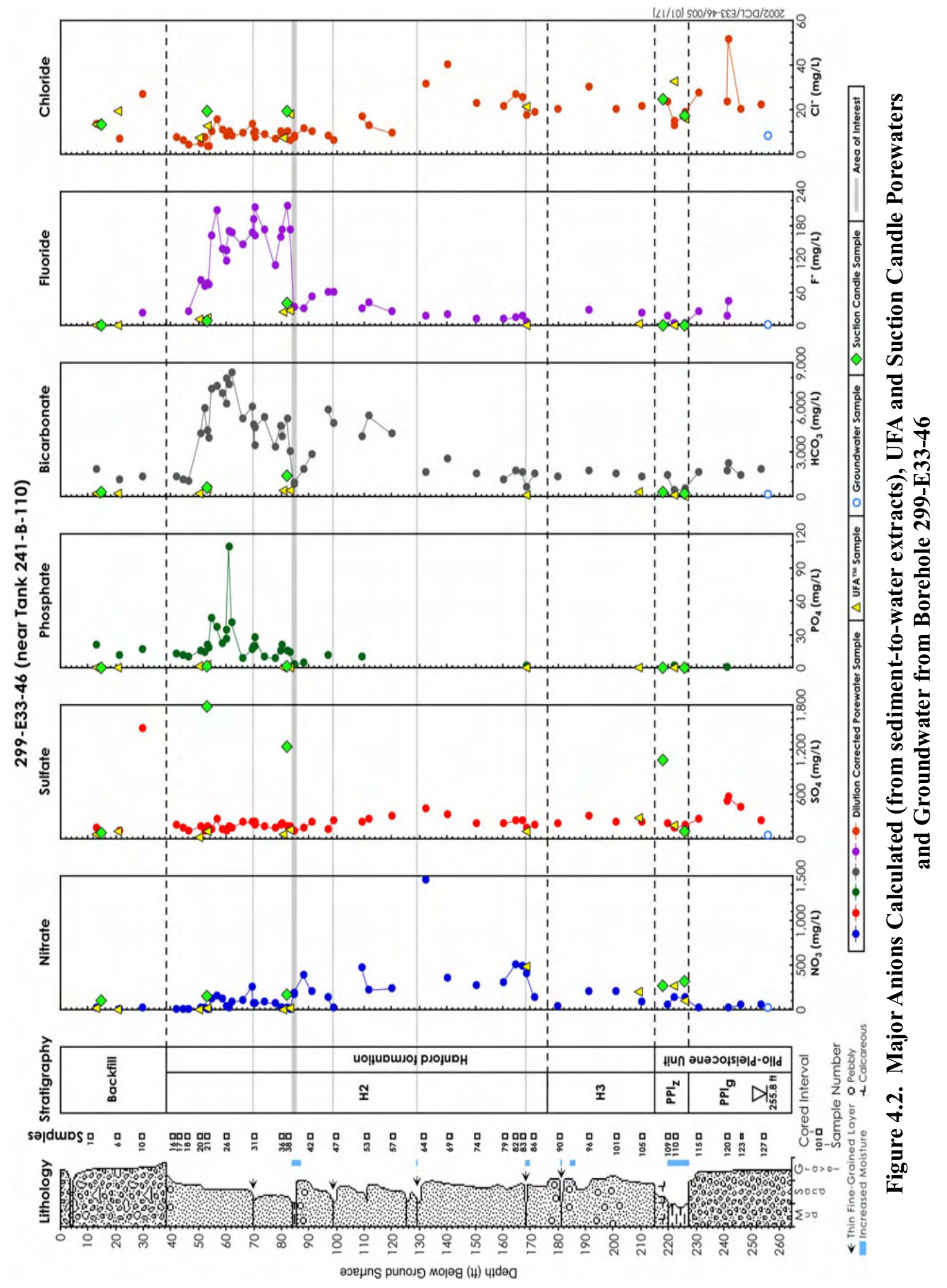




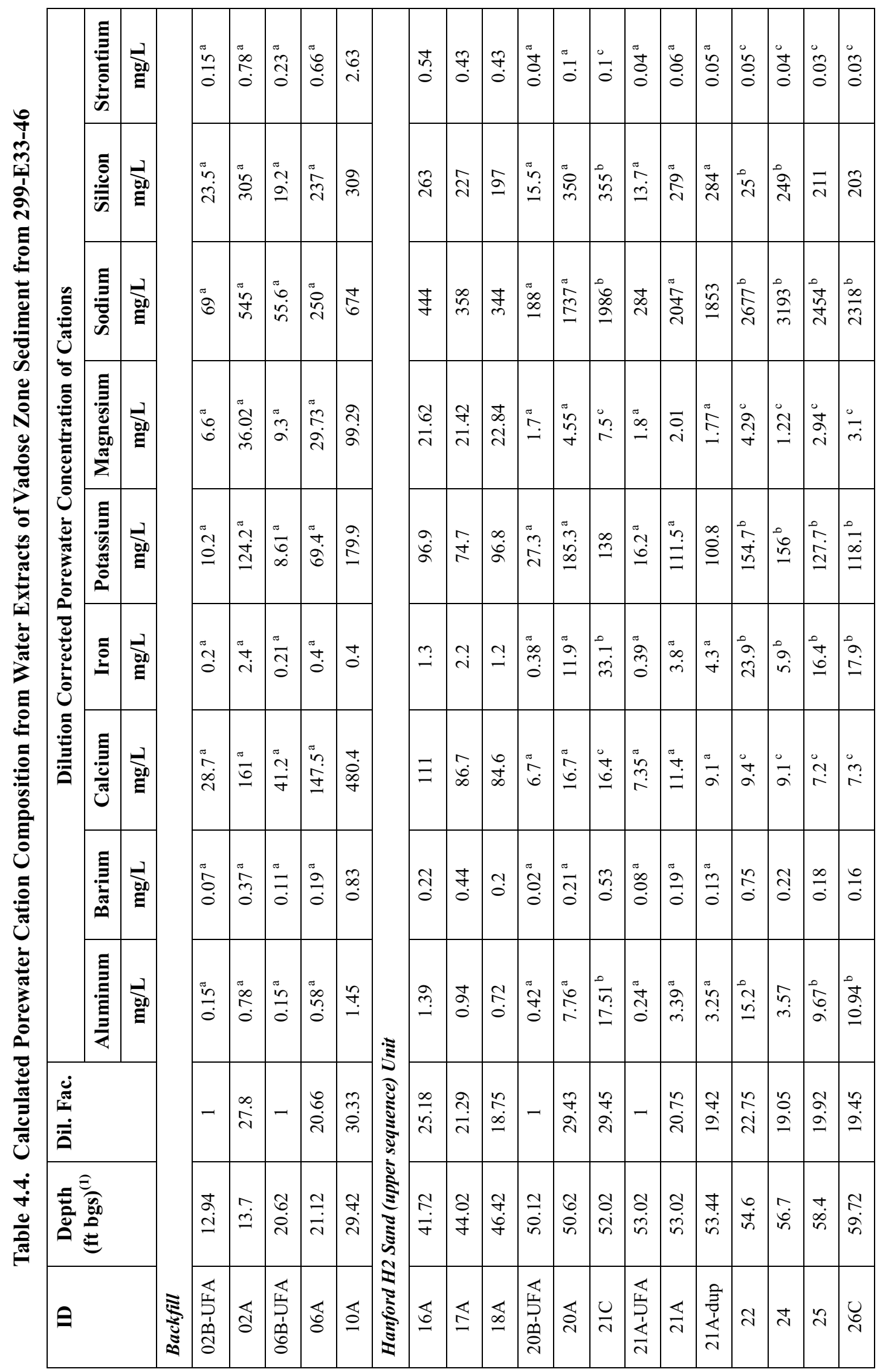




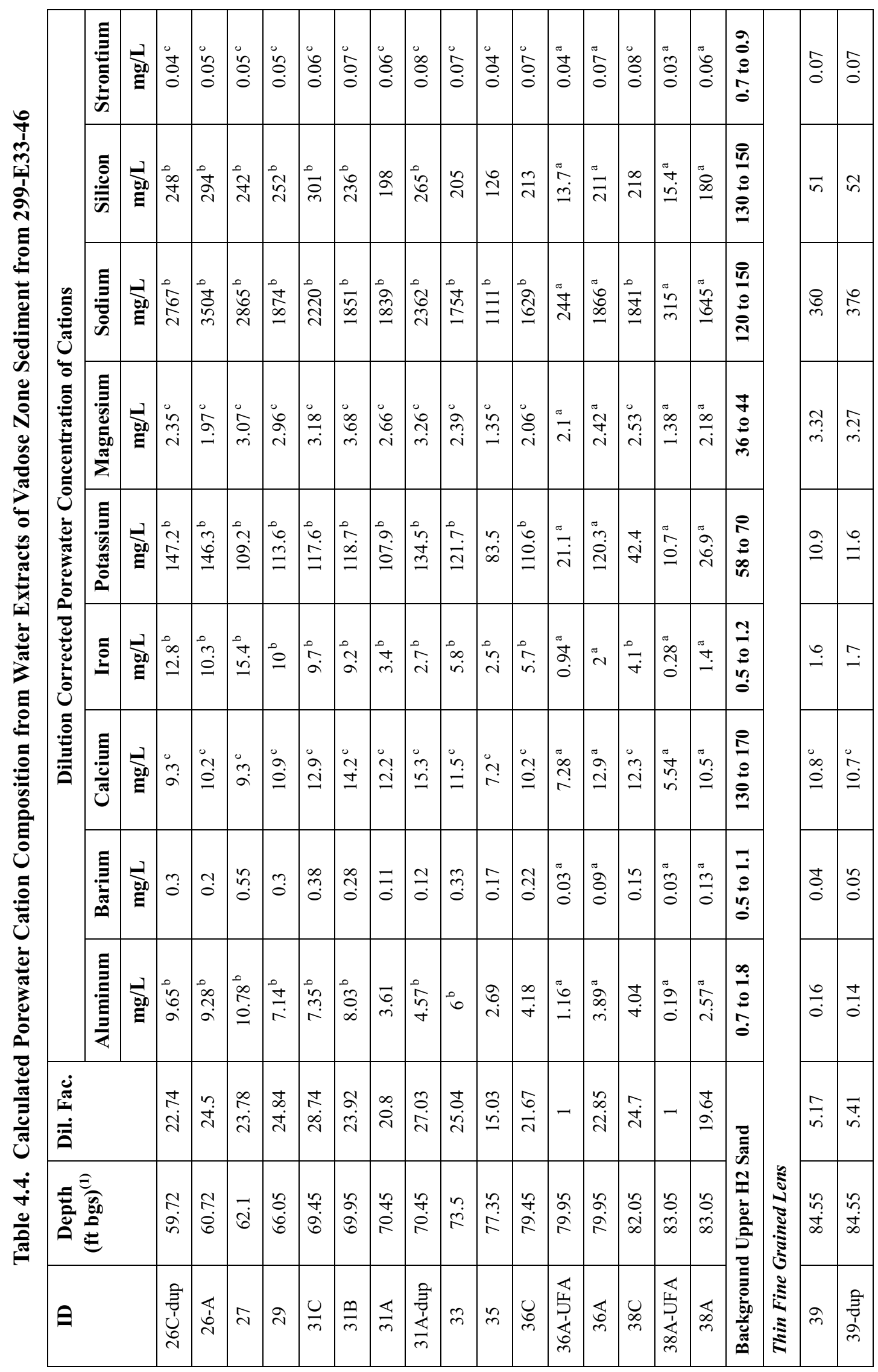




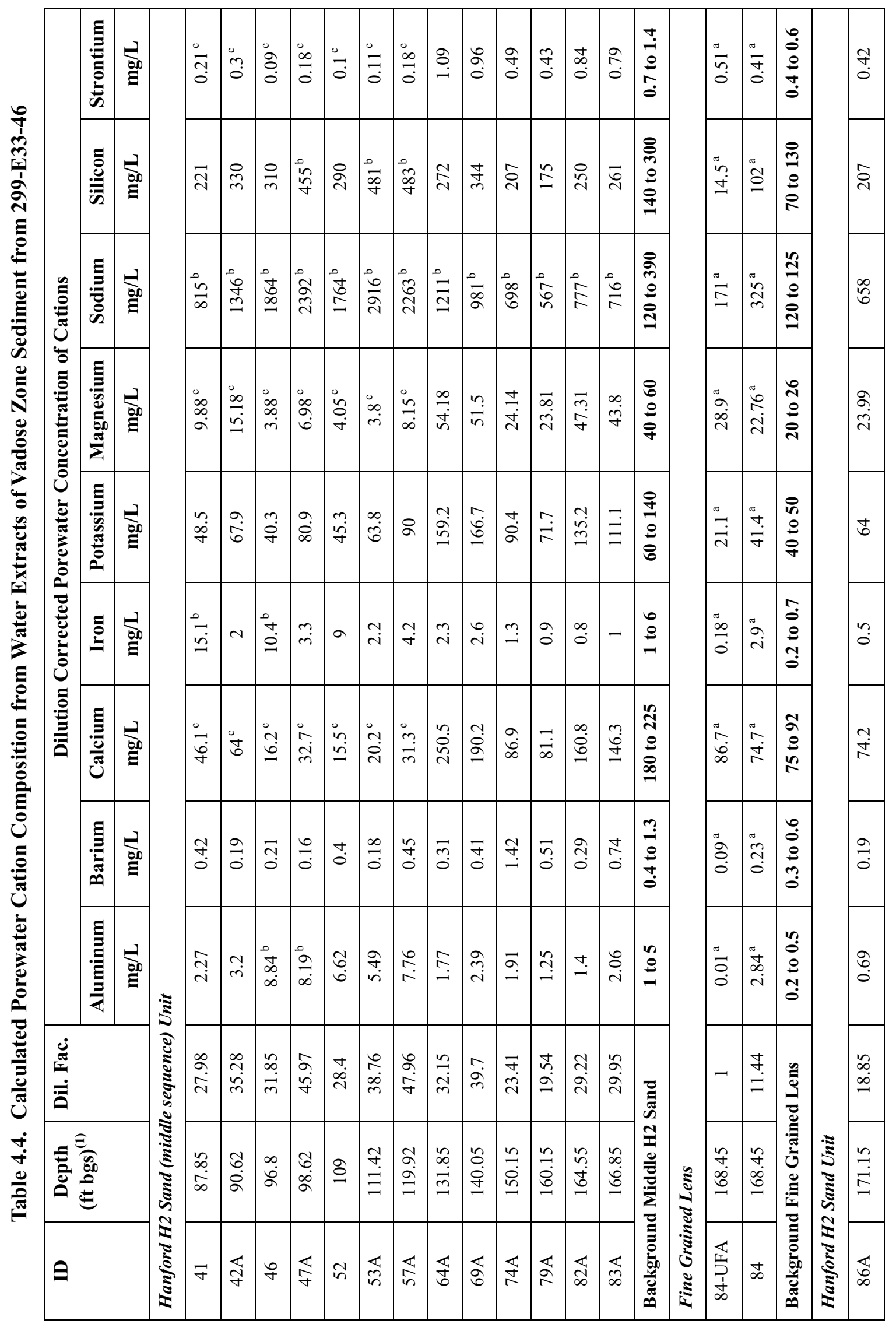




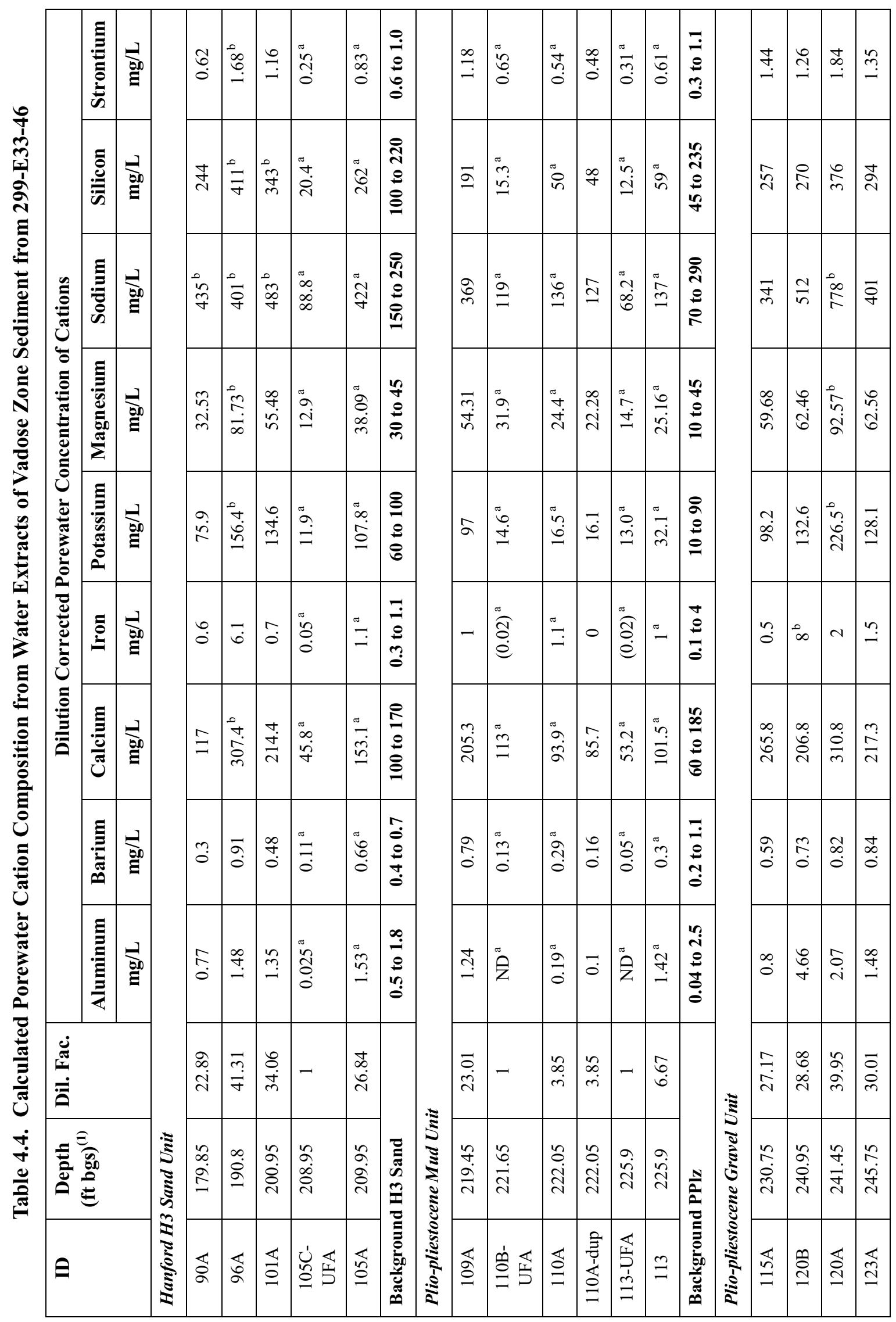




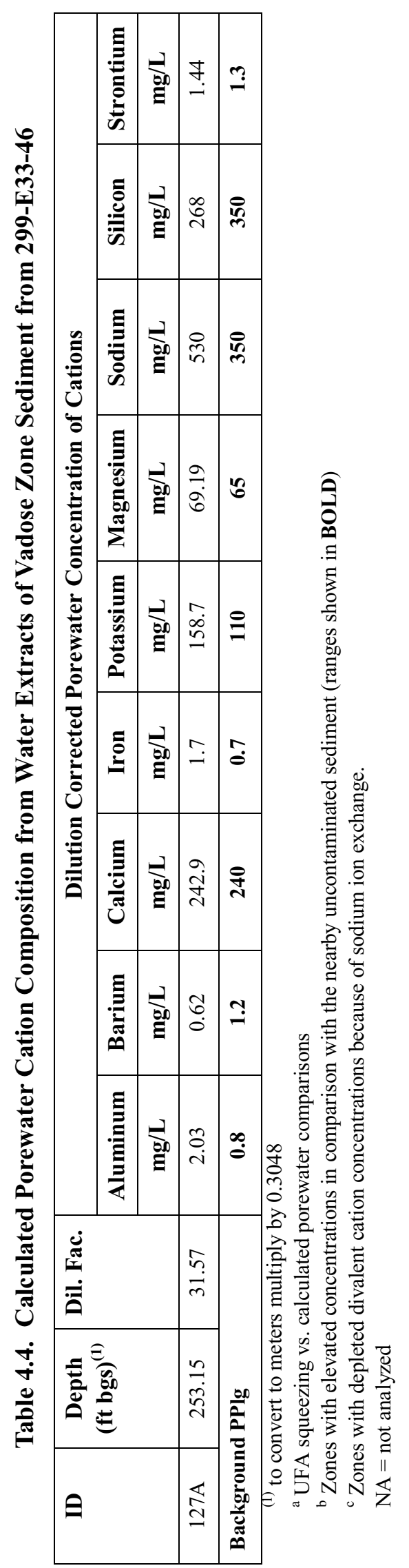




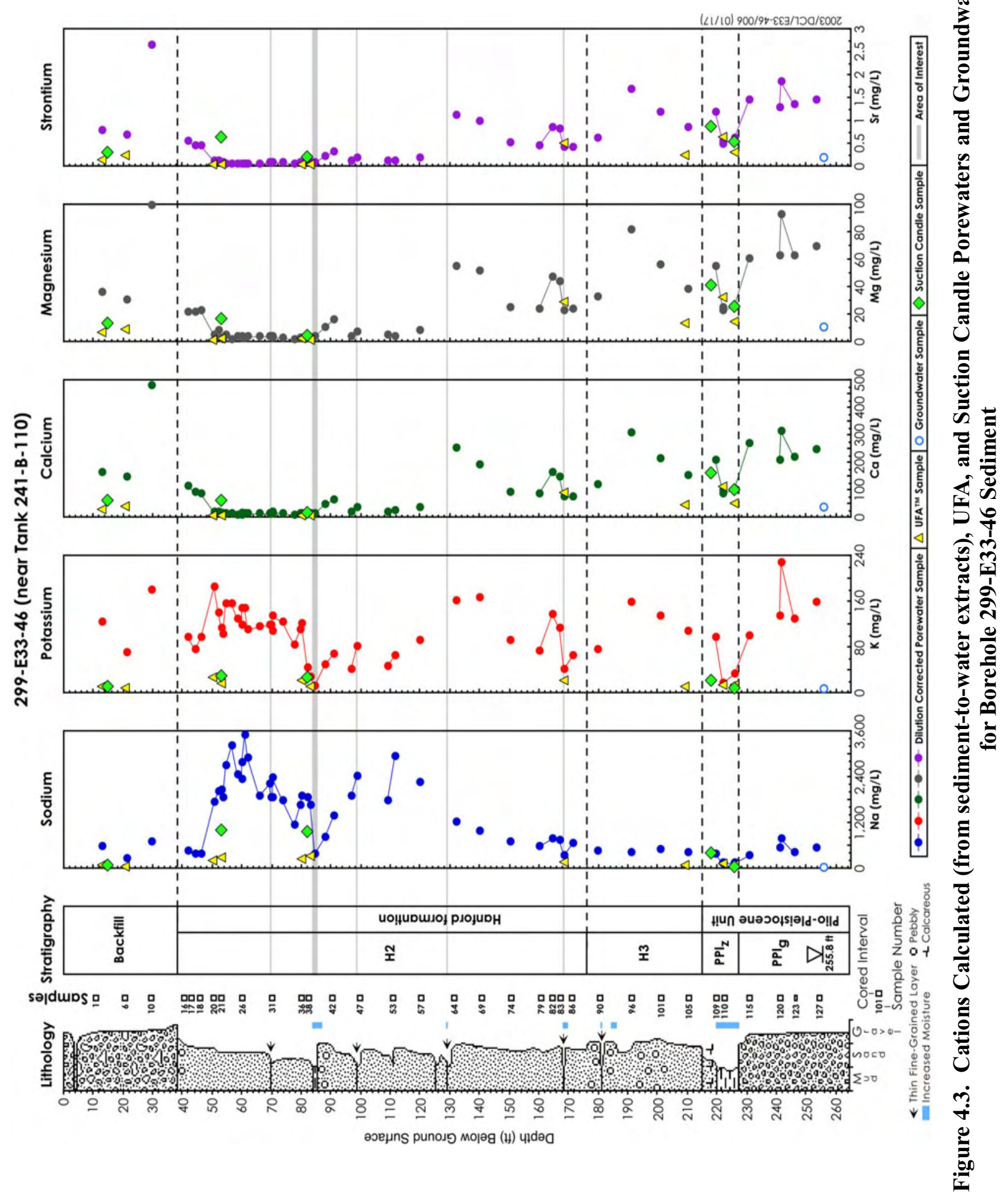


The maximum sodium porewater concentration is about $0.122 \mathrm{M}$ in the zone from 16.6 to $18.9 \mathrm{~m}$ (54.6 to $62.1 \mathrm{ft}$ ) bgs and $0.101 \mathrm{M}$ between 30 and $37 \mathrm{~m}$ (98 and $120 \mathrm{ft}$ ) bgs. The three highest porewaters based on electrical conductivity have a chemical composition that is essentially $0.15 \mathrm{M}$ sodium and $0.13 \mathrm{M}$ bicarbonate, $0.01 \mathrm{M}$ fluoride, $0.007 \mathrm{M}$ sulfate and $0.003 \mathrm{M}$ nitrate.

The actual porewater cation concentrations are in general always lower than the calculated porewater concentrations derived from dilution correcting the 1:1 sediment to water extracts. The actual cation concentrations vary from about one-half as large to one-seventh as large as the calculated porewater concentrations as shown in Table 4.4 in the green shading for samples from the same depth intervals. This suggests that there is readily dissolvable material in the vadose zone sediments that is not in the dissolved state prior to the sediment extraction process.

The divalent cation distributions right below $37 \mathrm{~m}(120 \mathrm{ft})$ bgs do not show significant increases above natural concentrations as would be expected at the very leading edge of the sodium ion exchange pulse. However, the vadose zone sediment at $58 \mathrm{~m}(190 \mathrm{ft})$ bgs does appear to show excess divalent cations, but because the sampling frequency near this depth is one sample every $3 \mathrm{~m}(10 \mathrm{ft})$ it is difficult to delineate whether there is in fact a zone of excess divalent cations at the very leading edge of the sodium plume. The sodium calculated porewater distribution does not show a distinct drop that could be a sign of the maximum vertical extent of the tank related fluid lost to the ground.

This differs from the cation profile from borehole 299-W23-19 that shows very distinct separation of the divalent cations from the sodium plume (see Figure 4.4 in Serne et al. 2002b) or the less pronounced but still discernable separation from the sodium profile at the two more saline plumes between SX-108 and SX-109 tanks (see Figures 4.3 in both Serne et al. 2002c and 2002d). Based on personal communication with Dr. Carl Steefel at Lawrence Livermore National Laboratory, the ion exchange separation of the divalent cations, which are naturally the dominant cations on Hanford sediment exchange sites, from the invading high sodium fluids is maximized when the invading sodium concentrations are not large and when the ion exchange capacity of the sediments is moderate. This was the case at 299-W23-19. The sodium concentrations observed at 299-E33-46 is about the same as at 299-W23-19 and fifty to one hundred thirty times less concentrated than the pore fluids around SX-108/SX-109. The cation exchange capacity of the sediments near the tank B-110 is smaller than the cation exchange capacity for the sediments below the SX tank farm. Both of these facts would make the separation of divalent cations from the sodium porewater plume at 299-E33-46 the same or slightly less than that observed at 299-W23-19. Thus, it seems strange that some separation is not observable at 299-E33-46. Perhaps the fact that sample frequency was only one sample per every $3 \mathrm{~m}(10 \mathrm{ft})$ in the deeper vadose zone at 299-E33-46 as compared to near continuous coring at 299-W23-19 is the problem. Because the chemical composition of the tank fluid lost near tank B-110 is not understood we can not evaluate whether the calculated porewater composition is consistent with the fluids that were lost from tank B-110. See the B-BX-BY FIR section 3.2.2.4 for more details. 


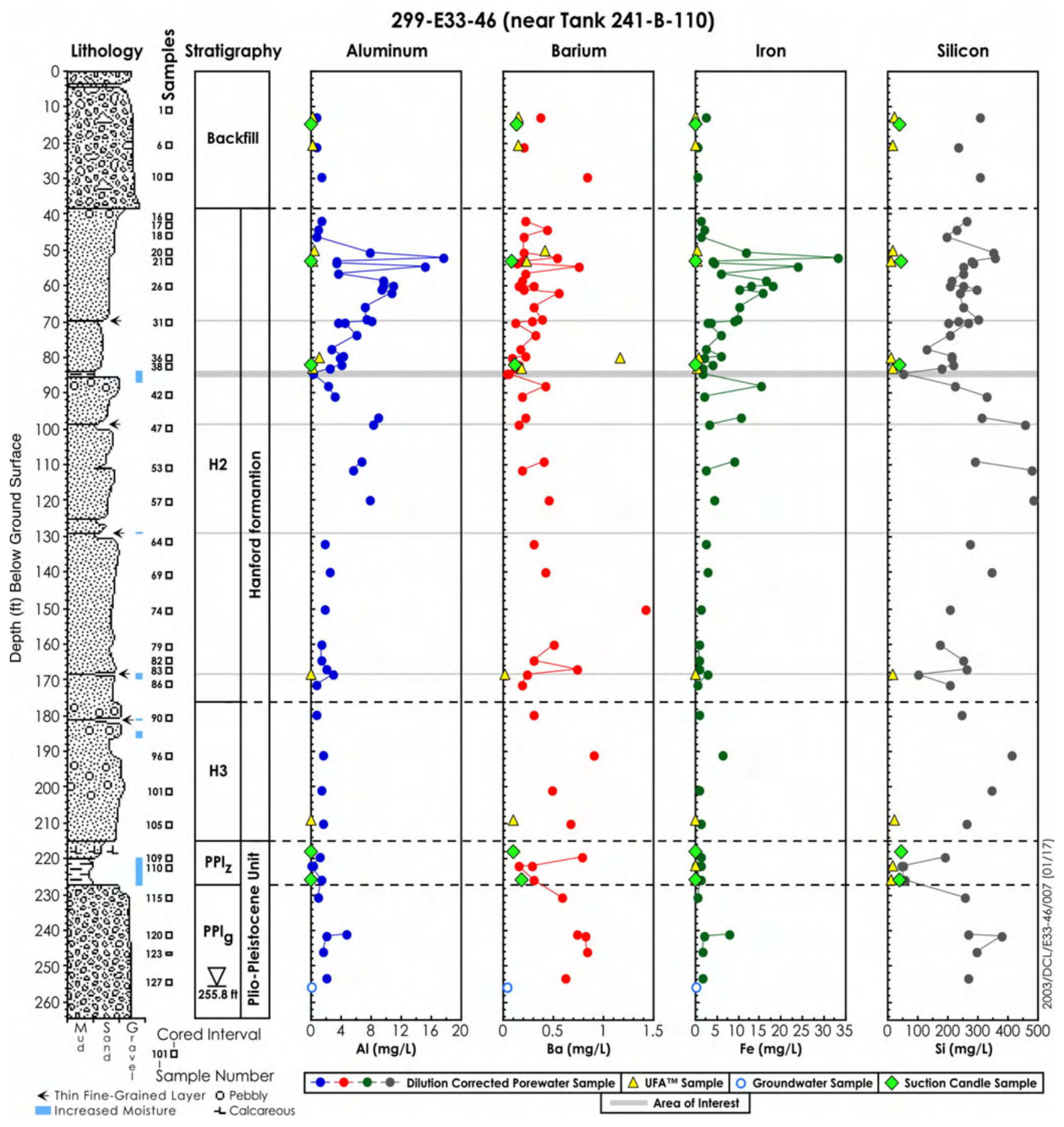

Figure 4.4. Pore Fluid Concentrations of Aluminum, Iron, Silicon, and Manganese (calculated from sediment-to-water extracts), UFA and Suction Candle Porewaters and Groundwater for 299-E33-46 Borehole Sediment 


\subsubsection{Porewater Trace Constituent Composition}

The last group of analyzed constituents included radionuclides and trace metals. Calculated porewater concentrations that were derived from dilution correction of the water extract values are listed in Table 4.5 and shown in Figure 4.5. No strontium- 90 above a detection limit of $9000 \mathrm{pCi} / \mathrm{L}$ was found in water extracts.

Because the sediments are very dry in the Hanford formation (i.e., dilution factors are large), the porewater technetium-99 concentrations appear to be between 39,800 and $89,800 \mathrm{pCi} / \mathrm{L}$ in places within the Hanford formation and as large as $230,000 \mathrm{pCi} / \mathrm{L}$ in the Plio-Pleistocene mud unit. The analytical data are difficult to interpret because of the low acid extractable and water extractable amount of technetium per gram of sediment (generally $<20$ and $<10 \mathrm{pCi} / \mathrm{g}$, respectively). Technetium- 99 water extract and porewater data that are unequivocally above the quantitation limit are shown in Table 4.5. All the data in the shallow depths is suspect thus it is difficult to determine if the technetium profile at 299-E33-46 from the tank B-110 transfer line leak can be traced from below the tank all the way to the groundwater and whether B-110 is the source of technetium-99 in the deep sediments and groundwater. Other sources could be nearby crib discharges.

Table 4.5 and Figure 4.5 show that there are elevated concentrations of uranium in the vadose zone pore water between 15.4 and $37 \mathrm{~m}(50.6$ and $120 \mathrm{ft}$ ) bgs (within the upper sand sequence of H2). There is no indication of elevated uranium in the $\mathrm{H} 3$ unit, PPlz or PPlg units. There is no indication that uranium has penetrated below $37 \mathrm{~m} \mathrm{(120} \mathrm{ft)} \mathrm{bgs} \mathrm{or} \mathrm{into} \mathrm{the} \mathrm{fine-grained} \mathrm{PPlz} \mathrm{strata} \mathrm{at} \mathrm{this} \mathrm{borehole.} \mathrm{Thus} \mathrm{the}$ source of the uranium in the groundwater near the B-BX tank farms is also not definitively explained from the data generated from this borehole. The tank overfill at BX-102 or other sources are much more probable sources for uranium in the groundwater below the B-BX-BY WMA. The pore water data for chromium, arsenic and selenium are not consistent or of sufficient quality, because of low concentrations, to evaluate their vertical distributions and to determine whether Tank B-110 fluids are present in the borehole sediments.

There is very good agreement between the technetium-99 and uranium-238 concentrations found in the actual porewater obtained using the UFA and the dilution corrected sediment-water extracts in all regions and lithologies. 
Table 4.5. Calculated and Actual Porewater Radionuclide Composition for Water Extracts of Sediment from 299-E33-46. (3 Pages)

\begin{tabular}{|c|c|c|c|c|c|}
\hline \multirow[t]{3}{*}{ ID } & \multirow{3}{*}{$\begin{array}{c}\text { Depth } \\
\text { (ft bgs) }^{(1)}\end{array}$} & \multicolumn{4}{|c|}{ Dilution Corrected Porewater Concentrations } \\
\hline & & \multirow[t]{2}{*}{ Dil. Fac. } & Technetium-99 & $\begin{array}{c}\text { Uranium- } \\
238\end{array}$ & $\begin{array}{c}\text { Strontium- } \\
90\end{array}$ \\
\hline & & & $\mathbf{p C i} / \mathbf{L}$ & $\mu \mathrm{g} / \mathrm{L}$ & $\mathrm{pCi} / \mathbf{L}$ \\
\hline \multicolumn{6}{|l|}{ Backfill } \\
\hline 02B-UFA & 12.94 & 1 & $<1000^{\mathrm{a}}$ & $32.2^{\mathrm{a}}$ & NA \\
\hline $02 \mathrm{~A}$ & 13.7 & 27.8 & $<10000^{\mathrm{a}}$ & $27^{\mathrm{a}}$ & $<9000$ \\
\hline 06B-UFA & 20.62 & 1 & $<1000^{\mathrm{a}}$ & $25.4^{\mathrm{a}}$ & NA \\
\hline $06 \mathrm{~A}$ & 21.12 & 20.66 & $<10000^{\mathrm{a}}$ & $24^{\mathrm{a}}$ & $<9000$ \\
\hline $10 \mathrm{~A}$ & 29.42 & 30.33 & $<10000$ & 15 & $<9000$ \\
\hline \multicolumn{6}{|c|}{ Hanford H2 Sand (upper sequence) Unit } \\
\hline $16 \mathrm{~A}$ & 41.72 & 25.18 & $<10000$ & 22 & $<9000$ \\
\hline $17 \mathrm{~A}$ & 44.02 & 21.29 & $<10000$ & 21 & $<9000$ \\
\hline $18 \mathrm{~A}$ & 46.42 & 18.75 & $<10000$ & 35 & $<9000$ \\
\hline 20B-UFA & 50.12 & 1 & $(1.35 \mathrm{E}+03)$ & 39.7 & NA \\
\hline $20 \mathrm{~A}$ & 50.62 & 29.43 & $<10000$ & $70^{b}$ & $<9000$ \\
\hline $21 \mathrm{C}$ & 52.02 & 29.45 & $(3496)$ & $63^{b}$ & $<9000$ \\
\hline 21A-UFA & 53.02 & 1 & $(1.12 \mathrm{E}+04)^{\mathrm{c}}$ & $93.6^{\mathrm{ab}}$ & NA \\
\hline $21 \mathrm{~A}$ & 53.02 & 20.75 & $<10000^{\mathrm{a}}$ & $69^{\mathrm{ab}}$ & $<9000$ \\
\hline 21A-dup & 53.44 & 19.42 & $<10000^{\mathrm{a}}$ & $66^{\mathrm{ab}}$ & $<9000$ \\
\hline 22 & 54.6 & 22.75 & $(3859)$ & $597^{b}$ & $<9000$ \\
\hline 24 & 56.7 & 19.05 & (3231) & $632^{b}$ & $<9000$ \\
\hline 25 & 58.4 & 19.92 & $(3040)$ & $175^{b}$ & $<9000$ \\
\hline $26 \mathrm{C}$ & 59.72 & 19.45 & (2968) & $148^{\mathrm{b}}$ & $<9000$ \\
\hline 26C-dup & 59.72 & 22.74 & $(3085)$ & $180^{b}$ & $<9000$ \\
\hline $26-\mathrm{A}$ & 60.72 & 24.5 & (2493) & $560^{b}$ & $<9000$ \\
\hline 27 & 62.1 & 23.78 & (2823) & $842^{b}$ & $<9000$ \\
\hline 29 & 66.05 & 24.84 & (3370) & $2056^{\mathrm{b}}$ & $<9000$ \\
\hline $31 \mathrm{C}$ & 69.45 & 28.74 & (5849) & $9714^{b}$ & $<9000$ \\
\hline $31 \mathrm{~B}$ & 69.95 & 23.92 & $(5275)$ & $9731^{b}$ & $<9000$ \\
\hline $31 \mathrm{~A}$ & 70.45 & 20.8 & $<10000$ & $8510^{b}$ & $<9000$ \\
\hline 31A-dup & 70.45 & 27.03 & $<10000$ & $10946^{\mathrm{b}}$ & $<9000$ \\
\hline 33 & 73.5 & 25.04 & (2972) & $2703^{b}$ & $<9000$ \\
\hline
\end{tabular}


Table 4.5. Calculated and Actual Porewater Radionuclide Composition for Water Extracts of Sediment from 299-E33-46. (3 Pages)

\begin{tabular}{|c|c|c|c|c|c|}
\hline \multirow[t]{3}{*}{ ID } & \multirow{3}{*}{$\begin{array}{c}\text { Depth } \\
\text { (ft bgs) }\end{array}$} & \multicolumn{4}{|c|}{ Dilution Corrected Porewater Concentrations } \\
\hline & & \multirow[t]{2}{*}{ Dil. Fac. } & Technetium-99 & $\begin{array}{c}\text { Uranium- } \\
238\end{array}$ & $\begin{array}{c}\text { Strontium- } \\
90\end{array}$ \\
\hline & & & $\mathrm{pCi} / \mathrm{L}$ & $\mu \mathrm{g} / \mathrm{L}$ & $\mathrm{pCi} / \mathrm{L}$ \\
\hline 35 & 77.35 & 15.03 & (2039) & $1351^{b}$ & $<9000$ \\
\hline $36 \mathrm{C}$ & 79.45 & 21.67 & $(2940)$ & $1847^{b}$ & $<9000$ \\
\hline 36A-UFA & 79.95 & 1 & $(2.03 \mathrm{E}+03)^{\mathrm{a}}$ & $638^{\mathrm{ab}}$ & $\mathrm{NA}$ \\
\hline $36 \mathrm{~A}$ & 79.95 & 22.85 & $(11627)^{\mathrm{a}}$ & $2161^{\mathrm{ab}}$ & $<9000$ \\
\hline $38 \mathrm{C}$ & 82.05 & 24.7 & $(2933)$ & 3547 & $<9000$ \\
\hline 38A-UFA & 83.05 & 1 & $(3.55 \mathrm{E}+03)^{\mathrm{a}}$ & $1215^{\mathrm{ab}}$ & NA \\
\hline $38 \mathrm{~A}$ & 83.05 & 19.64 & $(19315)^{\mathrm{a}}$ & $3425^{\mathrm{ab}}$ & $<9000$ \\
\hline \multicolumn{3}{|c|}{ Background Upper H2 Sand } & $<\mathbf{1 0 0 0 0}$ & 6 to 9 & \\
\hline \multicolumn{6}{|c|}{ Thin Fine Grained Lens } \\
\hline 39 & 84.55 & 5.17 & $(1314)$ & $312^{\mathrm{b}}$ & $<9000$ \\
\hline 39-dup & 84.55 & 5.41 & $(1467)$ & $270^{\mathrm{b}}$ & $<9000$ \\
\hline \multicolumn{6}{|c|}{ Hanford H2 Sand (middle sequence) Unit } \\
\hline 41 & 87.85 & 27.98 & $(4271)$ & 40 & $<9000$ \\
\hline $42 \mathrm{~A}$ & 90.62 & 35.28 & $<10000$ & $160^{\mathrm{b}}$ & $<9000$ \\
\hline 46 & 96.8 & 31.85 & $(3781)$ & $836^{\mathrm{b}}$ & $<9000$ \\
\hline $47 \mathrm{~A}$ & 98.62 & 45.97 & $<10000$ & $580^{\mathrm{b}}$ & $<9000$ \\
\hline 52 & 109 & 28.4 & $(8669)$ & $98^{\mathrm{b}}$ & $<9000$ \\
\hline $53 \mathrm{~A}$ & 111.42 & 38.76 & $(657)$ & $150^{\mathrm{b}}$ & $<9000$ \\
\hline $57 \mathrm{~A}$ & 119.92 & 47.96 & $<10000$ & $141^{\mathrm{b}}$ & $<9000$ \\
\hline $64 \mathrm{~A}$ & 131.85 & 32.15 & $(91071)$ & 31 & $<9000$ \\
\hline $69 \mathrm{~A}$ & 140.05 & 39.7 & $(30970)$ & 33 & $<9000$ \\
\hline $74 \mathrm{~A}$ & 150.15 & 23.41 & $(15088)$ & 32 & $<9000$ \\
\hline $79 \mathrm{~A}$ & 160.15 & 19.54 & $(15576)$ & 26 & $<9000$ \\
\hline $82 \mathrm{~A}$ & 164.55 & 29.22 & $(36181)$ & 43 & $<9000$ \\
\hline $83 \mathrm{~A}$ & 166.85 & 29.95 & $(40382)$ & 34 & $<9000$ \\
\hline \multicolumn{3}{|c|}{ Background Middle H2 Sand } & $<10000$ & 7 to 24 & \\
\hline \multicolumn{6}{|c|}{ Fine Grained Lens } \\
\hline 84-UFA & 168.45 & 1 & $3.90 \mathrm{E}+04^{\mathrm{ab}}$ & $32.3^{\mathrm{a}}$ & NA \\
\hline 84 & 168.45 & 11.44 & $31438^{\mathrm{ab}}$ & $18^{\mathrm{a}}$ & $<9000$ \\
\hline \multicolumn{3}{|c|}{ Background Fine Grained Lens } & $<10000$ & 7 to 10 & \\
\hline
\end{tabular}


Table 4.5. Calculated and Actual Porewater Radionuclide Composition for Water Extracts of Sediment from 299-E33-46. (3 Pages)

\begin{tabular}{|c|c|c|c|c|c|}
\hline \multirow[t]{3}{*}{ ID } & \multirow{3}{*}{$\begin{array}{c}\text { Depth } \\
(\text { ft bgs })^{(1)}\end{array}$} & \multicolumn{4}{|c|}{ Dilution Corrected Porewater Concentrations } \\
\hline & & \multirow[t]{2}{*}{ Dil. Fac. } & Technetium-99 & $\begin{array}{c}\text { Uranium- } \\
238\end{array}$ & $\begin{array}{c}\text { Strontium- } \\
90\end{array}$ \\
\hline & & & $\mathbf{p C i} / \mathbf{L}$ & $\mu \mathrm{g} / \mathrm{L}$ & $\mathbf{p C i} / \mathbf{L}$ \\
\hline \multicolumn{6}{|c|}{ Hanford H2 Sand Unit } \\
\hline $86 \mathrm{~A}$ & 171.15 & 18.85 & $(23013)$ & 33 & $<9000$ \\
\hline \multicolumn{6}{|c|}{ Hanford H3 Sand Unit } \\
\hline $90 \mathrm{~A}$ & 179.85 & 22.89 & $(24454)$ & 27 & $<9000$ \\
\hline $96 \mathrm{~A}$ & 190.8 & 41.31 & $(129618)$ & 24 & $<9000$ \\
\hline $101 \mathrm{~A}$ & 200.95 & 34.06 & $(164075)$ & 19 & $<9000$ \\
\hline 105C-UFA & 208.95 & 1 & $1.25 \mathrm{E}+05^{\mathrm{ab}}$ & $11.5^{\mathrm{a}}$ & NA \\
\hline $105 \mathrm{~A}$ & 209.95 & 26.84 & $(55542)^{a b}$ & $17^{\mathrm{a}}$ & $<9000$ \\
\hline \multicolumn{3}{|c|}{ Background H3 Sand } & $<10000$ & 8 to 13 & \\
\hline \multicolumn{6}{|c|}{ Plio-pliestocene Mud Unit } \\
\hline 109A & 219.45 & 23.01 & $(89756)$ & 17 & $<9000$ \\
\hline 110B-UFA & 221.65 & 1 & $3.09 \mathrm{E}+04$ & 22.4 & NA \\
\hline $110 \mathrm{~A}$ & 222.05 & 3.85 & 89755 & 5 & $<9000$ \\
\hline 110A-dup & 222.05 & 3.85 & 84523 & 4 & $<9000$ \\
\hline 113-UFA & 225.9 & 1 & $2.30 \mathrm{E}+05^{\mathrm{ab}}$ & $9.0^{\mathrm{a}}$ & NA \\
\hline 113 & 225.9 & 6.67 & $39832^{\mathrm{ab}}$ & $5^{\mathrm{a}}$ & $<9000$ \\
\hline \multicolumn{3}{|c|}{ Background PPlz } & $<10000$ & 2 to 10 & \\
\hline \multicolumn{6}{|c|}{ Plio-pliestocene Gravel Unit } \\
\hline $115 \mathrm{~A}$ & 230.75 & 27.17 & $(21656)$ & 12 & $<9000$ \\
\hline 120B & 240.95 & 28.68 & (11189) & 13 & $<9000$ \\
\hline $120 \mathrm{~A}$ & 241.45 & 39.95 & $<10000$ & 20 & $<9000$ \\
\hline $123 \mathrm{~A}$ & 245.75 & 30.01 & $(20867)$ & 10 & $<9000$ \\
\hline $127 \mathrm{~A}$ & 253.15 & 31.57 & $<10000$ & 12 & $<9000$ \\
\hline \multicolumn{3}{|c|}{ Background PPlg } & $<10000$ & 15 & \\
\hline
\end{tabular}

(1) to convert to meters multiply by 0.3048

${ }^{a}$ UFA squeezing vs. calculated porewater comparisons

${ }^{\mathrm{b}}$ Zones with elevated concentrations in comparison with the nearby uncontaminated sediment (uncontaminated ranges shown in BOLD)

$\mathrm{NA}=$ not analyzed

( ) = values in parentheses are below quantitation limit but above the detection limit and thus considered useful 


\subsubsection{Porewater Solute Ratios}

Besides plotting individual constituent porewater profiles versus depth, we calculated ratios of some of the major constituents in strontium recovery waste, which as discussed in the B-BX-BY FIR section 3.2.2.4 is the best guess as to the type of waste that was lost from piping associated with tank B-110. The best, yet incomplete, estimate of the chemical composition of strontium recovery waste is shown in Table 4.6, which is taken from Table 3.8 in the B-BX-BY FIR and originally from Larson 1967. The ratios for several key parameters in Larson's estimate are shown in Tables 4.7 and 4.8. These ratios have the units of $\mathrm{pCi} / \mathrm{mg}$ for the technetium-99 to fluoride or other chemicals and $\mathrm{mg} / \mathrm{mg}$ for the ratios of various chemicals to each other, excepting ratios with uranium that has units of $\mu \mathrm{g}$.

The dilution corrected porewaters in general do not appear to be of the same composition as this estimate for strontium recovery waste. The technetium-99 concentrations found in the porewaters are generally much lower than those that should be found in strontium recovery waste. Compared to the fluoride found in the porewater, both the technetium-99 and nitrate are too low based on Larson's estimates of the chemical composition of strontium recovery waste. Based on the sodium to fluoride ratios in the porewater, there is too little sodium by a factor of 2 to 4 in the zone where both chemicals are at their highest concentrations (from 15 to $25 \mathrm{~m}$ [50 to $83 \mathrm{ft}$ ] bgs). Two explanations are that the sodium is reacting with the sediments (adsorbing onto cation exchange sites) while fluoride does not interact as much or the Larson estimate may overestimate the sodium concentration in the waste stream. The sodium to fluoride ratio does approach Larson's ratio over the depth of 90 to near the bottom of the $\mathrm{H} 2$ sand unit at $51 \mathrm{~m}(168 \mathrm{ft}) \mathrm{bgs}$, above the fine-grained thin lens of silt. The bicarbonate to fluoride ratio in the porewater is much higher than Larson's estimate for strontium recovery waste excepting between 21 and $26 \mathrm{~m}$ ( 70 and $85 \mathrm{ft}$ ) bgs where the ratio agrees with the estimate. The sediment and the vadose air are large sources of inorganic carbon besides the waste stream so that one might expect the environment to dominate the ratio moreso than the waste stream. In Tables 4.7 and 4.8, the porewater ratios that are reasonably close to the Larson estimate for strontium recovery waste are shown in red type. Most of the porewater samples do not have ratios that are very close to the strontium recovery waste. However, as discussed in the B-BX-BY FIR the other waste streams considered are even further out of sync with the measured porewaters from borehole 299-E33-46. We agree with the summary statement made in the FIR:

"Neither the volume nor the waste type is well understood for the borehole placed near B-110. Soils analysis data from borehole 299-E33-46 indicate a waste stream rich in strontium-90, fluoride, and bicarbonate. Historical records suggest a plausible waste stream derived from strontium recovery waste from dissolved PUREX fuel as opposed to an initial conclusion (Jones et al. 2001) that the waste was a cesium recovery waste similar to that released by the tank BX-101 pump pit leak."

One method to evaluate vertical migration of mobile contaminants from the B-110 release would be to plot ratios of the key contaminants versus nitrate or some other conservative (non-sorbing) constituent in the leaked fluid. If tank liquor dilution with extant porewater, potable water line leaks, or recharge water were the only reasons for the decrease in concentrations for all the mobile constituents, then the ratios of one to another should remain constant from the source to the furthest extent of migration as long as the diluting water did not contain the mobile constituents. 
Table 4.6. Strontium-90 Recovery Waste Streams from Zirconium-Clad Fuel ${ }^{\text {(a) }}$

\begin{tabular}{|c|c||c|c|}
\hline Chemical / Radionuclide (M) & Concentration & Chemical / Radionuclide & Concentration \\
\hline Sodium & 3.3 & Phosphate (M) & $<0.003$ \\
\hline Aluminum & 0.0305 & Total Carbonate (M) & $0.8^{\text {(c) }}$ \\
\hline Iron & $<0.1$ & Fluoride (M) & 0.10 \\
\hline Chromium & 0.00545 & HEDTA (M) & 0.52 \\
\hline Hydrogen & (b) & Hydroxyacetic acid (M) & 0.25 \\
\hline Hydroxide & (b) & Cs-137 (Ci/gal) & Assumed $~ 2$ \\
\hline Nitrate & $3.1-4.0$ & $\mathrm{Sr}-90(\mathrm{Ci} / \mathrm{gal})$ & 0.43 \\
\hline Nitrite & $\mathrm{NR}$ & $\mathrm{Tc}-99$ & $0.00042 \mathrm{M}$ \\
\hline Sulfate & $<1.8$ & $\mathrm{pH}$ & $\sim 10$ (assumed) \\
\hline
\end{tabular}

(a) Data in this includes the 1AW data from Table 11 of Larson 1967

(b) Assumed waste stream neutralized to $\mathrm{pH} \sim 10$ with sodium carbonate.

(c) Assumed sodium carbonate used to neutralize HEDTA, AcOH, and initial acid.

Reference: Larson 1967, "B Plant Phase III Flowsheets", ISO-986. 


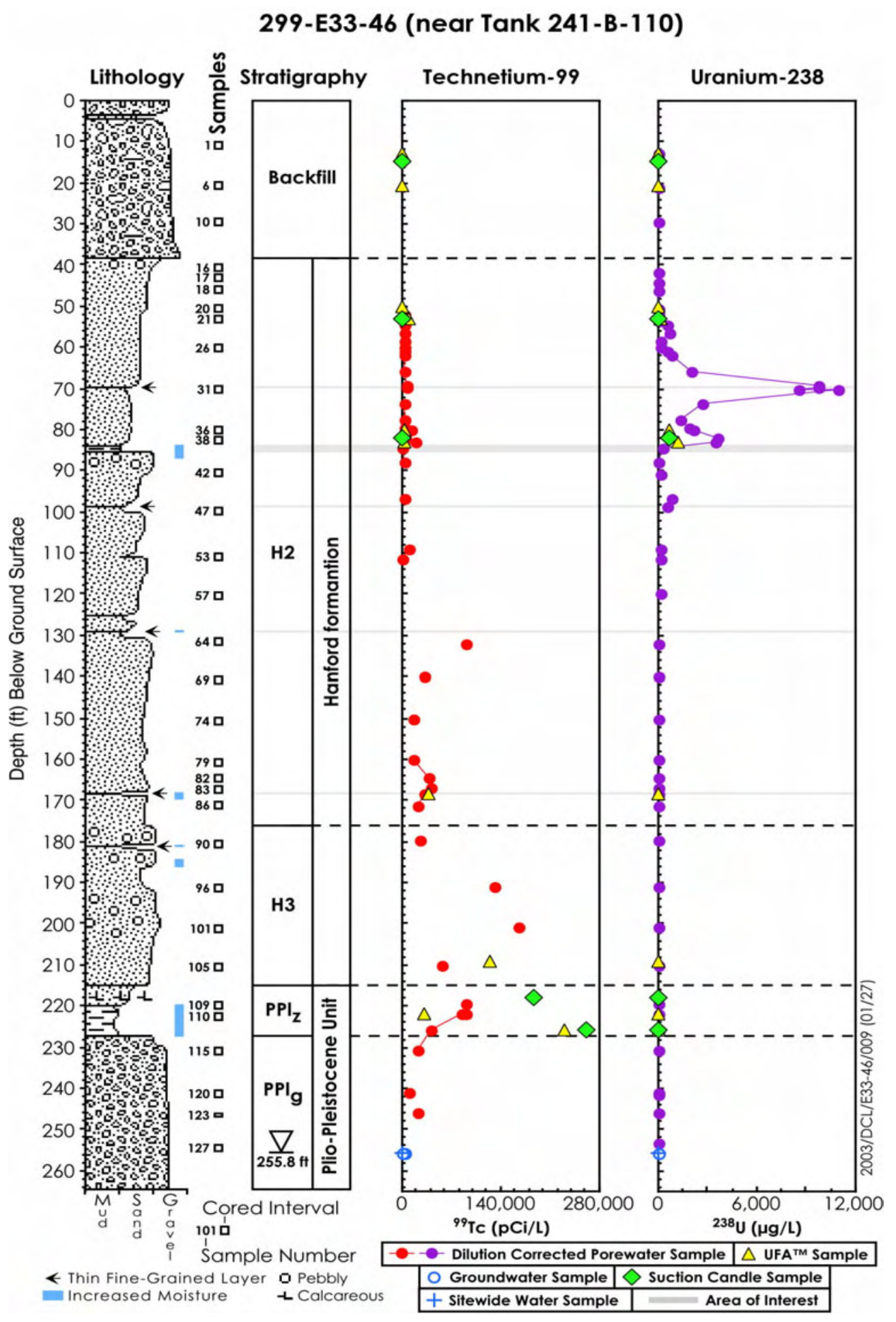

Figure 4.5 Radionuclide Pore Water (calculated from sediment-to-water extracts), UFA and Suction Candle Porewaters and Groundwater for 299-E33-46 Borehole Sediment 
Table 4.7. Ratio of Major Strontium Recovery Waste to Fluoride Found in Dilution Corrected 1:1 Water to Sediment Extracts

\begin{tabular}{|c|c|c|c|c|c|c|}
\hline ID & $\begin{array}{c}\text { Depth } \\
\text { (ft bgs) }^{(1)}\end{array}$ & $\begin{array}{c}\mathrm{NO}_{3} / \mathrm{F} \\
(\mathrm{mg} / \mathrm{mg})\end{array}$ & $\begin{array}{c}{ }^{99} \mathrm{Tc} / \mathrm{F} \\
(\mathrm{pCi} / \mathrm{mg})\end{array}$ & $\begin{array}{c}\mathrm{Na} / \mathrm{F} \\
(\mathrm{mg} / \mathrm{mg})\end{array}$ & $\begin{array}{c}\mathrm{SO}_{4} / \mathrm{F} \\
(\mathrm{mg} / \mathrm{mg})\end{array}$ & $\begin{array}{l}\mathrm{HCO}_{3} / \mathrm{F} \\
(\mathrm{mg} / \mathrm{mg})\end{array}$ \\
\hline \multicolumn{2}{|c|}{$\begin{array}{c}\text { Strontium Recovery Waste } \\
\text { Stream }\end{array}$} & 114 & $3.71 \mathrm{E}+05$ & 39.9 & 75.8 & 25.68 \\
\hline \multicolumn{7}{|l|}{ Backfill } \\
\hline $02 \mathrm{~A}$ & 13.70 & 0.74 & 0 & $39.2^{\mathrm{a}}$ & 10.4 & 130.95 \\
\hline $06 \mathrm{~A}$ & 21.12 & 0.6 & 0 & 24.2 & 10.0 & 110.35 \\
\hline $10 \mathrm{~A}$ & 29.42 & 0.58 & 0 & $32.2^{\mathrm{a}}$ & $71.2^{\mathrm{a}}$ & 64.00 \\
\hline \multicolumn{7}{|c|}{ Hanford H2 Sand (upper sequence) Unit } \\
\hline $16 \mathrm{~A}$ & 41.72 & 0.6 & 0.0 & 35.3 & 14.4 & 102.69 \\
\hline $17 \mathrm{~A}$ & 44.02 & 0.76 & 0.0 & 33.6 & 13.1 & 101.29 \\
\hline $18 \mathrm{~A}$ & 46.42 & 0.35 & 0.0 & 14.0 & 3.9 & 42.19 \\
\hline $20 \mathrm{~A}$ & 50.62 & 0.13 & 0.0 & 21.3 & 1.9 & 51.43 \\
\hline $21 \mathrm{C}$ & 52.02 & 0.23 & 49.7 & 28.2 & 1.4 & 83.32 \\
\hline $21 \mathrm{~A}$ & 53.02 & 0.09 & 0.0 & 27.2 & 2.2 & 59.03 \\
\hline 21A-dup & 53.44 & 0.10 & 0.0 & 25.9 & 1.9 & 54.27 \\
\hline 22 & 54.60 & 0.72 & 24.2 & 16.8 & 0.7 & 45.33 \\
\hline 24 & 56.70 & 0.75 & 15.7 & 15.5 & 1.2 & 35.90 \\
\hline 25 & 58.40 & 0.85 & 22.4 & 18.1 & 0.9 & 51.20 \\
\hline $26 \mathrm{C}$ & 59.72 & 0.29 & 25.7 & 20.1 & 0.9 & 53.78 \\
\hline 26C-dup & 59.72 & 0.31 & 22.9 & 20.5 & 0.9 & 58.81 \\
\hline $26-\mathrm{A}$ & 60.72 & 0.10 & 14.9 & 21.0 & 1.0 & 45.03 \\
\hline 27 & 62.10 & 0.54 & 17.2 & 17.4 & 0.8 & 50.85 \\
\hline 29 & 66.05 & 0.69 & 23.2 & 12.9 & 1.6 & 36.25 \\
\hline $31 \mathrm{C}$ & 69.45 & 1.51 & 35.5 & 13.5 & 1.4 & 36.23 \\
\hline $31 \mathrm{~B}$ & 69.95 & 0.37 & 27.9 & 9.8 & 1.1 & $25.56^{\mathrm{a}}$ \\
\hline $31 \mathrm{~A}$ & 70.45 & 0.39 & 0.0 & 11.5 & 1.1 & $21.08^{\mathrm{a}}$ \\
\hline 31A-dup & 70.45 & 0.31 & 0.0 & 11.2 & 1.1 & $21.98^{\mathrm{a}}$ \\
\hline 33 & 73.50 & 0.48 & 17.4 & 10.2 & 1.0 & $31.16^{\mathrm{a}}$ \\
\hline 35 & 77.35 & 0.69 & 19.1 & 10.4 & 1.3 & $30.65^{\mathrm{a}}$ \\
\hline $36 \mathrm{C}$ & 79.45 & 0.12 & 18.6 & 10.3 & 1.2 & $29.80^{\mathrm{a}}$ \\
\hline $36 \mathrm{~A}$ & 79.95 & 0.07 & 68.3 & 11.0 & 1.2 & $23.58^{\mathrm{a}}$ \\
\hline $38 \mathrm{C}$ & 82.05 & 0.06 & 13.8 & 8.7 & 0.8 & $24.37^{\mathrm{a}}$ \\
\hline
\end{tabular}


Table 4.7. Ratio of Major Strontium Recovery Waste to Fluoride Found in Dilution Corrected 1:1 Water to Sediment Extracts

\begin{tabular}{|c|c|c|c|c|c|c|}
\hline ID & $\begin{array}{c}\text { Depth } \\
\text { (ft bgs) }^{(1)}\end{array}$ & $\begin{array}{c}\mathrm{NO}_{3} / \mathrm{F} \\
(\mathrm{mg} / \mathrm{mg})\end{array}$ & $\begin{array}{c}{ }^{99} \mathrm{Tc} / \mathrm{F} \\
(\mathrm{pCi} / \mathrm{mg})\end{array}$ & $\begin{array}{c}\mathrm{Na} / \mathrm{F} \\
(\mathrm{mg} / \mathrm{mg})\end{array}$ & $\begin{array}{c}\mathrm{SO}_{4} / \mathrm{F} \\
(\mathrm{mg} / \mathrm{mg})\end{array}$ & $\begin{array}{l}\mathrm{HCO}_{3} / \mathrm{F} \\
(\mathrm{mg} / \mathrm{mg})\end{array}$ \\
\hline $38 \mathrm{~A}$ & 83.05 & 0.05 & 112.42 & 9.6 & 0.9 & 17.74 \\
\hline \multicolumn{7}{|c|}{ Thin Fine Grained Lens } \\
\hline 39 & 84.55 & 5.38 & 40.44 & 11.1 & 2.9 & $25.51^{\mathrm{a}}$ \\
\hline 39-dup & 84.55 & 5.55 & 43.80 & 11.2 & 3.0 & $26.17^{\mathrm{a}}$ \\
\hline \multicolumn{7}{|c|}{ Hanford H2 Sand (middle sequence) Unit } \\
\hline 41 & 87.85 & 13.26 & 144.5 & 27.6 & 4.8 & 62.57 \\
\hline $42 \mathrm{~A}$ & 90.62 & 4.03 & 0.0 & 27.1 & 4.4 & 56.49 \\
\hline 46 & 96.80 & 2.27 & 65.4 & $32.3^{a}$ & 2.0 & 100.65 \\
\hline $47 \mathrm{~A}$ & 98.62 & 0.24 & 0.0 & $39.7^{\mathrm{a}}$ & 4.2 & 81.58 \\
\hline 52 & 109.00 & 16.21 & 296.1 & $60.3^{a}$ & 7.7 & 137.77 \\
\hline $53 \mathrm{~A}$ & 111.42 & 5.40 & 16.6 & $73.8^{a}$ & 6.8 & 137.02 \\
\hline $57 \mathrm{~A}$ & 119.92 & 9.90 & 0.0 & $92.5^{\mathrm{a}}$ & 12.0 & 171.41 \\
\hline $64 \mathrm{~A}$ & 131.85 & $90.64^{\mathrm{a}}$ & 5664.7 & $75.3^{a}$ & 25.2 & 103.19 \\
\hline $69 \mathrm{~A}$ & 140.05 & 17.70 & 1560.3 & $49.4^{\mathrm{a}}$ & 16.4 & 125.77 \\
\hline $74 \mathrm{~A}$ & 150.15 & 23.30 & 1288.9 & $59.6^{\mathrm{a}}$ & 17.1 & 126.58 \\
\hline $79 \mathrm{~A}$ & 160.15 & 30.38 & 1594.2 & $58.0^{\mathrm{a}}$ & 20.2 & 118.11 \\
\hline $82 \mathrm{~A}$ & 164.55 & 34.84 & 2476.2 & $53.2^{\mathrm{a}}$ & 17.1 & 116.80 \\
\hline $83 \mathrm{~A}$ & 166.85 & 32.06 & 2696.7 & $47.8^{a}$ & 16.4 & 106.52 \\
\hline \multicolumn{7}{|c|}{ Fine Grained Lens } \\
\hline 84 & 168.45 & $88.24^{\mathrm{a}}$ & 6851.7 & $70.8^{\mathrm{a}}$ & 30.5 & 129.80 \\
\hline \multicolumn{7}{|c|}{ Hanford H2 Sand Unit } \\
\hline $86 \mathrm{~A}$ & 171.15 & 13.98 & 2442.3 & $69.9^{\mathrm{a}}$ & 18.3 & 162.47 \\
\hline \multicolumn{7}{|c|}{ Hanford H3 Sand Unit } \\
\hline $90 \mathrm{~A}$ & 179.85 & 2.58 & 2137 & $38.0^{\mathrm{a}}$ & 17.0 & 116.00 \\
\hline $96 \mathrm{~A}$ & 190.80 & 8.11 & 5061 & 15.6 & 12.1 & 68.55 \\
\hline $101 \mathrm{~A}$ & 200.95 & 11.46 & 9633 & 28.3 & 13.3 & 89.17 \\
\hline $105 \mathrm{~A}$ & 209.95 & 3.83 & 2523 & 19.2 & 9.8 & 59.51 \\
\hline \multicolumn{7}{|c|}{ Plio-pliestocene Mud Unit } \\
\hline $109 \mathrm{~A}$ & 219.45 & 3.20 & 5494 & 22.6 & 12.6 & 88.72 \\
\hline $110 \mathrm{~A}$ & 222.05 & 50.44 & 35282 & $53.5^{\mathrm{a}}$ & 57.9 & 153.48 \\
\hline 110A-dup & 222.05 & 48.57 & 31782 & $47.8^{a}$ & 50.5 & 138.92 \\
\hline 113 & 225.90 & 34.09 & 10474 & $36.1^{\mathrm{a}}$ & 48.6 & 130.64 \\
\hline
\end{tabular}


Table 4.7. Ratio of Major Strontium Recovery Waste to Fluoride Found in Dilution Corrected 1:1 Water to Sediment Extracts

\begin{tabular}{|c|c|c|c|c|c|c|}
\hline ID & $\begin{array}{c}\text { Depth } \\
(\mathbf{f t} \mathbf{b g s})^{(\mathbf{1})}\end{array}$ & $\begin{array}{c}\mathbf{N O}_{\mathbf{3}} / \mathbf{F} \\
(\mathbf{m g} / \mathbf{m g})\end{array}$ & $\begin{array}{c}{ }^{\mathbf{9 9}} \mathbf{T c} / \mathbf{F} \\
(\mathbf{p C i} / \mathbf{m g})\end{array}$ & $\begin{array}{c}\mathbf{N a} / \mathbf{F} \\
(\mathbf{m g} / \mathbf{m g})\end{array}$ & $\begin{array}{c}\mathbf{S O}_{\mathbf{4}} / \mathbf{F} \\
(\mathbf{m g} / \mathbf{m g})\end{array}$ & $\begin{array}{c}\mathbf{H C O}_{3} / \mathbf{F} \\
(\mathbf{m g} / \mathbf{m g})\end{array}$ \\
\hline \multicolumn{7}{|l|}{ Plio-pliestocene Gravel Unit } \\
\hline $115 \mathrm{~A}$ & 230.75 & 0.51 & 848.0 & 13.3 & 10.5 & 63.95 \\
\hline $120 \mathrm{~B}$ & 240.95 & 0.00 & 711.8 & $32.6^{\mathrm{a}}$ & 31.6 & 110.86 \\
\hline $120 \mathrm{~A}$ & 241.45 & 0.42 & 0 & 18.5 & 13.2 & 51.92 \\
\hline $123 \mathrm{~A}$ & 245.75 & 3.14 & 1390.74 & 26.7 & 27.9 & 93.99 \\
\hline $127 \mathrm{~A}$ & 253.15 & 3.04 & 0 & $33.6^{\mathrm{a}}$ & 15.7 & 114.58 \\
\hline
\end{tabular}

(1) to convert to meters multiply by 0.3048

${ }^{\text {a }}$ Samples whose ratios are consistent with being Strontium Recovery Waste

The porewater ratios of the key waste constituents versus each other are shown in Table 4.8 and Figures 4.6 through 4.9. These ratios have the units of $\mathrm{pCi} / \mathrm{mg}$ for the technetium-99 to any stable chemical and $\mu \mathrm{g} / \mathrm{mg}$ for the uranium to other stable constituents, and $\mathrm{mg} / \mathrm{mg}$ for chemicals versus each other. For the ratios where technetium or uranium are in the denominator the units are the reciprocal of those just stated. We also show the ratios for the strontium recovery waste stream (where available) that are plausible sources of the vadose zone contamination. The data for the waste streams are taken from Table 4.6 that is taken from Larson 1967.

None of the porewater ratios listed in Table 4.8 are close to the values for strontium recovery waste and more importantly none of the ratios for suspected mobile contaminants such as technetium-99, nitrate, and to lesser extents sodium, uranium, and sulfate to each other show a constant ratio over the depth ranges in the profile where elevated concentrations are found. About the only useful observation is that the porewater ratio of sodium to technetium (sodium/technetium) is significantly lower below $37 \mathrm{~m}$ $(120 \mathrm{ft})$ than in the shallower sediments. Because the bulk of the tank related fluid seems to still reside in the zone between the tank bottom and $37 \mathrm{~m}(120 \mathrm{ft}) \mathrm{bgs}$, and the fact that sodium does react with the sediments to a limited extent, the ratio should drop deeper in the profile where the small amount of technetium seems to reside either carried down deeper or brought in from another leak source.

Thus unlike the ratios for porewaters from the SX borehole, we do not see definitive signs that wastes are migrating vertically in unison with each other. It is likely that the low absolute concentrations of constituents such as technetium-99 and relatively low concentrations of nitrate and uranium found in the borehole 299-E33-46 porewater cause the ratio approach to be compromised by analytical error. This makes it difficult to show that several contaminants are traveling essentially in concert with each other through the vadose zone sediments even though we suspect that technetium- 99 and nitrate do migrate essentially un-retarded through the vadose zone sediments. The waste that was lost in the vicinity of tank B-110 did not contain significant amounts of either technetium-99 or nitrate or for that matter uranium, sulfate, or sodium compared to other tank leaks or overfills studied to date. 
There is also a zone below $55 \mathrm{~m}(180 \mathrm{ft})$ bgs to the water table where the technetium-99-to nitrate ratio ranges about 10 times higher than the ratios for porewaters above $55 \mathrm{~m}(180 \mathrm{ft})$ bgs. This change in technetium-99 to nitrate ratio might be explained by two different sources for the water that carries the contaminants. As stated previously the technetium to nitrate ratios for the strontium recovery waste do not correspond to the values found in the calculated porewaters. The observed values for the technetium $/ \mathrm{NO}_{3}$ ratio are significantly lower than the Larson estimate. The ratios for technetium-99-tonitrate, uranium-to-nitrate, uranium-to-technetium are plotted in Figure 4.7 and 4.8 for the dilution corrected porewaters, ultracentrifuged porewaters, and groundwater as a function of depth.

The technetium-99 to nitrate ratio for the groundwater at $78 \mathrm{~m}(255.8 \mathrm{ft}) \mathrm{bgs}$ is $111 \mathrm{pCi} / \mathrm{mg}$; a value considerably lower than for the porewater in the deep vadose zone of borehole 299-E33-46. This suggests that there may be a source of water that contains nitrate but not technetium in the groundwater. Overall, the ratio approach, where the main contaminants from the leaking tank are ratioed against each other, does not give a clear picture on the geochemistry of the vadose zone or the type of waste stream that leaked from the piping infrastructure associated with B-110. Part of the problem is that the porewaters at borehole 299-E33-46 are not very concentrated in chemicals in general, and the natural porewaters have most of the same chemicals at concentrations only 10 to 50 times less concentrated. These facts limit the usefulness in the ratio approach that was of much more value in interpreting the porewater data at the SX tank farm (see Serne et al. 2002b, c, and d.) 


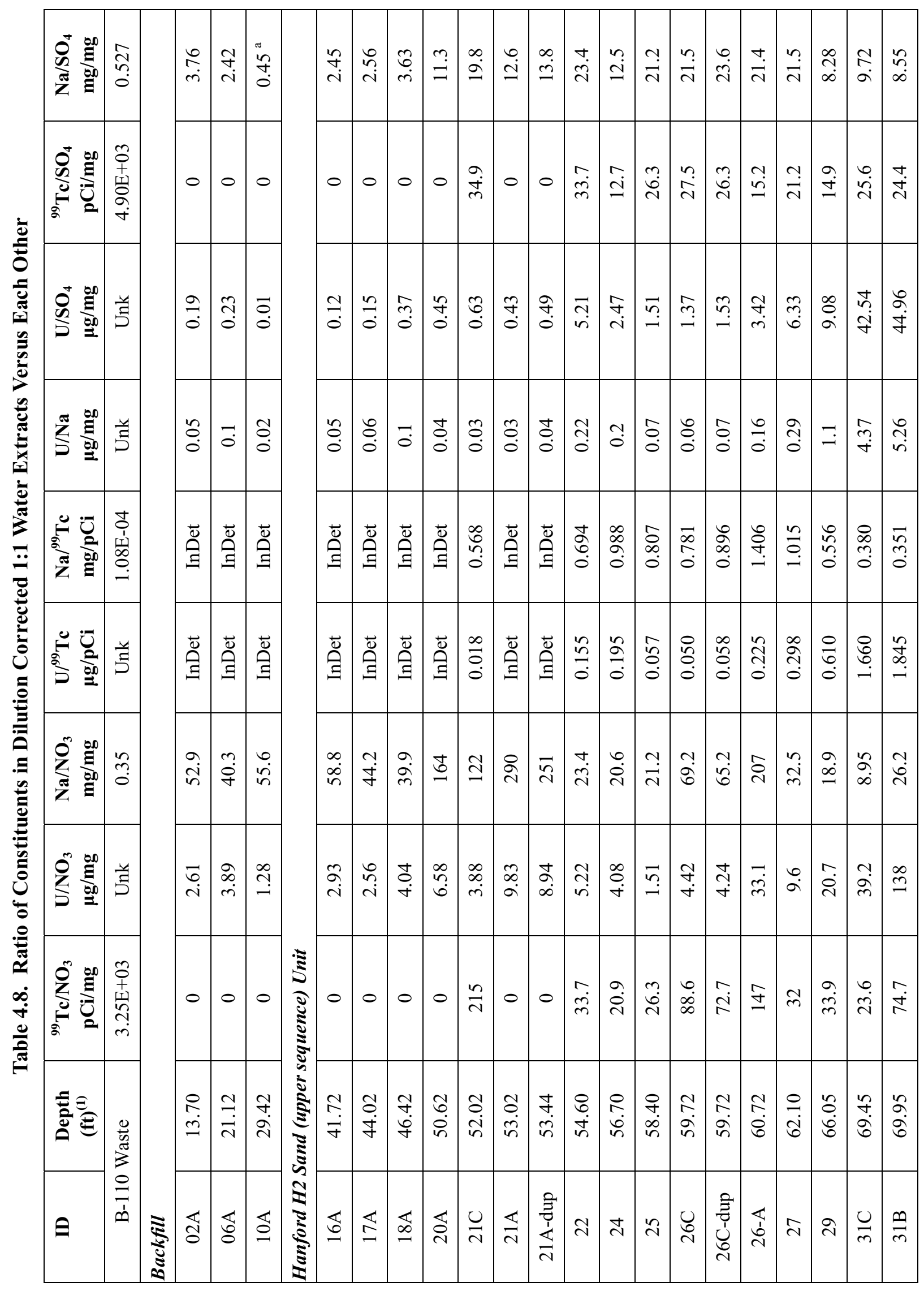




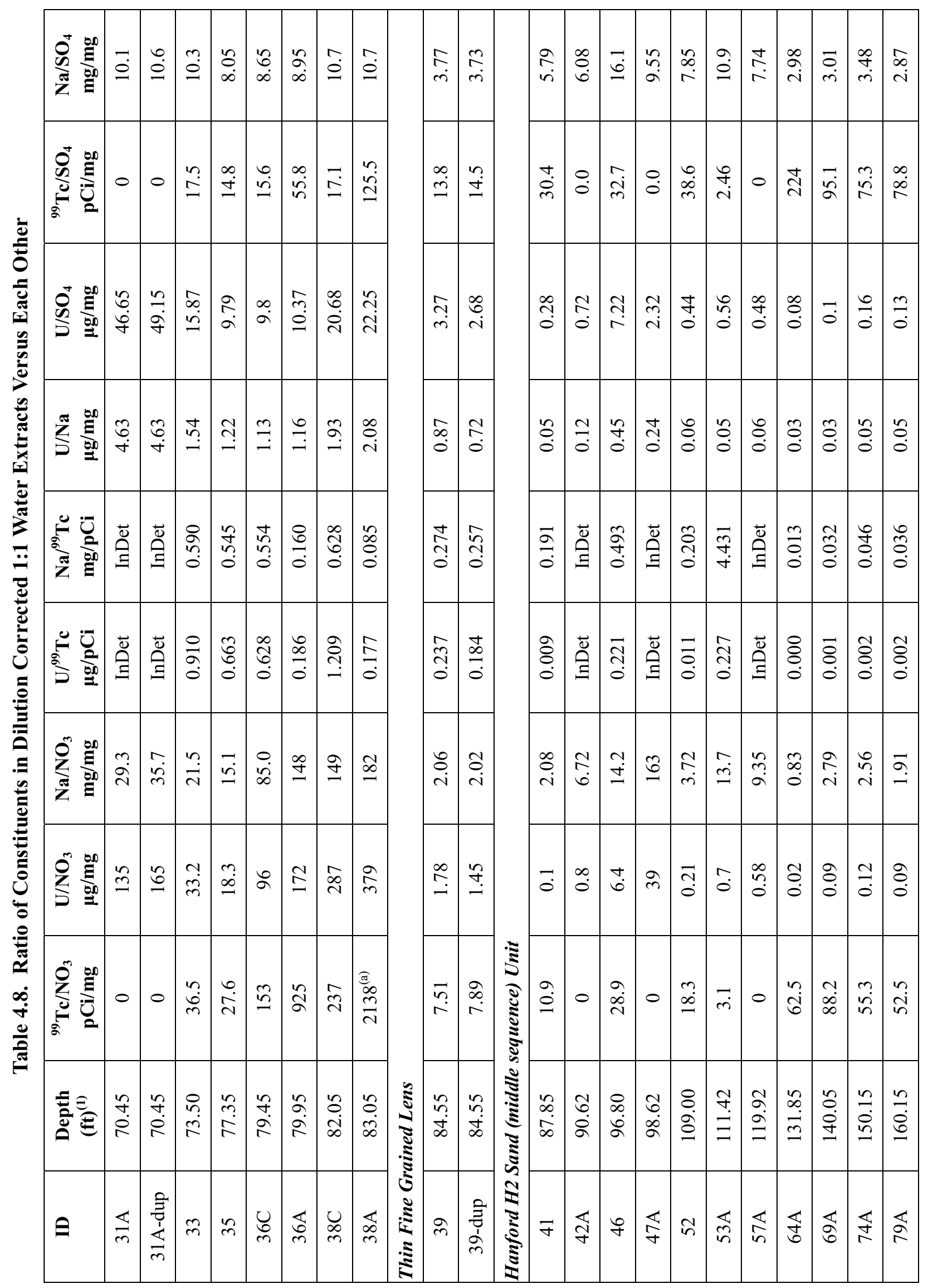




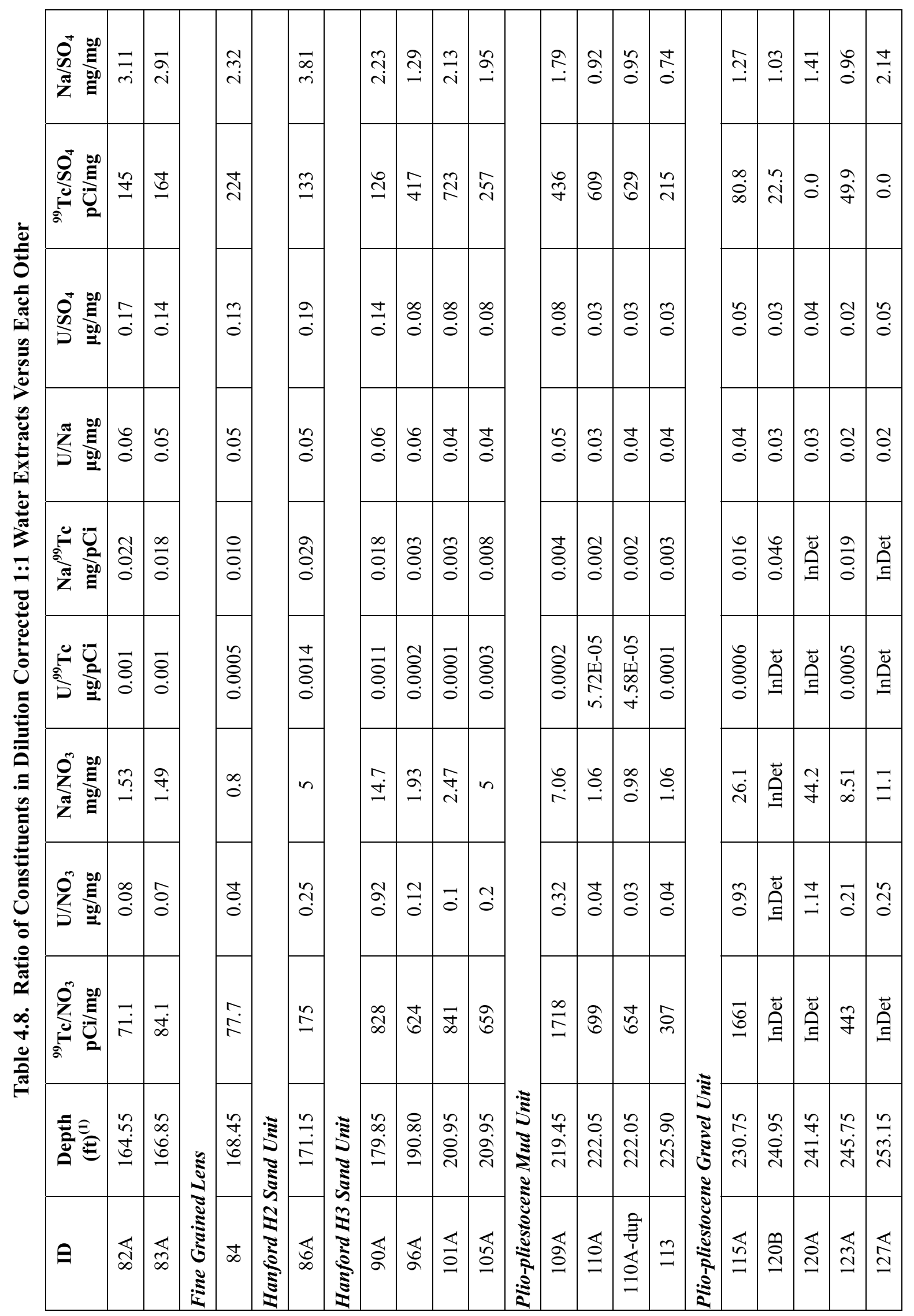




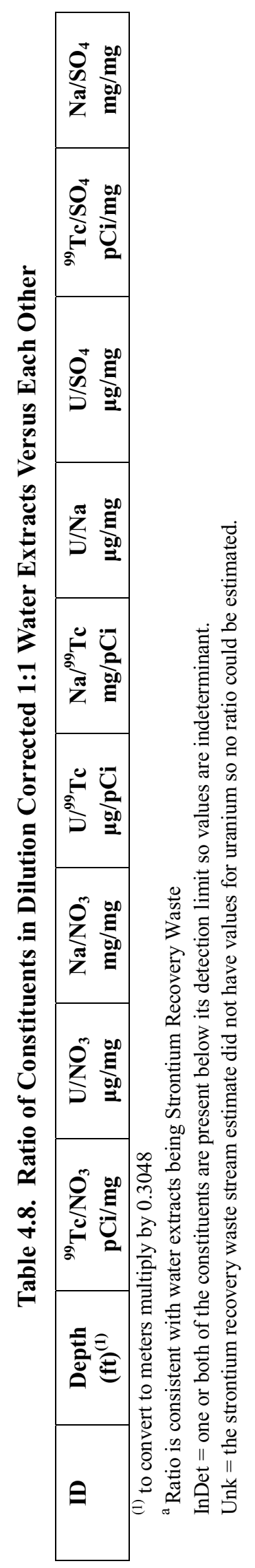




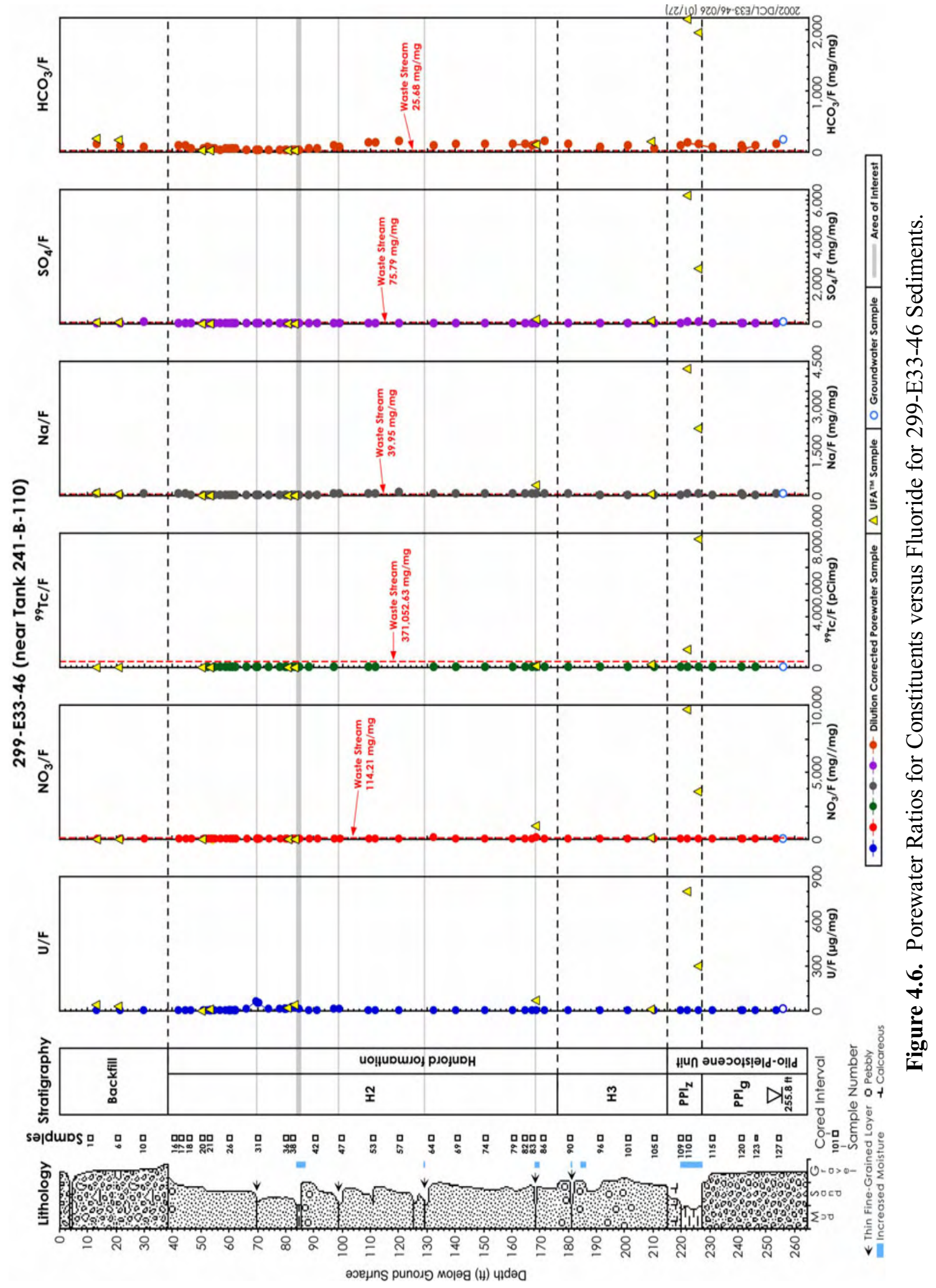




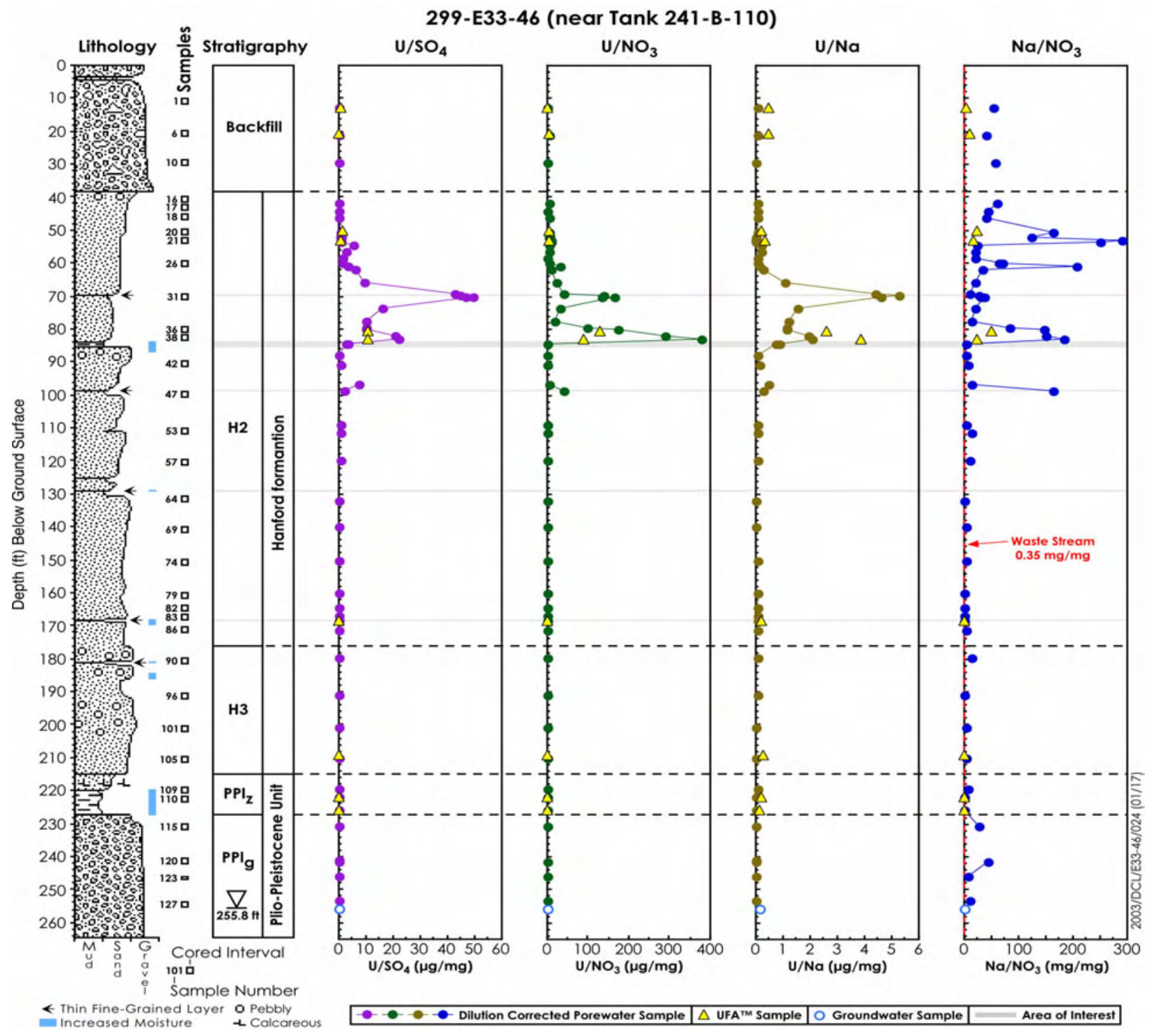

Figure 4.7. Porewater Ratios for Uranium and Sodium to Other Species. 


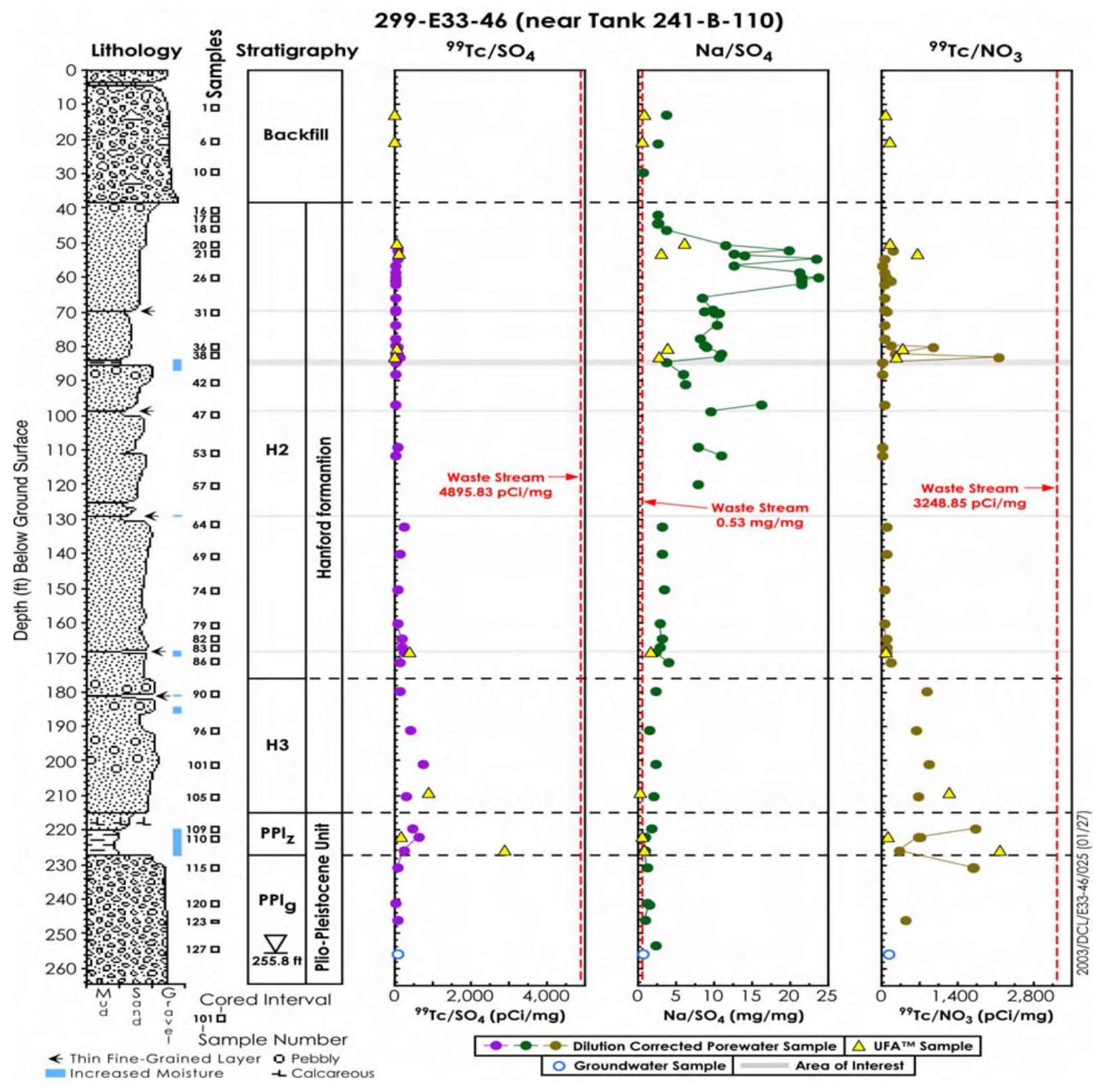

Figure 4.8. Porewater Ratios for Key Constituents versus Each Other 


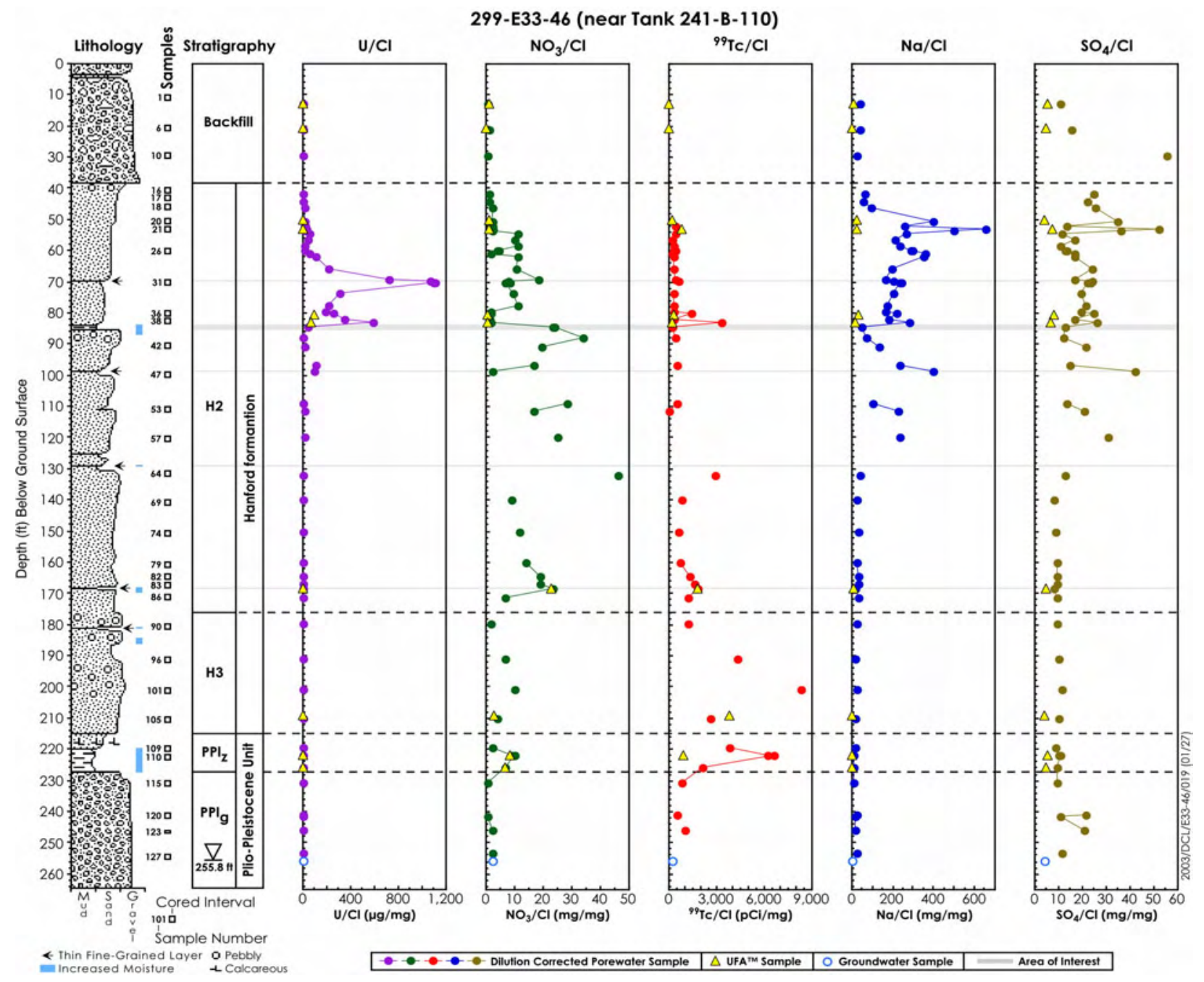

Figure 4.9. Porewater Ratios for Key Constituents versus Chloride. 


\subsection{Radionuclide Content in Vadose Zone Sediment}

The sediment cores from 299-E33-46 posed no worker dose challenges (did not contain much gamma radioactivity aside from bremsstrahlung radiation between 14 and $27 \mathrm{~m} \mathrm{[46} \mathrm{and} 89 \mathrm{ft}$ ] bgs). The radioanalytical analyses performed on the sediment included direct gamma energy analysis and tritium analysis of the one to one sediment to water extracts (assumed to be equivalent to the standard distillation of tritium out of the sediment and condensation on special targets). The technetium-99 and uranium-238 contents of the strong acid extracts were analyzed by ICP-MS to represent the total Hanford contribution to the sediments. The strontium- 90 content of the sediments was determined by strong acid extraction followed by liquid scintillation counting. The strontium- 90 content of the sediment to water extracts was determined by liquid scintillation with any further wet chemical separation because there was no other beta emitters present that could have interfered. The only Hanford derived radionuclides found in the sediments from 299-E33-46 were uranium, strontium-90, technetium-99 and tritium.

\subsubsection{Gamma Energy Analysis}

The GEA radionuclide content of the sediment is shown in Table 4.9. Potassium-40 was the only isotope quantitated in the profile, but the bremsstrahlung radiation was observed between the depths of 14 and $27 \mathrm{~m}$ (46 and $89 \mathrm{ft}$ ) bgs as evidenced by the higher detection limit for uranium-238 shown in Table 4.9. The uranium-238 activity was below the GEA detection limit for the entire vadose zone profile suggesting low concentrations are present. No detectable gamma emitting fission products such as cesium-137, europium-152, europium-154, antimony-125, or the activation product Cobalt-60, that are often observed in the field logging of the dry boreholes around Hanford's single shell tanks were observed in the sediments. Detection limits for these commonly found isotopes in the laboratory measurements varied from 0.2 to $0.6 \mathrm{pCi} / \mathrm{g}$ dependent on isotope. The vertical distributions of uranium and potassium-40 in the vadose zone sediment are plotted in Figure 4.10. Neither profile is noteworthy for delineating any zones of contamination excepting the zone with bremsstrahlung radiation that interferes with measuring the uranium-238, which is based on measuring its daughter thorium- 234 .

The potassium-40 distribution is somewhat featureless. There are no signs of elevated potassium-40 in the fine-grained lens within the Hanford formation sediments. At most we note a slightly increased concentration of potassium-40 in the Plio-Pleistocene silts, PPlz unit, in comparison to the shallower H3 unit and deeper Plio-Pleistocene gravelly sands (PPlg).

\subsubsection{Strontium-90 Content of Sediment from 299-E33-46}

Table 4.10 and Figure 4.11 show the distribution of strontium-90 in the vadose zone sediments from borehole 299-E33-46. Strontium-90 is considered to be the primary radionuclide released from tank B-110 transfer line and is concentrated in the sediment between 19 and $28 \mathrm{~m}$ (62 and $83 \mathrm{ft}$ ) bgs at concentrations between 1,000 and $11,250 \mathrm{pCi} / \mathrm{g}$. There is some strontium-90 as shallow as $14.2 \mathrm{~m}$ $(46.5 \mathrm{ft})$ bgs with $600 \mathrm{pCi} / \mathrm{g}$ concentration and the bottom of the plume lies between 27 and $33 \mathrm{~m}$ ( 89 and $111 \mathrm{ft}$ ) bgs where the concentrations range between 20 and $70 \mathrm{pCi} / \mathrm{g}$. As shown in Table 4.5, the strontium-90 in the sediments is not readily water leachable with distilled water after several hours contact. In general, the water leach and total acid leachable strontium in the vadose zone sediments suggest that the in-situ desorption $\mathrm{K}_{\mathrm{d}}$ value is $>100 \mathrm{ml} / \mathrm{g}$ for the diluted 1:1 sediment to water extract 
solution. More detailed studies on the leachability of the strontium-90 in these sediments is found in Appendix D2.4 of the B-BX-BY Field Investigation Report, where it is shown that the desorption of strontium-90 is highly dependent on solution composition and contact time. Simply stated, the strontium90 present in the vadose zone sediments between $14.2 \mathrm{~m}$ and $33 \mathrm{~m}$ (45.6 and $111 \mathrm{ft})$ bgs is not currently mobilized by dilute vadose zone recharge waters.

Table 4.9. Gamma Energy Analysis of Vadose Zone Sediment from Borehole 299-E33-46.

\begin{tabular}{|c|c|c|c|c|}
\hline \multirow{2}{*}{$\begin{array}{c}\text { Sample } \\
\text { ID }\end{array}$} & \multirow{2}{*}{$\begin{array}{c}\text { Depth } \\
{\text { (ft })^{(1)}}^{(1)}\end{array}$} & \multirow{2}{*}{$\begin{array}{c}\text { Uranium-238 } \\
\text { (GEA) } \\
(\mu \mathrm{g} / \mathrm{g})\end{array}$} & Potassium-40 & \pm Uncertainty \\
\hline & & & \multicolumn{2}{|c|}{$(\mathrm{pCi} / \mathrm{g})$} \\
\hline \multicolumn{5}{|l|}{ Backfill } \\
\hline $02 \mathrm{C}$ & 12.18 & $<11.6$ & $1.454 \mathrm{E}+01$ & $7.568 \mathrm{E}-01$ \\
\hline 02B & 12.94 & $<11.6$ & $1.426 \mathrm{E}+01$ & $1.522 \mathrm{E}+00$ \\
\hline $02 \mathrm{~A}$ & 13.7 & $<10.8$ & $1.417 \mathrm{E}+01$ & $1.338 \mathrm{E}+00$ \\
\hline $06 \mathrm{D}$ & 19.62 & $<12.1$ & $1.484 \mathrm{E}+01$ & $1.512 \mathrm{E}+00$ \\
\hline 06B & 20.62 & $<11.0$ & $1.024 \mathrm{E}+01$ & $6.651 \mathrm{E}-01$ \\
\hline 06A & 21.12 & $<11.4$ & $1.248 \mathrm{E}+01$ & $7.098 \mathrm{E}-01$ \\
\hline $10 \mathrm{C}$ & 28.42 & $<11.5$ & $1.083 \mathrm{E}+01$ & $1.457 \mathrm{E}+00$ \\
\hline $10 \mathrm{~B}$ & 28.92 & $<11.8$ & $1.224 \mathrm{E}+01$ & $1.400 \mathrm{E}+00$ \\
\hline $10 \mathrm{~A}$ & 29.42 & $<14.1$ & $1.596 \mathrm{E}+01$ & $2.076 \mathrm{E}+00$ \\
\hline \multicolumn{5}{|c|}{ Hanford H2 Sand (upper sequence) Unit } \\
\hline $16 \mathrm{D}$ & 39.97 & $<14.3$ & $2.039 \mathrm{E}+01$ & $1.074 \mathrm{E}+00$ \\
\hline $16 \mathrm{C}$ & 40.72 & $<13.9$ & $1.789 \mathrm{E}+01$ & $1.892 \mathrm{E}+00$ \\
\hline $16 \mathrm{~B}$ & 41.22 & $<12.6$ & $1.689 \mathrm{E}+01$ & $8.790 \mathrm{E}-01$ \\
\hline $16 \mathrm{~A}$ & 41.72 & $<15.9$ & $2.241 \mathrm{E}+01$ & $2.681 \mathrm{E}+00$ \\
\hline $17 \mathrm{D}$ & 42.52 & $<12.4$ & $1.346 \mathrm{E}+01$ & $1.569 \mathrm{E}+00$ \\
\hline $17 \mathrm{C}$ & 43.02 & $<12.9$ & $1.993 \mathrm{E}+01$ & $1.728 \mathrm{E}+00$ \\
\hline $17 \mathrm{~B}$ & 43.52 & $<18.0$ & $2.763 \mathrm{E}+01$ & $3.180 \mathrm{E}+00$ \\
\hline $17 \mathrm{~A}$ & 44.02 & $<16.2$ & $1.801 \mathrm{E}+01$ & $2.069 \mathrm{E}+00$ \\
\hline $18 \mathrm{D}$ & 44.92 & $<13.6$ & $1.934 \mathrm{E}+01$ & $1.763 \mathrm{E}+00$ \\
\hline $18 \mathrm{C}$ & 45.42 & $<22.2$ & $2.041 \mathrm{E}+01$ & $1.166 \mathrm{E}+00$ \\
\hline $18 \mathrm{~B}$ & 45.92 & $<22.3$ & $1.879 \mathrm{E}+01$ & $1.939 \mathrm{E}+00$ \\
\hline $18 \mathrm{~A}$ & 46.42 & $<33.5$ & $1.797 \mathrm{E}+01$ & $1.605 \mathrm{E}+00$ \\
\hline $20 \mathrm{D}$ & 49.12 & $<93.4$ & $2.170 \mathrm{E}+01$ & $1.353 \mathrm{E}+00$ \\
\hline $20 \mathrm{C}$ & 49.62 & $<45.7$ & $1.745 \mathrm{E}+01$ & $1.856 \mathrm{E}+00$ \\
\hline $20 \mathrm{~B}$ & 50.12 & $<88.9$ & $2.100 \mathrm{E}+01$ & $1.019 \mathrm{E}+00$ \\
\hline
\end{tabular}


Table 4.9. Gamma Energy Analysis of Vadose Zone Sediment from Borehole 299-E33-46.

\begin{tabular}{|c|c|c|c|c|}
\hline \multirow{2}{*}{$\begin{array}{c}\text { Sample } \\
\text { ID }\end{array}$} & \multirow{2}{*}{$\begin{array}{c}\text { Depth } \\
(\mathbf{f t})^{(1)}\end{array}$} & \multirow{2}{*}{$\begin{array}{c}\text { Uranium-238 } \\
\text { (GEA) } \\
(\mu \mathrm{g} / \mathrm{g})\end{array}$} & Potassium-40 & \pm Uncertainty \\
\hline & & & \multicolumn{2}{|c|}{$(\mathrm{pCi} / \mathrm{g})$} \\
\hline $20 \mathrm{~A}$ & 50.62 & $<81.6$ & $1.786 \mathrm{E}+01$ & $2.229 \mathrm{E}+00$ \\
\hline $21 \mathrm{D}$ & 51.52 & $<50.1$ & $1.867 \mathrm{E}+01$ & $1.797 \mathrm{E}+00$ \\
\hline $21 \mathrm{C}$ & 52.02 & $<72.1$ & $1.940 \mathrm{E}+01$ & $1.452 \mathrm{E}+00$ \\
\hline $21 \mathrm{~B}$ & 52.52 & $<63.2$ & $1.766 \mathrm{E}+01$ & $2.373 \mathrm{E}+00$ \\
\hline $21 \mathrm{~A}$ & 53.02 & $<88.4$ & $1.996 \mathrm{E}+01$ & $9.725 \mathrm{E}-01$ \\
\hline $26 \mathrm{D}$ & 59.22 & $<95.1$ & $1.876 \mathrm{E}+01$ & $2.529 \mathrm{E}+00$ \\
\hline $26 \mathrm{C}$ & 59.72 & $<79.6$ & $1.636 \mathrm{E}+01$ & $1.698 \mathrm{E}+00$ \\
\hline $26 \mathrm{~B}$ & 60.22 & $<83.1$ & $1.986 \mathrm{E}+01$ & $9.383 \mathrm{E}-01$ \\
\hline $26-\mathrm{A}$ & 60.72 & $<101.2$ & $1.642 \mathrm{E}+01$ & $2.655 \mathrm{E}+00$ \\
\hline $31 \mathrm{D}$ & 68.95 & $<38.6$ & $2.015 \mathrm{E}+01$ & $2.036 \mathrm{E}+00$ \\
\hline $31 \mathrm{C}$ & 69.45 & $<34.6$ & $2.084 \mathrm{E}+01$ & $1.734 \mathrm{E}+00$ \\
\hline $31 \mathrm{~B}$ & 69.95 & $<46.3$ & $1.929 \mathrm{E}+01$ & $2.547 \mathrm{E}+00$ \\
\hline $31 \mathrm{~A}$ & 70.45 & $<39.0$ & $1.786 \mathrm{E}+01$ & $1.704 \mathrm{E}+00$ \\
\hline $36 \mathrm{D}$ & 78.95 & $<64.1$ & $1.782 \mathrm{E}+01$ & $2.330 \mathrm{E}+00$ \\
\hline $36 \mathrm{C}$ & 79.45 & $<48.7$ & $1.645 \mathrm{E}+01$ & $9.125 \mathrm{E}-01$ \\
\hline $36 \mathrm{~B}$ & 79.95 & $<40.1$ & $1.713 \mathrm{E}+01$ & $1.547 \mathrm{E}+00$ \\
\hline $36 \mathrm{~A}$ & 80.35 & $<48.5$ & $1.526 \mathrm{E}+01$ & $2.281 \mathrm{E}+00$ \\
\hline $38 \mathrm{D}$ & 81.55 & $<32.4$ & $1.697 \mathrm{E}+01$ & $9.172 \mathrm{E}-01$ \\
\hline $38 \mathrm{C}$ & 82.05 & $<33.5$ & $1.952 \mathrm{E}+01$ & $1.850 \mathrm{E}+00$ \\
\hline $38 \mathrm{~B}$ & 82.55 & $<36.3$ & $1.979 \mathrm{E}+01$ & $2.307 \mathrm{E}+00$ \\
\hline $38 \mathrm{~A}$ & 83.05 & $<34.7$ & $1.913 \mathrm{E}+01$ & $2.678 \mathrm{E}+00$ \\
\hline \multicolumn{5}{|c|}{ Thin Fine Grained Lens } \\
\hline \multicolumn{5}{|c|}{ No sample was analyzed } \\
\hline \multicolumn{5}{|c|}{ Hanford H2 Sand (middle sequence) Unit } \\
\hline $42 \mathrm{C}$ & 89.62 & $<15.5$ & $1.665 \mathrm{E}+01$ & $2.359 \mathrm{E}+00$ \\
\hline 42B & 90.12 & $<13.0$ & $1.728 \mathrm{E}+01$ & $1.782 \mathrm{E}+00$ \\
\hline $42 \mathrm{~A}$ & 90.62 & $<11.4$ & $1.650 \mathrm{E}+01$ & $1.235 \mathrm{E}+00$ \\
\hline $47 \mathrm{C}$ & 98.62 & $<13.0$ & $1.749 \mathrm{E}+01$ & $1.790 \mathrm{E}+00$ \\
\hline 47B & 99.12 & $<10.7$ & $1.719 \mathrm{E}+01$ & $1.227 \mathrm{E}+00$ \\
\hline $47 \mathrm{~A}$ & 98.62 & $<14.8$ & $1.669 \mathrm{E}+01$ & $1.092 \mathrm{E}+00$ \\
\hline $53 \mathrm{D}$ & 109.92 & $<12.7$ & $1.672 \mathrm{E}+01$ & $8.839 \mathrm{E}-01$ \\
\hline $53 \mathrm{C}$ & 110.42 & $<12.4$ & $1.754 \mathrm{E}+01$ & $1.534 \mathrm{E}+00$ \\
\hline
\end{tabular}


Table 4.9. Gamma Energy Analysis of Vadose Zone Sediment from Borehole 299-E33-46.

\begin{tabular}{|c|c|c|c|c|}
\hline \multirow{2}{*}{$\begin{array}{c}\text { Sample } \\
\text { ID }\end{array}$} & \multirow{2}{*}{$\begin{array}{c}\text { Depth } \\
(\mathbf{f t})^{(1)}\end{array}$} & \multirow{2}{*}{$\begin{array}{c}\text { Uranium-238 } \\
\text { (GEA) } \\
(\mu \mathrm{g} / \mathrm{g})\end{array}$} & Potassium-40 & \pm Uncertainty \\
\hline & & & \multicolumn{2}{|c|}{$(\mathrm{pCi} / \mathrm{g})$} \\
\hline $53 \mathrm{~B}$ & 110.92 & $<15.3$ & $1.847 \mathrm{E}+01$ & $2.157 \mathrm{E}+00$ \\
\hline $53 \mathrm{~A}$ & 111.42 & $<11.8$ & $1.918 \mathrm{E}+01$ & $1.435 \mathrm{E}+00$ \\
\hline $57 \mathrm{~A}$ & 119.92 & $<15.6$ & $1.468 \mathrm{E}+01$ & $2.465 \mathrm{E}+00$ \\
\hline 62 & 126.75 & $<15.0$ & Not Reported & \\
\hline $64 \mathrm{~A}$ & 131.85 & $<12.5$ & $1.681 \mathrm{E}+01$ & $1.754 \mathrm{E}+00$ \\
\hline $69 \mathrm{~A}$ & 140.05 & $<11.6$ & $1.665 \mathrm{E}+01$ & 8.341E-01 \\
\hline $74 \mathrm{~A}$ & 150.15 & $<15.1$ & $1.701 \mathrm{E}+01$ & $1.973 \mathrm{E}+00$ \\
\hline $79 \mathrm{~A}$ & 160.15 & $<14.8$ & $1.713 \mathrm{E}+01$ & $1.819 \mathrm{E}+00$ \\
\hline $82 \mathrm{~A}$ & 164.55 & $<12.9$ & $1.863 \mathrm{E}+01$ & $9.431 \mathrm{E}-01$ \\
\hline $83 \mathrm{~A}$ & 166.85 & $<13.7$ & $1.634 \mathrm{E}+01$ & $1.907 \mathrm{E}+00$ \\
\hline \multicolumn{5}{|c|}{ Fine Grained Lens } \\
\hline $86 \mathrm{~A}$ & 171.15 & $<12.3$ & $1.655 \mathrm{E}+01$ & 8.635E-01 \\
\hline \multicolumn{5}{|c|}{ Hanford H3 Sand Unit } \\
\hline $90 \mathrm{~A}$ & 179.85 & $<14.8$ & $1.574 \mathrm{E}+01$ & $1.086 \mathrm{E}+00$ \\
\hline $96 \mathrm{~A}$ & 190.8 & $<12.8$ & $1.424 \mathrm{E}+01$ & $1.646 \mathrm{E}+00$ \\
\hline $101 \mathrm{~A}$ & 200.95 & $<10.5$ & $1.475 \mathrm{E}+01$ & 7.331E-01 \\
\hline $105 \mathrm{~A}$ & 209.95 & $<15.2$ & $1.425 \mathrm{E}+01$ & $1.042 \mathrm{E}+00$ \\
\hline \multicolumn{5}{|c|}{ Plio-pliestocene Mud Unit } \\
\hline $109 \mathrm{~A}$ & 219.45 & $<13.3$ & $1.515 \mathrm{E}+01$ & $8.835 \mathrm{E}-01$ \\
\hline $110 \mathrm{~A}$ & 222.05 & $<14.9$ & $1.869 \mathrm{E}+01$ & $1.763 \mathrm{E}+00$ \\
\hline \multicolumn{5}{|c|}{ Plio-pliestocene Gravel Unit } \\
\hline $115 \mathrm{~A}$ & 230.75 & $<13.5$ & $1.671 \mathrm{E}+01$ & $1.960 \mathrm{E}+00$ \\
\hline $120 \mathrm{~A}$ & 241.45 & $<10.9$ & $1.122 \mathrm{E}+01$ & $6.808 \mathrm{E}-01$ \\
\hline $123 \mathrm{~A}$ & 245.75 & $<09.8$ & $1.507 \mathrm{E}+01$ & $6.876 \mathrm{E}-01$ \\
\hline $127 \mathrm{~A}$ & 253.15 & $<14.9$ & $1.305 \mathrm{E}+01$ & $1.839 \mathrm{E}+00$ \\
\hline
\end{tabular}

\footnotetext{
(1) to convert to meters multiply by 0.3048
} 
Table 4.10. Total Radionuclide Content of Vadose Zone Sediments from Borehole 299-E33-46

\begin{tabular}{|c|c|c|c|c|}
\hline ID & $\begin{array}{c}\text { Depth } \\
\text { (ft bgs) }^{(1)}\end{array}$ & $\begin{array}{c}\text { Technetium-99 } \\
\text { (pCi/g) }\end{array}$ & $\begin{array}{c}\text { Uranium-238 } \\
(\mu \mathrm{g} / \mathrm{g})\end{array}$ & $\begin{array}{l}\text { Strontium-90 } \\
(\mathrm{pCi} / \mathrm{g})\end{array}$ \\
\hline \multicolumn{5}{|l|}{ Backfill } \\
\hline $02 \mathrm{~A}$ & 13.70 & $(1.45 \mathrm{E}+00)$ & $<10.8$ & $1.07 \mathrm{E}+01$ \\
\hline 06A & 21.12 & NA & $<11.4$ & NA \\
\hline $10 \mathrm{~A}$ & 29.42 & $(1.46 \mathrm{E}+00)$ & $<14.1$ & $6.57 \mathrm{E}+00$ \\
\hline \multicolumn{5}{|c|}{ Hanford H2 Sand (upper sequence) Unit } \\
\hline $16 \mathrm{~A}$ & 41.72 & $(3.73 \mathrm{E}+00)$ & 33 & $2.72 \mathrm{E}+00$ \\
\hline $17 \mathrm{~A}$ & 44.02 & NA & $<16.2$ & $2.13 \mathrm{E}+01$ \\
\hline $20 \mathrm{~A}$ & 50.62 & $(1.57 \mathrm{E}+00)$ & NA & $6.34 \mathrm{E}+03$ \\
\hline $21 \mathrm{C}$ & 52.02 & $(3.76 \mathrm{E}+00)$ & NA & $7.857 \mathrm{E}+03$ \\
\hline $21 \mathrm{~A}$ & 53.02 & $(8.09 \mathrm{E}+00)$ & NA & $5.93 \mathrm{E}+03$ \\
\hline 21A-dup & 53.44 & $(2.57 \mathrm{E}+00)$ & NA & $7.80 \mathrm{E}+03$ \\
\hline 22 & 54.60 & $(3.77 \mathrm{E}+00)$ & NA & $6.533 \mathrm{E}+03$ \\
\hline 24 & 56.70 & $(5.18 \mathrm{E}+00)$ & NA & $1.096 \mathrm{E}+04$ \\
\hline 25 & 58.40 & $(4.62 \mathrm{E}+00)$ & NA & $8.559 \mathrm{E}+03$ \\
\hline $26 \mathrm{C}$ & 59.72 & $(4.99 \mathrm{E}+00)$ & NA & $9.517 \mathrm{E}+03$ \\
\hline 26C-dup & 59.72 & $(4.56 \mathrm{E}+00)$ & NA & $8.341 \mathrm{E}+03$ \\
\hline $26-\mathrm{A}$ & 60.72 & $(3.58 \mathrm{E}+00)$ & 12.9 & $1.05 \mathrm{E}+04$ \\
\hline 27 & 62.10 & $(4.97 \mathrm{E}+00)$ & NA & $1.125 \mathrm{E}+04$ \\
\hline 29 & 66.05 & $(4.58 \mathrm{E}+00)$ & NA & $7.760 \mathrm{E}+03$ \\
\hline $31 \mathrm{C}$ & 69.45 & $(4.74 \mathrm{E}+00)$ & NA & $1.603 \mathrm{E}+03$ \\
\hline $31 \mathrm{~B}$ & 69.95 & $(5.43 \mathrm{E}+00)$ & 13.5 & NA \\
\hline $31 \mathrm{~A}$ & 70.45 & $(2.64 \mathrm{E}+01)$ & NA & $1.57 \mathrm{E}+03$ \\
\hline 31A-dup & 70.45 & $(2.58 \mathrm{E}+01)$ & NA & $\mathrm{NA}$ \\
\hline 33 & 73.50 & $(5.75 \mathrm{E}+00)$ & NA & $5.467 \mathrm{E}+03$ \\
\hline 35 & 77.35 & $(4.52 \mathrm{E}+00)$ & NA & $5.053 \mathrm{E}+03$ \\
\hline $36 \mathrm{C}$ & 79.45 & $(4.70 \mathrm{E}+00)$ & NA & $3.399 \mathrm{E}+03$ \\
\hline $36 \mathrm{~A}$ & 79.95 & $(1.42 \mathrm{E}+01)$ & NA & $2.21 \mathrm{E}+03$ \\
\hline $38 \mathrm{C}$ & 82.05 & $(4.61 \mathrm{E}+00)$ & NA & $1.811 \mathrm{E}+03$ \\
\hline $38 \mathrm{~A}$ & 83.05 & $(2.19 \mathrm{E}+01)$ & NA & $6.89 \mathrm{E}+02$ \\
\hline
\end{tabular}


Table 4.10. Total Radionuclide Content of Vadose Zone Sediments from Borehole 299-E33-46

\begin{tabular}{|c|c|c|c|c|}
\hline ID & $\begin{array}{c}\text { Depth } \\
\text { (ft bgs) }^{(1)}\end{array}$ & $\begin{array}{c}\text { Technetium-99 } \\
\text { (pCi/g) }\end{array}$ & $\begin{array}{c}\text { Uranium-238 } \\
(\mu \mathrm{g} / \mathrm{g})\end{array}$ & $\begin{array}{l}\text { Strontium-90 } \\
\quad(\mathrm{pCi} / \mathrm{g})\end{array}$ \\
\hline \multicolumn{5}{|c|}{ Thin Fine Grained Lens } \\
\hline 39 & 84.55 & $(4.98 \mathrm{E}+00)$ & NA & $9.563 \mathrm{E}+02$ \\
\hline 39-dup & 84.55 & NA & NA & NA \\
\hline \multicolumn{5}{|c|}{ Hanford H2 Sand (middle sequence) Unit } \\
\hline 41 & 87.85 & $(3.63 \mathrm{E}+00)$ & NA & $5.281 \mathrm{E}+01$ \\
\hline $42 \mathrm{~A}$ & 90.62 & $(4.41 \mathrm{E}+00)$ & 17.1 & $4.44 \mathrm{E}+00$ \\
\hline 46 & 96.80 & $(4.60 \mathrm{E}+00)$ & NA & $7.122 \mathrm{E}+01$ \\
\hline $47 \mathrm{~A}$ & 98.62 & $(4.74 \mathrm{E}+00)$ & $<14.8$ & $1.54 \mathrm{E}+01$ \\
\hline 52 & 109.00 & $(3.75 \mathrm{E}+00)$ & NA & NA \\
\hline $53 \mathrm{~A}$ & 111.42 & $(1.40 \mathrm{E}+00)$ & $<11.8$ & $2.58 \mathrm{E}+01$ \\
\hline $57 \mathrm{~A}$ & 119.92 & $(2.12 \mathrm{E}+00)$ & $<15.6$ & $3.84 \mathrm{E}-01$ \\
\hline $64 \mathrm{~A}$ & 131.85 & $(3.04 \mathrm{E}+00)$ & $<12.5$ & $5.96 \mathrm{E}+00$ \\
\hline $69 \mathrm{~A}$ & 140.05 & $(7.65 \mathrm{E}-01)$ & $<11.6$ & $2.94 \mathrm{E}+00$ \\
\hline $74 \mathrm{~A}$ & 150.15 & $(3.12 \mathrm{E}+00)$ & $<15.1$ & $5.39 \mathrm{E}+00$ \\
\hline $79 \mathrm{~A}$ & 160.15 & $(3.11 \mathrm{E}+00)$ & $<8.5$ & $8.53 \mathrm{E}+00$ \\
\hline $82 \mathrm{~A}$ & 164.55 & $(1.52 \mathrm{E}+00)$ & $<12.9$ & $1.99 \mathrm{E}+00$ \\
\hline $83 \mathrm{~A}$ & 166.85 & $(1.53 \mathrm{E}+00)$ & $<13.7$ & $3.17 \mathrm{E}-01$ \\
\hline \multicolumn{5}{|c|}{ Fine Grained Lens } \\
\hline 84 & 168.45 & $(7.18 \mathrm{E}+00)$ & NA & NA \\
\hline \multicolumn{5}{|c|}{ Hanford H2 Sand Unit } \\
\hline $86 \mathrm{~A}$ & 171.15 & $(3.02 \mathrm{E}+00)$ & $<8.8$ & $3.35 \mathrm{E}+00$ \\
\hline \multicolumn{5}{|c|}{ Hanford H3 Sand Unit } \\
\hline $90 \mathrm{~A}$ & 179.85 & $(1.45 \mathrm{E}+00)$ & $<14.8$ & $2.57 \mathrm{E}+00$ \\
\hline $96 \mathrm{~A}$ & 190.80 & $(7.72 \mathrm{E}+00)$ & $<12.8$ & $3.99 \mathrm{E}+00$ \\
\hline $101 \mathrm{~A}$ & 200.95 & $(7.72 \mathrm{E}+00)$ & $<8.4$ & $1.66 \mathrm{E}+00$ \\
\hline $105 \mathrm{~A}$ & 209.95 & $(8.43 \mathrm{E}+00)$ & $<15.2$ & $1.70 \mathrm{E}+00$ \\
\hline \multicolumn{5}{|c|}{ Plio-pliestocene Mud Unit } \\
\hline $109 \mathrm{~A}$ & 219.45 & $(9.93 \mathrm{E}+00)$ & $<13.3$ & $1.35 \mathrm{E}+00$ \\
\hline $110 \mathrm{~A}$ & 222.05 & $5.22 \mathrm{E}+01$ & $<7.8$ & $2.50 \mathrm{E}+00$ \\
\hline 110A-dup & 222.05 & $4.52 \mathrm{E}+01$ & NA & $6.11 \mathrm{E}+00$ \\
\hline 113 & 225.90 & $(2.36 \mathrm{E}+01)$ & 27.3 & NA \\
\hline
\end{tabular}


Table 4.10. Total Radionuclide Content of Vadose Zone Sediments from Borehole 299-E33-46

\begin{tabular}{|c|c|c|c|c|}
\hline ID & $\begin{array}{c}\text { Depth } \\
(\mathbf{f t} \text { bgs) }\end{array}$ & $\begin{array}{c}\text { Technetium-99 } \\
(\mathbf{p C i} / \mathbf{g})\end{array}$ & $\begin{array}{c}\text { Uranium-238 } \\
(\boldsymbol{\mu g} / \mathbf{g})\end{array}$ & $\begin{array}{c}\text { Strontium-90 } \\
(\mathbf{p C i} / \mathbf{g})\end{array}$ \\
\hline \multicolumn{5}{|c|}{ Plio-pliestocene Gravel Unit } \\
\hline $115 \mathrm{~A}$ & 230.75 & $(3.48 \mathrm{E}+00)$ & $<9$ & $2.58 \mathrm{E}+00$ \\
\hline $120 \mathrm{~B}$ & 240.95 & $(4.69 \mathrm{E}+00)$ & NA & NA \\
\hline $120 \mathrm{~A}$ & 241.45 & $(7.26 \mathrm{E}-01)$ & $<10.9$ & $8.37 \mathrm{E}+00$ \\
\hline $123 \mathrm{~A}$ & 245.75 & $(7.43 \mathrm{E}-01)$ & $<7.7$ & $1.29 \mathrm{E}+01$ \\
\hline $127 \mathrm{~A}$ & 253.15 & $(2.40 \mathrm{E}+01)$ & $<14.9$ & $3.96 \mathrm{E}-02$ \\
\hline
\end{tabular}

(1) to convert to meters multiply by 0.3048

(Values) are below quantification level but thought to be useful

$\mathrm{NA}=$ not analyzed; for $\mathrm{U}$ used XRF when available and GEA when XRF not available; High strontium-90 interfered with uranium analysis.

As discussed in the B-BX-BY FIR section 3.2.2.4 and Appendix D2.2.3.1.3 it was originally thought that the fluid that leaked from the transfer line contained a complexing agent NTA (nitrilo-triacetic acid or trimethylaminetricarboxylic acid; $\mathrm{C}_{6} \mathrm{H}_{9} \mathrm{NO}_{6}$ ). Data presented in Appendix D2.2.3.1.3 show that the presence of NTA at $15 \mathrm{mmol} / \mathrm{L}$ in $0.015 \mathrm{~mol} / \mathrm{L} \mathrm{NaHCO}_{3}$ background electrolyte, the approximate vadose zone pore fluid in contact with the strontium-90 contaminated sediments, reduced the $\mathrm{Sr}^{2+}-\mathrm{K}_{\mathrm{d}}$ in $\mathrm{B}$ tank farm composite sediment from approximately $56 \mathrm{ml} / \mathrm{g}$ to $3.16 \mathrm{ml} / \mathrm{g}$. But when the NTA concentration was lowered to $1.5 \mathrm{mmol} / \mathrm{L}$, NTA had no effect on $\mathrm{Sr}^{2+}$ ion exchange adsorption in $\mathrm{HCO}_{3}$ electrolyte. We analyzed 1:1 sediment to water extracts from the zone of strontium-90 contamination for NTA using ion chromatography. Results are shown in Table 4.11. We did not find any traces of water extractable NTA in the water extracts but could readily measure, with $100 \%$ recovery, 16 ppm of NTA that was spiked into the water extracts. The sensitivity of the ion chromatograph (IC) for determining NTA was very good. The 16 ppm spike equals $8.4 \times 10^{-3} \mathrm{mM}$ about 2000 times below the concentration that was found to impact the strontium adsorption-desorption $\mathrm{K}_{\mathrm{d}}$ values. This suggests that there is no indication that water soluble NTA is present today in the vadose zone where the strontium-90 contamination currently resides. It has since been determined that the strontium recovery waste stream did not contain NTA as originally thought so the results in Table 4.11 confirm the absence. As mentioned, using the water extract and acid extract data we find the current in-situ desorption $\mathrm{K}_{\mathrm{d}}$ for strontium- 90 is greater than $100 \mathrm{~mL} / \mathrm{g}$.

Table 4.11. NTA Analyses for Selected 1:1 Sediment to Water Extracts From Strontium-90 Contaminated Sediments. (2 Pages)

\begin{tabular}{|l|c|}
\hline \multicolumn{1}{|c|}{ Sample Name } & $\begin{array}{c}\text { Area } \\
\text { (arbitrary units) }\end{array}$ \\
\hline NTA 16 PPM & 1.332 \\
\hline 21A--53.02 ft bgs & 0.00 \\
\hline 26A--60.72 ft bgs & 0.00 \\
\hline
\end{tabular}


Table 4.11. NTA Analyses for Selected 1:1 Sediment to Water Extracts From Strontium-90 Contaminated Sediments. (2 Pages)

\begin{tabular}{|l|c|}
\hline \multicolumn{1}{|c|}{ Sample Name } & $\begin{array}{c}\text { Area } \\
\text { (arbitrary units) }\end{array}$ \\
\hline 31A--70.45 ft bgs & 0.00 \\
\hline 36A--80.35 ft bgs & 0.00 \\
\hline 21A SPK 16 PPM NTA & 1.326 \\
\hline 26A SPK 16 PPM NTA & 1.350 \\
\hline 31A SPK 16 PPM NTA & 1.339 \\
\hline 36A SPK 16 PPM NTA & 1.339 \\
\hline NTA 16 PPM II & 1.269 \\
\hline
\end{tabular}

Instrument was not Calibrated for NTA so results are area under curve where NTA eluted

Dr. Rick McCain, currently at S. M. Stoller, did a detailed analysis of the field gamma ray logging of borehole 299-E33-46 through the zone where bremsstrahlung radiation was present with the laboratory derived strontium-90 measurements on the sediments obtained by split spoon sampling. The details are found in Appendix C. The goal was to determine if a simple empirical calibration factor between bremsstrahlung signal (as quantified as counts in specified energy channels in the gamma log) and the direct lab measurements of strontium-90 could be derived. As described in Appendix C, there is some theory that can be used defend the concept. The results of the analyses were that a fairly strong correlation was found between the bremsstrahlung signal and lab measured strontium-90 concentration for borehole 299-E33-46 as shown in Figure 4.12 but the correlation value was not the same as theory. The fact that the casing used to drive borehole 299-E33-46 was significantly thicker than the casings used in the 1970s to install other dry well monitoring boreholes around the single-shell tanks was thought to be key to the disagreement. The correlation between observed bremsstrahlung and actual strontium-90 concentrations in surrounding sediments is dependent on casing thickness and the distribution of strontium-90 in the vadose zone sediments. The dependence of the gamma signal to these two factors, casing thickness and contaminant distribution, is not well understood. Therefore the hope that some general correlation between measured bremsstrahlung signal and actual vadose zone strontium- 90 concentration has not been successfully demonstrated. Thus although there are other wells, especially in the B Tank Farm that show characteristic bremsstrahlung signal it is not possible to determine accurately the strontium-90 concentration because of the differences in casing thickness and unknown effect of differing contaminant distributions. Several recommendations of additional activities that could be pursued to further attempt to derive more general correlations between bremsstrahlung radiation and quantifying strontium-90 are discussed in Appendix C. 


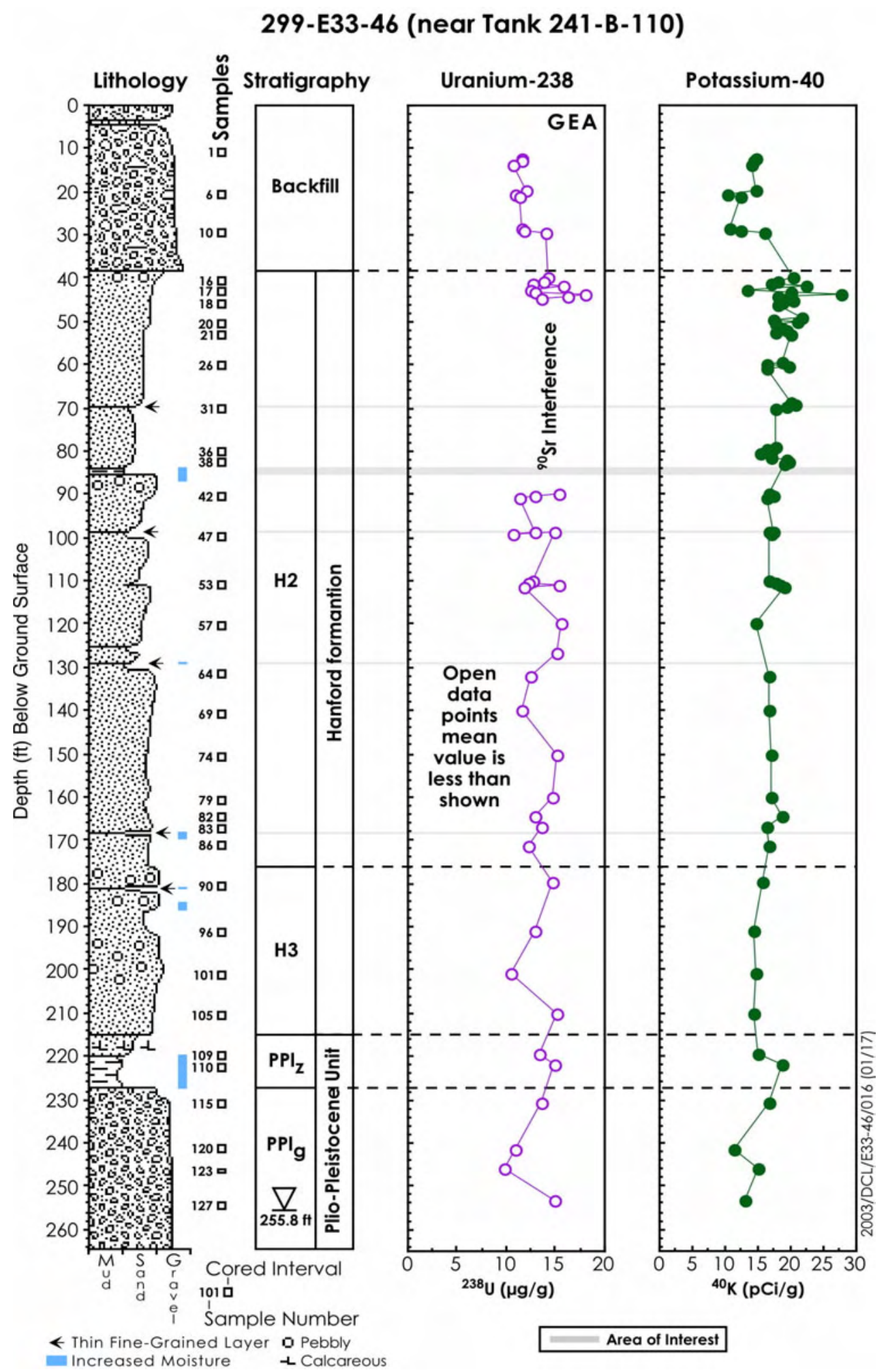

Figure 4.10. Uranium-238 and Potassium-40 Content in Sediment from Borehole 299-E33-46. 


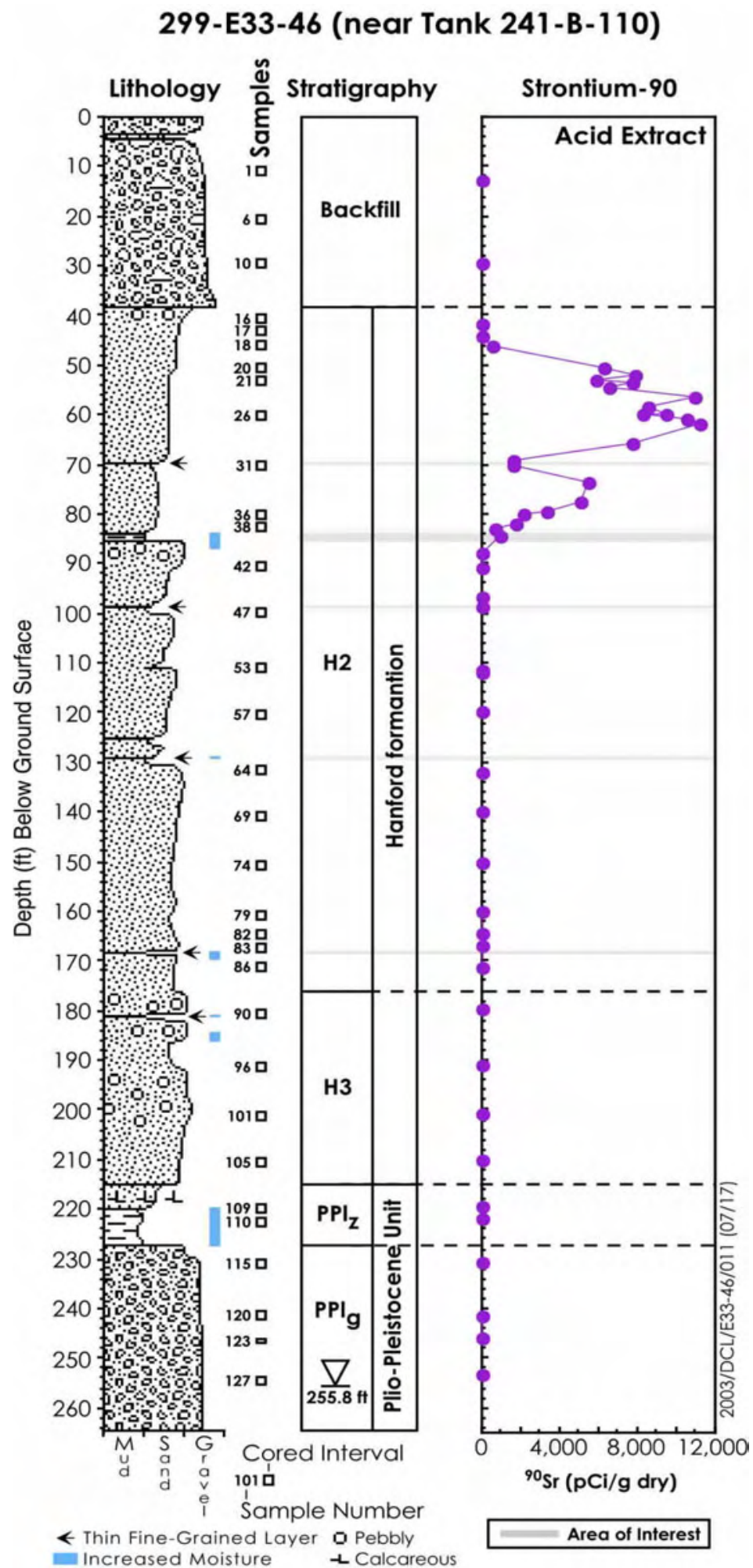

Figure 4.11. Strontium-90 Content of Borehole 299-E33-46 Vadose Zone Sediments. 


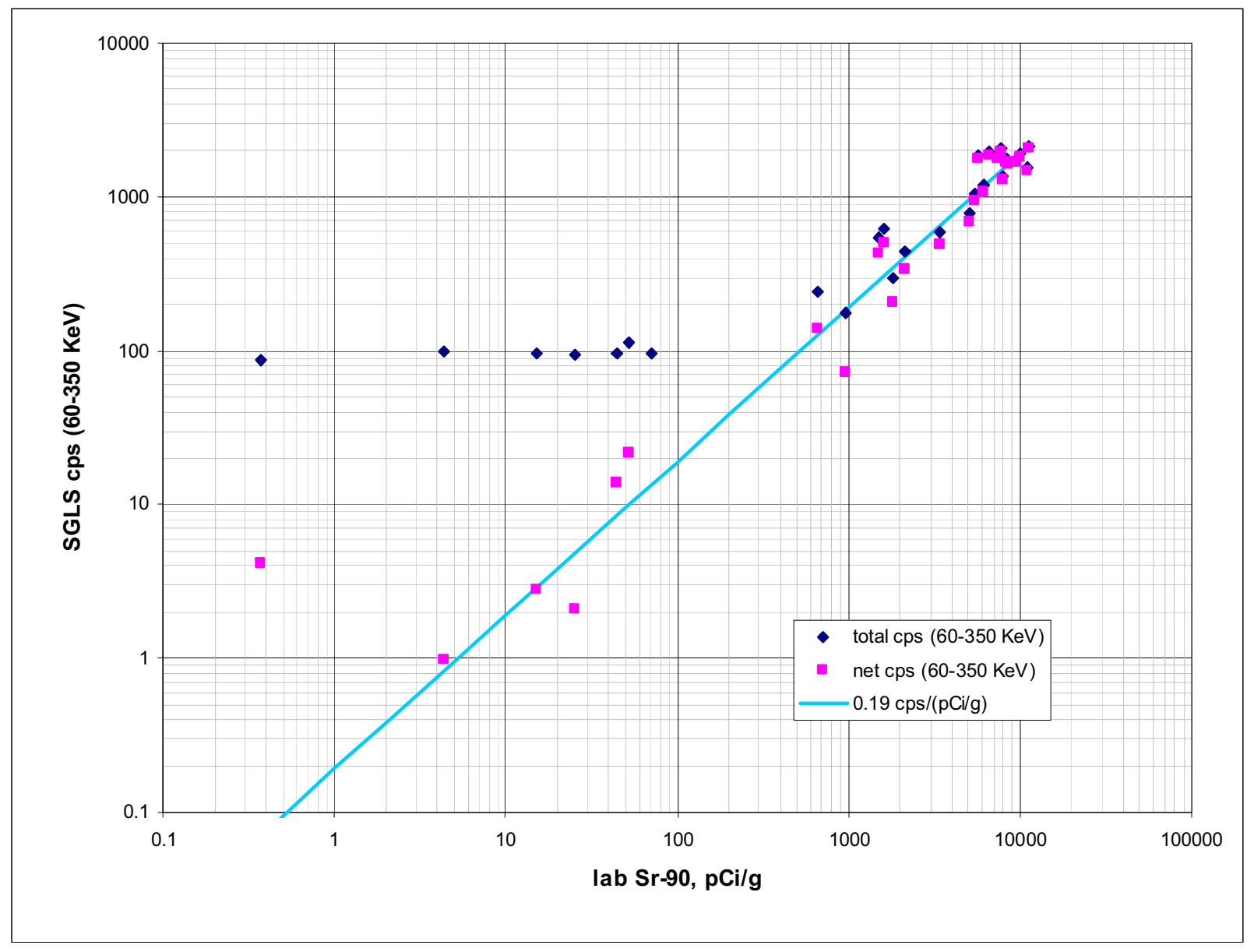

Figure 4.12. Correlation Between Bremsstrahlung Signal (count rate between 60 and 350 kev) and Actual Strontium-90 Concentration in Vadose Zone Sediments from Borehole 299-E33-46

\subsubsection{Uranium Content in Sediment}

Figure 4.10 shows the uranium content of the sediment using spectral gamma measurements. Uranium concentrations in the sediment are not distinguishable from natural background but the zone immediately below the bottom of the tank was not adequately measured because gamma energy analysis was affected by the bremsstrahlung signal from the strontium- 90 present in the sediments.

A second characterization that combined the results from measuring the total uranium content in the sediments by three different methods is shown in Table 4.12 and Figure 4.13. The three methods are 1) measuring uranium- 238 by the gamma emission from the short-lived thorium- 234 daughter and converting activity to mass; 2) directly measuring total uranium mass by $\mathrm{x}$-ray fluorescence (XRF); 3 ) and performing the strong nitric acid extract and measuring the uranium-238 mass by ICP-MS. In general, the agreement between the three methods was shown to be good at the BX-102 tank overfill borehole (299-E33-45) where there was elevated uranium concentrations (see Serne et al. 2002e). However, at borehole 299-E33-46 where there is very little uranium, aside from natural background levels, the acid extract data show much lower concentrations than the total uranium concentrations 
measured by GEA and XRF. This shows that the natural uranium is bound tightly in crystal lattice sites in minerals that are only partially dissolved in the $8 \mathrm{M}$ nitric acid extraction. Throughout the sediment, acid extraction did not remove more than $3 \mu \mathrm{g} / \mathrm{g}$ of uranium. Such values are similar to the total concentrations of uranium in uncontaminated sediments. The XRF data does suggest that two samples have elevated uranium but the first one at $12.72 \mathrm{~m}(41.72 \mathrm{ft})$ bgs seems too shallow compared to the depths where other chemicals suggest tank fluid resides. The second high value is at $68 \mathrm{~m}(222 \mathrm{ft}) \mathrm{bgs}$ in the Plio-Pliestocene mud and could reflect natural uranium accumulation in the mud. Neither of these two higher XRF values is supported by the less sensitive GEA analyses, therefore it is difficult to assess whether there is any uranium in the sediments at borehole 299-E33-46 from Hanford activities.

However, the water extractable uranium values shown in Table 4.5 and Figure 4.5 suggest that there is uranium from Hanford fuel reprocessing activities at low concentrations between the depths of 15.4 and $37 \mathrm{~m}(50.6$ and $120 \mathrm{ft}) \mathrm{bgs}$. The deepest penetration of Hanford-related uranium is down to the thin finegrained bed in the Hanford $\mathrm{H} 2$ unit at approximately $37 \mathrm{~m}$ (120 ft) bgs.

An indication of the present uranium mobility is calculated based on the ease of water extraction of the uranium compared to the total uranium in the sediment. If one assumes that the dilution corrected 1:1 water extract is equivalent to the uranium content in the porewater, then an in-situ $\mathrm{K}_{\mathrm{d}}$ value can be calculated. Table 4.13 shows in-situ $\mathrm{K}_{\mathrm{d}}$ values based on taking the best data for the total $\mathrm{U}$ in the dry sediment and the calculated porewater concentrations from Table 4.5. In all cases the total uranium measured also includes the uranium that was in the porewater such that a small correction should be made for those samples where appreciable uranium is water leachable. Such corrections only affect a few of the values in Table 4.13 and because most of the measured total uranium concentrations in the solid were less than values, the $\mathrm{K}_{\mathrm{d}}$ values shown represent the lowest values one should expect if only natural recharge water was the mobilizing fluid in the future.

Table 4.12. Total Uranium Content in Vadose Zone Sediments Determined by Three Methods. (3 Pages)

\begin{tabular}{|c|c|c|c|c|c|c|c|c|c|}
\hline ID & $\begin{array}{c}\text { Depth } \\
\text { (ft bgs) }^{(1)}\end{array}$ & $\begin{array}{r}\text { GEA } \\
(\mu \mathrm{g} / \mathrm{g})\end{array}$ & $\begin{array}{c}\text { XRF } \\
(\mu \mathrm{g} / \mathrm{g})\end{array}$ & $\begin{array}{c}\text { Acid } \\
(\mu \mathrm{g} / \mathrm{g})\end{array}$ & ID & $\begin{array}{c}\text { Depth } \\
\text { (ft bgs) }^{(1)}\end{array}$ & $\begin{array}{r}\text { GEA } \\
(\mu \mathrm{g} / \mathrm{g})\end{array}$ & $\begin{array}{c}\text { XRF } \\
(\mu \mathrm{g} / \mathrm{g})\end{array}$ & $\begin{array}{c}\text { Acid } \\
(\mu \mathrm{g} / \mathrm{g})\end{array}$ \\
\hline \multicolumn{5}{|l|}{ Backfill } & $36 \mathrm{D}$ & 78.95 & $<64.1$ & NA & 0.88 \\
\hline $02 \mathrm{C}$ & 12.18 & $<11.6$ & NA & NA & $36 \mathrm{C}$ & 79.45 & $<48.7$ & NA & 0.78 \\
\hline 02B & 12.94 & $<11.6$ & NA & 0.47 & $36 \mathrm{~B}$ & 79.95 & $<40.1$ & NA & NA \\
\hline $02 \mathrm{~A}$ & 13.7 & $<10.8$ & NA & NA & $36 \mathrm{~A}$ & 80.35 & $<48.5$ & NA & NA \\
\hline 06D & 19.62 & $<12.1$ & NA & NA & $38 \mathrm{D}$ & 81.55 & $<32.4$ & NA & 1.08 \\
\hline 06B & 20.62 & $<11.0$ & NA & NA & $38 \mathrm{C}$ & 82.05 & $<33.5$ & NA & 1.20 \\
\hline $06 \mathrm{~A}$ & 21.12 & $<11.4$ & NA & NA & $38 \mathrm{~B}$ & 82.55 & $<36.3$ & NA & 1.09 \\
\hline $10 \mathrm{C}$ & 28.42 & $<11.5$ & NA & NA & $38 \mathrm{~A}$ & 83.05 & $<34.7$ & NA & 1.21 \\
\hline 10B & 28.92 & $<11.8$ & NA & NA & \multicolumn{5}{|c|}{ Thin Fine Grained Lens } \\
\hline
\end{tabular}


Table 4.12. Total Uranium Content in Vadose Zone Sediments Determined by Three Methods. (3 Pages)

\begin{tabular}{|c|c|c|c|c|c|c|c|c|c|}
\hline ID & $\begin{array}{c}\text { Depth } \\
\text { (ft bgs) }^{(1)}\end{array}$ & $\begin{array}{c}\text { GEA } \\
(\mu \mathrm{g} / \mathrm{g})\end{array}$ & $\begin{array}{c}\text { XRF } \\
(\mu g / g)\end{array}$ & $\begin{array}{c}\text { Acid } \\
(\mu \mathrm{g} / \mathrm{g})\end{array}$ & ID & $\begin{array}{c}\text { Depth } \\
\text { (ft bgs) }^{(1)}\end{array}$ & $\begin{array}{c}\text { GEA } \\
(\mu \mathrm{g} / \mathrm{g})\end{array}$ & $\begin{array}{c}\text { XRF } \\
(\mu \mathrm{g} / \mathrm{g})\end{array}$ & $\begin{array}{r}\text { Acid } \\
(\mu \mathrm{g} / \mathrm{g})\end{array}$ \\
\hline $10 \mathrm{~A}$ & 29.42 & $<14.1$ & NA & 0.56 & \multicolumn{5}{|c|}{ NO SAMPLES ANALYZED } \\
\hline \multicolumn{5}{|c|}{ Hanford H2 Sand (upper sequence) Unit } & \multicolumn{5}{|c|}{ Hanford H2 Sand (middle sequence) Unit } \\
\hline $16 \mathrm{D}$ & 39.97 & $<14.3$ & NA & NA & $42 \mathrm{C}$ & 89.62 & $<15.5$ & NA & 0.52 \\
\hline $16 \mathrm{C}$ & 40.72 & $<13.9$ & NA & NA & 42B & 90.12 & $<13.0$ & NA & 0.59 \\
\hline $16 \mathrm{~B}$ & 41.22 & $<12.6$ & NA & 0.68 & $42 \mathrm{~A}$ & 90.62 & $<11.4$ & $17.1^{\mathrm{a}}$ & 0.58 \\
\hline $16 \mathrm{~A}$ & 41.72 & $<15.9$ & $33.2^{b}$ & NA & $47 \mathrm{C}$ & 98.62 & $<13.0$ & NA & NA \\
\hline $17 \mathrm{D}$ & 42.52 & $<12.4$ & NA & NA & 47B & 99.12 & $<10.7$ & NA & NA \\
\hline $17 \mathrm{C}$ & 43.02 & $<12.9$ & NA & NA & $47 \mathrm{~A}$ & 98.62 & $<14.8$ & NA & 0.46 \\
\hline 17B & 43.52 & $<18.0$ & NA & 0.55 & $53 \mathrm{D}$ & 109.92 & $<12.7$ & NA & NA \\
\hline $17 \mathrm{~A}$ & 44.02 & $<16.2$ & NA & NA & $53 \mathrm{C}$ & 110.42 & $<12.4$ & NA & NA \\
\hline $18 \mathrm{D}$ & 44.92 & $<13.6$ & NA & NA & $53 \mathrm{~B}$ & 110.92 & $<15.3$ & NA & 0.46 \\
\hline $18 \mathrm{C}$ & 45.42 & $<22.2$ & NA & NA & $53 \mathrm{~A}$ & 111.42 & $<11.8$ & NA & 0.47 \\
\hline $18 \mathrm{~B}$ & 45.92 & $<22.3$ & NA & 0.53 & $57 \mathrm{~A}$ & 119.92 & $<15.6$ & NA & NA \\
\hline $18 \mathrm{~A}$ & 46.42 & $<33.5$ & NA & NA & 62 & 126.75 & $<15.0$ & NA & 0.50 \\
\hline $20 \mathrm{D}$ & 49.12 & $<93.4$ & NA & NA & $64 \mathrm{~A}$ & 131.85 & $<12.5$ & NA & 0.43 \\
\hline $20 \mathrm{C}$ & 49.62 & $<45.7$ & NA & NA & $69 \mathrm{~A}$ & 140.05 & $<11.6$ & NA & 0.49 \\
\hline $20 \mathrm{~B}$ & 50.12 & $<88.9$ & NA & 0.53 & $74 \mathrm{~A}$ & 150.15 & $<15.1$ & $<8.5$ & 0.45 \\
\hline $20 \mathrm{~A}$ & 50.62 & $<81.6$ & NA & NA & $79 \mathrm{~A}$ & 160.15 & $<14.8$ & NA & 0.34 \\
\hline $21 \mathrm{D}$ & 51.52 & $<50.1$ & NA & 0.47 & $82 \mathrm{~A}$ & 164.55 & $<12.9$ & NA & 0.42 \\
\hline $21 \mathrm{C}$ & 52.02 & $<72.1$ & NA & NA & $83 \mathrm{~A}$ & 166.85 & $<13.7$ & $<8.8$ & 0.45 \\
\hline $21 \mathrm{~B}$ & 52.52 & $<63.2$ & NA & 0.79 & \multicolumn{5}{|c|}{ Fine Grained Lens } \\
\hline $21 \mathrm{~A}$ & 53.02 & $<88.4$ & NA & 0.63 & \multicolumn{5}{|c|}{ NO SAMPLES ANALYZED } \\
\hline 21A-DUP & 53.02 & NA & NA & 0.71 & \multicolumn{5}{|c|}{ Hanford H2 Sand Unit } \\
\hline 22 & 54.6 & NA & NA & 0.75 & $86 \mathrm{~A}$ & 171.15 & $<12.3$ & NA & 0.43 \\
\hline 22-DUP & 54.6 & NA & NA & 0.59 & \multicolumn{5}{|c|}{ Hanford H3 Sand Unit } \\
\hline 24 & 56.7 & NA & NA & 0.72 & $90 \mathrm{~A}$ & 179.85 & $<14.8$ & NA & 0.62 \\
\hline 25 & 58.4 & NA & NA & 0.54 & $96 \mathrm{~A}$ & 190.8 & $<12.8$ & $<8.4$ & 0.42 \\
\hline $26 \mathrm{D}$ & 59.22 & $<95.1$ & NA & 0.58 & $101 \mathrm{~A}$ & 200.95 & $<10.5$ & NA & 0.44 \\
\hline $26 \mathrm{C}$ & 59.72 & $<79.6$ & NA & NA & $105 \mathrm{~A}$ & 209.95 & $<15.2$ & NA & 0.47 \\
\hline $26 \mathrm{~B}$ & 60.22 & $<83.1$ & NA & 0.56 & \multicolumn{5}{|c|}{ Plio-pliestocene Mud Unit } \\
\hline $26 \mathrm{~A}$ & 60.72 & $<101.2$ & $12.9^{\mathrm{a}}$ & 1.66 & $109 \mathrm{~A}$ & 219.45 & $<13.3$ & $<7.8$ & 1.12 \\
\hline
\end{tabular}


Table 4.12. Total Uranium Content in Vadose Zone Sediments Determined by Three Methods. (3 Pages)

\begin{tabular}{|c|c|c|c|c|c|c|c|c|c|}
\hline ID & $\begin{array}{c}\text { Depth } \\
\text { (ft bgs) }^{(1)}\end{array}$ & $\begin{array}{c}\text { GEA } \\
(\mu \mathrm{g} / \mathrm{g})\end{array}$ & $\begin{array}{c}\text { XRF } \\
(\mu g / g)\end{array}$ & $\begin{array}{c}\text { Acid } \\
(\mu \mathrm{g} / \mathrm{g})\end{array}$ & ID & $\begin{array}{c}\text { Depth } \\
(\text { ft bgs) }\end{array}$ & $\begin{array}{c}\text { GEA } \\
(\mu \mathrm{g} / \mathrm{g})\end{array}$ & $\begin{array}{c}\text { XRF } \\
(\mu g / g)\end{array}$ & $\begin{array}{r}\text { Acid } \\
(\mu \mathrm{g} / \mathrm{g})\end{array}$ \\
\hline 27 & 62.1 & NA & NA & 1.04 & $110 \mathrm{~A}$ & 222.05 & $<14.9$ & $27.3^{b}$ & NA \\
\hline 29 & 66.05 & NA & NA & 1.03 & 113 & 225.9 & NA & $<9$ & 0.41 \\
\hline $31 \mathrm{D}$ & 68.95 & $<38.6$ & NA & 1.87 & \multicolumn{5}{|c|}{ Plio-pliestocene Gravel Unit } \\
\hline $31 \mathrm{C}$ & 69.45 & $<34.6$ & NA & 2.12 & $115 \mathrm{~A}$ & 230.75 & $<13.5$ & NA & 0.34 \\
\hline $31 \mathrm{~B}$ & 69.95 & $<46.3$ & $13.5^{\mathrm{a}}$ & 1.63 & $120 \mathrm{~A}$ & 241.45 & $<10.9$ & $<7.7$ & 0.33 \\
\hline $31 \mathrm{~A}$ & 70.45 & $<39.0$ & NA & 0.94 & $123 \mathrm{~A}$ & 245.75 & $<09.8$ & NA & 2.48 \\
\hline 33 & 73.5 & NA & NA & 0.99 & $127 \mathrm{~A}$ & 253.15 & $<14.9$ & NA & NA \\
\hline
\end{tabular}

(1) to convert to meters multiply by 0.3048

${ }^{a}$ Values may be higher than background values for comparable uncontaminated Hanford formation sediments

${ }^{\mathrm{b}}$ Values may signify tank related contamination.

$\mathrm{NA}=$ sample was not analyzed by the designated technique; GEA = gamma energy analyses XRF $=\mathrm{x}$-ray fluorescence and Acid $=8 \mathrm{M}$ nitric acid extraction. 


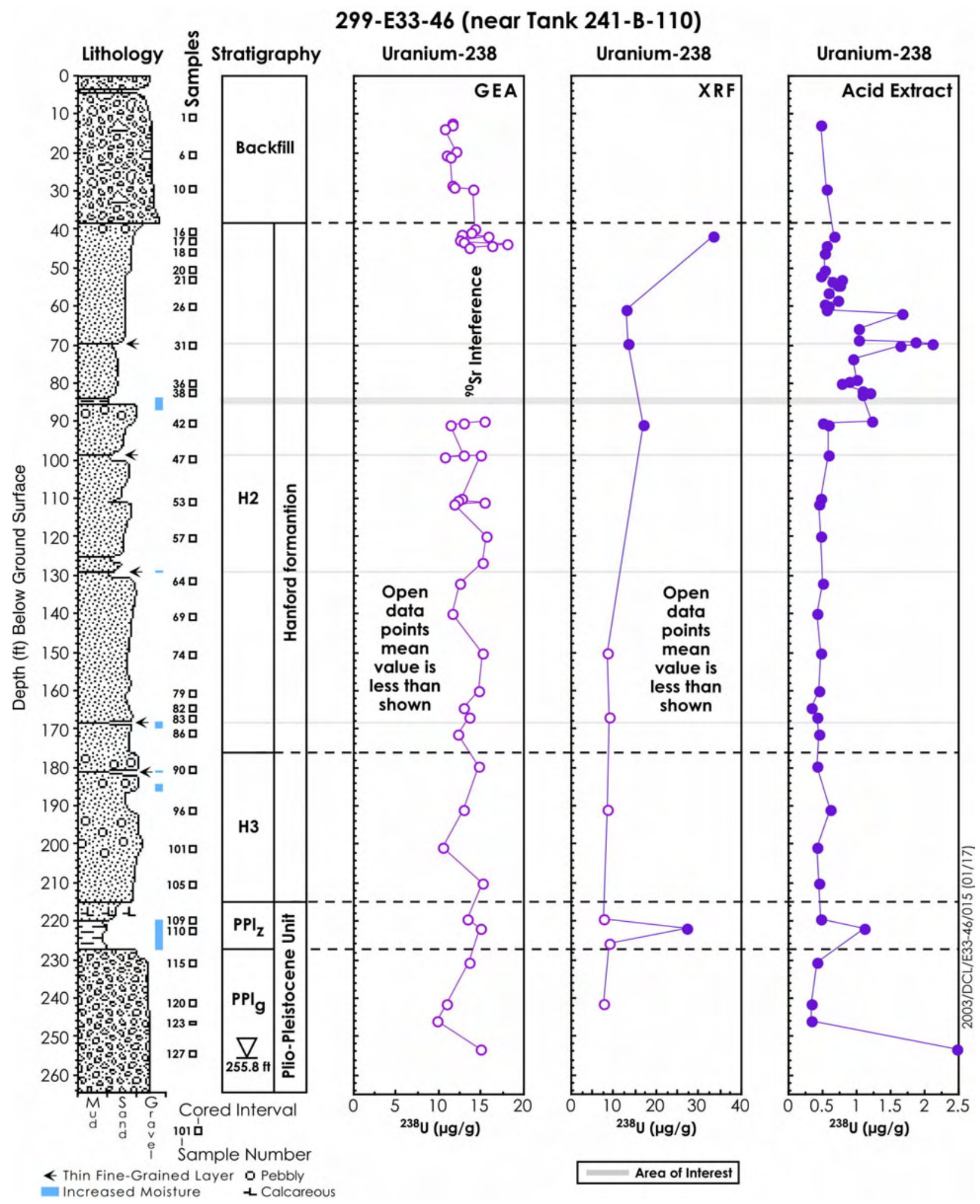

Figure 4.13. Total Uranium in Sediment Based on Three Techniques 
The values in Table 4.13 that are denoted with ${ }^{(b)}$ show low $\mathrm{K}_{\mathrm{d}}$ values that indicate some uranium mobility or alternatively a significant fraction of the uranium is in the porewater. The calculated in situ desorption $K_{d}$ values for the samples between the depths of 60.7 and approximately $30 \mathrm{~m}(99 \mathrm{ft})$ bgs (shown in Table 4.13 in red type) are low (range 1.4 to $107 \mathrm{~mL} / \mathrm{g}$; average $23 \mathrm{~mL} / \mathrm{g}$ ). In the narrow zone between 20 and $23 \mathrm{~m}$ (66 and $74 \mathrm{ft}$ ) bgs the in-situ desorption $\mathrm{K}_{\mathrm{d}}$ for uranium averages $3.2 \mathrm{ml} / \mathrm{g}$ but is not as low as for the uranium at borehole 299-E33-45 near the BX-102 overfill of uranium metals waste from the bismuth phosphate reprocessing campaigns (see Serne et al. 2002e).

Table 4.13. Calculated In Situ Desorption $K_{d}$ Values for Uranium in Vadose Sediments at 299-E33-46

\begin{tabular}{|c|c|c|c|c|}
\hline ID & $\begin{array}{c}\text { Depth } \\
\text { (ft bgs) }^{(1)}\end{array}$ & $\begin{array}{l}\text { U sol'n } \\
(\mu \mathrm{g} / \mathrm{L})\end{array}$ & $\begin{array}{c}\text { U solid } \\
(\mu \mathrm{g} / \mathrm{g})\end{array}$ & $\begin{array}{c}\mathbf{K}_{\mathbf{d}} \\
(\mathrm{mL} / \mathrm{g})\end{array}$ \\
\hline \multicolumn{5}{|l|}{ Backfill } \\
\hline 02B-UFA & 12.94 & 32.2 & $<11.60$ & $>360$ \\
\hline $02 \mathrm{~A}$ & 13.7 & 27 & $<10.8$ & $>400$ \\
\hline 06B-UFA & 20.62 & 25.4 & $<11$ & $>433$ \\
\hline $06 \mathrm{~A}$ & 21.12 & 24 & $<11.4$ & $>475$ \\
\hline $10 \mathrm{~A}$ & 29.42 & 15 & $<14.1$ & $>940$ \\
\hline \multicolumn{5}{|c|}{ Hanford H2 Sand (upper sequence) Unit } \\
\hline $16 \mathrm{~A}$ & 41.72 & 22 & $<15.9$ & $>723$ \\
\hline $17 \mathrm{~A}$ & 44.02 & 21 & $<16.2$ & $>771$ \\
\hline $18 \mathrm{~A}$ & 46.42 & 35 & & \\
\hline $20 \mathrm{~A}$ & 50.62 & $70^{\mathrm{a}}$ & & \\
\hline $21 \mathrm{C}$ & 52.02 & $63^{\mathrm{a}}$ & & \\
\hline $21 \mathrm{~A}$ & 53.02 & $69^{\mathrm{a}}$ & & \\
\hline 22 & 54.6 & $597^{\mathrm{a}}$ & & \\
\hline 24 & 56.7 & $632^{\mathrm{a}}$ & & \\
\hline 26-A & 60.72 & $560^{\mathrm{a}}$ & 12.9 & $\mathbf{2 3}^{\mathrm{ab}}$ \\
\hline 27 & 62.1 & $842^{\mathrm{a}}$ & & \\
\hline 29 & 66.05 & $2056^{\mathrm{a}}$ & & \\
\hline $31 \mathrm{C}$ & 69.45 & $9714^{a}$ & $<34.6$ & $3.56^{\mathrm{ab}}$ \\
\hline $31 \mathrm{~B}$ & 69.95 & $9731^{a}$ & 13.5 & $1.39^{\mathrm{ab}}$ \\
\hline $31 \mathrm{~A}$ & 70.45 & $8510^{a}$ & $<39$ & $\mathbf{4 . 5 8}^{\mathrm{ab}}$ \\
\hline 33 & 73.5 & $2703^{a}$ & & \\
\hline 35 & 77.35 & $1351^{a}$ & & \\
\hline $36 \mathrm{C}$ & 79.45 & $1847^{\mathrm{a}}$ & $<48.7$ & $26^{\mathrm{ab}}$ \\
\hline $36 \mathrm{~A}$ & 79.95 & $2161^{a}$ & $<48.5$ & $22^{\mathrm{ab}}$ \\
\hline
\end{tabular}


Table 4.13. Calculated In Situ Desorption $K_{d}$ Values for Uranium in Vadose Sediments at 299-E33-46

\begin{tabular}{|c|c|c|c|c|}
\hline ID & $\begin{array}{c}\text { Depth } \\
\text { (ft bgs) }^{(1)}\end{array}$ & $\begin{array}{l}\text { U sol'n } \\
(\mu \mathrm{g} / \mathrm{L})\end{array}$ & $\begin{array}{c}\text { U solid } \\
(\mu \mathrm{g} / \mathrm{g})\end{array}$ & $\begin{array}{c}\mathbf{K}_{\mathbf{d}} \\
(\mathbf{m L} / \mathbf{g})\end{array}$ \\
\hline $38 \mathrm{C}$ & 82.05 & $3547^{\mathrm{a}}$ & $<33.5$ & $9^{\mathrm{ab}}$ \\
\hline $38 \mathrm{~A}$ & 83.05 & $3425^{\mathrm{a}}$ & $<34.7$ & $\mathbf{1 0}^{\mathrm{ab}}$ \\
\hline \multicolumn{2}{|c|}{ Background Upper H2 Sand } & 6 to 9 & & \\
\hline \multicolumn{5}{|c|}{ Thin Fine Grained Lens } \\
\hline 39 & 84.55 & 312 & & \\
\hline 39-dup & 84.55 & 270 & & \\
\hline \multicolumn{5}{|c|}{ Hanford H2 Sand (middle sequence) Unit } \\
\hline 41 & 87.85 & 40 & & \\
\hline $42 \mathrm{~A}$ & 90.62 & $160^{\mathrm{a}}$ & 17.1 & 107 \\
\hline 46 & 96.8 & $836^{\mathrm{a}}$ & & \\
\hline $47 \mathrm{~A}$ & 98.62 & $580^{\mathrm{a}}$ & $<14.8$ & $>26^{\mathrm{ab}}$ \\
\hline $53 \mathrm{~A}$ & 111.42 & $150^{\mathrm{a}}$ & $<11.8$ & $>79$ \\
\hline $57 \mathrm{~A}$ & 119.92 & $141^{\mathrm{a}}$ & $<15.6$ & $>111$ \\
\hline $64 \mathrm{~A}$ & 131.85 & 31 & $<12.5$ & $>403$ \\
\hline $69 \mathrm{~A}$ & 140.05 & 33 & $<11.6$ & $>352$ \\
\hline $74 \mathrm{~A}$ & 150.15 & 32 & $<8.5$ & $>266$ \\
\hline $79 \mathrm{~A}$ & 160.15 & 26 & $<14.8$ & $>569$ \\
\hline $82 \mathrm{~A}$ & 164.55 & 43 & $<12.9$ & $>300$ \\
\hline $83 \mathrm{~A}$ & 166.85 & 34 & $<8.8$ & $>259$ \\
\hline \multicolumn{2}{|c|}{ Background Middle H2 Sand } & 7 to 24 & & \\
\hline \multicolumn{5}{|c|}{ Fine Grained Lens } \\
\hline 84-UFA & 168.45 & 32.3 & & \\
\hline 84 & 168.45 & 18 & & \\
\hline \multicolumn{2}{|c|}{ Background Fine Grained Lens } & 7 to 10 & & \\
\hline \multicolumn{5}{|c|}{ Hanford H2 Sand Unit } \\
\hline $86 \mathrm{~A}$ & 171.15 & 33 & $<12.3$ & $>373$ \\
\hline \multicolumn{5}{|c|}{ Hanford H3 Sand Unit } \\
\hline $90 \mathrm{~A}$ & 179.85 & 27 & $<14.8$ & $>548$ \\
\hline $96 \mathrm{~A}$ & 190.8 & 24 & $<12.8$ & $>533$ \\
\hline $101 \mathrm{~A}$ & 200.95 & 19 & $<10.5$ & $>553$ \\
\hline $105 \mathrm{~A}$ & 209.95 & 17 & $<15.2$ & $>894$ \\
\hline \multicolumn{2}{|c|}{ Background H3 Sand } & 8 to 13 & & \\
\hline
\end{tabular}


Table 4.13. Calculated In Situ Desorption $K_{d}$ Values for Uranium in Vadose Sediments at 299-E33-46

\begin{tabular}{|c|c|c|c|c|}
\hline ID & $\begin{array}{c}\text { Depth } \\
\text { (ft bgs) }^{(1)}\end{array}$ & $\begin{array}{l}\text { U sol'n } \\
(\mu \mathrm{g} / \mathrm{L})\end{array}$ & $\begin{array}{c}\text { U solid } \\
(\mu \mathrm{g} / \mathrm{g})\end{array}$ & $\begin{array}{c}\mathbf{K}_{\mathrm{d}} \\
(\mathrm{mL} / \mathrm{g})\end{array}$ \\
\hline \multicolumn{5}{|c|}{ Plio-pliestocene Mud Unit } \\
\hline $109 \mathrm{~A}$ & 219.45 & 17 & $<7.8$ & $>459$ \\
\hline $110 \mathrm{~A}$ & 222.05 & 5 & 27.3 & 5460 \\
\hline 113 & 225.9 & 5 & $<9$ & $>1800$ \\
\hline \multicolumn{2}{|c|}{ Background PPlz } & 2 to 10 & & \\
\hline \multicolumn{5}{|c|}{ Plio-pliestocene Gravel Unit } \\
\hline $115 \mathrm{~A}$ & 230.75 & 12 & $<13.5$ & $>1125$ \\
\hline $120 \mathrm{~A}$ & 241.45 & 20 & $<10.9$ & $>545$ \\
\hline $123 \mathrm{~A}$ & 245.75 & 10 & $<9.8$ & $>980$ \\
\hline $127 \mathrm{~A}$ & 253.15 & 12 & $<14.9$ & $>1242$ \\
\hline \multicolumn{2}{|c|}{ Background PPlg } & 15 & & \\
\hline
\end{tabular}

(1) to convert to meters multiply by 0.3048

${ }^{a}$ Zones with elevated concentrations in comparison with the nearby uncontaminated sediment (background sediment ranges shown in BOLD)

${ }^{b} K_{d}$ values are low reflecting presence of $U(V I)$ from liquid waste when compared to $K_{d}$ values for natural $U$ that leaches from sediments

Empty cells indicate no analyses were performed. Background ranges are from clean sediment at borehole 299-E33-338 east of B Tank Farm fence line.

\subsubsection{Technetium-99 Content in the Vadose Zone Sediments}

Technetium-99 was measured unequivocally at low concentrations only in the PPlz unit between 68 and $69 \mathrm{~m} \mathrm{(222} \mathrm{and} 226 \mathrm{ft})$ bgs at concentrations between 40 and $50 \mathrm{pCi} / \mathrm{g}$ in the sediment (Table 4.10). Above in the Hanford sediments, there may be very trace concentrations of technetium between 20 to 25, 15 to 20 , and 7 to $10 \mathrm{pCi} / \mathrm{g}$ at 21, 24 to 25 , and 58 to $67 \mathrm{~m} \mathrm{(70,79} \mathrm{to} \mathrm{83,} \mathrm{and} 190$ to $220 \mathrm{ft}$ ) bgs, respectively. Depending on acid matrix, the detection limit for total technetium-99 in the sediments was between 3 to $6 \mathrm{pCi} / \mathrm{g}$ therefore most of the observed values in the Hanford formation are close to the detection limit. The water leachable technetium-99 data are shown in Table 4.5 and Figure 4.5 after conversion to porewater concentrations. The water versus acid extractable technetium data are shown in Figure 4.14 in units of pCi per gram of sediment. The data are not of sufficient quality to calculate or discuss technetium in situ desorption $\mathrm{K}_{\mathrm{d}}$ values. We do not believe that there is any indication that technetium is being sorbed/bound to the vadose zone sediments. 


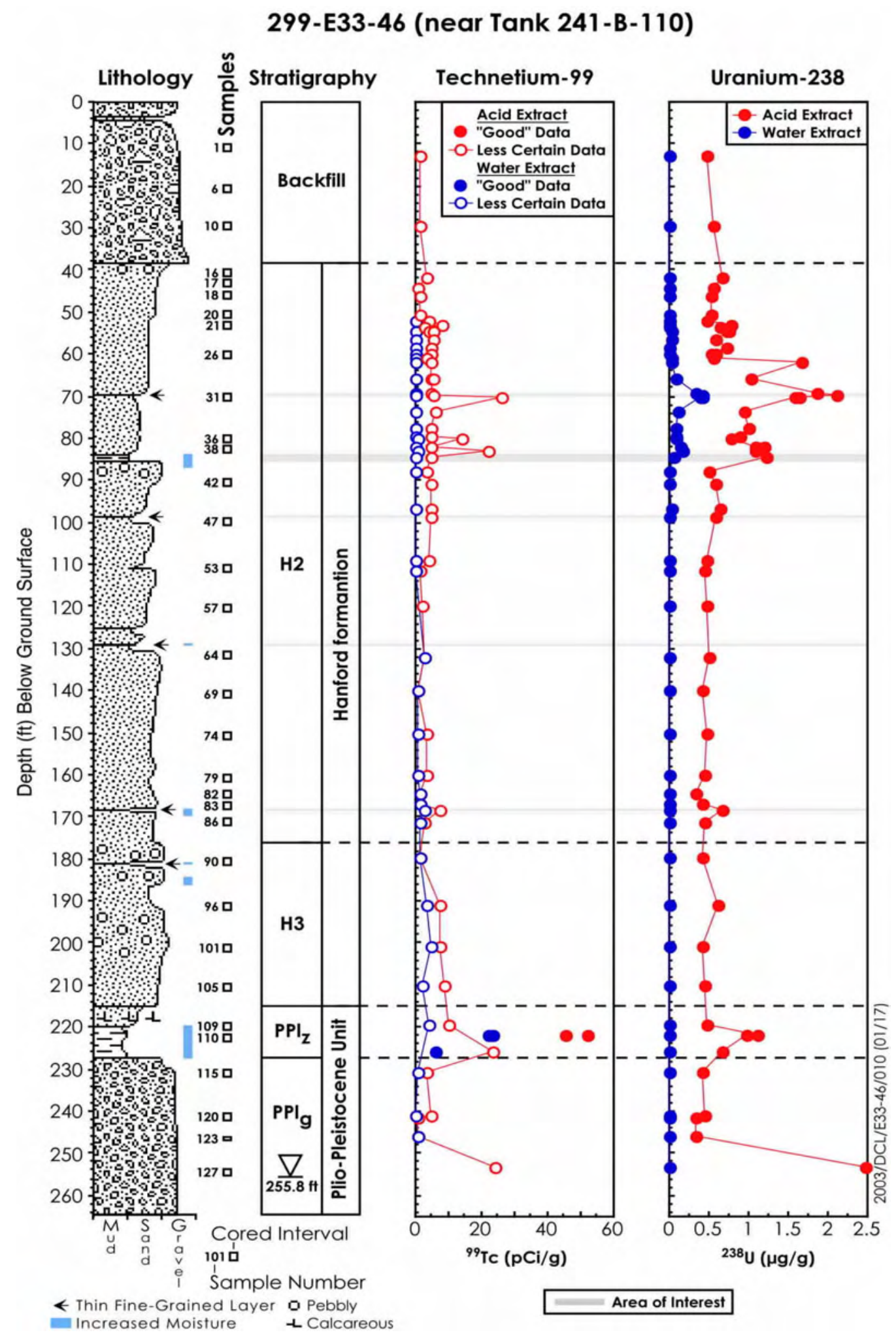

Figure 4.14. Technetium-99 and Uranium Concentrations in Acid and Water Extracts 


\subsubsection{Recharge Estimates Based on Technetium-99 Distribution in Sediments from Borehole 299-E33-46}

If our conclusion that the water and acid extract data discussed in Section 4.3.4 shows that technetium is a non-reacting constituent, then it is possible to generate an estimate of the recharge rate in the vicinity of borehole 299-E33-46. If we assume that the transfer line loss, which occurred in 1972, has been pushed deeper into the vadose zone profile solely by natural recharge, we can estimate the recharge rate from the position of the peak in technetium- 99 in the borehole. There are three depths at which there are small peaks of technetium-99 observed in the borehole sediments. Using a simple steady-state model, equation shown below, with all of the "facts" known about the tank farm construction (depth of the transfer line) and geology (depth to groundwater, depth of penetration of non-reacting technetium-99, water content of sediments), and estimates for other parameters, we calculated a range of recharge values (shown in Table 4.14).

$$
R=\theta(\Delta L / T)
$$

where:

$$
\begin{aligned}
& \mathrm{R}=\text { recharge rate in } \mathrm{mm} / \mathrm{yr} \\
& \theta=\text { volumetric water content }(\mathrm{vol} / \mathrm{vol}) \\
& \Delta \mathrm{L}=\text { travel distance in } \mathrm{mm} \\
& \mathrm{T}=\text { travel time in years. }
\end{aligned}
$$

Known "facts" for borehole 299-E33-46 and tank B-110 include:

- Transfer Line Leak depth from bgs $7.6 \mathrm{~m}$ (25 feet).

- Year elapsed between leak and sampling (1972 to 2001$)=$ approximately 30 years

- Travel Length of technetium-99 minor peak in Hanford H2 unit (Dlmin) $=32.61 \mathrm{~m}$ $(132-25 \mathrm{ft}$ bgs)

- Travel Length of technetium-99 peak in Hanford H3 unit (Dlmid) $=53.64 \mathrm{~m}(201-25 \mathrm{ft}$ bgs)

- Travel Length of technetium peak in PPlz unit (Dlmax) $=61.26 \mathrm{~m}(226-25 \mathrm{ft} \mathrm{bgs})$

- Average gravimetric water content (based on Table 4.1 from 20 to $201 \mathrm{ft} \mathrm{bgs}$ ) is $=0.043 \mathrm{~g} / \mathrm{g}$ or 4.3 wt. $\%$.

To convert to volumetric moisture content one multiplies by sediment bulk density, but we have no direct measurements of bulk density. Thus assuming a range of bulk densities from 1.6 to $1.8 \mathrm{~g} / \mathrm{cm}^{3}$ for the sediments underneath tank B-110, we calculate the recharge rates found in Table 4.14. 
Table 4.14. Estimated recharge rates based on Tc-99 plume depth beneath B-110

\begin{tabular}{|c|c|c|c|c|c|}
\hline $\begin{array}{c}\text { Water Content } \\
(\mathbf{v o l} / \mathbf{v o l})\end{array}$ & $\begin{array}{c}\text { Estimated } \\
\text { Bulk Density } \\
\left(\mathbf{g} / \mathbf{c m}^{\mathbf{3}}\right)\end{array}$ & $\begin{array}{c}\text { Time } \\
(\mathbf{y r s})\end{array}$ & $\begin{array}{c}\text { Depth } \\
\mathbf{( m )}\end{array}$ & $\begin{array}{c}\text { Depth } \\
(\mathbf{m m})\end{array}$ & $\begin{array}{c}\text { Recharge } \\
(\mathbf{m m} / \mathbf{y r})\end{array}$ \\
\hline 0.0688 & 1.6 & 30 & 32.61 & 32614 & 74.7 \\
\hline 0.0730 & 1.7 & 30 & 32.61 & 32614 & 79.4 \\
\hline 0.0773 & 1.8 & 30 & 32.61 & 32614 & 84.1 \\
\hline 0.0688 & 1.6 & 30 & 53.64 & 53645 & 122.9 \\
\hline 0.0730 & 1.7 & 30 & 53.64 & 53645 & 130.6 \\
\hline 0.0773 & 1.8 & 30 & 53.64 & 53645 & 138.3 \\
\hline 0.0688 & 1.6 & 30 & 61.26 & 61265 & 140.4 \\
\hline 0.0730 & 1.7 & 30 & 61.26 & 61265 & 149.2 \\
\hline 0.0773 & 1.8 & 30 & 61.26 & 61265 & 158.0 \\
\hline
\end{tabular}

If the distance traveled since the leak occurred is assumed to be represented by the minor peak (shown in Figure 4.5 in the Hanford H2 sand unit at approximately $40 \mathrm{~m}(132 \mathrm{ft})$ bgs DLmin $(32.61 \mathrm{~m})$ and the average volumetric water content is in the range from 0.069 to 0.077 , the range of recharge is from 74.7 to $84.1 \mathrm{~mm} / \mathrm{yr}$. If the distance that the technetium-99 traveled from the transfer line leak is assumed to be measured by the larger peak in Figure 4.5 in the Hanford H3 sand unit at approximately $61 \mathrm{~m}(201 \mathrm{ft})$ bgs DLmid $(53.64 \mathrm{~m})$, then the recharge rate is considerably higher (range from 122.9 to $138.3 \mathrm{~mm} / \mathrm{yr}$ ). If we assume that the technetium-99 in the PPlz mud unit is from the B-110 transfer line leak, then the recharge estimate is between 140 and $158 \mathrm{~mm} / \mathrm{yr}$. Based on the fact that the average annual precipitation at Hanford is approximately $162 \mathrm{~mm} / \mathrm{yr}$ and lysimeter studies for un-vegetated Hanford sediments have yielded recharge estimates between 40 and $111 \mathrm{~mm} / \mathrm{yr}$ (see Gee et al. 1992), we feel that the latter two estimates based on the technetium-99 distributions in the Hanford H3 sand unit and the PPlz mud unit are unrealistically high. This indicates that either another source of contamination likely placed these two deeper zones of technetium-99 in the vadose zone profile or that other sources of water besides natural recharge have moved the technetium-99 deeper into the profile. The data for the small technetium-99 plume at approximately $38 \mathrm{~m}(126 \mathrm{ft}) \mathrm{bgs}$ in the Hanford $\mathrm{H} 2$ sand unit seems more reasonable as the extent of migration since the transfer line leak in 1972 at tank B-110.

Another very recent analysis of natural recharge rates is being created by S. M. Narbutovskih at PNNL for inclusion in the Hanford Site Wide Groundwater Monitoring annual report for fiscal year 2002 (PNNL-14187, draft). She has observed most of the wells in the B-BX-BY WMA that are monitored for Tc-99 exhibited simultaneous Tc-99 peaks in November 2000 that have since started to diminish.

Narbutovskih concludes that Tc-99 from the vadose zone has drained into the groundwater throughout the WMA in response to meteoric water inputs (e.g., winter rains and snowmelt events) or some wide-spread source of water from Hanford activities. Narbutovskih's recharge estimate is approximately $115 \mathrm{~mm} / \mathrm{yr}$. Note that such a calculation does not preclude individual tank leaks, such as that from B110 to arrive later than November 2000. Based on this analysis we suggest that the minor peak, detected in sediment 
samples taken from borehole 299-E33-46, is associated with the transfer line leak from B110 and the deeper technetium-99 peak is related to other sources.

\subsubsection{Tritium Content in Vadose Zone Sediments}

Table 4.15 lists the tritium content of the 1:1 sediment to water extracts reported per gram of dry sediment. For most of the samples two to four replicates were analyzed and the table shows the average and standard deviation of the measurements. Only one water extract appears to contain measurable tritium above the detection limit. The sample was measured only once so it may not be as reliable as the other data from sediment extracts that were measured several times. The one apparent tritium containing sample was from a depth of $17 \mathrm{~m}(56.7 \mathrm{ft}) \mathrm{bgs}$, which is a sample with definite high sodium, nitrate, strontium-90 and other contaminants. The groundwater at $78 \mathrm{~m}(255.8 \mathrm{ft})$ bgs contains $2810 \mathrm{pCi} / \mathrm{L}$ of tritium but it is not likely that the tritium comes from the borehole 299-E33-46 sediments.

\subsection{Total Carbon, Calcium Carbonate, and Organic Carbon Content of Vadose Zone Sediment}

Table 4.16 shows the total carbon, inorganic carbon, and organic carbon contents of the vadose zone sediment at selected depths. The inorganic carbon was also converted to the equivalent calcium carbonate content. The sediment in the backfill, upper sand sequence and middle sand sequence of the $\mathrm{H} 2$ unit are relatively low in carbonate and organic carbon with the calcium carbonate equivalent content ranging from 1.14 to $1.33 \%$ by weight. The two thin lenses in the Hanford $\mathrm{H} 2$ unit have slightly higher calcium carbonate contents ( 1.5 to $2.1 \%$ by weight). The Hanford $\mathrm{H} 3$ unit has only $1.1 \%$ by weight calcium carbonate equivalent content. The fine- grained PPlz mud shows slightly higher calcium carbonate, averaging $1.7 \%$ by weight. The coarse grained PPlg contains the least calcium carbonate, averaging $0.475 \%$ and low organic carbon content. There is no evidence of rich calcareous zones in the entire profile such is found underlying the PPlz unit in 200 West Area. The calcium carbonate equivalent carbon in the contaminated sediments is very similar to the ranges of carbonate measured in the clean borehole (average and standard deviation by lithology is shown in Table 4.16 and total data set is found in Lindenmeier et al. 2002). 
Table 4.15. Tritium Content in Vadose Zone Sediments Based on Water Extracts (pCi/g). (2 Pages)

\begin{tabular}{|c|c|c|c|}
\hline ID & $\begin{array}{c}\text { Depth } \\
\text { (ft bgs) }^{(1)}\end{array}$ & $\begin{array}{c}\text { Tritium } \\
\text { pCi/g }\end{array}$ & $\begin{array}{c} \pm \boldsymbol{\sigma} \\
\mathbf{p C i} / \mathbf{g}\end{array}$ \\
\hline \multicolumn{4}{|l|}{ Backfill } \\
\hline $02 \mathrm{~A}$ & 13.7 & $-1.85^{\mathrm{a}}$ & 2.95 \\
\hline 06A & 21.12 & $-5.05^{\mathrm{a}}$ & 0.81 \\
\hline $10 \mathrm{~A}$ & 29.42 & $-1.06^{\mathrm{a}}$ & 0.53 \\
\hline \multicolumn{4}{|c|}{ Hanford H2 Sand (upper sequence) Unit } \\
\hline $16 \mathrm{~A}$ & 41.72 & $-1.19^{\mathrm{a}}$ & 4.69 \\
\hline $17 \mathrm{~A}$ & 44.02 & 2.11 & \\
\hline $18 \mathrm{~A}$ & 46.42 & 2.04 & 2.55 \\
\hline $20 \mathrm{~A}$ & 50.62 & 1.64 & 2.2 \\
\hline $21 \mathrm{~A}$ & 53.02 & 2.77 & 3.79 \\
\hline 24 & 56.7 & $32.64^{\mathrm{b}}$ & \\
\hline $26 \mathrm{C}$ & 59.72 & 0.58 & 1.8 \\
\hline $31 \mathrm{C}$ & 69.45 & $-1.02^{\mathrm{a}}$ & 2.07 \\
\hline $31 \mathrm{~A}$ & 70.45 & $-1.79^{\mathrm{a}}$ & 2.24 \\
\hline $36 \mathrm{~A}$ & 79.95 & $-2.88^{\mathrm{a}}$ & \\
\hline $38 \mathrm{~A}$ & 83.05 & 0.27 & \\
\hline \multicolumn{4}{|c|}{ Thin Fine Grained Lens } \\
\hline 39 & 84.55 & $-0.9^{\mathrm{a}}$ & 1.05 \\
\hline \multicolumn{4}{|c|}{ Hanford H2 Sand (middle sequence) Unit } \\
\hline $42 \mathrm{~A}$ & 90.62 & $-1.51^{\mathrm{a}}$ & 0.03 \\
\hline $47 \mathrm{~A}$ & 98.62 & $-2.56^{\mathrm{a}}$ & \\
\hline $53 \mathrm{~A}$ & 111.42 & $-3.14^{\mathrm{a}}$ & 1.19 \\
\hline $57 \mathrm{~A}$ & 119.92 & $-0.5^{\mathrm{a}}$ & \\
\hline $64 \mathrm{~A}$ & 131.85 & $-0.93^{\mathrm{a}}$ & 0.29 \\
\hline $69 \mathrm{~A}$ & 140.05 & $-1.35^{\mathrm{a}}$ & \\
\hline $74 \mathrm{~A}$ & 150.15 & 1.08 & \\
\hline $79 \mathrm{~A}$ & 160.15 & $-2.58^{\mathrm{a}}$ & \\
\hline $82 \mathrm{~A}$ & 164.55 & $-0.52^{\mathrm{a}}$ & \\
\hline $83 \mathrm{~A}$ & 166.85 & 4.65 & \\
\hline \multicolumn{4}{|c|}{ Fine Grained Lens } \\
\hline 84 & 168.45 & -3.5 & 2.59 \\
\hline
\end{tabular}


Table 4.15. Tritium Content in Vadose Zone Sediments Based on Water Extracts (pCi/g). (2 Pages)

\begin{tabular}{|c|c|c|c|}
\hline ID & $\begin{array}{c}\text { Depth } \\
\text { (ft bgs) }^{(1)}\end{array}$ & $\begin{array}{c}\text { Tritium } \\
\text { pCi/g }\end{array}$ & $\begin{array}{c} \pm \sigma \\
\mathrm{pCi} / \mathrm{g}\end{array}$ \\
\hline \multicolumn{4}{|c|}{ Hanford H2 Sand Unit } \\
\hline $86 \mathrm{~A}$ & 171.15 & -0.4 & \\
\hline \multicolumn{4}{|c|}{ Hanford H3 Sand Unit } \\
\hline $90 \mathrm{~A}$ & 179.85 & 0.24 & \\
\hline $96 \mathrm{~A}$ & 190.8 & -2.91 & \\
\hline $101 \mathrm{~A}$ & 200.95 & 7.76 & 1.17 \\
\hline $105 \mathrm{~A}$ & 209.95 & -0.02 & 0.09 \\
\hline \multicolumn{4}{|c|}{ Plio-pliestocene Mud Unit } \\
\hline $109 \mathrm{~A}$ & 219.45 & -1.06 & 1.93 \\
\hline $110 \mathrm{~A}$ & 222.05 & -0.82 & 2.7 \\
\hline 113 & 225.9 & 1.21 & 5.91 \\
\hline \multicolumn{4}{|c|}{ Plio-pliestocene Gravel Unit } \\
\hline $115 \mathrm{~A}$ & 230.75 & -1.13 & 0.34 \\
\hline $120 \mathrm{~A}$ & 241.45 & 1.43 & 0.03 \\
\hline $123 \mathrm{~A}$ & 245.75 & -2.38 & 0.09 \\
\hline $127 \mathrm{~A}$ & 253.15 & -1.83 & 2.05 \\
\hline
\end{tabular}

(1) to convert to meters multiply by 0.3048

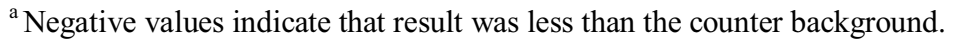

${ }^{\mathrm{b}}$ Value may indicate presence of tritium.

Empty cells indicate that no analyses were performed.

$\sigma$ represents standard deviation of duplicate analyses.

Table 4.16. Carbon Content in Vadose Sediment from 299-E33-46

\begin{tabular}{|c|c|c|c|c|c|}
\hline ID & $\begin{array}{c}\text { Depth } \\
\text { (ft bgs) }^{(\mathbf{1})}\end{array}$ & $\begin{array}{c}\text { Total Carbon } \\
\text { (\% wt) }\end{array}$ & $\begin{array}{c}\text { Inorganic Carbon } \\
\text { (\% wt) }\end{array}$ & $\begin{array}{c}\text { Organic Carbon } \\
\text { (\% wt) }\end{array}$ & $\begin{array}{c}\text { IC as } \mathbf{C a C O}_{3} \\
\text { (\% wt) }\end{array}$ \\
\hline Backfill \\
\hline $02 \mathrm{~A}$ & 13.7 & 0.22 & 0.17 & 0.05 & 1.42 \\
\hline $06 \mathrm{~A}$ & 21.12 & 0.18 & 0.13 & 0.05 & 1.08 \\
\hline $10 \mathrm{~A}$ & 29.42 & 0.18 & 0.11 & 0.07 & 0.92 \\
\hline Hanford H2 Sand (upper sequence) Unit & \multicolumn{5}{|l}{} \\
\hline 16A & 41.72 & 0.25 & 0.18 & 0.06 & 1.50 \\
\hline 17A & 44.02 & 0.29 & 0.24 & 0.05 & 2.00 \\
\hline
\end{tabular}


Table 4.16. Carbon Content in Vadose Sediment from 299-E33-46

\begin{tabular}{|c|c|c|c|c|c|}
\hline ID & $\begin{array}{c}\text { Depth } \\
\text { (ft bgs) }^{(1)}\end{array}$ & $\begin{array}{c}\text { Total Carbon } \\
\text { (\% wt) }\end{array}$ & $\begin{array}{c}\text { Inorganic Carbon } \\
(\% \mathrm{wt})\end{array}$ & $\begin{array}{c}\text { Organic Carbon } \\
(\% \mathrm{wt})\end{array}$ & $\begin{array}{c}\mathrm{IC} \text { as } \mathrm{CaCO}_{3} \\
\text { (\% wt) }\end{array}$ \\
\hline $18 \mathrm{~A}$ & 46.42 & 0.3 & 0.23 & 0.07 & 1.92 \\
\hline $20 \mathrm{~A}$ & 50.62 & 0.28 & 0.22 & 0.06 & 1.83 \\
\hline $21 \mathrm{~A}$ & 53.02 & 0.236 & 0.184 & 0.050 & 1.53 \\
\hline 22 & 54.6 & 0.08 & 0.07 & 0.01 & 0.58 \\
\hline 24 & 56.7 & 0.02 & 0.16 & 0.04 & 1.33 \\
\hline 25 & 58.4 & 0.19 & 0.14 & 0.05 & 1.17 \\
\hline $26 \mathrm{C}$ & 59.72 & 0.18 & 0.13 & 0.05 & 1.08 \\
\hline $26-\mathrm{A}$ & 60.72 & 0.17 & 0.08 & 0.09 & 0.67 \\
\hline 27 & 62.1 & 0.17 & 0.13 & 0.04 & 1.08 \\
\hline 29 & 66.05 & 0.14 & 0.09 & 0.05 & 0.75 \\
\hline $31 \mathrm{~B}$ & 69.95 & 0.19 & 0.15 & 0.04 & 1.25 \\
\hline $31 \mathrm{~A}$ & 70.45 & 0.23 & 0.19 & 0.05 & 1.58 \\
\hline 33 & 73.5 & 0.23 & 0.17 & 0.06 & 1.42 \\
\hline 35 & 77.35 & 0.2 & 0.2 & 0 & 1.67 \\
\hline $36 \mathrm{~A}$ & 79.95 & 0.18 & 0.14 & 0.04 & 1.17 \\
\hline $38 \mathrm{~A}$ & 83.05 & 0.21 & 0.17 & 0.04 & 1.42 \\
\hline \multicolumn{3}{|c|}{ Background Upper H2 Sand } & & & $1.23 \pm 0.23$ \\
\hline \multicolumn{6}{|c|}{ Thin Fine Grained Lens } \\
\hline 39 & 84.55 & 0.25 & 0.18 & 0.07 & 1.50 \\
\hline \multicolumn{6}{|c|}{ Hanford H2 Sand (middle sequence) Unit } \\
\hline 41 & 87.85 & 0.16 & 0.1 & 0.06 & 0.83 \\
\hline $42 \mathrm{~A}$ & 90.62 & 0.19 & 0.14 & 0.04 & 1.17 \\
\hline 46 & 96.8 & 0.19 & 0.15 & 0.04 & 1.25 \\
\hline $47 \mathrm{~A}$ & 98.62 & 0.15 & 0.12 & 0.03 & 1.00 \\
\hline $53 \mathrm{~A}$ & 111.42 & 0.22 & 0.18 & 0.04 & 1.50 \\
\hline $57 \mathrm{~A}$ & 119.92 & 0.18 & 0.14 & 0.04 & 1.17 \\
\hline $64 \mathrm{~A}$ & 131.85 & 0.14 & 0.1 & 0.04 & 0.83 \\
\hline $69 \mathrm{~A}$ & 140.05 & 0.38 & 0.31 & 0.07 & 2.58 \\
\hline $74 \mathrm{~A}$ & 150.15 & 0.165 & 0.13 & 0.035 & 1.08 \\
\hline $79 \mathrm{~A}$ & 160.15 & 0.14 & 0.09 & 0.05 & 0.75 \\
\hline $82 \mathrm{~A}$ & 164.55 & 0.18 & 0.12 & 0.06 & 1.00 \\
\hline $83 \mathrm{~A}$ & 166.85 & 0.18 & 0.14 & 0.04 & 1.17 \\
\hline
\end{tabular}


Table 4.16. Carbon Content in Vadose Sediment from 299-E33-46

\begin{tabular}{|c|c|c|c|c|c|}
\hline ID & $\begin{array}{c}\text { Depth } \\
\text { (ft bgs) }^{(1)}\end{array}$ & $\begin{array}{c}\text { Total Carbon } \\
(\% \mathrm{wt})\end{array}$ & $\begin{array}{c}\text { Inorganic Carbon } \\
(\% \mathrm{wt})\end{array}$ & $\begin{array}{c}\text { Organic Carbon } \\
(\% \mathrm{wt})\end{array}$ & $\begin{array}{c}\text { IC as } \mathrm{CaCO}_{3} \\
(\% \mathrm{wt})\end{array}$ \\
\hline \multicolumn{3}{|c|}{ Background Middle H2 Sand } & & & $1.23 \pm 0.23$ \\
\hline \multicolumn{6}{|c|}{ Fine Grained Lens } \\
\hline 84 & 168.45 & 0.19 & 0.13 & 0.06 & 1.08 \\
\hline \multicolumn{3}{|c|}{ Background Fine Grained Lens } & & & NA \\
\hline \multicolumn{6}{|c|}{ Hanford H2 Sand Unit } \\
\hline $86 \mathrm{~A}$ & 171.15 & 0.33 & 0.25 & 0.08 & 2.08 \\
\hline \multicolumn{6}{|c|}{ Hanford H3 Sand Unit } \\
\hline $90 \mathrm{~A}$ & 179.85 & 0.19 & 0.16 & 0.03 & 1.33 \\
\hline $96 \mathrm{~A}$ & 190.8 & 0.13 & 0.11 & 0.02 & 0.92 \\
\hline $101 \mathrm{~A}$ & 200.95 & 0.19 & 0.15 & 0.04 & 1.25 \\
\hline $105 \mathrm{~A}$ & 209.95 & 0.14 & 0.1 & 0.04 & 0.83 \\
\hline \multicolumn{3}{|c|}{ Background H3 Sand } & & & $0.67 \pm 0.01$ \\
\hline \multicolumn{6}{|c|}{ Plio-pliestocene Mud Unit } \\
\hline $109 \mathrm{~A}$ & 219.45 & 0.175 & 0.125 & 0.05 & 1.04 \\
\hline $110 \mathrm{~A}$ & 222.05 & 0.34 & 0.27 & 0.09 & 2.25 \\
\hline 113 & 225.9 & 0.22 & 0.22 & 0.00 & 1.83 \\
\hline \multicolumn{3}{|c|}{ Background PPIz } & & & $1.69 \pm 0.28$ \\
\hline \multicolumn{6}{|c|}{ Plio-pliestocene Gravel Unit } \\
\hline $115 \mathrm{~A}$ & 230.75 & 0.13 & 0.09 & 0.04 & 0.75 \\
\hline $120 \mathrm{~B}$ & 240.95 & 0.09 & 0.08 & 0.01 & 0.67 \\
\hline $120 \mathrm{~A}$ & 241.45 & 0.1 & 0.06 & 0.04 & 0.50 \\
\hline $123 \mathrm{~A}$ & 245.75 & 0.03 & 0 & 0.03 & 0.00 \\
\hline $127 \mathrm{~A}$ & 253.15 & 0.08 & 0.02 & 0.06 & 0.17 \\
\hline \multicolumn{3}{|c|}{ Background PPIg } & & & 0.72 \\
\hline
\end{tabular}

(1) to convert to meters multiply by 0.3048

BOLD denotes values for background sediments from same lithology from clean borehole 299-E33-338.

\subsection{M Nitric Acid Extractable Amounts of Selected Elements}

The amount of material that was extractable from the vadose zone sediment into $8 \mathrm{M}$ nitric acid is shown in Tables 4.17 and 4.18. Prior to gaining access to an x-ray fluorescence unit that can determine the total composition of contaminated sediment directly, we had no accurate method to determine directly the total elemental composition of the contaminated sediment. As described in Serne et al. (2002a), we tried total fusion digestion of sediment as well as $8 \mathrm{M}$ nitric acid. Neither technique works well for 
Hanford vadose zone sediment. The total fusion dilutes the acid-extract solution too much to get useful data for most trace metals and based on the x-ray fluorescence analyses, the $8 \mathrm{M}$ nitric acid extraction dissolves only a few percent to at best $50 \%$ of various major constituents.

The $8 \mathrm{M}$ nitric acid extraction is a protocol used by the U.S. Environmental Protection Agency to estimate the maximum concentrations of regulated metals in contaminated sediment that would be biologically available. We subjected aliquots of contaminated sediment from the 299-E33-46 borehole to the acid extraction to search for obvious signs of elevated concentrations of elements from leaked tank fluids.

Both tables include the range for acid extractable sediments from the background or clean borehole (299-E33-338) just east of the B tank farm fence line for the same lithologies. It would appear that the major cation data in Table 4.17 shows that borehole 299-E33-46 contains elevated concentrations of acid extractable sodium between 16 and $21 \mathrm{~m} \mathrm{(53} \mathrm{and} 69.5 \mathrm{ft})$ bgs. Aside from sodium there does not appear to be elevated concentrations of acid extractable major or RCRA metals although the arsenic data in Table 4.18 does appear to show elevated levels in the 299-E33-46 borehole. However, the measurement of arsenic by ICP-MS in difficult matrices such as $8 \mathrm{M}$ nitric acid is fraught with difficulty. We do not believe that the differences in the clean and contaminated boreholes' acid extractable arsenic is meaningful because often the mass spectrometer shows sporadic mass interferences for arsenic isotopes that we have not resolved.

In general, the percentages of the common cations and RCRA metals that was water extractable versus acid extractable are quite low, similar to natural sediments that do not contain large amounts of waste. For the slant borehole sediments under SX-108 tank, greater than $80 \%$ of the sodium that was acid extractable was also water extractable showing the large mass of sodium that leaked from the SX-108 tank (see Serne et al. 2002c for more details). No dramatic water leachable versus acid extractable percentages were observed for the sediments from 299-E33-46 because the composition of the fluids that leaked into the sediments was not as highly concentrated as the solutions that leaked at the SX tank farm. 


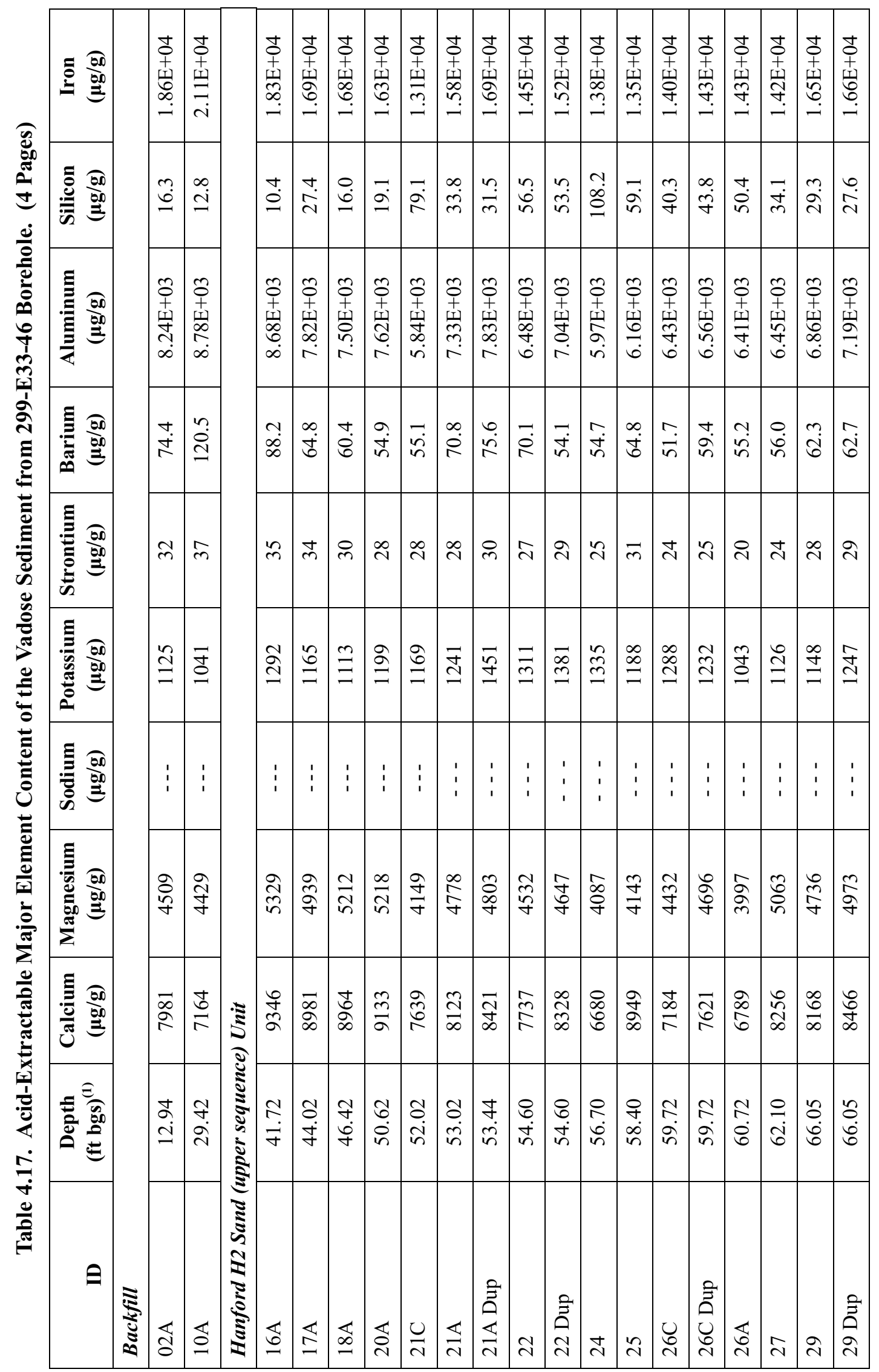




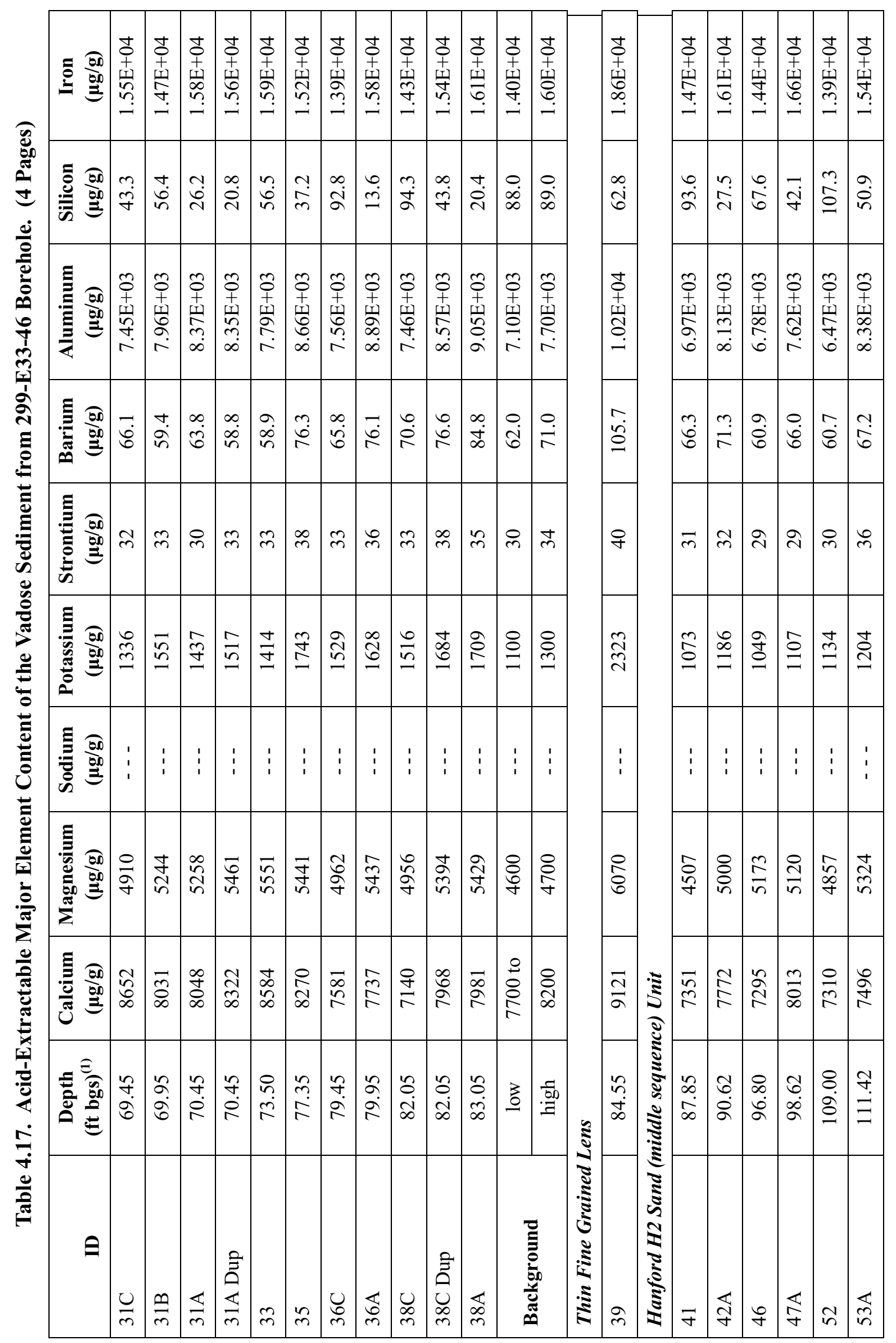




\begin{tabular}{|c|c|c|c|c|c|c|c|c|c|c|c|c|c|c|c|c|c|c|c|c|c|c|}
\hline 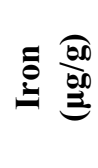 & 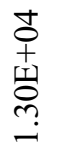 & 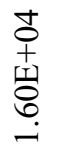 & 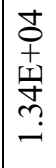 & 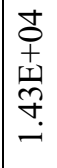 & 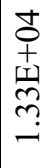 & 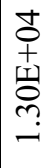 & $\begin{array}{l} \pm \\
0 \\
+ \\
+1 \\
m \\
m \\
-\end{array}$ & 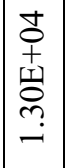 & 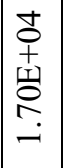 & & 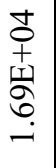 & & 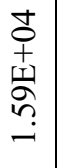 & 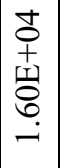 & 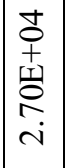 & & 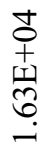 & 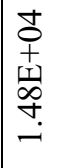 & 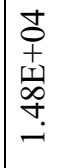 & 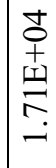 & 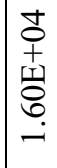 & $\begin{array}{l}+ \\
0 \\
+ \\
\text { ज्ञ } \\
\stackrel{2}{i} \\
\text { i }\end{array}$ \\
\hline 苛 & $\begin{array}{l}\infty \\
\emptyset \\
\emptyset\end{array}$ & $\underset{\sim}{\tilde{n}}$ & $\begin{array}{l}0 \\
\dot{0}\end{array}$ & $\begin{array}{l}\infty \\
\dot{\gamma}\end{array}$ & 每 & 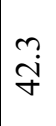 & $\frac{0}{\dot{m}}$ & $\begin{array}{l}0 \\
\dot{+}\end{array}$ & $\begin{array}{l}\stackrel{0}{0} \\
\stackrel{0}{O}\end{array}$ & & $\stackrel{\infty}{\dot{m}}$ & & $\stackrel{\text { ̊ }}{\stackrel{n}{n}}$ & $\infty$ & $\begin{array}{l}0 \\
\dot{\infty} \\
\stackrel{0}{0}\end{array}$ & & ָָ & $\stackrel{\sim}{ָ}$ & 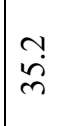 & $\hat{\sigma}$ & $\stackrel{0}{\infty}$ & $\mid \begin{array}{l}0 \\
\infty \\
\infty \\
0\end{array}$ \\
\hline 罗 & $\begin{array}{l}m \\
0 \\
+ \\
1 \\
+1 \\
n \\
6 \\
0\end{array}$ & 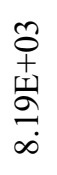 & 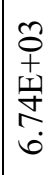 & $\begin{array}{l}m \\
0 \\
+ \\
1 \\
\\
\infty \\
r \\
r\end{array}$ & $\begin{array}{l}0 \\
\vdots \\
+ \\
1 \\
\\
\infty \\
0 \\
0\end{array}$ & $\begin{array}{l}\hat{o} \\
+ \\
\underline{\omega} \\
\hat{\sigma} \\
\hat{\sigma}\end{array}$ & 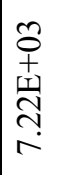 & $\begin{array}{c}n \\
0 \\
+ \\
\pm \\
\tilde{y} \\
0 \\
0 \\
0\end{array}$ & $\begin{array}{c}m \\
0 \\
+ \\
\text { ț } \\
\vdots \\
\vdots \\
r\end{array}$ & & $\begin{array}{l}m \\
+ \\
+1 \\
m \\
\vec{m} \\
a\end{array}$ & & $\begin{array}{l}0 \\
+ \\
+ \\
1 \\
0 \\
0 \\
r\end{array}$ & $\begin{array}{c}m \\
0 \\
+ \\
\text { 떵 } \\
8 \\
a \\
\sigma\end{array}$ & 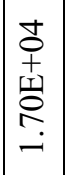 & & \begin{tabular}{l}
$n$ \\
+ \\
+ \\
+1 \\
\multirow{+}{*}{} \\
$r$
\end{tabular} & $\begin{array}{l}\stackrel{3}{0} \\
+ \\
\text { 떵 } \\
\vdots \\
\end{array}$ & $\begin{array}{l}3 \\
0 \\
+ \\
\text { T1 } \\
0 \\
0 \\
r\end{array}$ & \begin{tabular}{l}
$m$ \\
0 \\
+ \\
$\Psi$ \\
\multirow{f}{*}{} \\
$r$
\end{tabular} & $\begin{array}{l}n \\
0 \\
+ \\
\text { y } \\
0 \\
n \\
0\end{array}$ & 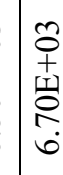 \\
\hline 恶 & $\begin{array}{l}n \\
\infty \\
\infty\end{array}$ & $\overrightarrow{8}$ & $\stackrel{0}{\dot{\sigma}}$ & in & $\overrightarrow{\mathrm{d}}$ & $\begin{array}{l}0 \\
\text { î }\end{array}$ & $\begin{array}{l}\hat{\tilde{n}} \\
\hat{n}\end{array}$ & $\begin{array}{l}0 \\
\text { in }\end{array}$ & $\stackrel{\circ}{\check{r}}$ & & $\stackrel{n}{\stackrel{n}{*}}$ & & $\stackrel{a}{i}$ & $\hat{6}$ & 웅 & & $\stackrel{\nabla}{r}$ & กี่ & $\begin{array}{l}N \\
\infty \\
n\end{array}$ & $\begin{array}{l}0 \\
0 \\
0\end{array}$ & $\frac{0}{6}$ & ôd \\
\hline 总 & $\hat{\sim}$ & $\stackrel{\infty}{m}$ & in & $\tilde{n}$ & $\hat{\sim}$ & in & లి & $\stackrel{\imath}{i}$ & r & & $\bar{\gamma}$ & & $\hat{m}$ & $\stackrel{F}{+}$ & 6 & & $\stackrel{m}{m}$ & กิ & શे & $\widetilde{\sim}$ & নे & $\bar{m}$ \\
\hline 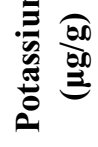 & $\approx$ & $\stackrel{\infty}{=}$ & $\bar{\Xi}$ & $\stackrel{2}{6}$ & లో & ஸે & $\stackrel{n}{0}$ & $\stackrel{9}{\stackrel{9}{0}}$ & 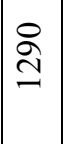 & & $\begin{array}{l}\infty \\
\stackrel{\infty}{ \pm}\end{array}$ & & $\stackrel{\sim}{\beth}$ & 8 & $\begin{array}{l}8 \\
\infty \\
\text { N }\end{array}$ & & $\stackrel{\tilde{\Xi}}{\simeq}$ & ฉ̆ & $\frac{n}{a}$ & $\begin{array}{l}0 \\
\sigma \\
\sigma\end{array}$ & જૂ & $\mathscr{\&}$ \\
\hline 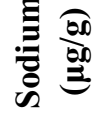 & : & : & : & : & : & : & : & : & : & & : & & i & : & : & & : & $\begin{array}{l}1 \\
\vdots \\
1\end{array}$ & $\vdots$ & : & : & ! \\
\hline 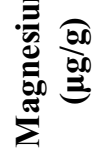 & \begin{tabular}{l}
$\forall$ \\
\multirow{Z}{*}{}
\end{tabular} & $\frac{\nabla}{\circ}$ & $\underset{\mathcal{F}}{\overparen{J}}$ & 志 & $\underset{⿱}{\stackrel{\nabla}{\sigma}}$ & $\underset{\substack{\infty \\
\infty}}{+}$ & $\begin{array}{l}\infty \\
\stackrel{\infty}{\infty} \\
+\end{array}$ & $\begin{array}{l}8 \\
8 \\
8 \\
+\end{array}$ & 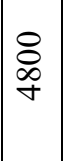 & & $\begin{array}{l}8 \\
\infty \\
\infty \\
n\end{array}$ & & 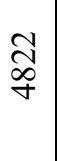 & $\begin{array}{l}8 \\
8 \\
\vdots \\
n\end{array}$ & \& & & 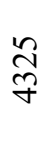 & 㔯 & $\begin{array}{l}\infty \\
\dot{0} \\
f\end{array}$ & $\underset{⿱ 乛}{\stackrel{\Xi}{+}}$ & ஓ & \& \\
\hline 恶 & $\begin{array}{l}8 \\
\text { కా }\end{array}$ & $\stackrel{n}{2}$ & స్ & 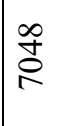 & $\frac{\infty}{\frac{\infty}{\sigma}}$ & $\stackrel{\widetilde{\sigma}}{\widetilde{\sigma}}$ & $\begin{array}{l}\vec{\infty} \\
\text { ర్ర }\end{array}$ & $\begin{array}{l}8 \\
8 \\
0 \\
0\end{array}$ & 웅 & & $\frac{ \pm}{\sigma}$ & & $\begin{array}{l}\stackrel{8}{\infty} \\
\stackrel{\infty}{+}\end{array}$ & 方 & 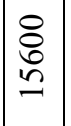 & & $\underset{\sigma}{\stackrel{N}{\sigma}}$ & $\begin{array}{l}\text { ర్ } \\
\text { రె }\end{array}$ & $\begin{array}{l}n \\
\tilde{n} \\
6\end{array}$ & 呑 & ¿ి & \& \\
\hline 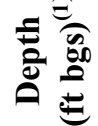 & $\sigma^{\alpha}$ & $\begin{array}{l}n \\
\infty \\
\end{array}$ & $\begin{array}{l}2 \\
\stackrel{0}{0} \\
\dot{+}\end{array}$ & \begin{tabular}{l}
$n$ \\
\hdashline \\
$i$ \\
$n$
\end{tabular} & $\frac{n}{8}$ & 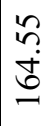 & $\begin{array}{l}n \\
0 \\
0 \\
0 \\
0\end{array}$ & 立 &. & & 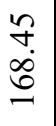 & & $\begin{array}{l}n \\
\stackrel{n}{\rightleftarrows} \\
=\end{array}$ & 3 & 总 & & $\begin{array}{l}n \\
\infty \\
\stackrel{2}{2}\end{array}$ & $\begin{array}{l}\stackrel{0}{0} \\
\stackrel{0}{\circ}\end{array}$ & ấ & 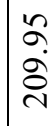 & 家 &.$\overline{00}$ \\
\hline ق & $\underset{n}{\mathbb{n}}$ & $\underset{\mathbb{J}}{\mathbb{J}}$ & శ্ & $\underset{\nwarrow}{\mathbb{I}}$ & ঝু & 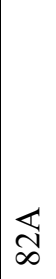 & $\underset{\infty}{\infty}$ & $\begin{array}{l}0 \\
0 \\
0 \\
0\end{array}$ & مَ & 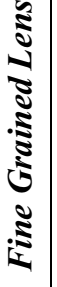 & ষ & 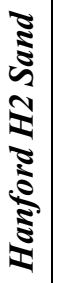 & $\overleftrightarrow{\infty}$ & 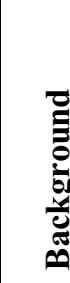 & 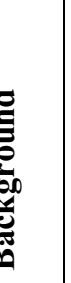 & 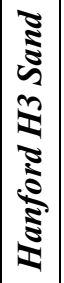 & \&্ & $\overleftrightarrow{\delta}$ & 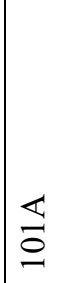 & 芯 & & 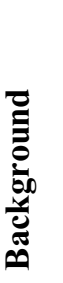 \\
\hline
\end{tabular}




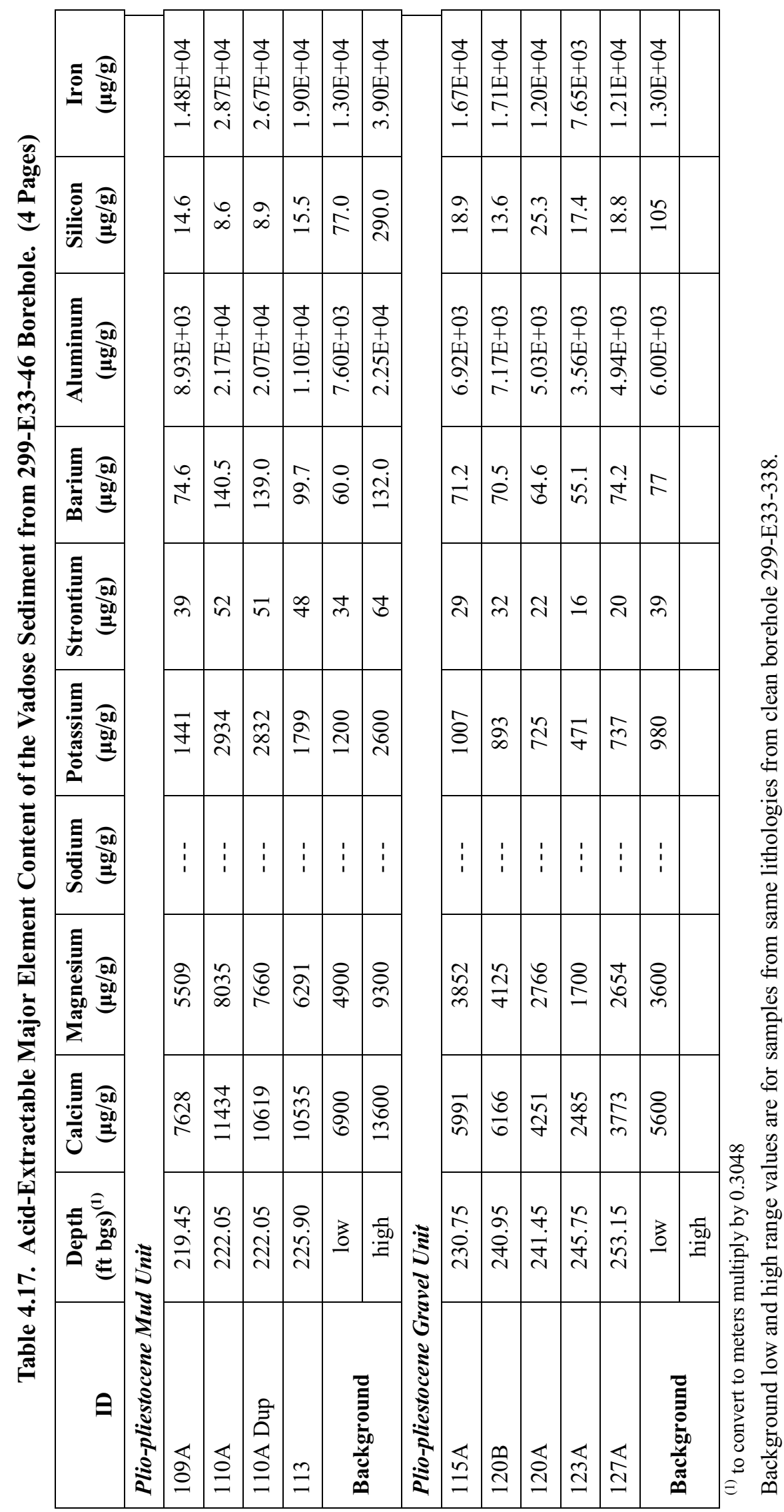


Table 4.18. Acid-Extractable RCRA Metal Content of the Vadose Sediment from 299-E33-46 Borehole. (3 Pages)

\begin{tabular}{|c|c|c|c|c|c|c|c|}
\hline ID & $\begin{array}{l}\text { Depth } \\
\text { ft bgs }\end{array}$ & $\begin{array}{c}\text { Arsenic } \\
(\mu \mathrm{g} / \mathrm{g})\end{array}$ & $\begin{array}{c}\text { Selenium } \\
(\mu \mathrm{g} / \mathrm{g})\end{array}$ & $\begin{array}{l}\text { Silver } \\
(\mu \mathrm{g} / \mathrm{g})\end{array}$ & $\begin{array}{c}\text { Cadium } \\
(\mu \mathrm{g} / \mathrm{g})\end{array}$ & $\begin{array}{c}\text { Lead } \\
(\mu \mathrm{g} / \mathrm{g})\end{array}$ & $\begin{array}{c}\text { Chromium } \\
(\mu \mathrm{g} / \mathrm{g})\end{array}$ \\
\hline \multicolumn{8}{|l|}{ Backfill } \\
\hline $02 \mathrm{~A}$ & 12.94 & 2.22 & $(7.03 \mathrm{E}-02)$ & 0.03 & 0.07 & 3.38 & 8.6 \\
\hline $10 \mathrm{~A}$ & 29.42 & 1.24 & $(4.88 \mathrm{E}-02)$ & 0.02 & 0.05 & 2.64 & 13.2 \\
\hline \multicolumn{8}{|c|}{ Hanford H2 Sand (upper sequence) Unit } \\
\hline $16 \mathrm{~A}$ & 41.72 & 2.96 & $(3.57 \mathrm{E}-02)$ & 0.03 & 0.06 & 3.91 & 11.6 \\
\hline $17 \mathrm{~A}$ & 44.02 & 2.21 & $<2.20 \mathrm{E}-01$ & 0.03 & 0.05 & 3.64 & 8.9 \\
\hline $18 \mathrm{~A}$ & 46.42 & 3.82 & $(3.27 \mathrm{E}-02)$ & 0.04 & 0.07 & 4.66 & 11.2 \\
\hline $20 \mathrm{~A}$ & 50.62 & 3.00 & $(4.20 \mathrm{E}-02)$ & 0.04 & 0.06 & 3.51 & 10.7 \\
\hline $21 \mathrm{C}$ & 52.02 & & & & & & 7.9 \\
\hline $21 \mathrm{~A}$ & 53.02 & 2.24 & $(3.93 \mathrm{E}-02)$ & 0.03 & 0.05 & 3.71 & 9.5 \\
\hline 21A Dup & 53.44 & 2.72 & $(3.15 \mathrm{E}-02)$ & 0.03 & 0.07 & 3.10 & 10.3 \\
\hline 22 & 54.60 & & & & & & 9.6 \\
\hline 22 Dup & 54.60 & & & & & & 9.6 \\
\hline 24 & 56.70 & & & & & & 7.6 \\
\hline 25 & 58.40 & & & & & & 8.7 \\
\hline $26 \mathrm{C}$ & 59.72 & & & & & & 9.5 \\
\hline 26C Dup & 59.72 & & & & & & 11.8 \\
\hline $26 \mathrm{~A}$ & 60.72 & 2.70 & $(5.11 \mathrm{E}-02)$ & 0.04 & 0.06 & 3.91 & 7.6 \\
\hline 27 & 62.10 & & & & & & 9.4 \\
\hline 29 & 66.05 & & & & & & 9.9 \\
\hline 29 Dup & 66.05 & & & & & & 11.4 \\
\hline $31 \mathrm{C}$ & 69.45 & & & & & & 11.5 \\
\hline $31 \mathrm{~B}$ & 69.95 & & & & & & 15.5 \\
\hline $31 \mathrm{~A}$ & 70.45 & $4.62^{\mathrm{a}}$ & (5.91E-02) & 0.04 & 0.08 & 4.82 & 14.7 \\
\hline 31A Dup & 70.45 & $3.69^{\mathrm{a}}$ & $(1.26 \mathrm{E}-02)$ & 0.04 & 0.07 & 4.08 & 14.1 \\
\hline 33 & 73.50 & & & & & & 15.3 \\
\hline 35 & 77.35 & & & & & & 16.2 \\
\hline $36 \mathrm{C}$ & 79.45 & & & & & & 13.2 \\
\hline $36 \mathrm{~A}$ & 79.95 & $3.71^{\mathrm{a}}$ & $(2.49 \mathrm{E}-02)$ & 0.04 & 0.07 & 3.69 & 15.4 \\
\hline $38 \mathrm{C}$ & 82.05 & & & & & & 14.1 \\
\hline
\end{tabular}


Table 4.18. Acid-Extractable RCRA Metal Content of the Vadose Sediment from 299-E33-46 Borehole. (3 Pages)

\begin{tabular}{|c|c|c|c|c|c|c|c|}
\hline ID & $\begin{array}{l}\text { Depth } \\
\text { ft bgs }\end{array}$ & $\begin{array}{c}\text { Arsenic } \\
(\mu \mathrm{g} / \mathrm{g})\end{array}$ & $\begin{array}{c}\text { Selenium } \\
(\mu \mathrm{g} / \mathrm{g})\end{array}$ & $\begin{array}{l}\text { Silver } \\
(\mu \mathrm{g} / \mathrm{g})\end{array}$ & $\begin{array}{c}\text { Cadium } \\
(\mu \mathrm{g} / \mathrm{g})\end{array}$ & $\begin{array}{c}\text { Lead } \\
(\mu \mathrm{g} / \mathrm{g})\end{array}$ & $\begin{array}{c}\text { Chromium } \\
(\mu \mathrm{g} / \mathrm{g})\end{array}$ \\
\hline 38C Dup & 82.05 & & & & & & 16.7 \\
\hline $38 \mathrm{~A}$ & 83.05 & $3.93^{\mathrm{a}}$ & $(9.61 \mathrm{E}-03)$ & 0.04 & 0.08 & 4.20 & 15.9 \\
\hline \multirow{2}{*}{ Background } & low & 0.80 & 0.05 & 0.025 & 0.06 & 2.30 & 6.40 \\
\hline & high & 1.00 & 0.06 & 0.028 & 0.07 & 2.90 & 7.70 \\
\hline \multicolumn{8}{|c|}{ Thin Fine Grained Lens } \\
\hline 39 & 84.55 & & & & & & 18.2 \\
\hline \multicolumn{8}{|c|}{ Hanford H2 Sand (middle sequence) Unit } \\
\hline 41 & 87.85 & & & & & & 11.3 \\
\hline $42 \mathrm{~A}$ & 90.62 & 2.67 & $(1.47 \mathrm{E}-02)$ & 0.03 & 0.06 & 3.23 & 11.1 \\
\hline 46 & 96.80 & & & & & & 14.0 \\
\hline $47 \mathrm{~A}$ & 98.62 & 3.03 & $(1.30 \mathrm{E}-02)$ & 0.04 & 0.06 & 3.43 & 11.1 \\
\hline 52 & 109.00 & & & & & & 11.2 \\
\hline $53 \mathrm{~A}$ & 111.42 & 2.57 & $<2.00 \mathrm{E}-01$ & 0.03 & 0.05 & 3.58 & 11.4 \\
\hline $57 \mathrm{~A}$ & 119.92 & 2.35 & $(5.38 \mathrm{E}-03)$ & 0.03 & 0.05 & 2.59 & 10.9 \\
\hline $64 \mathrm{~A}$ & 131.85 & 2.47 & $(6.26 \mathrm{E}-03)$ & 0.03 & 0.06 & 2.61 & 13.6 \\
\hline $69 \mathrm{~A}$ & 140.05 & 2.07 & $<2.24 \mathrm{E}-01$ & 0.03 & 0.06 & 2.92 & 10.2 \\
\hline $74 \mathrm{~A}$ & 150.15 & 2.73 & $(1.35 \mathrm{E}-03)$ & 0.03 & 0.07 & 3.02 & 14.1 \\
\hline $79 \mathrm{~A}$ & 160.15 & 2.35 & (9.19E-03) & 0.04 & 0.06 & 2.67 & 12.1 \\
\hline $82 \mathrm{~A}$ & 164.55 & 2.55 & $<2.30 \mathrm{E}-01$ & 0.08 & 0.06 & 2.94 & 12.4 \\
\hline $83 \mathrm{~A}$ & 166.85 & 2.43 & $<2.25 \mathrm{E}-01$ & 0.04 & 0.06 & 2.81 & 13.2 \\
\hline \multirow{2}{*}{ Background } & low & 0.90 & 0.04 & 0.03 & 0.06 & 2.50 & 12.00 \\
\hline & high & 1.26 & 0.08 & 0.04 & 0.10 & 4.00 & 14.50 \\
\hline \multicolumn{8}{|c|}{ Fine Grained Lens } \\
\hline 84 & 168.45 & & & & & & 18.0 \\
\hline \multicolumn{8}{|c|}{ Hanford H2 Sand Unit } \\
\hline $86 \mathrm{~A}$ & 171.15 & 2.81 & $(4.73 \mathrm{E}-02)$ & 0.04 & 0.06 & 3.61 & 11.0 \\
\hline \multirow{2}{*}{ Background } & low & 1.20 & 0.05 & 0.04 & 0.09 & 3.60 & 17.0 \\
\hline & high & 2.70 & 0.06 & 0.08 & 0.23 & 7.00 & 36.0 \\
\hline \multicolumn{8}{|c|}{ Hanford H3 Sand Unit } \\
\hline $90 \mathrm{~A}$ & 179.85 & 2.40 & $(2.54 \mathrm{E}-02)$ & 0.03 & 0.07 & 2.91 & 8.5 \\
\hline
\end{tabular}


Table 4.18. Acid-Extractable RCRA Metal Content of the Vadose Sediment from 299-E33-46 Borehole. (3 Pages)

\begin{tabular}{|l|c|c|c|c|c|c|c|}
\hline \multicolumn{1}{|c|}{ ID } & $\begin{array}{c}\text { Depth } \\
\mathbf{f t} \text { bgs }\end{array}$ & $\begin{array}{c}\text { Arsenic } \\
(\boldsymbol{\mu g} / \mathbf{g})\end{array}$ & $\begin{array}{c}\text { Selenium } \\
(\boldsymbol{\mu g} / \mathbf{g})\end{array}$ & $\begin{array}{c}\text { Silver } \\
(\boldsymbol{\mu g} / \mathbf{g})\end{array}$ & $\begin{array}{c}\text { Cadium } \\
(\boldsymbol{\mu g} / \mathbf{g})\end{array}$ & $\begin{array}{c}\text { Lead } \\
(\boldsymbol{\mu g} / \mathbf{g})\end{array}$ & $\begin{array}{c}\text { Chromium } \\
(\boldsymbol{\mu g} / \mathbf{g})\end{array}$ \\
\hline $96 \mathrm{~A}$ & 190.80 & 2.21 & $<2.13 \mathrm{E}-01$ & 0.03 & 0.06 & 2.99 & 10.9 \\
\hline $101 \mathrm{~A}$ & 200.95 & 2.12 & $(4.02 \mathrm{E}-02)$ & 0.03 & 0.05 & 2.91 & 10.7 \\
\hline $105 \mathrm{~A}$ & 209.95 & 2.25 & $(2.19 \mathrm{E}-02)$ & 0.03 & 0.07 & 12.32 & 10.7 \\
\hline \multirow{2}{*}{ Background } & low & 0.70 & 0.05 & 0.02 & 0.07 & 2.10 & 9.0 \\
\cline { 2 - 9 } & high & 0.80 & 0.08 & 0.03 & 0.08 & 2.50 & 11.0 \\
\hline Plio-pliestocene Mud Unit & 219.45 & 2.93 & $(1.34 \mathrm{E}-02)$ & 0.03 & 0.07 & 3.08 & 18.2 \\
\hline 109A & 222.05 & 6.08 & $<2.09 \mathrm{E}-01$ & 0.10 & 0.24 & 13.38 & 28.4 \\
\hline 110A & 222.05 & 5.40 & $<2.06 \mathrm{E}-01$ & 0.09 & 0.22 & 12.59 & 26.5 \\
\hline 110A Dup & 225.90 & \multicolumn{7}{|l|}{} & & & & 20.9 \\
\hline 113 & low & 1.30 & 0.05 & 0.03 & 0.08 & 2.80 & 9.0 \\
\hline \multirow{2}{*}{ Background } & high & 5.90 & 0.10 & 0.12 & 0.27 & 21.00 & 11.0 \\
\hline
\end{tabular}

(1) to convert to meters multiply by 0.3048

${ }^{a}$ Zones with elevated concentrations in comparison with the nearby uncontaminated sediment (uncontaminated ranges shown for same lithologies in samples from borehole 299-E33-338.

( ) Values in parentheses are below quantification limit but above the detection limit and thus considered useful.

Blank spaces denote no analyses performed for these samples 


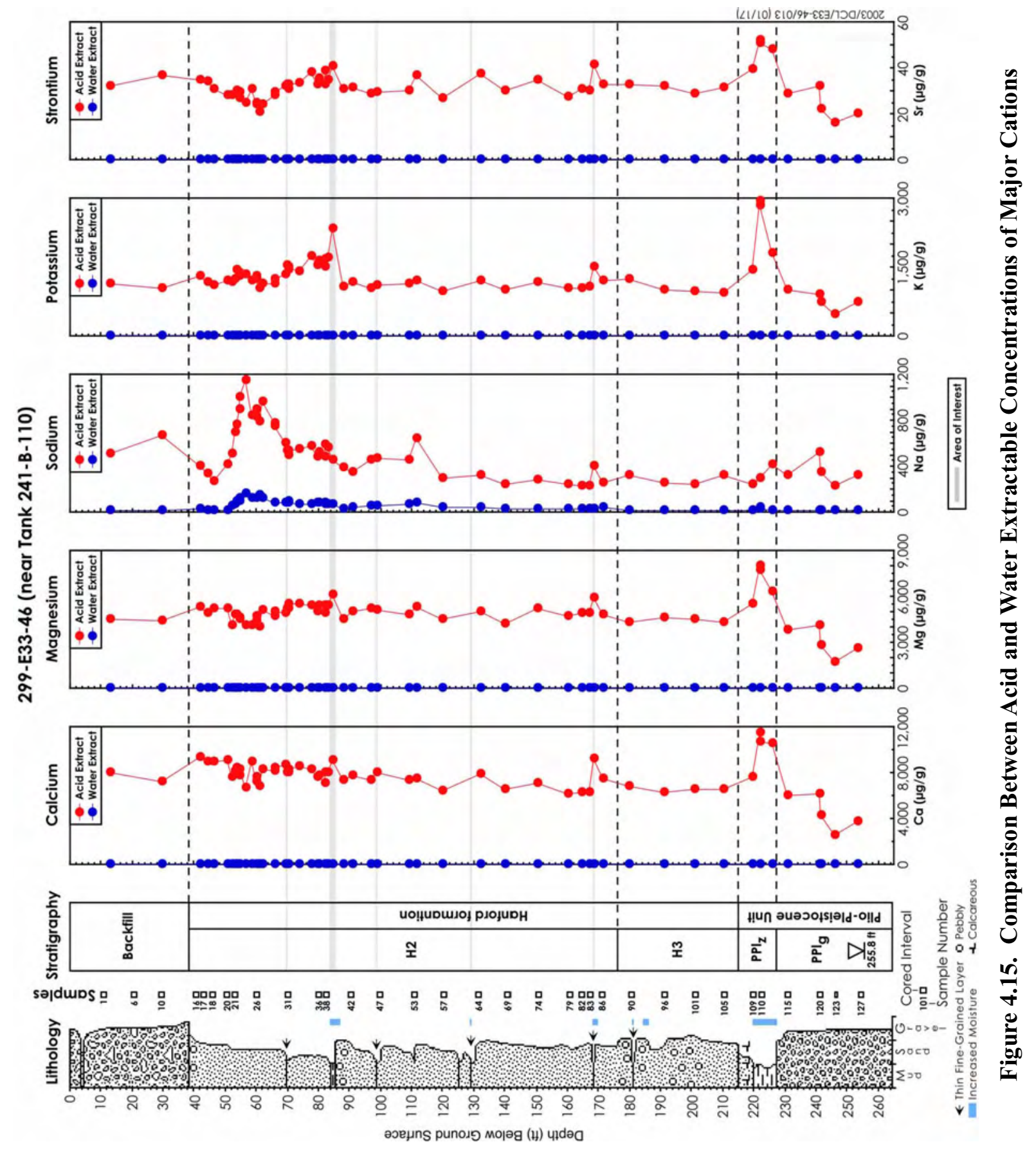




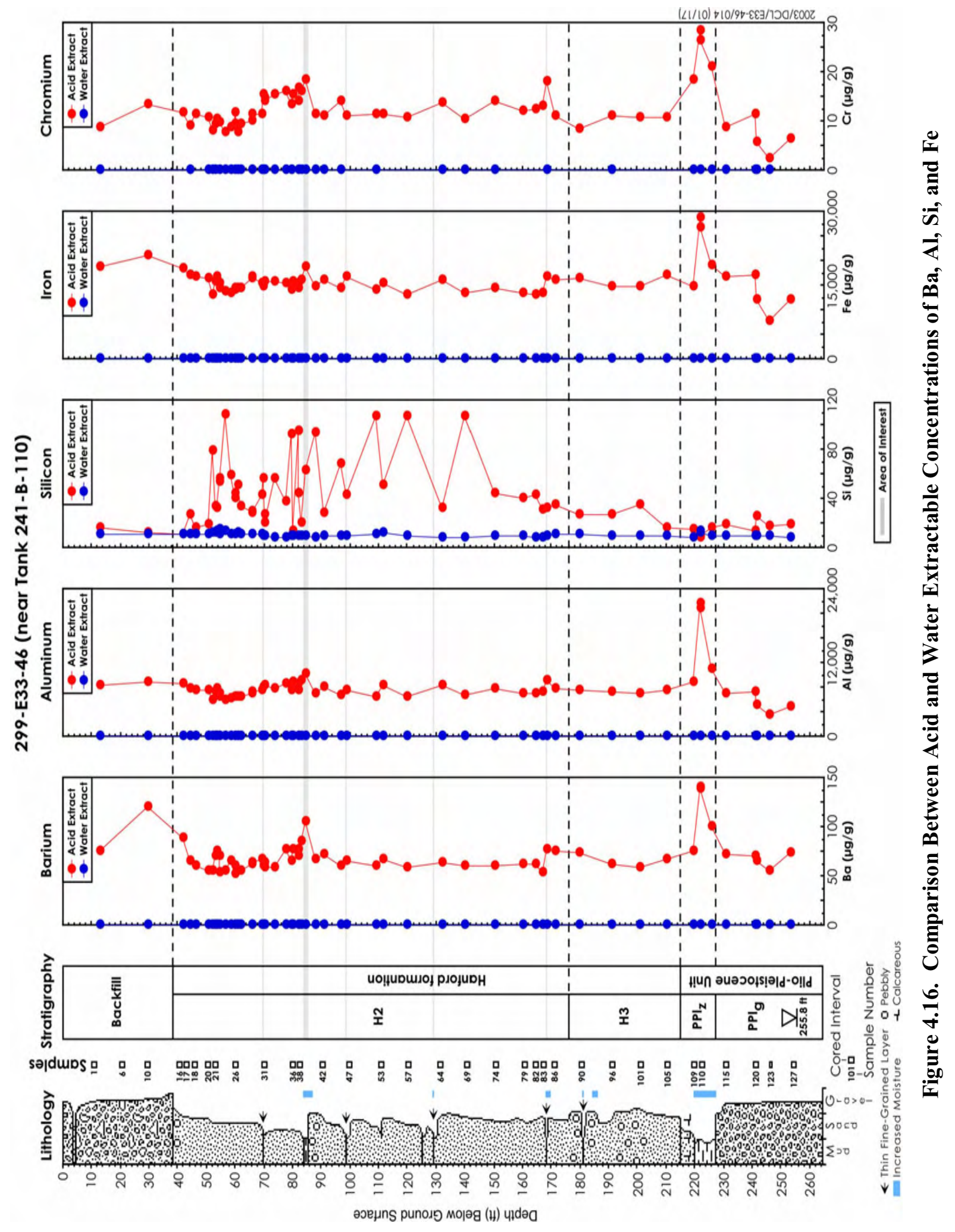




\subsection{Sediment Total Oxide Composition}

Eleven samples of the bulk vadose zone sediment from the 299-E33-46 borehole were crushed and analyzed with X-ray fluorescence to obtain the complete composition of the sediment. Additional aliquots of the same eleven samples were subjected to particle size analysis and the clay separates were retained. The total oxide composition of the bulk sediments was used to aid in the quantification of mineralogy that will be discussed later.

The total elemental oxide composition for the bulk sediment is shown in Table 4.19. Using two types of x-ray fluorescence instruments, we were able to analyze for all natural elements from sodium through uranium. We lack the capability for measuring the concentrations of only carbon, beryllium, boron, fluorine, lithium, and nitrogen. However, the carbon content of the bulk sediment was analyzed, as discussed in Section 4.4, so data for that component is available. The beryllium, boron, fluorine, and lithium content of the sediment likely is small; therefore, the oxide mass of the sediment should be able to be calculated and come close to $100 \%$ mass balance. We have assumed that the iron present in the sediment is all iron (III) oxide though there may be some reduced (ferrous oxides) iron also present.

The mass balances for the bulk sediment vary from 90.3 to $99.3 \%$ by weight. The low mass balances for samples in the PPlz mud unit appear to be caused by low silica values and perhaps low alumina values. The same low mass balances were found in the analyses of the sediments from the PPlz unit at the contaminated borehole (299-E33-45) east of tank BX-102. We suspect that there is a matrix correction that has not been optimized for the mineralogy in this lithology that is causing us to under predict the silica content. As found for uncontaminated sediment from outside other tank farms, the Hanford formation sediment is dominated by silica and alumina. Calcium, carbonate, iron, magnesium, potassium, sodium, and titanium make up most of the rest of the oxides. We do not have a large database of total elemental compositions but when compared to the two clean RCRA boreholes near SX Tank Farm (see Serne et al. 2002a), and the clean borehole east of the B Tank Farm (see Lindenmeier et al. 2002), the contaminated sediment at 299-E33-46 does not show significantly higher contents of any element. The total elemental composition of uncontaminated sediments from the clean borehole east of the B Tank Farm, 299-E33-338 and presented in Lindenmeier et al. (2002), was determined using total fusion and ICP and ICP-MS by an outside analytical vendor as compared to the XRF analyses performed on the contaminated sediments such that direct comparison is not easy. For the major constituents, the XRF data for silica in the PPlz unit presented in Table 4.19 does appear to be low by approximately $5 \mathrm{wt}$ $\%$ based on data from the clean borehole.

For some trace constituents such as tin, antimony, and cesium the XRF results shown in Table 4.20 are higher by a factor of ten than values for comparable samples from the clean borehole (see Lindenmeier et al. 2002). We do not believe that the higher values for some trace metals in the contaminated sediments from borehole 299-E33-46 reflect contamination. It is much more probable that the observed differences reflect the two totally independent analytical methods used to obtain the data. 


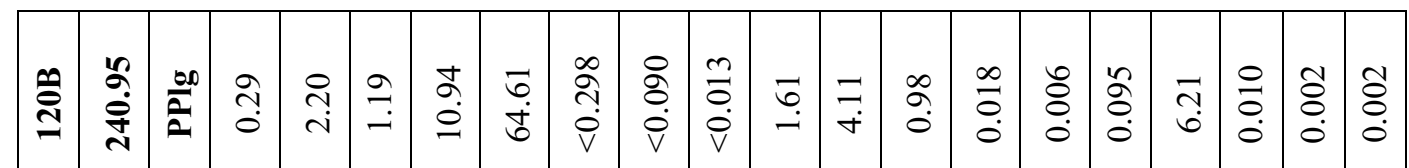

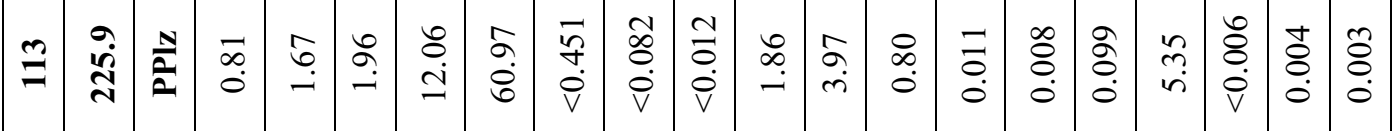

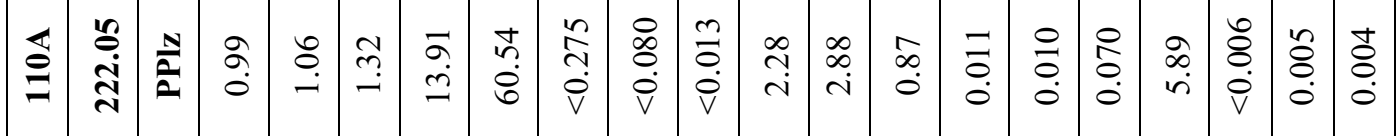

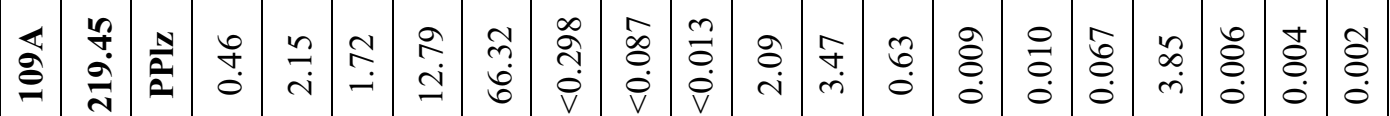

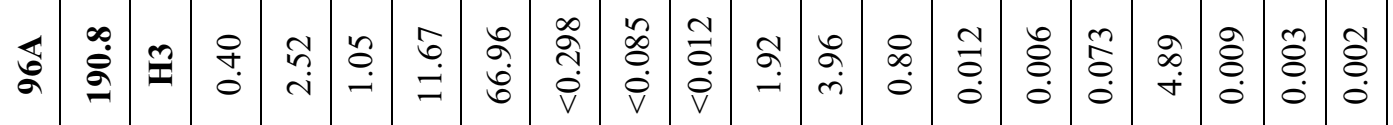

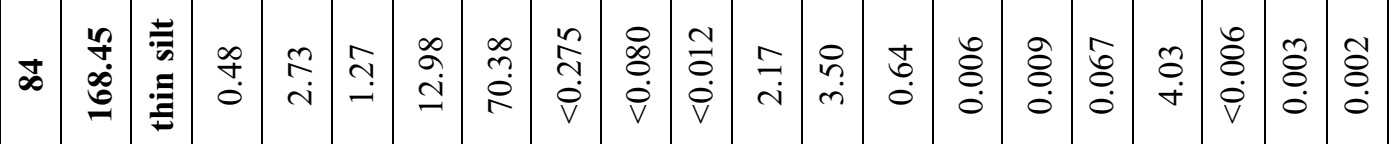

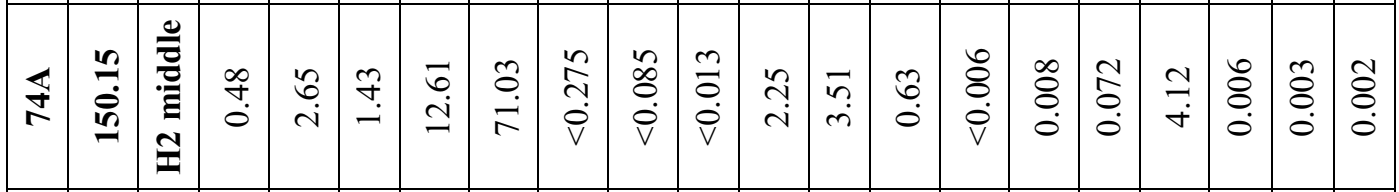

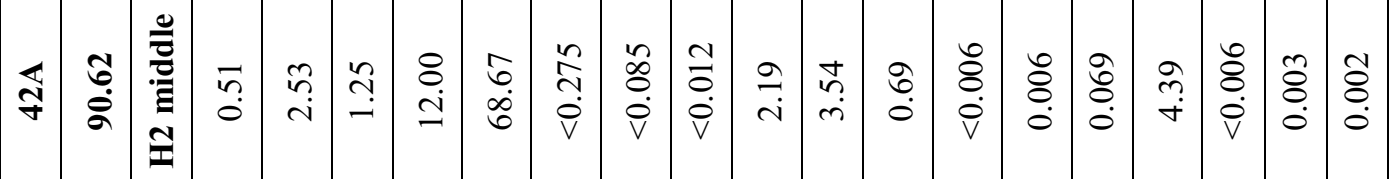

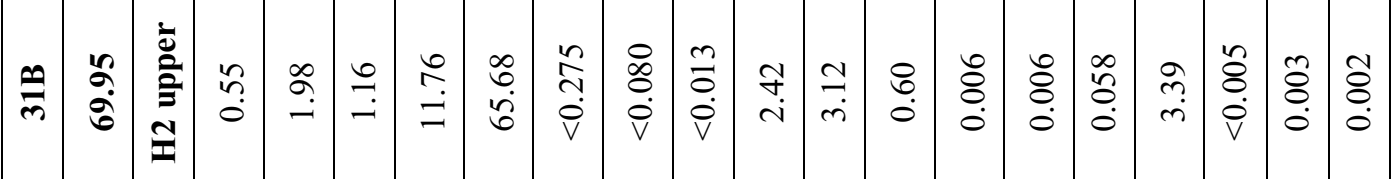

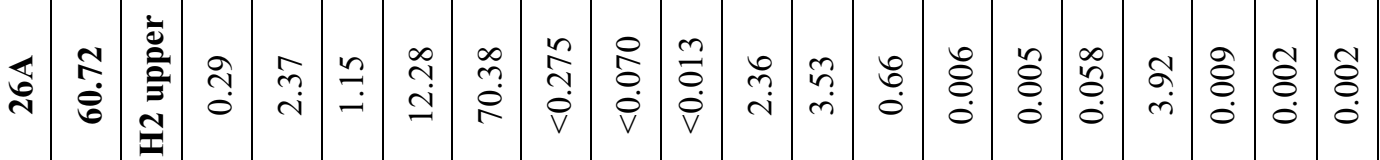

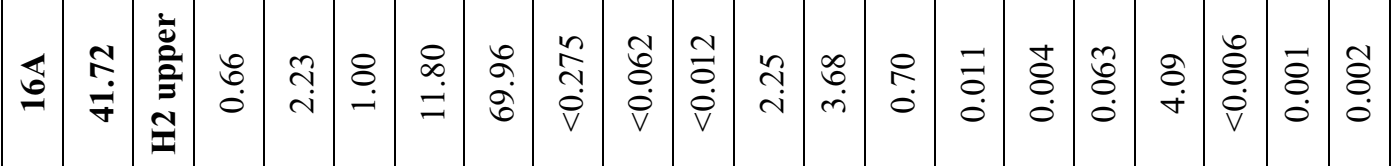

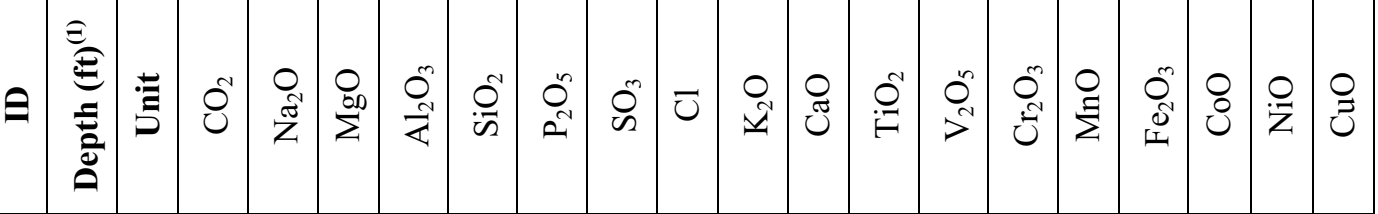




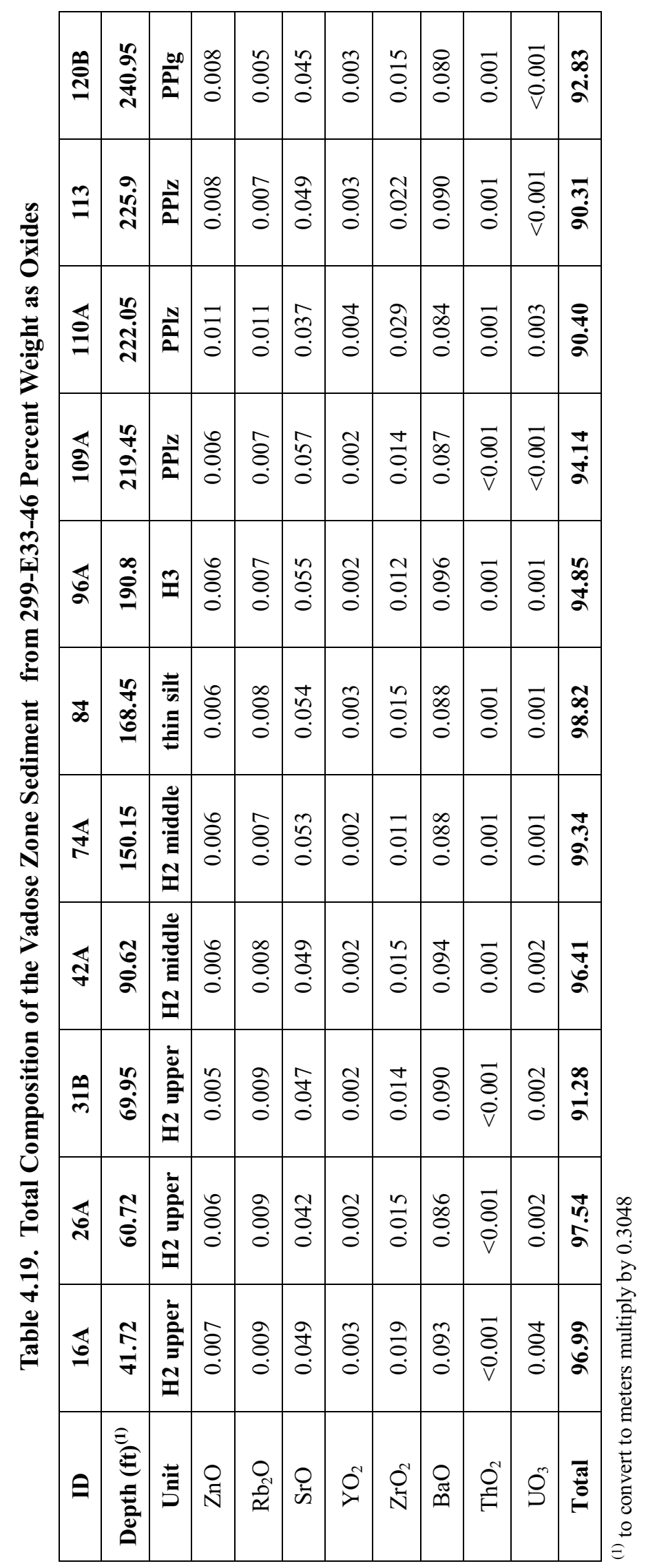




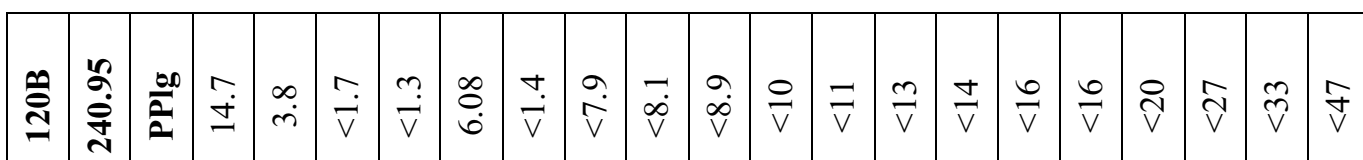

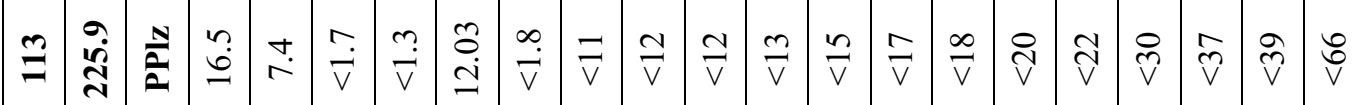

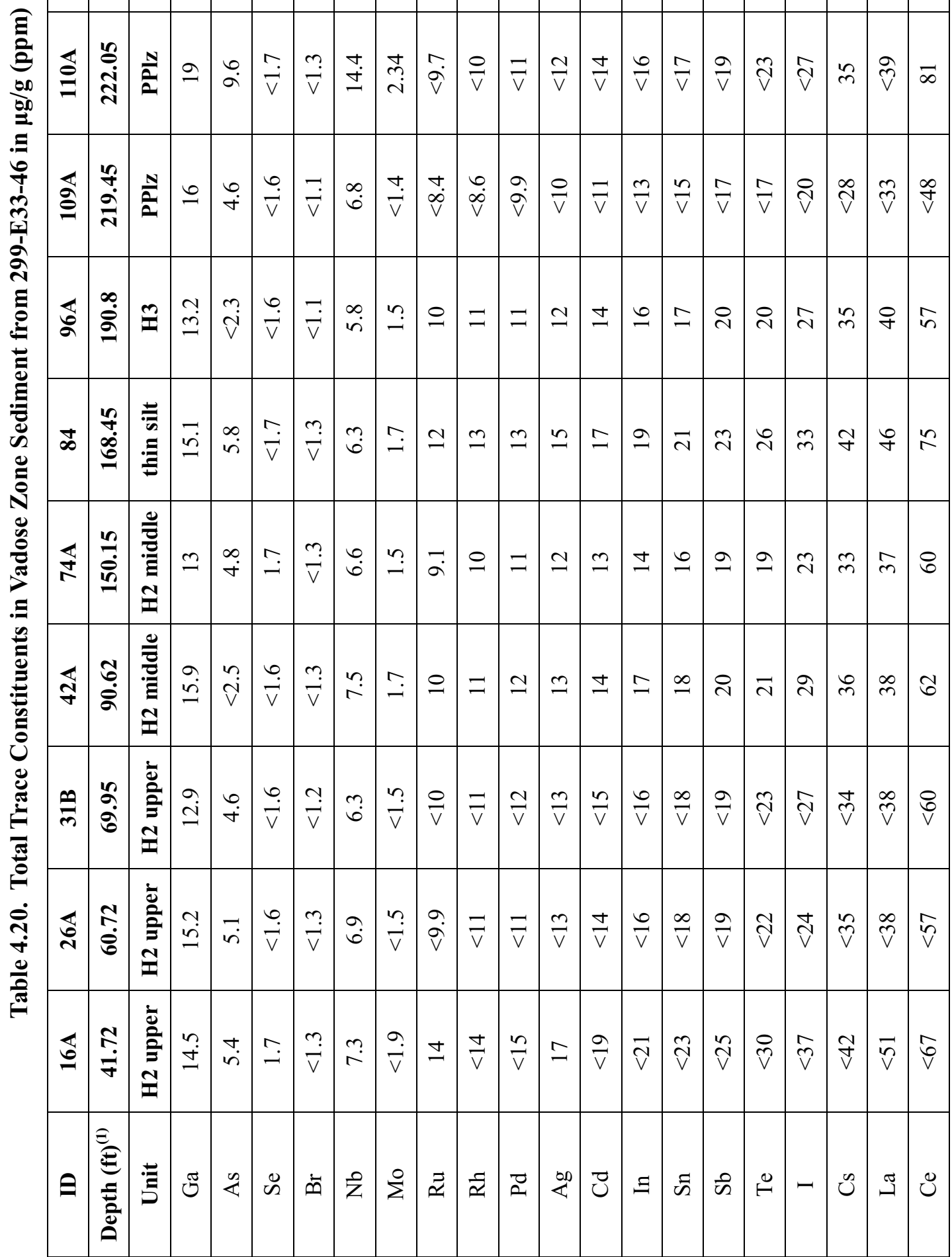




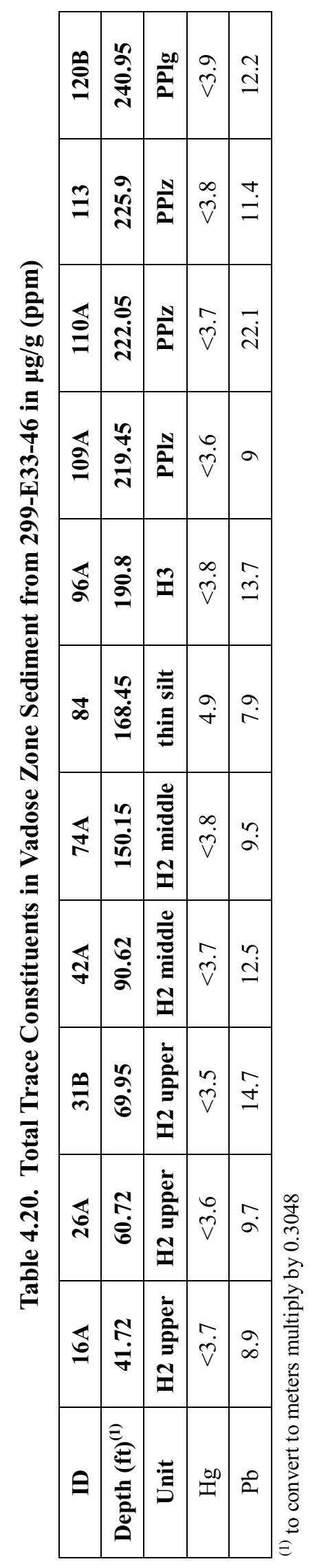




\subsection{Particle Size Measurements on Vadose Zone Sediment}

The hydrometer method was used to determine the particle size distributions of several samples from 299-E33-46 as shown in Table 4.21. No wet sieving was done to separate the gravel and sand fractions from each other so the particle size data shows only combined gravel + sand, silt, and clay fractions. The thin fine-grained lenses and Plio-Pleistocene silts are highlighted in yellow shading in the table. One sample at the very top of the Plio-Pleistocene silt (sample 109A) does not contain very much silt and clay even though it is assigned to the silt layer. The same situation was found at borehole 299-E33-45 such that we conclude that the uppermost portion of the PPlz unit is in fact coarser grained than the middle and deepest portions.

Besides the hydrometer estimate of clay-size particles, we physically separated the clay material from the silt by performing numerous re-suspensions of the slurry and decanting off the clays after the silts had settled. The mineralogical characterization of this clay fraction is described below in section 4.9.

\subsection{Particle Density of Bulk Sediment}

The particle density for each of the 299-E33-46 borehole samples that were used in the hydrometer procedure is shown in Table 4.22. The values are similar to those for uncontaminated sediment from the same lithologic facies found in 200W (see Serne et al. 2002a) and in general are about 0.05 to $0.10 \mathrm{~g} / \mathrm{cm}^{3}$ higher than values measured for the uncontaminated sediments from borehole 299-E33-338 located east of the B Tank Farm. The differences in particle density between the sediment samples from this contaminated and the uncontaminated borehole are likely caused by analyst's artifacts. Differences on the order of $0.1 \mathrm{~g} / \mathrm{cm}^{3}$ have been found on identical samples that were analyzed by three different lab staff during the characterization of the SX Tank Farm vadose zone sediments. There does not appear to be any statistically significant differences in the particle densities for the 299-E33-46 or for that matter 299-E33-338 clean or background sediments versus lithologic unit. The average value for all the Hanford formation sediments for boreholes 299-E33-46 and 299-E33-338 is $2.76 \pm 0.14 \mathrm{~g} / \mathrm{cm}^{3}$ similar to the value $2.78 \mathrm{~g} / \mathrm{cm}^{3}$ often used for generic Hanford formation sediments. The average particle density for the Plio-pleistocene sediments from the two boreholes is $2.78 \pm 0.07 \mathrm{~g} / \mathrm{cm}^{3}$.

\subsection{Mineralogy}

XRD analysis of the 11-bulk sediment samples from borehole 299-E33-46 shows the samples to all have a similar mineralogical signature. XRD analysis the sediment shows the samples collected from the Hanford formation (16A, 26A, 31B, 42A, 74A, and 84A) appear to be mineralogically similar. The sediments are mostly quartz and feldspar (both plagioclase and alkali-feldspar), with trace amounts of mica, chlorite, and an amphibole. Samples examined from the lower Hanford unit (H3) along with samples from the PPlz and PPlg unit all contain quartz and feldspars, along with significant amounts of clay material, predominantly mica and chlorite. For example, the XRD tracing of a typical sediment sample (110A) from the PPlz unit is provided in Figure 4.17, along with a quartz reference pattern. The main reflection for quartz is $26.63^{\circ} 2 \theta$, followed by less intense reflections at $20.86,36.53,39.46,42.43$, $50.12,59.92^{\circ} 2 \theta$. The main reflections associated with feldspar minerals are found between $27.34^{\circ} 2 \theta$ and $27.92^{\circ} 2 \theta$, with the higher $2 \theta$ values belonging to the plagioclase series. Chlorite and mica minerals were identified on the $x$-ray tracings by the reflections at $6.3^{\circ} 2 \theta$ and $8.8^{\circ} 2 \theta$, respectively. The presence 
of an amphibole was established by the characteristic $100 \%$ reflection at $10.5^{\circ} 2 \theta$. Additionally, trace amounts of the zeolite, laumontite, were identified in most of the samples by a diffraction peak positioned at $9.36^{\circ} 2 \theta$.

One interesting observation was noted on samples 96A and 109A. The XRD tracings from these two samples indicate an unusually high concentration of the amphibole mineral (hornblende) compared to all the other samples. Hornblende is typically found in most Hanford sediments, but only as trace amounts.

Table 4.21. Particle Size Distribution Percent Weight

\begin{tabular}{|c|c|c|c|c|}
\hline ID & $\begin{array}{c}\text { Depth } \\
(\text { ft bgs })^{(1)}\end{array}$ & $\begin{array}{c}\% \text { Gravel plus } \\
\text { \%Sand }\end{array}$ & $\%$ Silt & $\%$ Clay \\
\hline \multicolumn{5}{|l|}{ Backfill } \\
\hline \multicolumn{5}{|c|}{ No Sample Analyzed } \\
\hline \multicolumn{5}{|c|}{ Hanford H2 Sand (upper sequence) Unit } \\
\hline $16 \mathrm{~A}$ & 41.72 & 95.90 & 2.60 & 1.50 \\
\hline $26 \mathrm{~A}$ & 60.72 & 96.16 & 1.92 & 1.92 \\
\hline $31 \mathrm{~B}$ & 69.95 & 96.10 & 2.96 & 0.94 \\
\hline \multicolumn{5}{|c|}{ Thin Fine Grained Lens } \\
\hline \multicolumn{5}{|c|}{ No Sample Analyzed } \\
\hline \multicolumn{5}{|c|}{ Hanford H2 Sand (middle sequence) Unit } \\
\hline $42 \mathrm{~A}$ & 90.62 & 91.31 & 2.79 & 5.91 \\
\hline $74 \mathrm{~A}$ & 150.15 & 91.43 & 5.83 & 2.74 \\
\hline \multicolumn{5}{|c|}{ Fine Grained Lens } \\
\hline 84 & 168.45 & $68.06^{\mathrm{a}}$ & $28.85^{\mathrm{a}}$ & $3.08^{\mathrm{a}}$ \\
\hline \multicolumn{5}{|c|}{ Hanford H3 Sand Unit } \\
\hline $96 \mathrm{~A}$ & 190.8 & 96.54 & 2.21 & 1.25 \\
\hline \multicolumn{5}{|c|}{ Plio-pliestocene Mud Unit } \\
\hline $109 \mathrm{~A}$ & 219.45 & 89.48 & 8.97 & 1.55 \\
\hline $110 \mathrm{~A}$ & 222.05 & $7.00^{\mathrm{a}}$ & $85.73^{\mathrm{a}}$ & $7.27^{\mathrm{a}}$ \\
\hline 113 & 225.9 & $53.74^{\mathrm{a}}$ & $39.82^{\mathrm{a}}$ & $6.44^{\mathrm{a}}$ \\
\hline \multicolumn{5}{|c|}{ Plio-pliestocene Gravel Unit } \\
\hline $120 \mathrm{~B}$ & 240.95 & 87.44 & 9.81 & 2.76 \\
\hline
\end{tabular}

(1) to convert to meters multiply by 0.3048

${ }^{\text {a }}$ Fine grained samples 
Table 4.22. Particle Density of Bulk Sediment from 299-E33-46

\begin{tabular}{|c|c|c|c|}
\hline ID & $\begin{array}{c}\text { Depth } \\
(\mathbf{f t} \text { bgs) }\end{array}$ & $\begin{array}{l}\text { Ave. Particle Density } \\
\qquad\left(\mathrm{g} / \mathrm{cm}^{3}\right)\end{array}$ & $\begin{array}{c}\sigma \\
\left(\mathrm{g} / \mathrm{cm}^{3}\right)\end{array}$ \\
\hline \multicolumn{4}{|l|}{ Backfill } \\
\hline \multicolumn{4}{|c|}{ No Sample Analyzed } \\
\hline \multicolumn{4}{|c|}{ Hanford H2 Sand (upper sequence) Unit } \\
\hline $16 \mathrm{~A}$ & 41.72 & 2.81 & 0.097 \\
\hline $26 \mathrm{~A}$ & 60.72 & 2.65 & 0.028 \\
\hline $31 \mathrm{~B}$ & 69.95 & 2.90 & 0.238 \\
\hline \multicolumn{4}{|c|}{ Thin Fine Grained Lens } \\
\hline \multicolumn{4}{|c|}{ No Sample Analyzed } \\
\hline \multicolumn{4}{|c|}{ Hanford H2 Sand (middle sequence) Unit } \\
\hline $42 \mathrm{~A}$ & 90.62 & 2.89 & 0.017 \\
\hline $74 \mathrm{~A}$ & 150.15 & 2.91 & 0.047 \\
\hline \multicolumn{4}{|c|}{ Fine Grained Lens } \\
\hline 84 & 168.45 & 2.79 & 0.019 \\
\hline \multicolumn{4}{|c|}{ Hanford H3 Sand Unit } \\
\hline $96 \mathrm{~A}$ & 190.8 & 2.91 & 0.018 \\
\hline \multicolumn{4}{|c|}{ Plio-pliestocene Mud Unit } \\
\hline $109 \mathrm{~A}$ & 219.45 & 2.91 & 0.020 \\
\hline $110 \mathrm{~A}$ & 222.05 & 2.82 & 0.024 \\
\hline 113 & 225.9 & 2.71 & 0.061 \\
\hline \multicolumn{4}{|c|}{ Plio-pliestocene Gravel Unit } \\
\hline $120 \mathrm{~B}$ & 240.95 & 2.78 & 0.024 \\
\hline
\end{tabular}

(1) to convert to meters multiply by 0.3048 


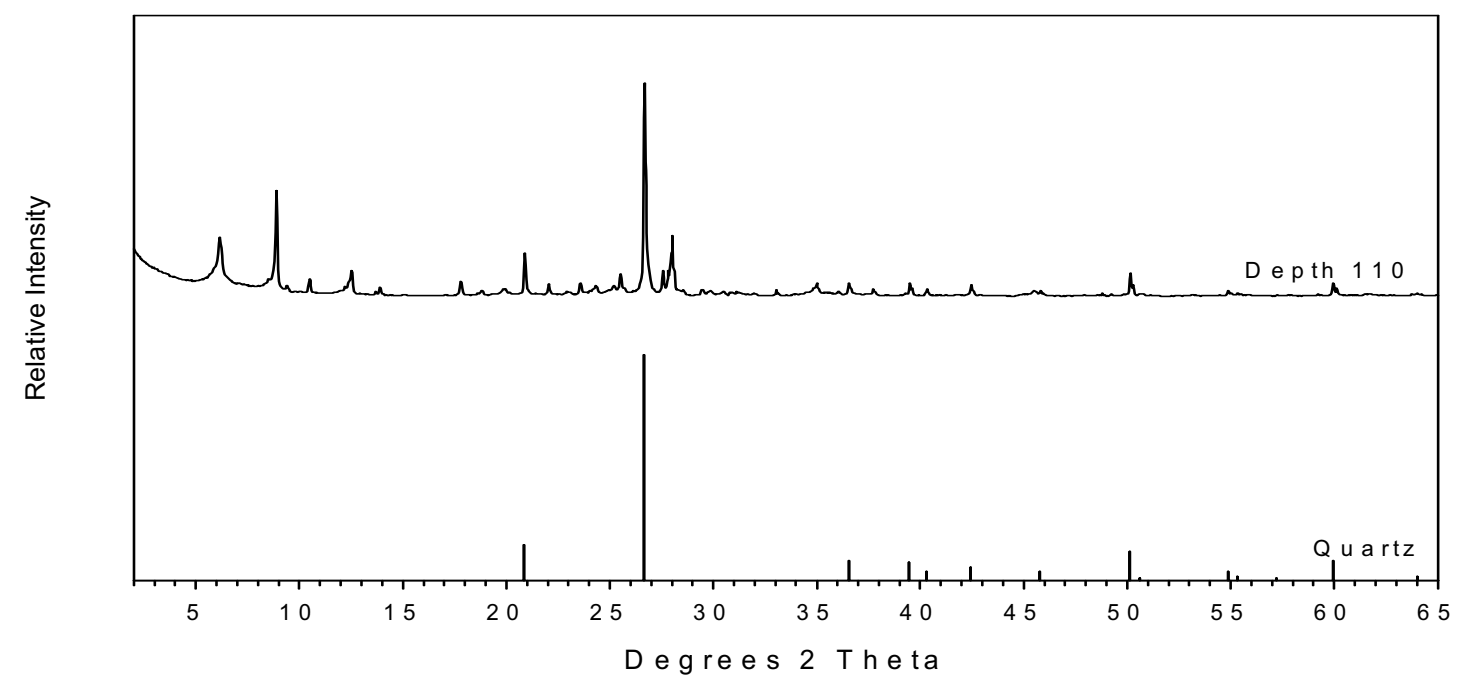

Figure 4.17. XRD Tracing of sample 110A along with the standard reference pattern for quartz.

Results from the semi quantification of the minerals in the bulk samples are provided in Table 4.23. Quartz concentrations ranged from $22.4 \mathrm{wt} \%$ (96A) to $43.5 \mathrm{wt} \%$ (31B), with an average concentration of $33 \pm 6 \mathrm{wt} \%$. The borehole sediment contained plagioclase feldspar concentrations from 10 to $34 \mathrm{wt} \%$ and potassium feldspar content measured between 8 to $37 \mathrm{wt}-\%$. Plagioclase feldspar was more abundant than potassium feldspar in all but three samples (16A, 26A, and 84A). Over all, the feldspar content (both plagioclase and alkali feldspars) averaged about $43 \pm 6 \mathrm{wt}-\%$. The amphibole phase comprised $<9 \mathrm{wt} \%$ at most, with the majority of samples having concentrations in the 2 to $4 \mathrm{wt} \%$ range.

Clay minerals identified in the whole rock sediment included mica and chlorite. Mica concentrations ranged from a low of $6.5 \mathrm{wt} \%(120 \mathrm{~B})$ to a high of $32 \mathrm{wt} \%(113 \mathrm{~A})$, with most of the intervals having concentrations between 7 and $15 \mathrm{wt} \%$. Chlorite concentrations were $<7 \mathrm{wt} \%$ in all sediments analyzed with the exception of two samples in the Plio-Pleistocene Mud Unit. Samples 109A and 110A contained 11.7 and 21.2 wt \% chlorite, respectively. Smectite and kaolinite minerals were not identified in the whole rock sediment samples due in part to the sample preparation technique and the low overall concentration.

X-ray diffraction analysis was performed on the $<2$ micron fraction of each sample and the results are presented below. The clay fraction is dominated by four clay minerals: smectite, chlorite, illite, and kaolinite with minor amounts of quartz and feldspar. Figure 4.18 provides XRD-tracings of a typical clay fraction (from sample 110A) following four different treatments. Smectites are considered the fraction of the magnesium-saturated sub-sample that gives a basal reflection at $5.85^{\circ} 2 \theta$ and expands to $5.28^{\circ} 2 \theta$ 
upon solvation with ethylene glycol. Saturation with a potassium cation shifts the reflection down to $7.3^{\circ}$ $2 \theta$ followed by the irreversible collapse to $8.88^{\circ} 2 \theta$ after heating for one hour at $575^{\circ} \mathrm{C}$.

Illite is the simplest of the four clay mineral phases to identify in this sediment. The basal reflections are located at $8.88,17.8$, and $26.7^{\circ} 2 \theta$. The various treatments including cation saturation, solvation with ethylene glycol, and heating do not affect the structure of the illite. This is shown in Figure 4.18 by examination of the illite basal reflection at $8.88^{\circ} 2 \theta$. The increase in intensity of the $8.88^{\circ} 2 \theta$ reflection between the heated and the unheated potassium-saturated sample is due to the incorporation of the smectite reflection resulting from the smectite structure collapsing.

Table 4.23. Semi-quantitative XRD Results of Minerals from the S01052 Borehole.

\begin{tabular}{|c|c|c|c|c|c|c|c|}
\hline \multirow{2}{*}{$\begin{array}{c}\text { Sample } \\
\text { ID }\end{array}$} & \multicolumn{6}{|c|}{ Mineral Phase (wt-\%) } & \multirow{2}{*}{$\begin{array}{c}\text { Goodness } \\
\text { of fit }^{1}\end{array}$} \\
\hline & Quartz & Amphibole & Plagioclase & K-Spar & Mica & Chlorite & \\
\hline \multicolumn{8}{|c|}{ Hanford H2 Sand (upper sequence) Unit } \\
\hline $16 \mathrm{~A}$ & 34.8 & 1.0 & 12.7 & 36.6 & 10.4 & 4.5 & 0.57 \\
\hline $26 \mathrm{~A}$ & 33.3 & 0.5 & 9.6 & 37.2 & 14.2 & 5.2 & 0.78 \\
\hline $31 \mathrm{~B}$ & 43.5 & 2.8 & 27.4 & 13.2 & 9.1 & 4.0 & 0.46 \\
\hline \multicolumn{8}{|c|}{ Hanford H2 Sand (middle sequence) Unit } \\
\hline $42 \mathrm{~A}$ & 38.5 & 3.1 & 28.5 & 16.5 & 9.4 & 4.0 & 0.41 \\
\hline $74 \mathrm{~A}$ & 39.6 & 2.0 & 23.0 & 20.2 & 11.8 & 3.5 & 0.71 \\
\hline \multicolumn{8}{|c|}{ Fine Grained Lens } \\
\hline $84 \mathrm{~A}$ & 34.5 & 2.9 & 19.5 & 29.1 & 8.5 & 5.6 & 0.81 \\
\hline \multicolumn{8}{|c|}{ Hanford H3 Sand Unit } \\
\hline $96 \mathrm{~A}$ & 22.4 & 4.0 & 29.1 & 12.3 & 27.0 & 5.2 & 0.22 \\
\hline \multicolumn{8}{|c|}{ Plio-Pleistocene Mud Unit } \\
\hline $109 \mathrm{~A}$ & 31.1 & 7.6 & 27.9 & 14.3 & 7.5 & 11.7 & 0.22 \\
\hline $110 \mathrm{~A}$ & 26.5 & 4.7 & 14.1 & 18.8 & 14.6 & 21.2 & 0.30 \\
\hline $113 \mathrm{~A}$ & 25.3 & 3.5 & 24.8 & 7.8 & 31.7 & 6.9 & 0.17 \\
\hline \multicolumn{8}{|c|}{ Plio-Pleistocene Gravel Unit } \\
\hline $120 \mathrm{~B}$ & 32.6 & 8.7 & 34.1 & 13.4 & 6.5 & 4.6 & 0.20 \\
\hline
\end{tabular}

\footnotetext{
${ }^{1}$ Values closest to 1.0 represent an ideal refinement.
} 


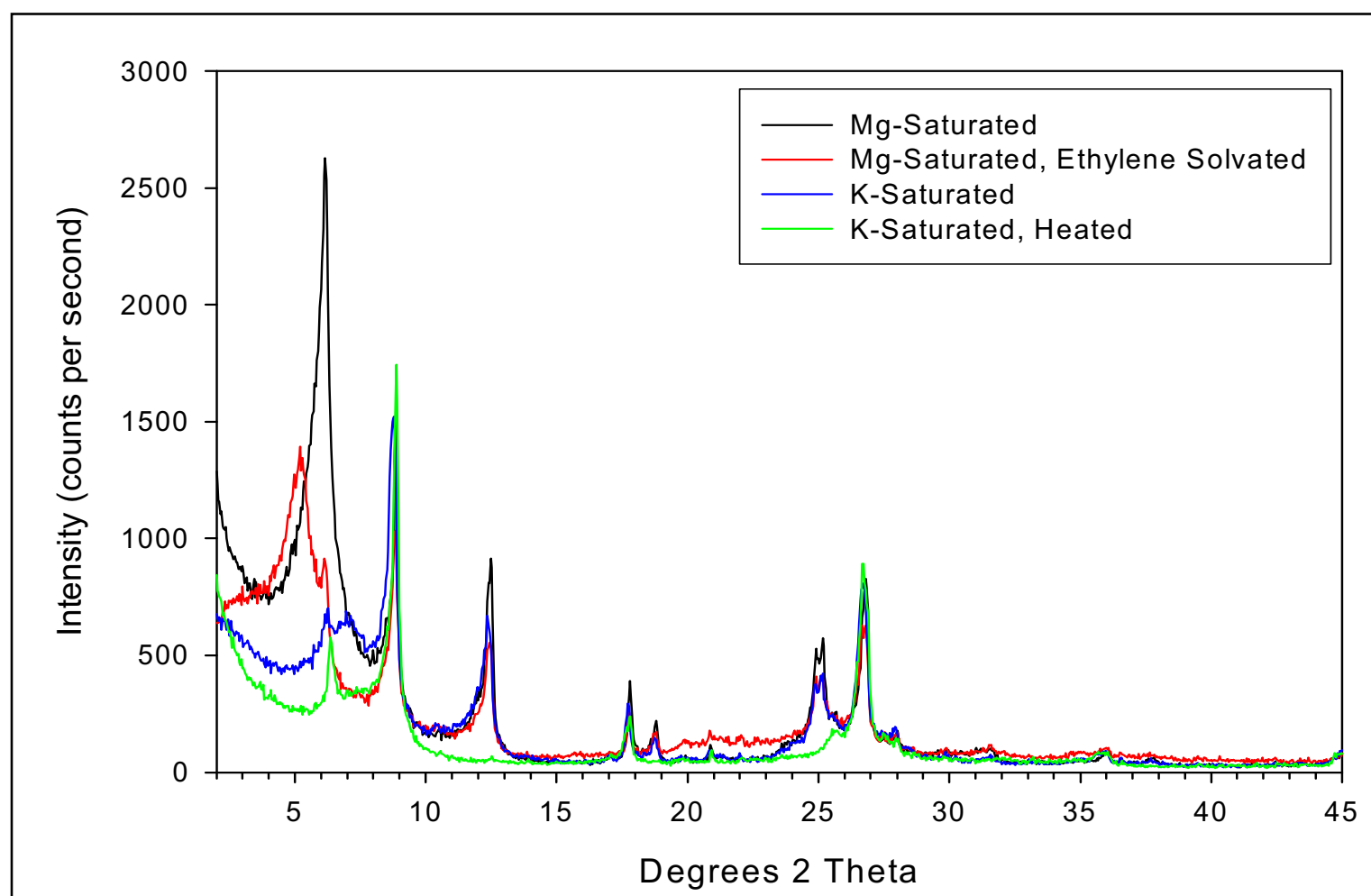

The scans were collected from 2 to $45^{\circ} 2 \theta$ with a $0.04^{\circ}$ step and 2-second dwell time. The black line represents the $\mathrm{Mg}$-saturated fraction and the red line represents the same fraction solvated with ethylene glycol. The blue line indicates the saturation with $\mathrm{K}^{+}$cation and the green line is the $\mathrm{K}^{+}$saturated sample heated to $575^{\circ} \mathrm{C}$ for one hour.

Figure 4.18. XRD tracings of preferentially oriented clay slides taken from Borehole 299-E33-46 sample 110A

Chlorites are identified by their basal series of diffraction peaks at $6.24,12.5,18.8$, and $25.2^{\circ} 2 \theta$, which are unaffected by cation saturation or ethylene glycol solvation. Heating to $575^{\circ} \mathrm{C}$ shifts the first order reflection to $6.37^{\circ} 2 \theta$ and also tends to diminish or eliminate the higher order reflections (12.5, 18.8, and $25.2^{\circ} 2 \theta$ ) as shown in Figure 4.18. Kaolinite is difficult to identify in the presence of a chlorite mineral. Basal reflections characteristic to kaolinite are positioned at 12.5 and $24.9^{\circ} 2 \theta$, which are superimposed on the even-order chlorite peaks. These kaolinite reflections are unaffected by cation saturation and ethylene glycol solvation. When heated the kaolinite structure becomes amorphous and the reflections are eliminated. Positive identification of kaolinite in the presence of chlorite can be determined by examination of the 24.9 to $25.2^{\circ} 2 \theta$ region of the XRD tracing. The kaolinite basal reflection at $24.9^{\circ} 2 \theta$ can be distinguished from the chlorite $25.2^{\circ} 2 \theta$ reflection (Figure 4.18 ). Furthermore, published reports characterizing similar clay fractions of Hanford sediment identify kaolinite by electron microscopy. 
Trace amounts of quartz are evident by the diffraction peak located at $20.85^{\circ} 2 \theta$. The $100 \%$ reflection for quartz $\left(26.6^{\circ} 2 \theta\right)$ is hidden by the third basal reflection of illite located at $26.6^{\circ} 2 \theta$. Plagioclase feldspar is also identified in the clay fraction by the minor diffraction peak at $27.8^{\circ} 2 \theta$.

Semi-quantification results of the clay minerals in the $<2$ micron fraction are presented in Table 4.24. Total recoveries were normalized to $100 \%$ and the normalization factor used for each sample is provided in the last column. Smectites ranged in concentrations from a low of $22 \mathrm{wt} \%$ (74A) to a high of $50 \mathrm{wt} \%(110 \mathrm{~A})$. Illite amounts varied from 30 to $56 \mathrm{wt} \%$ with the majority of samples having concentrations in the 40 to $50 \mathrm{wt} \%$ range. Chlorite and kaolinite were the least abundant of the clay minerals identified in the samples with concentrations equal to or less than $20 \mathrm{wt} \%$ and $9 \mathrm{wt} \%$, respectively. Quartz and feldspar minerals were present as trace amounts in the clay fraction and therefore were not included in totals presented in Table 4.24.

Total clay recoveries were within $\pm 25 \%$ of the "ideal" $100 \%$ for eight of the 11 samples analyzed. Factors affecting the semi-quantification procedure (preparation and condition of the clay filter cake) were generally controlled and not thought to be a significant factor. Quantitative analysis is considered good if errors amount to $\pm 10 \%$ of the amounts present for major constituents and $\pm 20 \%$ for minerals whose concentrations are less than 20\% (Moore and Reynolds, 1997). Other x-ray diffractograms of the bulk sediment and clay fractions are presented in Appendix D.

Table 4.24. Semi-quantitative XRD Results of Clay Minerals Separated from the Sediment Collected from Borehole 299-E33-46

\begin{tabular}{|c|c|c|c|c|c|}
\hline \multirow{2}{*}{$\begin{array}{c}\text { Sample } \\
\text { ID }\end{array}$} & \multicolumn{4}{|c|}{ Mineral Phase (wt-\%) } & \multirow{2}{*}{$\begin{array}{c}\text { Normalization } \\
\text { Factor }\end{array}$} \\
\cline { 2 - 5 } & Smectite & Illite & Chlorite & Kaolinite & 0.87 \\
\hline $16 \mathrm{~A}$ & 30 & 48 & 12 & 9 & 0.86 \\
\hline $26 \mathrm{~A}$ & 27 & 52 & 13 & 8 & 0.67 \\
\hline $31 \mathrm{~B}$ & 23 & 56 & 12 & 9 & 0.66 \\
\hline $42 \mathrm{~A}$ & 35 & 44 & 13 & 8 & 1.01 \\
\hline $74 \mathrm{~A}$ & 22 & 53 & 18 & 8 & 1.25 \\
\hline $84 \mathrm{~A}$ & 46 & 30 & 20 & 5 & 1.10 \\
\hline $96 \mathrm{~A}$ & 32 & 44 & 16 & 9 & 0.88 \\
\hline $109 \mathrm{~A}$ & 28 & 49 & 17 & 6 & 0.75 \\
\hline $110 \mathrm{~A}$ & 50 & 38 & 6 & 6 & 0.84 \\
\hline $113 \mathrm{~A}$ & 32 & 46 & 13 & 9 & 2.26 \\
\hline $120 \mathrm{~B}$ & 39 & 40 & 15 & 6 & \\
\hline
\end{tabular}




\subsection{Matric Suction Potential Measurements}

Water-potential measurements have been included in the Hanford Tank Farm Vadose Zone Characterization Program to document the energy state of pore waters in the tank farm sediments. At the tank farms, vegetation is absent, surface soils are coarse-textured, and the potential for drainage (recharge) is high (Gee 1987; Gee et al. 1992). However, actual drainage rates are generally unknown. Attempts are currently being made to determine the soil water matrix potential and use the analysis to confirm the occurrence of recharge within the Hanford Site Tank Farms.

The status of soil water can be defined by either the amount of water in the soil (water content) or by the force that holds water in the soil matrix (i.e., the matric potential or suction) (Or and Wraith, 2002). In recent studies, Serne et al. (2002e) measured both gravimetric water content and matric water potential (filter paper method) on core samples obtained from borehole 299-E33-45 in the BX environs. The same filter paper technique was used at 299-E33-46 and 299-E33-338, within the B-BX-BY WMA. All core samples from 299-E33-46 from the surface to the water table were analyzed. A sandwich of three Whatman \#42 filter papers was placed in the sediment, sealed, and equilibrated for at least 21 days. The water content of the middle filter paper (not allowed to collect sediment particles) was subsequently measured and the water potential obtained from a predetermined water-retention characteristic curve. The filter-paper method provides a good estimate of water potentials over the range from -0.01 to $-2 \mathrm{MPa}$ (1 to $200 \mathrm{~m}$ (3.3 to $656 \mathrm{ft})$ suction head) (Deka et al. 1995).

Table 4.25 and Figure 4.19 show the matric potentials as a function of depth for the 299-E33-46 samples. Also plotted in Figure 4.19 is the gravity head expressed in pressure units (MPa). The gravity head is zero at the water table and increases linearly with height to the soil surface. For 299-E33-46, the water potential, as measured from the core samples, is much less than the gravity potential from the surface down to $70 \mathrm{~m}(230 \mathrm{ft})$ excepting one data point at about $44 \mathrm{~m}(145 \mathrm{ft}) \mathrm{bgs}$, which appears to be a bad data point. The general trend is that the water potentials are consistent with a draining profile (water potentials wetter than $-0.01 \mathrm{MPa})$. Below $71 \mathrm{~m}(233 \mathrm{ft})$ to the water table at approximately $78 \mathrm{~m}$ (approximately $255.8 \mathrm{ft}$ ), there appears to be a drier condition than above these depths. Note that the lower depths contain coarse materials, so sample handling (e.g. drying) may be responsible for the apparent drier matric potentials. In any case, it appears that borehole 299-E33-46 has a matric potential profile that strongly suggests drainage is occurring. The green line in Figure 4.19 is the theoretical line that represents the steady state unit gradient condition, which represents a matric potential in a sediment profile that is neither draining or drier than (actively evapotranspiring) than equilibrium conditions. Matric potential values to the left of the unit gradient line suggest a draining profile.

For borehole 299-E33-338 (C3391), located outside the southeast corner of the B tank farm in relatively undisturbed terrain, the matric potential data are considerably drier than at 299-E33-46 borehole, particularly near the surface. These matric potential data (see Figure 4.20) are consistent with the hypothesis that non-vegetated areas, with coarse-textured surfaces, drain more than areas with similar soil, but with vegetation present. It appears that the wetting from meteoric sources has not reached to the water table at the 299-E33-338 site. 
Table 4.25. Matric Potential Measurements on Core and Grab Samples from Borehole 299-E33-46

\begin{tabular}{|c|c|c|c|c|c|c|c|c|}
\hline $\begin{array}{r}\text { Depth } \\
\text { (ft bgs) } \\
\text { (1) }\end{array}$ & $\begin{array}{c}\text { Measured } \\
\text { Core } \\
\text { (Mpa) }\end{array}$ & $\begin{array}{l}\text { Theoretical } \\
\text { Matric } \\
\text { Potential } \\
\text { (Mpa) }\end{array}$ & $\begin{array}{l}\text { Depth } \\
\text { (ft bgs) } \\
\text { (1) }\end{array}$ & $\begin{array}{c}\text { Measured } \\
\text { Core } \\
\text { (Mpa) }\end{array}$ & $\begin{array}{l}\text { Theoretical } \\
\text { Matric } \\
\text { Potential } \\
\text { (Mpa) }\end{array}$ & $\begin{array}{c}\text { Depth } \\
\text { (ft bgs) } \\
\text { (1) }\end{array}$ & $\begin{array}{c}\text { Measured } \\
\text { Core } \\
\text { (Mpa) }\end{array}$ & $\begin{array}{c}\text { Theoretical } \\
\text { Matric } \\
\text { Potential } \\
\text { (Mpa) }\end{array}$ \\
\hline \multicolumn{3}{|c|}{ Backfill } & \multicolumn{3}{|c|}{ Thin Fine-grained Lens } & \multicolumn{3}{|c|}{ H2-lower sand } \\
\hline 12.94 & 0.0031 & 0.7402 & \multicolumn{3}{|c|}{ No sample } & 170.9 & 0.0191 & 0.2588 \\
\hline 14.07 & 0.0292 & 0.7368 & \multicolumn{3}{|c|}{ H2-middle sand } & 171.4 & 0.0090 & 0.2573 \\
\hline 20.87 & 0.0606 & 0.7161 & 90.37 & 0.0181 & 0.5042 & \multicolumn{3}{|c|}{ H3 sand } \\
\hline 21.37 & 0.0124 & 0.7145 & 90.87 & 0.0420 & 0.5027 & 179.6 & 0.0101 & 0.2323 \\
\hline 29.17 & 0.0041 & 0.6908 & 99.37 & 0.1044 & 0.4768 & 180.1 & 0.0067 & 0.2307 \\
\hline 29.67 & 0.1435 & 0.6892 & 98.87 & 0.0954 & 0.4783 & 190.6 & 0.0175 & 0.1987 \\
\hline \multicolumn{3}{|c|}{ H2-upper sand } & 111.17 & 0.0140 & 0.4408 & 191 & 0.0166 & 0.1975 \\
\hline 41.47 & 0.0036 & 0.6533 & 111.67 & 0.0199 & 0.4393 & 200.7 & 0.0109 & 0.1679 \\
\hline 41.97 & 0.0033 & 0.6518 & 119.67 & 0.0091 & 0.4149 & 201.2 & 0.0197 & 0.1664 \\
\hline 43.77 & 0.0043 & 0.6463 & 120.17 & 0.0105 & 0.4134 & 209.7 & 0.0089 & 0.1405 \\
\hline 44.27 & 0.0031 & 0.6447 & 131.6 & 0.0128 & 0.3786 & 210.2 & 0.0069 & 0.1390 \\
\hline 46.17 & 0.0037 & 0.6390 & 132.1 & 0.0057 & 0.3770 & \multicolumn{3}{|c|}{ PPlz mud } \\
\hline 46.67 & 0.0038 & 0.6374 & 139.8 & 0.0133 & 0.3536 & 219.2 & 0.0356 & 0.1116 \\
\hline 50.37 & 0.0021 & 0.6262 & 140.3 & 1.0656 & 0.3520 & 219.7 & 0.0251 & 0.1100 \\
\hline 50.87 & 0.0026 & 0.6246 & 149.9 & 0.0097 & 0.3228 & 221.9 & 0.0303 & 0.1033 \\
\hline 52.77 & 0.0030 & 0.6188 & 150.4 & 0.0135 & 0.3213 & \multicolumn{3}{|c|}{ PPlg gravelly sand } \\
\hline 53.27 & 0.0029 & 0.6173 & 159.9 & 0.0048 & 0.2923 & 230.5 & 0.0014 & 0.0771 \\
\hline 60.47 & 0.0026 & 0.5954 & 160.4 & 0.0093 & 0.2908 & 241.2 & 0.1963 & 0.0445 \\
\hline 60.97 & 0.0030 & 0.5938 & 164.3 & 0.0094 & 0.2789 & 253.9 & 0.0916 & 0.0058 \\
\hline 70.2 & 0.0057 & 0.5657 & 164.8 & 0.0077 & 0.2774 & 253.4 & 0.0295 & 0.0073 \\
\hline 70.7 & 0.0036 & 0.5642 & 166.6 & 0.0103 & 0.2719 & & & \\
\hline 79.2 & 0.0068 & 0.5383 & 167.1 & 0.0117 & 0.2704 & & & \\
\hline 79.7 & 0.0087 & 0.5368 & \multicolumn{3}{|c|}{ Thin Fine-grained Lens } & & & \\
\hline 82.8 & 0.0059 & 0.5273 & \multicolumn{3}{|c|}{ No sample } & & & \\
\hline 83.3 & 0.0097 & 0.5258 & & & & & & \\
\hline
\end{tabular}

(1) to convert to meters multiply by 0.3048 


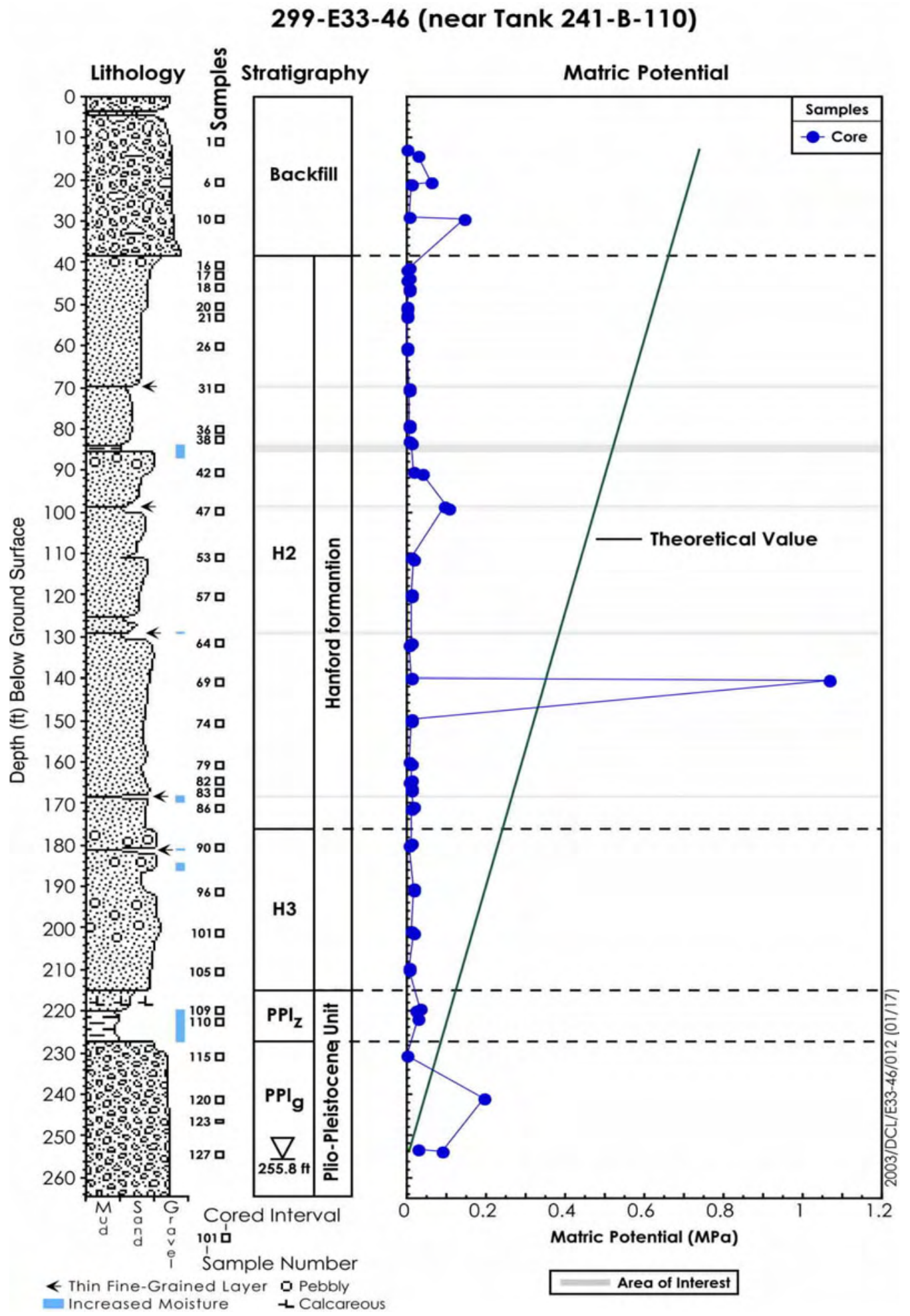

Figure 4.19. Matric Water Potential Measured by Filter Paper Technique on Core Samples from Borehole 299-E33-46 


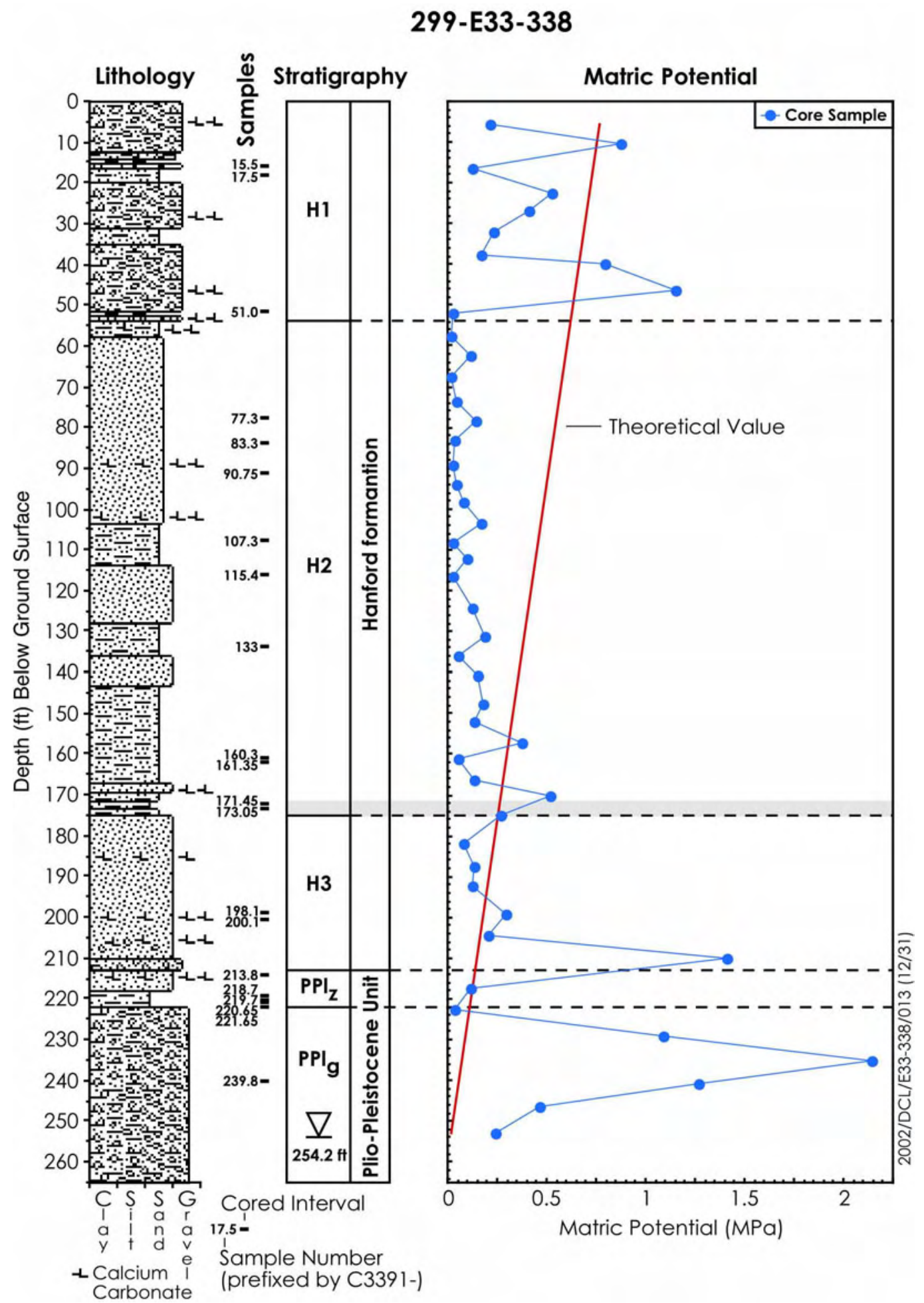

Figure 4.20. Matric Water Potential Measured by Filter Paper Technique on Core Samples from Borehole 299-E33-338 Located Outside the SE Perimeter of the B Tank Farm. 


\subsection{Vadose Zone Monitoring System}

A series of instruments was placed in the vadose zone sediments at borehole 299-E33-46 as the casing was being pulled out of the ground in July and August 2001. The Vadose Zone Monitoring

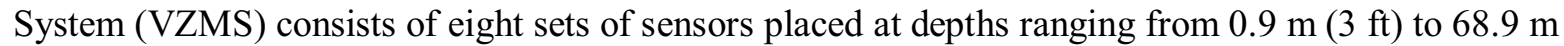
$(226 \mathrm{ft}) \mathrm{bgs}$. The sensors are used for continuous monitoring of vadose-zone hydraulic properties at and beneath the surface of the tank farm. The VZMS sensor arrays consisted of advanced tensiometers, water contents sensors, heat-dissipation units, solution samplers (also called suction candles), temperature sensors, and a water-flux meter. Figure 4.21 shows the configuration of the sensor nest before insertion into the borehole. Gee et al. $(2001,2003)$ provide details on the installation and a description of each instrument. Table 4.26 shows the depths below ground surface at which the instruments are deployed. The instruments are surrounded by silica flour (SCS-90, U. S. Silica, Ottawa, IL) that was wetted with potable water (Columbia River source) during the installation as the casing was being removed. The silica flour was poured as a slurry such that it made good contact between the formation and the sensors. The slurry was allowed to settle and then a $0.3 \mathrm{~m}$ layer of sand ( $30 \mathrm{mesh})$ was added above the slurry. The rest of the borehole up to the next instrument nest was filled with bentonite granules as the casing was withdrawn.

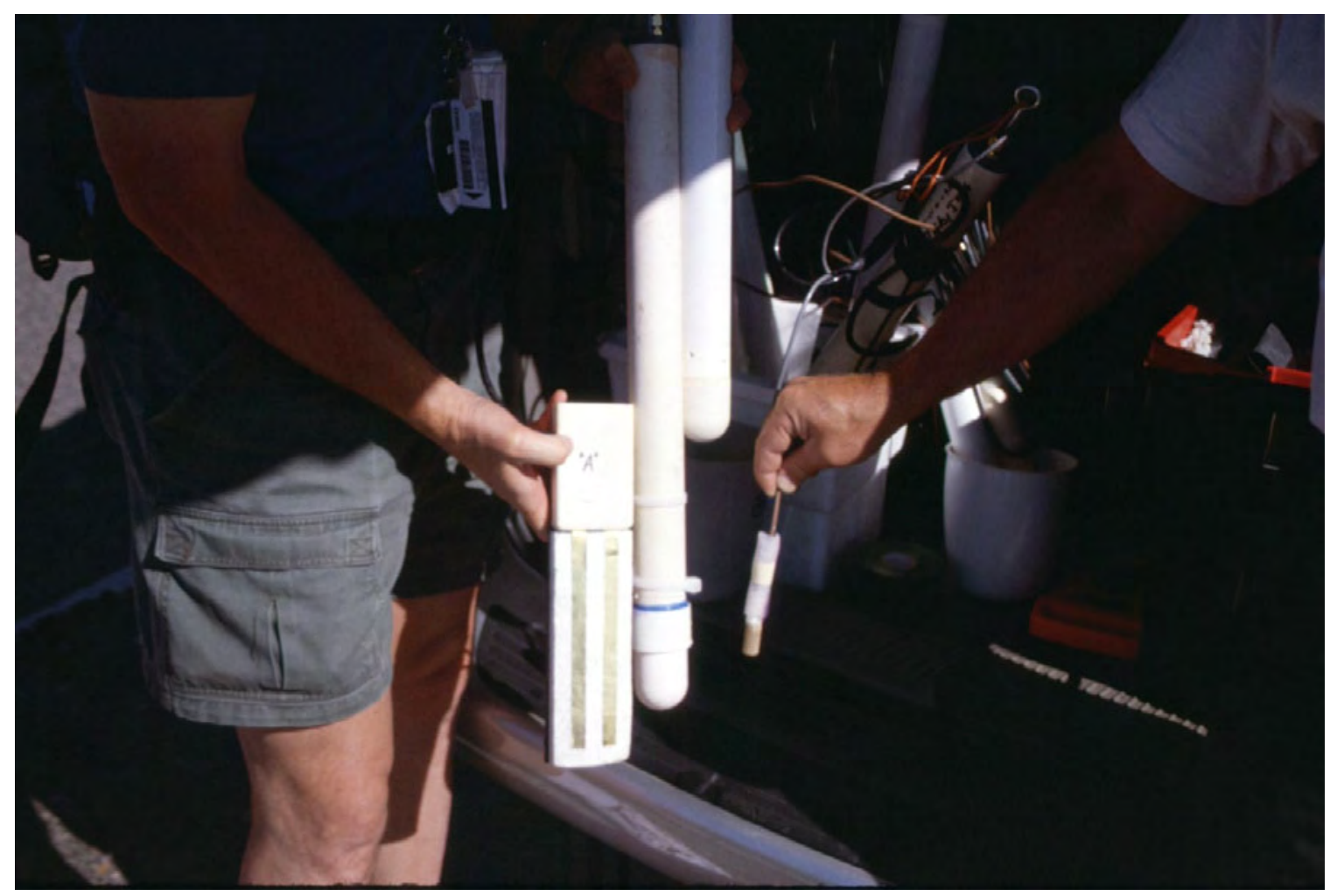

Figure 4.21. Vadose-Zone Monitoring System (without water-flux meter and temperature sensor) Before Deployment in B Tank Farm. Sensors from left to right are the Modified CSI Water Content Sensor, Advanced Tensiometer, Suction Candle, and Heat-Dissipation Unit. 
Table 4.26. VZMS Sensor Placement in Borehole 299-E33-46 near Tank B110 in B Tank Farm

\begin{tabular}{|c|c|c|c|c|c|c|}
\hline Depth (bgs) & WFM $^{(\mathbf{a})}$ & $\mathbf{A T}$ & $\mathbf{H D U}^{(\mathbf{b})}$ & $\mathbf{W C}^{(\mathbf{c})}$ & $\mathbf{T e m p}$ & $\mathbf{S C}^{(\mathbf{d})}$ \\
\hline 3 & & $\mathrm{X}$ & & $\mathrm{X}$ & $\mathrm{X}$ & \\
\hline 6 & $\mathrm{X}$ & $\mathrm{X}$ & $\mathrm{X}$ & $\mathrm{X}$ & $\mathrm{X}$ & \\
\hline 9 & & $\mathrm{X}$ & & $\mathrm{X}$ & $\mathrm{X}$ & \\
\hline 15 & & $\mathrm{X}$ & $\mathrm{X}$ & $\mathrm{X}$ & $\mathrm{X}$ & $\mathrm{X}$ \\
\hline 53 & & $\mathrm{X}$ & & $\mathrm{X}$ & $\mathrm{X}$ & $\mathrm{X}$ \\
\hline 82 & & $\mathrm{X}$ & $\mathrm{X}$ & $\mathrm{X}$ & $\mathrm{X}$ & $\mathrm{X}$ \\
\hline 218 & & $\mathrm{X}$ & & $\mathrm{X}$ & $\mathrm{X}$ & $\mathrm{X}$ \\
\hline 226 & & $\mathrm{X}$ & $\mathrm{X}$ & $\mathrm{X}$ & $\mathrm{X}$ & $\mathrm{X}$ \\
\hline
\end{tabular}

\footnotetext{
(a) WFM =Water Flux Meter;

(b) $\mathrm{HDU}=$ Heat Dissipation Unit;

(c) $\mathrm{WC}=$ Water Content Sensor

(d) $\mathrm{SC}=$ Suction Candle (solution sampler)
}

The instruments were deployed at each depth from the deepest to the shallowest depth through the casing as it was withdrawn. The casing was raised to just above the depth of interest and the instrument cluster, silica flour, sand introduced down the casing into the open hole at the desired depth. The casing was cut off at the surface as lengths were withdrawn. The uppermost 3 depths were not instrumented with solution samplers (suction candles).

Data have been collected from each instrument since February 2002 and vadose zone porewater has been extracted from all the suction candles on the following dates: 02/12/2002, 05/17/2002, 07/02/2002, $07 / 30 / 2002$, and $9 / 24 / 2002$. The chemical composition of the waters removed from the suction candles are reported in Tables 4.27 to 4.29. The chemical composition of the porewaters obtained through the suction candle devices shows that the first sampling after installation has rather dilute concentrations more reflective of the potable water (from the Columbia River) that was used to wet the solids that were packed around the instrument sensors. Subsequent samples of porewater extracted approximately three to seven months after sensor installation show that the waters are gaining dissolved salts. The chemical composition of the porewaters obtained through the suction candles for some constituents appears to be reaching a steady state value most similar to the porewaters obtained out of the core materials using the ultra centrifuge (UFA) but for other constituents the concentrations versus time are either still rising (especially at and below $82 \mathrm{ft}$ bgs) or in a few instances fluctuating or even dropping. Further, the trends versus time for the chemical evolution of any given constituent shows variation with depth; that is the chemical evolution is not the same for each constituent at all depths. Most of the variation in composition versus time is not analytical vagaries but must reflect actual variation because the duplicate measurements on field duplicate samples are showing excellent reproducibility. It will be interesting to follow the evolution of the chemical composition of the porewater with time and to attempt to correlate the variations with other data being collected from the other sensors deployed at the same depths. 


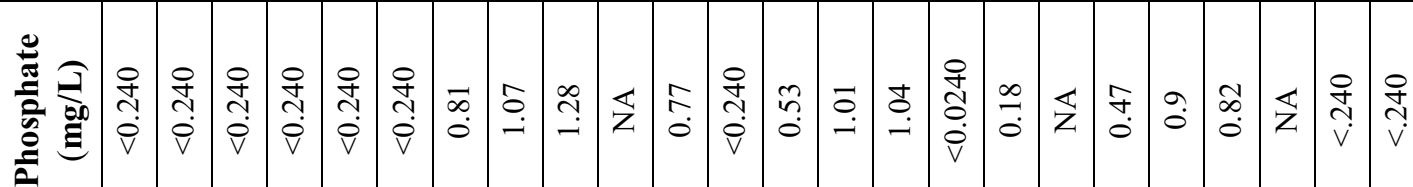

\begin{tabular}{|c|c|c|c|c|c|c|c|c|c|c|c|c|c|c|c|c|c|c|c|c|c|c|c|c|}
\hline 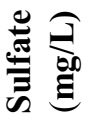 & 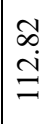 & $\begin{array}{l}\infty \\
\dot{0} \\
\dot{\theta}\end{array}$ & $\begin{array}{l}\underset{J}{\Xi} \\
=\end{array}$ & $\stackrel{\text { 艺}}{=}$ & $\begin{array}{l}\Omega \\
\Xi \\
=\end{array}$ & $\begin{array}{l}\infty \\
\infty \\
=\end{array}$ & $\begin{array}{l}\vec{\nabla} \\
\dot{\infty}\end{array}$ & $\begin{array}{l}\vec{\gamma} \\
\infty \\
\infty \\
n\end{array}$ & $\begin{array}{l}\hat{2} \\
\hat{\sigma} \\
\tilde{\sigma}\end{array}$ & $\overleftrightarrow{z}$ & $\underset{\substack{n \\
\infty}}{\stackrel{\infty}{N}}$ & $\stackrel{9}{\stackrel{9}{\infty}}$ & $\begin{array}{l}\stackrel{a}{+} \\
\dot{\infty}\end{array}$ & 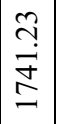 & $\frac{5}{a}$ & $\frac{\infty}{\infty}$ & $\begin{array}{l}\infty \\
\stackrel{\infty}{a}\end{array}$ & 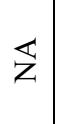 & $\stackrel{\infty}{\stackrel{\infty}{1}}$ & $\begin{array}{l}\mathscr{0} \\
\dot{+} \\
\dot{0}\end{array}$ & $\begin{array}{l}n \\
\infty \\
\dot{j} \\
\infty\end{array}$ & $\overleftrightarrow{Z}$ & ণ্ & $\frac{n}{n}$ \\
\hline 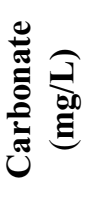 & $\begin{array}{l}\stackrel{0}{1} \\
\stackrel{0}{\sim}\end{array}$ & $\frac{1}{a}$ & $\begin{array}{l}\triangleright \\
\infty \\
\dot{d}\end{array}$ & $\stackrel{I}{a}$ & $\frac{n}{a}$ & $\begin{array}{l}8 \\
\text { à } \\
\text { à }\end{array}$ & $\frac{\sqrt{6}}{\sqrt{n}}$ & $\frac{\bar{a}}{\mathfrak{n}}$ & $\begin{array}{l}\stackrel{0}{1} \\
\infty \\
\infty \\
\end{array}$ & 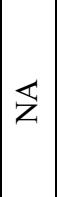 & $\begin{array}{l}\infty \\
\infty \\
\dot{0} \\
\stackrel{\sim}{*}\end{array}$ & 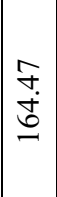 & $\begin{array}{l} \pm \\
\dot{v} \\
\stackrel{p}{m}\end{array}$ & $\begin{array}{l}\infty \\
\infty \\
\tilde{R} \\
\hat{n}\end{array}$ & $\begin{array}{c}\mathbb{J} \\
0 \\
0 \\
0 \\
0 \\
\end{array}$ & $\begin{array}{l}0 \\
0 \\
0 \\
\stackrel{0}{0}\end{array}$ & $\stackrel{\stackrel{\Xi}{ָ}}{\stackrel{+}{\sim}}$ & $\overleftrightarrow{z}$ & 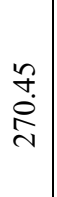 & $\frac{\stackrel{\sim}{+}}{\stackrel{+}{\sigma}}$ & $\stackrel{n}{\sigma}$ & $\overleftrightarrow{z}$ & 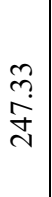 & 蒙 \\
\hline 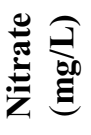 & $\stackrel{N}{\stackrel{\infty}{0}}$ & $\begin{array}{l}\circ \\
n \\
0\end{array}$ & $\begin{array}{l}\infty \\
n \\
o \\
0\end{array}$ & $\stackrel{\infty}{+}$ & $\begin{array}{l}\widetilde{a} \\
\text { ָे } \\
\hat{\nabla}\end{array}$ & $\stackrel{n}{n}$ & $\begin{array}{l}\stackrel{0}{a} \\
\text { à }\end{array}$ & 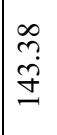 & $\begin{array}{l}\mathscr{f} \\
\stackrel{\infty}{\infty} \\
\infty\end{array}$ & $\overleftrightarrow{Z}$ & 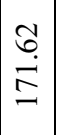 & 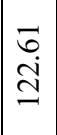 & 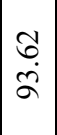 & 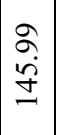 & \begin{tabular}{l}
0 \\
+ \\
\multirow{2}{*}{}
\end{tabular} & 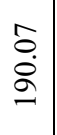 & $\begin{array}{c}\text { ֻે } \\
\text { ญิ }\end{array}$ & 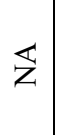 & 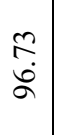 & $\frac{n}{\stackrel{9}{ \pm}}$ & $\begin{array}{l}\infty \\
m \\
m \\
m\end{array}$ & 乙 & $\begin{array}{l}\text { ते } \\
\text { లై } \\
\text { ¿े }\end{array}$ & $\begin{array}{l}\stackrel{8}{0} \\
\stackrel{1}{I}\end{array}$ \\
\hline 践 & 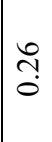 & $\frac{\hat{m}}{\dot{\nabla}}$ & $\begin{array}{l}\hat{m} \\
\dot{\vec{v}}\end{array}$ & $\frac{\tilde{m}}{\dot{\hat{v}}}$ & $\begin{array}{l}\hat{n} \\
\vec{\nabla}\end{array}$ & $\begin{array}{l}\hat{n} \\
\vec{\nabla}\end{array}$ & 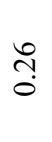 & $\overrightarrow{0}$ & $\stackrel{\Xi}{\beth}$ & $\overleftrightarrow{z}$ & $\stackrel{n}{n}$ & $\stackrel{n}{n}$ & 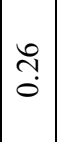 & $\stackrel{8}{8}$ & $\hat{n}$ & ?ִ & 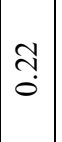 & $\overleftrightarrow{Z}$ & $\stackrel{m}{0}$ & $\stackrel{+}{n}$ & $\because$ & $\overleftrightarrow{Z}$ & $\underset{\dot{\sigma}}{\exists}$ & $\stackrel{\sim}{+}$ \\
\hline 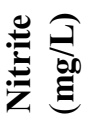 & $\begin{array}{l}\stackrel{0}{\infty} \\
\stackrel{0}{0} \\
\dot{\nabla}\end{array}$ & $\begin{array}{l}\stackrel{0}{\infty} \\
\stackrel{0}{0} \\
\dot{P}\end{array}$ & $\begin{array}{l}\text { oे } \\
\stackrel{0}{0}\end{array}$ & $\overrightarrow{0}$ & $\begin{array}{l}\infty \\
\stackrel{1}{0}\end{array}$ & $\stackrel{0}{\stackrel{0}{0}}$ & $\begin{array}{l}\stackrel{0}{\infty} \\
\stackrel{0}{0} \\
\dot{\hat{V}}\end{array}$ & m. & $=$ & $\overleftrightarrow{Z}$ & $\stackrel{\mathscr{P}}{\circ}$ & $\stackrel{9}{\circ}$ & $\begin{array}{l}\stackrel{8}{\infty} \\
\stackrel{0}{0} \\
\stackrel{0}{0}\end{array}$ & $\begin{array}{l}0 \\
\infty \\
0 \\
0\end{array}$ & $\stackrel{ \pm}{\stackrel{0}{0}}$ & $\stackrel{\overbrace{}}{0}$ & $\stackrel{+}{0}$ & $\overleftrightarrow{Z}$ & $\begin{array}{l}\stackrel{0}{\infty} \\
\stackrel{0}{0} \\
\dot{\nabla}\end{array}$ & $\stackrel{n}{n}$ & $\frac{1}{0}$ & 飞 & $\frac{\infty}{\stackrel{0}{0}}$ & $\stackrel{n}{\circ}$ \\
\hline 冚 & $\begin{array}{l}\infty \\
\stackrel{\sim}{a}\end{array}$ & $\stackrel{m}{\sim}$ & 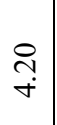 & $\stackrel{\infty}{\underset{\nabla}{+}}$ & $\underset{\sim}{\stackrel{ }{+}}$ & $\ddot{m}$ & $\begin{array}{l}\mathscr{D} \\
\dot{I}\end{array}$ & $\begin{array}{l}\text { ণे } \\
\text { ஸे }\end{array}$ & $\stackrel{\text { I }}{\Xi}$ & 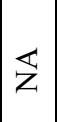 & $\stackrel{n}{ \pm}$ & $\stackrel{\sigma}{\Xi}$ & $\underset{\Xi}{ \pm}$ & $\underset{\dot{v}}{\stackrel{\partial}{v}}$ & $\begin{array}{l}\tilde{\alpha} \\
\end{array}$ & $\begin{array}{l} \pm \\
\infty \\
\infty\end{array}$ & $\stackrel{9}{\rightrightarrows}$ & $\overleftrightarrow{Z}$ & $\begin{array}{l}\forall \\
\stackrel{\sigma}{-}\end{array}$ & $\stackrel{m}{a}$ & $\stackrel{0}{=}$ & 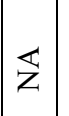 & $\begin{array}{l}0 \\
\infty \\
\infty\end{array}$ & $\begin{array}{l}\Omega \\
\dot{J}\end{array}$ \\
\hline 尝 & $\stackrel{\overbrace{}}{\stackrel{9}{0}}$ & $\stackrel{9}{\circ}$ & $\stackrel{\simeq}{\stackrel{0}{0}}$ & $\begin{array}{l}\stackrel{a}{o} \\
\stackrel{0}{0}\end{array}$ & $\begin{array}{l}\circ \\
\stackrel{2}{\circ}\end{array}$ & $\frac{1}{0}$ & خे & $\underset{\infty}{\infty}$ & $\begin{array}{l}\bar{\sigma} \\
\stackrel{n}{m}\end{array}$ & $\overleftrightarrow{z}$ & 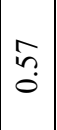 & $\stackrel{+}{\stackrel{d}{0}}$ & 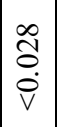 & $\begin{array}{l}\infty \\
m \\
\infty \\
\infty\end{array}$ & $\begin{array}{l}\text { 足 } \\
\dot{f}\end{array}$ & $\stackrel{n}{n}$ & $\begin{array}{l}\stackrel{0}{0} \\
\stackrel{0}{0}\end{array}$ & $\overleftrightarrow{Z}$ & $\stackrel{\sim}{?}$ & $n$ & $\begin{array}{l}\hat{\sigma} \\
\dot{q}\end{array}$ & 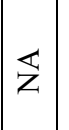 & $n$ & $\stackrel{9}{\circ}$ \\
\hline U & $\begin{array}{l}\vec{m} \\
\infty \\
\dot{0}\end{array}$ & $\frac{\Omega}{\sigma}$ & $\frac{0}{2}$ & $\frac{n}{2}$ & $\frac{\mathbb{N}}{\stackrel{0}{0}}$ & $\frac{N}{\dot{N}}$ & $\begin{array}{l}\overrightarrow{\bar{D}} \\
\dot{\infty} \\
\dot{0}\end{array}$ & $\stackrel{\text { Y }}{+}$ & $\begin{array}{l}\stackrel{\partial}{0} \\
\stackrel{i}{i}\end{array}$ & $\begin{array}{l}\infty \\
\sim \\
i \\
i\end{array}$ & 壱 & $\frac{8}{0}$ & $\frac{0}{0}$ & $\begin{array}{l}8 \\
8 \\
7 \\
+\end{array}$ & $\begin{array}{l}\mathfrak{n} \\
\infty \\
i\end{array}$ & $\begin{array}{c}\infty \\
n \\
n \\
\sim \\
-\end{array}$ & \begin{tabular}{|l|}
$\infty$ \\
$\infty$ \\
0 \\
0 \\
0
\end{tabular} & $\begin{array}{l}+ \\
\infty \\
0 \\
0 \\
0\end{array}$ & $\begin{array}{l}\frac{8}{0} \\
0 \\
0\end{array}$ & $\stackrel{\vartheta}{\vec{\nabla}}$ & $\begin{array}{l}\tilde{m} \\
\tilde{m} \\
\tilde{m}\end{array}$ & $\begin{array}{l}\infty \\
0 \\
m \\
m \\
m\end{array}$ & 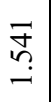 & $\frac{2}{2}$ \\
\hline$\frac{\pi}{2}$ & 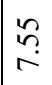 & $\stackrel{2}{\pi}$ & $\frac{n}{\pi}$ & $\stackrel{m}{\sim}$ & \begin{tabular}{l}
0 \\
\hdashline \\
-1
\end{tabular} & $\stackrel{\square}{\nearrow}$ & $\stackrel{\infty}{\infty}$ & $\stackrel{9}{\infty}$ & $\begin{array}{l}\tilde{N} \\
\infty\end{array}$ & $\underset{\infty}{\stackrel{f}{0}}$ & $\hat{a}$ & 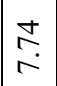 & $\hat{\sigma}$ & $\begin{array}{l}\hat{0} \\
\infty\end{array}$ & $\begin{array}{l}\dot{m} \\
\infty \\
\infty\end{array}$ & $\stackrel{\infty}{\infty}$ & 蒙 & $\begin{array}{c}n \\
n \\
n\end{array}$ & $\stackrel{\overbrace{}}{\infty}$ & $\stackrel{*}{\infty}$ & $\underset{\infty}{\infty}$ & $\begin{array}{l}\infty \\
\infty \\
\infty\end{array}$ & $\underset{\infty}{\stackrel{\infty}{ }}$ & $\underset{\infty}{\infty}$ \\
\hline 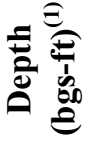 & $n$ & $\tilde{n}$ & ๙ & 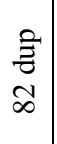 & $\stackrel{\infty}{\sim}$ & $\begin{array}{l}\stackrel{\sim}{N} \\
\text { N }\end{array}$ & $n$ & $\hat{n}$ & స్ & 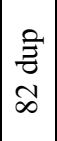 & $\frac{\infty}{\sim}$ & $\begin{array}{l}\stackrel{\sim}{N} \\
\text {. }\end{array}$ & $n$ & $\hat{n}$ & $\infty$ & $\frac{\infty}{\sim}$ & $\stackrel{\circ}{\stackrel{N}{N}}$ & 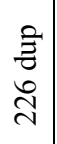 & $\because$ & $n$ & ๙ & 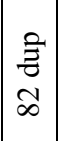 & $\frac{\infty}{\sim}$ & $\begin{array}{l}\stackrel{2}{N} \\
\text { a }\end{array}$ \\
\hline 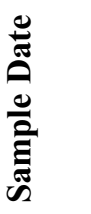 & 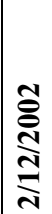 & & & & & & 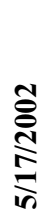 & & & & & & 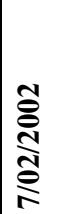 & & & & & & 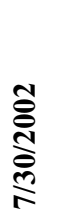 & & & & & \\
\hline
\end{tabular}



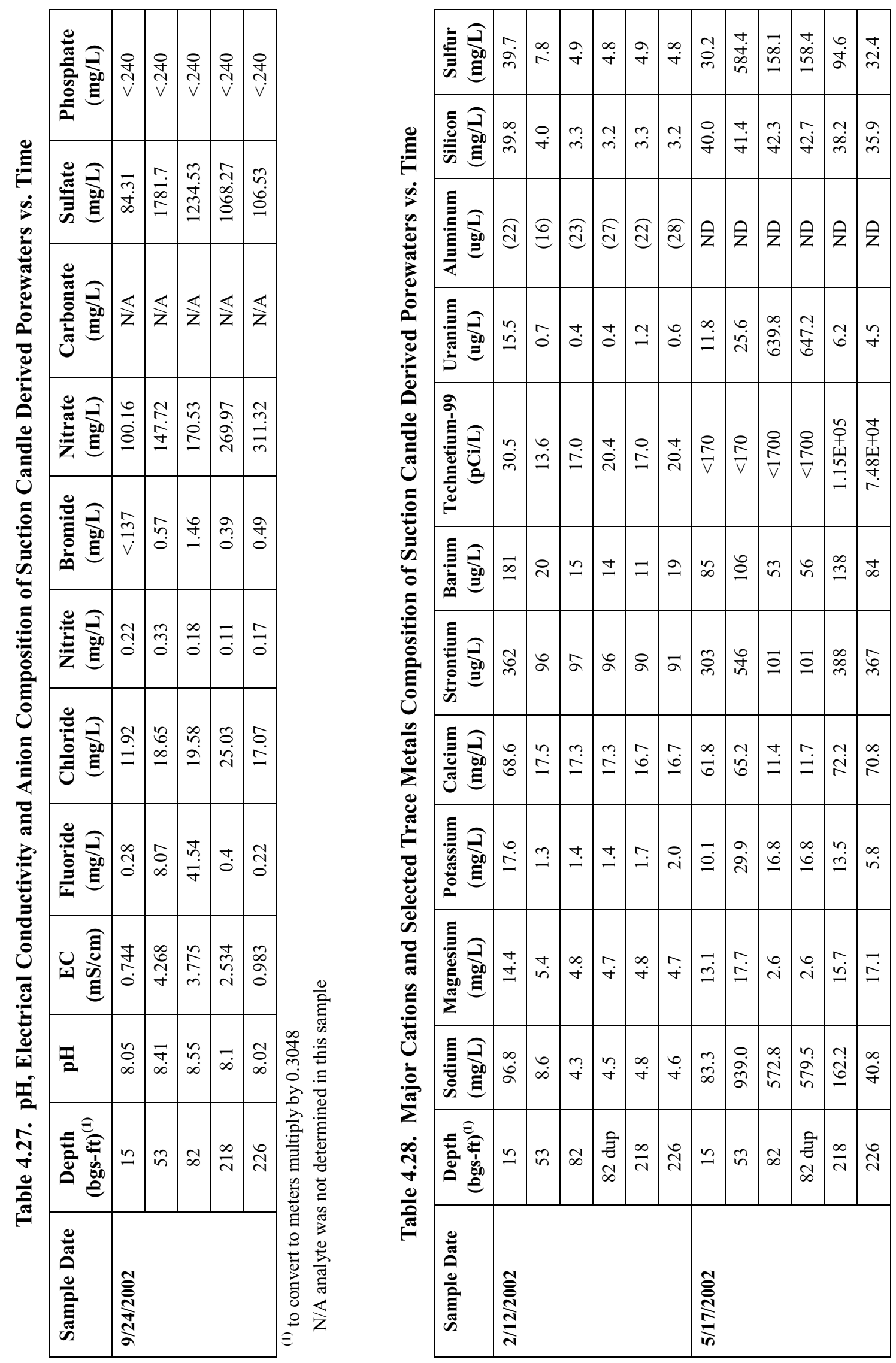


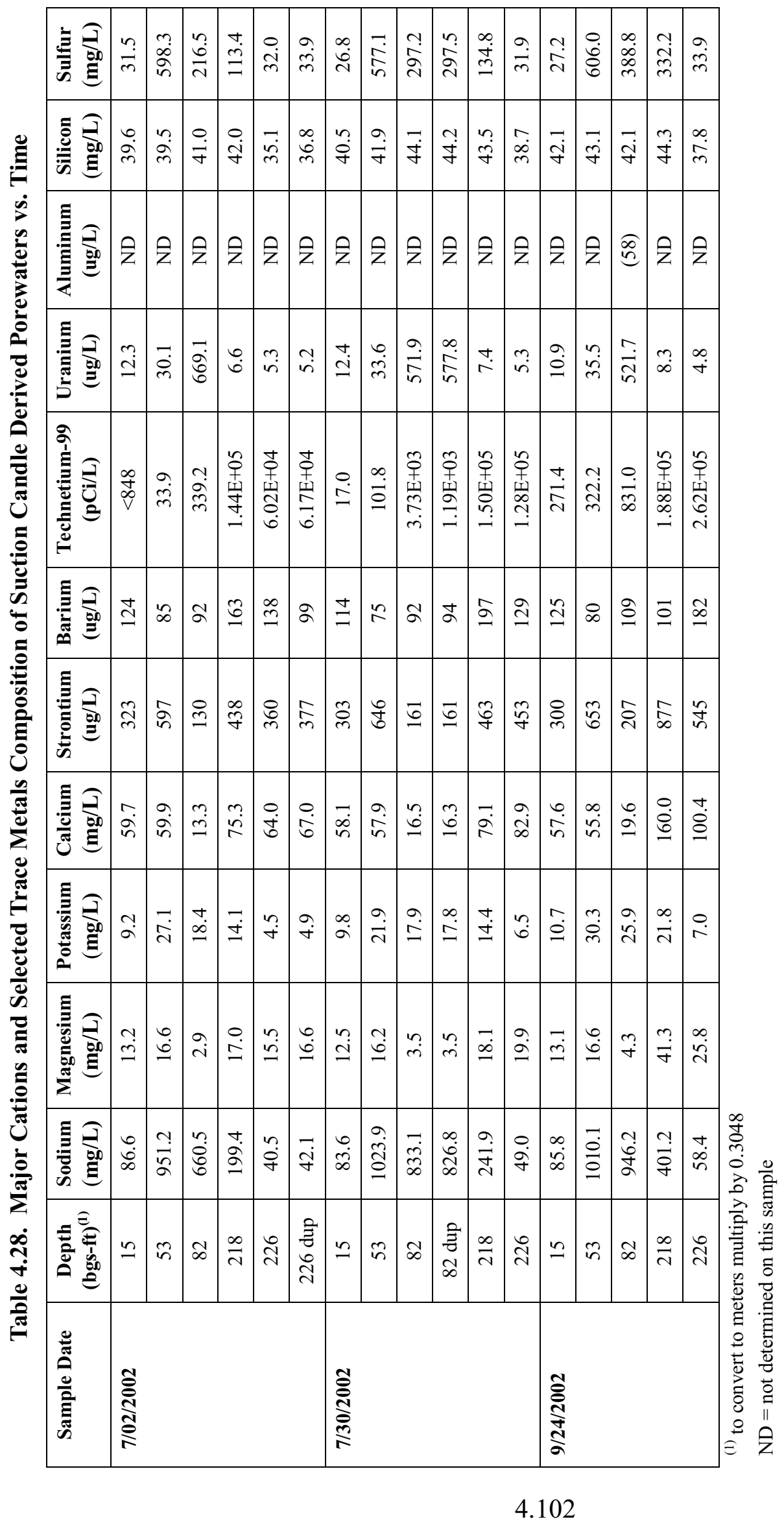




\begin{tabular}{|c|c|c|c|c|c|c|c|c|c|c|c|c|c|c|c|c|c|c|}
\hline 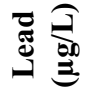 & 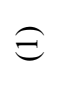 & e & $\mathcal{Ð}$ & $\stackrel{\mathcal{J}}{ }$ & 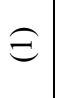 & 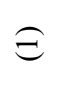 & $\begin{array}{l}\infty \\
\infty \\
\text { r. }\end{array}$ & $\begin{array}{l}\hat{\sigma} \\
\stackrel{e}{e}\end{array}$ & $\stackrel{\sim}{\stackrel{i}{i}}$ & $\underset{\mathrm{i}}{\vec{i}}$ & $\stackrel{?}{\rightarrow}$ & $\stackrel{\infty}{\stackrel{\infty}{e}}$ & $\hat{e}$ & $\stackrel{f}{e}$ & ڤે & 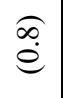 & $\stackrel{f}{e}$ & 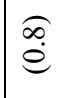 \\
\hline 音 & $\stackrel{\varrho}{=}$ & ङ & $\stackrel{\overbrace ?}{=}$ & $\stackrel{\overbrace ָ}{=}$ & $\stackrel{6}{e}$ & $\stackrel{\sigma}{\oplus}$ & $\begin{array}{l}\vec{\Xi} \\
\stackrel{\infty}{0} \\
0\end{array}$ & 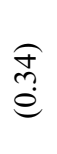 & $\stackrel{\tilde{\vartheta}}{\stackrel{e}{e}}$ & $\stackrel{\overbrace{}}{\stackrel{\overbrace{}}{e}}$ & 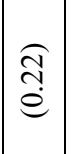 & $\begin{array}{l}\infty \\
\stackrel{\infty}{e} \\
\stackrel{e}{e}\end{array}$ & $\begin{array}{l}\widehat{\widehat{\hat{~}}} \\
\stackrel{e}{e}\end{array}$ & $\stackrel{\vec{m}}{\stackrel{e}{e}}$ & 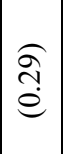 & $\begin{array}{l}\frac{6}{e} \\
\frac{e}{e}\end{array}$ & $\frac{\partial}{\vec{e}}$ & ڤิ) \\
\hline 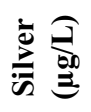 & $\overrightarrow{\dot{v}}$ & $\overrightarrow{\dot{\theta}}$ & $\overrightarrow{\dot{v}}$ & $\overrightarrow{\dot{v}}$ & $\overrightarrow{\dot{v}}$ & $\overrightarrow{\dot{v}}$ & $\begin{array}{l}8 \\
\stackrel{0}{\circ} \\
\text { V. }\end{array}$ & $\begin{array}{l}\stackrel{8}{!} \\
\dot{0}\end{array}$ & $\begin{array}{l}\hat{8} \\
\stackrel{8}{9}\end{array}$ & $\begin{array}{l}\stackrel{8}{:} \\
\stackrel{0}{*}\end{array}$ & $\frac{8}{\stackrel{8}{+}}$ & 官 & $\begin{array}{l}\stackrel{8}{0} \\
\stackrel{+}{\dot{v}}\end{array}$ & $\begin{array}{l}\stackrel{8}{:} \\
\stackrel{0}{\mathrm{~V}}\end{array}$ & $\begin{array}{l}\stackrel{8}{:} \\
\stackrel{0}{*}\end{array}$ & $\begin{array}{l}\stackrel{8}{0} \\
\stackrel{0}{\mathrm{v}}\end{array}$ & $\begin{array}{l}8 \\
\stackrel{0}{0} \\
\dot{\nabla}\end{array}$ & $\begin{array}{l}8 \\
\stackrel{0}{0} \\
\text { V }\end{array}$ \\
\hline 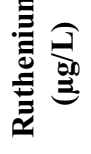 & $\overleftrightarrow{z}$ & $\overleftrightarrow{Z}$ & $\overleftrightarrow{z}$ & $\overleftrightarrow{z}$ & $\overleftrightarrow{z}$ & $\overleftrightarrow{z}$ & $\begin{array}{l}\widehat{\sigma} \\
\stackrel{e}{e}\end{array}$ & $\widehat{\widehat{a}}$ & ڤิ & તิ & $\stackrel{n}{n}$ & $\frac{\Re}{\stackrel{n}{0}}$ & $\widehat{\widehat{a}}$ & ๙ิ? & 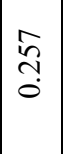 & $\stackrel{n}{\stackrel{2}{g}}$ & $\begin{array}{l}\infty \\
0 \\
0 \\
0\end{array}$ & $\frac{m}{n}$ \\
\hline 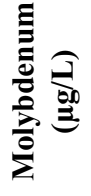 & $\stackrel{\Delta}{\stackrel{\sim}{\sim}}$ & $\underset{\mathbb{d}}{\overparen{J}}$ & $\stackrel{\overbrace =}{\varrho}$ & $\underset{Ð}{\Xi}$ & త్ & $\overparen{\overparen{d}}$ & $\stackrel{\circ}{\stackrel{+}{d}}$ & $\stackrel{\infty}{\circ}$ & $\stackrel{\bullet}{\sim}$ & $\stackrel{\infty}{\stackrel{\sim}{\sim}}$ & $\ddot{\dot{a}}$ & 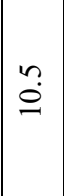 & $\stackrel{\sim}{\sim}$ & జె & $\widehat{ત}$ & نे & $\stackrel{\infty}{\stackrel{\infty}{r}}$ & $\stackrel{8}{\stackrel{0}{0}}$ \\
\hline 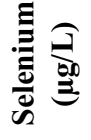 & $\begin{array}{l}\stackrel{\leftrightarrow}{8} \\
\stackrel{n}{V}\end{array}$ & $\widehat{e}$ & $\begin{array}{l}\stackrel{0}{0} \\
\stackrel{n}{V}\end{array}$ & $\begin{array}{l}\stackrel{0}{0} \\
\stackrel{\nabla}{V}\end{array}$ & $\begin{array}{l}\stackrel{0}{0} \\
\stackrel{n}{V}\end{array}$ & $\begin{array}{l}\stackrel{0}{0} \\
\stackrel{\leftrightarrow}{V}\end{array}$ & $\stackrel{\overbrace{}}{\dddot{m}}$ & $\overrightarrow{\mathrm{I}}$ & $\stackrel{\infty}{\stackrel{0}{\varrho}}$ & $\grave{\circ}$ & बे. & $\underset{\sim}{\stackrel{丶}{+}}$ & $\underset{-}{\vec{\sigma}}$ & $\underset{\infty}{\infty}$ & $\overrightarrow{\mathrm{I}}$ & $\stackrel{ \pm}{\circ}$ & $\begin{array}{l}\infty \\
\infty \\
\end{array}$ & $\stackrel{n}{\rightarrow}$ \\
\hline 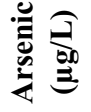 & (2) & $\begin{array}{l}\stackrel{0}{\dot{8}} \\
\stackrel{n}{V}\end{array}$ & $\begin{array}{l}0 \\
\stackrel{8}{0} \\
v\end{array}$ & $\begin{array}{l}0 \\
\stackrel{0}{0} \\
\stackrel{n}{V}\end{array}$ & $\begin{array}{l}0 \\
\stackrel{8}{v} \\
v\end{array}$ & $\begin{array}{l}0 \\
\stackrel{8}{V} \\
\vee\end{array}$ & $\stackrel{m}{\pi}$ & $\begin{array}{l}\infty \\
\text { in }\end{array}$ & $\stackrel{\beth}{\Xi}$ & $\stackrel{\beth}{\beth}$ & $\underset{\infty}{\stackrel{f}{\infty}}$ & $\hat{\alpha}$ & $\begin{array}{l}8 \\
\infty \\
\infty\end{array}$ & $\begin{array}{l}n \\
\stackrel{n}{f}\end{array}$ & $\widetilde{\sigma}$ & $\vec{\sigma}$ & $\begin{array}{l}+ \\
\infty \\
\sigma \\
\sigma\end{array}$ & a \\
\hline 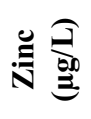 & $\mathbb{z}$ & $\mathbb{z}$ & $\overleftrightarrow{z}$ & $\overleftrightarrow{z}$ & $\overleftrightarrow{z}$ & $\overleftrightarrow{z}$ & $\stackrel{0}{m}$ & 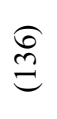 & $\underset{\Xi}{\stackrel{\Xi}{\Xi}}$ & $\stackrel{\widehat{\cong}}{\Xi}$ & $\underset{F}{\nabla}$ & 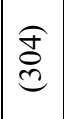 & ஓి & $\stackrel{\circ}{2}$ & $\widetilde{m}$ & 守 & $\stackrel{\sim}{\approx}$ & $\overline{\vec{v}}$ \\
\hline 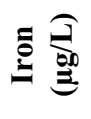 & $\overleftrightarrow{z}$ & $\overleftrightarrow{z}$ & $\overleftrightarrow{z}$ & $\overleftrightarrow{z}$ & $\overleftrightarrow{Z}$ & $\overleftrightarrow{z}$ & $\overleftrightarrow{Z}$ & $\overleftrightarrow{z}$ & $\overleftrightarrow{Z}$ & $\overleftrightarrow{z}$ & $\overleftrightarrow{z}$ & $\overleftrightarrow{z}$ & $\stackrel{\curvearrowright}{\S}$ & $\begin{array}{l}\stackrel{6}{\varrho} \\
\stackrel{2}{n}\end{array}$ & $\stackrel{\overbrace{}}{6}$ & $\stackrel{\overbrace \infty}{\varrho}$ & ڤ્సે & ฮิ \\
\hline 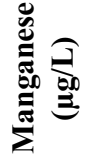 & $\approx$ & in & in & $i$ & in & F & $\overleftrightarrow{z}$ & $\overleftrightarrow{z}$ & $\overleftrightarrow{z}$ & $\overleftrightarrow{z}$ & $\overleftrightarrow{z}$ & Z & 之 & 之 & 之 & 之 & 之 & 乙 \\
\hline 总 & $\overleftrightarrow{z}$ & $\overleftrightarrow{z}$ & $\overleftrightarrow{z}$ & $\overleftrightarrow{z}$ & $\overleftrightarrow{z}$ & $\overleftrightarrow{z}$ & 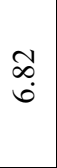 & $\stackrel{a}{r}$ & $\begin{array}{l} \pm \\
\infty \\
\infty\end{array}$ & $\vec{a}$ & $\stackrel{g}{\stackrel{9}{=}}$ & $\begin{array}{l}\infty \\
\stackrel{\infty}{0} \\
\infty\end{array}$ & $\stackrel{\sim}{\sim}$ & $\mid \begin{array}{l}1 \\
\infty \\
\infty \\
\infty\end{array}$ & $\stackrel{\infty}{n}$ & $\begin{array}{l}\vec{\infty} \\
\stackrel{f}{f}\end{array}$ & $\begin{array}{l}\tilde{n} \\
\stackrel{n}{n}\end{array}$ & $\begin{array}{l}J \\
\dot{I}\end{array}$ \\
\hline 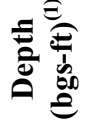 & $\simeq$ & $n$ & 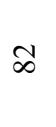 & 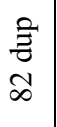 & $\stackrel{\infty}{\sim}$ & ָे & $\because$ & $\hat{n}$ & న & $\begin{array}{l}\tilde{\Xi} \\
\text { ते } \\
\infty\end{array}$ & $\stackrel{\infty}{\vec{\sim}}$ & ते & $\cong$ & $\hat{n}$ & ळ & $\stackrel{\infty}{\sim}$ & స̊ & 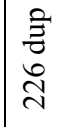 \\
\hline 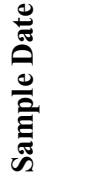 & 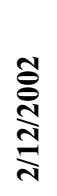 & & & & & & 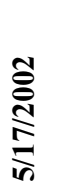 & & & & & & 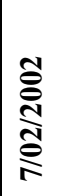 & & & & & \\
\hline
\end{tabular}




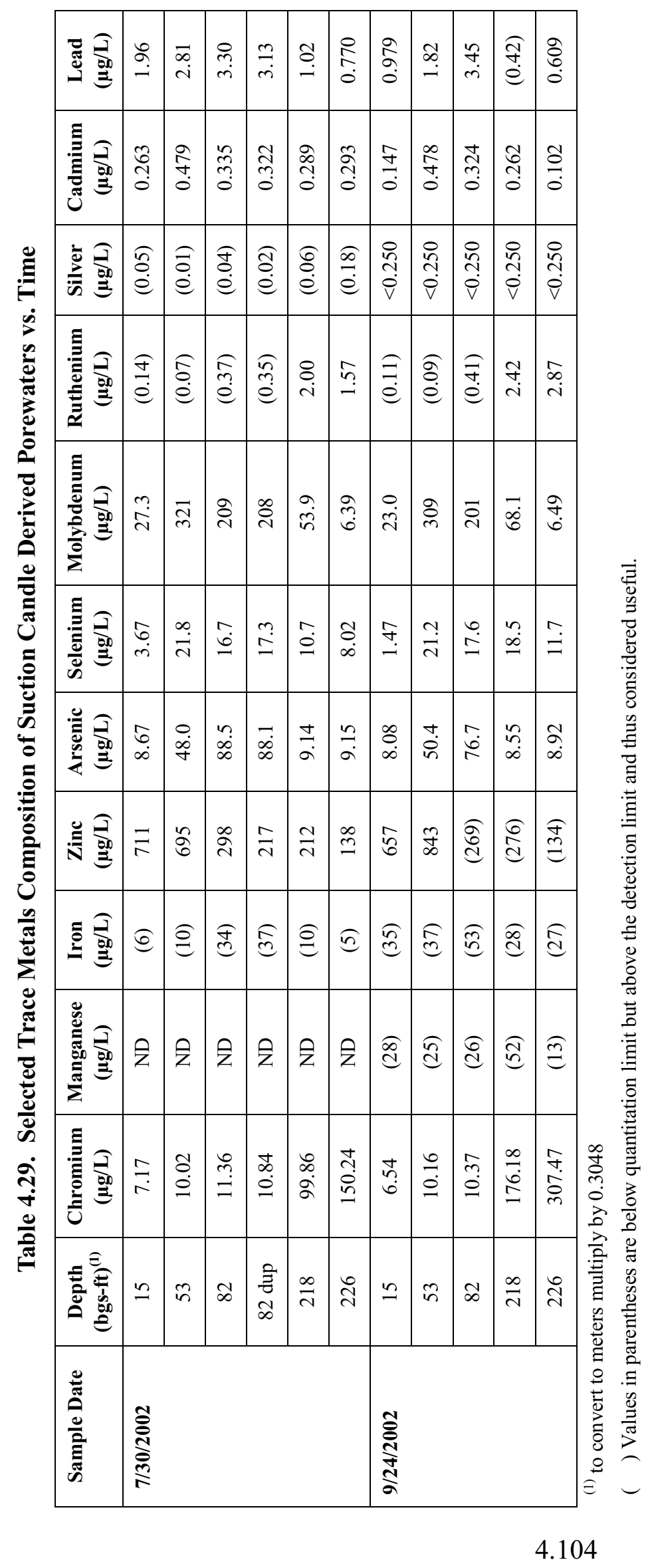


An average value for the last two to three suction candle samplings for the major cations, anions, and trace metals of interest (technetium-99 and uranium) are plotted along with the porewaters obtained from the cores using ultracentrifugation and the dilution corrected porewaters obtained from the 1:1 sediment to water extracts in Figures 4.1 through 4.5. In general, the suction candle generated porewaters show the same trends as discussed in Section 4.2 where the dilution corrected 1:1 sediment to water extracts and UFA porewater results are described. Namely the $\mathrm{pH}$ of the suction candle samples at 16 and $25 \mathrm{~m} \mathrm{(53}$ and $82 \mathrm{ft}$ ) bgs are higher than in the rest of the borehole profile suggesting the presence of caustic fluid from the tank. The electrical conductivity of the suction candle samples is highest for the $16 \mathrm{~m} \mathrm{(53 \textrm {ft } ) \mathrm { bgs }}$ depth and at $25 \mathrm{~m}(82 \mathrm{ft})$ bgs is higher than the rest of other shallower and deeper profile values suggesting that the contamination plume is still located predominately between these two depths. There is high fluoride at $25 \mathrm{~m}(82 \mathrm{ft}) \mathrm{bgs}$ that is not increasing with time. The nitrate concentrations in the suction candle samples is increasing versus time below $25 \mathrm{~m}(82 \mathrm{ft})$ bgs and is highest at $66 \mathrm{~m}(218 \mathrm{ft})$ bgs. The sulfate concentration is also increasing versus time and is high between the depths of 16 and $66 \mathrm{~m}$ (53 and $218 \mathrm{ft}$ ) bgs. As shown in Figure 4.2, the suction candle sulfate values are much higher than the UFA squeezed porewaters and the dilution corrected water extract values. There may be sulfate in the materials used to pack around the sensors or in some of the sensors themselves (gypsum?).

The suction candle cation data show high sodium between the depths of 16 and $25 \mathrm{~m}$ (52 and $82 \mathrm{ft}$ ) bgs as would be expected based on other measurements shown in Figure 4.3. The sodium concentrations at most depths where suction candles are present appear to be increasing with time. The divalent cations (calcium, magnesium, and strontium) are all low in the suction candle-obtained porewater at $25 \mathrm{~m}(82 \mathrm{ft})$ bgs. The low concentrations reflect the effects of the high sodium in the leaked tank fluids causing ion exchange reactions that push the divalent cations deeper in the vadose zone sediment profile.

The technetium-99 and uranium concentrations in the suction candle porewater are similar to the values from the other two porewaters collected with the UFA or calculated from the water extracts. Namely, elevated uranium concentrations are found at $25 \mathrm{~m}(82 \mathrm{ft})$ bgs and to a lesser extent at $16 \mathrm{~m}$ (53 ft) bgs. The technetium-99 suction candle values are high at both 66 and $69 \mathrm{~m}$ (218 and $226 \mathrm{ft})$ bgs and much lower at shallower depths suggesting that either the entire technetium plume has been pushed into the Plio-Pliestocene mud unit from above or that the technetium has migrated into the sediments horizontally for other sources than the tank B-110 transfer line leak.

\subsection{Groundwater Analyses}

The chemical composition of the groundwater is reported in Table 4.30. The data are also plotted along with the calculated porewater (obtained from the dilution corrected 1:1 water extracts), ultracentrifuged porewaters taken from the core samples and in the in-situ suction candle samples obtained over time. All the data are plotted in Figures 4.1 through 4.5. In general, the vadose zone porewater obtained from the cores by ultracentrifugation and the suction candles still emplaced in the decommissioned borehole, obtained by drawing a vacuum periodically to extract fluid, contain more dissolved common cations and anions than the groundwater sample. The groundwater sample is influenced by inputs from uncontaminated recharge water, as well as fluids disposed to cribs, trenches and ponds that had lower concentrations of contaminants than tank fluids thus we would expect the groundwater to be more dilute. 
The technetium-99 and nitrate concentrations in the groundwater are $1815 \mathrm{pCi} / \mathrm{L}$ and $16.4 \mathrm{mg} / \mathrm{L}$, respectively. This yields a ratio of $111 \mathrm{pCi} / \mathrm{mg}$. For the overlying Hanford $\mathrm{H} 3$ sand unit (UFA squeezed) and in the Plio-Pleistocene mud unit (both UFA squeezed and suction candle), the ratio ranges from 760 and 400 to $900 \mathrm{pCi} / \mathrm{mg}$, respectively. This suggests that the technetium- 99 in the groundwater at 299-E33-46 has been diluted with waters with another source of nitrate provided that the technetium-99 has entered the groundwater from vertically descending through the vadose zone sediments.

The tritium concentration in the groundwater does not appear to come from the vadose sediments at borehole 299-E33-46 that overly the water table because no tritium was found, excepting at depths from about 14 to $18 \mathrm{~m}$ (46 to $60 \mathrm{ft}$ ) bgs, in the vadose zone profile. At the value found in the groundwater $(2810 \mathrm{pCi} / \mathrm{L})$ we should have been able to measure tritium in the overlying sediments. It is thus not clear that the source of the contamination in the groundwater obtained from the water table at 299-E33-46 before the borehole was decommissioned is from the vadose zone near tank B-110.

For a few of the constituents the vadose zone water and groundwater have similar concentrations, such as alkalinity, fluoride, phosphate, aluminum, barium and silicon. These constituents are likely controlled by dissolution reactions with the sediments.

Table 4.30. Composition of Groundwater Taken from Borehole 299-E33-46 at $255.8 \mathrm{ft}$ bgs.

\begin{tabular}{|l|c|c|l|c|c|}
\hline \multicolumn{1}{|c|}{ Constituent } & Units & Value & \multicolumn{1}{c|}{ Constituent } & Units & Value \\
\hline pH Measurement & & $7.87 \pm 0.05$ & Chromium & $\mathrm{ug} / \mathrm{L}$ & 7 \\
\hline Specific Conductance & $\mathrm{uS} / \mathrm{cm}$ & 360 & Cobalt & $\mathrm{ug} / \mathrm{L}$ & $<8.2$ \\
\hline Dissolved organic carbon & $\mathrm{ug} / \mathrm{L}$ & $390 \pm 120$ & Copper & $\mathrm{ug} / \mathrm{L}$ & $<1.2$ \\
\hline Alkalinity as $\mathrm{CaC0}_{3}$ & $\mathrm{mg} / \mathrm{L}$ & 100 & Iron & $\mathrm{ug} / \mathrm{L}$ & 38.1 \\
\hline Chloride & $\mathrm{mg} / \mathrm{L}$ & 7.8 & Magnesium & $\mathrm{mg} / \mathrm{L}$ & 9.95 \\
\hline Cyanide & $\mathrm{ug} / \mathrm{L}$ & $<2.5$ & Manganese & $\mathrm{ug} / \mathrm{L}$ & 29.2 \\
\hline Fluoride & $\mathrm{mg} / \mathrm{L}$ & 0.31 & Nickel & $\mathrm{ug} / \mathrm{L}$ & 3.4 \\
\hline Nitrate & $\mathrm{mg} / \mathrm{L}$ & 16.4 & Potassium & $\mathrm{mg} / \mathrm{L}$ & 4.62 \\
\hline Nitrite & $\mathrm{mg} / \mathrm{L}$ & $<0.007$ & Sodium & $\mathrm{mg} / \mathrm{L}$ & 16.1 \\
\hline Sulfate & $\mathrm{mg} / \mathrm{L}$ & 33.7 & Strontium & $\mathrm{mg} / \mathrm{L}$ & 0.185 \\
\hline Phosphate & $\mathrm{mg} / \mathrm{L}$ & $"--"$ & Silicon & $\mathrm{mg} / \mathrm{L}$ & $"--"$ \\
\hline Aluminum & $\mathrm{ug} / \mathrm{L}$ & $<7$ & Zinc & $\mathrm{ug} / \mathrm{L}$ & 9.5 \\
\hline Barium & $\mathrm{ug} / \mathrm{L}$ & 35.9 & Technetium-99 & $\mathrm{pCi} / \mathrm{L}$ & $1815 \pm 118$ \\
\hline Cadmium & $\mathrm{ug} / \mathrm{L}$ & $<0.15$ & Tritium & $\mathrm{pCi} / \mathrm{L}$ & 2810 \\
\hline Calcium & $\mathrm{mg} / \mathrm{L}$ & 34.8 & Uranium & $\mathrm{ug} / \mathrm{L}$ & $2.76 \pm 0.09$ \\
\hline
\end{tabular}

“_ constituent was not measured 


\subsection{Summary and Conclusions}

In this section, we present summary information on what the 299-E33-46 sediment characterization data means. Conclusions are included to aid in making decisions on what interim actions and future studies are needed to make current and future tank farm operations less likely to unfavorably effect the environment.

\subsection{Conceptual Model of the Geology at 299-E33-46}

Borehole 299-E33-46 is located approximately $15 \mathrm{ft}$ from the northeast edge of single-shell tank 241-B-110. The vertical borehole was installed by using the cable-tool technique between May 8 and June 26, 2001. Total depth of the borehole was $264.4 \mathrm{ft}$ and groundwater was encountered at $255.8 \mathrm{ft}$ bgs. Anticipated perched-water conditions were not encountered atop a fine-grained silt layer at $220 \mathrm{ft}$ bgs. A total of 33 two-ft long, 4-inch diameter split-spoon core samples were obtained by pushing the sampler out ahead of the advancing casing. Grab samples were collected between these core sample intervals to yield near continuous samples to a depth of $78.3 \mathrm{~m}(257 \mathrm{ft})$. Eight vadose zone porewater sensor arrays were installed in the borehole at selected depths prior to removal of temporary casing and decommissioning the borehole.

Each of the 33 split spoon cores contained four 6-in long liners that were opened in the chemistry lab and geologically described during the sub-sampling process to obtain aliquots used in the various characterization activities. In addition 54 out of a total of 120 composite grab samples were also geologically described and characterized.

Three primary stratigraphic units were penetrated by this borehole: 1) backfill materials, 2) the Hanford formation, and 3) the Plio-Pleistocene unit. Backfill material consists of predominantly dark to olive gray, moderately sorted, silty sandy gravel to gravelly sand, which is unconsolidated and weakly to strongly calcareous. The backfill extends from the ground surface to a depth of $11.7 \mathrm{~m}(38.5 \mathrm{ft})$.

The Hanford formation is divided into three informal units ( $\mathrm{H} 1, \mathrm{H} 2$, and $\mathrm{H} 3)$. However, it appears that the $\mathrm{H} 1$ unit was completely removed during excavation in the vicinity of borehole 299-E33-46, and then later used as backfill. The Hanford formation beneath the backfill consists of mostly sand separated by several distinctly finer (fine sand to silt) strata. A total of three moisture spikes occur within the Hanford formation associated with these fine-grained intervals and/or other interfaces between strata with contrasting grain sizes.

The Hanford formation $\mathrm{H} 2$ unit is present between 38.5 to $176 \mathrm{ft}$ bgs. The Hanford formation $\mathrm{H} 2$ unit consists of mostly olive gray, moderately to well sorted, fine- to coarsegrained sand beds. These beds show occasional weak horizontal laminations and are generally non-calcareous to weakly calcareous. The most common sediment type within the $\mathrm{H} 2$ unit, a medium-to coarse grained sand is often described as "salt and pepper" sands because of the 
roughly equal amounts of dark- (basaltic) and light-colored (quartz and feldspar) grains. Dispersed within the Hanford formation $\mathrm{H} 2$ unit is four separate, relatively thin $(\leq 2 \mathrm{ft})$, olive brown to grayish brown, compact, well-sorted fine sand to silt beds. These occur at depths of about $69.7,98.5,123$, and $168 \mathrm{ft}$ bgs.

Below the $\mathrm{H} 2$ unit lays the $\mathrm{H} 3$ unit, a predominantly coarser-grained gravelly sand sequence that extends to base of the Hanford formation at $65.5 \mathrm{~m}(215 \mathrm{ft}) \mathrm{bgs}$. The top of the Hanford formation $\mathrm{H} 3$ unit is defined by a transition from predominantly sand to slightly gravelly sand at

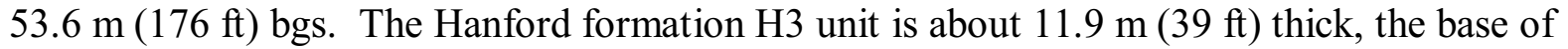

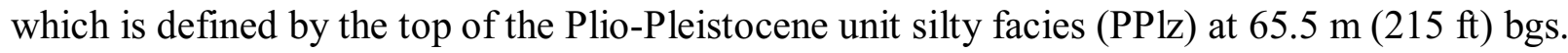
The H3 unit is unconsolidated and non-calcareous to weakly calcareous. The H3 unit in 299E33-46 grades downward into medium to coarse sand with depth.

A fine-grained sediment that we designate as the PPlz unit underlies the basalt-rich sands of the Hanford formation in borehole 299-E33-46 between $65.5 \mathrm{~m}(215 \mathrm{ft})$ and $69.4 \mathrm{~m}(227.7 \mathrm{ft})$ bgs. This unit can be subdivided into two facies types in borehole 299-E33-46. The upper part of the PPlz unit consists of a pale olive, loose, laminated, very-well sorted, calcareous, fine- to medium-grained, quartzo-feldspathic sand. The lower part of the PPlz unit consists of a grayish brown, laminated to massive, compacted and very well sorted, moderately calcareous, silt to silty fine sand.

The defining characteristics of the sediment from the PPlz unit include its relatively high calcium carbonate content, uniform texture, and predominantly quartzo-feldspathic mineralogy. Relatively high neutron moisture and gamma activity on geophysical logs in addition to the core and grab samples that were visually inspected corroborate that the lower part of the PPlz unit in this borehole is fine-grained (mostly silt).

A sequence of sandy gravel to gravelly sand was encountered starting at a depth of $69.4 \mathrm{~m}$ (227.7 ft) bgs. This material, designated as the PPlg unit, consists of mostly olive gray, loose, clast-supported, moderately to poorly sorted mixtures of gravel and sand. This unit contains a moderate amount $(\sim 30-50 \%)$ of basalt and is non-calcareous. The PPlg unit extends beyond the bottom of the borehole, which was terminated at $264.4 \mathrm{ft}$ bgs.

The most striking features in the field logs are several thin zones of increased moisture and a zone of high total gamma reading. Starting from the ground surface, a zone of increased moisture appears to conform with a $1.5 \mathrm{ft}$ thick layer of fine sand sandwiched between layers of coarse sand at 84.0-85.5 ft bgs. A similar spike in neutron-moisture logs occurs in several nearby tank vadose zone dry wells (20-10-02, 20-07-11, and 20-08-07). Another high-moisture zone is associated with a thin $(0.3 \mathrm{ft})$ silt layer at $168.1-168.4 \mathrm{ft}$ bgs; a core sample obtained from this zone yielded almost $20 \mathrm{wt} \%$ water in the laboratory. A third increase in moisture lies near a sand-gravelly sand interface, perhaps associated with some fine and organic(?)-rich layers (between 185 to $190 \mathrm{ft}$ bgs). A final sharp increase in neutron moisture occurs at a depth between 220-228 $\mathrm{ft}$ bgs associated with the silt-dominated facies (PPLz) of the Plio-Pleistocene 
unit. These three thin lenses may cause significant horizontal spreading of liquid fluxes from the tank farms.

A few other fine-grained beds are present (i.e., 69.7, 98.5, and $129 \mathrm{ft}$ depths), however these do not show up as increased-moisture zones on either the neutron-moisture log or in the laboratory analyses, probably because they are thin $(0.5-1.0 \mathrm{~cm}[0.016-0.03 \mathrm{ft}])$. These thin finegrained beds also probably escaped sub-sampling for moisture in the laboratory.

The total gamma log shows a significant zone, $\sim 12 \mathrm{~m}$ (40 ft) thick, of radionuclide contamination that has been confirmed by laboratory analyses to be Sr-90 occurs at the top of the Hanford formation $\mathrm{H} 2$ unit starting just below the interface with the overlying coarse-grained backfill. The base of the Sr-90 contamination as defined by bremmstrahlung radiation in the spectral gamma log is well defined and occurs just above a $0.5 \mathrm{~m}(1.5 \mathrm{ft})$ thick very fine sand layer at $85 \mathrm{ft}$ bgs, which may have acted as a localized perched zone or capillary boundary.

The discharge of large volumes of waste water in the early 1950s, raised the water table in the vicinity of the 241-B Tank Farm to over $4.9 \mathrm{~m}$ (16 ft) above pre-Hanford conditions. Based on historical well water level measurements, the groundwater reached a maximum elevation of approximate $124 \mathrm{~m}(407 \mathrm{ft}) \mathrm{MSL}$ in the 1967-68 time frame, with a secondary maximum, just below this in the 1986-89 time frame. Water levels have declined approximately 7-8 $\mathrm{ft}$ since 1989 at a rate of approximately $20 \mathrm{~cm} / \mathrm{yr}(0.7 \mathrm{ft} / \mathrm{yr})$. The maximum water table is estimated to have reached a depth of about $76.2 \mathrm{~m}(250 \mathrm{ft}) \mathrm{bgs}$, well below the fine silt PPlz unit that could act as a perched water table. The geologists logs made during the drilling of 299-E33-46 indicate that the groundwater table was encountered at a depth of $77.9 \mathrm{~m}(255.8 \mathrm{ft}) \mathrm{bgs}$. This suggests that the groundwater level has dropped almost $2 \mathrm{~m}(6 \mathrm{ft})$ in the vicinity of borehole 299-E33-46 since the late 1980s. There was no sign of perched water in the vicinity of $220 \mathrm{ft}$ bgs as was found at the borehole drilled east of the BX tank farm, 299-E33-45.

In general, the near horizontal fine-grained thin lenses in the Hanford formation and the thick Plio-Pleistocene mud unit likely cause anisotropy in water flow. The vertical distribution of technetium-99, nitrate and tritium in the vadose zone does not readily lead to the observed concentrations in the groundwater.

\subsection{Vertical Extent of Contamination}

The following paragraphs describe measurements of various parameters that help us determine the extent of vertical migration of the tank leak plume. We used several parameters including electrical conductivity, nitrate, $\mathrm{pH}$, sodium, and technetium-99 concentrations in water extracts for our main indicators to determine the leading edge of the tank leak plume. The concentrations of acid-extractable or directly measured constituents in the sediment were used to delineate the total inventory of constituents within the plume. For technetium-99, the waterextractable and acid/total concentrations were similar, signifying that this mobile constituent does remain in the vadose zone porewater and hardly interacts with the sediment. 
Based on evaluating all these measurements, we cannot conclude that the borehole data establishes the vertical extent of tank contamination.

The moisture content is a direct measure of the mass of fluid in the vadose zone sediment. One would logically assume that wetter than normal conditions would represent the existence of leaked tank liquor but as found at most of the boreholes studied, the moisture content is indicative mainly of grain size. The first region with elevated moisture is the 1.5 - $\mathrm{ft}$ thick mud lens at 84 to $85.5 \mathrm{ft}$ bgs [22.86 m] within the Hanford $\mathrm{H} 2$ sand unit. Near the bottom of the Hanford $\mathrm{H} 2$ unit at $168 \mathrm{ft}$ bgs is a moist $\sim 0.3 \mathrm{ft}$ thick lens of fine-grained material with moisture contents of $20.2 \%$ by weight. Within the Hanford $\mathrm{H} 3$ unit there is a slightly moist lens at $185 \mathrm{ft}$ bgs with a moisture content of 12.3 wt. \% compared to values of 3 to 4 wt \% nearby. The PPlz lithology between 220 and $226 \mathrm{ft} \mathrm{bgs}$ is the wettest material in the borehole with moisture contents ranging from 15 to $29 \mathrm{wt} \%$. The gravels below this PPlz silt are relatively dry down to the water table that currently is found at $255.8 \mathrm{ft}$ bgs.

The second parameter measured was the $\mathrm{pH}$ of water extracts of the vadose zone sediment. The $\mathrm{pH}$ profile shows that between 52 and 83 feet (30.48 and 45.72 meters) bgs (in the Hanford formation $\mathrm{H} 2$ middle sand sequence), there are elevated values [8.5 to 9.5] suggesting the presence of caustic waste interaction. Below the fine-grained lens at $\sim 84$ to $85 \mathrm{ft}$ bgs is another lobe of slightly elevated $\mathrm{pH}$ with values between 8.8 and 9.1. This deeper zone with elevated $\mathrm{pH}$ extends from 96 to $120 \mathrm{ft}$ bgs and is also within the Hanford formation $\mathrm{H} 2$ unit. The thin finegrained lens at $\sim 85 \mathrm{ft}$ bgs does not show elevated $\mathrm{pH}$ or elevated electrical conductivity and thus appears to be acting as a partial barrier to tank related fluid migration. The observed $\mathrm{pH}$ values are not nearly as high as would be expected for sediment completely saturated with tank liquor. One plausible explanation for the lower than expected $\mathrm{pH}$ is that the $\mathrm{pH}$ re-neutralizes with time from slow dissolution of alumino-silicates or with absorption of carbon dioxide that exists in the vadose zone air-filled porosity. Both processes would mute the initial $\mathrm{pH}$ excursion to high values over time.

The third parameter that was assessed to estimate the vertical extent of the leak plume was dilution-corrected electrical conductivity for water extracts. The electrical conductivity profile is similar to the elevated $\mathrm{pH}$ profile in that it shows two regions of high values. The shallower region of elevated EC starts a bit shallower [at $50.6 \mathrm{ft} \mathrm{bgs}$ ] than the elevated $\mathrm{pH}$ region and extends down to the thin fine-grained lens at $84-85 \mathrm{ft}$ bgs. The dilution corrected (calculated) porewater electrical conductivity ranges from 6.5 to $15 \mathrm{mS} / \mathrm{cm}$ in this region. The deeper elevated EC zone extends from 90.6 to $140 \mathrm{ft}$ bgs with calculated porewater conductivities ranging from 5.7 to $12.75 \mathrm{mS} / \mathrm{cm}$. This zone of elevated electrical conductivity is less concentrated than the shallow zone and resides within the lower portion of the Hanford formation $\mathrm{H} 2$ unit. The porewaters that were extracted from selected samples using the ultracentrifuge [UFA] show slightly lower $\mathrm{pH}$ values than the 1:1 sediment to water extracts and the actual porewater electrical conductivity values are often significantly lower than calculated porewater conductivities obtained by making dilution corrections on the 1:1 sediment to water extracts. This discrepancy was also found at borehole 299-E33-45 east of the BX-102 tank. 
The fourth parameter that was measured to define the vertical extent of contamination was nitrate. There is shallow nitrate contamination starting at about $50.6 \mathrm{ft}$ bgs that extends to $77.4 \mathrm{ft}$ bgs, perhaps reaching the thin fine-grained lens at $84.5 \mathrm{ft}$ bgs. Still within the Hanford formation $\mathrm{H} 2$ unit between the depths of 87.8 and $168 \mathrm{ft}$ bgs is a more concentrated nitrate plume. At 134 $\mathrm{ft}$ bgs the highest nitrate calculated porewater concentration is found $[\sim 1500 \mathrm{mg} / \mathrm{L}]$. The H2 sediment porewater between 164.5 and $168.5 \mathrm{ft}$ bgs contains $\sim 500 \mathrm{mg} / \mathrm{L}$ nitrate. The Hanford formation $\mathrm{H} 3$ sediment also contains elevated nitrate porewater concentrations that vary between 100 to $200 \mathrm{mg} / \mathrm{L}$. The PPlz unit also appears to contain slightly elevated nitrate porewater concentrations at $\sim 130 \mathrm{mg} / \mathrm{L}$. The 299-E33-46 borehole sediments in the PPlg coarse-grained unit may also contain elevated nitrate porewater concentrations of $\sim 50 \mathrm{mg} / \mathrm{L}$. Thus the sediment water extracts from this borehole appear to show elevated nitrate is present all the way to the groundwater; however the bulk of the nitrate is found in the sediment between the depth of 110 to $168.5 \mathrm{ft} \mathrm{bgs}$ in the Hanford $\mathrm{H} 2$ sand sequence with values reaching as high as $6.15 \mathrm{~g} / \mathrm{L}$ or $\sim 0.1 \mathrm{M}$ at 47.6 meters (156.2 feet) bgs.

The porewater fluoride concentrations are elevated above the uncontaminated sediment baseline range of 0.4 to $23 \mathrm{mg} / \mathrm{L}$ over a depth region from 50.6 to $111.4 \mathrm{ft}$ bgs. The highest fluoride porewater concentrations are found between 61 and $83 \mathrm{ft}$ bgs within the Hanford formation $\mathrm{H} 2$ unit at values that range from 110 to $210 \mathrm{mg} / \mathrm{L}$.

The bicarbonate concentration in the porewaters also is elevated in the $\mathrm{H} 2$ middle sand sequence between 75 and $167 \mathrm{ft} \mathrm{bgs}$; both above and within in the same zone with the largest nitrate concentrations. Interestingly, the bicarbonate distribution in the sediment water extracts mimics the elevated $\mathrm{pH}$ profile suggesting that either dissolution of natural carbonate minerals or capture of vadose zone carbon dioxide during tank waste fluid neutralization might be the cause. The porewater bicarbonate maximum concentration varies between 0.1 and $0.21 \mathrm{M}$ between 110 to $130 \mathrm{ft}$ bgs.

The porewater sulfate concentrations appear to be slightly elevated in the deeper depths of the borehole, rather than within the Hanford $\mathrm{H} 2$ unit where tank related fluids are generally found. The most significant concentrations of sulfate in the shallow vadose zone are found in a narrow zone within the middle sand sequence of the $\mathrm{H} 2$ unit between 140 and $166 \mathrm{ft}$ bgs. No UFA squeezings were obtained from sediments from this narrow zone and the natural background sediments in the borehole to the east, 299-E33-338 are also elevated. More puzzling are the elevated sulfate concentrations in the PPlg lithology at the bottom of the borehole. The dilution corrected porewater concentrations reach values $\sim 500 \mathrm{mg} / \mathrm{L}$ compared to natural background values of $\sim 40 \mathrm{mg} / \mathrm{L}$.

The porewater chloride concentrations do not appear to be significantly elevated compared to the nearby natural sediments from borehole 299-E33-338. Thus the observed chloride profile likely reflects natural conditions. The phosphate porewater distribution in the vadose zone sediment at borehole 299-E33-46 shows elevated concentrations between $\sim 54.6$ and $82 \mathrm{ft}$ bgs 
within the $\mathrm{H} 2$ upper sand sequence, the maximum concentrations are found in a thin zone at $\sim 60$ $\mathrm{ft}$ bgs with a dilution corrected value of $108 \mathrm{mg} / \mathrm{L}(0.0011 \mathrm{M})$.

The fifth indicator species used to define the vertical extent of contamination was sodium in the water extract. Sodium is the dominant cation in tank liquor. The maximum sodium porewater concentration is about $0.122 \mathrm{M}$ in the zone from 54.6 to $62.1 \mathrm{ft}$ bgs and $0.101 \mathrm{M}$ between 98 and $120 \mathrm{ft}$ bgs. The three highest porewaters based on electrical conductivity have a chemical composition that is essentially $0.15 \mathrm{M}$ sodium and $0.13 \mathrm{M}$ bicarbonate, $0.01 \mathrm{M}$ fluoride, $0.007 \mathrm{M}$ sulfate and $0.003 \mathrm{M}$ nitrate. The actual porewater cation concentrations are in general always lower than the calculated porewater concentrations derived from dilution correcting the 1:1 sediment to water extracts.

The depth profiles for the divalent alkaline earth cations calcium, magnesium, and strontium and show remarkable similarities. All show depleted concentrations over the depth range from between 50.6 or $52 \mathrm{ft}$ bgs down to $120 \mathrm{ft}$ bgs where the concentrations return to values similar to those found in uncontaminated sediments. Conversely, the porewater sodium concentration is elevated from $50.6 \mathrm{ft}$ bgs down to $201 \mathrm{ft} \mathrm{bgs}$ in the $\mathrm{H} 3$ sand sequence. The cation profiles for the divalent cations $(\mathrm{Ca}, \mathrm{Mg}$, and $\mathrm{Sr}$ ) and the mono-valent cations ( $\mathrm{K}$ and $\mathrm{Na}$ ) are related through ion exchange reactions wherein the divalent cations that dominant the exchange sites in the natural sediments are stripped off and replaced by the sodium and potassium (perhaps an impurity in the sodium hydroxide used at Hanford to neutralize acidic waste streams.

Finally, there also appears to be elevated concentrations of soluble $\mathrm{Al}$ and $\mathrm{Fe}$ in the shallow profile between 52 and 70 and 52 and $80 \mathrm{ft}$ bgs, respectively. Soluble Si also appears elevated in discontinuous zones between 52 and $120 \mathrm{ft}$ bgs. These zones of high readily water soluble Al, $\mathrm{Fe}$, and Si may represent amorphous reaction or weathering products from tank waste interactions with the vadose zone sediments.

Potassium-40 was the only gamma-emitting isotope quantitated in the profile, but the bremsstrahlung radiation was observed between the depths of 46 and $89 \mathrm{ft}$ bgs. The uranium238 activity was below the GEA detection limit for the entire vadose zone profile suggesting low concentrations are present. No detectable gamma emitting fission products such as ${ }^{137} \mathrm{Cs},{ }^{1{ }^{12}} \mathrm{Eu}$, ${ }^{154} \mathrm{Eu},{ }^{125} \mathrm{Sb}$, or the activation product ${ }^{60} \mathrm{Co}$, that are often observed in the field logging of the dry boreholes around Hanford's single shell tanks were observed in the sediments.

Strontium-90 is considered to be the primary radionuclide released from tank B-110 transfer line and is concentrated in the sediment between 19 and $28 \mathrm{~m}(62$ and $83 \mathrm{ft})$ bgs at concentrations between 1,000 and $11,250 \mathrm{pCi} / \mathrm{g}$. Strontium- 90 in the sediments is not readily water leachable with distilled water and several hours contact. In general the water leach and total acid leachable $\mathrm{Sr}$ in the vadose zone sediments suggest that the in-situ desorption $\mathrm{Kd}$ value is $>100 \mathrm{ml} / \mathrm{g}$ for the diluted 1:1 sediment to water extract solution. 
All the technetium-99 data in the shallow depths is suspect thus it is difficult to determine if the technetium profile at 299-E33-46 from the tank B-110 transfer line leak can be traced from below the tank all the way to the groundwater and whether B-110 is the source of technetium-99 in the deep sediments and groundwater. Other sources could be nearby crib discharges. If we put credence in the technetium-99 depth profile, then simple steady-state recharge analyses suggest that the slight technetium-99 peak in the $\mathrm{H} 2$ unit at $132 \mathrm{ft}$ bgs is where the transfer line leak has migrated to over the last 30 years. The two apparent more concentrated peaks of technetium-99 found in the deep $\mathrm{H} 3$ unit and the PPlz unit would require unrealistically high recharge rates to have been occurring in the last 30 years to drive the technetium to these depths. It is more likely that the technetium found at the deeper depths is from some horizontal migration of fluids containing technetium-99 from other sources that was carried to depth by active disposal of large quantities of contaminated water or some other driving force such as domestic water line leaks, recharge from topographic lows for snow melt etc.

There are elevated concentrations of uranium in the vadose zone pore water between 50.6 and $120 \mathrm{ft}$ bgs (within the upper sand sequence of $\mathrm{H} 2$ ). There is no indication of elevated uranium in the $\mathrm{H} 3$ unit, PPlz or PPlg units.

In summary, the moisture content, $\mathrm{pH}$, electrical conductivity, fluoride, sulfate, phosphate, sodium, strontium-90 and uranium profiles do not identify the leading edge of the plume. The profiles of only nitrate, suggests that the leading edge of the plume could have reached the water table at borehole 299-E33-46; however horizontal migration of nitrate rich waters in the PPlz unit might be the cause of the higher than background nitrate concentrations in the deep vadose zone profile. The majority of the tank fluids still resides in the shallow Hanford $\mathrm{H} 2$ sand unit.

\subsection{Detailed Characterization to Elucidate Controlling Geochemical Processes}

The more detailed characterization activities of the cores from 299-E33-46 borehole added some insight on the processes that control the observed vertical distribution of contaminants and on their migration potential into the future. The first key finding was that the 1:1 sediment to water extracts are a reasonable estimate of the porewater chemistry in the vadose zone sediment. We extracted porewater from eleven sediment samples using high-speed centrifugation. The chemical composition of the actual porewater was found to be adequately estimated by dilution correcting the 1:1 water extracts. Because it is much easier to obtain a water extract of the vadose zone sediment this finding is important to understanding the porewater chemistry throughout the vadose zone plumes under disposal facilities and leaking tanks. Constituents that showed the best agreement include electrical conductivity, nitrate, sodium, and technetium.

The porewaters in the sediment from the cores in the Hanford formation unit (H2) were dominated by sodium and bicarbonate. The three most concentrated porewaters based on electrical conductivity have a chemical composition that is essentially $0.15 \mathrm{M}$ sodium and $0.13 \mathrm{M}$ bicarbonate, $0.01 \mathrm{M}$ fluoride, $0.007 \mathrm{M}$ sulfate and $0.003 \mathrm{M}$ nitrate. The actual porewater 
cation concentrations are in general always lower than the calculated porewater concentrations derived from dilution correcting the 1:1 sediment to water extracts. These concentrations are more dilute than porewaters found at 299-E33-45 east of the BX-102 tank and much more dilute than porewaters under the self boiling REDOX waste tanks in SX tank farm that reached 16 to $17 \mathrm{M}$ sodium nitrate with one molar concentrations of calcium, $0.5 \mathrm{M}$ chromate, and several tenths molar chloride, magnesium, potassium, and sulfate. There is also a faint indication that water extractable uranium is elevated in the vadose zone pore water between 50.6 and $120 \mathrm{ft}$ bgs (within the upper sand sequence of $\mathrm{H} 2$ ). There is no indication of elevated uranium in the H3 unit, PPlz or PPlg units.

There is no indication that there are elevated concentrations of RCRA metals in acid or water extracts from 299-E33-46 borehole sediment.

The water-extractable major cations suggest that an ion-exchange process dominates the porewater/sediment interactions where tank fluid passed by or currently exists. The depth profiles for the divalent alkaline earth cations calcium, magnesium, and strontium and show remarkable similarities. All show depleted concentrations over the depth range from between 50.6 or $52 \mathrm{ft}$ bgs down to $120 \mathrm{ft}$ bgs where the concentrations return to values similar to those found in uncontaminated sediments. Conversely, the porewater sodium concentration is elevated from $50.6 \mathrm{ft}$ bgs down to $201 \mathrm{ft}$ bgs in the $\mathrm{H} 3$ sand sequence. The cation profiles for the divalent cations $(\mathrm{Ca}, \mathrm{Mg}$, and $\mathrm{Sr}$ ) and the mono-valent cations $(\mathrm{K}$ and $\mathrm{Na})$ are related through ion exchange reactions wherein the divalent cations that dominant the exchange sites in the natural sediments are stripped off and replaced by the sodium and potassium (perhaps an impurity in the sodium hydroxide used at Hanford to neutralize acidic waste streams.

\subsection{Estimates of Sorption-Desorption Values}

In this section, we discuss our measurement and data synthesis used to quantify the adsorption-desorption values for the major contaminants found in the sediment at 299-E33-46 borehole. We estimated the $\mathrm{K}_{\mathrm{d}}$ for various contaminants using one method. By combining the data from the dilution corrected 1:1 water extracts, which represent the porewater, with the activities measured on the sediment, we can get a semi-quantitative sense of what the desorption $\mathrm{K}_{\mathrm{d}}$ is. For a contaminant that has very little water-soluble mass, such as cesium-137, the $\mathrm{K}_{\mathrm{d}}$ can be approximated as the amount of mass in the total sample per gram of dry sediment divided by the amount of mass in the porewater per milliliter. For a contaminant that is quite soluble in the water extract ( equivalent to saying that the contaminant resides mainly in the porewater within the sediment), one needs to subtract the amount that was water extractable from the total amount present in the moist sediment sample to obtain a value for the amount that would remain on the solid at equilibrium with the pore fluid.

Using these measured distributions, the in-situ desorption $K_{d}$ for strontium-90 was consistently $>100 \mathrm{ml} / \mathrm{g}$. The technetium-99 desorption data were not of sufficient quality to determine quantitative values because of the low concentrations present but we do not believe 
that the technetium-99 is adsorbing to the sediments. Therefore a desorption $\mathrm{K}_{\mathrm{d}}$ of zero, meaning that the technetium-99 is not interacting with the sediment, should be assumed. The technetium in-situ desorption $\mathrm{K}_{\mathrm{d}}$ data are consistent with a wealth of literature that finds essentially no technetium adsorption onto Hanford Site sediment (Kaplan and Serne 1995; Kaplan and Serne 2000).

A second method of determining $\mathrm{K}_{\mathrm{d}}$ values would be laboratory batch tests. Batch desorption tests were performed for strontium-90 for several time periods using numerous solutions by the by the Science and Technology Program (see Appendix D in the B-BX-BY FIR (Knepp 2002).

\subsection{Other Characterization Observations}

The ratio of one ostensibly mobile species to others in the porewaters can be used to determine relative mobilities. If the absolute concentrations of co-migrating species are changed solely by dilution with existing porewater, then the ratio of the two should remain constant. Unlike similar ratio discussions for other contaminated boreholes (SX-41-09-39 and 299-W23-19; see Serne et al. 2002b and 2002d), the ratios for the porewaters from borehole 299-E33-46 are not constant. It is likely that the low absolute concentrations of constituents such as technetium-99 and relatively low concentrations of nitrate and uranium cause the ratio approach to be compromised by analytical error.

Further, the dilution corrected porewaters in general do not appear to be of the same composition as this estimate for Sr recovery waste. The technetium-99 concentrations found in the porewaters are generally much lower than those that should be found in Sr recovery waste. Compared to the fluoride found in the porewater both the technetium-99 and nitrate are too low based on Larson's estimates of the chemical composition of Sr recovery waste.

The percentage of the total sediment metal concentrations that is acid extractable from the contaminated sediment is slightly higher than for uncontaminated sediment for only sodium. The anthropomorphic sodium does show a higher percentage of the total concentrations are acid extractable from the sediment between 53 and $69.5 \mathrm{ft}$ bgs compared to uncontaminated sediment. Except for the sodium results, we expected there to be a larger increase than was observed for the contaminated sediment suggesting that the comparison of percentages of the total composition of any element that is acid extractable is not a very sensitive indicator of the presence of tank liquors or its reaction products with vadose zone sediment. More discussions on looking for alteration products is found in the mineralogy section.

As part of our characterization of the contaminated sediment, parameters that can control contaminant migration were measured. Key parameters that were measured on the borehole sediment include the calcium carbonate content, particle size distribution, and bulk and clay size mineralogy. 
Particle size measurements showed that the fine grained thin lens at $84 \mathrm{ft}$ bgs within the $\mathrm{H} 2$ unit has at least $6.5 \%$ silts and sands compared to most of the Hanford formation that is $\sim 90$ to $95 \%$ sand. The middle and lower portion of the PPlz unit also contains a high percentage of fines.

There is no evidence of rich calcareous zones in the entire profile such is found underlying the PPlz unit in 200 West Area. The calcium carbonate content of the Hanford formation sediments vary between 0.6 to $2.6 \%$ by weight with an average of $1.3 \pm 0.4 \mathrm{wt} \%$. The fine grained PPlz mud shows slightly higher calcium carbonate, averaging $1.7 \%$ by weight. The coarse grained PPlg contains the least calcium carbonate (average $0.475 \%$ by weight).

As found for uncontaminated sediment from outside other tank farms, the Hanford formation sediment is dominated by silica and alumina. Calcium, carbonate, iron, magnesium, potassium, sodium, and titanium make up most of the rest of the oxides.

XRD analysis of the 11-bulk sediment samples from borehole 299-E33-46 shows the samples to all have a similar mineralogical signature. Quartz concentrations in the bulk sediments ranged from $22.4 \mathrm{wt}-\%$ to $43.5 \mathrm{wt}-\%$, with an average concentration of $33 \pm 6 \mathrm{wt}-\%$. The bulk sediments contained plagioclase feldspar concentrations from 10 to $34 \mathrm{wt}-\%$ and potassium feldspar content measured between 8 to $37 \mathrm{wt}-\%$. The borehole sediment contained plagioclase feldspar concentrations from 10 to $34 \mathrm{wt}-\%$ and potassium feldspar content measured between 8 to $37 \mathrm{wt}-\%$. Plagioclase feldspar was more abundant than potassium feldspar in all but three samples. Over all, the feldspar content (both plagioclase and alkali feldspars) averaged about $43 \pm 6 \mathrm{wt}-\%$. The amphibole phase comprised $<9 \mathrm{wt}-\%$ at most, with the majority of samples having concentrations in the 2 to $4 \mathrm{wt}-\%$ range. Clay minerals identified in the whole rock sediment included mica and chlorite. Mica concentrations ranged from a low of $6.5 \mathrm{wt}-\%$ to a high of $32 \mathrm{wt}-\%$, with most of the intervals having concentrations between 7 and $15 \mathrm{wt}-\%$. Chlorite concentrations were $<7-\mathrm{wt} \%$ in all sediments analyzed with the exception of two samples in the Plio-Pleistocene Mud Unit that contained 11.7 and $21.2 \mathrm{wt}-\%$ chlorite, respectively.

The clay fraction is dominated by four clay minerals: smectite, chlorite, illite, and kaolinite with minor amounts of quartz and feldspar. Semi-quantification results of the clay minerals in the $<2$ micron fraction showed that smectites ranged in concentrations from a low of $22 \mathrm{wt}-\%$ to a high of $50 \mathrm{wt}-\%$. Illite amounts varied from 30 to $56 \mathrm{wt}-\%$ with the majority of samples having concentrations in the 40 to $50 \mathrm{wt}-\%$ range. Chlorite and kaolinite were the least abundant of the clay minerals identified in the samples with concentrations equal to or less than $20 \mathrm{wt}-\%$ and $9 \mathrm{wt}-\%$, respectively. Quartz and feldspar minerals were present as trace amounts in the clay fraction. 
No evidence of mineral alteration or precipitation resulting from the interaction of the tank liquor with the sediment was observed based on the x-ray diffraction measurements. However, SEM scans, which are much more sensitive and more appropriate for finding subtle indications of caustic attack were not performed.

The matric potential of all cores samples from 299-E33-46 from the surface to the water table was determined by the filter paper method. For 299-E33-46, the water potential is much less than the gravity potential from the surface down to $70 \mathrm{~m}(230 \mathrm{ft})$ excepting one data point at about $145 \mathrm{ft}$ bgs, which appears to be a bad data point. The general trend is that the water potentials are consistent with a draining profile (water potentials wetter than -0.01 MPa). Below $71 \mathrm{~m}(233 \mathrm{ft})$ and to the water table at $\sim 78 \mathrm{~m}(\sim 255.8 \mathrm{ft})$, there appears to be a drier condition than above that depth. But these lower depths contain coarse materials, so sample handling (e.g. drying) may be responsible for the apparent drier matric potentials. In any case, it appears that borehole 299-E33-46 has a matric potential profile that strongly suggests drainage is occurring.

A series of instruments was placed in the vadose zone sediments at borehole 299-E33-46 as the casing was being pulled out of the ground in July and August 2001. The sensors are used for continuous monitoring of vadose-zone hydraulic properties and porewater at and beneath the surface of the tank farm. Vadose zone porewater has been extracted from suction candles periodically. Porewater extracted $\sim$ three to seven months after sensor installation shows that the waters are gaining dissolved salts. The chemical composition of the porewaters obtained through the suction candles for some constituents appears to be reaching a steady state value most similar to the porewaters obtained out of the core materials using the ultra centrifuge. Further, the trends versus time for the chemical evolution of any given constituent shows variation with depth; that is the chemical evolution is not the same for a constituent at all depths. Most of the variation in composition versus time is not analytical vagaries but must reflect actual variation because duplicate samples are showing excellent reproducibility. It will be interesting to follow the evolution of the chemical composition of the porewater with time and to attempt to correlate the variations with other data being collected from the other sensors deployed at the same depths. In general, the suction candle generated porewaters show $\mathrm{pH}$ values at 53 and $82 \mathrm{ft}$ bgs that are higher than in the rest of the borehole profile suggesting the presence of caustic fluid from the tank. The electrical conductivity of the suction candle samples is highest for the $53 \mathrm{ft}$ bgs depth and at $82 \mathrm{ft} \mathrm{bgs}$ is higher than the rest of the shallower and deeper profile suggesting that the contamination plume is still located between these depths. There is high fluoride at $82 \mathrm{ft}$ bgs that is not increasing with time. The nitrate concentrations in the suction candle samples is increasing versus time below $82 \mathrm{ft}$ bgs and is highest at $218 \mathrm{ft}$ bgs. The sulfate concentration is also increasing versus time and is high between the depths of 53 and $218 \mathrm{ft}$ bgs. The suction candle sulfate values are much higher than the UFA squeezed porewaters and the dilution corrected water extract values. There may be sulfate in the materials used to pack around the sensors or in some of the sensors themselves. The technietium- 99 suction candle values are high at both 218 and $226 \mathrm{ft}$ bgs and much lower above suggesting that either the technetium plume has been pushed into the Plio-Pliestocene mud unit from above or horizontally for other sources than the B-110 tank transfer line leak. 
The technetium-99 to nitrate ratio in the groundwater at 299-E33-46 is much lower than in the overly vadose zone porewaters suggesting that the groundwater has been diluted with waters with another source of nitrate if the technetium-99 has entered the groundwater from vertically descending through the vadose zone sediments.

It is thus not clear that the source of the contamination for any constituent in the groundwater obtained before borehole 299-E33-46 was decommissioned is from the vadose zone sediments near tank B-110. 


\subsection{References}

American Society of Agronomy (ASA). 1986a. "Hydrometer Method." Chapter 15-5 in Methods of Soil Analysis-Part 1, $2^{\text {nd }}$ edition of Physical and Mineralogical Methods, SSSA Book Series No. 5, ed. A Klute, pp. 404-408. Soil Science Society of America, Madison, Wisconsin.

American Society of Agronomy (ASA). 1986b. "Pynchnometer Method." Chapter 14-3 in Methods of Soil Analysis-Part 1, $2^{\text {nd }}$ Edition of Physical and Mineralogical Methods, SSSA Book Series No. 5, ed .A Klute, pp. 378-379. Soil Science Society of America, Madison, Wisconsin.

American Society of Agronomy (ASA). 1996. "Elemental Analysis by XRF Spectroscopy." Chapter 7 in Methods of Soil Analysis-Part 3, Chemical Methods, SSSA Book Series 5, ed. DL Sparks, pp. 161-223. Soil Science Society of America, Madison, Wisconsin.

American Society for Testing and Materials (ASTM) D4129-88. 1988. "Standard Test Method for Total and Organic Carbon in Water by High Temperature Oxidation and by Coulometric Detection." American Society for Testing and Materials, West Conshohocken, Pennsylvania.

American Society for Testing and Materials (ASTM) D2488-93. 1993. "Standard Practice for Description and Identification of Soils (Visual-Manual Procedure)." American Society for Testing and Materials, West Conshohocken, Pennsylvania.

American Society for Testing and Materials (ASTM) D2216-98. 1998. "Test Method for Laboratory Determination of Water (Moisture) Content of Soil and Rock." American Society for Testing and Materials, West Conshohocken, Pennsylvania.

American Society for Testing and Materials (ASTM) D-5298-94. 2002. "Test Method for Measurement of Soil Potential (Suction) Using Filter Paper." American Society for Testing and Materials, West Conshohocken, Pennsylvania.

Baker VR, BN Bjornstad, AJ Busacca, KR Fecht, EP Kiver, UL Moody, JG Rigby, DF Stradling, and AM Tallman. 1991. "Quanternary Geology of the Columbia Plateau." In Quaternary Nonglacial Geology, ed. RB Morisson, Geol. Soc. Am. K-2:215-250. Conterminous U.S. Geology of North America, Boulder, Colorado.

Bjornstad BN, KR Fecht, and CJ Pluhar. 2001. "Long History of Pre-Wisconsin, Ice-Age, Cataclysmic Floods: Evidence from Southeastern Washington State", J. of Geology. Volume 109, p. 695-713.

Brindley G.W, and G. Brown (eds.). 1980. "Crystal Structures of Clay Minerals and Their X-Ray Identification.” Monograph No. 5, Mineralogical Society, London, England. 
Caggiano JA. 1996. Assessment Groundwater Monitoring Plan for Single Shell Tank Waste Management Area B-BX-BY. WHC-SD-ENV-AP-002. Westinghouse Hanford Company, Richland, Washington.

Caggiano, J.A., and S.M. Goodwin. 1991. Interim Status Groundwater Monitoring Plan for the Single-Shell Tanks. WHC-SD-EN-AP-012, Westinghouse Hanford Company, Richland, Washington.

CH2M HILL. 2000. Site Specific SST Phase 1 RFI/CMS Work Plan Addendum for $W M A-B-B X-B Y$. RPP-6072, Rev. 1. CH2M HILL Hanford Group, Inc. Richland, Washington.

Connelly, M.P., B.H. Ford, J.W. Lindberg, S.J. Trent, C.D. Delaney, and J.V. Borghese. 1992. Hydrogeologic Model for the 200 East Groundwater Aggregate Area. WHC-SD-EN-TI-019, Westinghouse Hanford Company, Richland, Washington.

Deka RN, M Wairiu, PW Mtakwa, CE Mullins, EM Veenendaal, and J Towend. 1995. "Use and Accuracy of the Filter Paper Method for Measuring Soil Matric Potential," European J. of Soil Sci. 46:233-238.

DOE. 1988. Consultation Draft Site Characterization Plan. DOE/RL-0164, 9 volumes, U.S. Department of Energy, Richland Operations Office, Richland, Washington.

DOE. 1999. Phase 1 RCRA Facility Investigation/Corrective Measures Study Work Plan for the SST Waste Management Areas. DOE/RL-99-36, Rev. 0, U.S. Department of Energy, Richland Operations Office, Richland, Washington.

DOE-GJPO. 1999a. Vadose Zone Characterization Project at the Hanford Tank Farms: B Tank Farm Report. GJO-HAN-28, prepared by U.S. Department of Energy Grand Junction Office for U.S. Department of Energy, Richland Operations Office, Richland Washington.

DOE-GJPO. 1999b. Vadose Zone Characterization Project at the Hanford Tank Farms: Tank summary data report for Tank B-110. GJO-HAN-131, prepared by U.S. Department of Energy Grand Junction Office for U.S. Department of Energy Office of River Protection, Richland Washington.

Drever JI. 1973. "The Preparation of Oriented Clay Mineral Specimens for X-Ray Diffraction Analysis by a Filter-Membrane Peel Technique." Amer. Minerl. 58:553-554.

EPA Method 300.0A. 1984. Test Method for the Determination of Inorganic Anions in Water by Ion Chromatography. EPA-600/4-84-017, U.S. Environmental Protection Agency, Washington, D.C.

EPA Method 3050B. 2000a. "Acid Digestion of Sediments, Sludges, and Soils." Test Methods for Evaluating Solid Waste, Physical/Chemical Methods. EPA Publication SW-846, available online http://www.epa.gov/epaoswer/hazwaste/test/sw846.htm 
EPA Method 6010B. 2000b. "Inductively Coupled Plasma-Atomic Emission Spectrometry." Test Methods for Evaluating Solid Waste, Physical/Chemical Methods. EPA Publication SW-846, available online http://www.epa.gov/epaoswer/hazwaste/test/sw846.htm

EPA Method 6020. 2000c. "Inductively Coupled Plasma-Mass Spectrometry." Test Methods for Evaluating Solid Waste, Physical/Chemical Methods. EPA Publication SW-846, available online http://www.epa.gov/epaoswer/hazwaste/test/sw846.htm

Folk RL. 1968. Petrology of Sedimentary Rocks. Hemphill, Austin, Texas.

Gee G.W. 1987. Recharge at the Hanford Site. Status Report. PNL-6403. Pacific Northwest Laboratory, Richland, Washington.

Gee GW, MJ Fayer, ML Rockhold, and MD Campbell. 1992. "Variations in Recharge at the Hanford Site," NW Sci. 66:237-250.

Gee GW, AL Ward, JB Sisson, JM Hubbell, and HA Sydnor. 2001. Installation of a Hydrologic Characterization Network for Vadose Zone Monitoring of a Single-Shell Tank Farm at the U. S. Department of Energy Hanford Site. PNNL-13172, Pacific Northwest National Laboratory, Richland, WA (see http://vadose.pnl.gov).

Gee, G. W., A. L. Ward, J. B. Sisson, J. M. Hubbell, D. A. Myers, and H. A. Sydnor. 2003. Hydrologic Characterization Using Vadose Zone Monitoring Tools: Status Report.

PNNL-14115, Pacific Northwest National Laboratory, Richland, WA (see http://vadose.pnl.gov).

Jackson ML. 1969. Soil Chemical Analysis - Advanced Course $-2^{\text {nd }}$ Edition. Department of Soil Science, University of Wisconsin, Madison.

Jones TE, BC Simpson, MI Wood, and RA Corbin. 2001. Preliminary Inventory Estimates for Single-Shell Leaks in B, BX, and BY Tank Farms. RPP-7389, Rev. 0, CH2M-HILL Hanford Group, Inc., Richland, Washington.

Kaplan DI, and RJ Serne. 1995. Distribution Coefficient Values Describing Iodine, Neptunium, Selenium, Technetium, and Uranium Sorption to Hanford Sediment. PNL-10379, Supplement 1, Pacific Northwest Laboratory, Richland, Washington.

Kaplan DI, and RJ Serne. 2000. Geochemical Data Package for the Hanford Immobilized LowActivity Tank Waste Performance Assessment (ILAW-PA). PNNL-13037, Rev.1, Pacific Northwest National Laboratory, Richland, Washington.

Knepp AJ. 2002a. Field Investigation Report for Waste Management Area B-BX-BY. RPP-10098, CH2M HILL Hanford Group, Inc., Richland, Washington.

Knepp AJ. 2002b. Field Investigation Report for Waste Management Area S-SX. RPP-7884, Rev. 0, CH2M HILL Hanford Group, Inc., Richland, Washington. 
Larson, D. E. 1967. B-Plant Phase III Flowsheets. ISO-986, Isochem, Inc, Richland, Washington.

Last GV, BN Bjornstad, MP Bergeron, DW Wallace, DR Newcomer, JA Schramke, MA Chamness, CS Cline, SP Airhart, and JS Wilbur. 1989. Hydrogeology of the 200 Areas Low-Level Burial Grounds - An Interim Report. PNL-6820, 2 volumes, Pacific Northwest Laboratory, Richland, Washington.

Lindenmeier CW, RJ Serne, BN Bjornstad, GW Gee, HT Schaef, DC Lanigan, MJ Lindberg, RE Clayton, VL LeGore, IV Kutnyakov, SR Baum, KN Geiszler, KMM Valenta, TS Vickerman, and LJ Royack. 2002, Characterization of Vadose Zone Sediment: RCRA Borehole 299-E33-338 Located Near the B-BX-BY Waste Management Area, PNNL-14121, Pacific Northwest National Laboratory, Richland, Washington.

Lindsey KA, BN Bjornstad, JW Lindberg, and KM Hoffman. 1992. Geologic Setting of the 200 East Area: An Update. WHC-SD-EN-TI-012, Westinghouse Hanford Company, Richland, Washington.

Lindsey KA, SP Reidel, KR Fecht, JL Slate, AG Law, and AM Tallman. 1994. "Geohydrologic Setting of the Hanford Site, South-Central Washington." In Geologic Field Trips in the Pacific Northwest. eds. DA Swanson and RA Hagerud, pp. 1C-1 to 1C-16. Geological Society of America Meeting, Geological Society of America, Boulder, Colorado.

Lindsey, K. A., S. E. Kos, and K. D. Reynolds. 2000. Vadose Zone Geology of Boreholes 299-W22-50 and 299-W23-19 S-SX Waste Management Area, Hanford Site, South-Central Washington. RPP-6149, Rev. 0. Waste Management Technical Services, Richland, Washington.

Lindsey KA, SE Kos, and KD Reynolds. September 2001. Vadose Zone Geology of Boreholes 299-E33-45 and 299-E33-46 B-BX-BY Waste Management Area, Hanford Site, South-Central Washington. RPP-8681, Rev. 0. Prepared for the Office of River Protection, CH2M HILL Hanford Group, Inc., Richland, Washington.

Moore DM, and RC Reynolds, Jr. 1997. X-Ray Diffraction and the Identification and Analysis of Clay Minerals. Oxford University Press, New York.

Narbutovskih SM. 1998. Results of Phase I Groundwater Quality Assessment for Single Shell Tank Waste Management Areas B-BX-BY at the Hanford Site. PNNL-11826, Pacific Northwest National Laboratory, Richland, Washington.

Or D, and JM Wraith. 2002. "Soil Water Content and Water Potential Relationships," pp. 49-84. In: Soil Physics Companion, ed. AW Warrick, CRC Press, Boca Raton, Florida.

Pacific Northwest Laboratory (PNL). 1990a. Procedures for Groundwater Investigations. PNL-MA-567-DO-1, Pacific Northwest Laboratory, Richland, Washington. 
Pacific Northwest Laboratory (PNL). 1990b. Procedures for Groundwater Investigations. PNL-MA-567-SFA-2, Pacific Northwest Laboratory, Richland, Washington.

Pacific Northwest National Laboratory (PNNL). 1997. Gamma Energy Analysis Operation and Instrument Verification Using the Genie2000 ${ }^{T M}$ Support Software. PNNL-RRL-01, Pacific Northwest National Laboratory, Richland, Washington.

Pacific Northwest National Laboratory (PNNL). 1998. Inductively Coupled Plasma Mass Spectrometric (ICP-MS) Analysis. PNNL-AGG-415, Pacific Northwest National Laboratory, Richland, Washington.

Pacific Northwest National Laboratory (PNNL). 1999. Visual Description and Classification of Potentially Contaminated Borehole Samples. PNL Procedure D9T81-99-GVL-1, Pacific Northwest National Laboratory, Richland, Washington.

Pacific Northwest National Laboratory (PNNL). 2000. Liquid Scintillation Counting and Instrument Verification Using the 1400 DSMTM Support Software. PNNL-AGG-002 Pacific Northwest National Laboratory, Richland, Washington.

Puget Sound Power and Light (PSPL). 1982. Skagit/Hanford Nuclear Project, Preliminary Safety Analysis Report. v. 4. Appendix 20. Amendment 23, Puget Sound Power and Light Company. Bellevue, Washington.

Price, WH and KR Fecht. 1976. Geology of the 241-B Tank Farm. ARH-LD-129, Atlantic Richfield Hanford Company, Richland, Washington.

Reidel SP, and KR Fecht. 1994. Geologic Map of the Priest Rapids 1:100,000 Quadrangle, Washington. Washington Division of Geology and Earth Resources Open-File Report 94-13, $22 \mathrm{p}$.

Reynolds KD. 2001. Summary Report: 241-B-110 Well (C3360) 299-E33-46. RPP-8633, Rev. 0, Prepared for CH2M Hill Hanford Group, Inc., by Duratek Federal Services, Inc., Northwest Operations, Richland, Washington.

Rhoades JD. 1996. "Salinity: Electrical Conductivity and Total Dissolved Solids." In Methods of Soil Analysis Part 3. ed. JM Bigham, pp. 417-435. American Society of Agronomy, Madison, Wisconsin.

Serne RJ, HT Schaef, BN Bjornstad, BA Williams, DC Lanigan, DG Horton, RE Clayton, VL LeGore, MJ O’Hara, CF Brown, KE Parker, IV Kutnyakov, JN Serne, AV Mitroshkov, GV Last, SC Smith, CW Lindenmeier, JM Zachara, and DS Burke. 2002a. Characterization of Vadose Zone Sediment: Uncontaminated RCRA Borehole Core Samples and Composite Samples. PNNL-13757-1, Pacific Northwest National Laboratory, Richland, Washington. 
Serne RJ, HT Schaef, BN Bjornstad, DC Lanigan, GW Gee, CW Lindenmeier, RE Clayton, VL LeGore, MJ O'Hara, CF Brown, RD Orr, G.V Last, IV Kutnyakov, DS Burke, TC Wilson, and BA Williams. 2002b. Characterization of Vadose Zone Sediment: Borehole 299-W23-19 [SX-115] in the S-SX Waste Management Area. PNNL-13757-2, Pacific Northwest National Laboratory, Richland, Washington.

Serne RJ, GV Last, HT Schaef, DC Lanigan, CW Lindenmeier, CC Ainsworth, RE Clayton, VL LeGore, MJ O'Hara, CF Brown, RD Orr, IV Kutnyakov, TC Wilson, KB Wagnon, BA Williams, and DB Burke. 2002c. Characterization of Vadose Zone Sediment, Part 4: Slant Borehole SX-108 in the S-SX Waste Management Area. PNNL-13757-4, Pacific Northwest National Laboratory, Richland, Washington.

Serne RJ, GV Last, GW Gee, HT Schaef, DC Lanigan, CW Lindenmeier, RE Clayton, VL LeGore, RD Orr, MJ O’Hara, CF Brown, DS Burke, AT Owen, IV Kutnyakov, and TC Wilson. 2002d. Characterization of Vadose Zone Sediment: Borehole 41-09-39 in the S-SX Waste Management Area. PNNL-13757-3, Pacific Northwest National Laboratory, Richland, Washington.

Serne, RJ, GV Last, GW Gee, HT Schaef, DC Lanigan, CW Lindenmeier, MJ Lindberg, RE Clayton, VL LeGore, RD Orr, IV Kutnyakov, SR Baum, KN Geiszler, CF Brown, MM. Valenta, and TS Vickerman. 2002e. Characterization of Vadose Zone Sediment: Borehole 299-E33-45 Near BX-102 in the B-BX-BY Waste Management Area. PNNL-14083, Pacific Northwest National Laboratory, Richland, Washington.

Slate JL. 2000. Nature and Variability of the Plio-Pleistocene Unit in the 200 West Area of the Hanford Site. BHI-01203, Rev. 0, Bechtel Hanford, Inc., Richland, Washington.

Tallman AM, KR Fecht, MC Marratt, and GV Last. 1979. Geology of the Separations Areas, Hanford Site, South-Central Washington. RHO-ST-23, Rockwell Hanford Operations, Richland, Washington.

United States Geological Survey (USGS). 2001. "Alkalinity and Acid Neutralizing Capacity." National Field Manual for the Collection of Water-Quality Data. Available online at http//water.usgs.gov/owq/FieldManual/Chapter6/6.6-contents.html

Wentworth CK. 1922. "A grade scale and class terms for clastic sediments." Journal of Geology, Vol. 30, p. 377-392.

Williams, B.A., B.N. Bjornstad, R. Schalla, and W.D. Webber. 2000. Revised Hydrogeology for the Suprabasalt Aquifer System, 200-East Area and Vicinity, Hanford Site, Washington.

PNNL-12261, Pacific Northwest National Laboratory, Richland, Washington.

Wood MI, TE Jones, R Schalla, BN Bjornstad, and SM Narbutovskih. 2000. Subsurface Conditions Description of the B-BX-BY Waste Management Area. HNF-5507, Rev. 0A. CH2M HILL Hanford Group, Inc., Richland, Washington. 


\section{Appendix A}

299-E33-46

Geologic Descriptions of Split-Spoon and Grab Samples Performed During Core/Sample Opening In PNNL Laboratory 


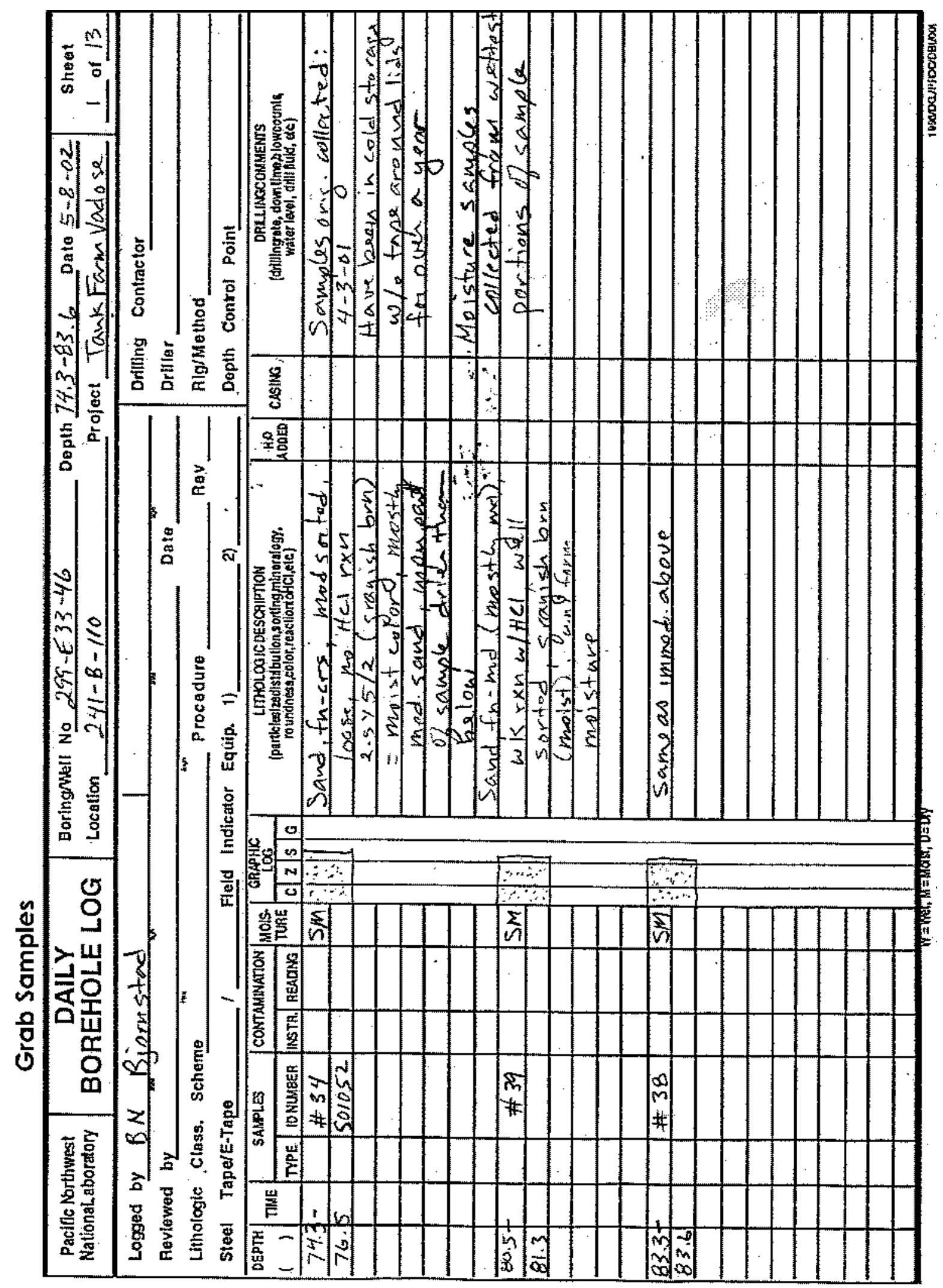




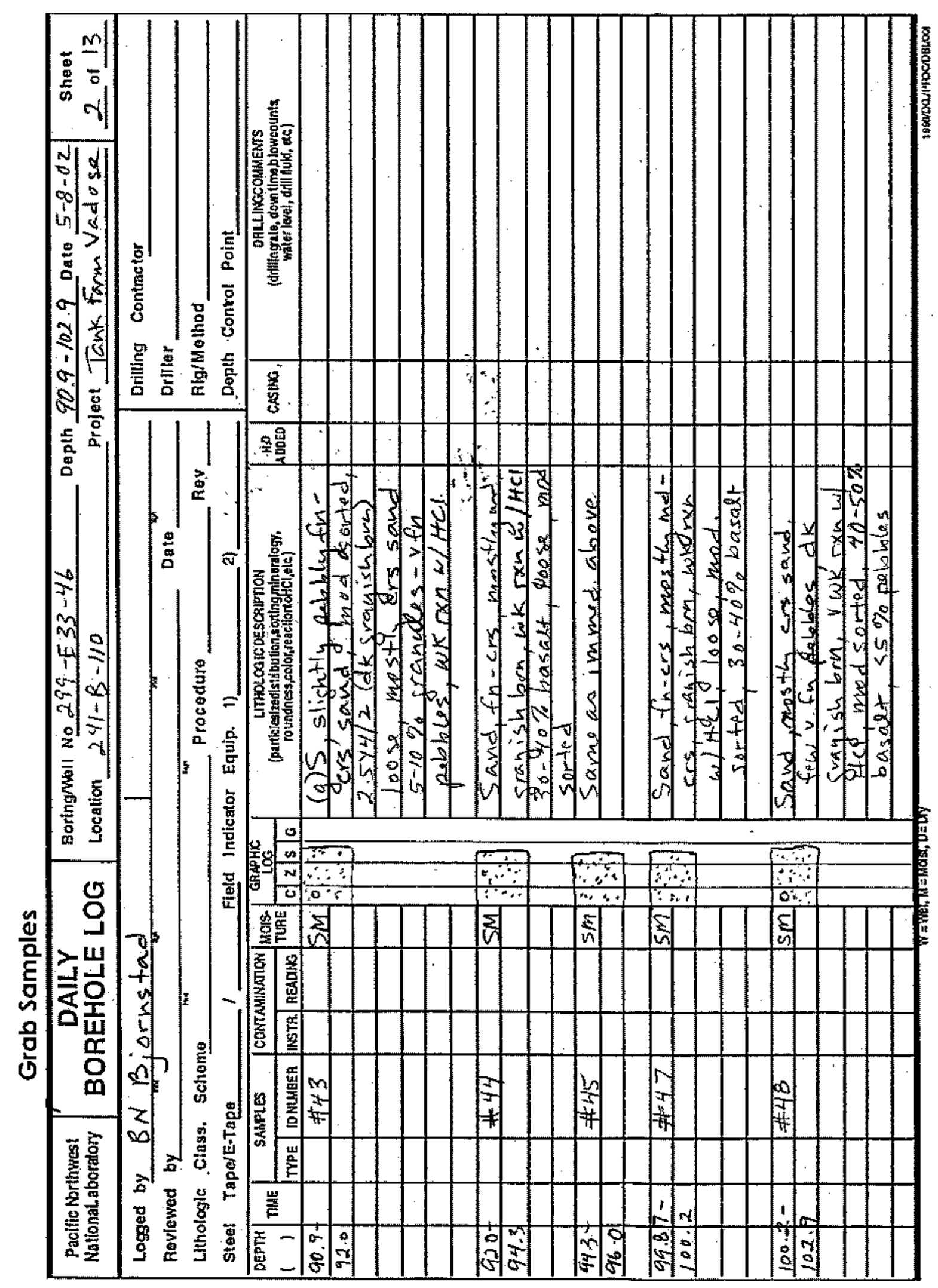




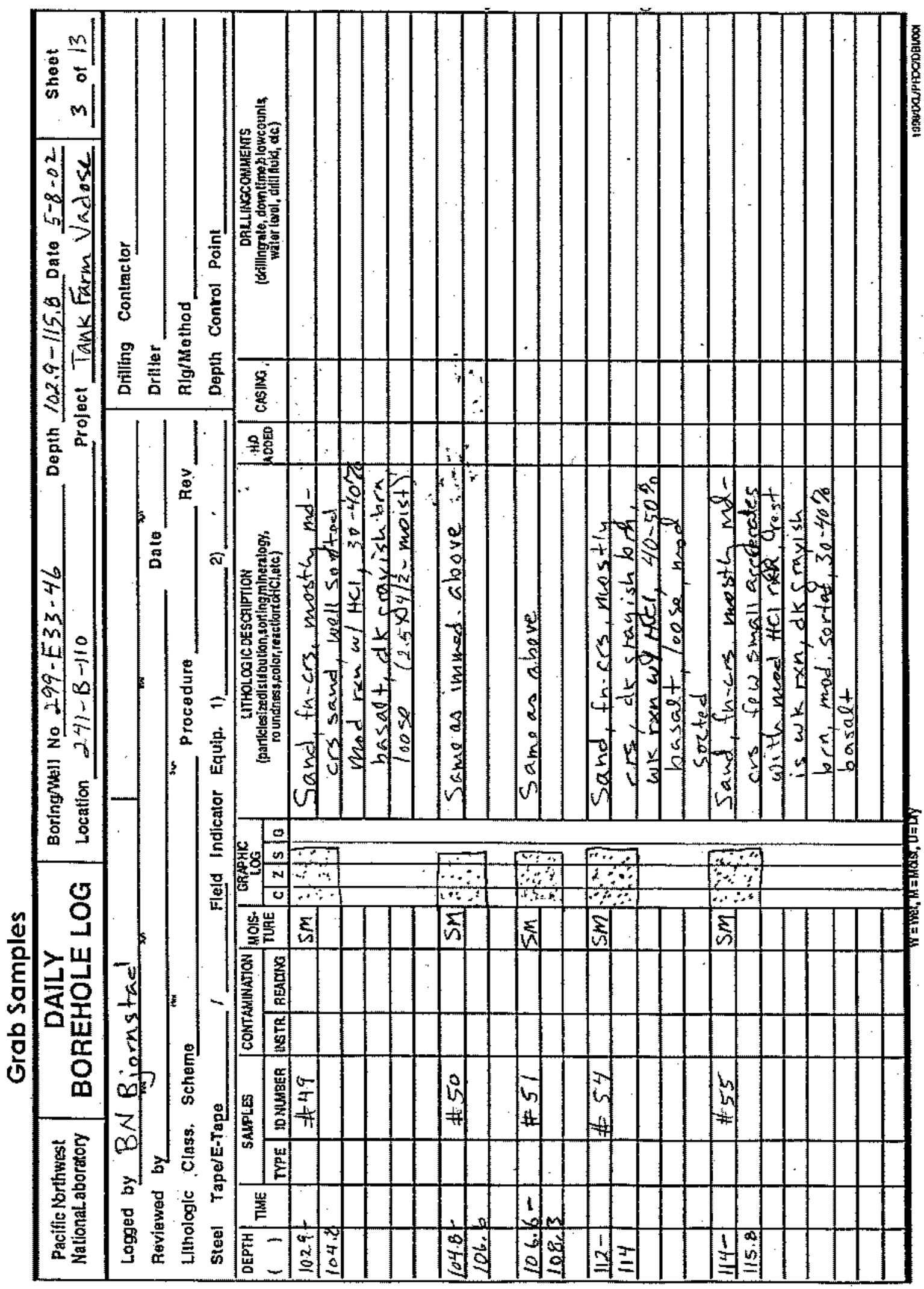




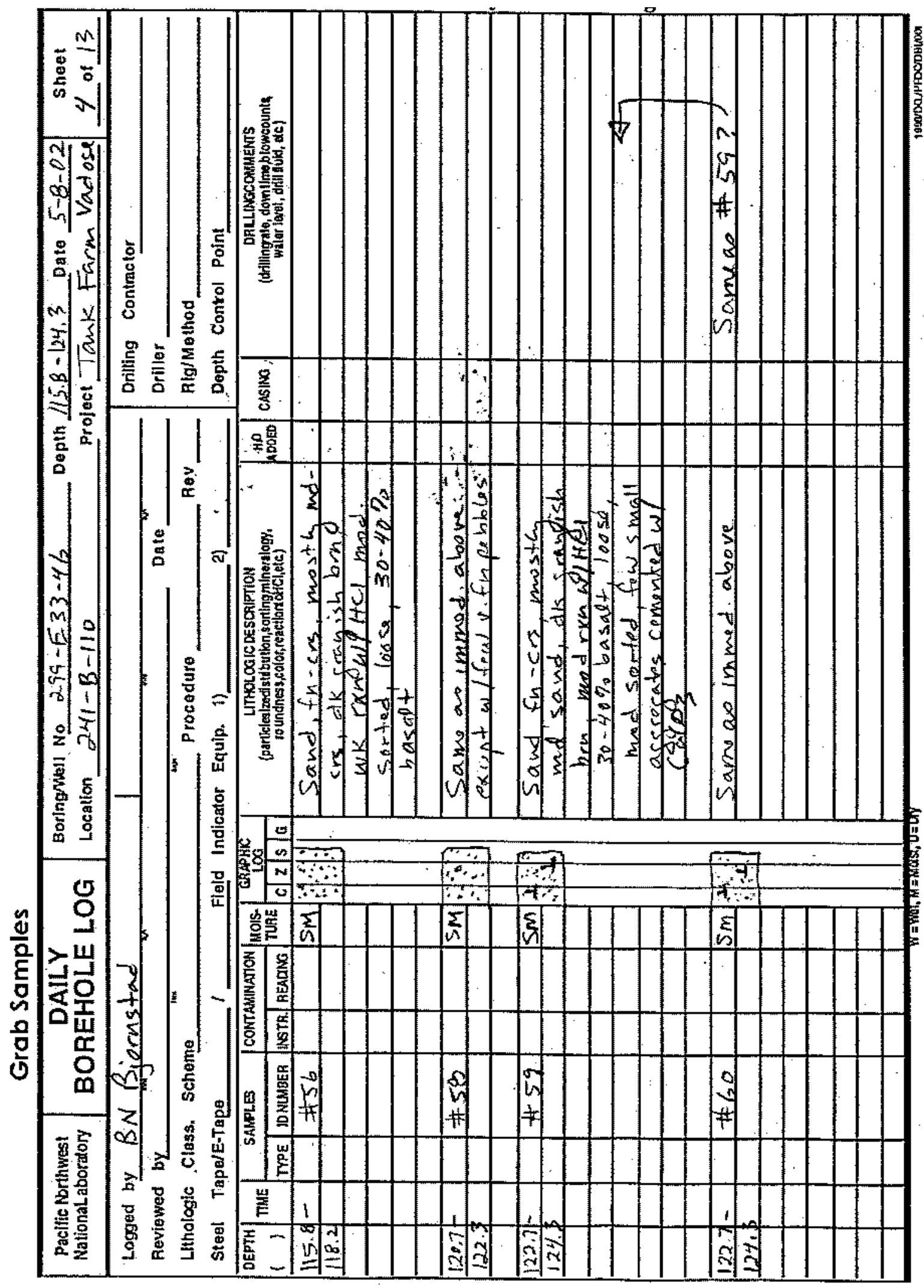




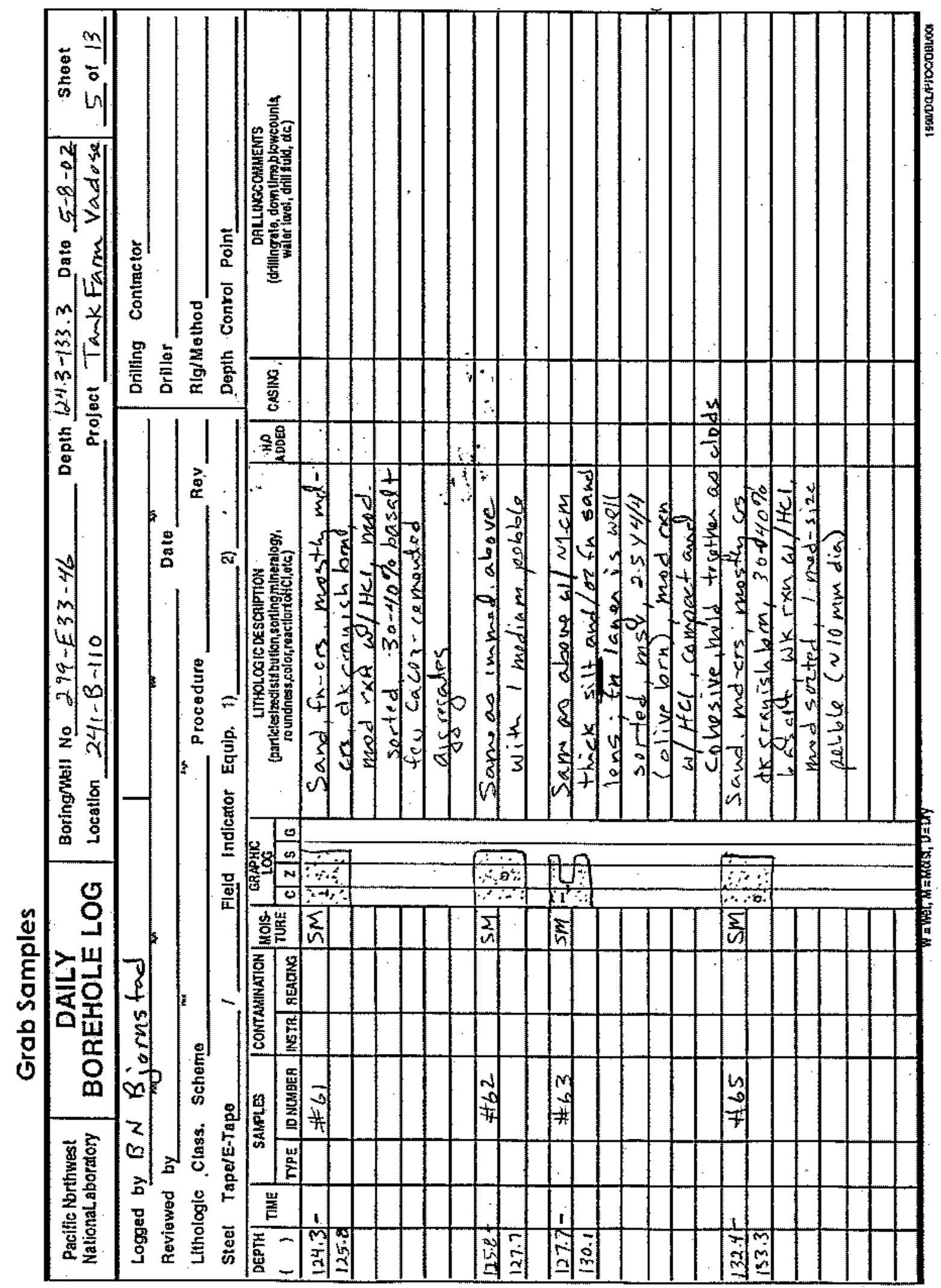




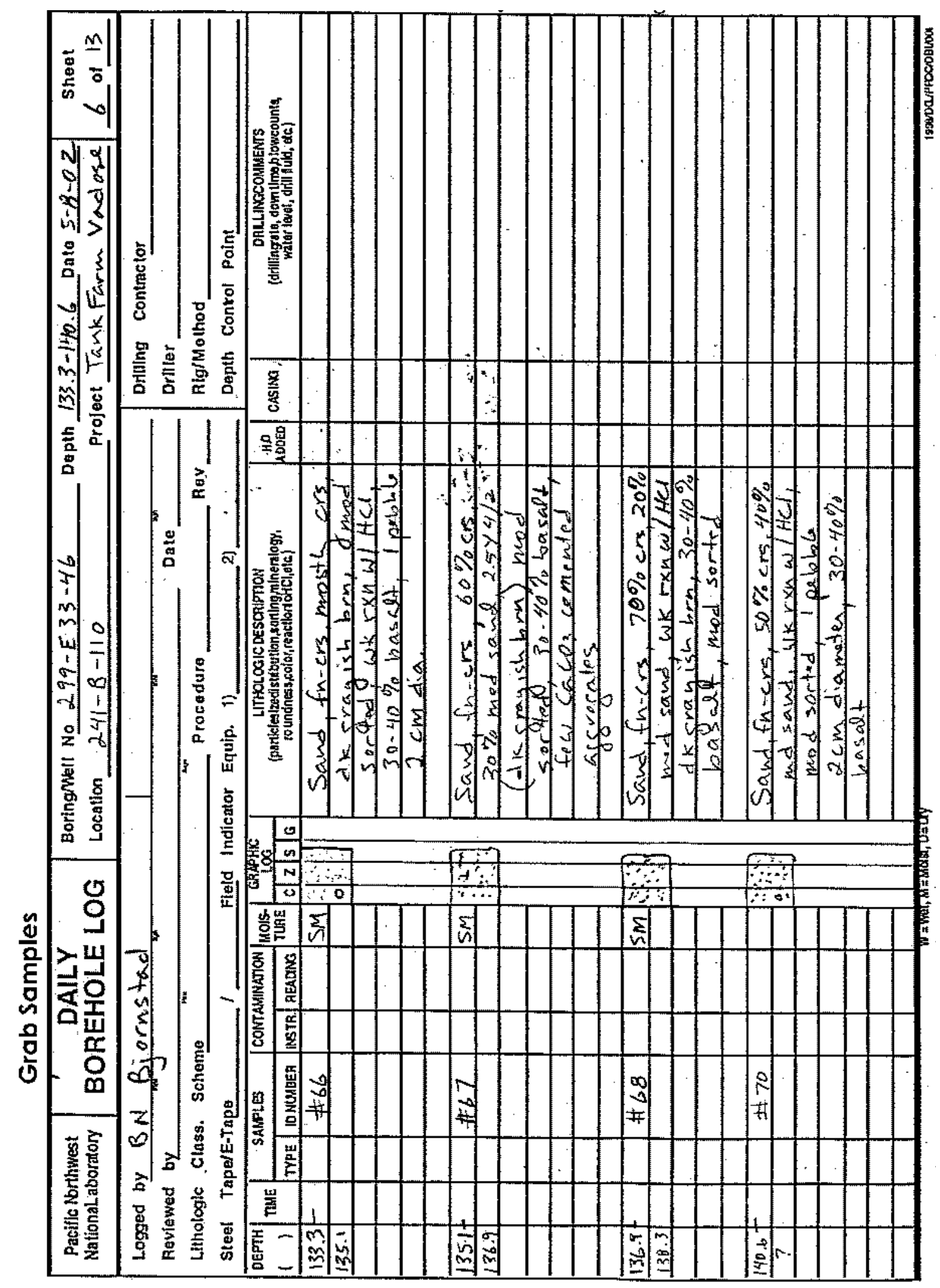




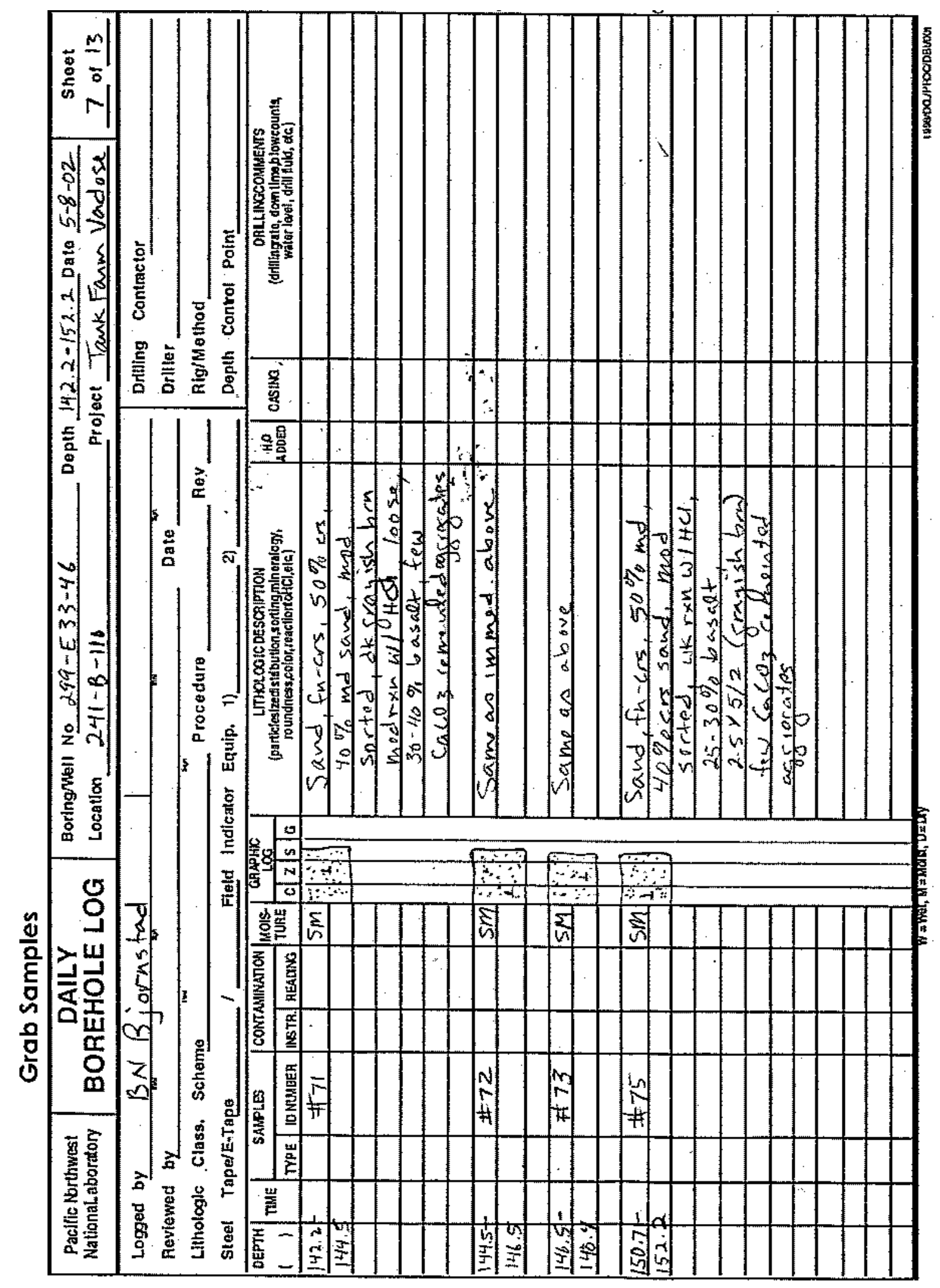




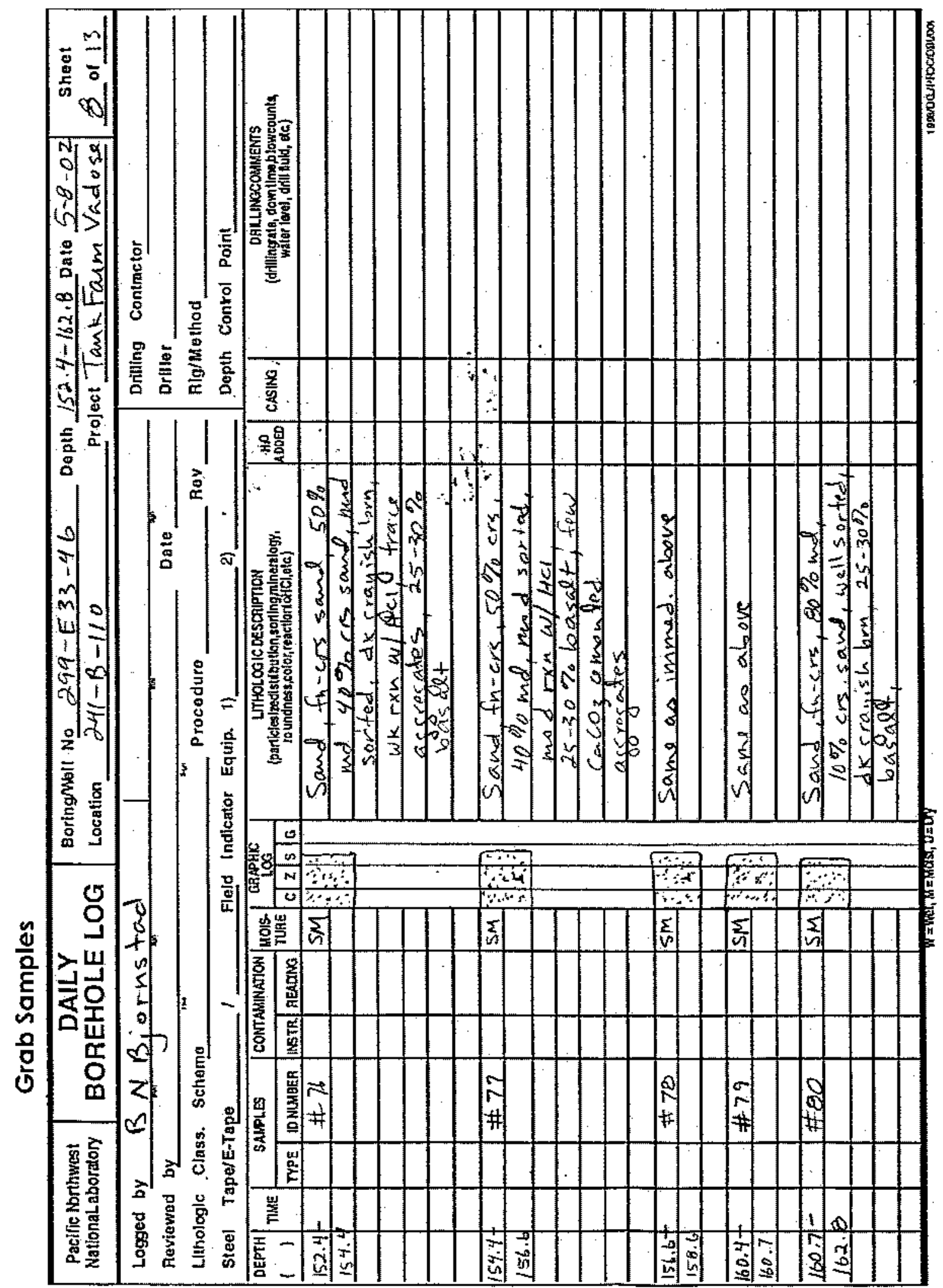




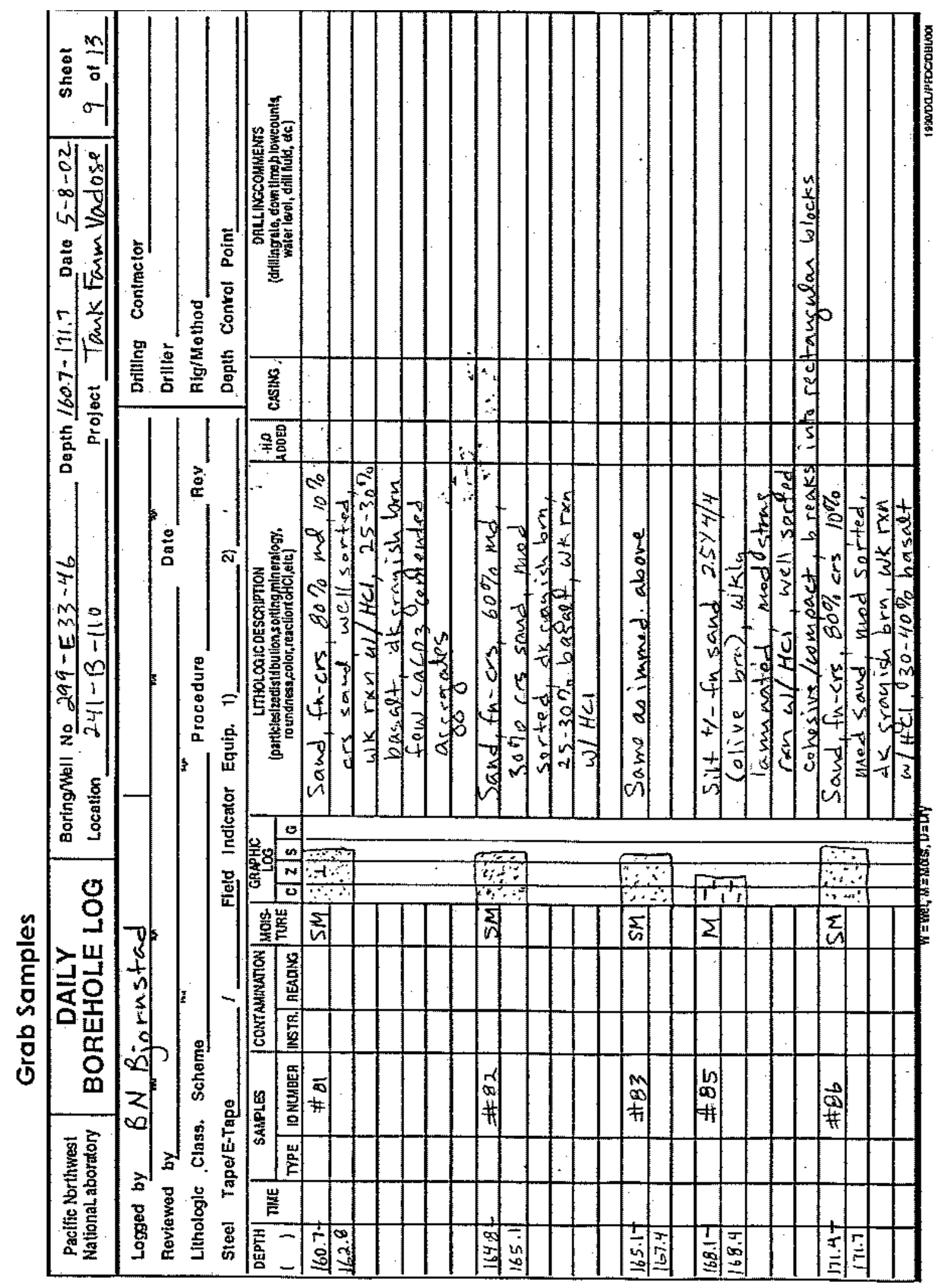




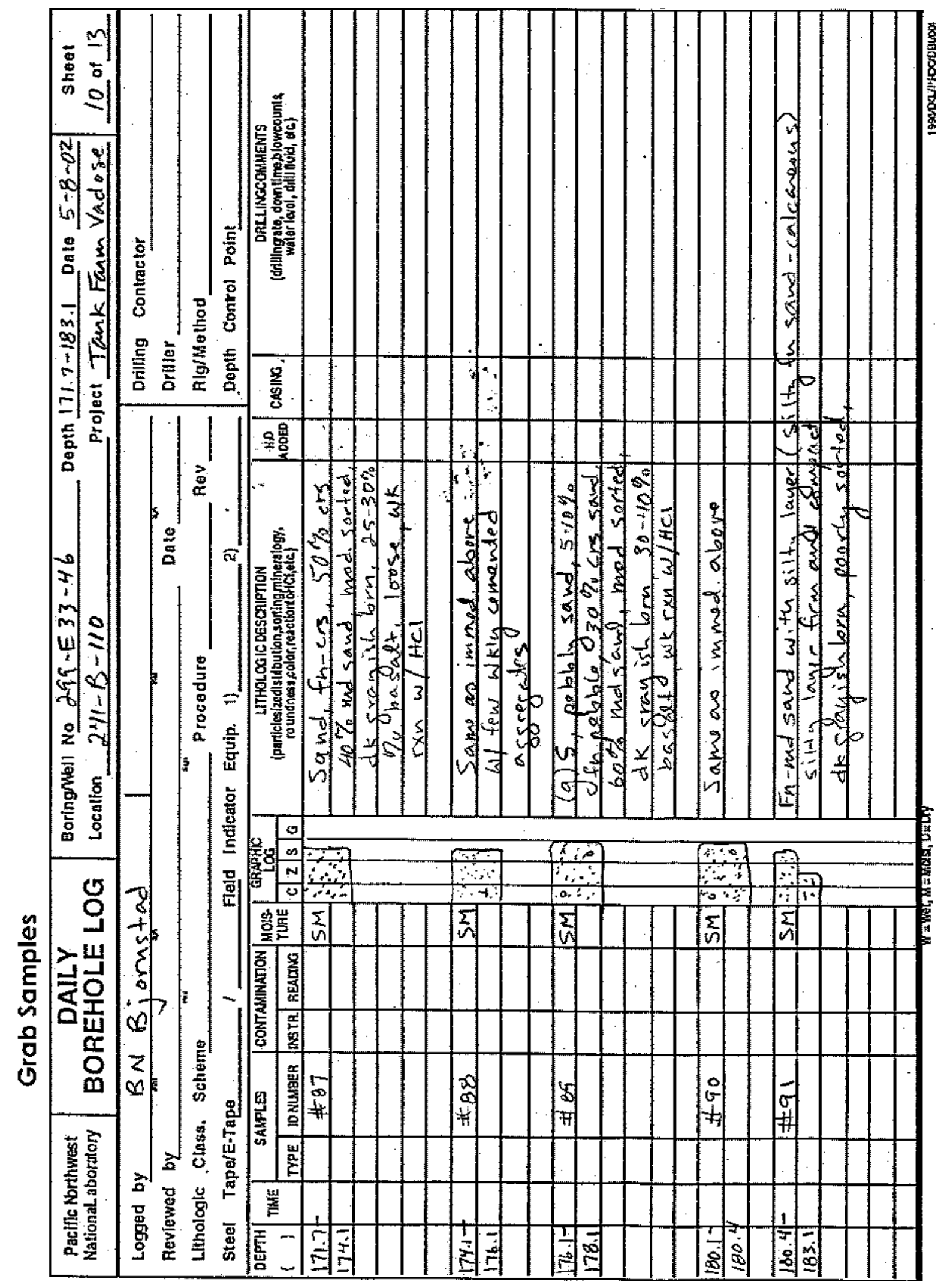




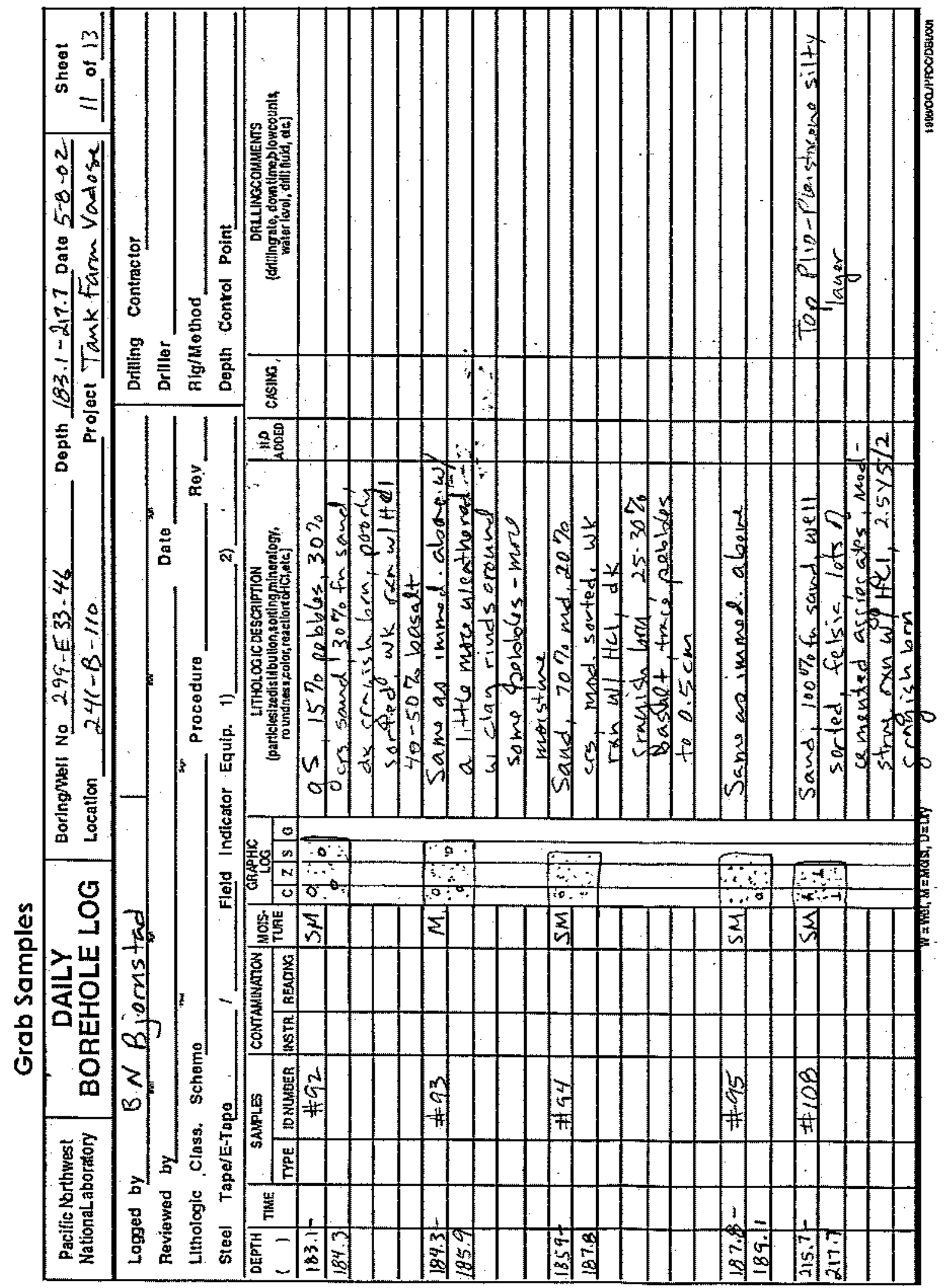




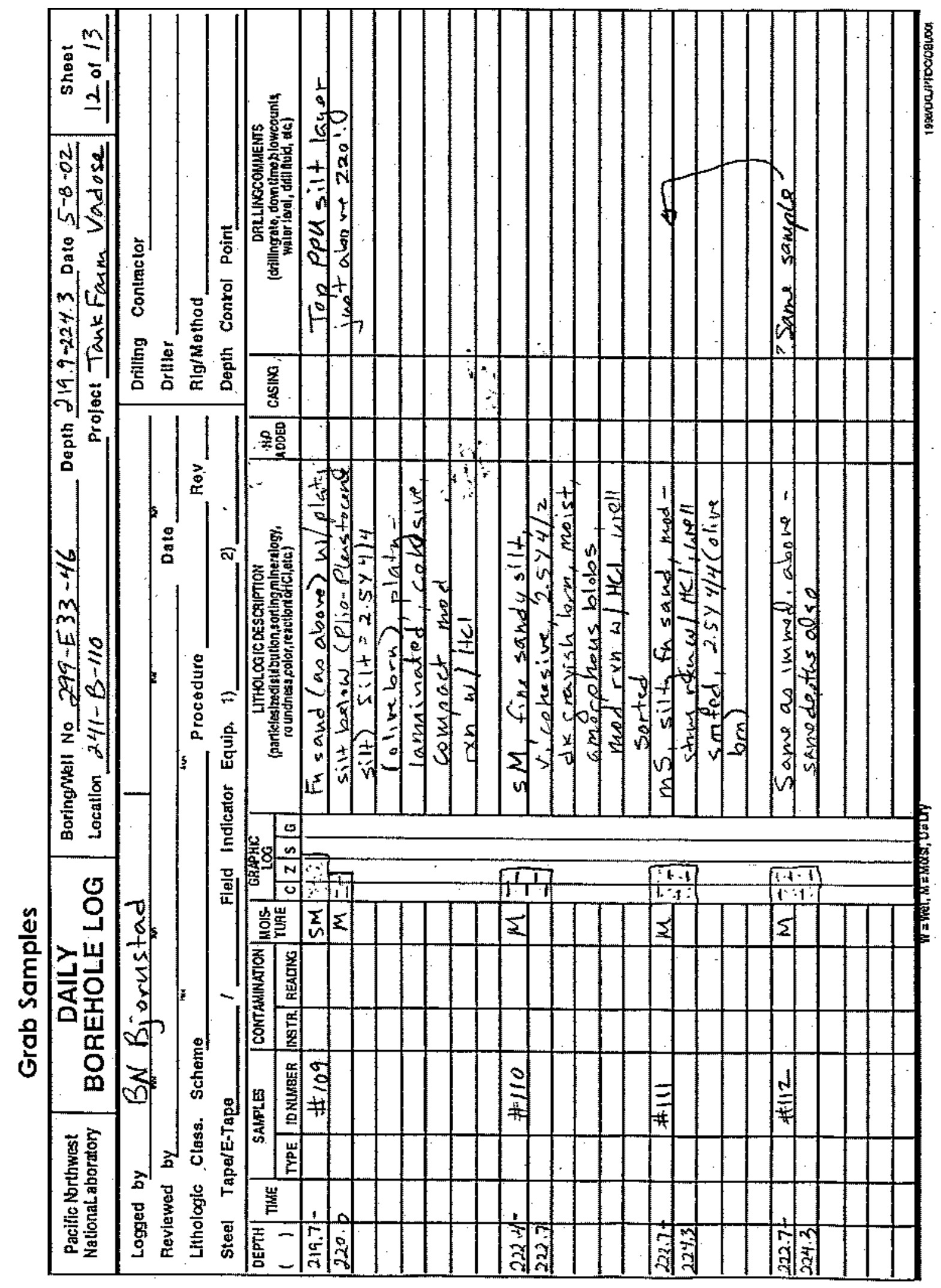




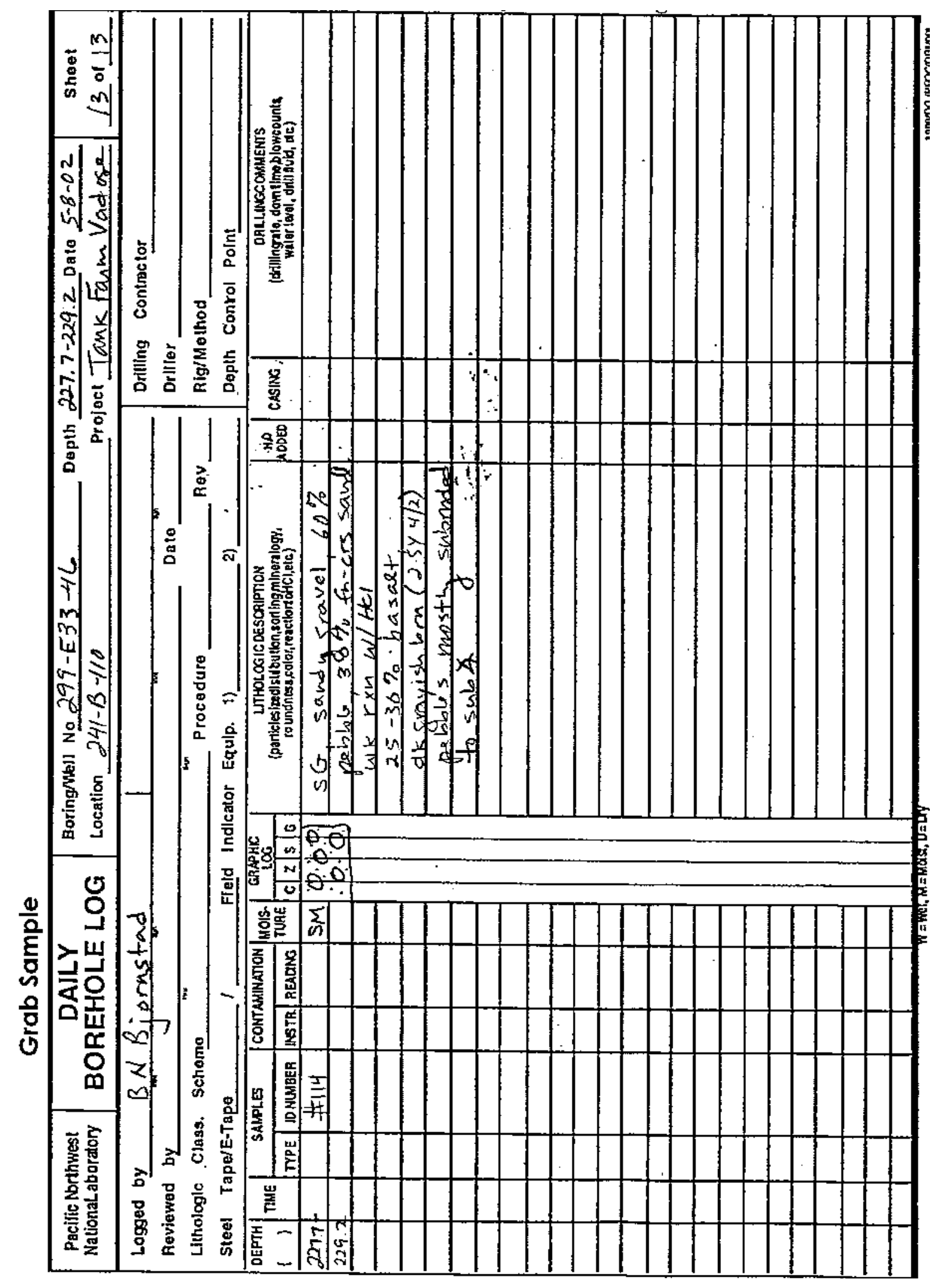




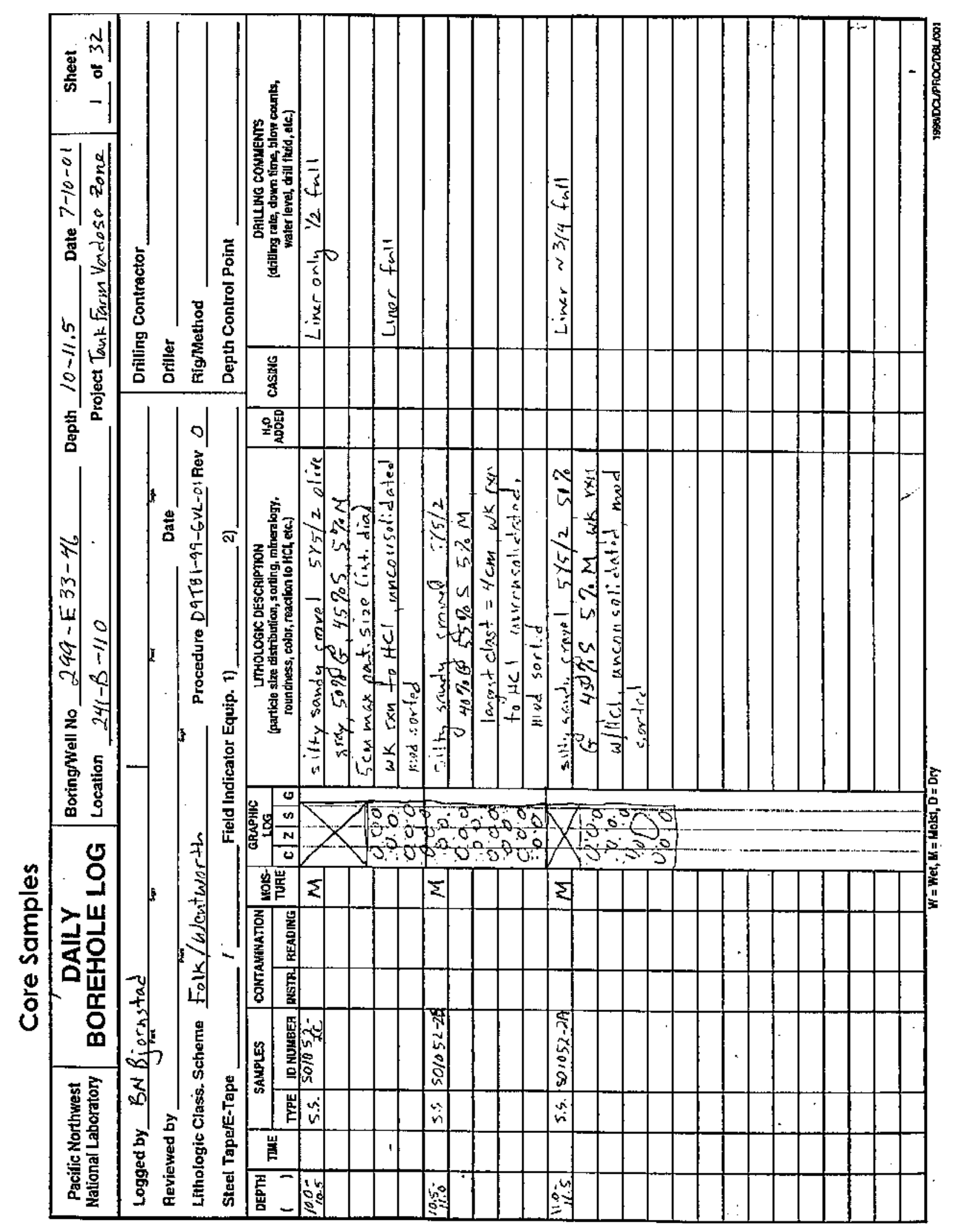




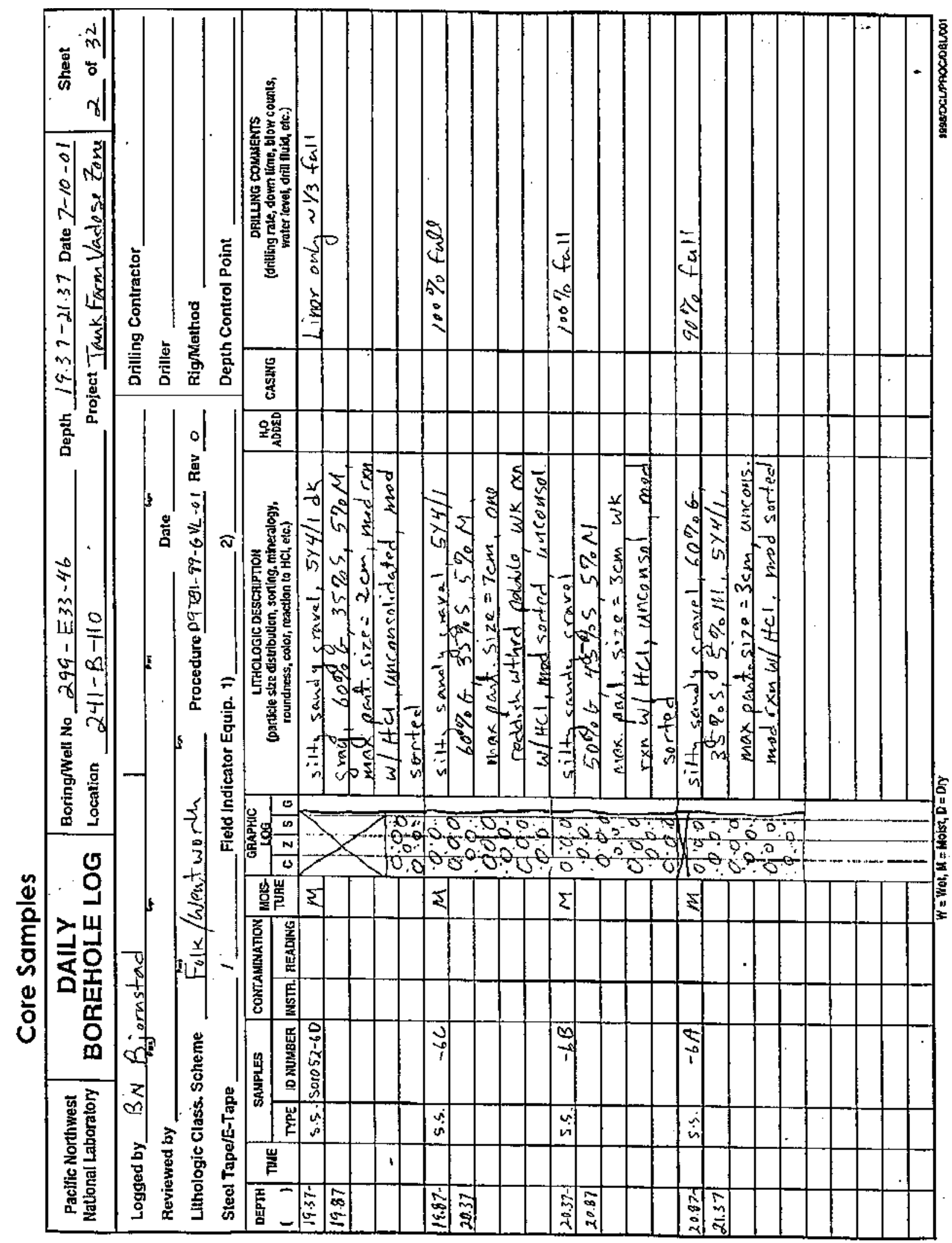




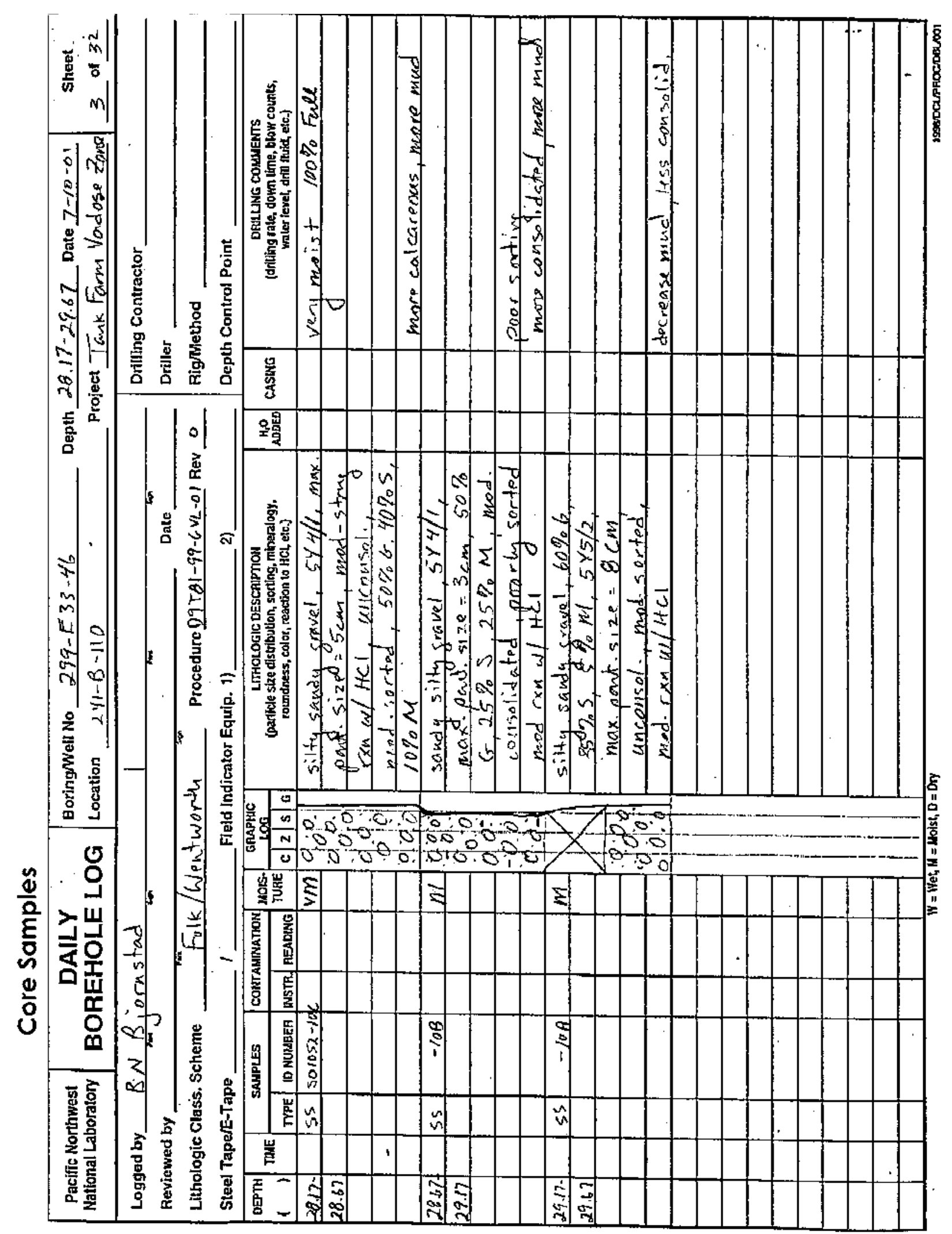




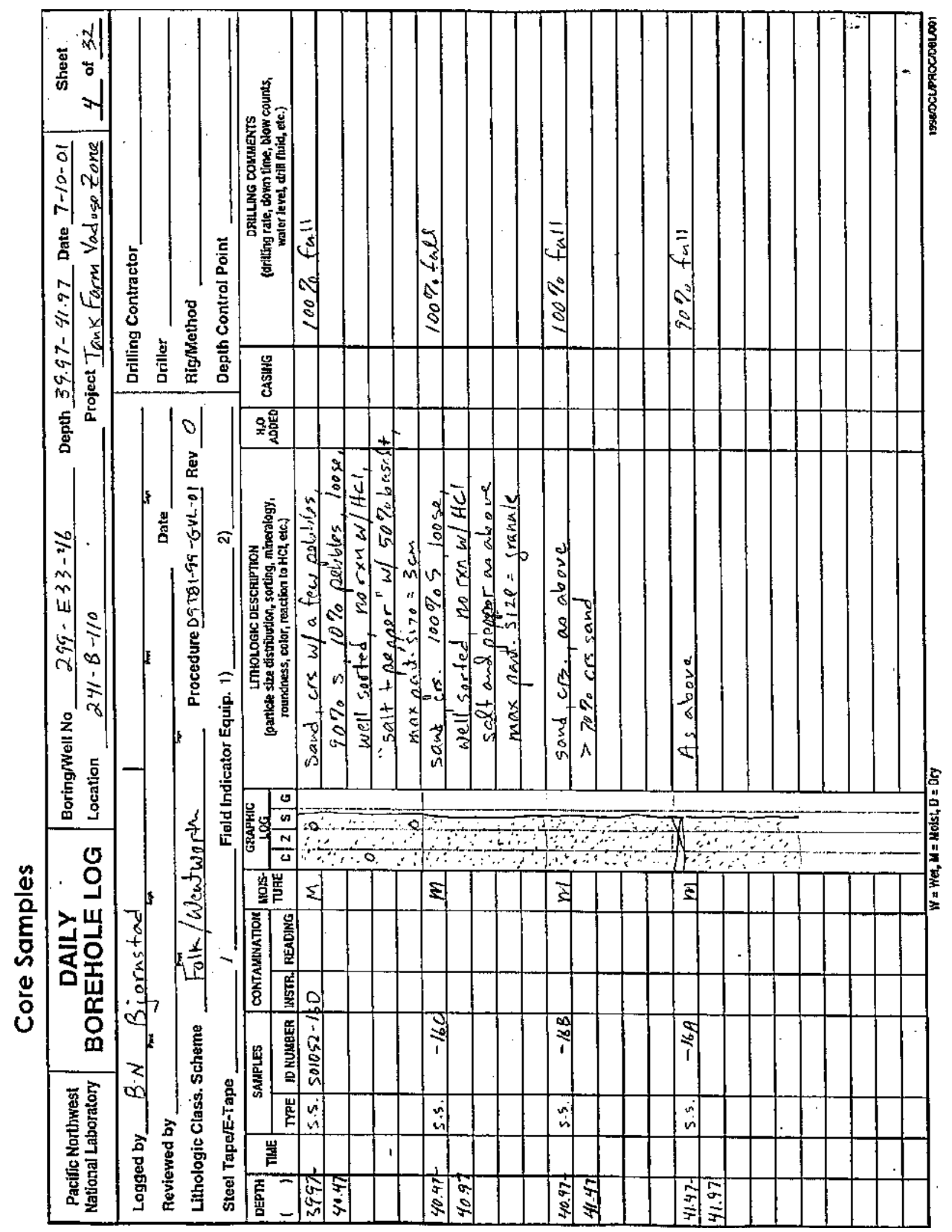




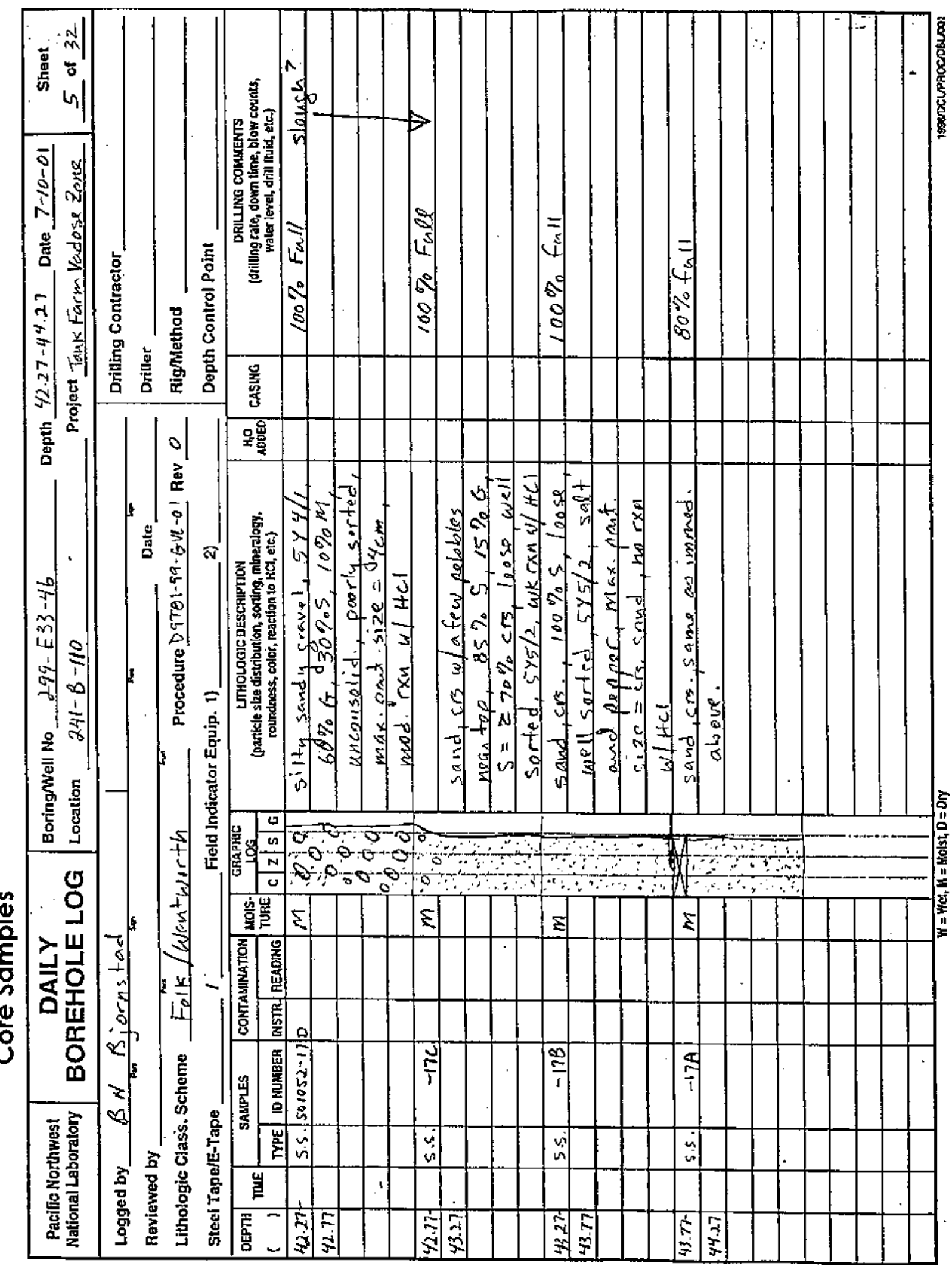




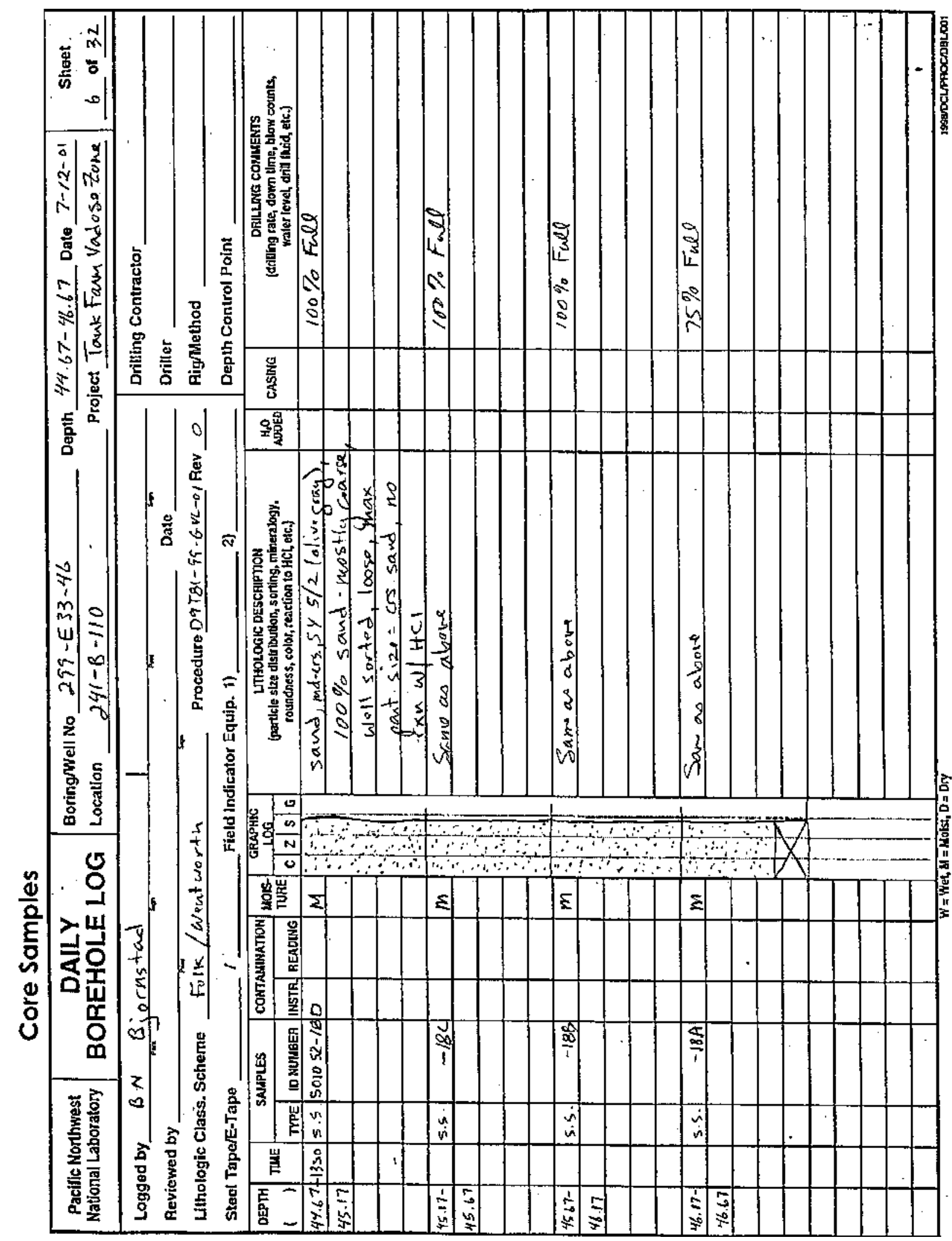




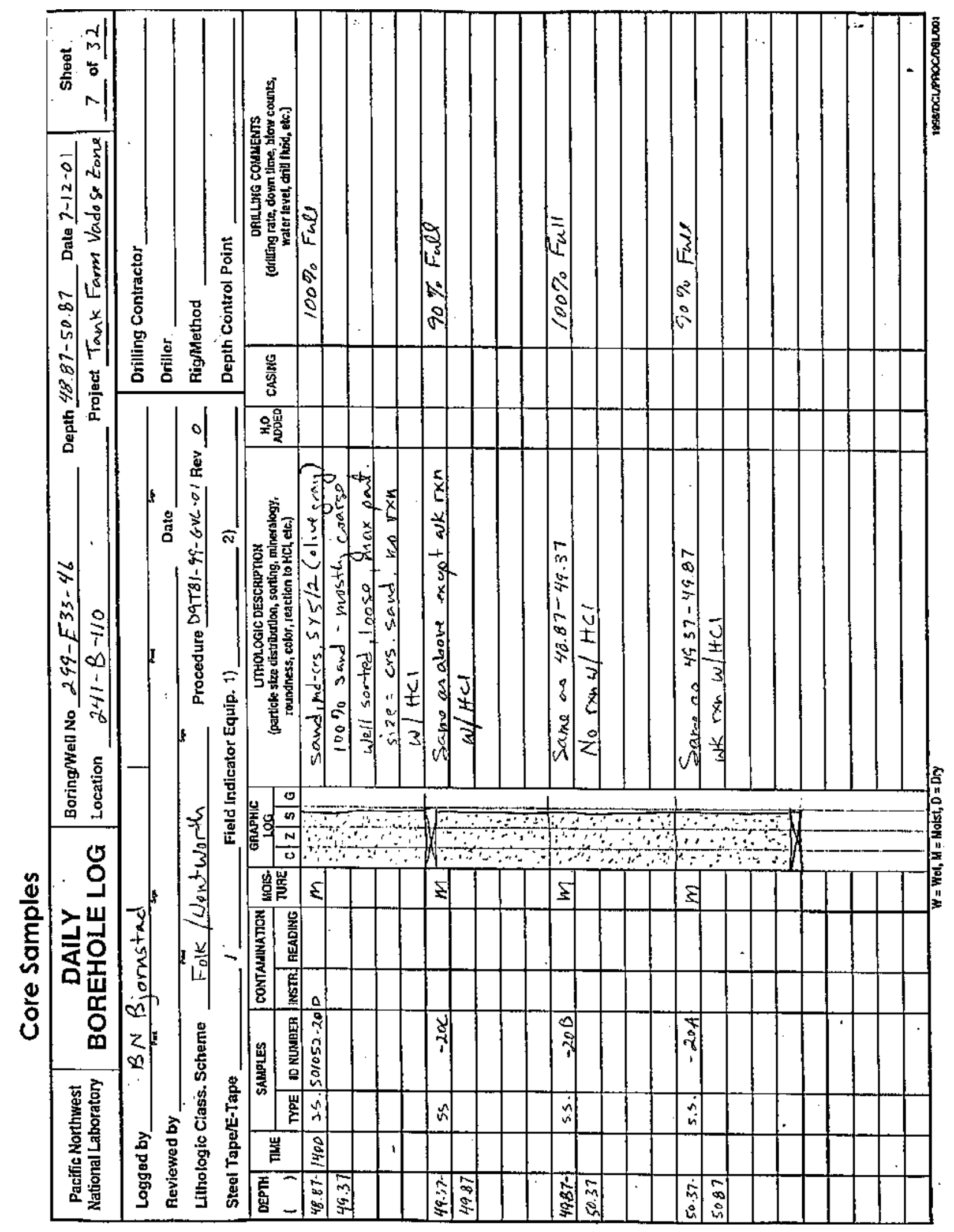




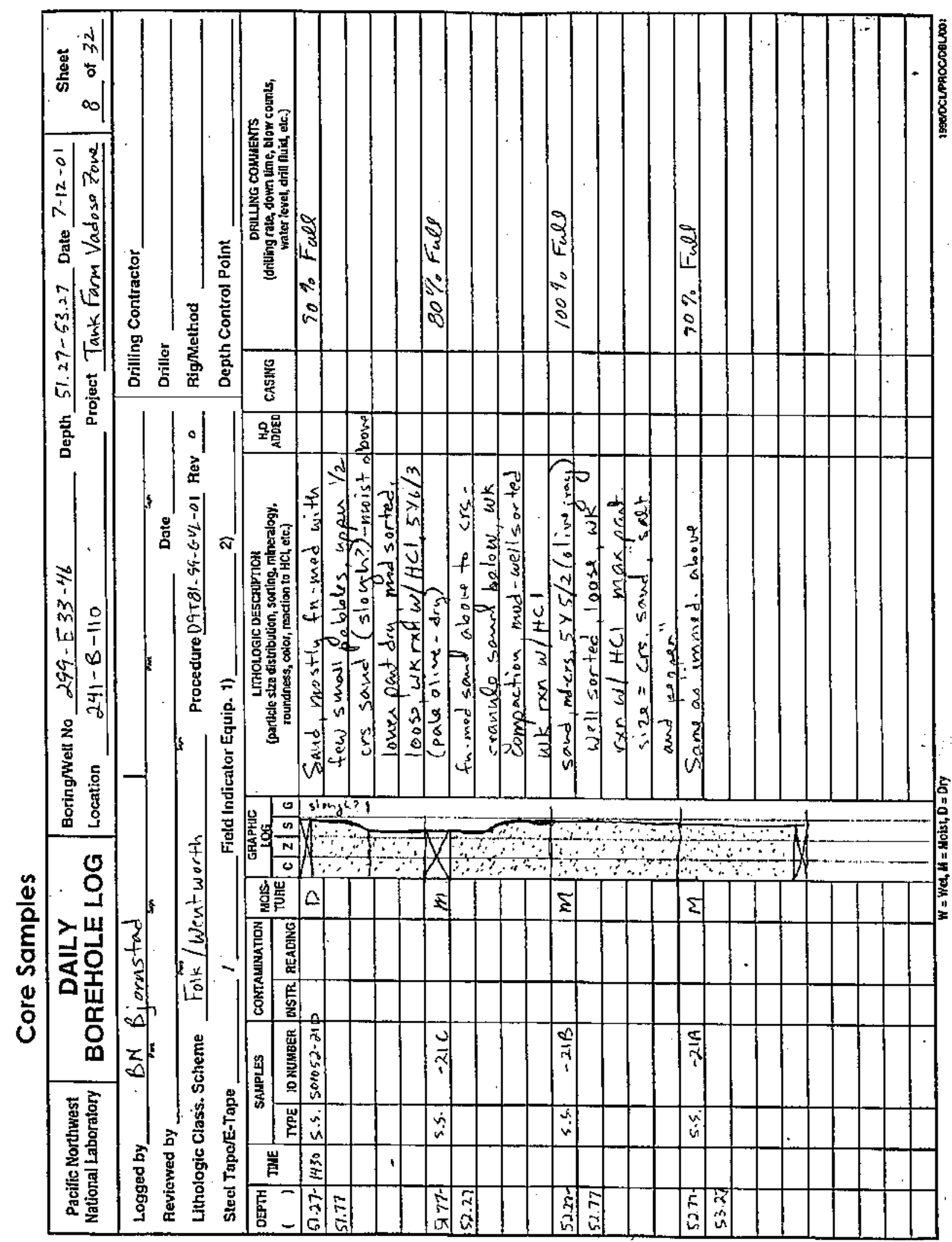




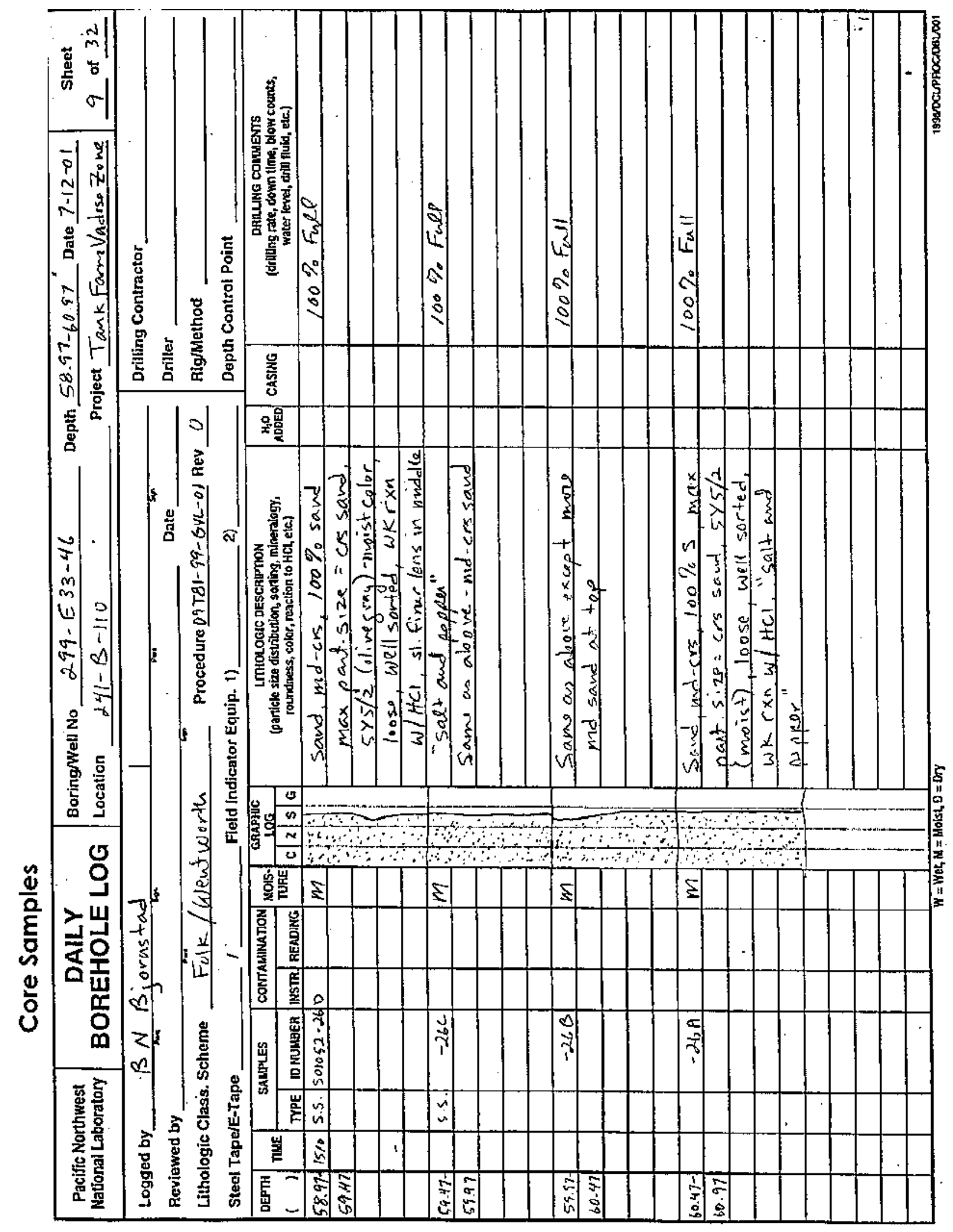




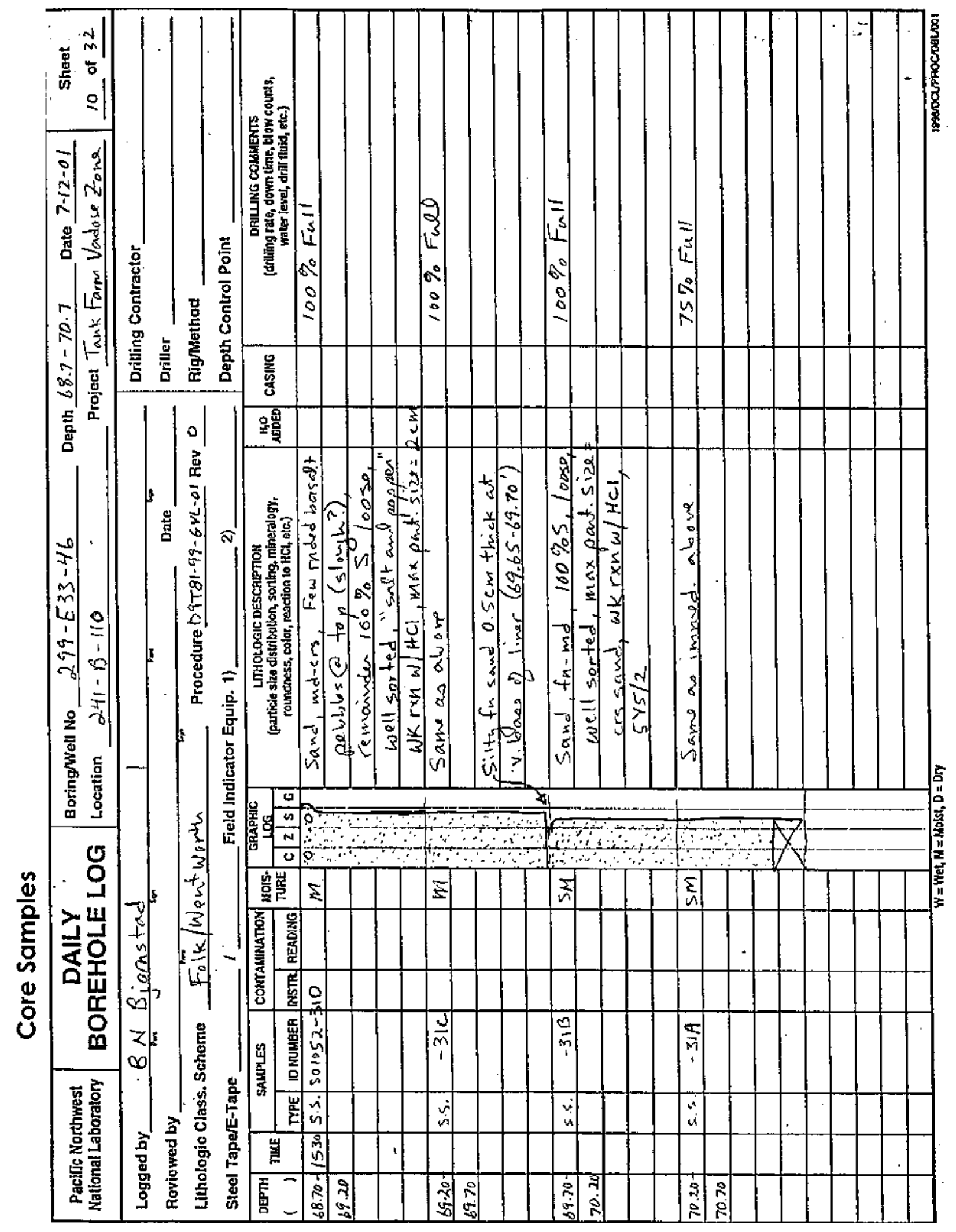




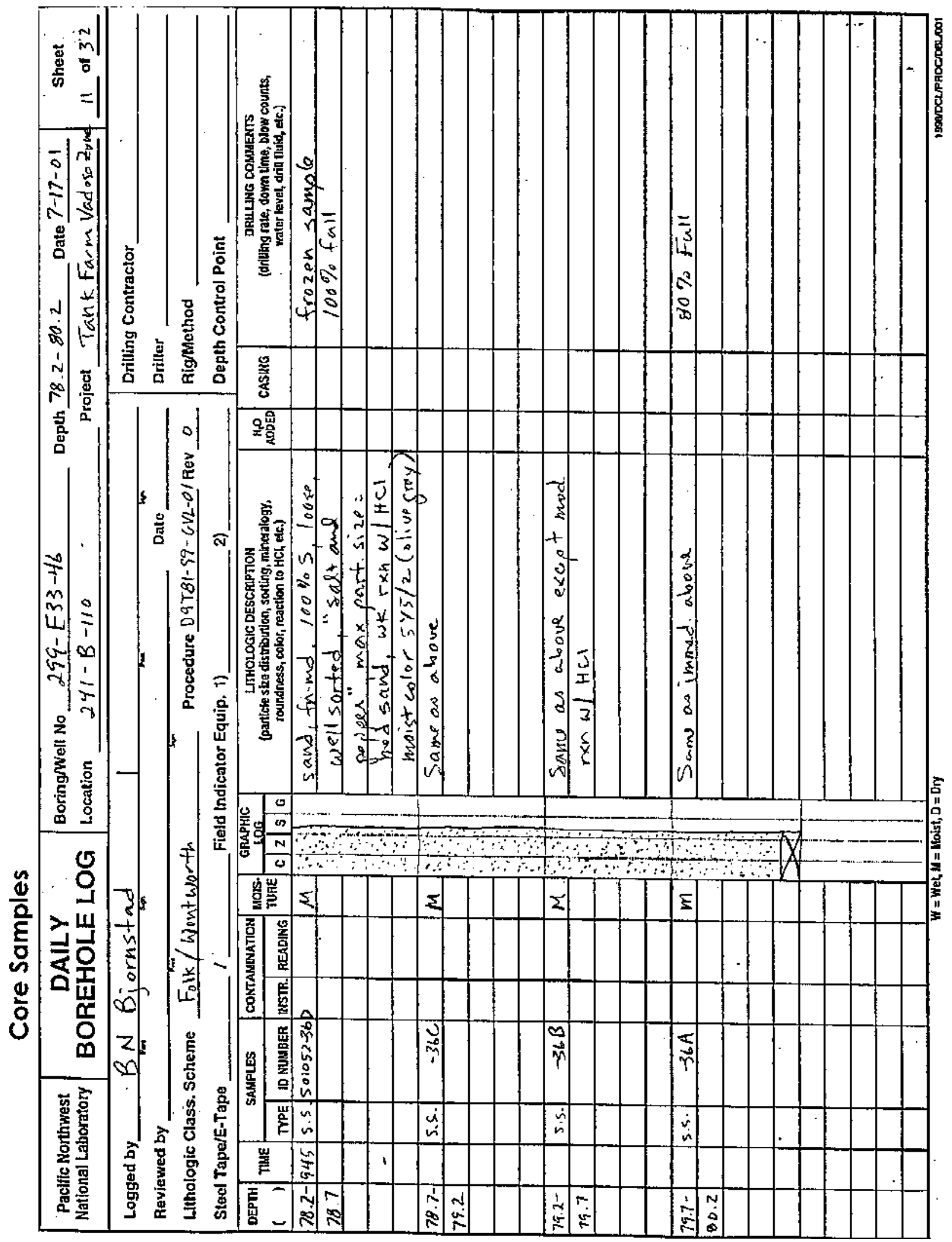




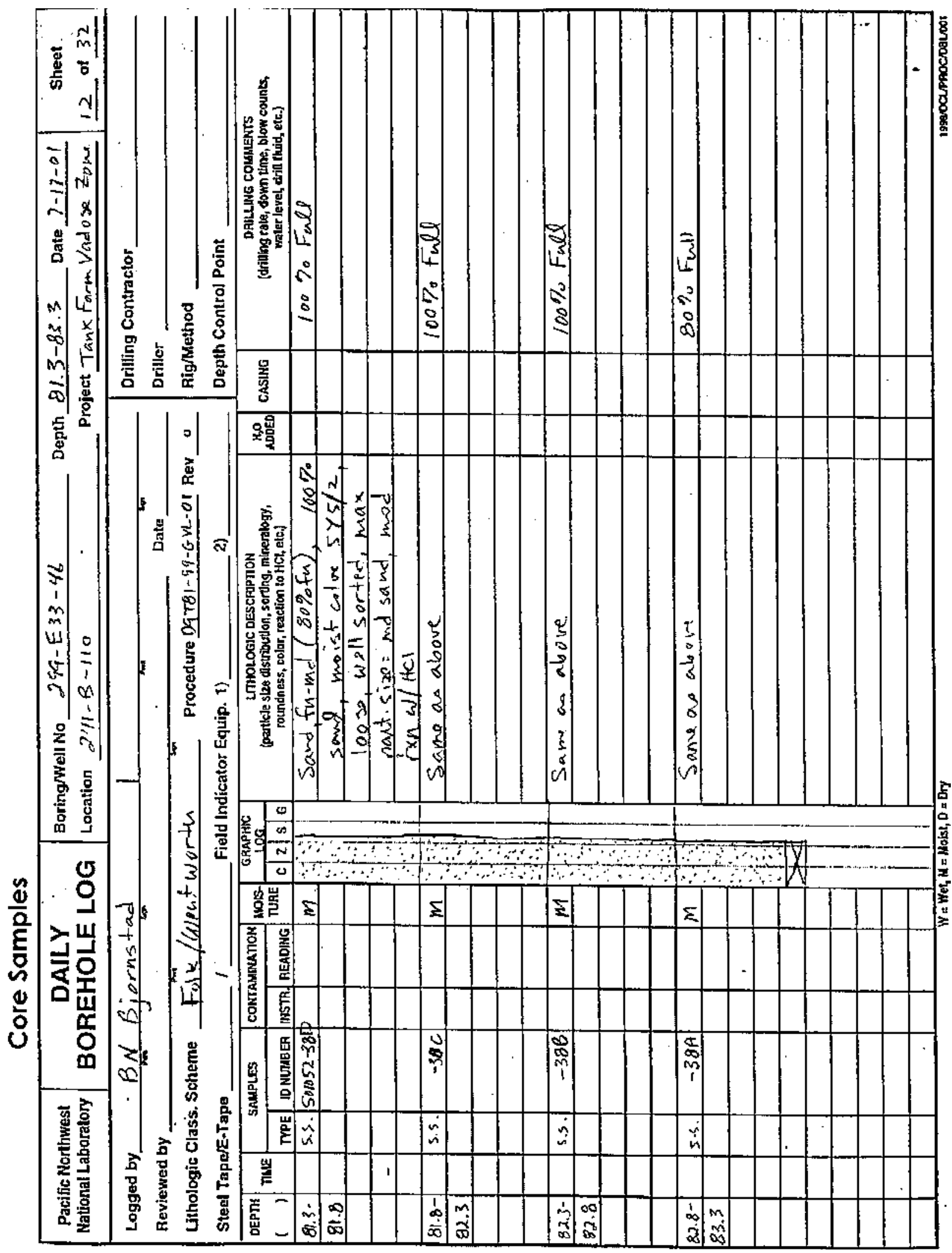




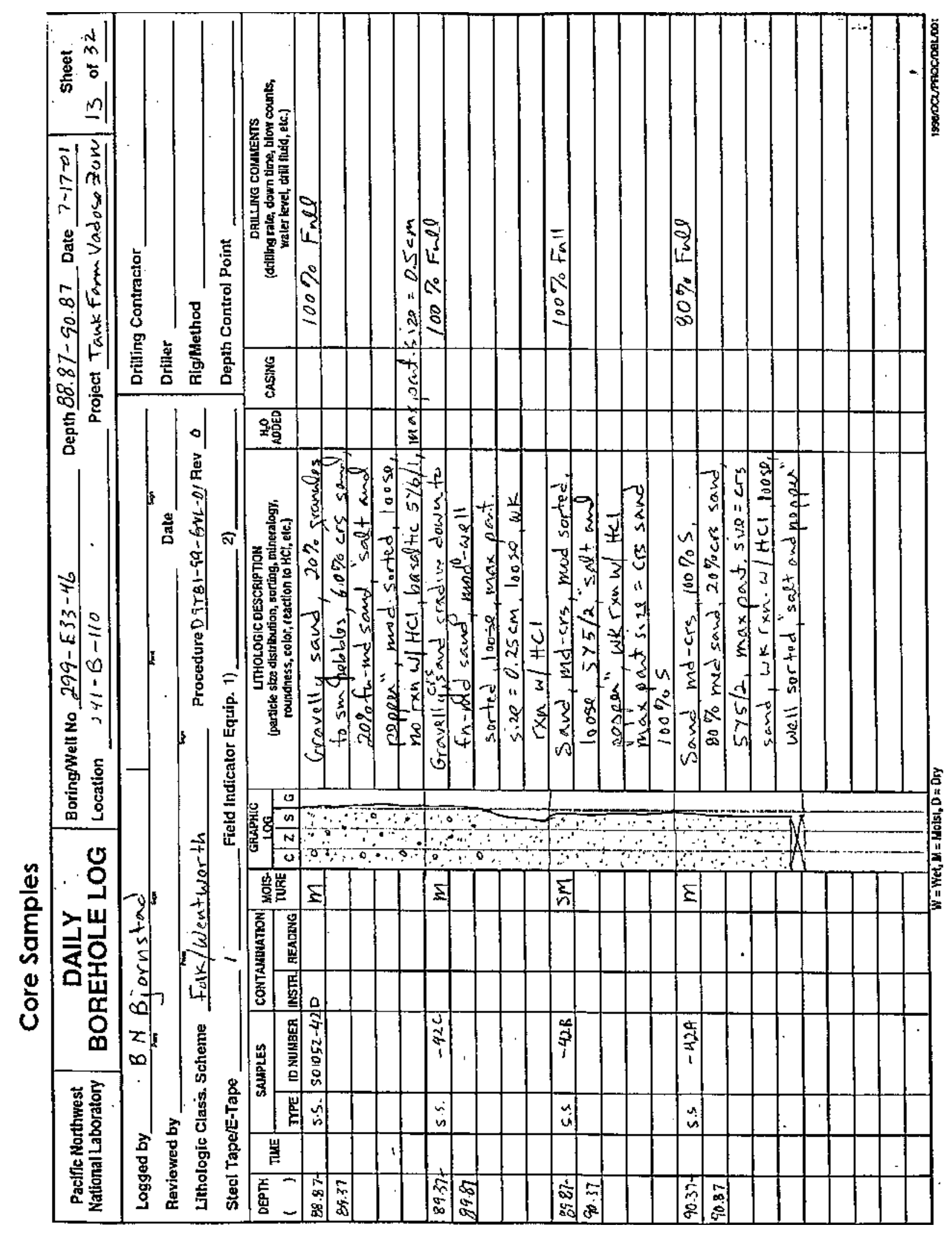




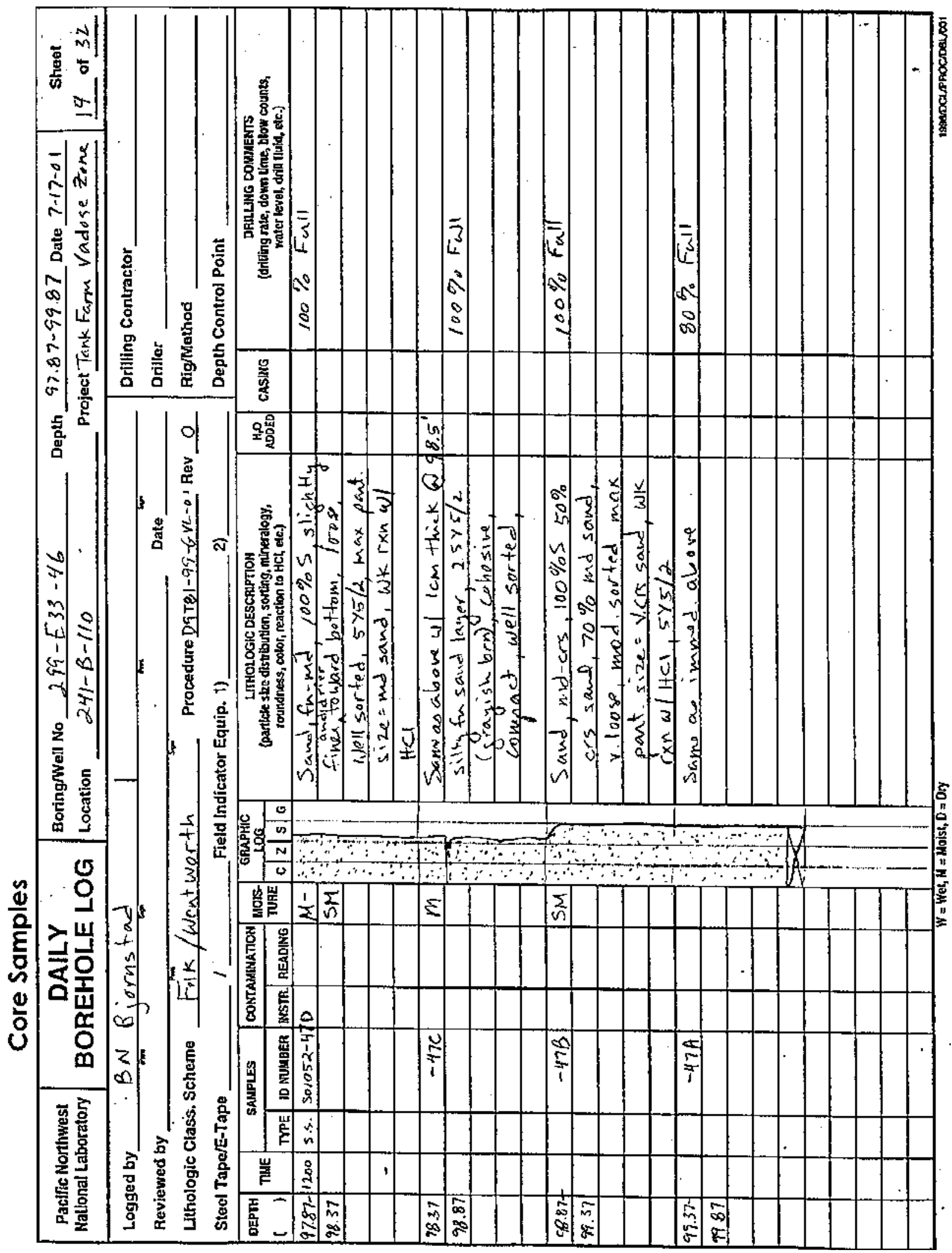




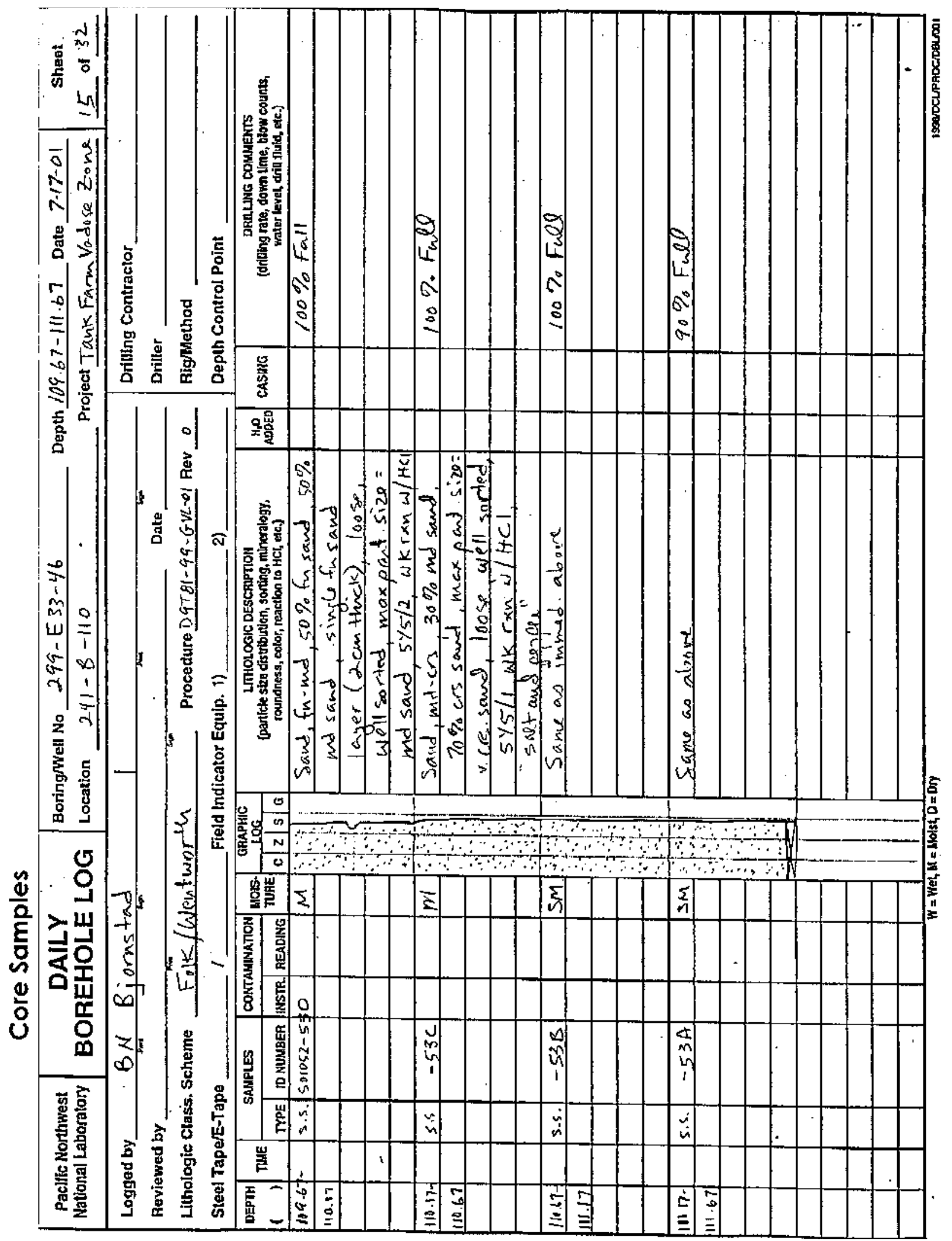




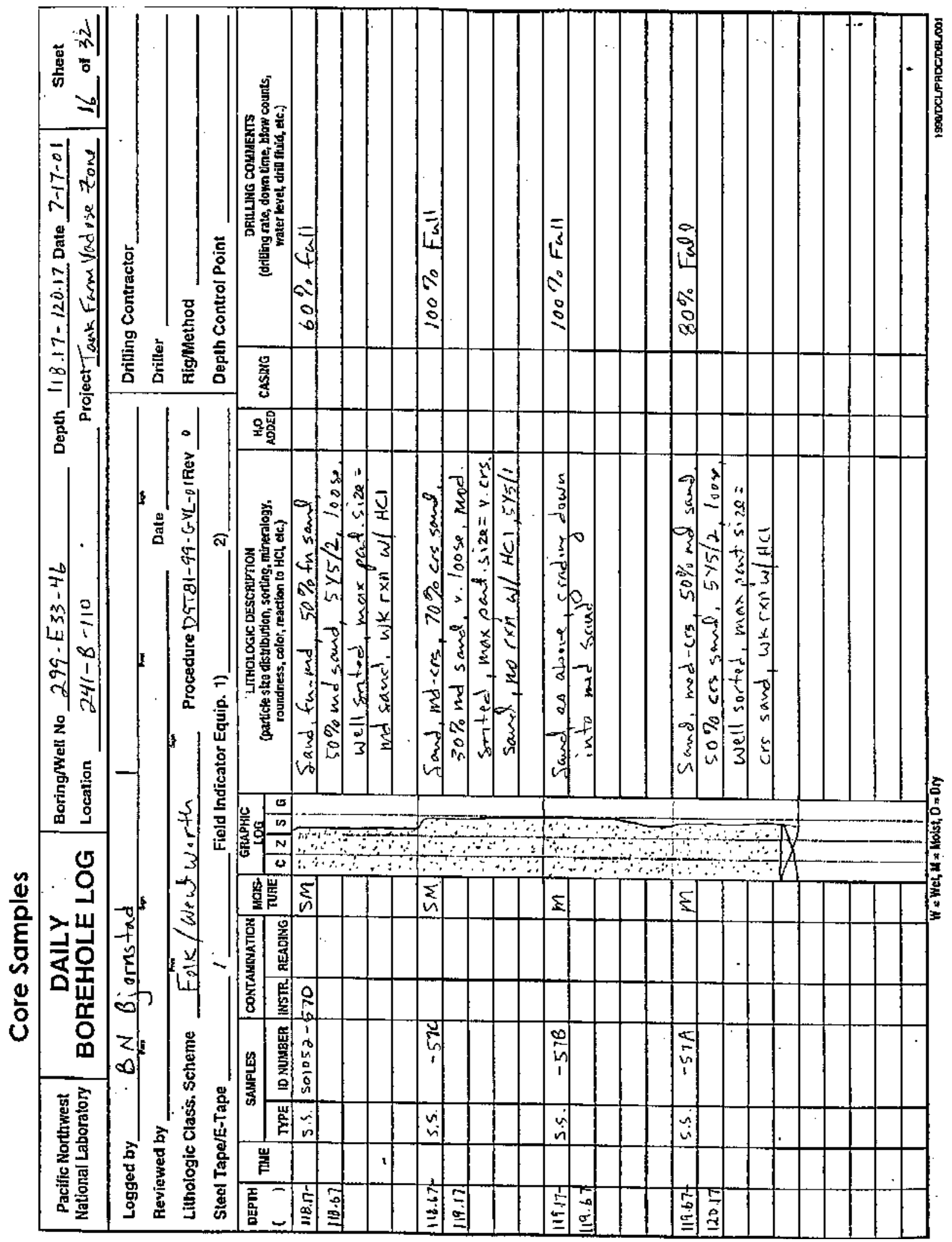




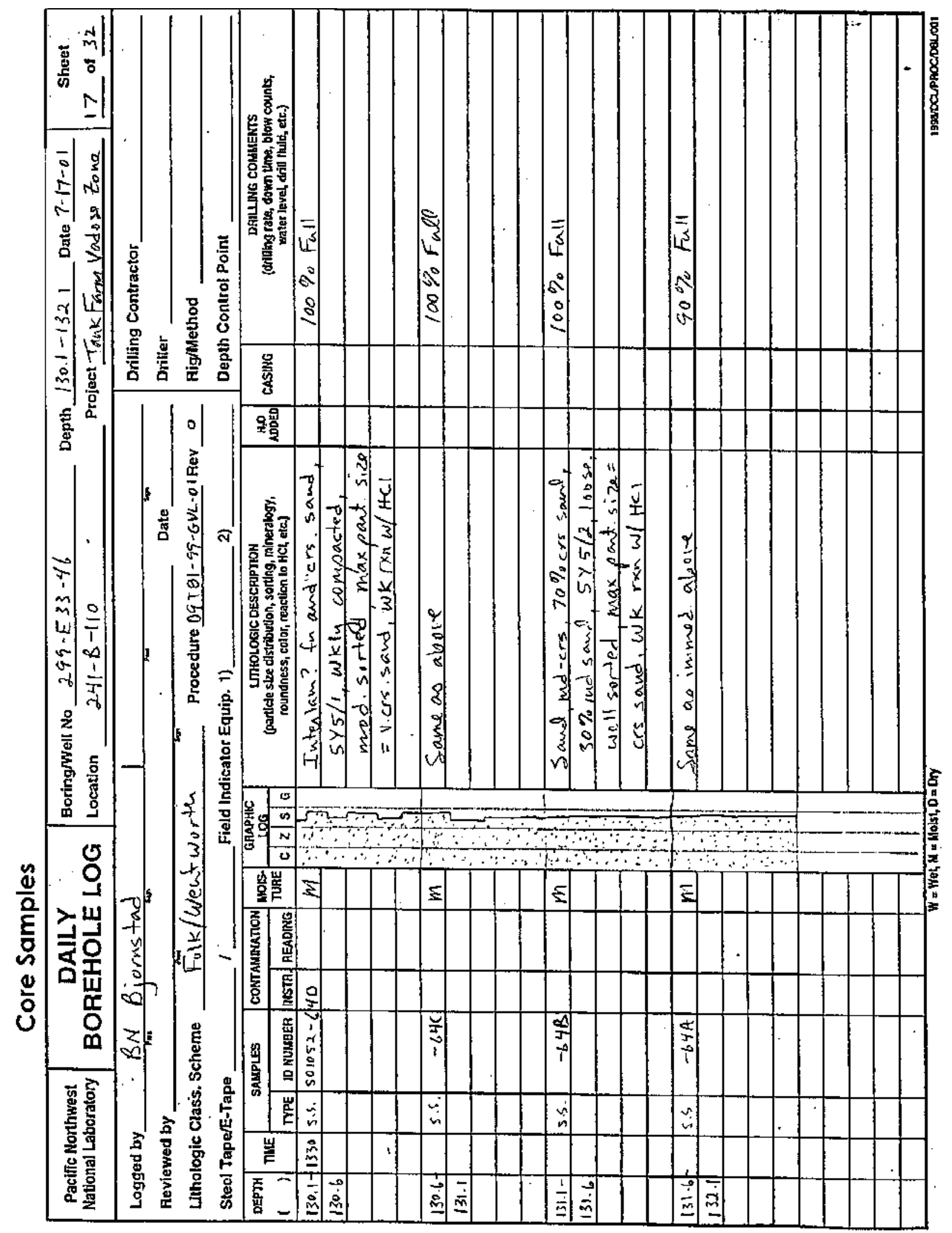




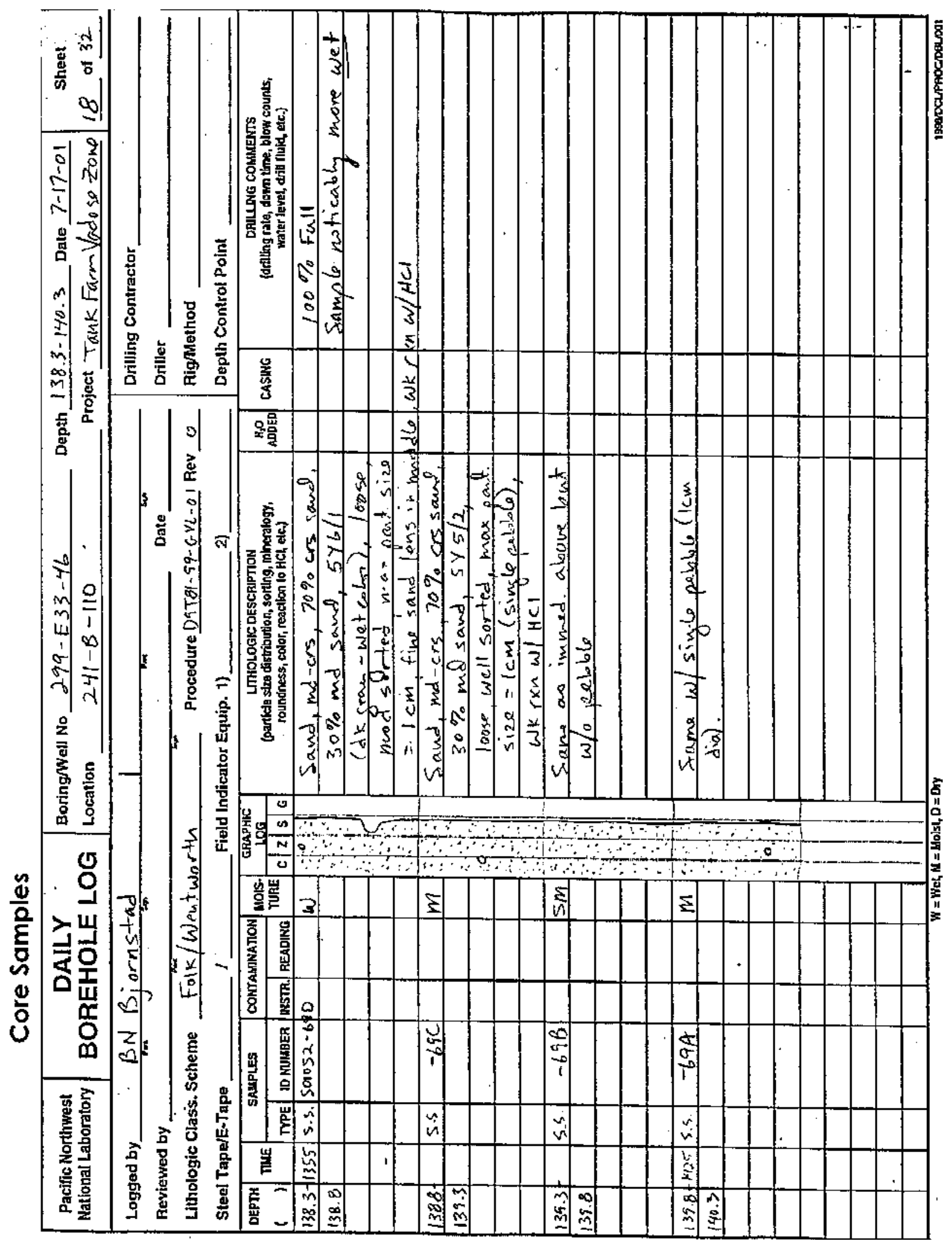




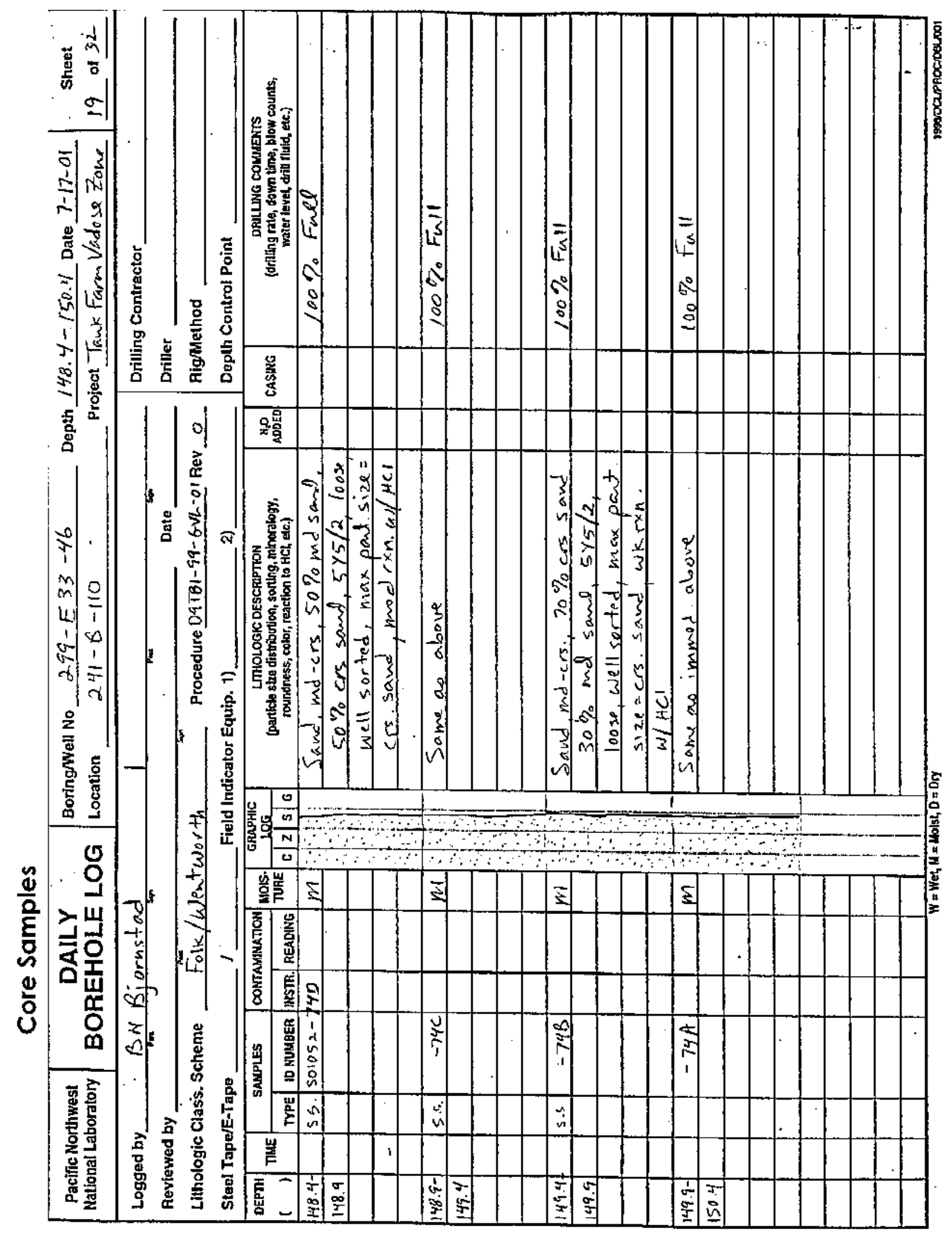




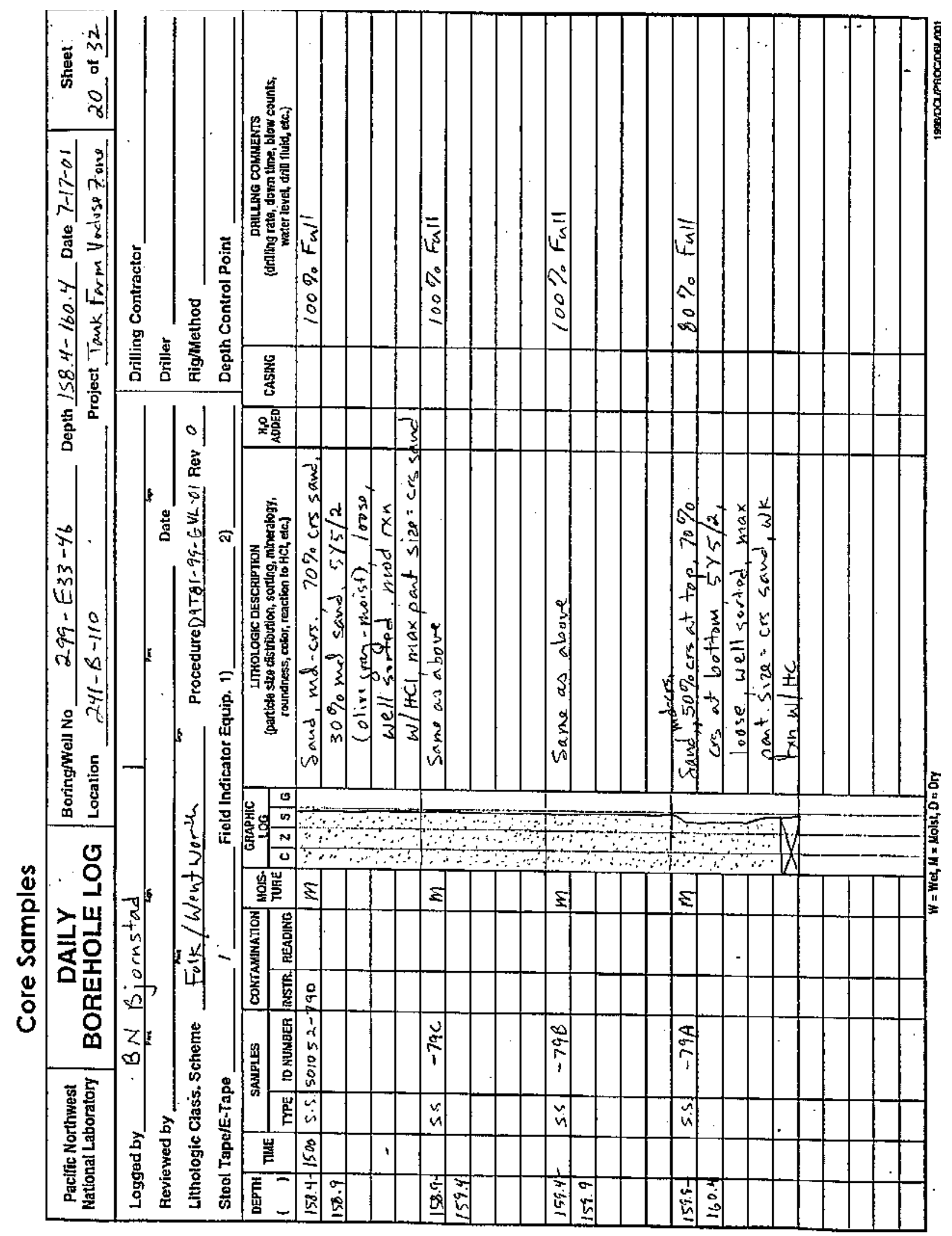




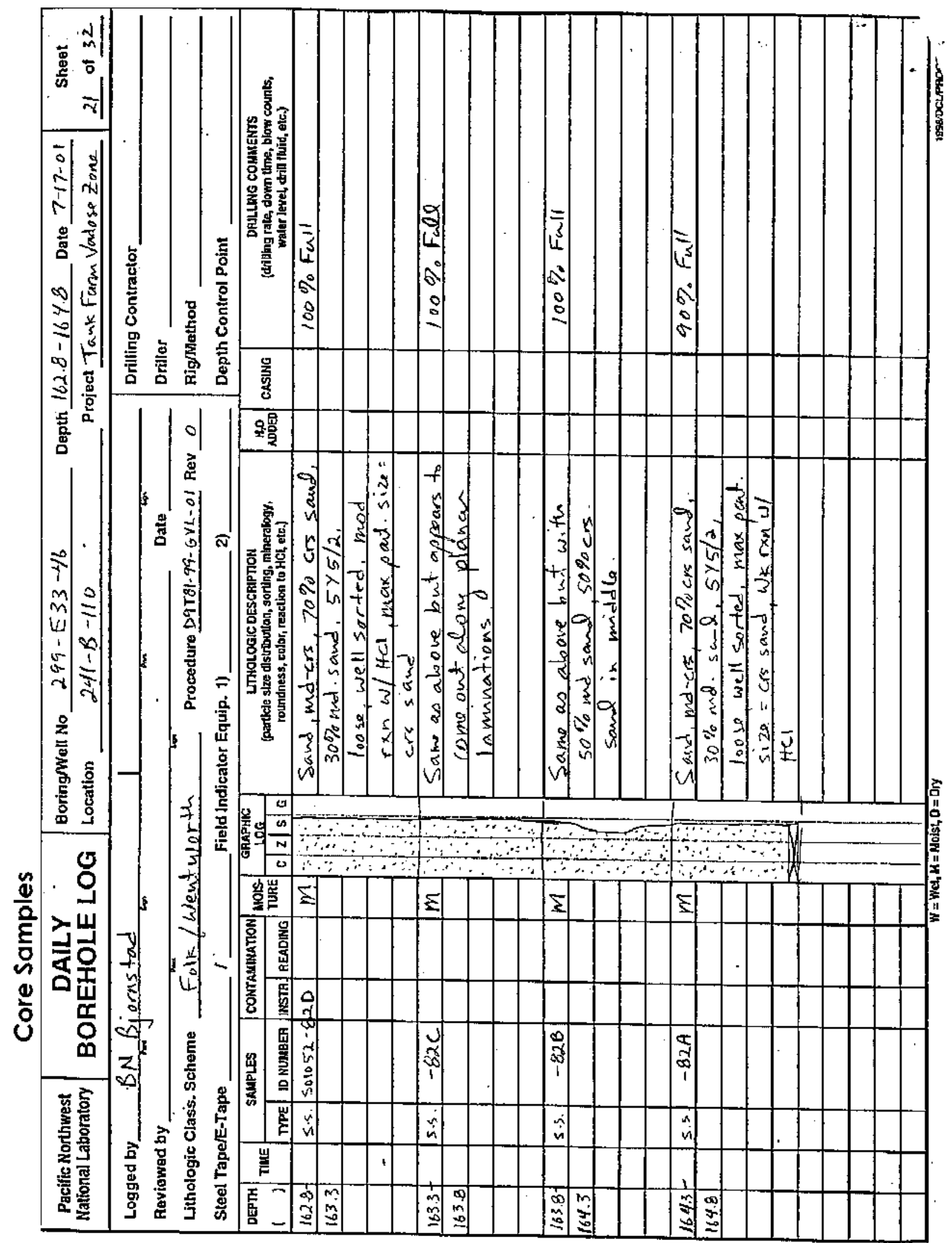




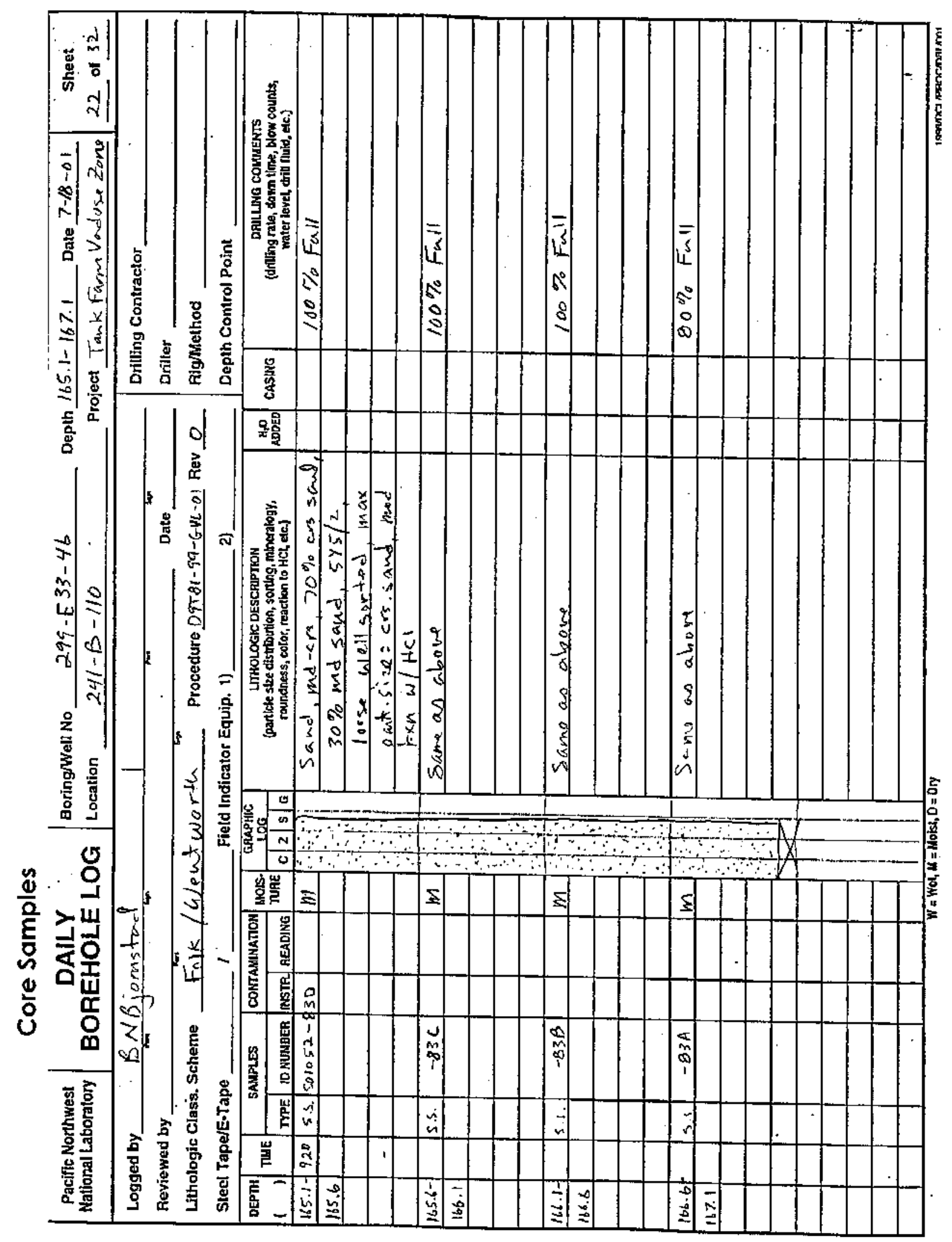




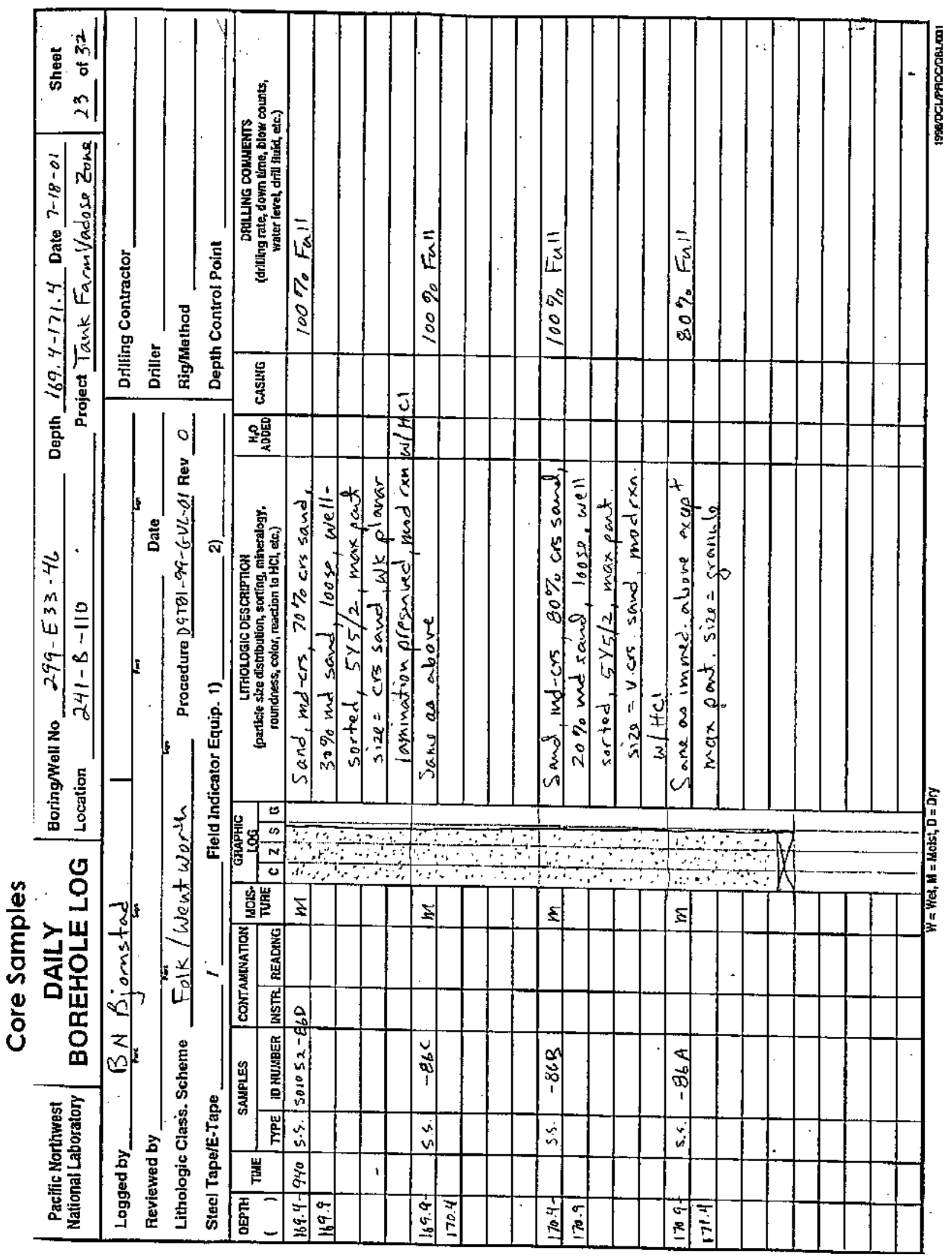




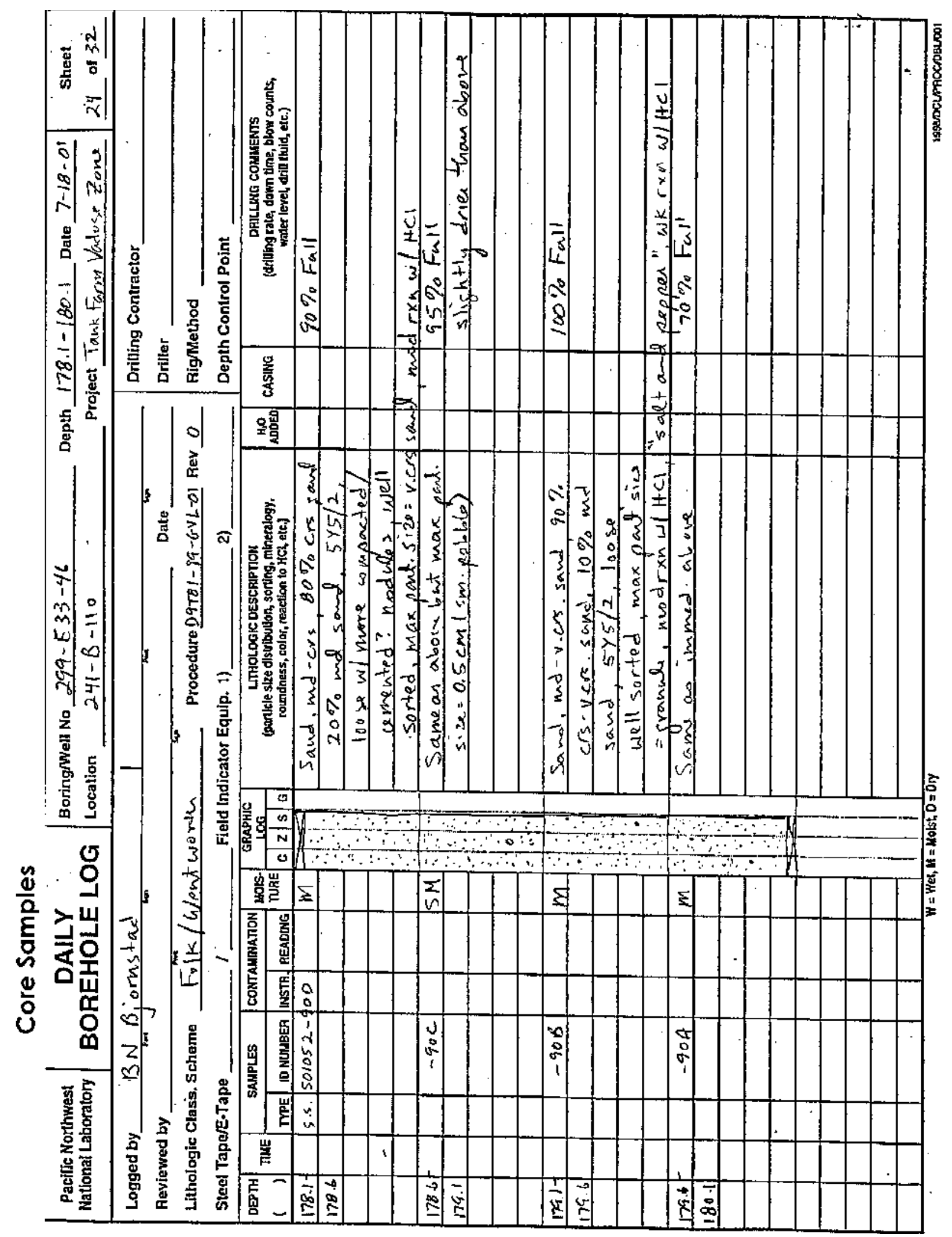




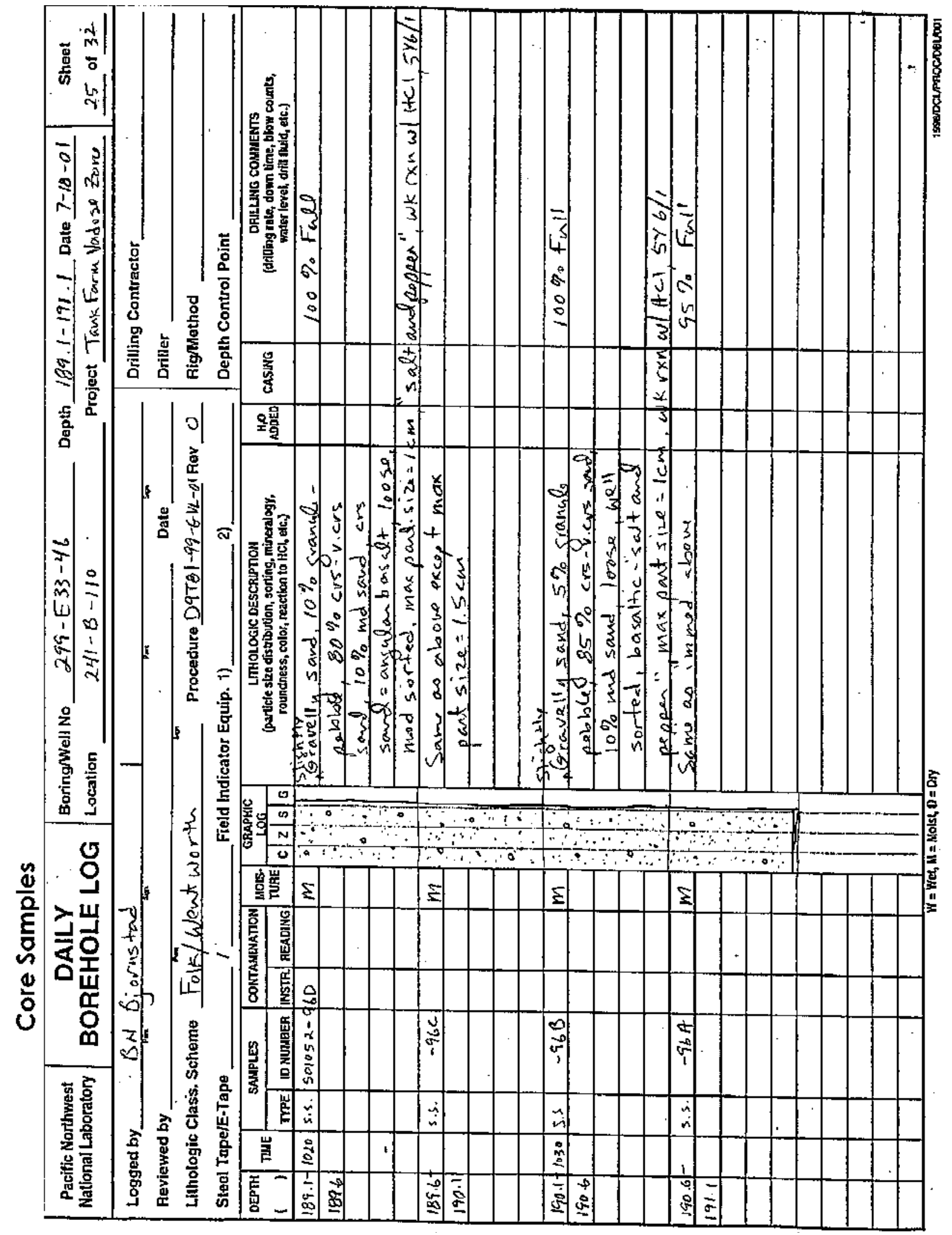




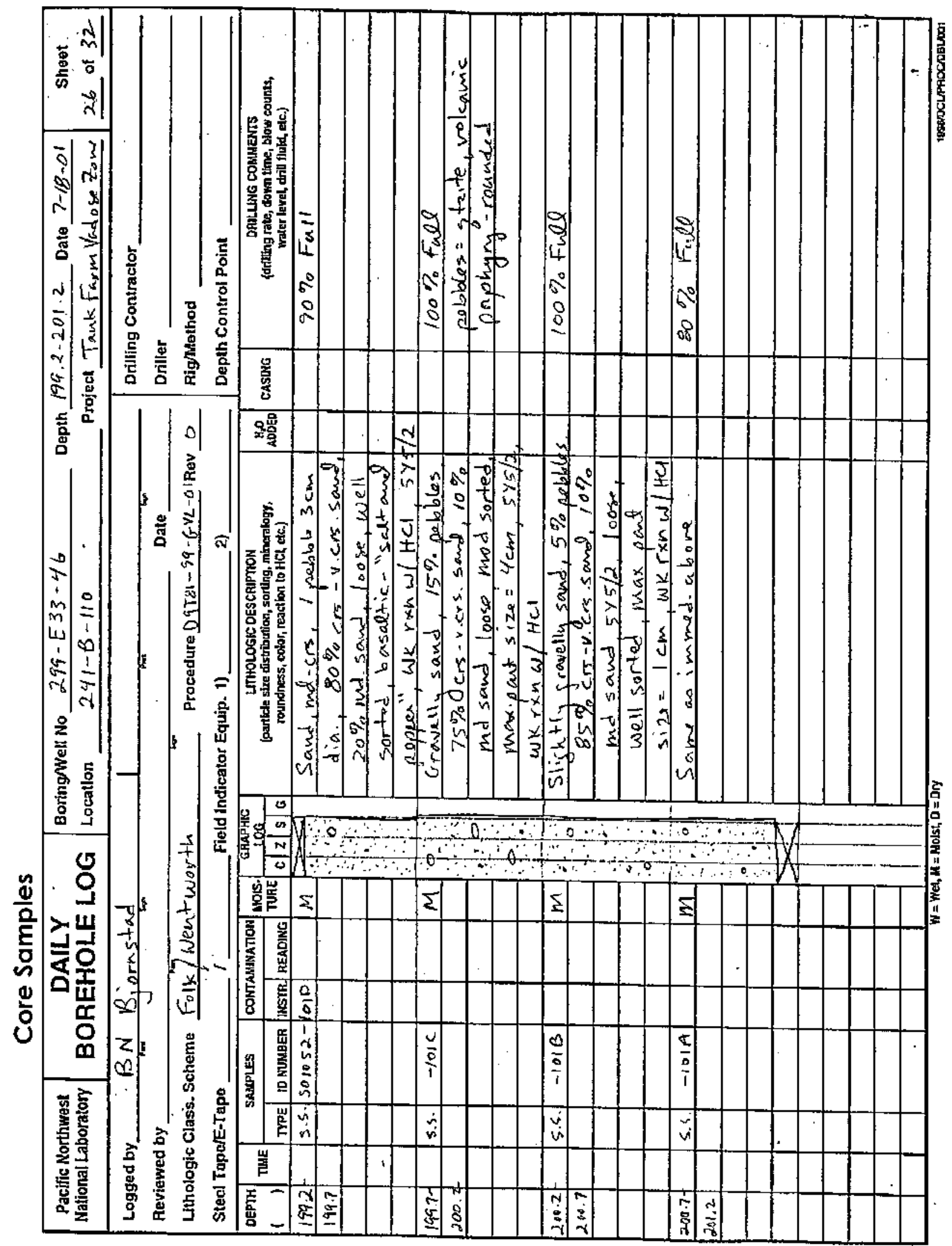




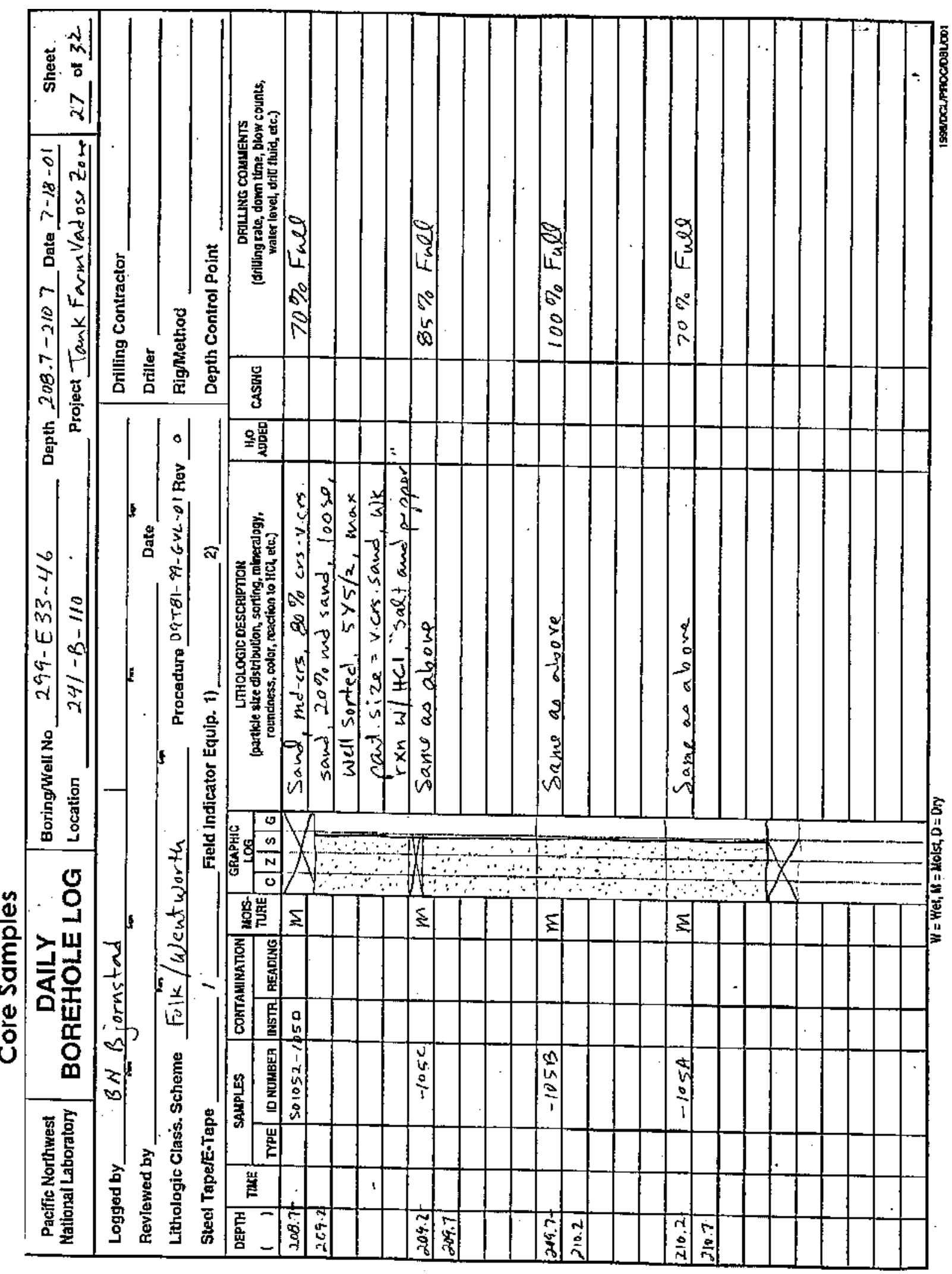




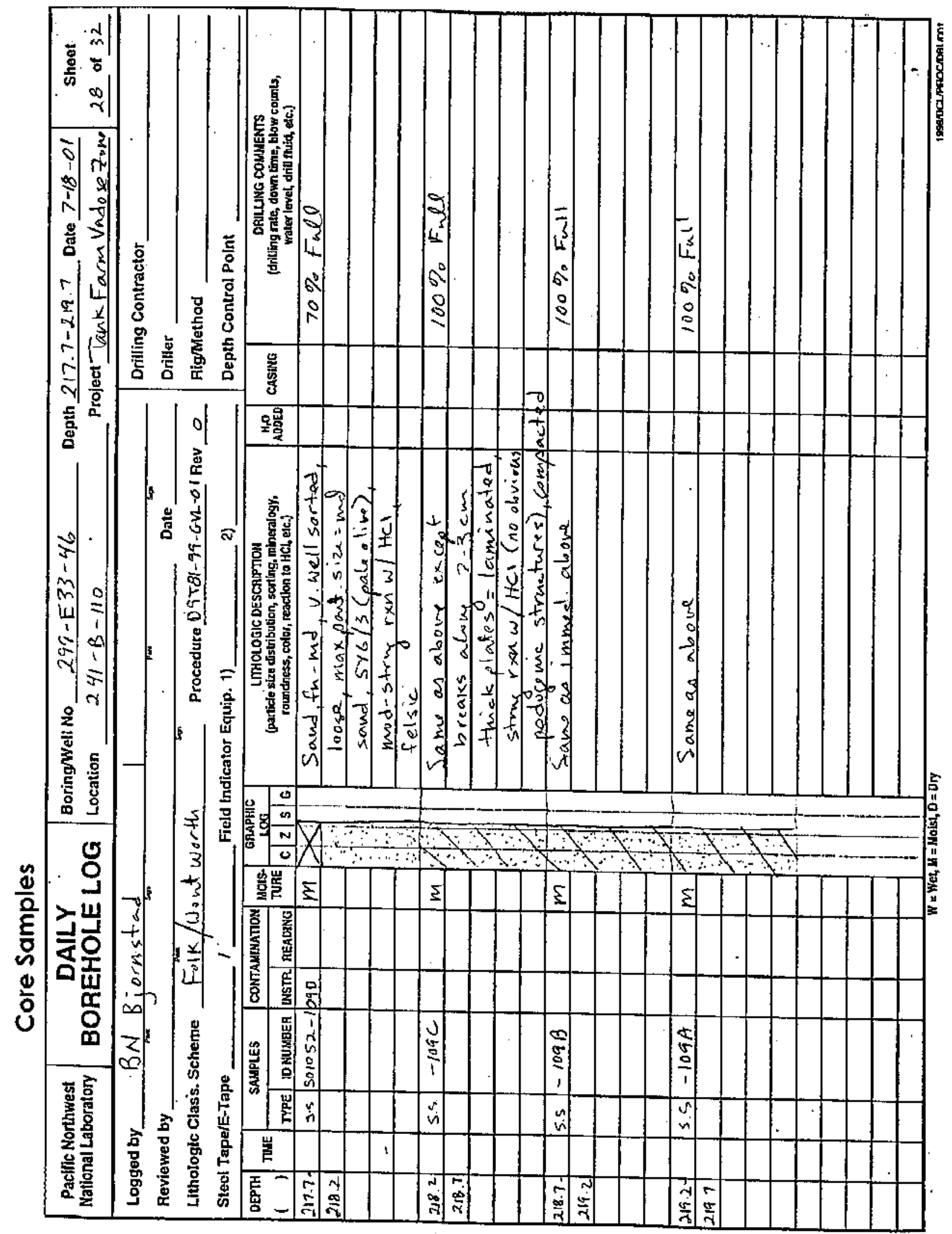




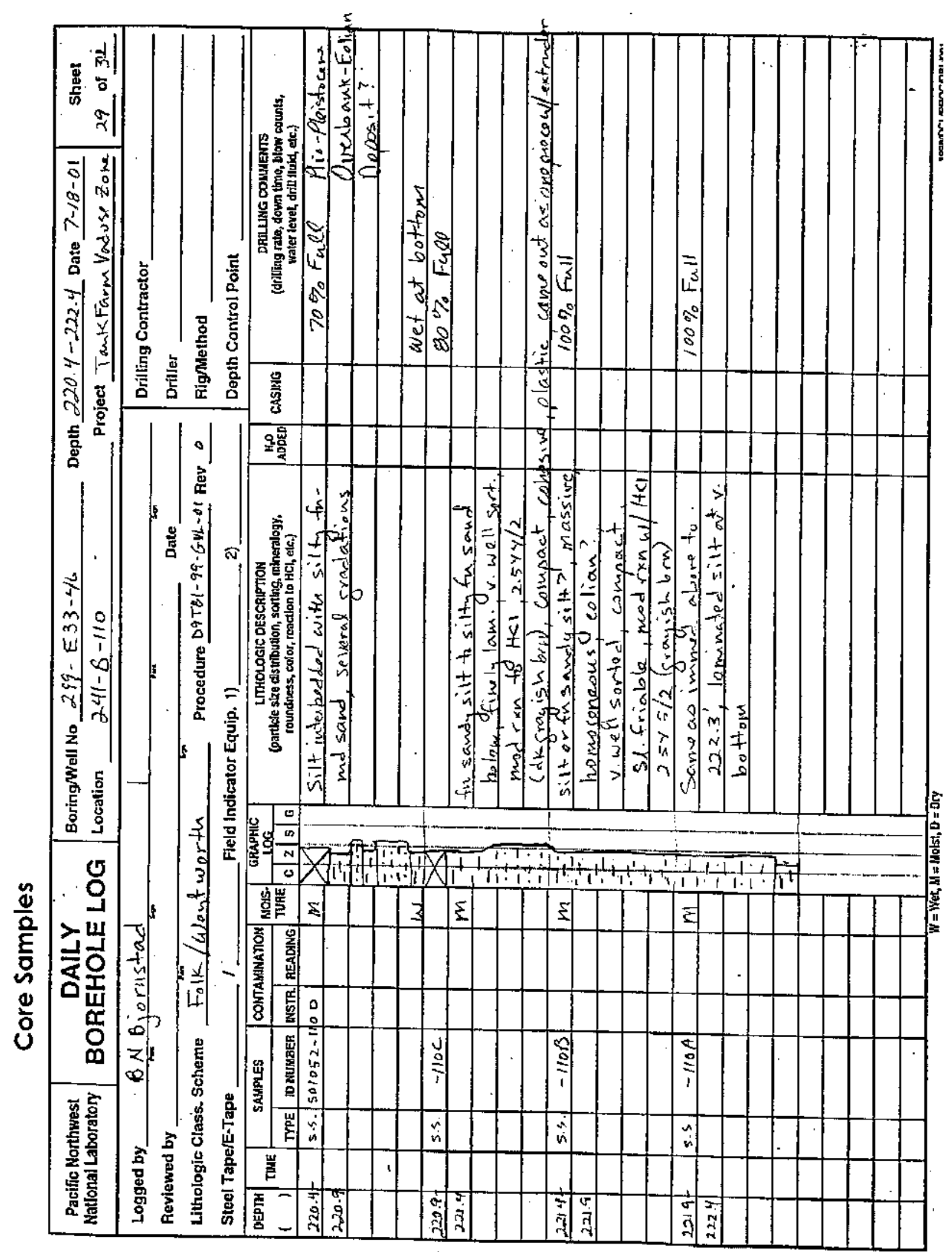




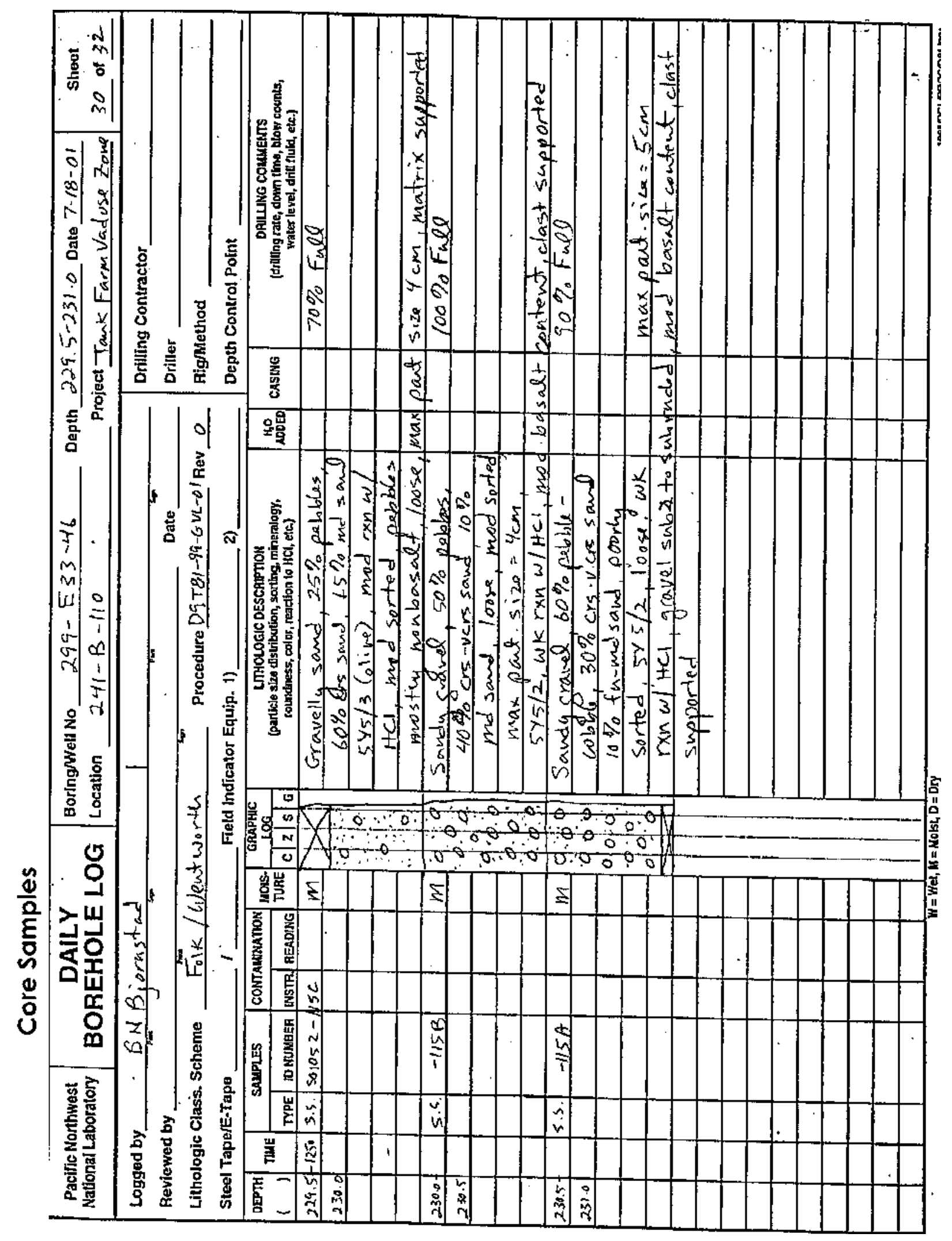




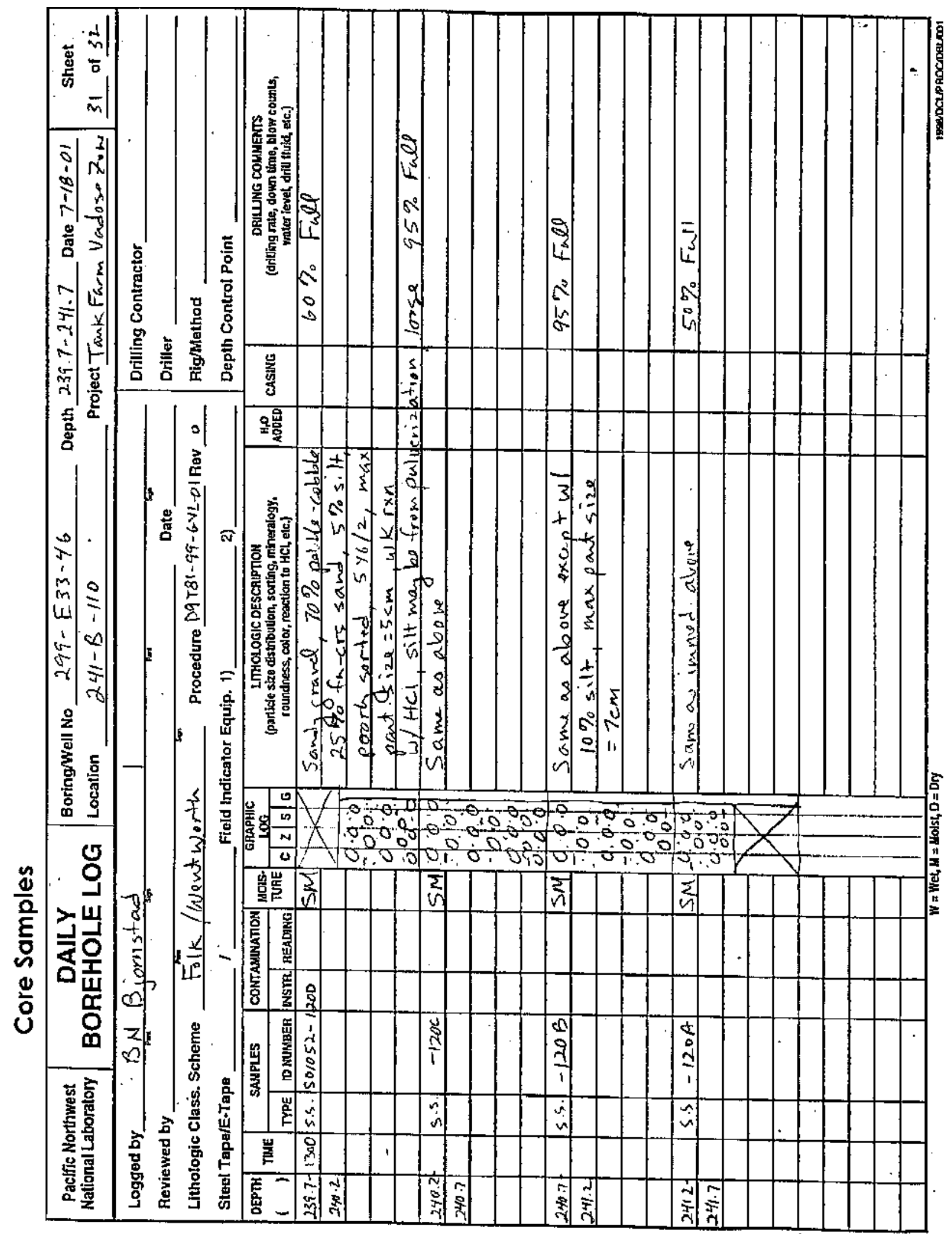




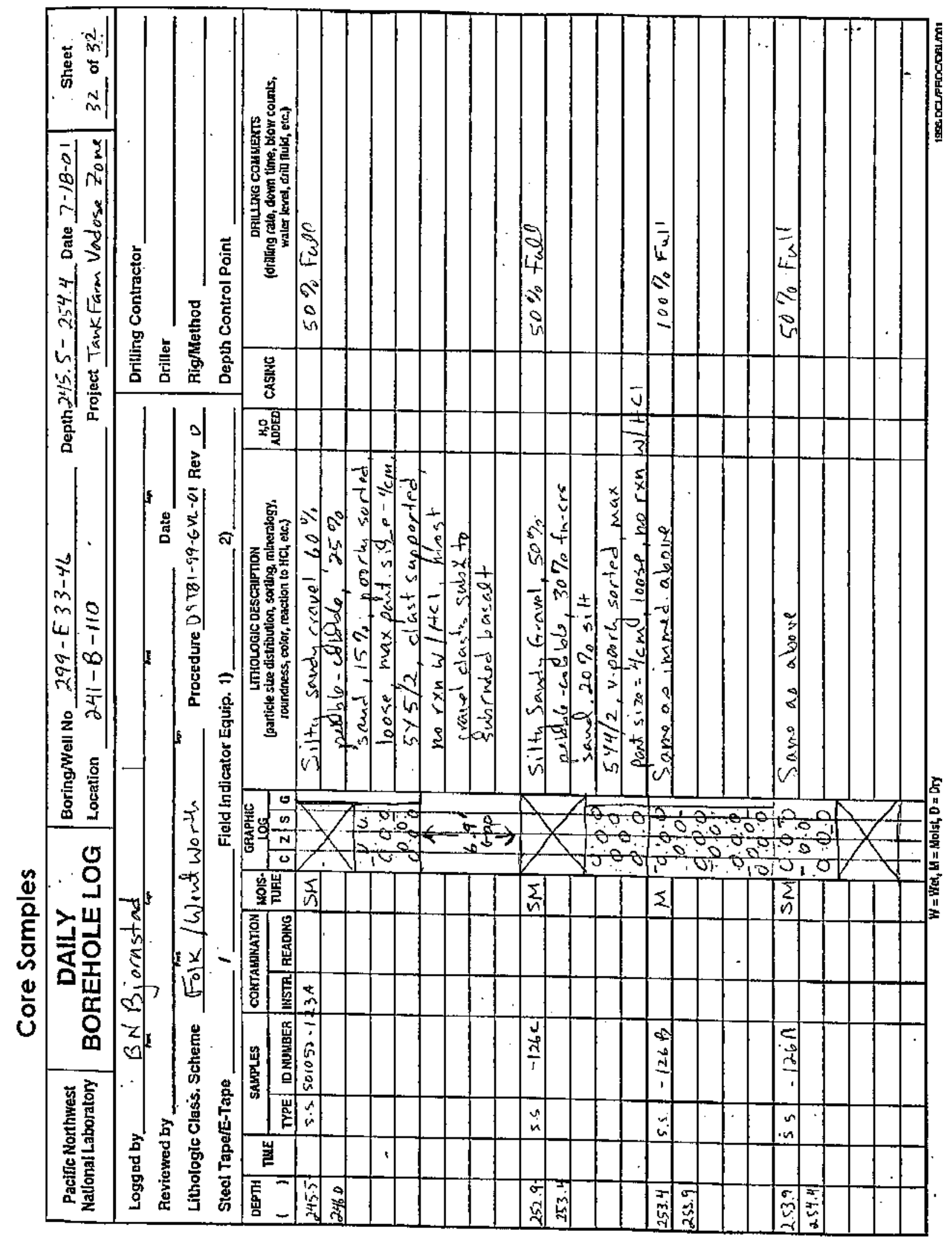




\title{
Appendix B-1
}

\author{
299-E33-46 \\ Splitspoon Core \\ Sample Photographs
}




\section{Appendix B-1}

\section{9-E33-46 \\ Splitspoon Core \\ Sample Photographs}

The following photographs were taken during the opening of the samples for performing the geologic descriptions and for aliquoting for chemical analyses. The photographs are sequenced from shallow depths to deeper depths. On the figure and in the captions we show the sample number designation, the orientation of the picture/core sample, the depth interval below ground surface that the sample represents and the lithology name assigned to the sample.

B. 1 


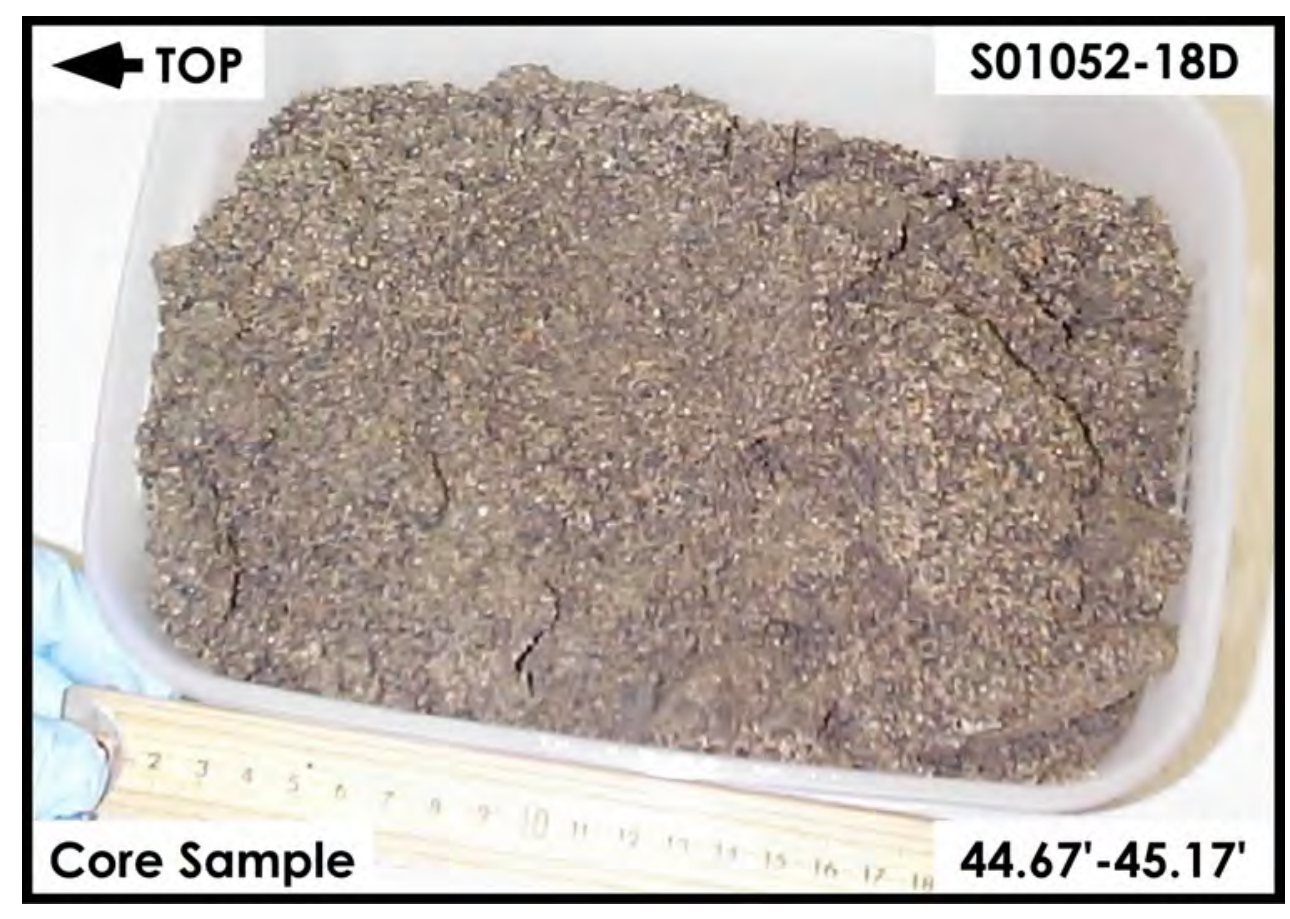

H2-Upper Sand and Gravel Sequence

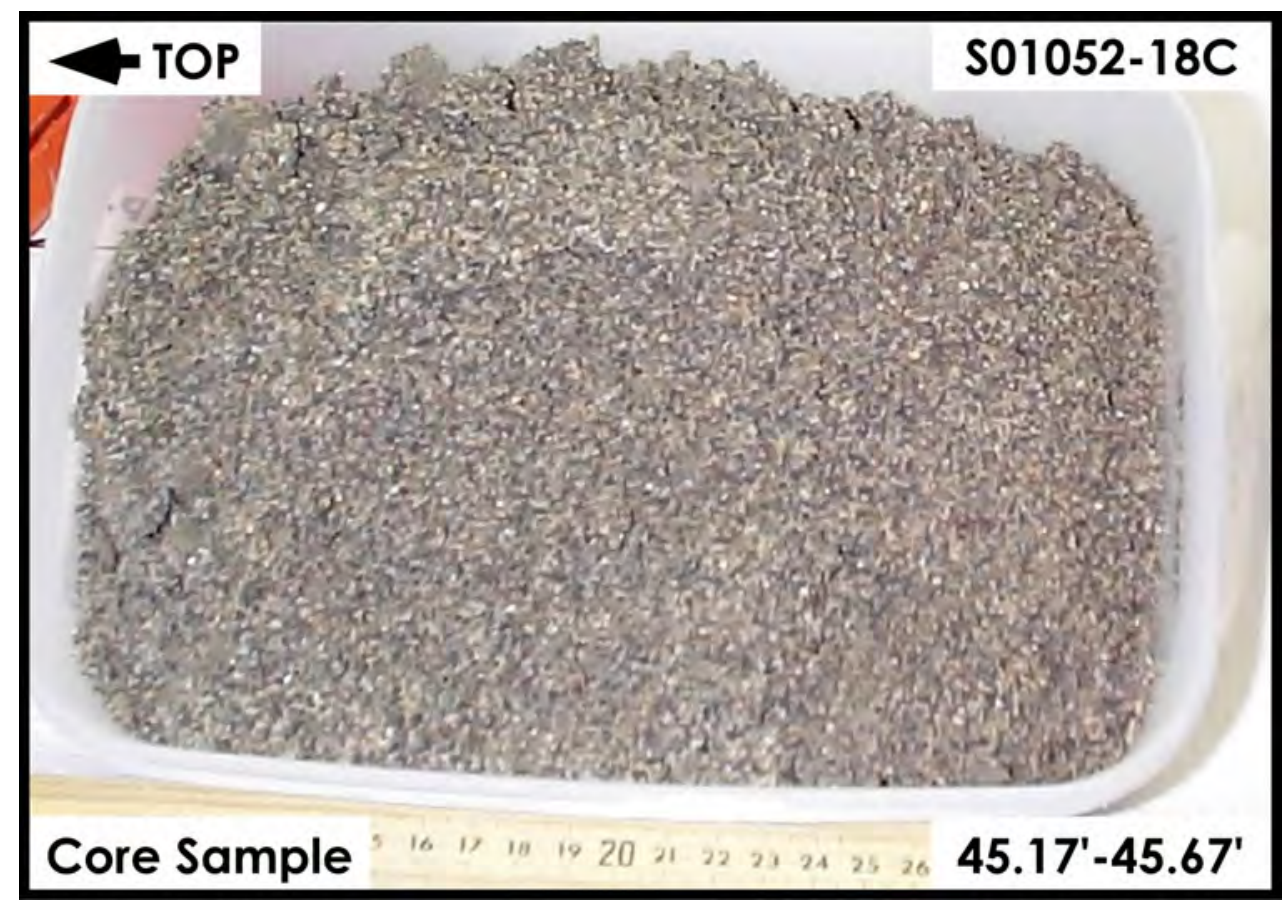

H2-Upper Sand and Gravel Sequence 


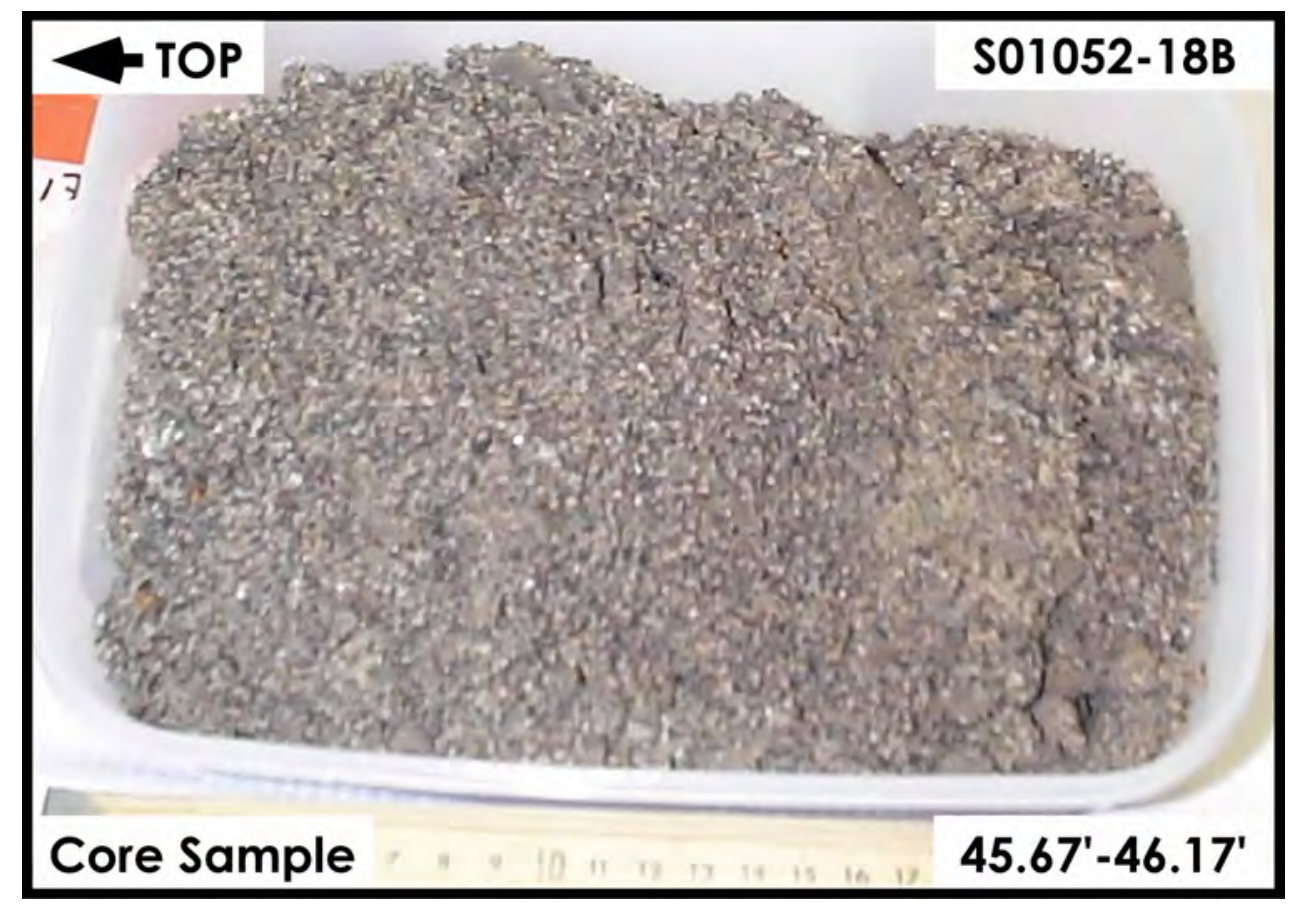

H2-Upper Sand and Gravel Sequence

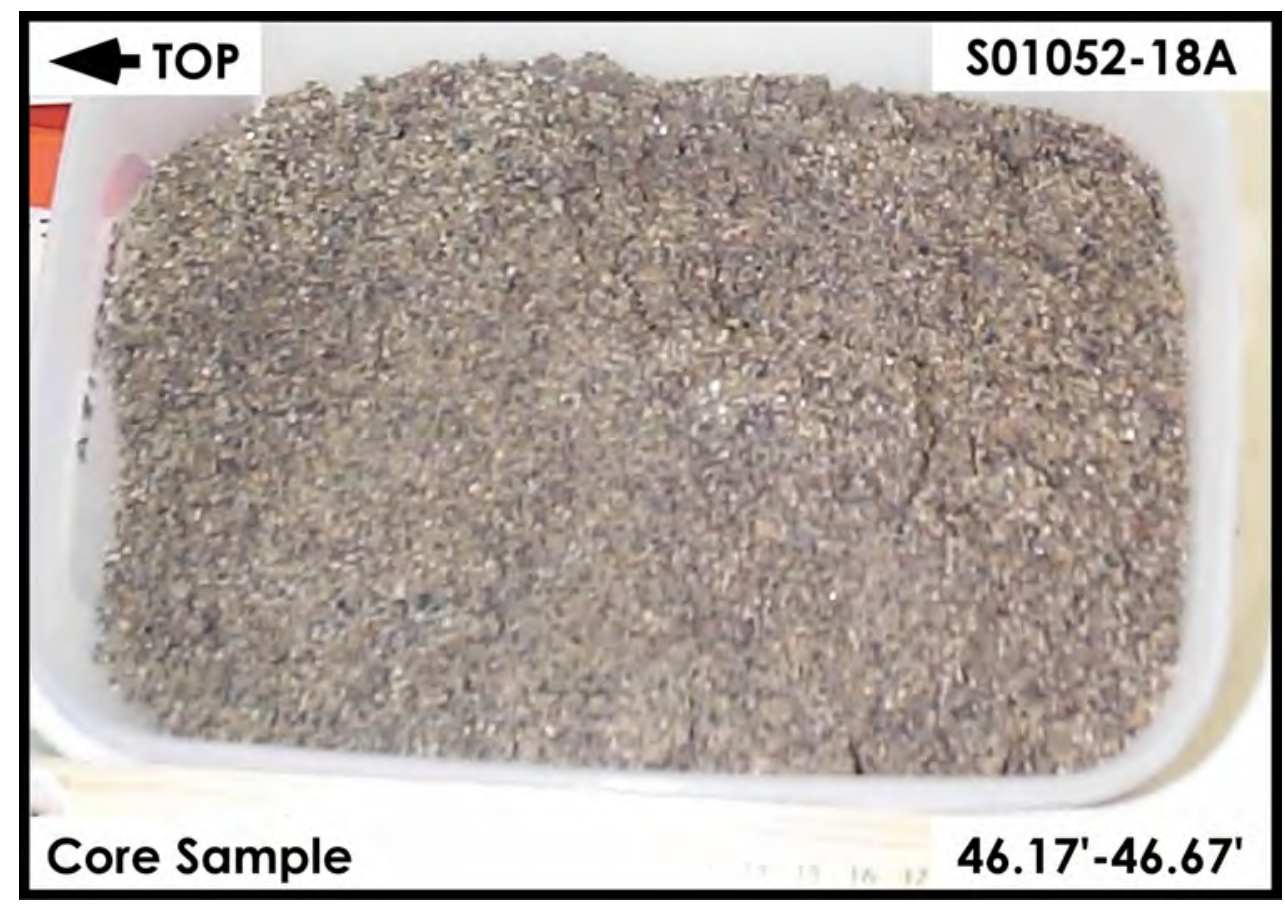

H2-Upper Sand and Gravel Sequence 


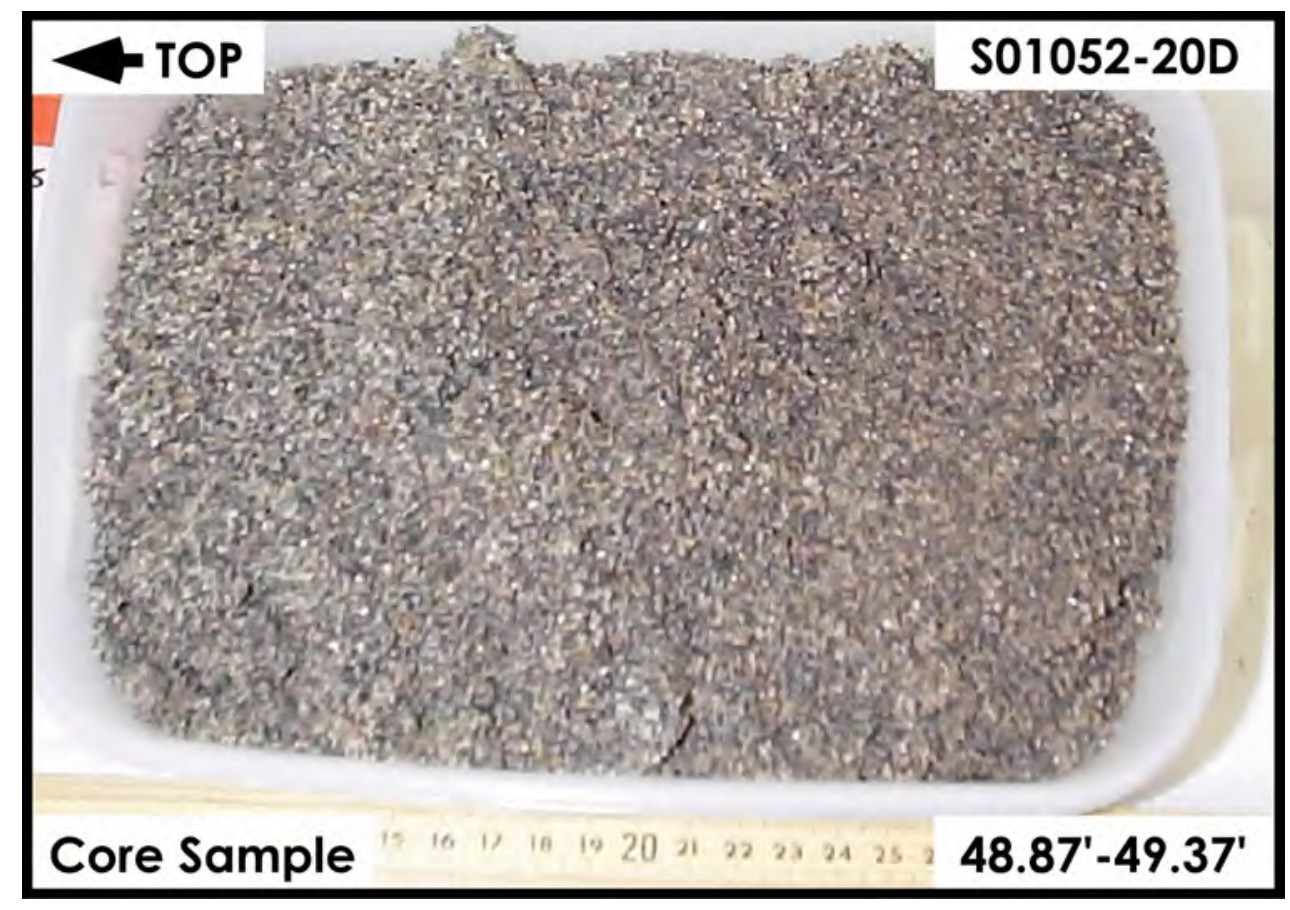

H2-Upper Sand and Gravel Sequence

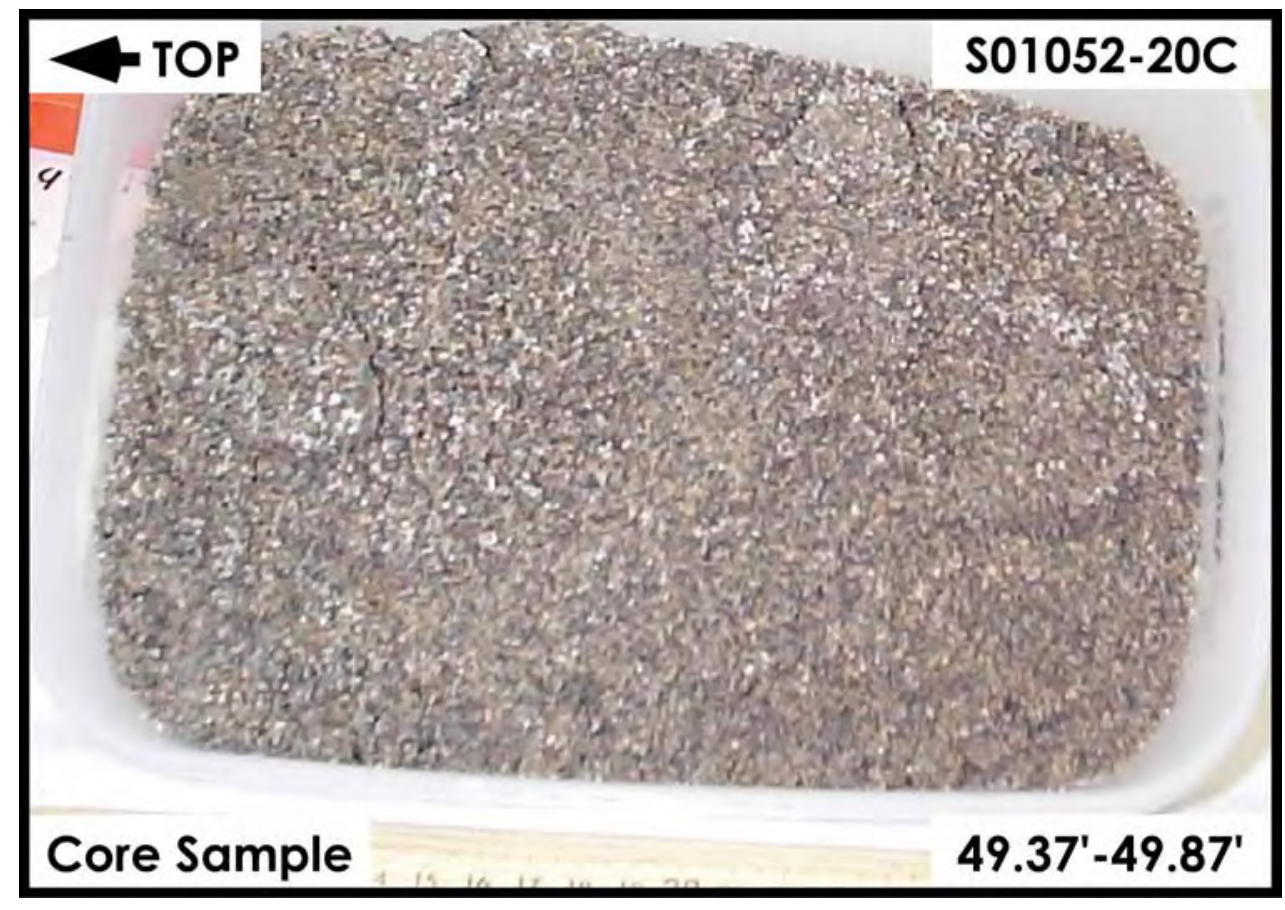

H2-Upper Sand and Gravel Sequence 


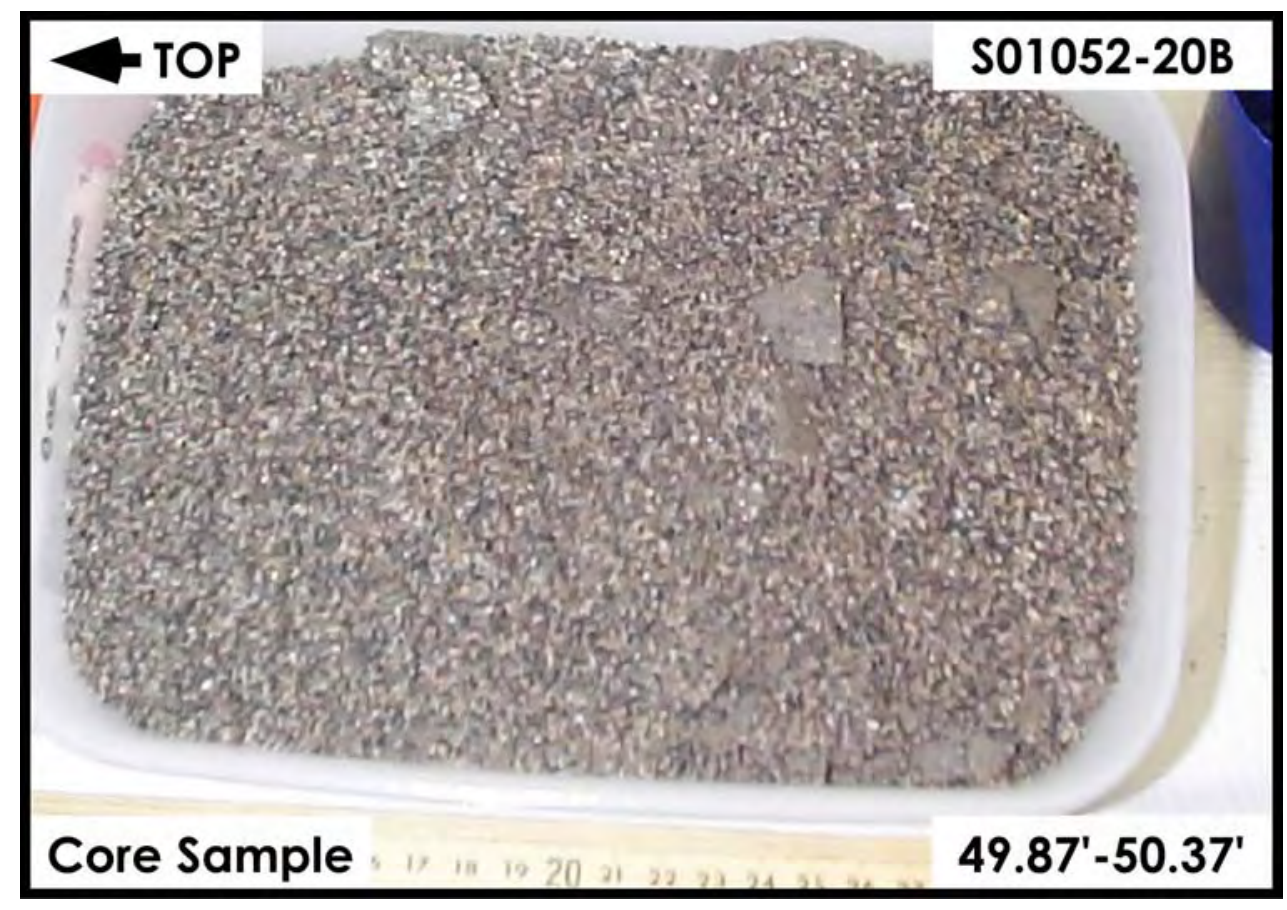

H2-Upper Sand and Gravel Sequence

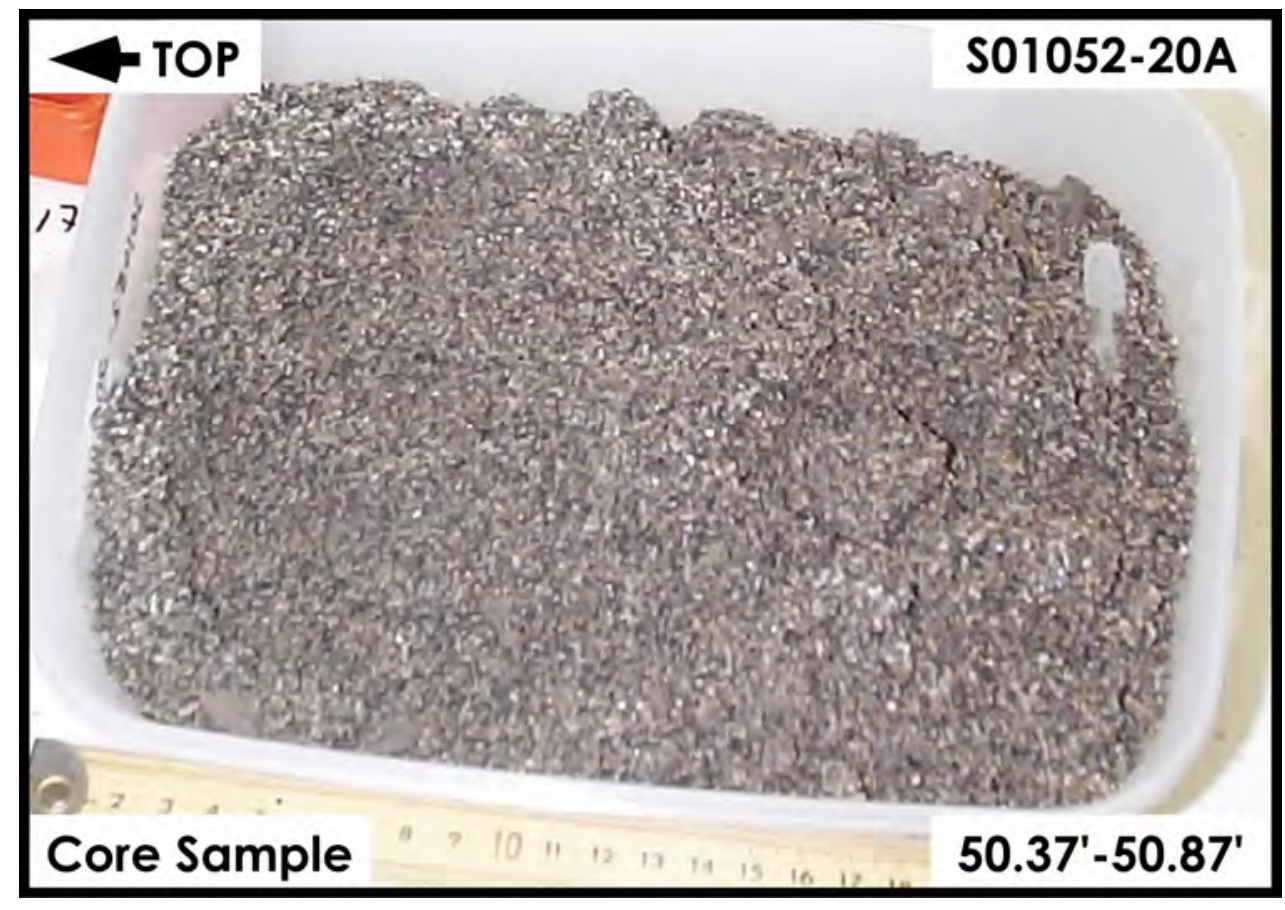

H2-Upper Sand and Gravel Sequence 


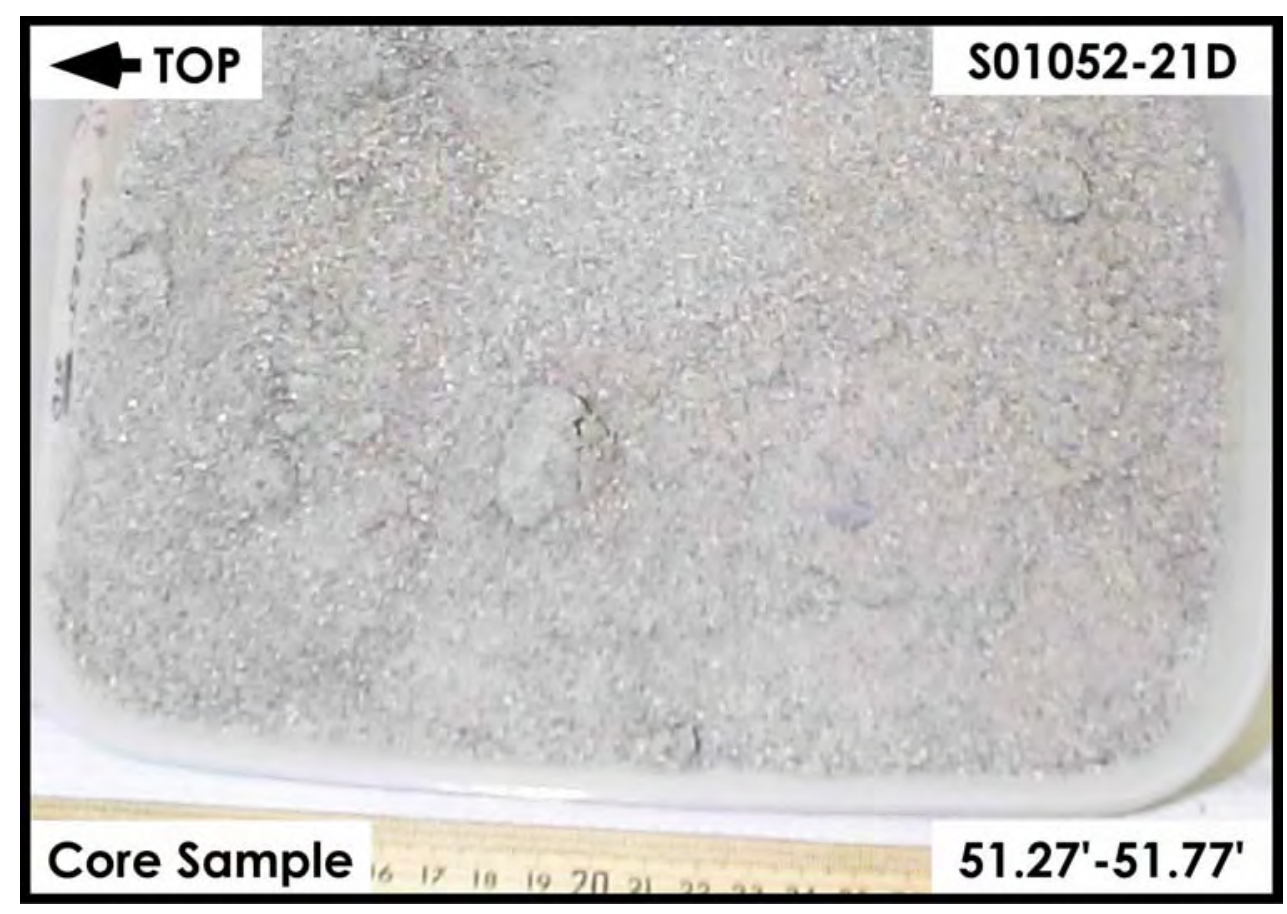

H2-Upper Sand and Gravel Sequence

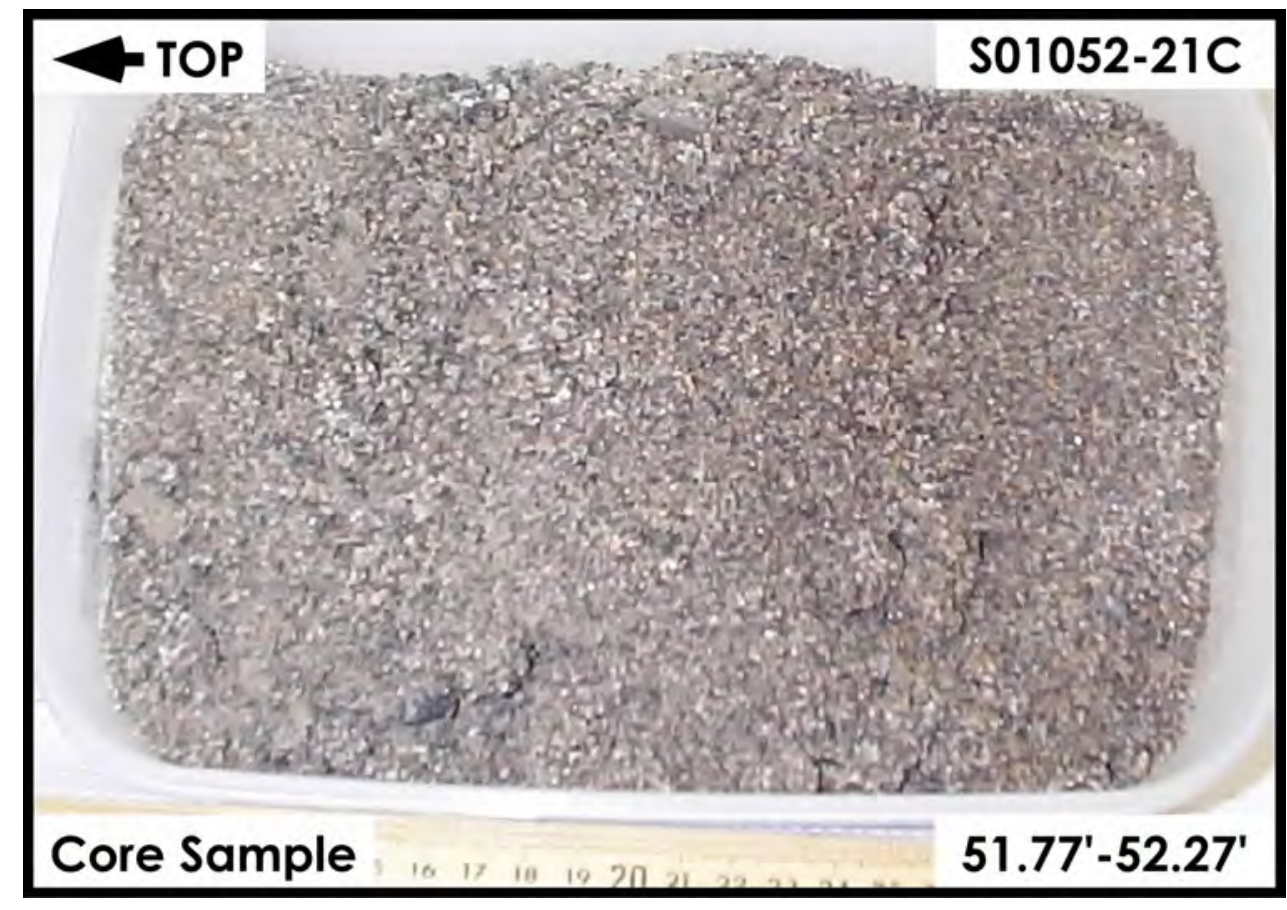

H2-Upper Sand and Gravel Sequence 


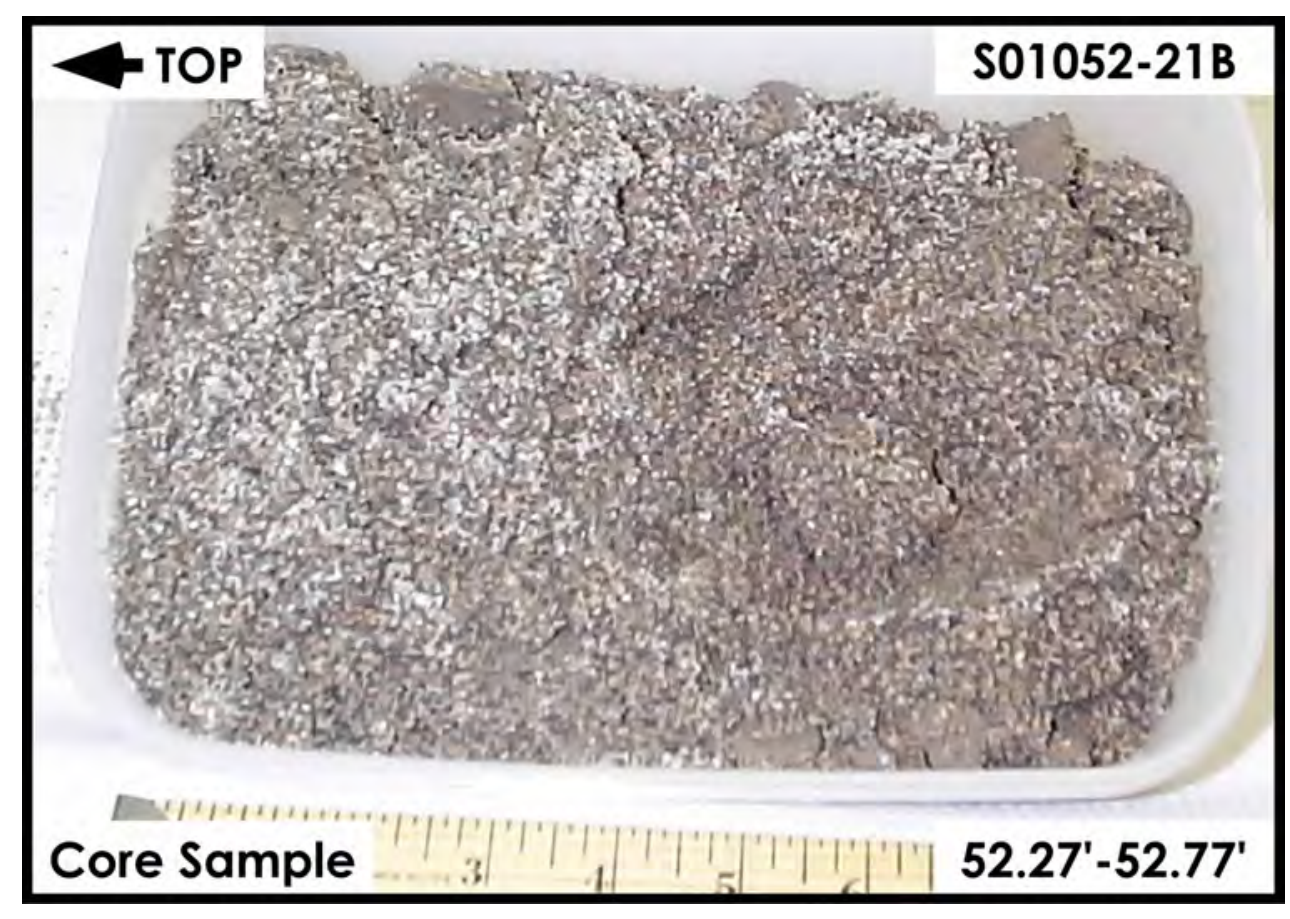

H2-Upper Sand and Gravel Sequence

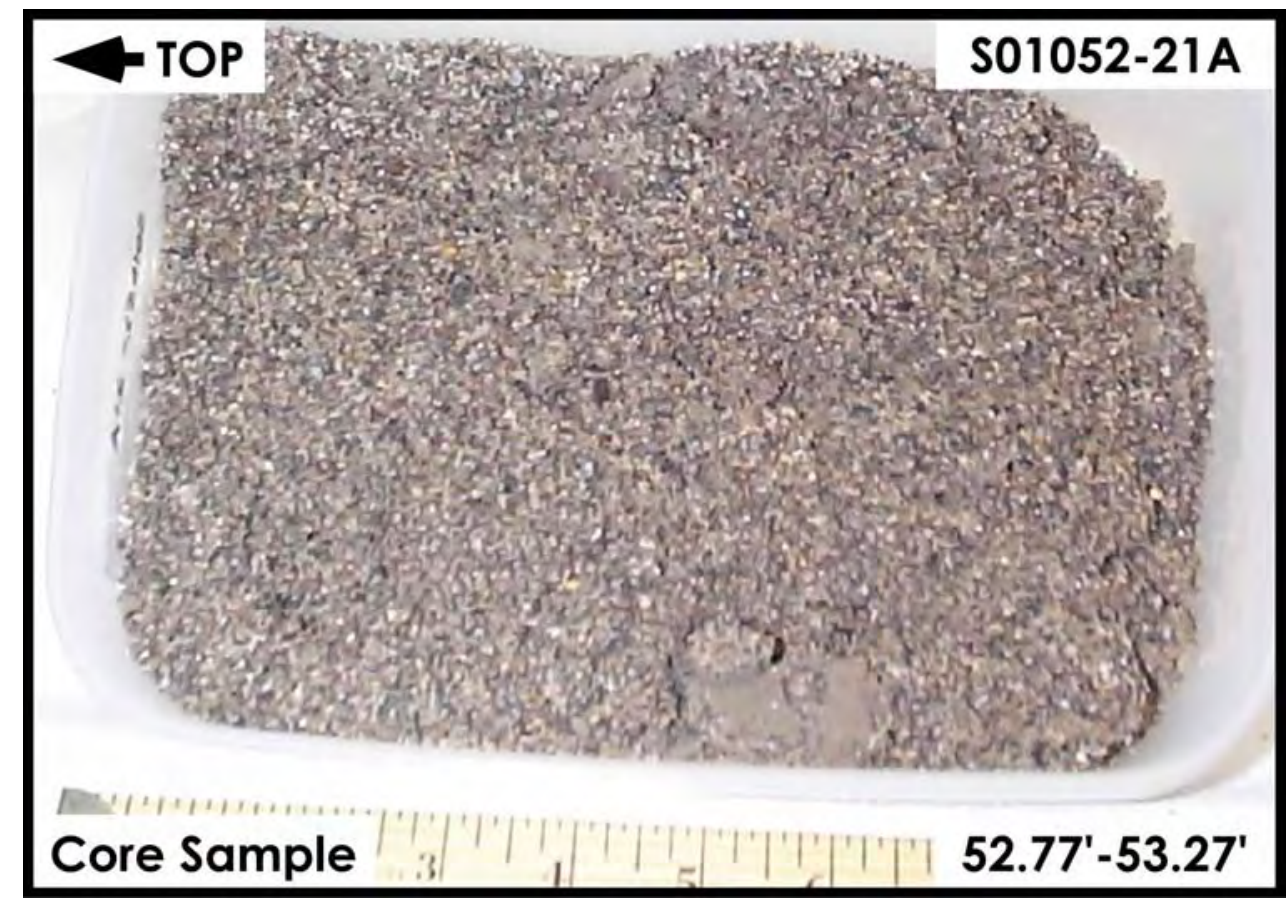

H2-Upper Sand and Gravel Sequence 


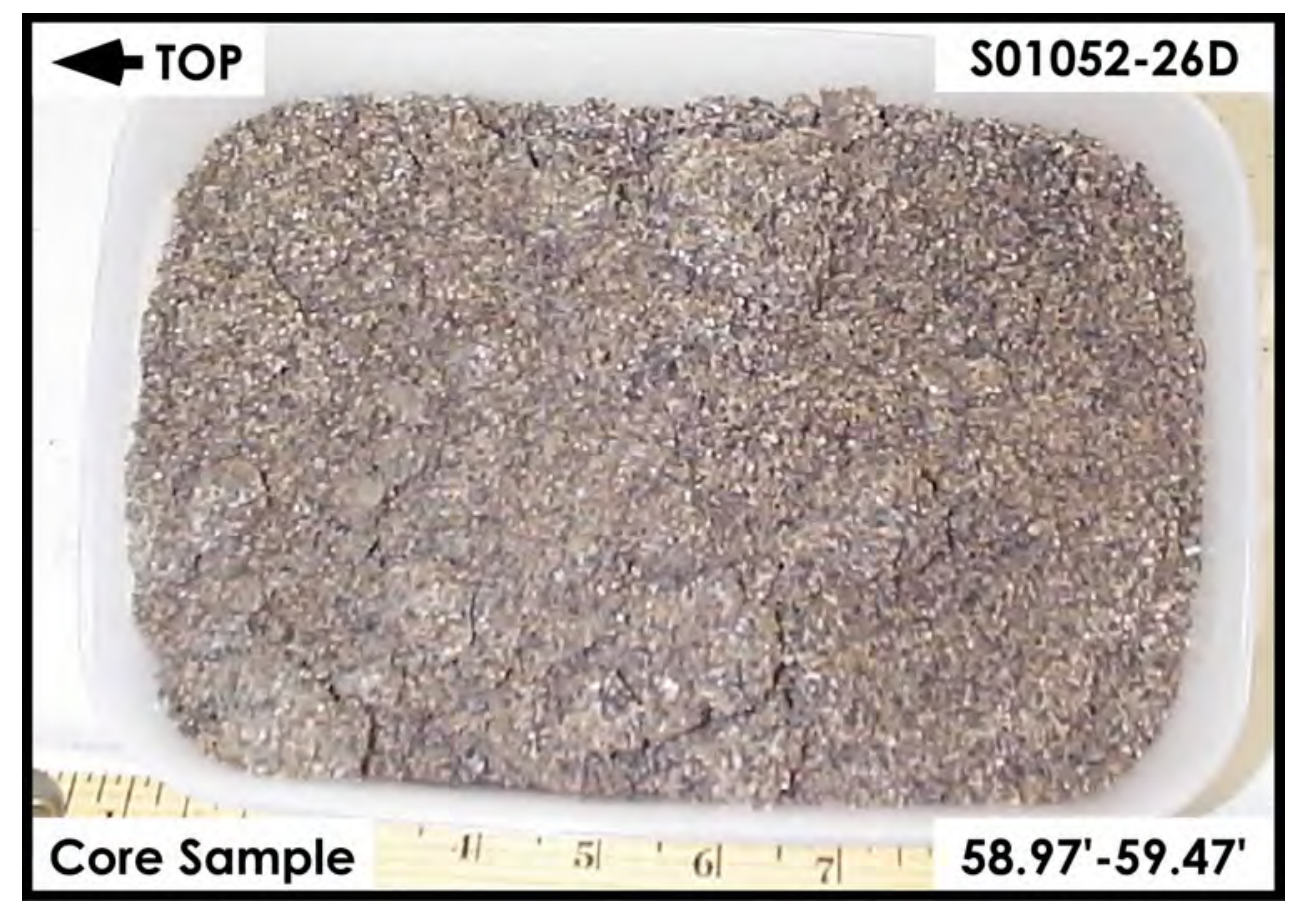

H2-Upper Sand and Gravel Sequence

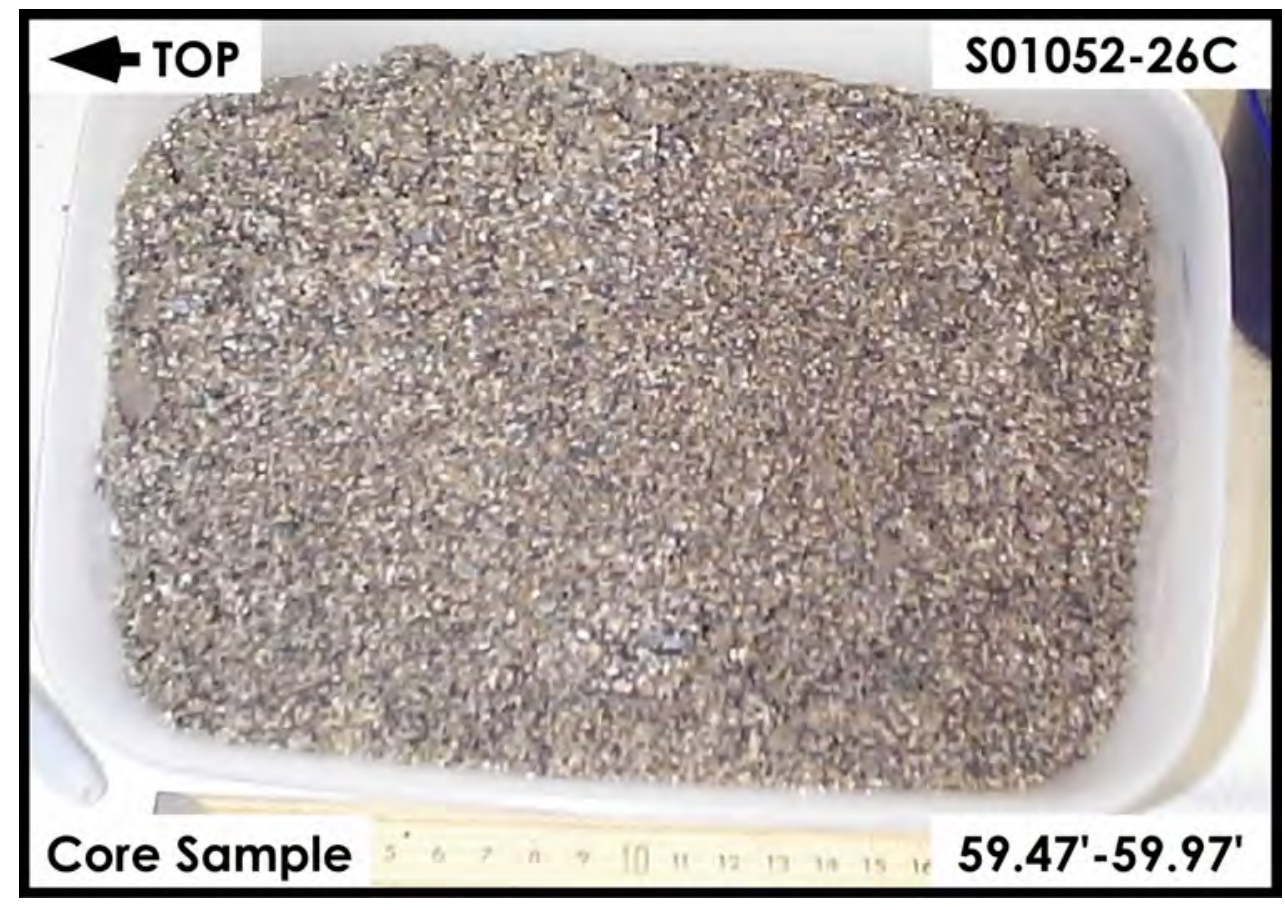

H2-Upper Sand and Gravel Sequence 


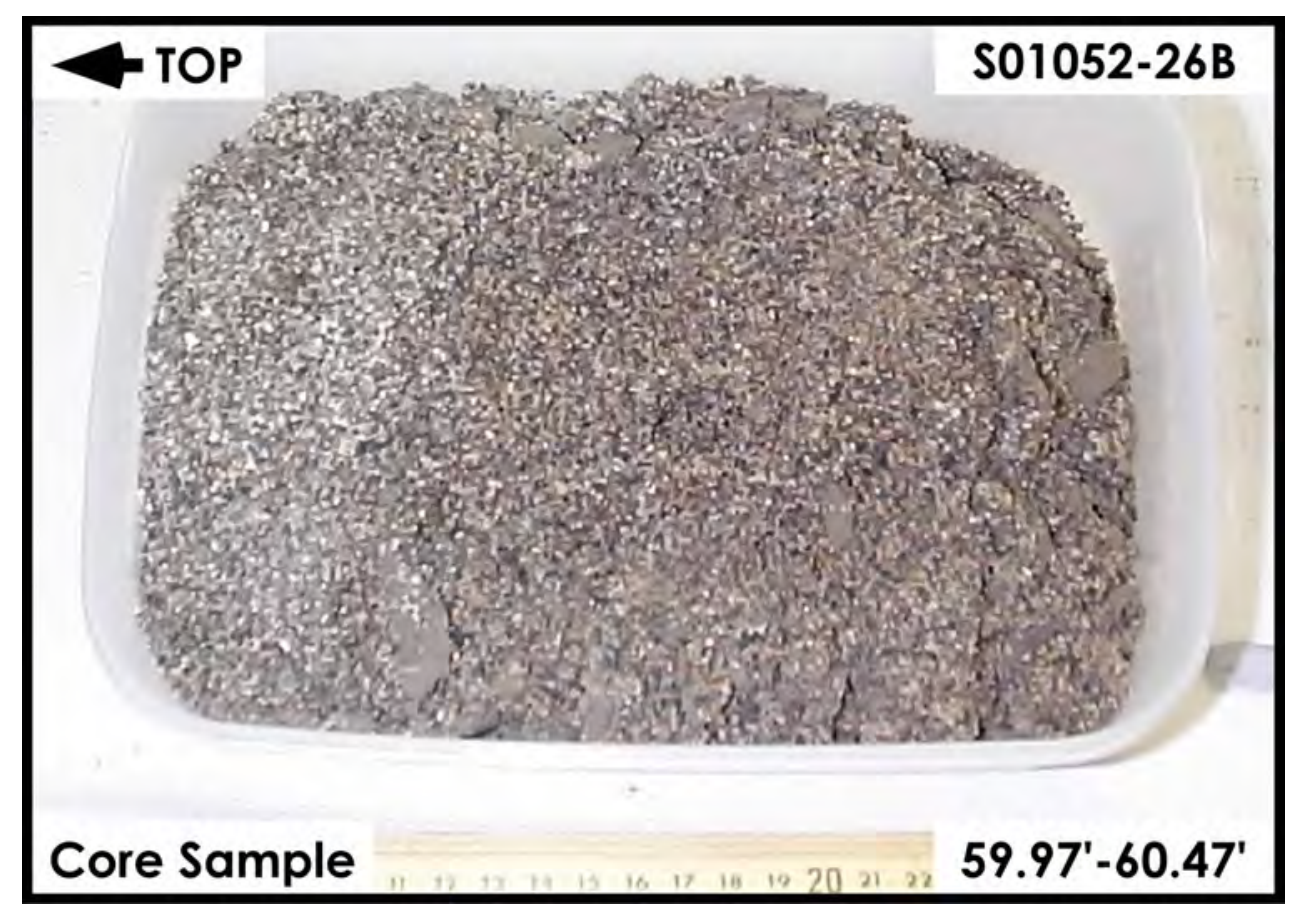

H2-Upper Sand and Gravel Sequence

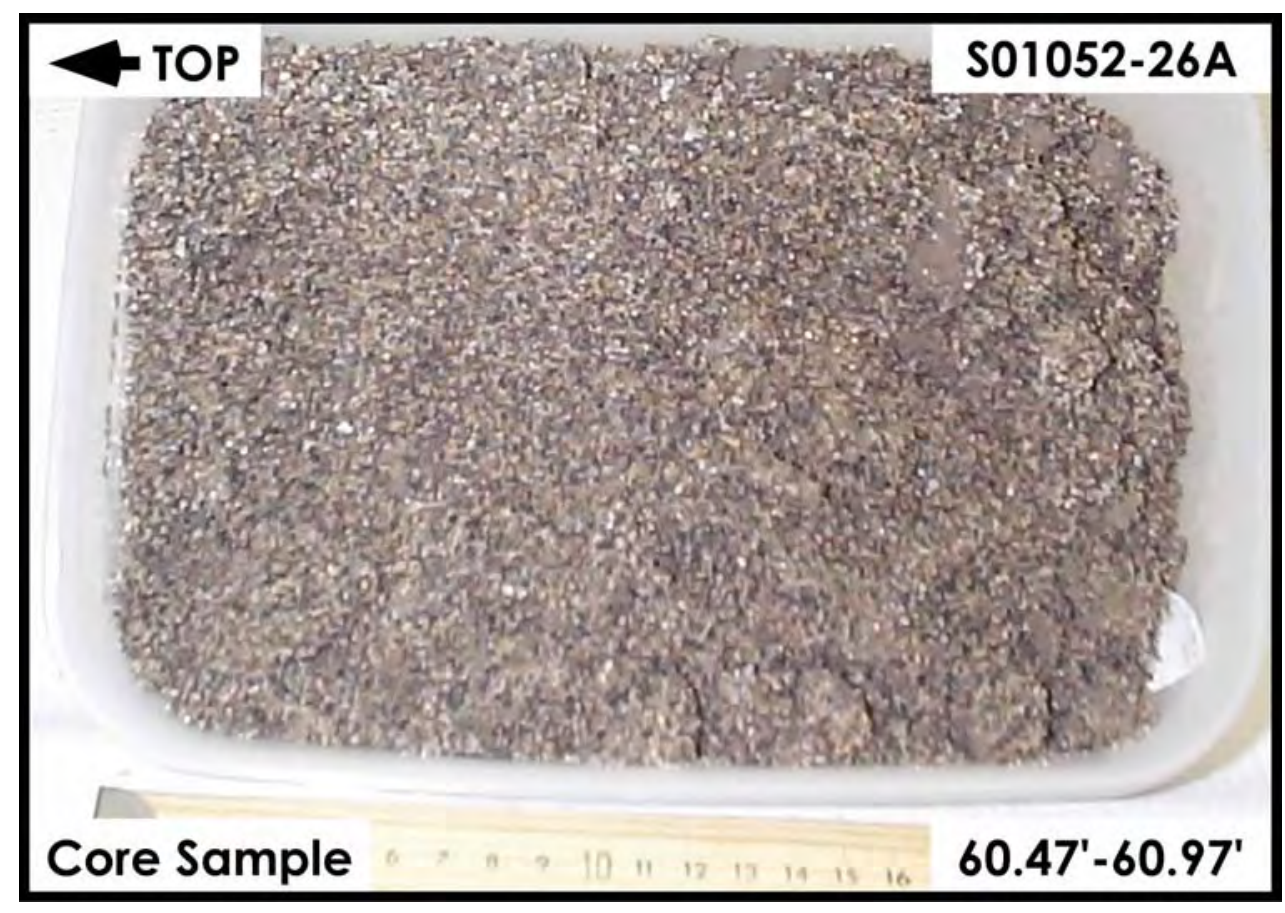

H2-Upper Sand and Gravel Sequence 


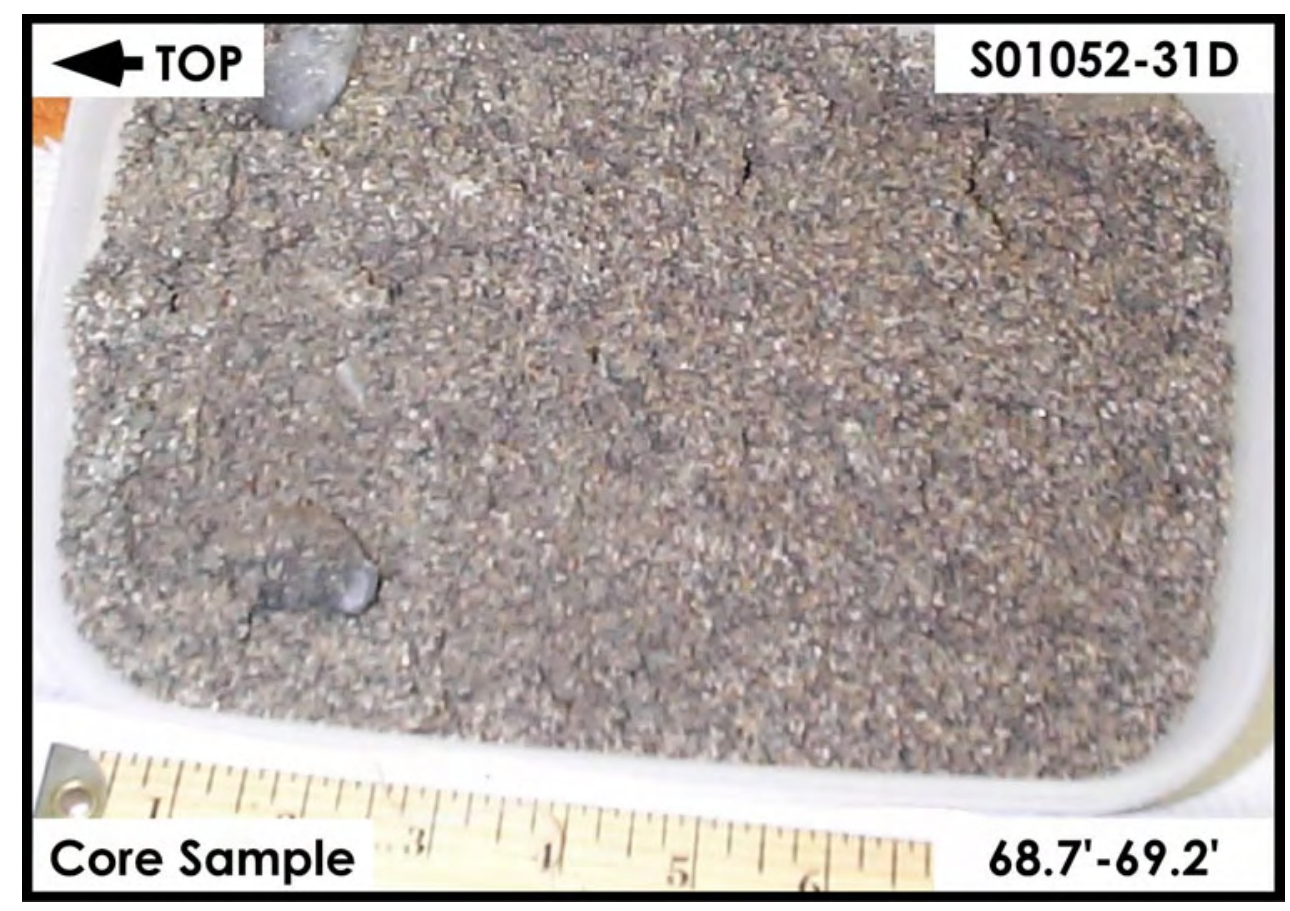

H2-Upper Sand and Gravel Sequence

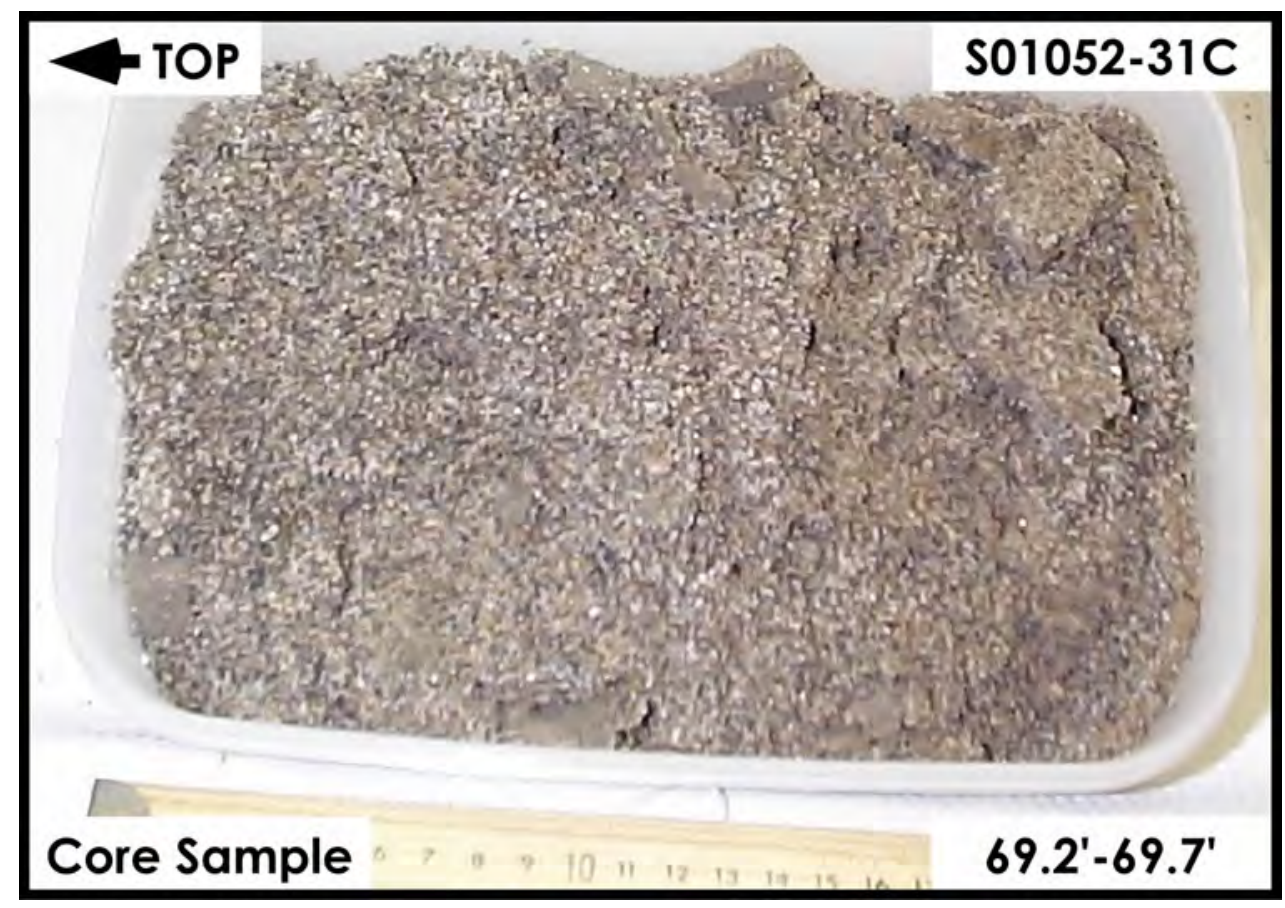

H2-Upper Sand and Gravel Sequence

B. 10 


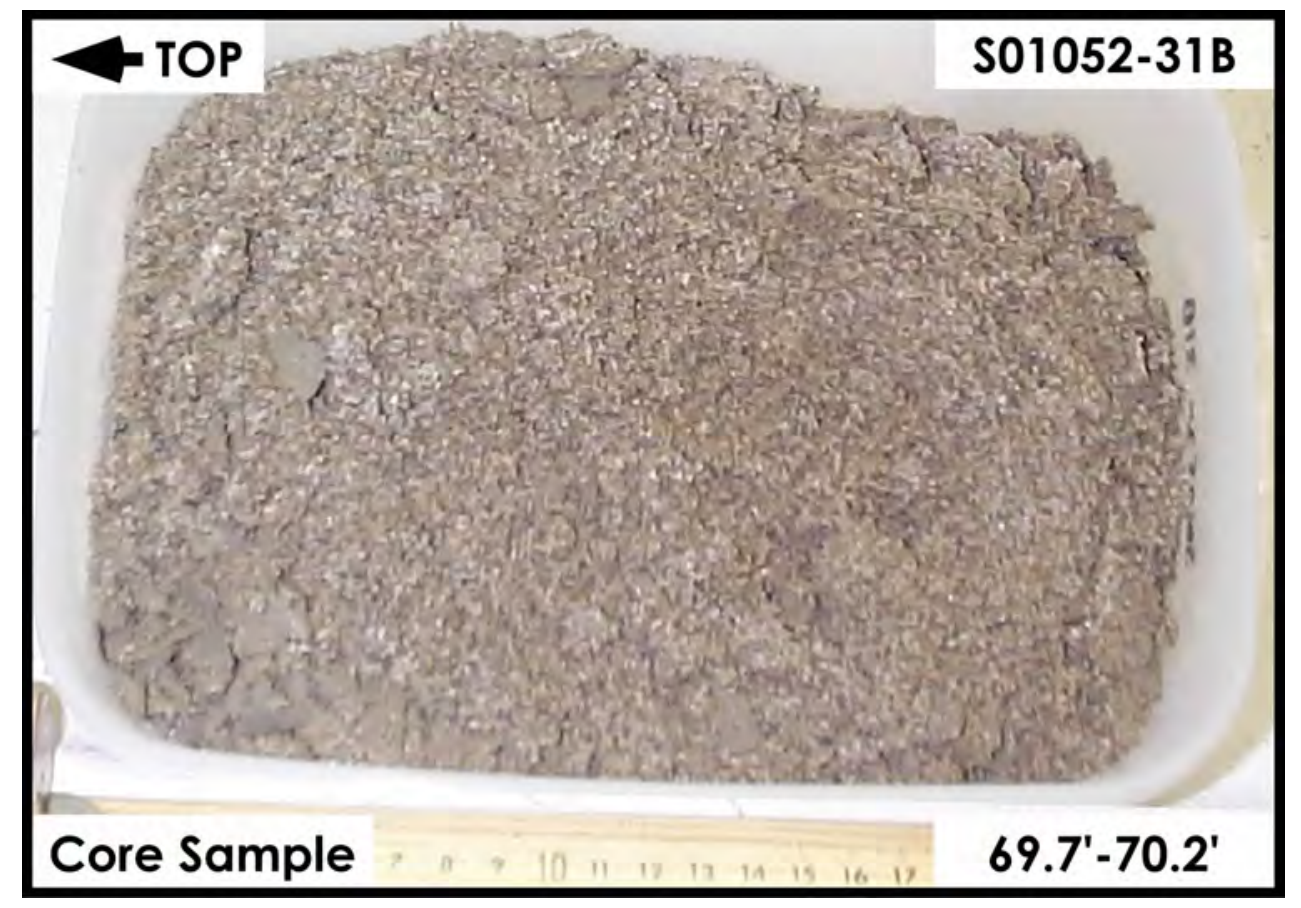

H2-Upper Sand and Gravel Sequence

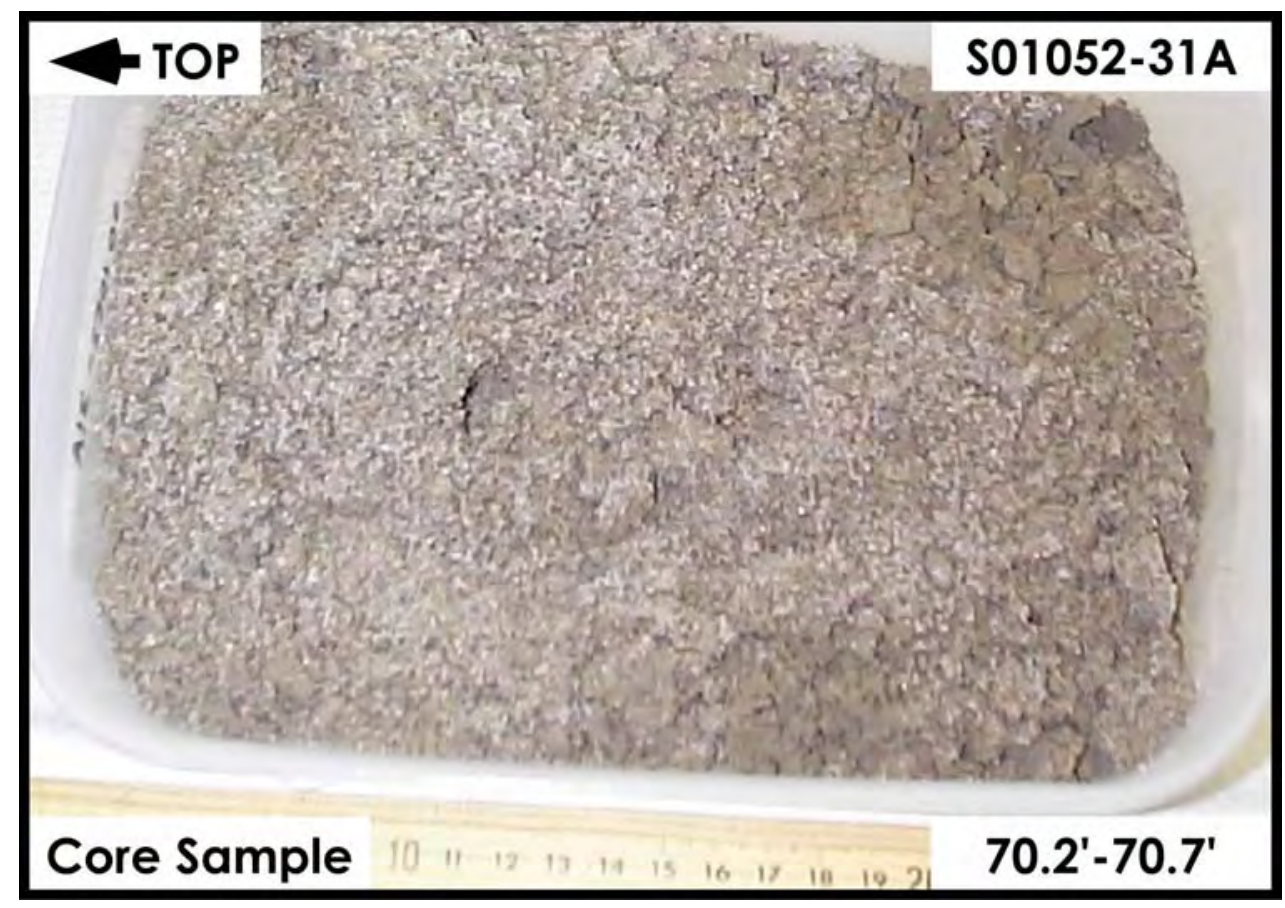

H2-Upper Sand and Gravel Sequence 


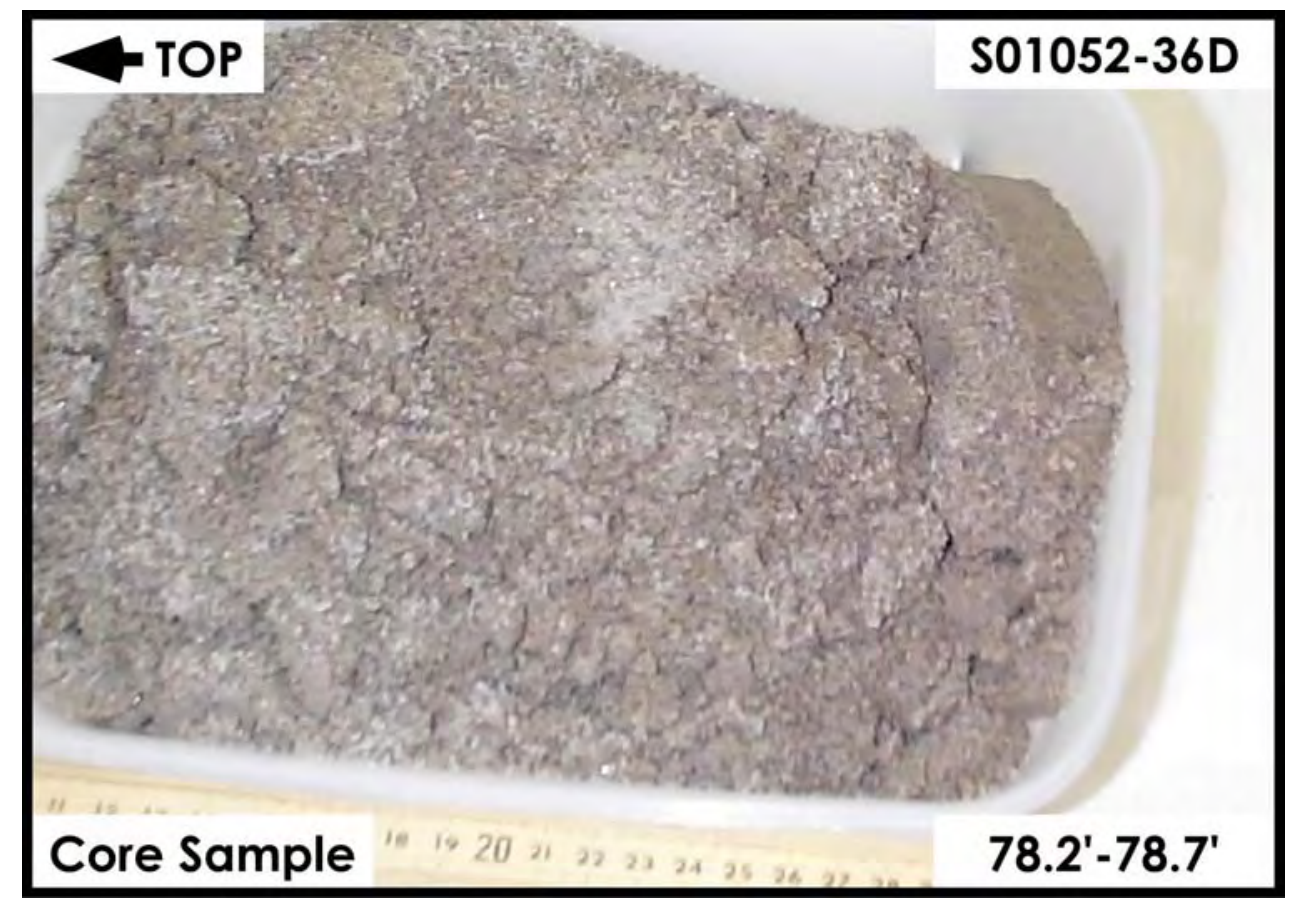

H2-Upper Sand and Gravel Sequence

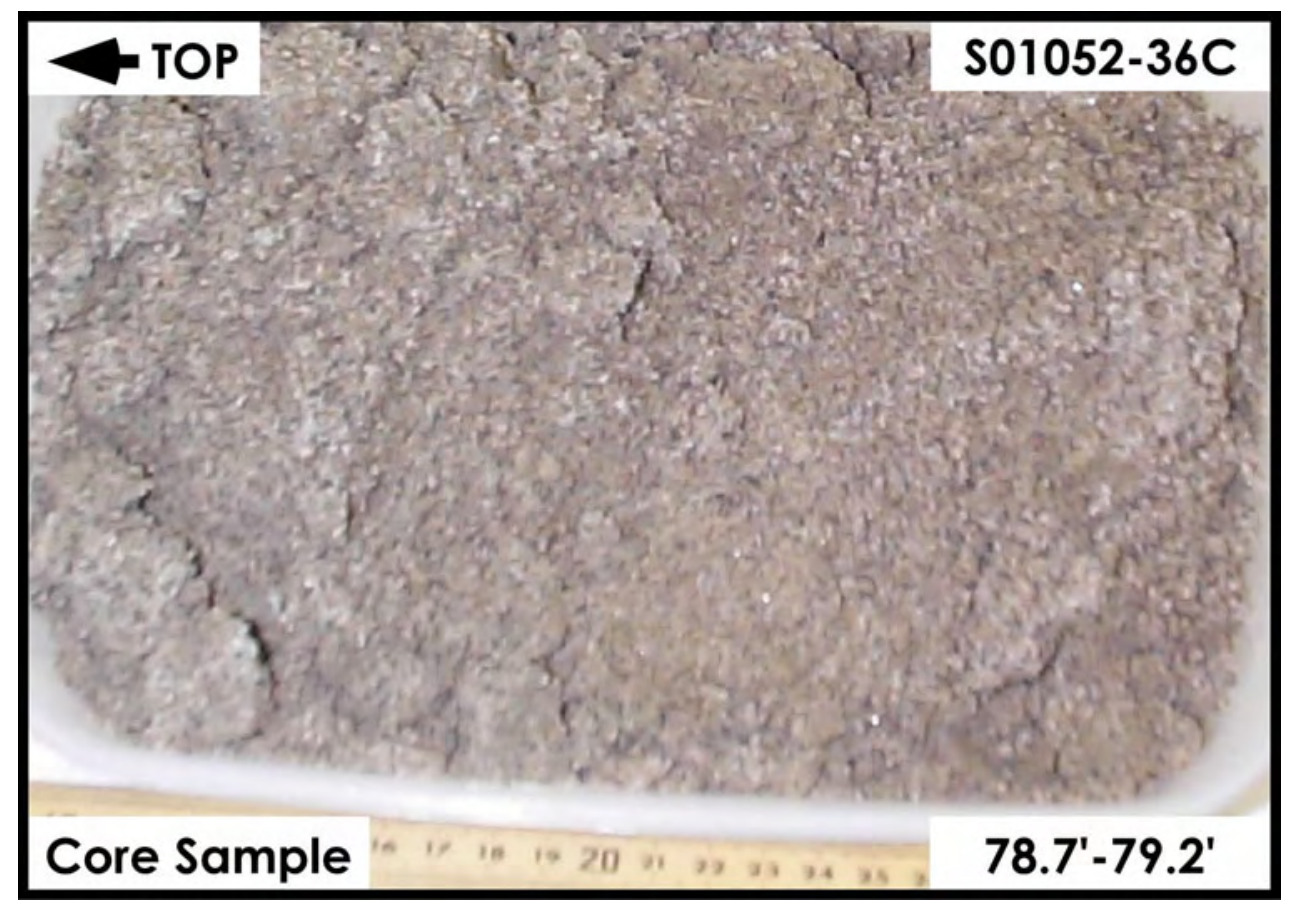

H2-Upper Sand and Gravel Sequence 


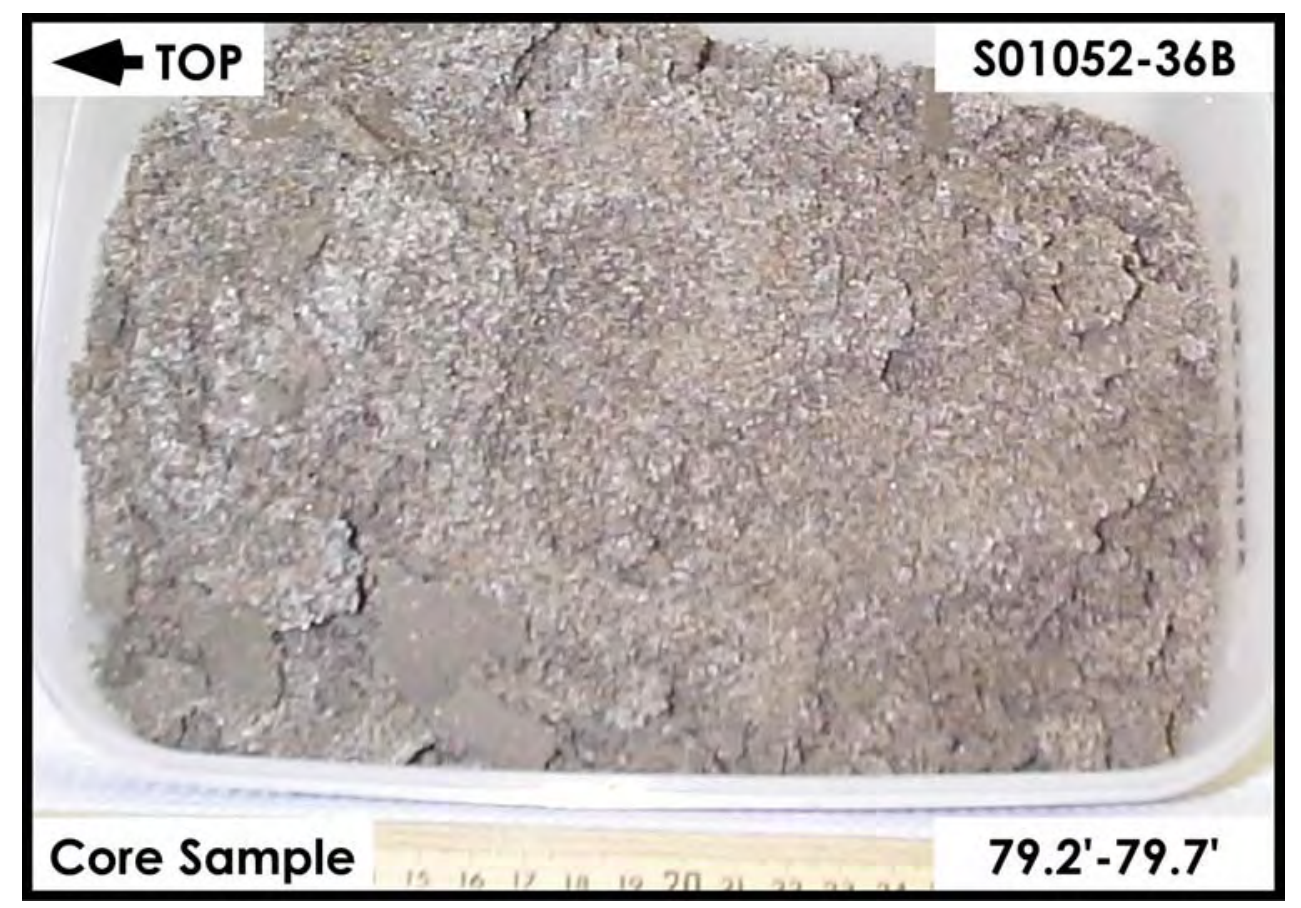

H2-Upper Sand and Gravel Sequence

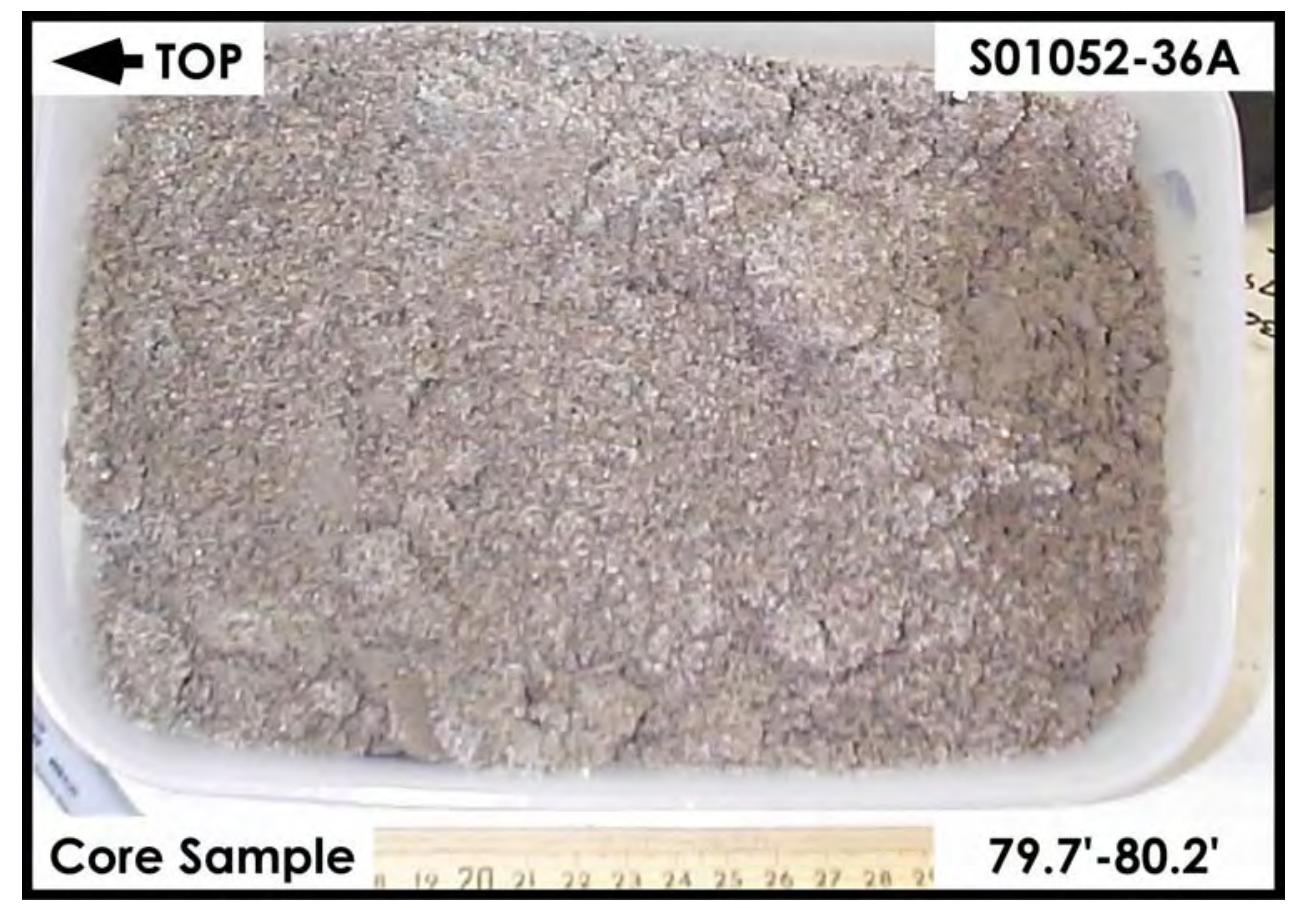

H2-Upper Sand and Gravel Sequence 


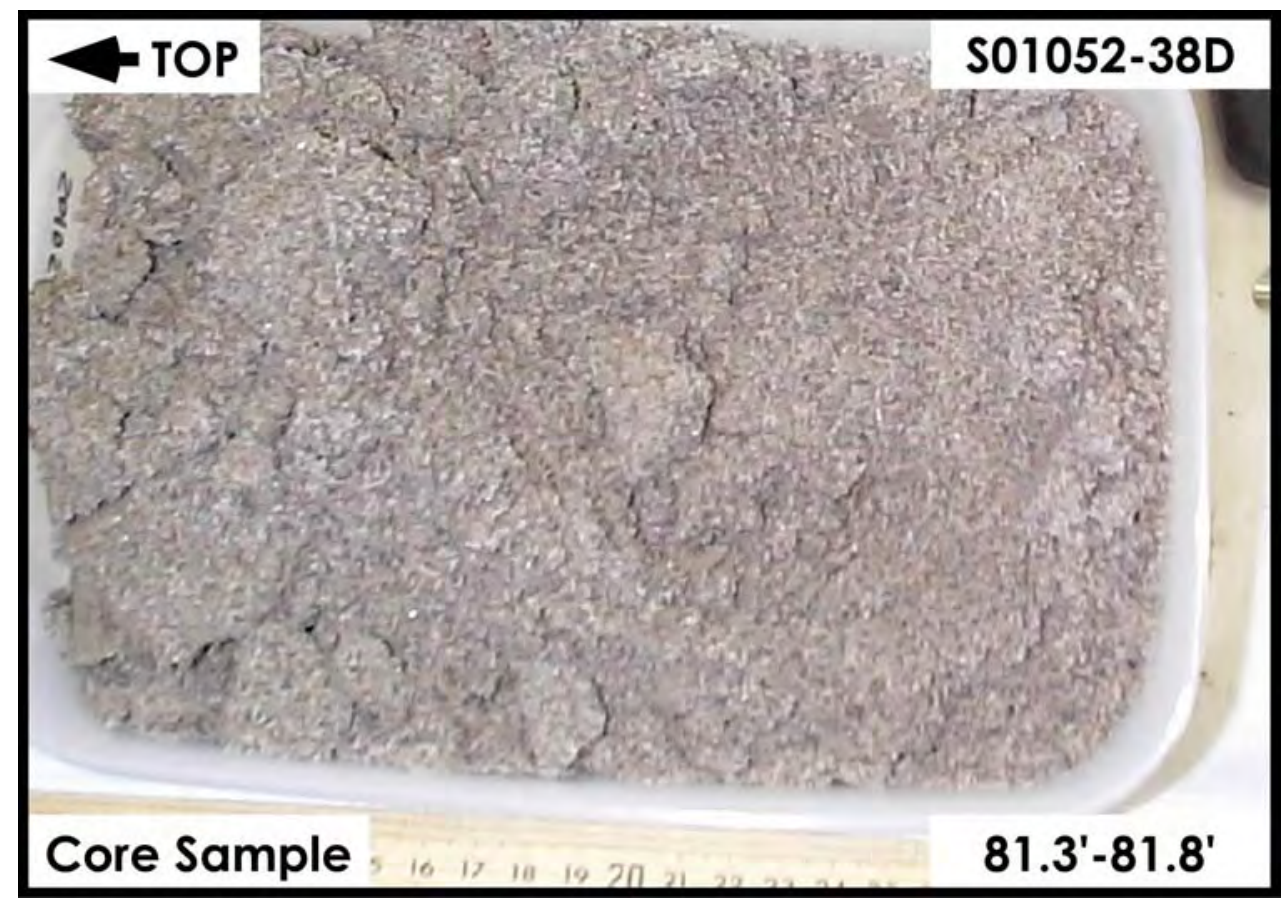

H2-Upper Sand and Gravel Sequence

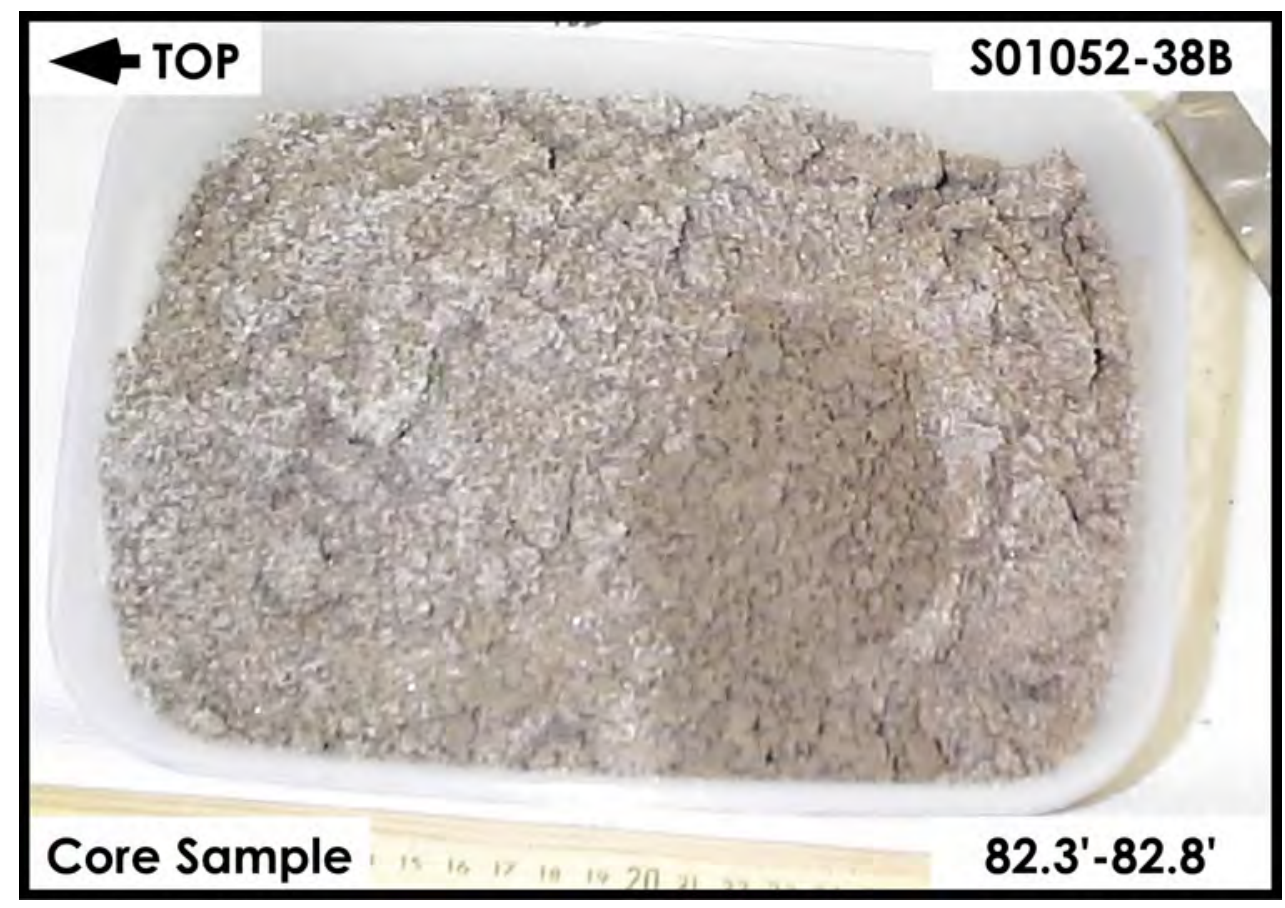

H2-Upper Sand and Gravel Sequence 


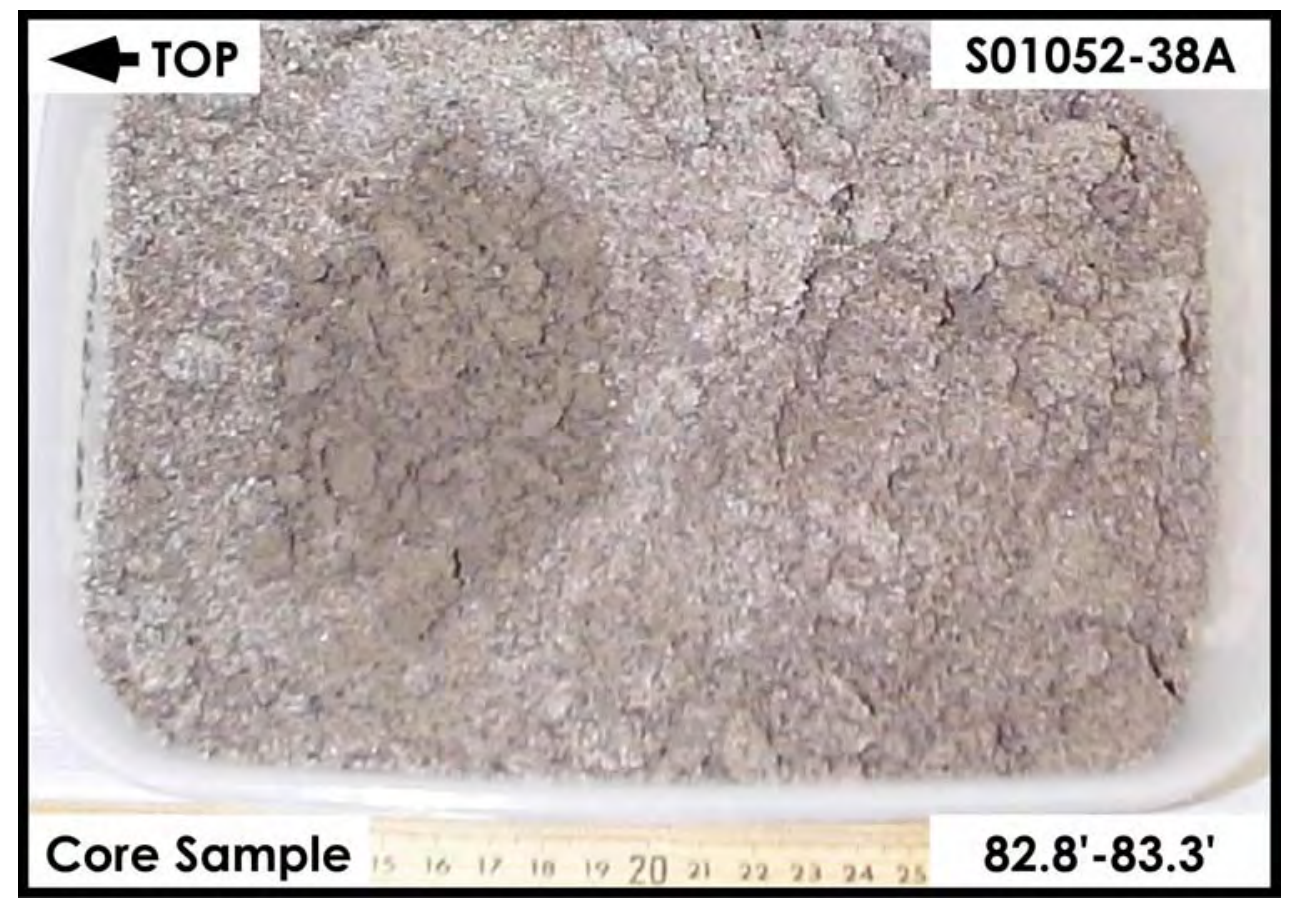

H2-Upper Sand and Gravel Sequence

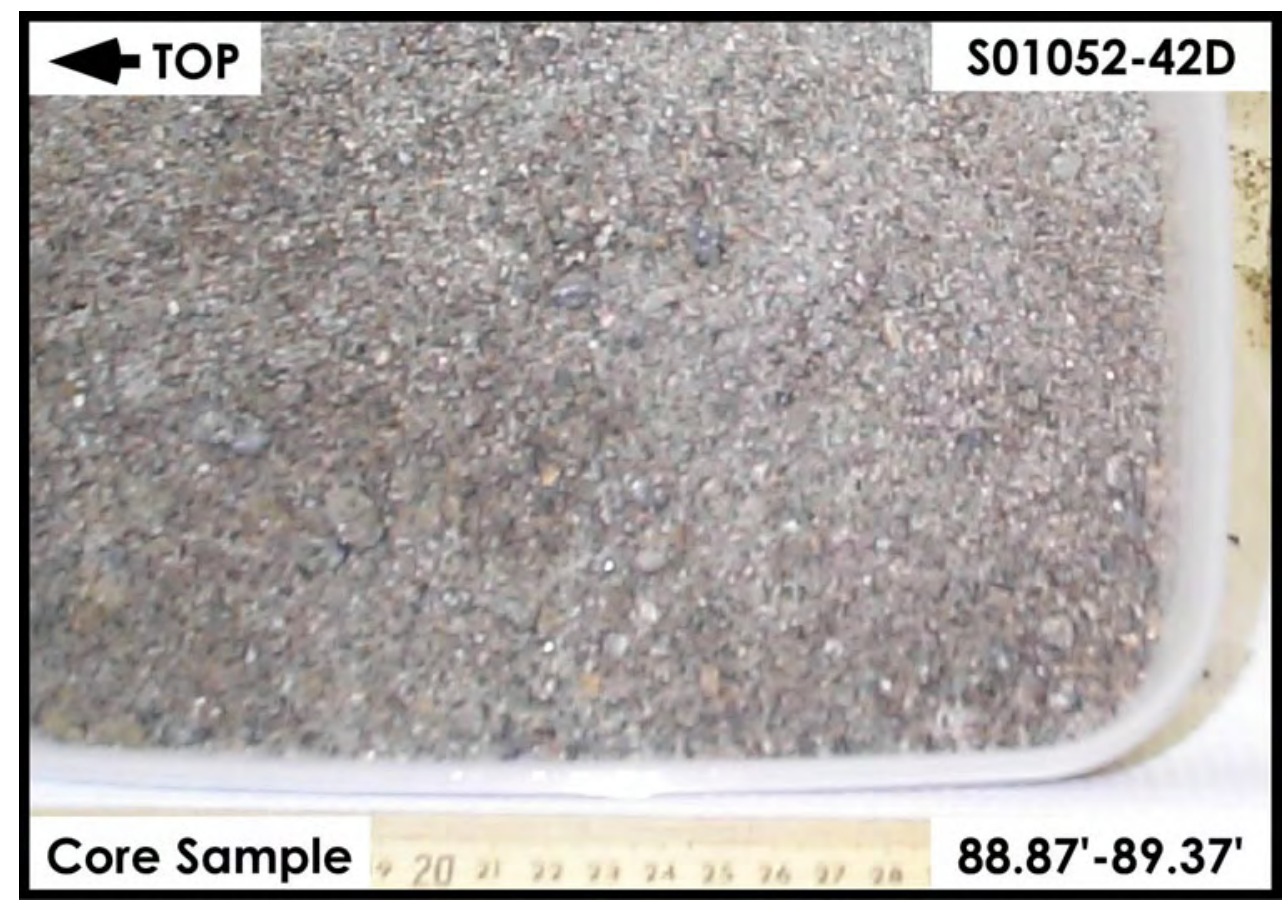

H2-Upper Sand and Gravel Sequence

B. 15 


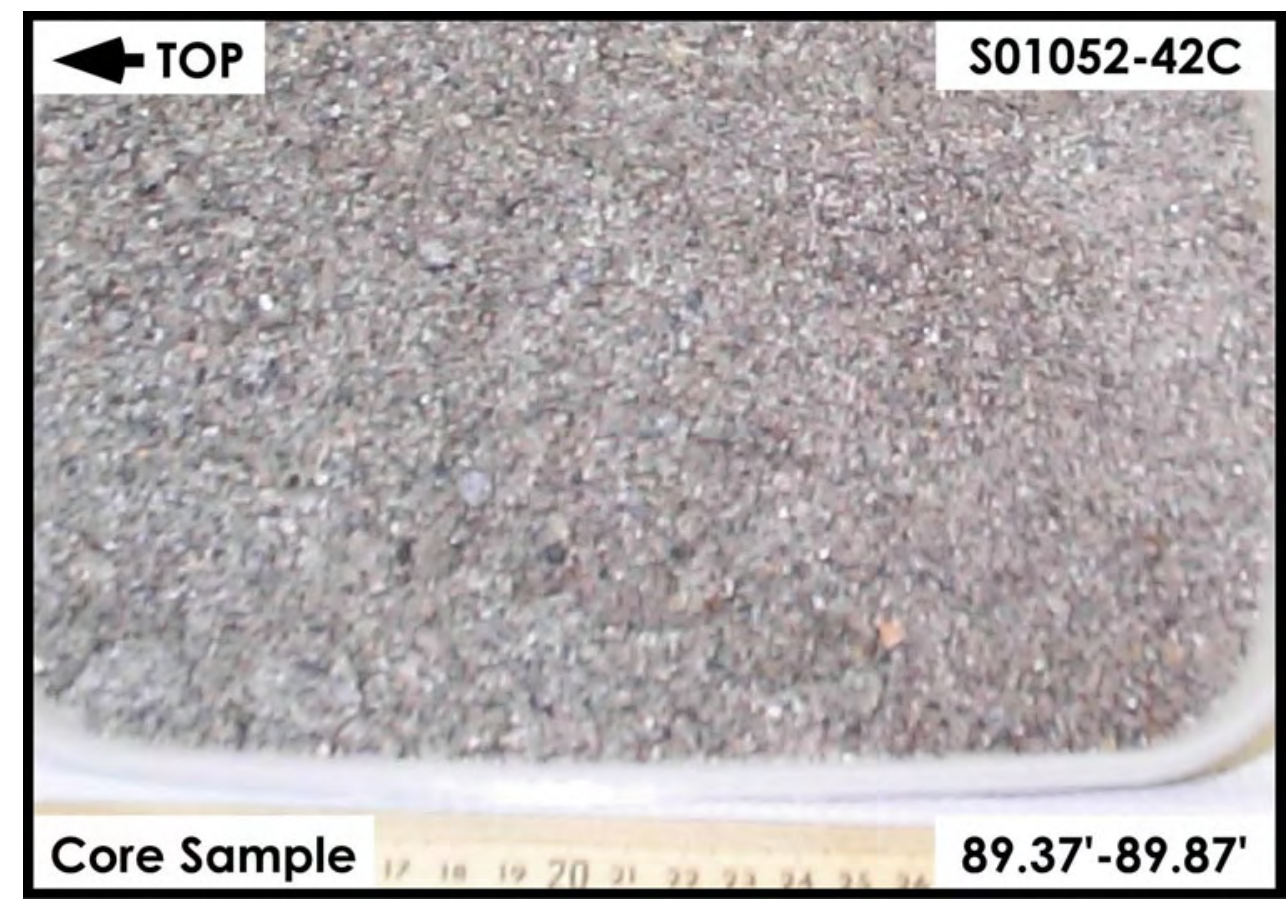

H2-Upper Sand and Gravel Sequence

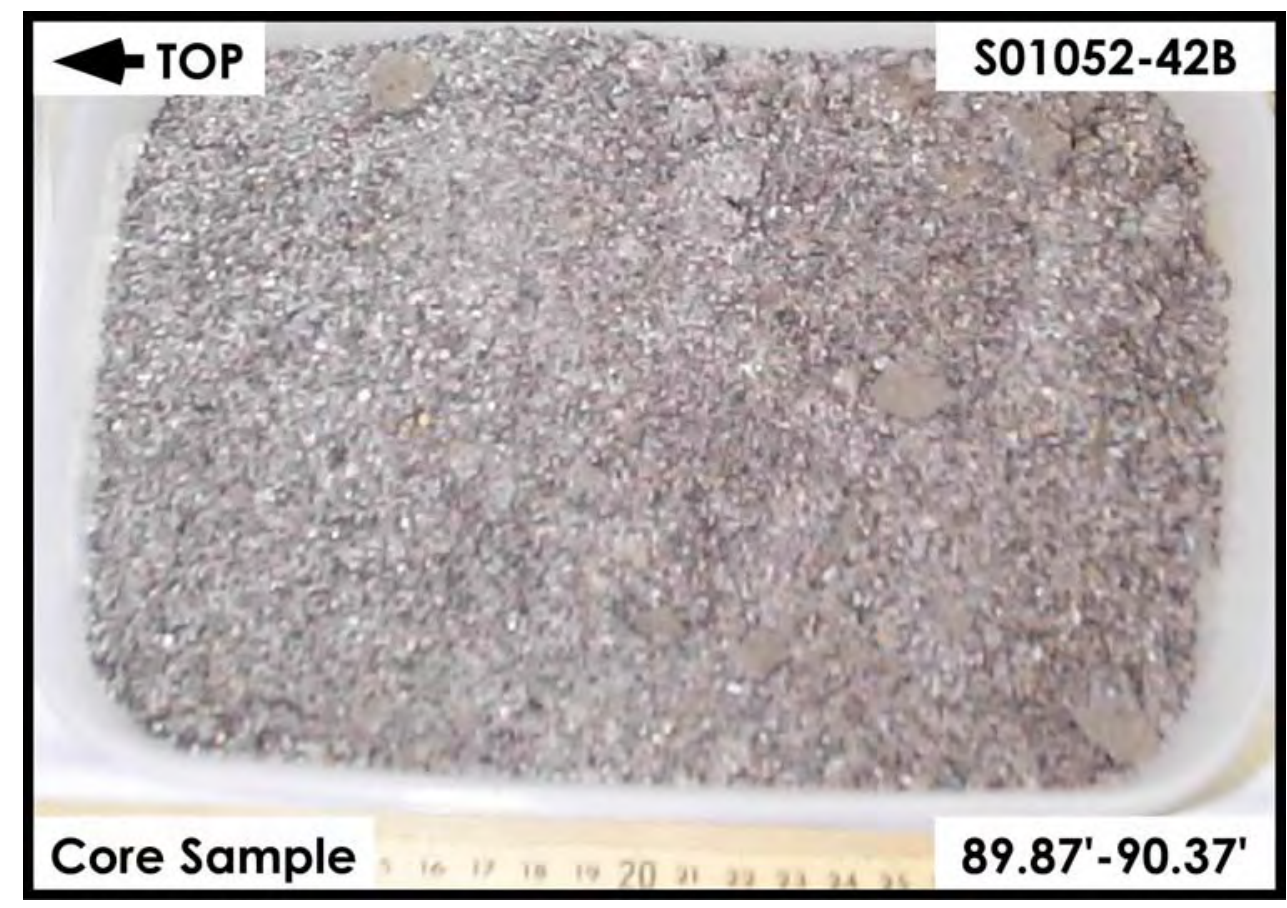

H2-Upper Sand and Gravel Sequence 


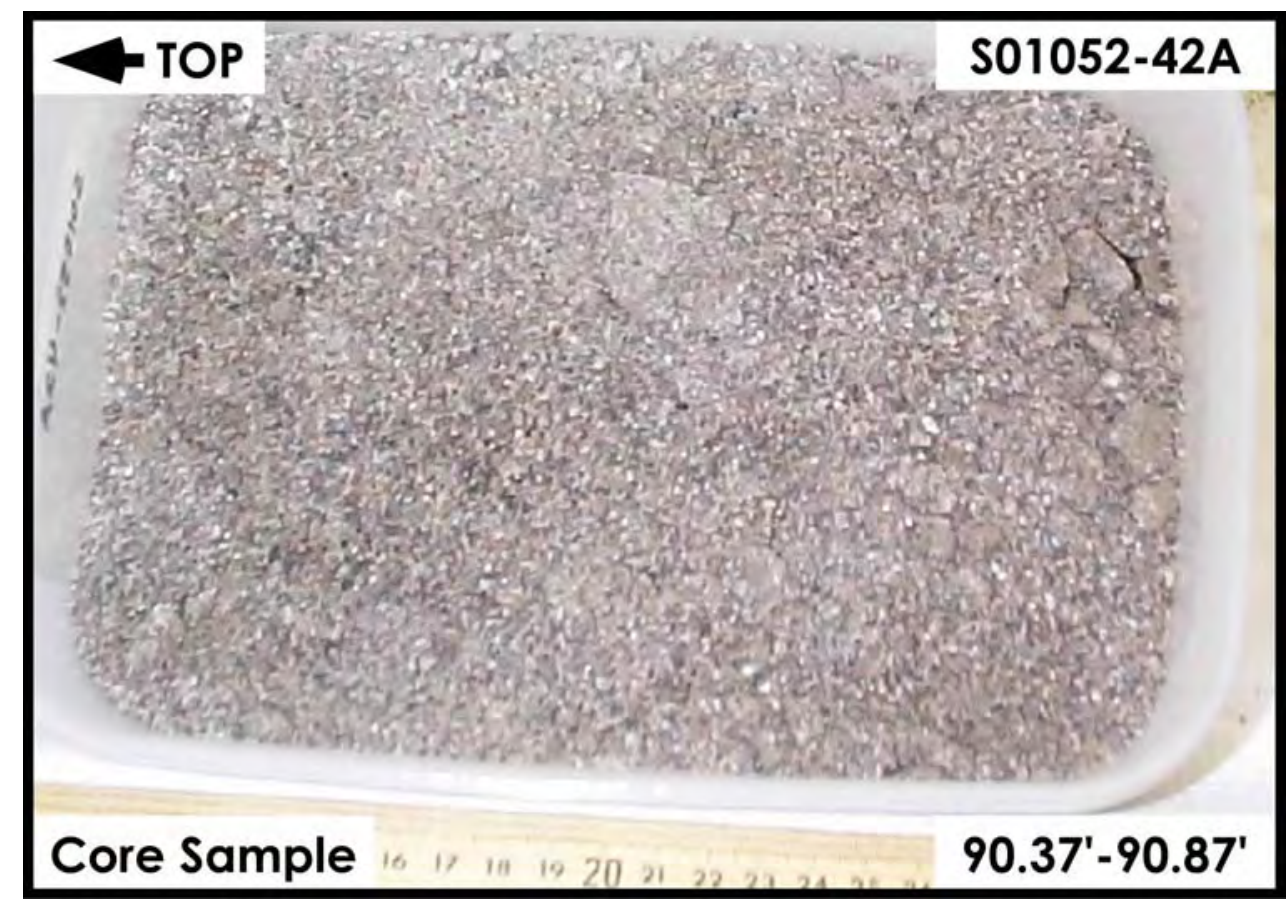

H2-Upper Sand and Gravel Sequence

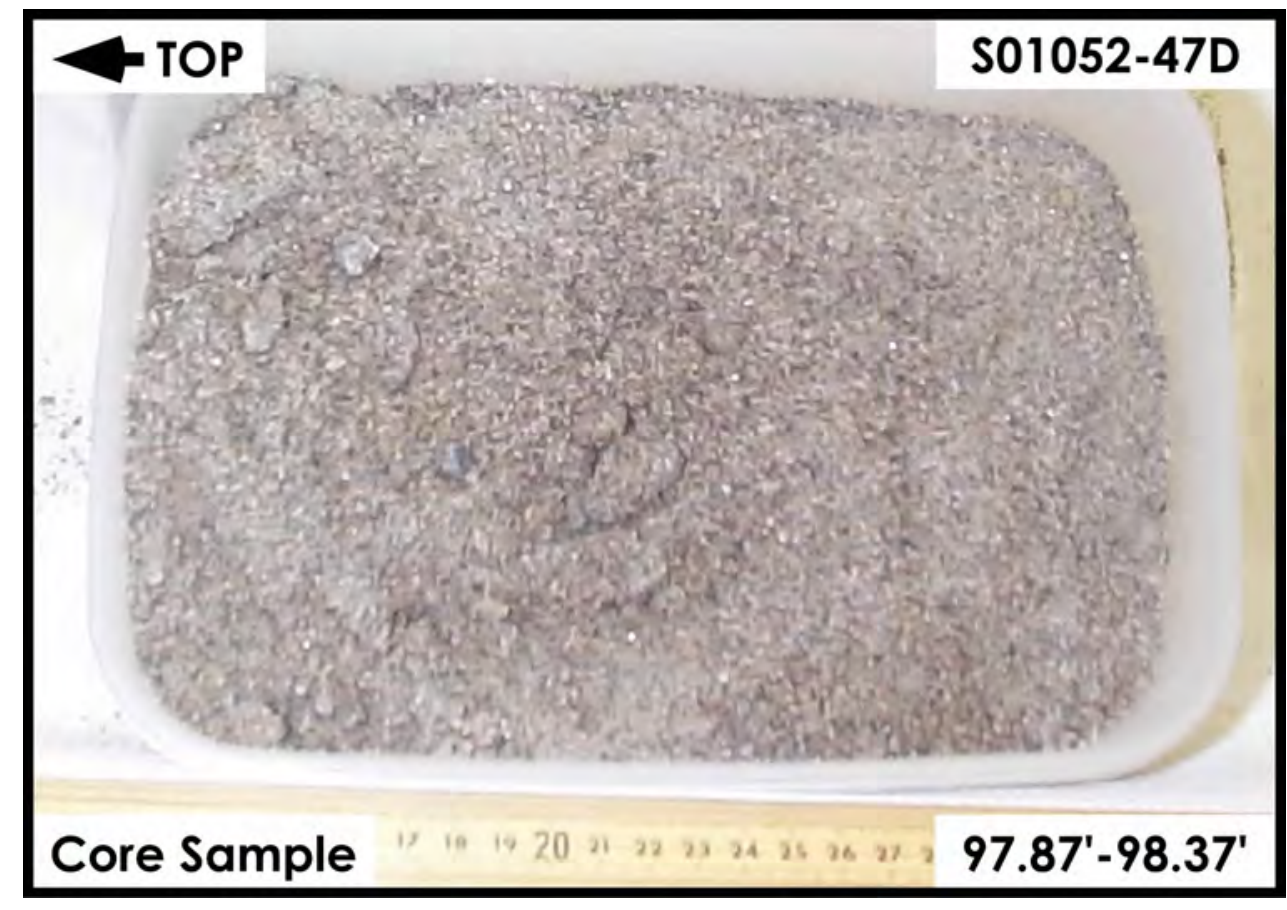

H2-Upper Sand and Gravel Sequence 


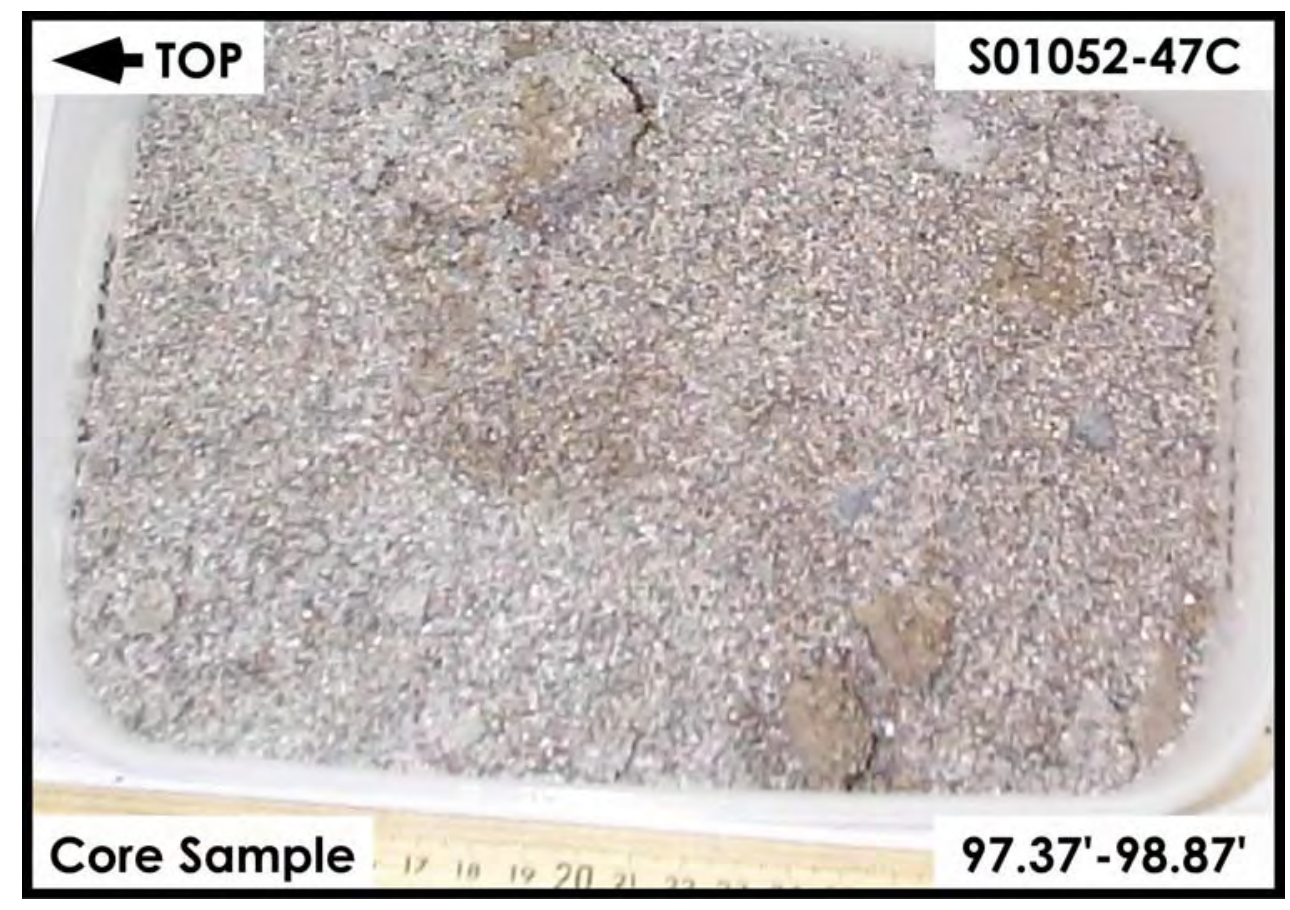

H2-Upper Sand and Gravel Sequence

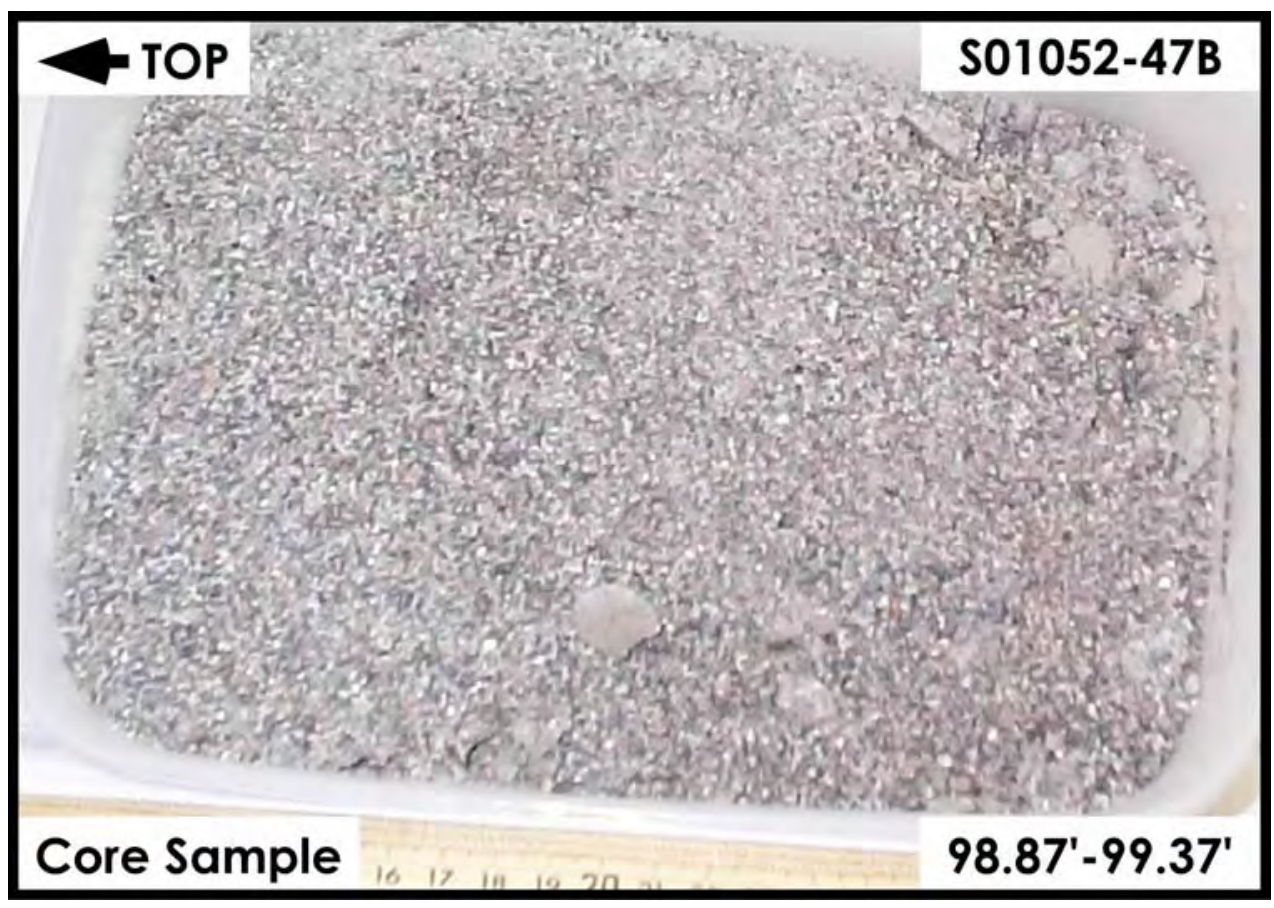

H2-Upper Sand and Gravel Sequence 


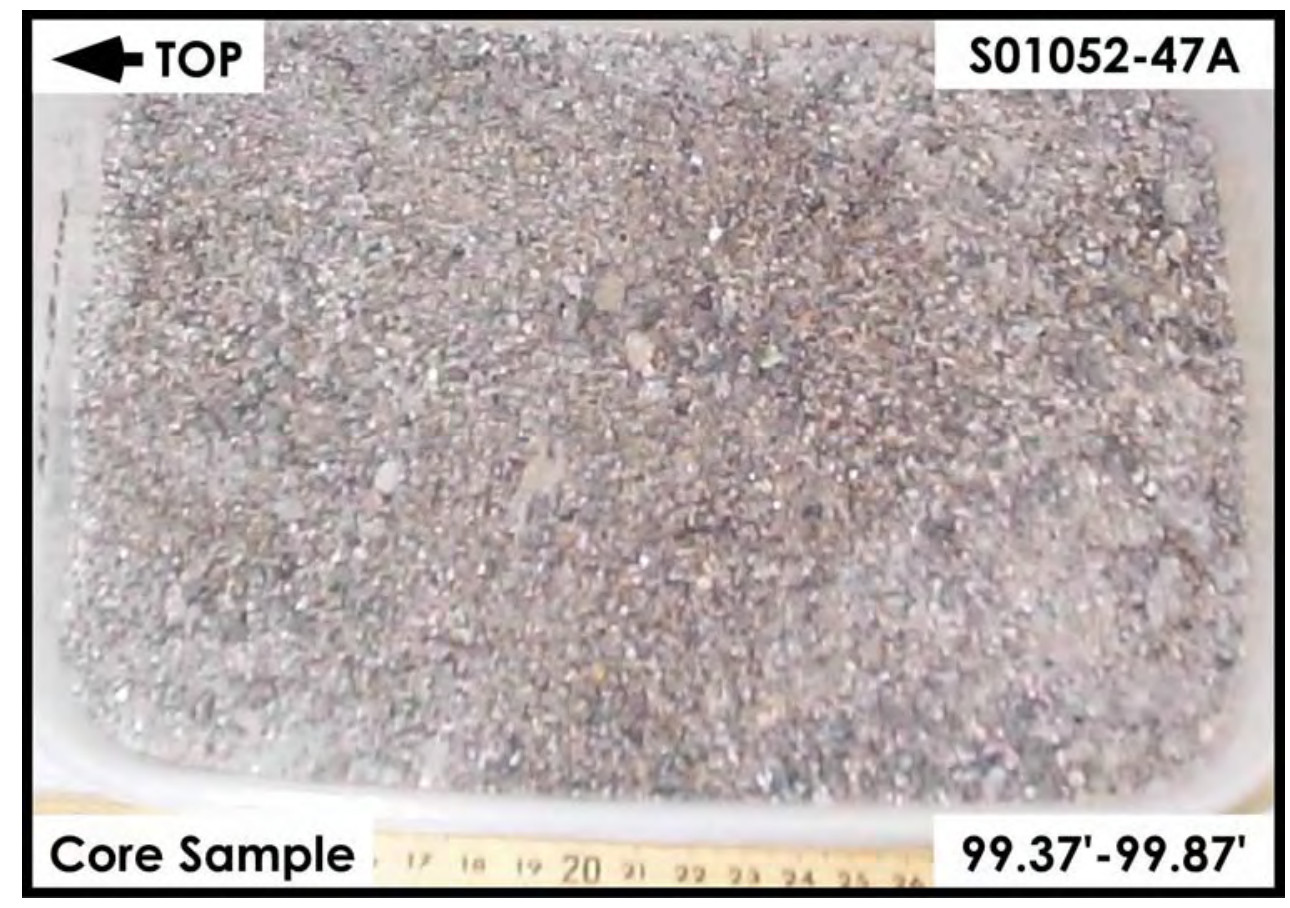

H2-Upper Sand and Gravel Sequence

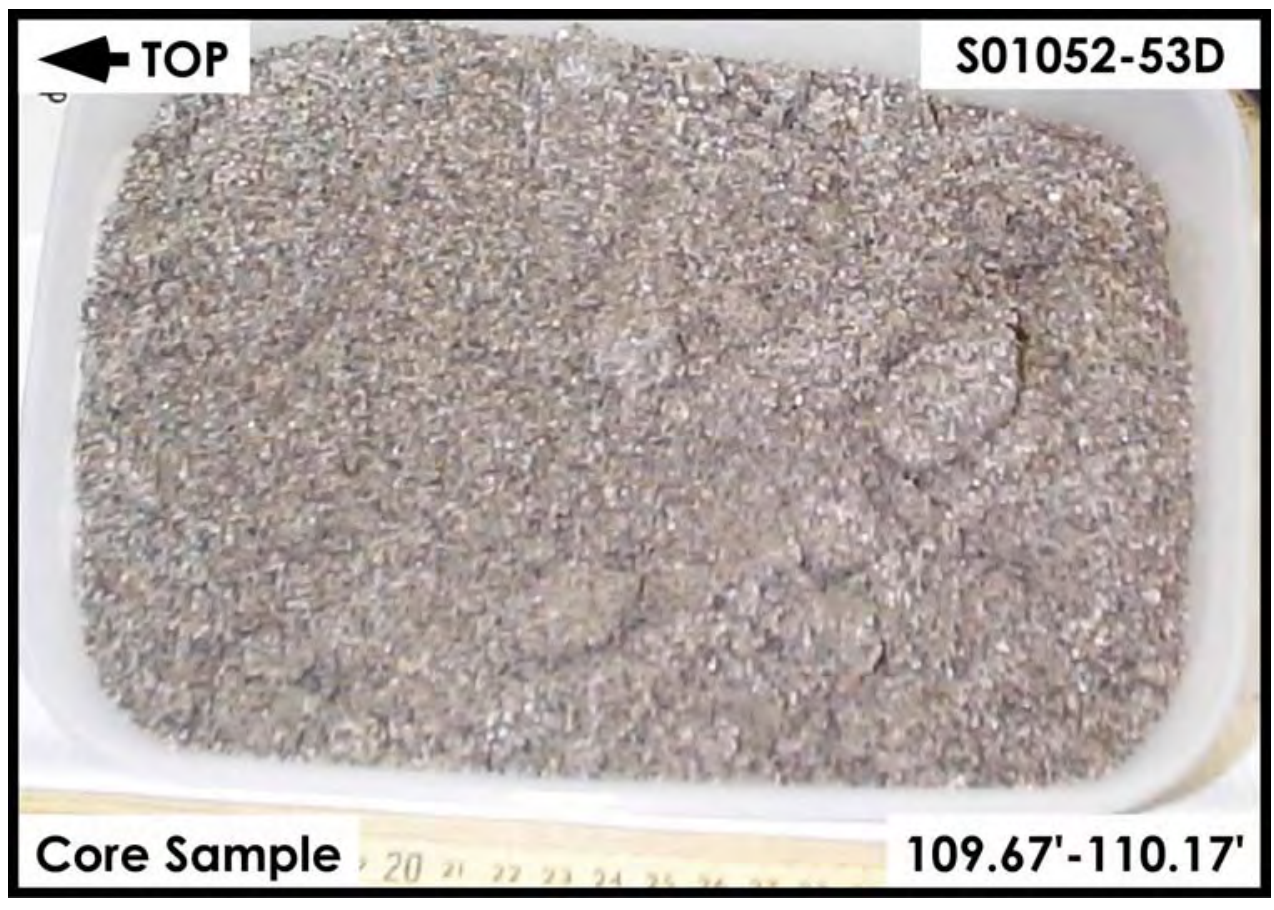

H2-Upper Sand and Gravel Sequence 


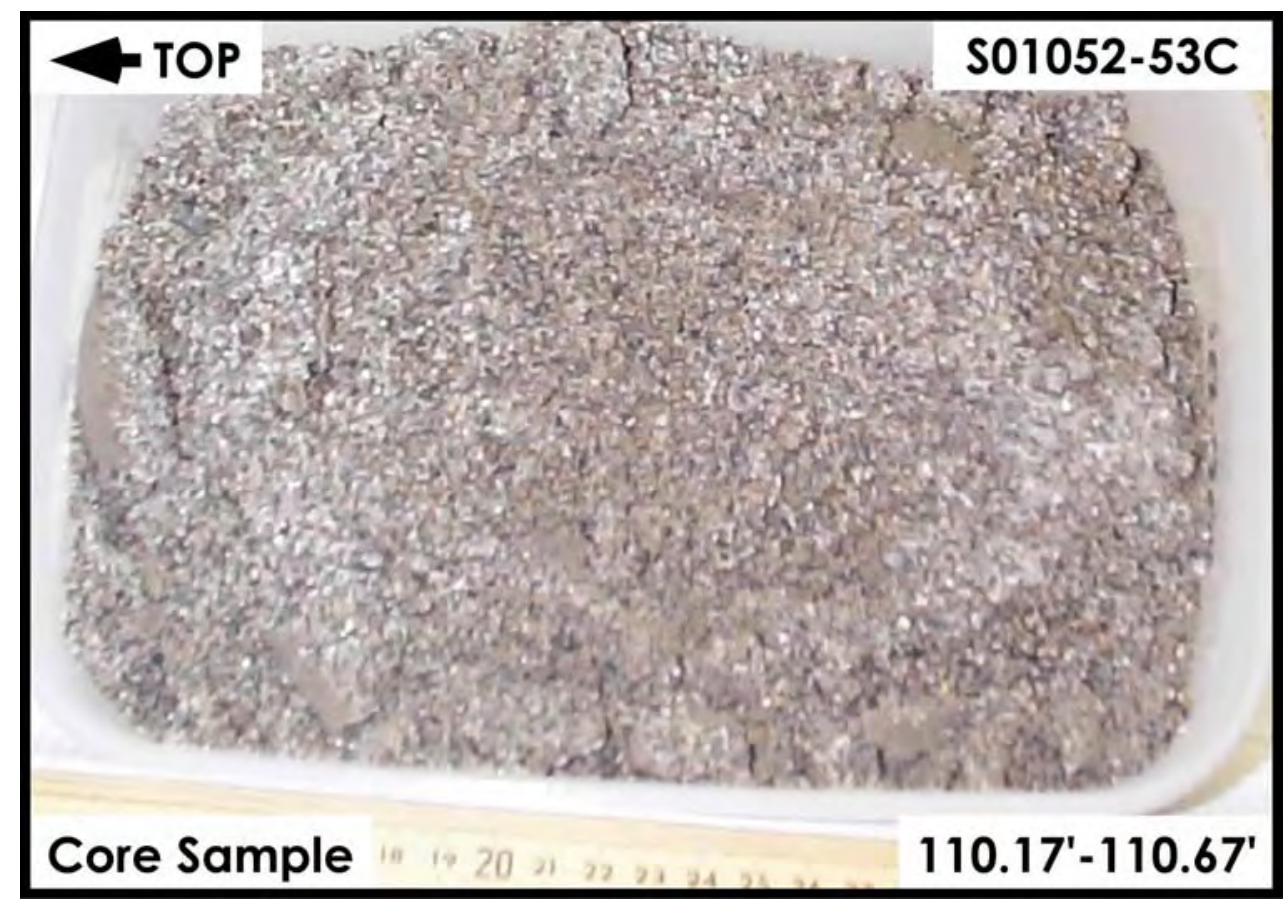

H2-Upper Sand and Gravel Sequence

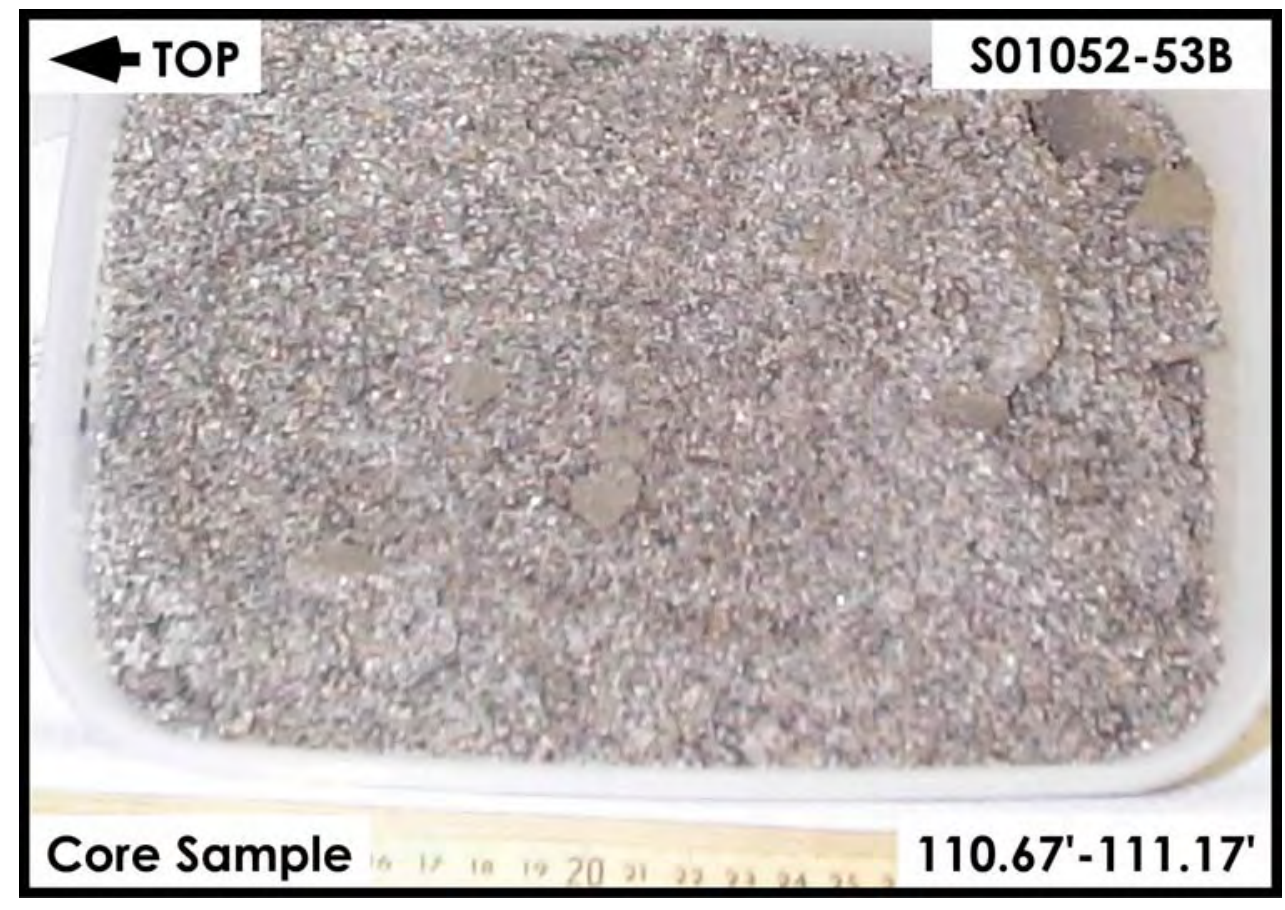

H2-Upper Sand and Gravel Sequence 


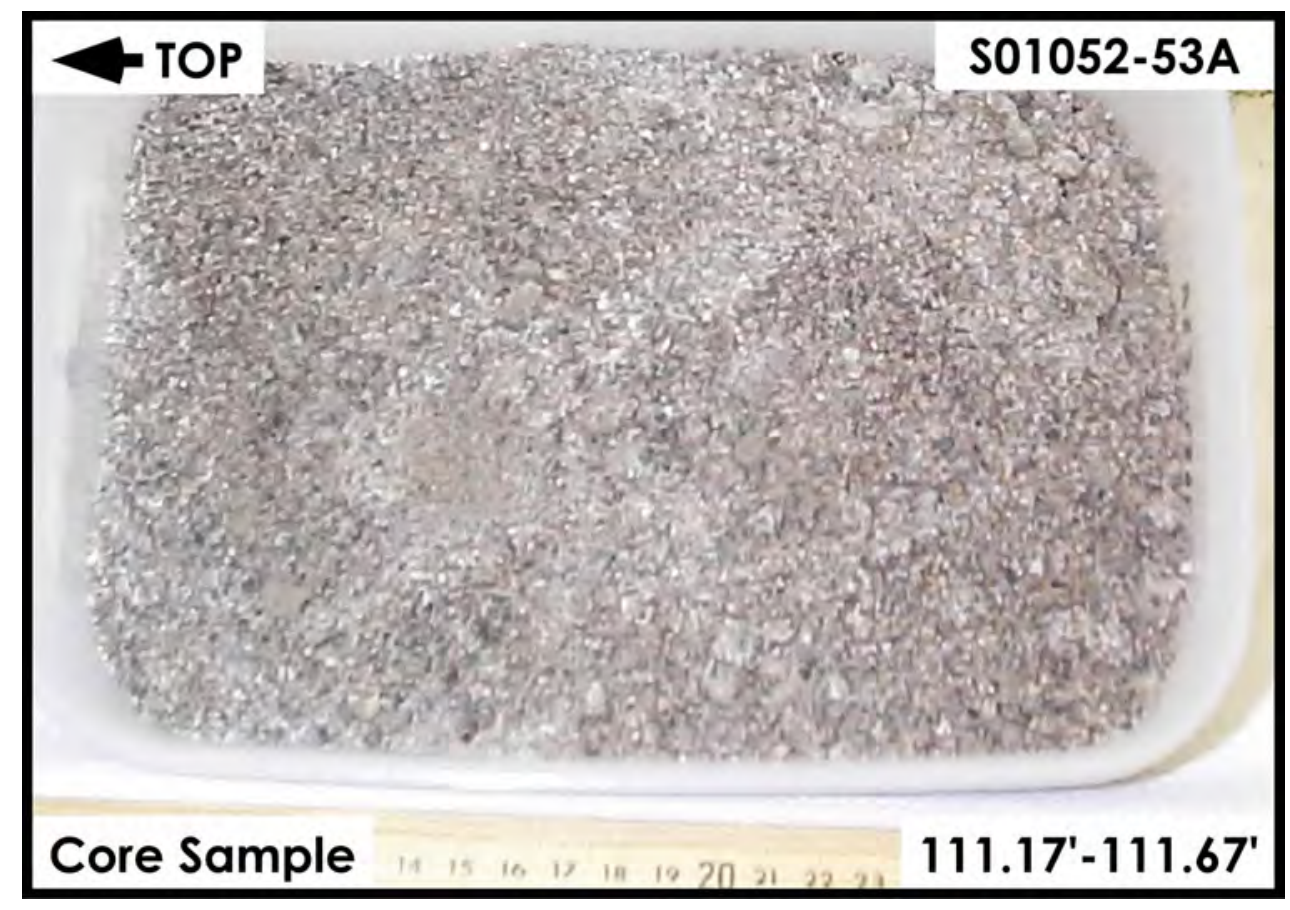

H2-Upper Sand and Gravel Sequence

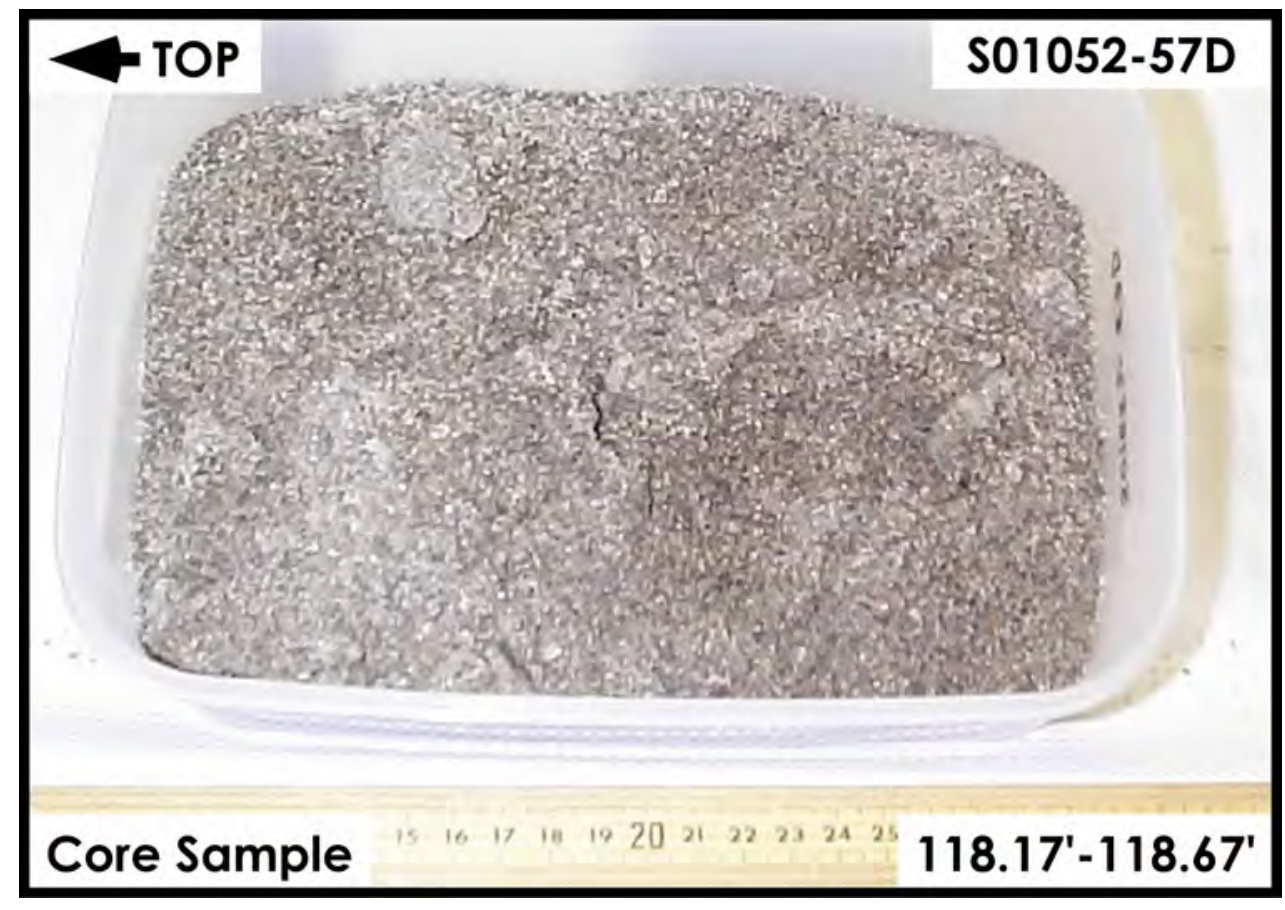

H2-Upper Sand and Gravel Sequence 


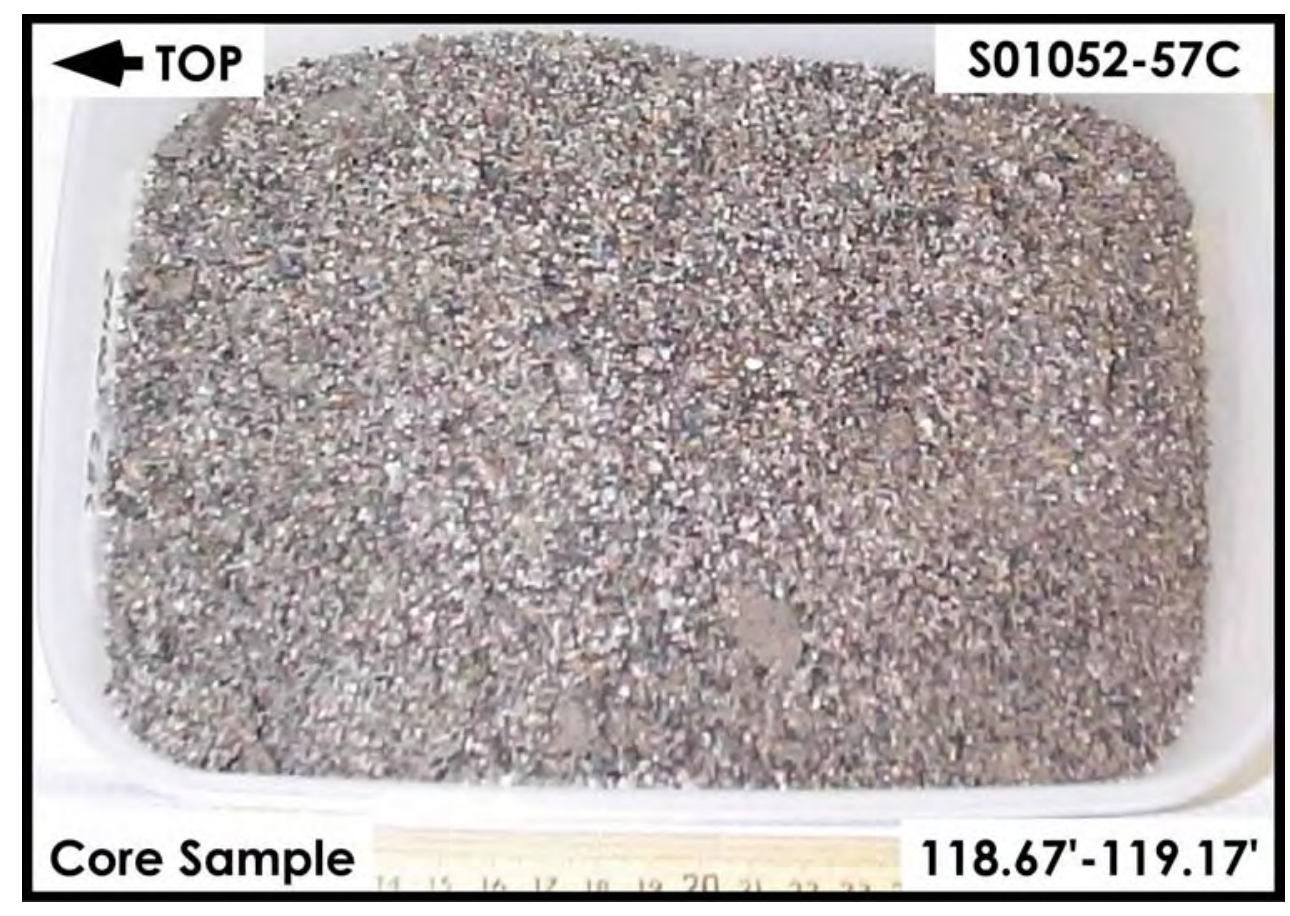

H2-Upper Sand and Gravel Sequence

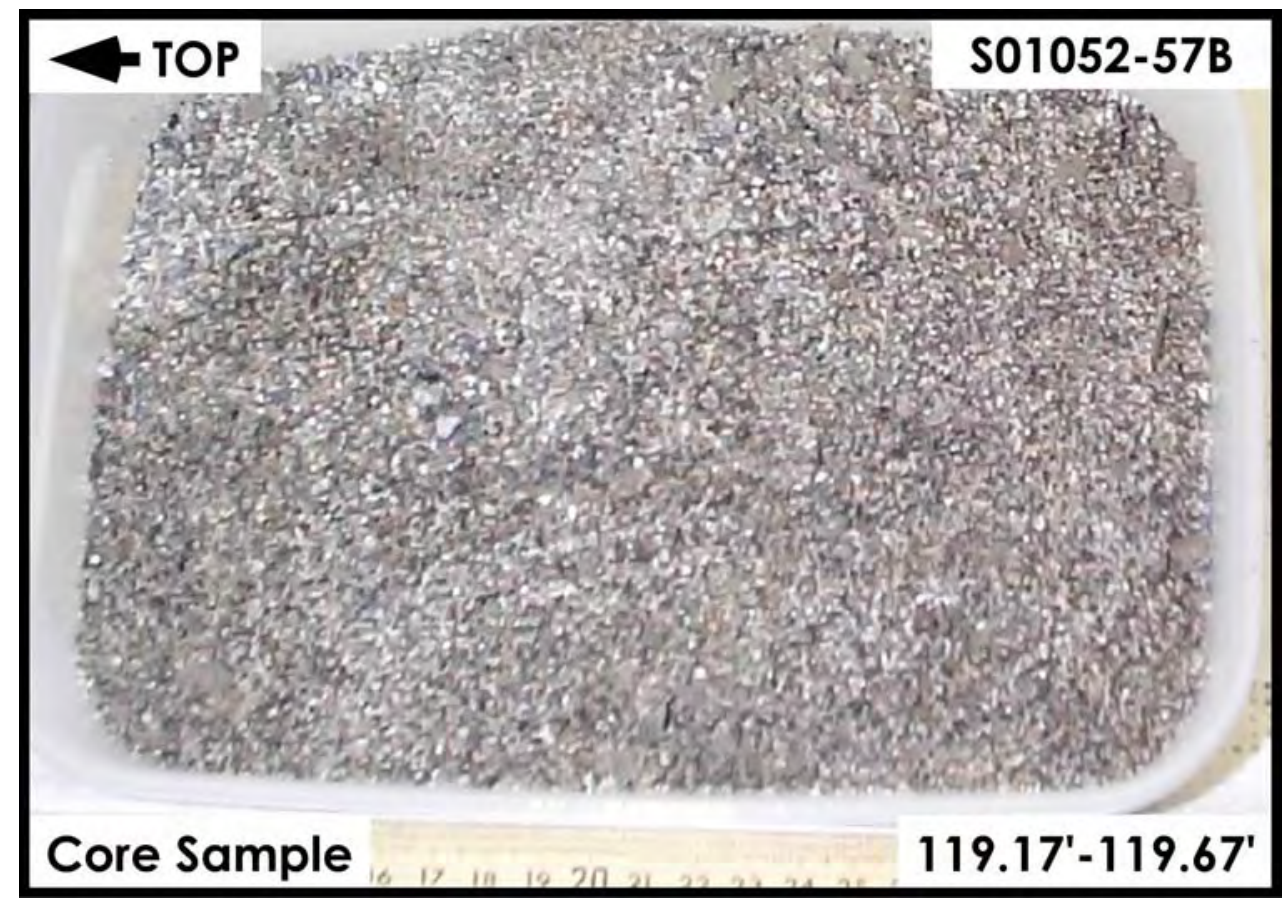

H2-Upper Sand and Gravel Sequence 


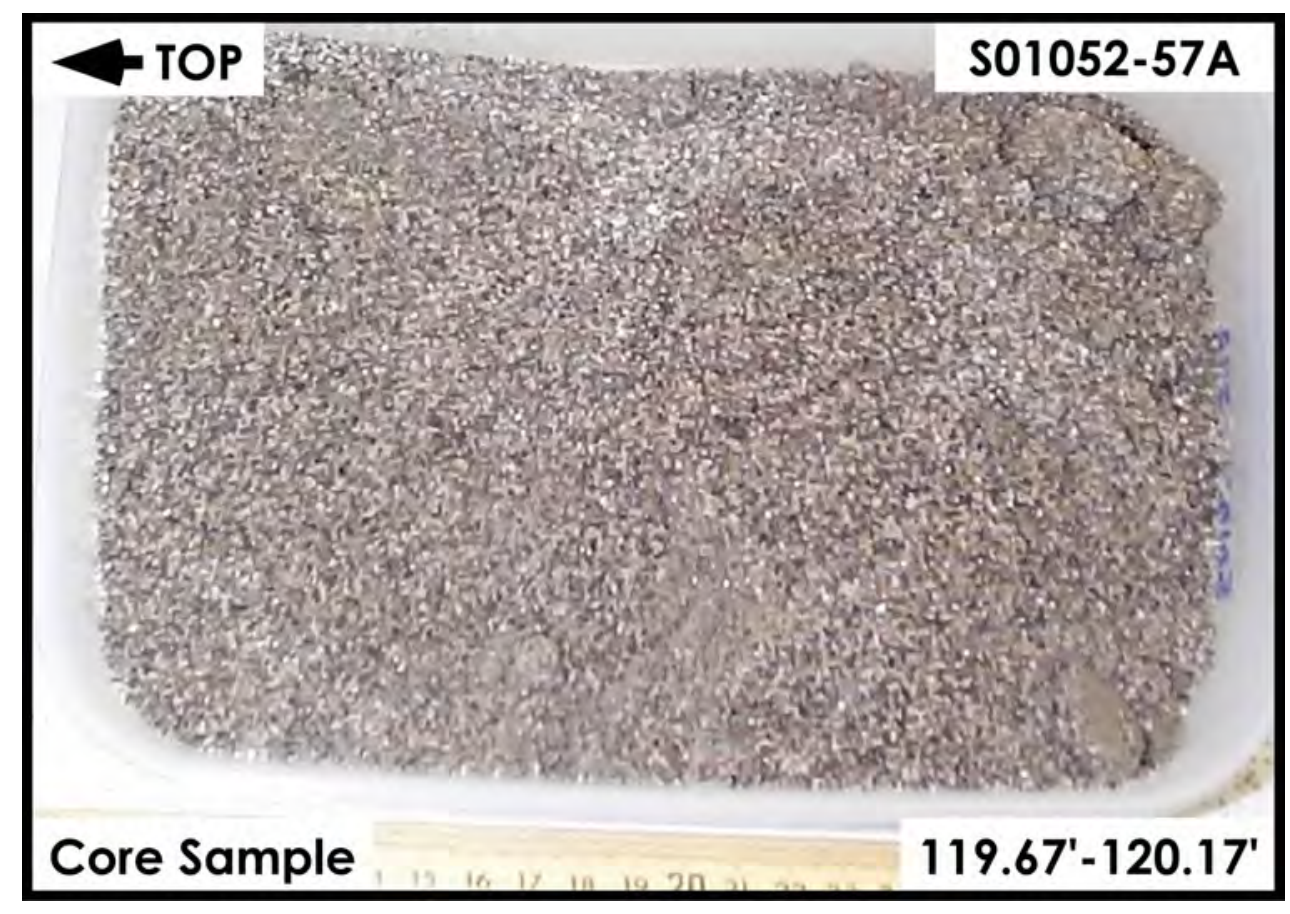

H2-Upper Sand and Gravel Sequence

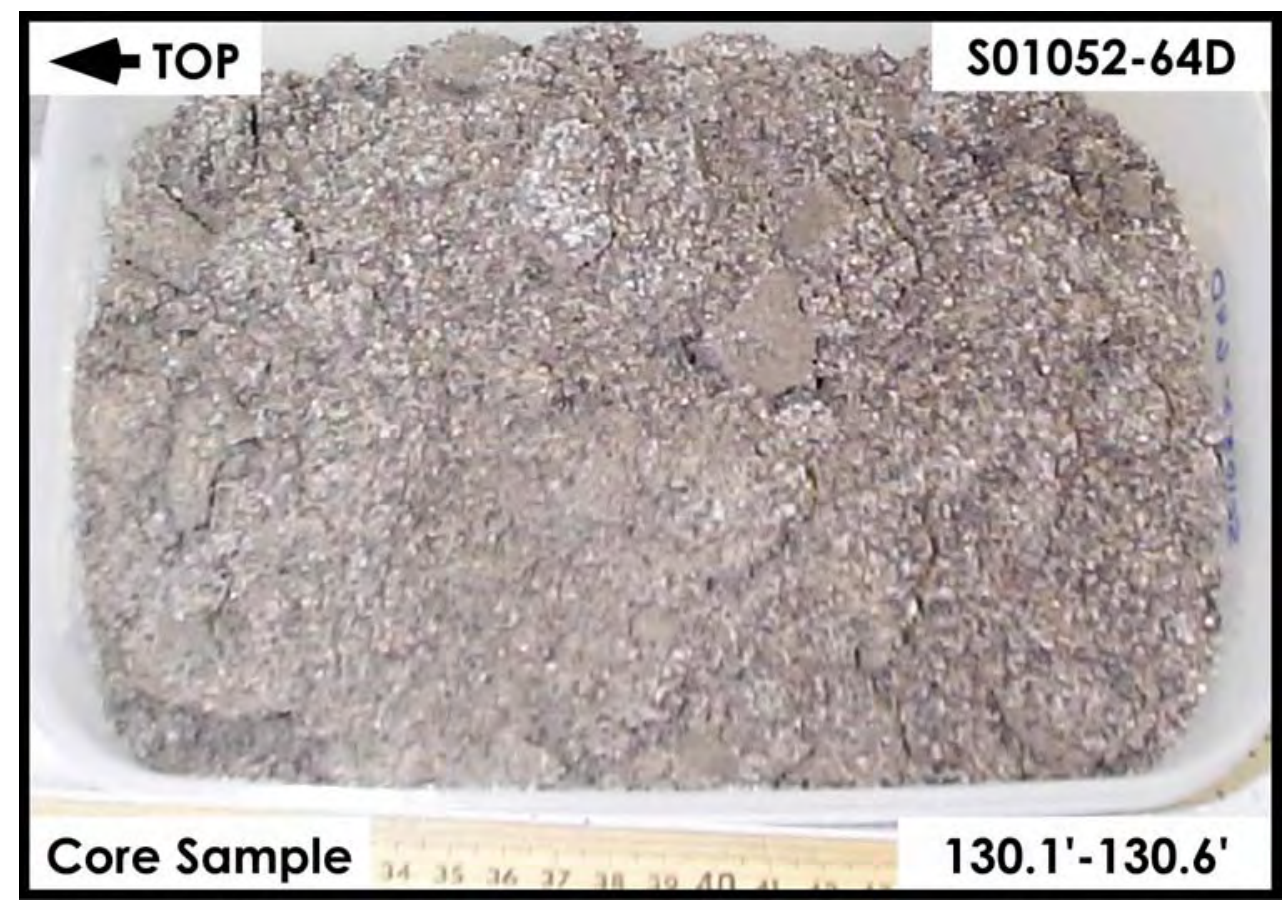

H2-Upper Sand and Gravel Sequence 


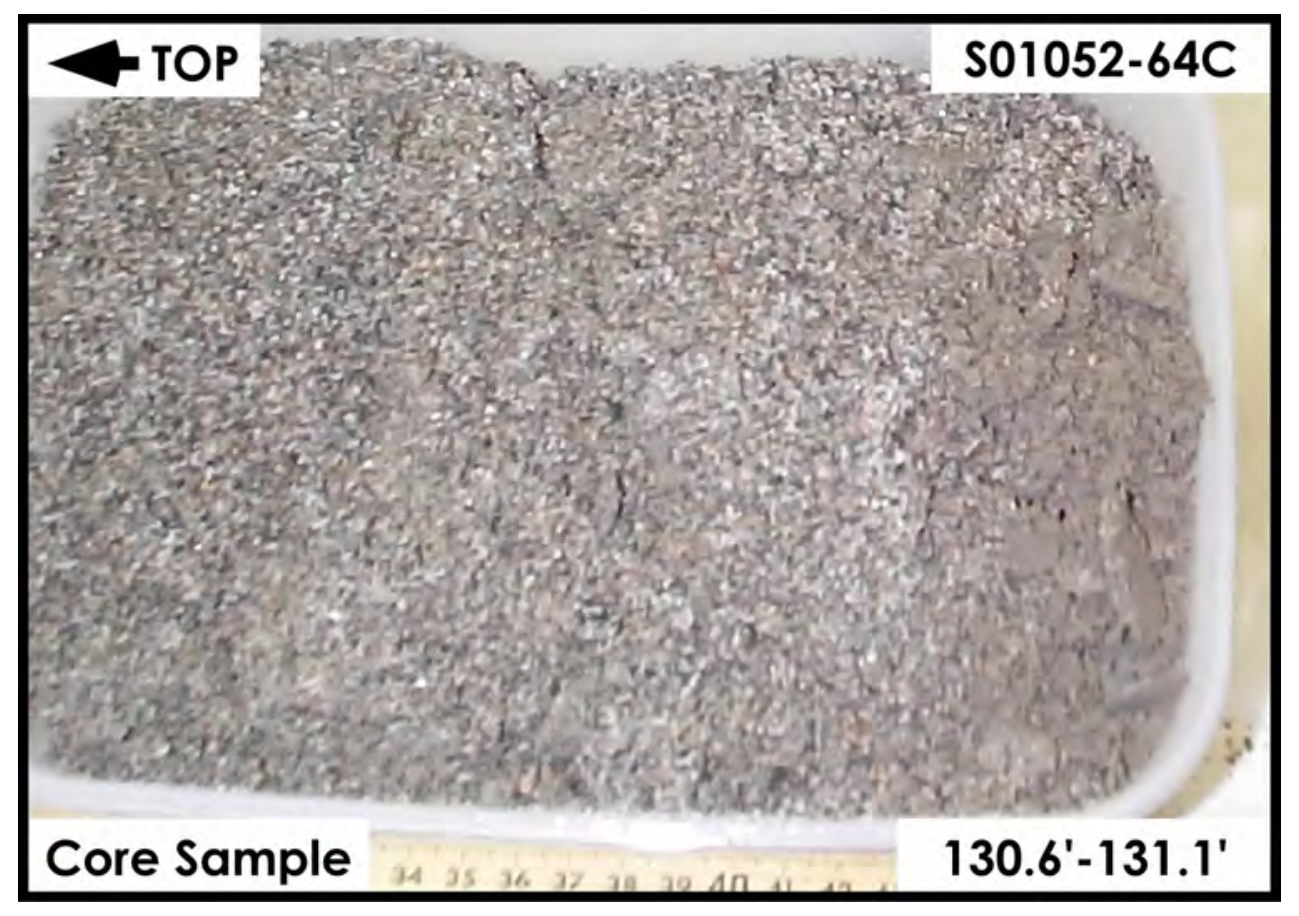

H2-Upper Sand and Gravel Sequence

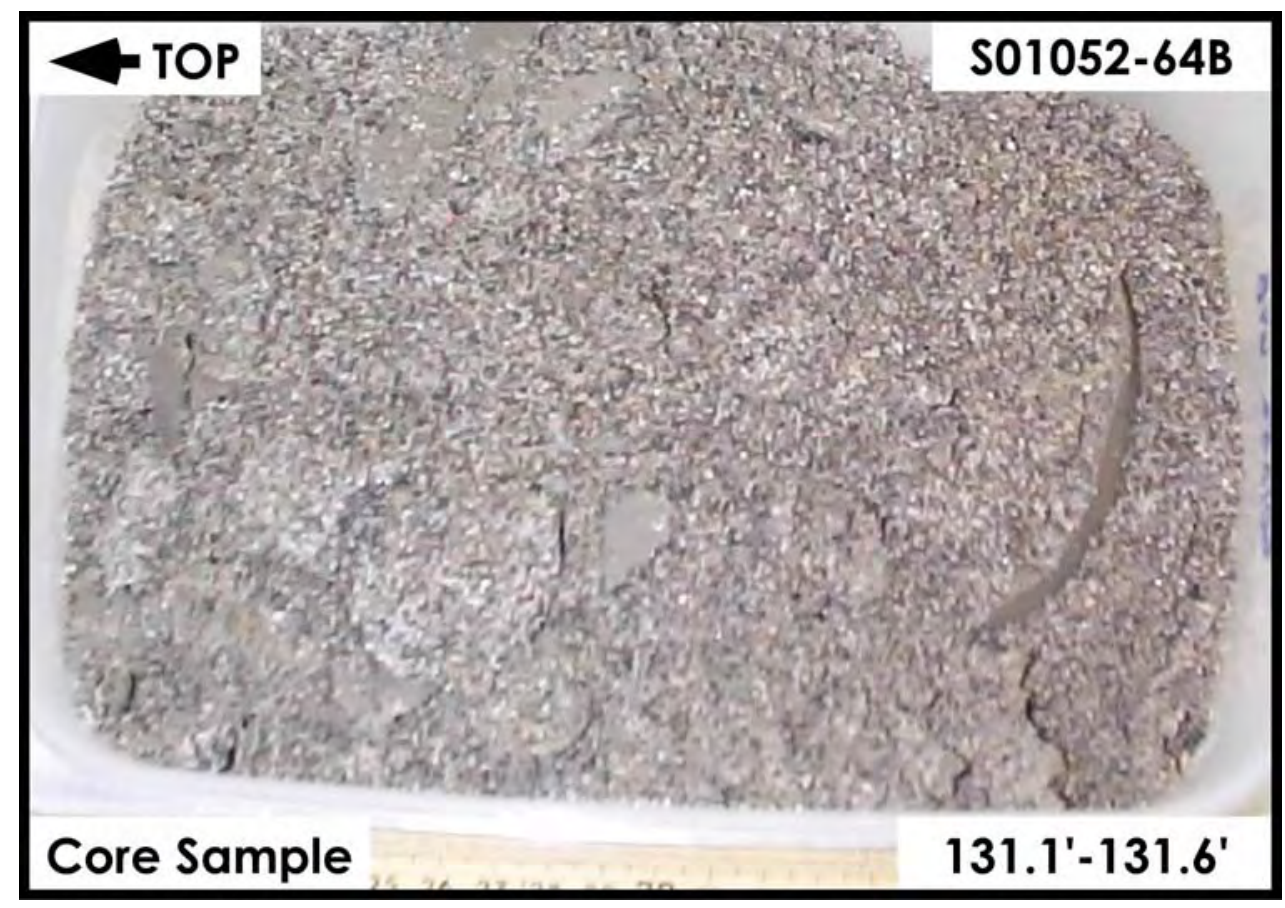

H2-Upper Sand and Gravel Sequence 


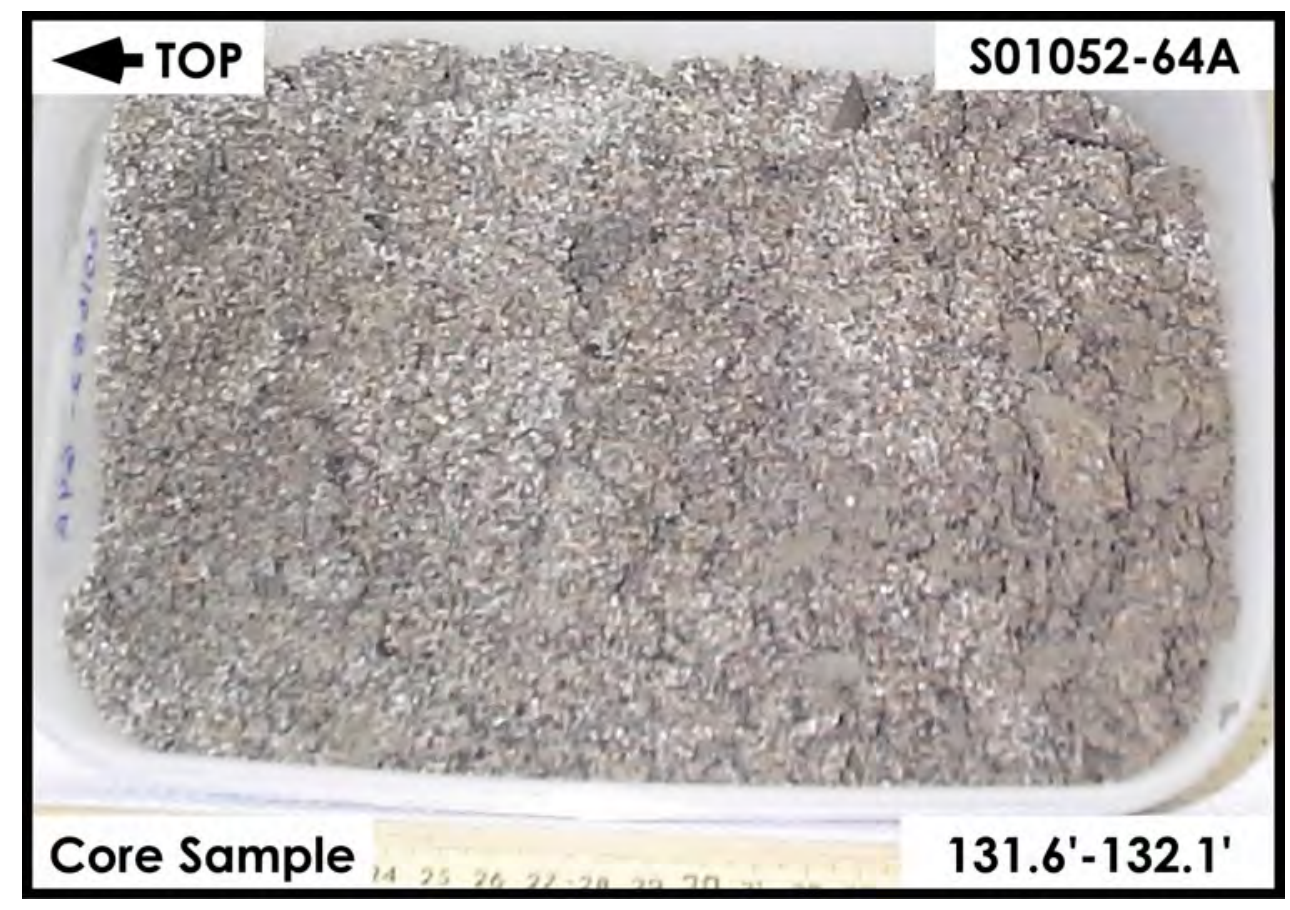

H2-Upper Sand and Gravel Sequence

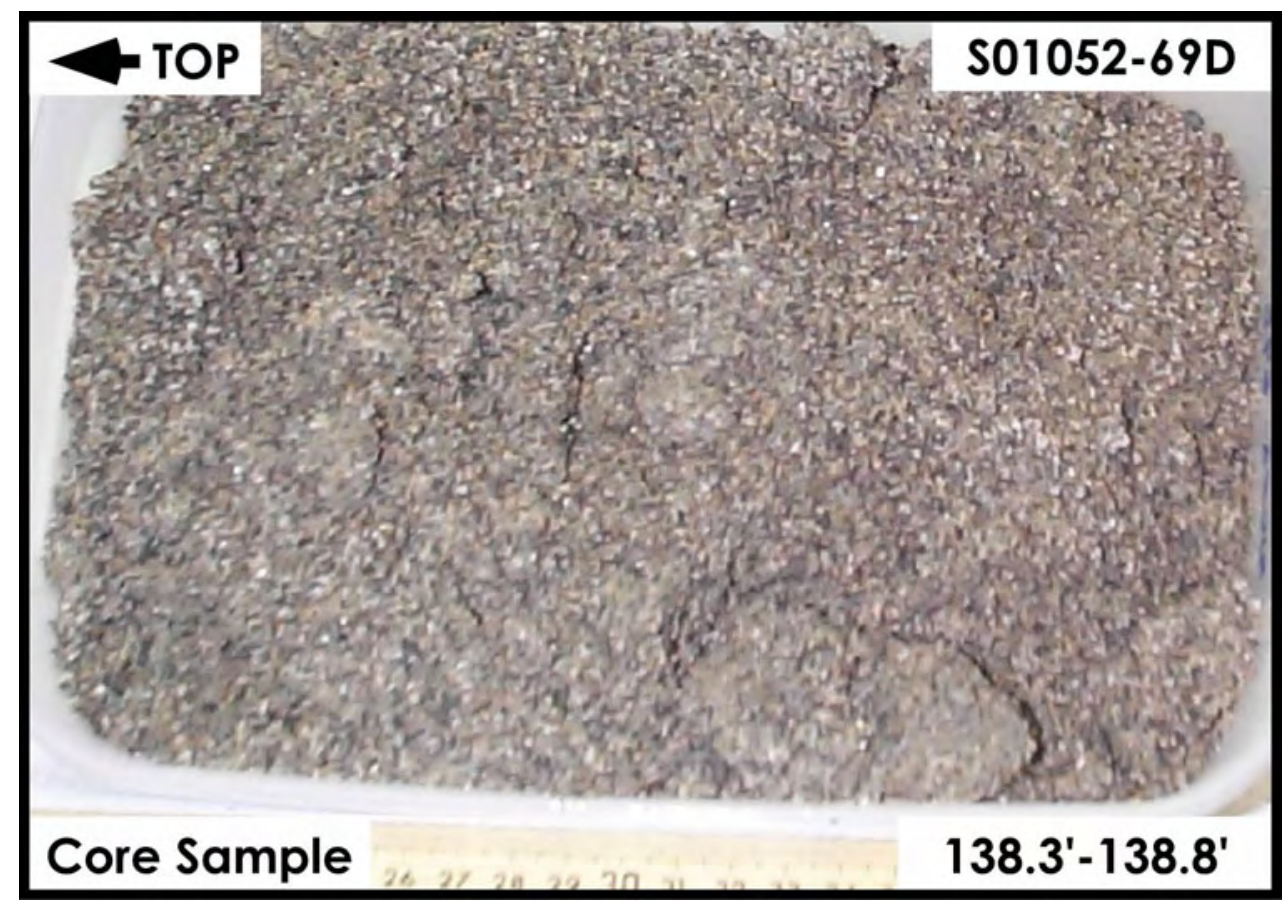

H2-Upper Sand and Gravel Sequence 


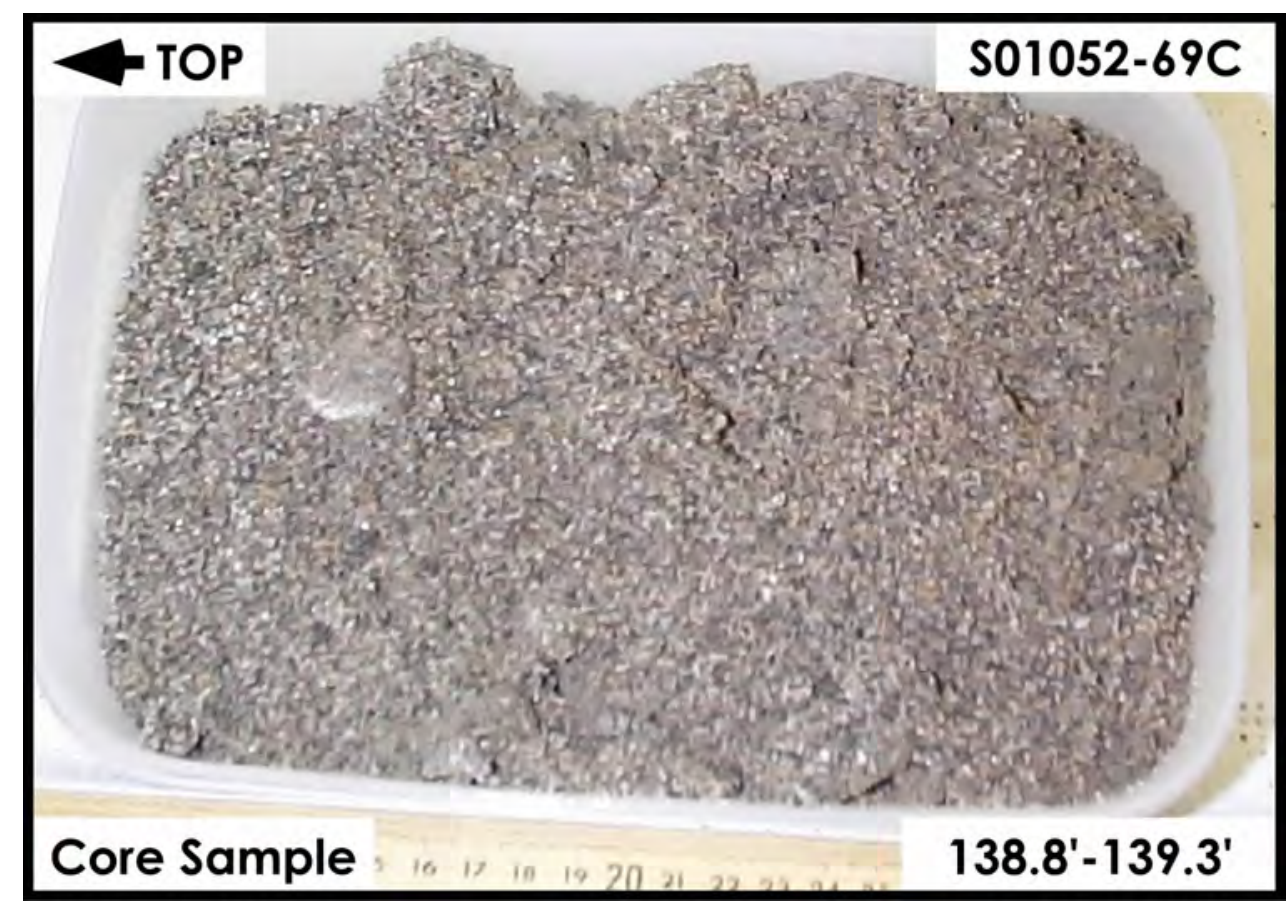

H2-Upper Sand and Gravel Sequence

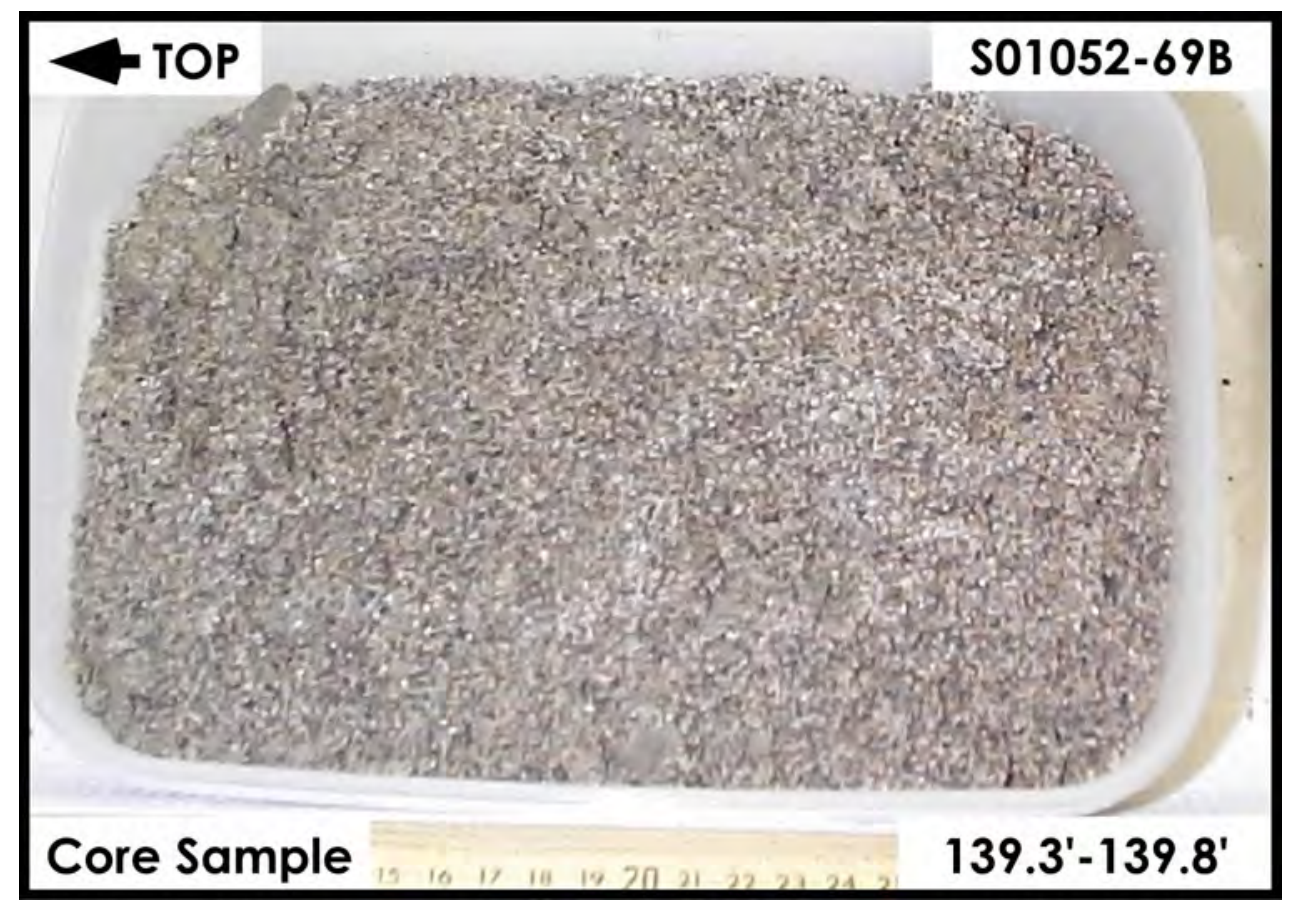

H2-Upper Sand and Gravel Sequence 


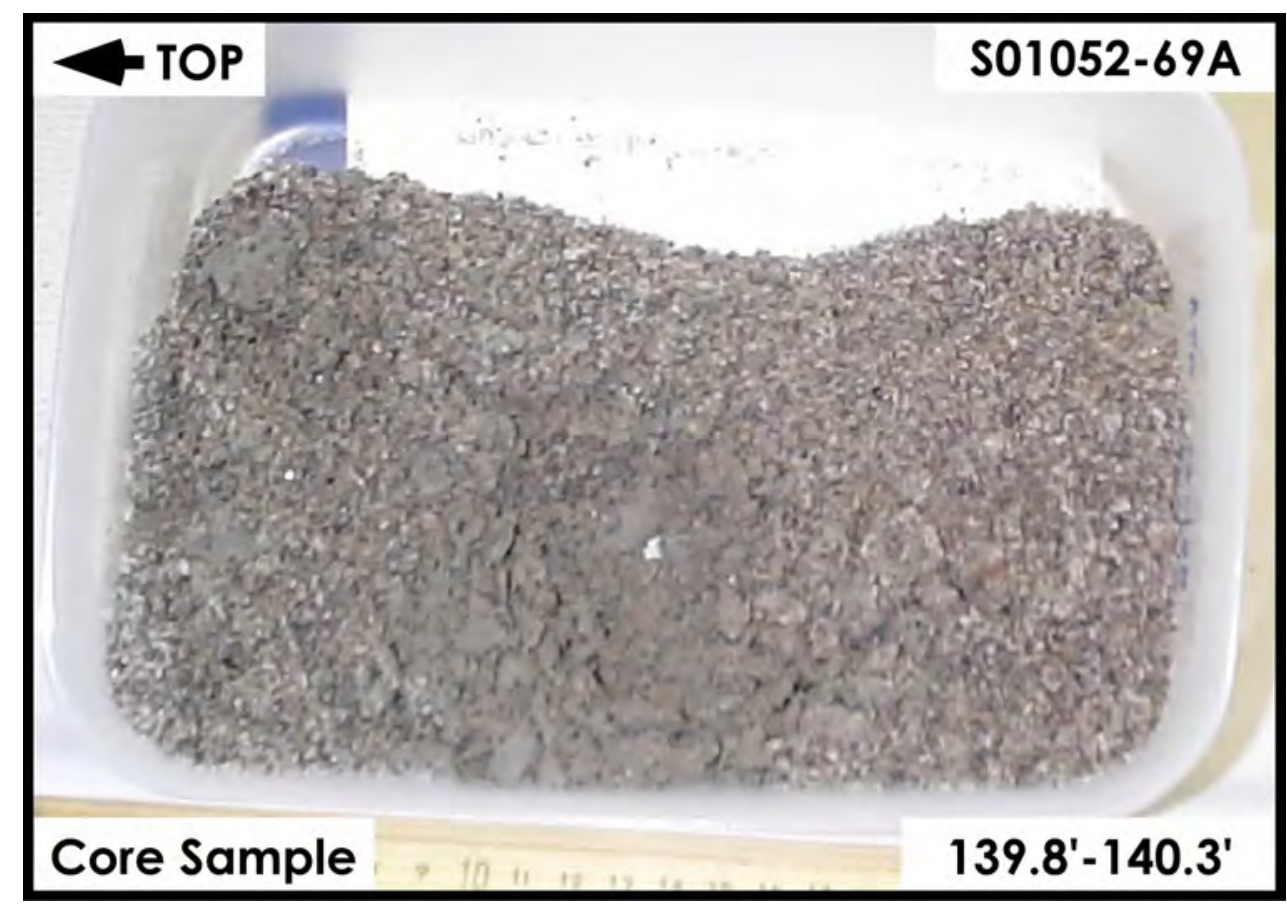

H2-Upper Sand and Gravel Sequence

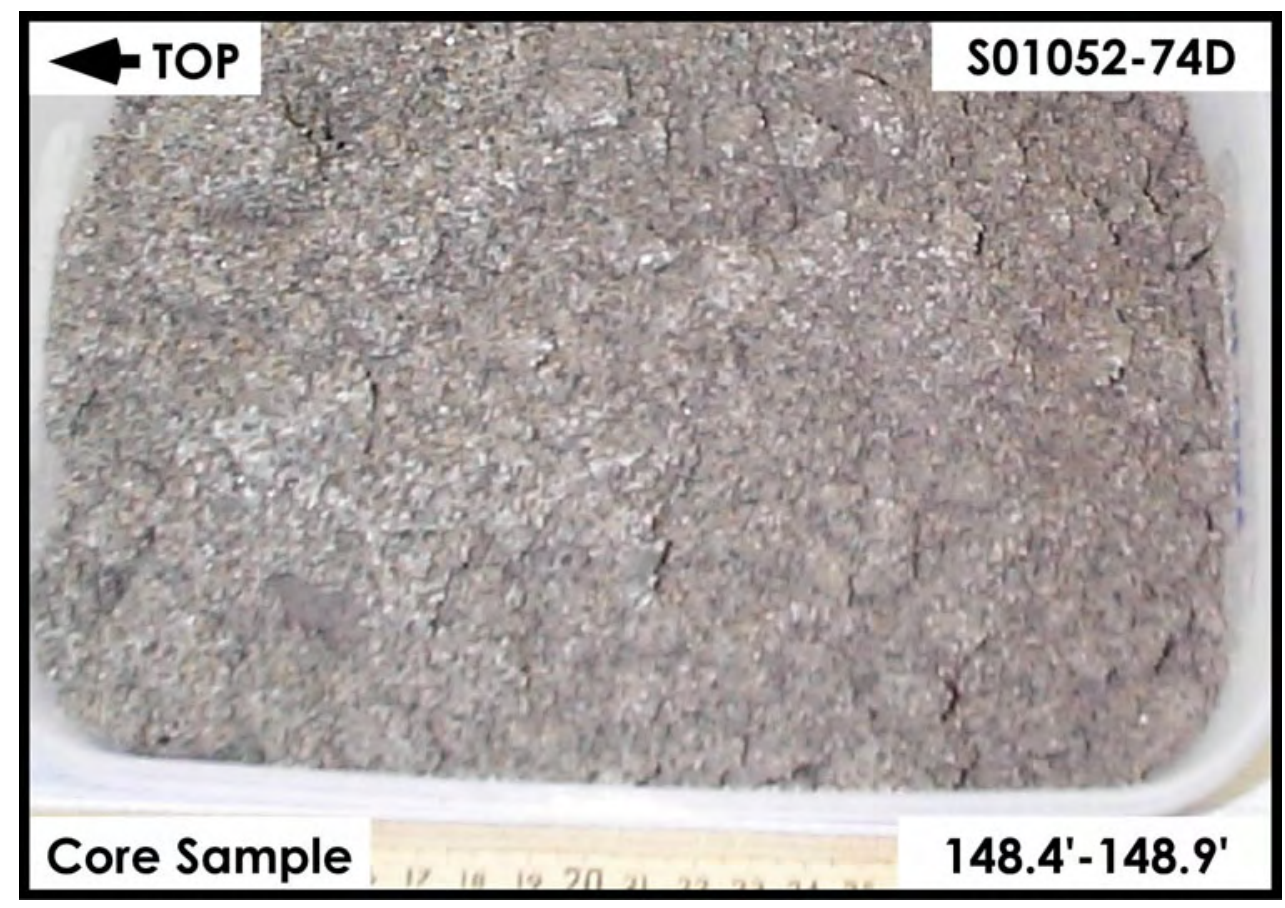

H2-Upper Sand and Gravel Sequence 


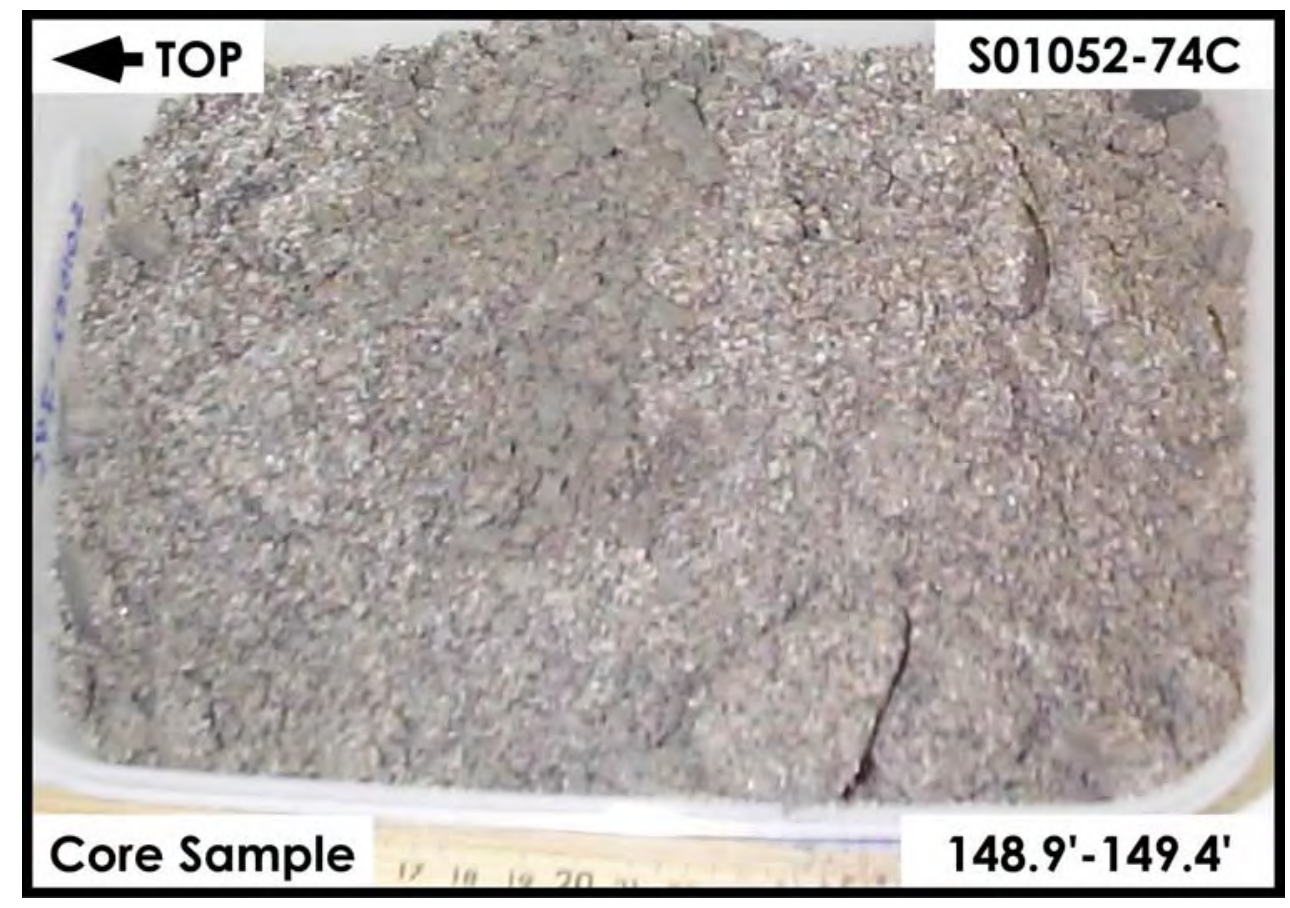

H2-Upper Sand and Gravel Sequence

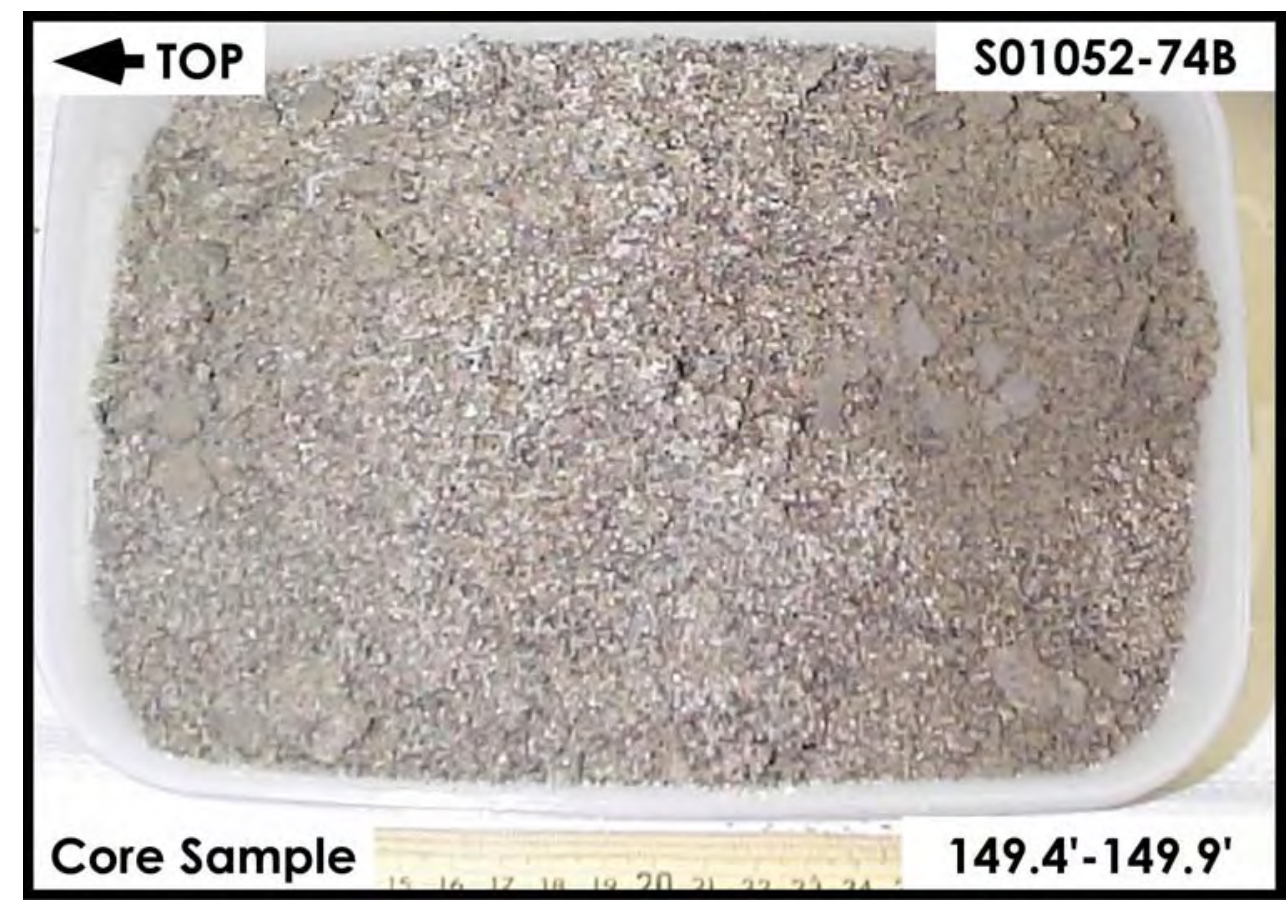

H2-Upper Sand and Gravel Sequence 


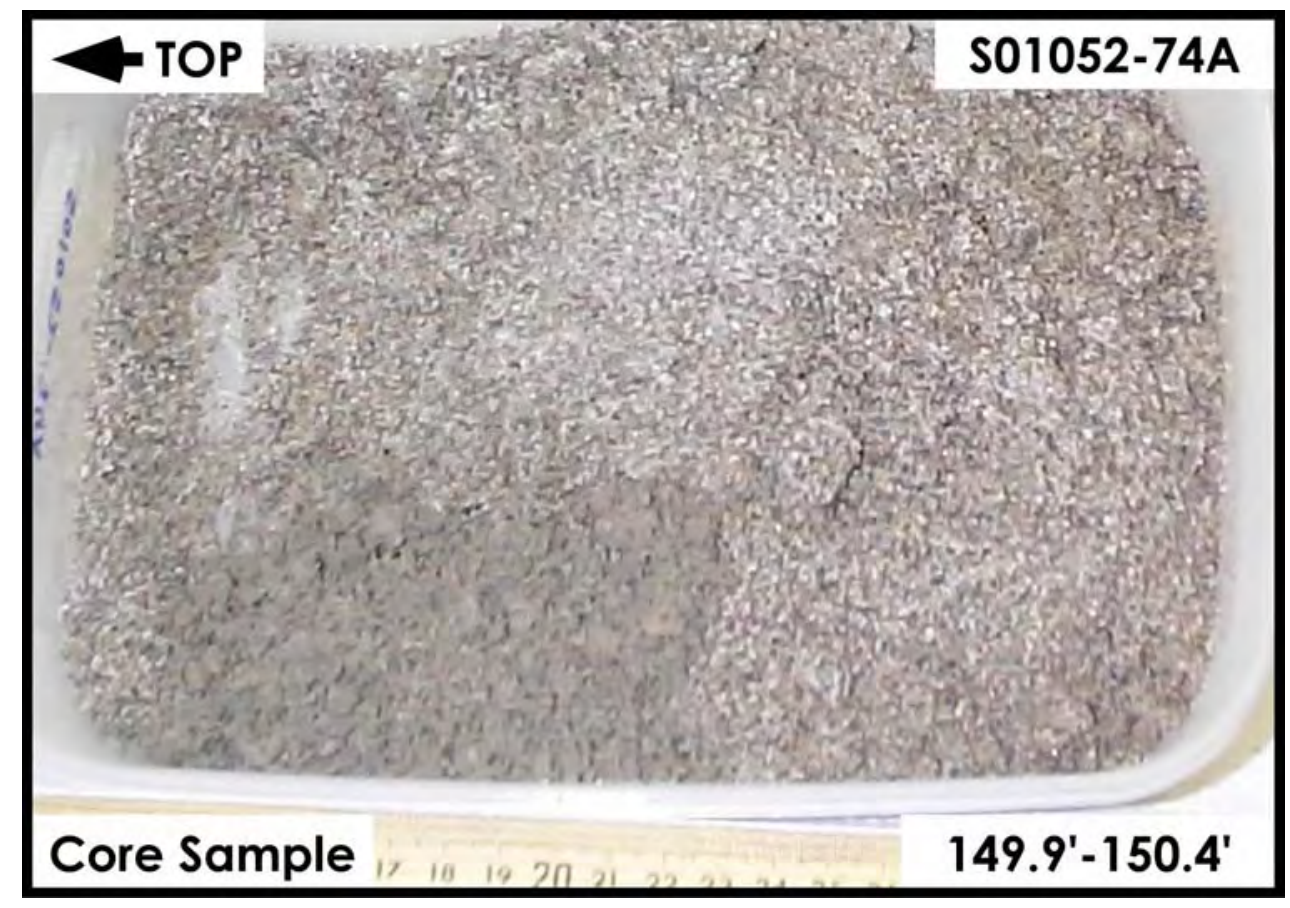

H2-Upper Sand and Gravel Sequence

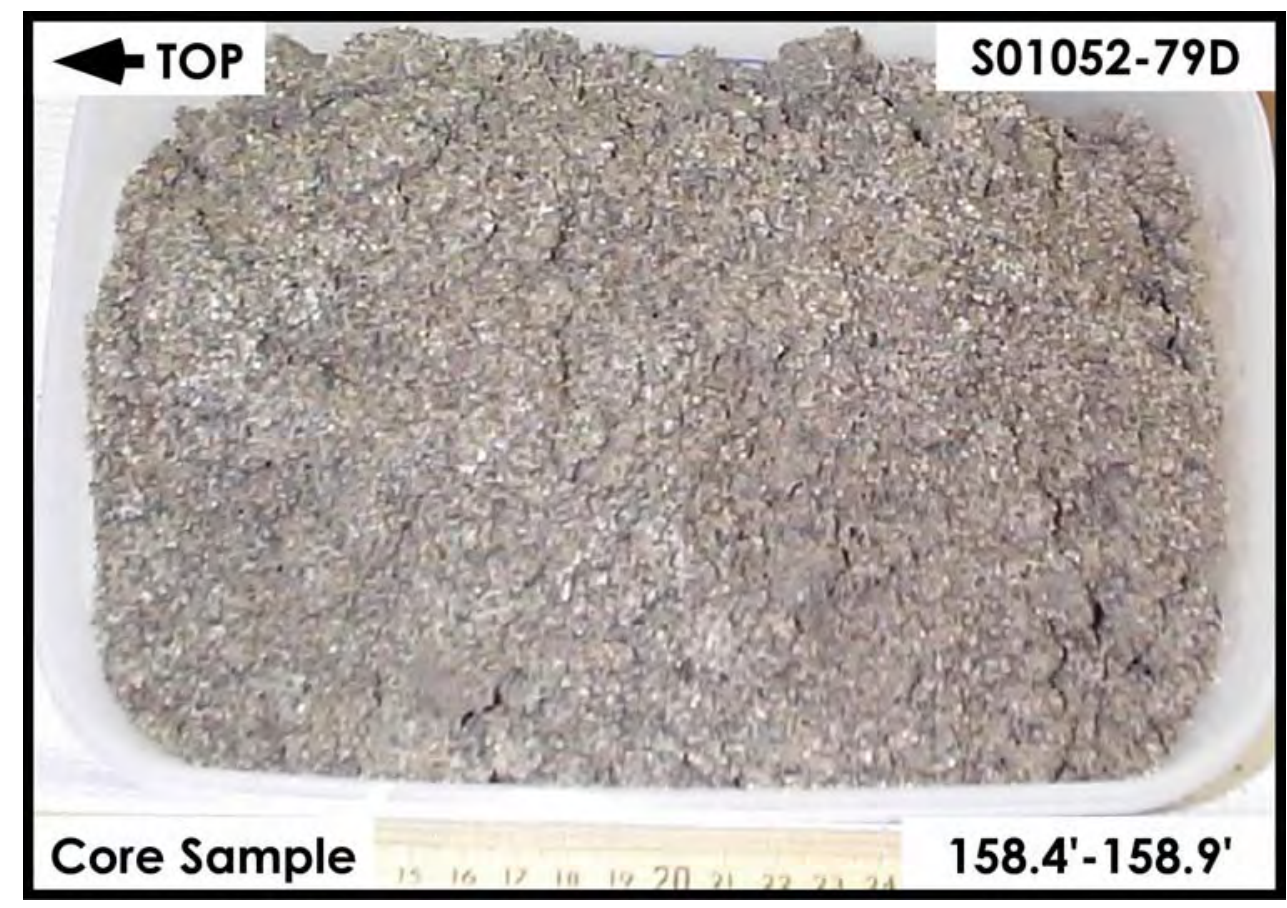

H2-Upper Sand and Gravel Sequence 


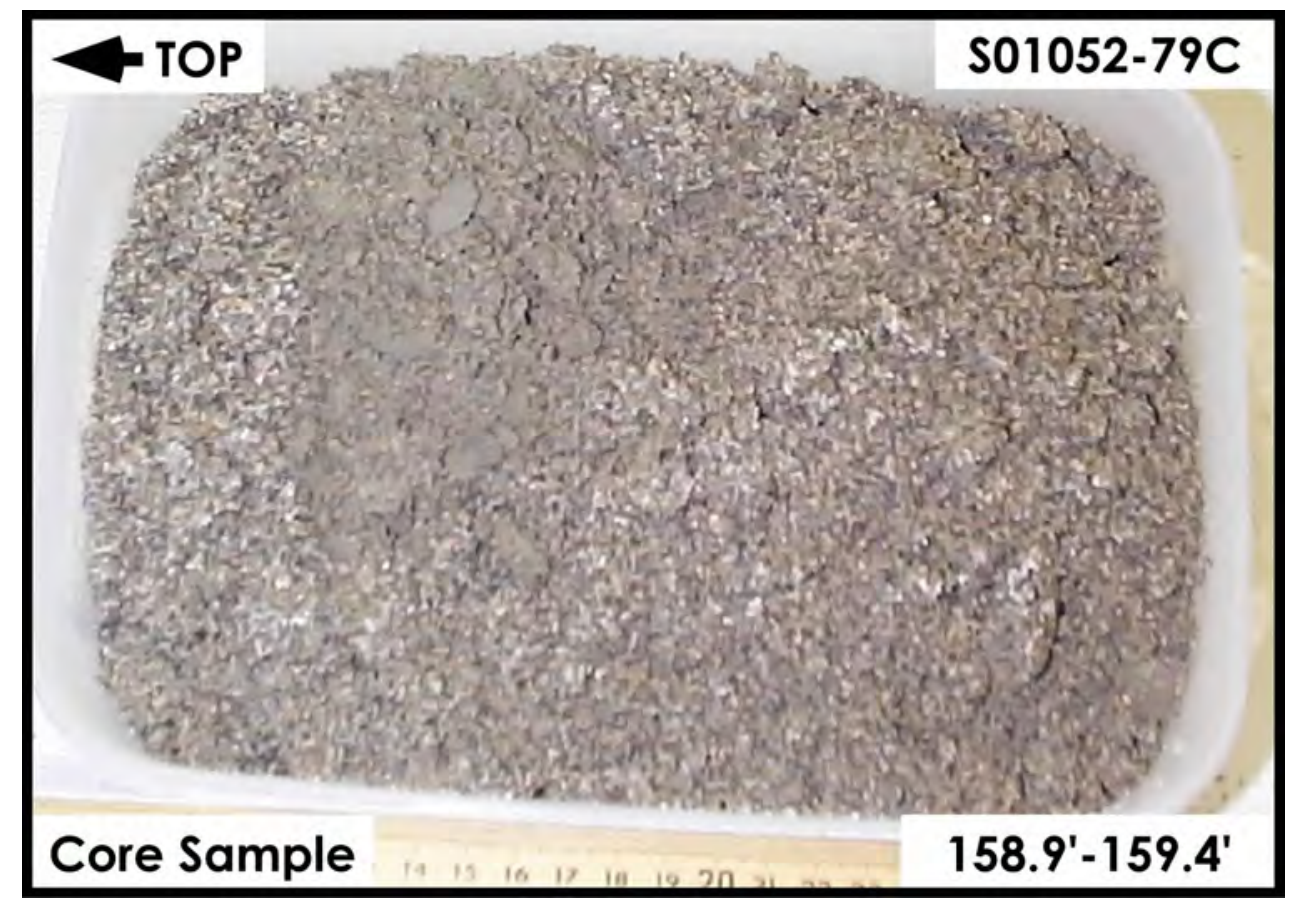

H2-Upper Sand and Gravel Sequence

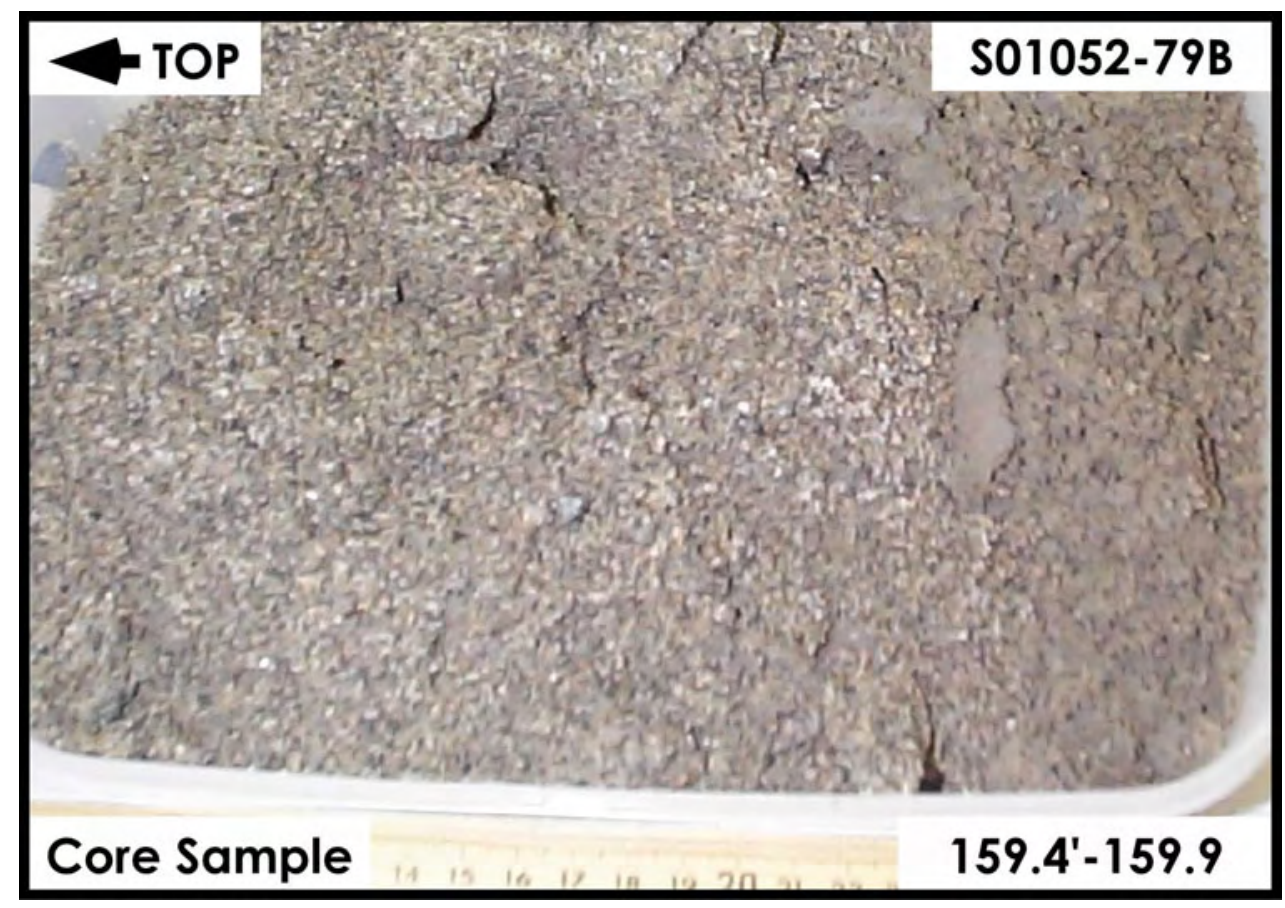

H2-Upper Sand and Gravel Sequence 


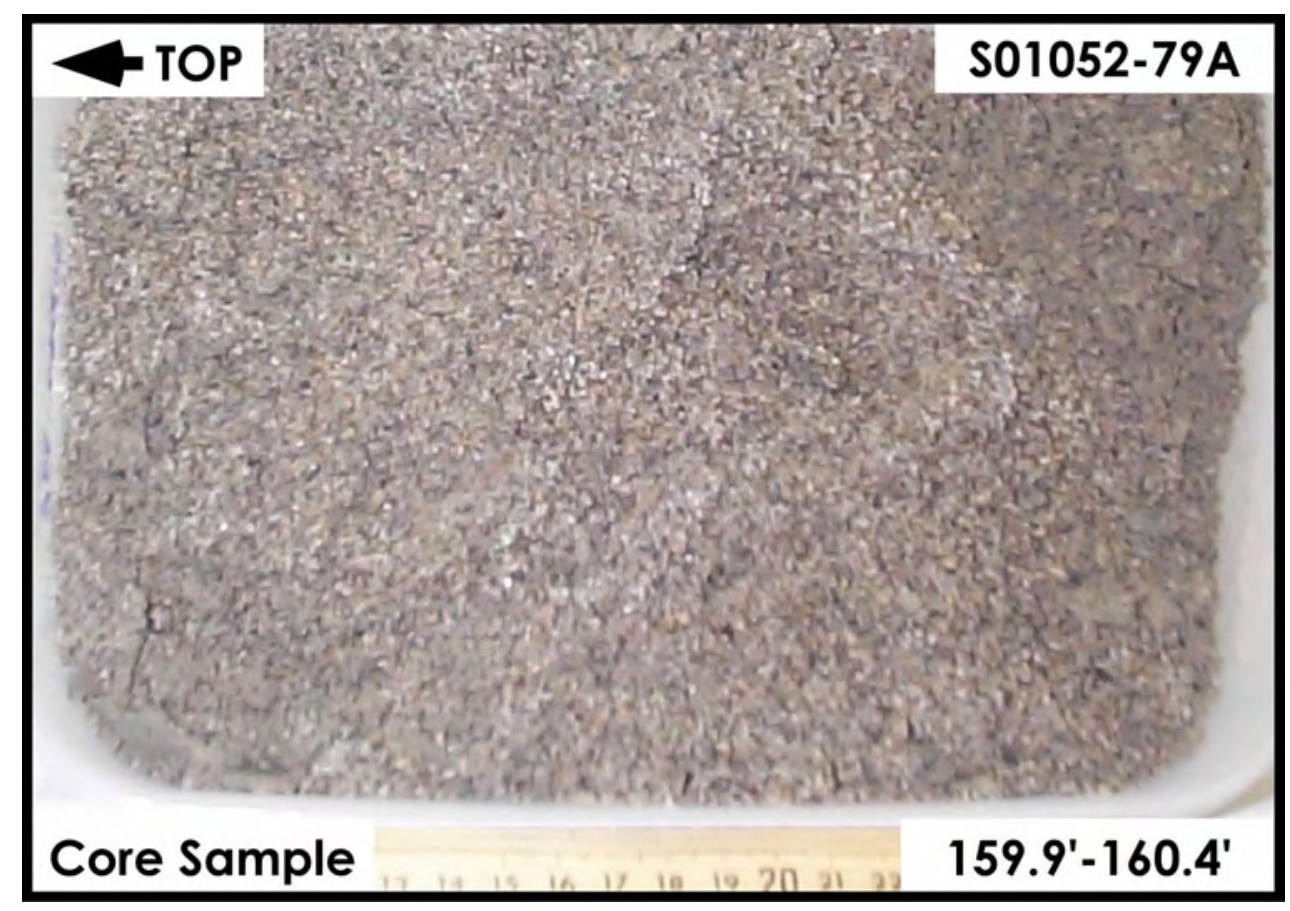

H2-Upper Sand and Gravel Sequence

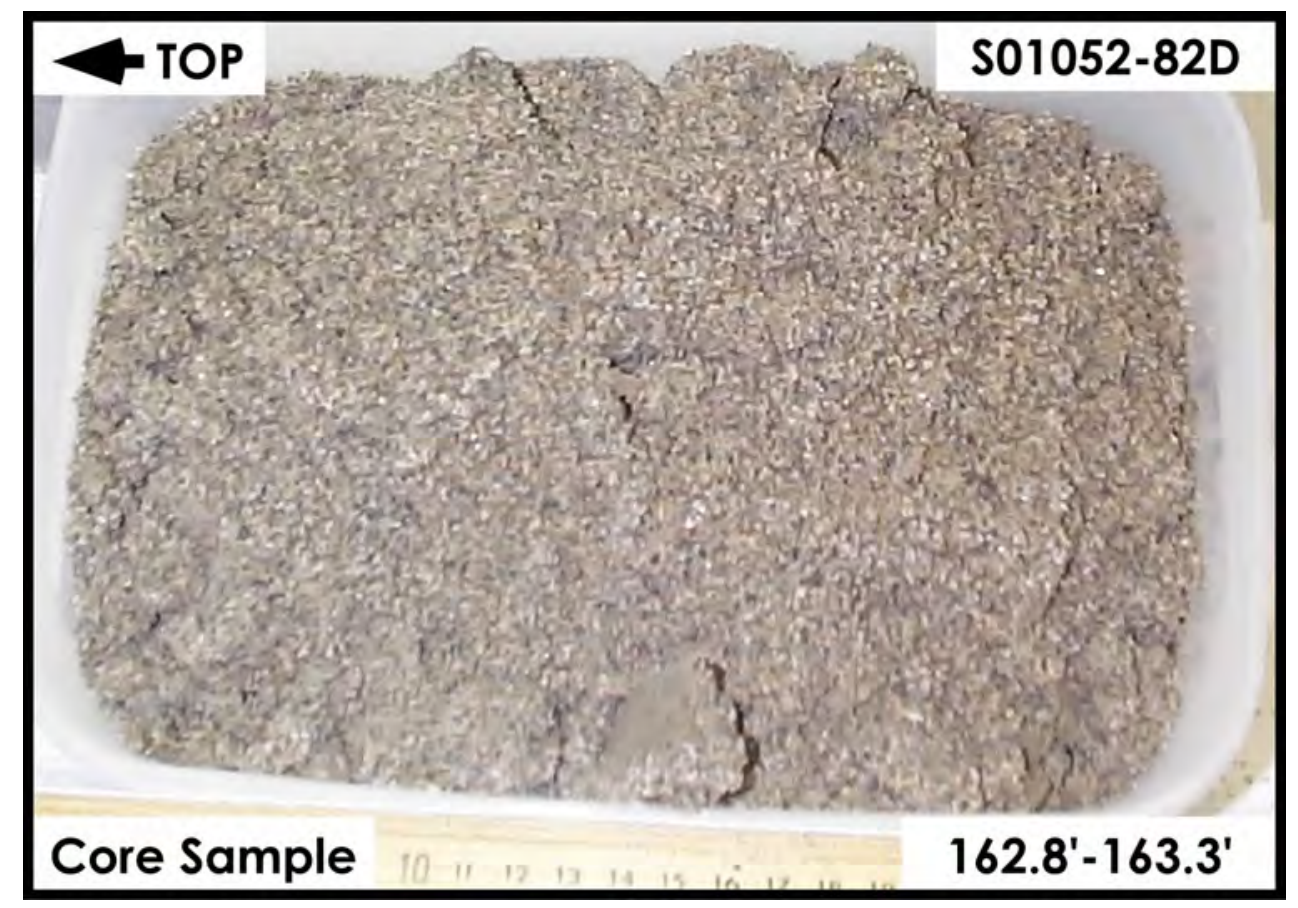

H2-Upper Sand and Gravel Sequence 


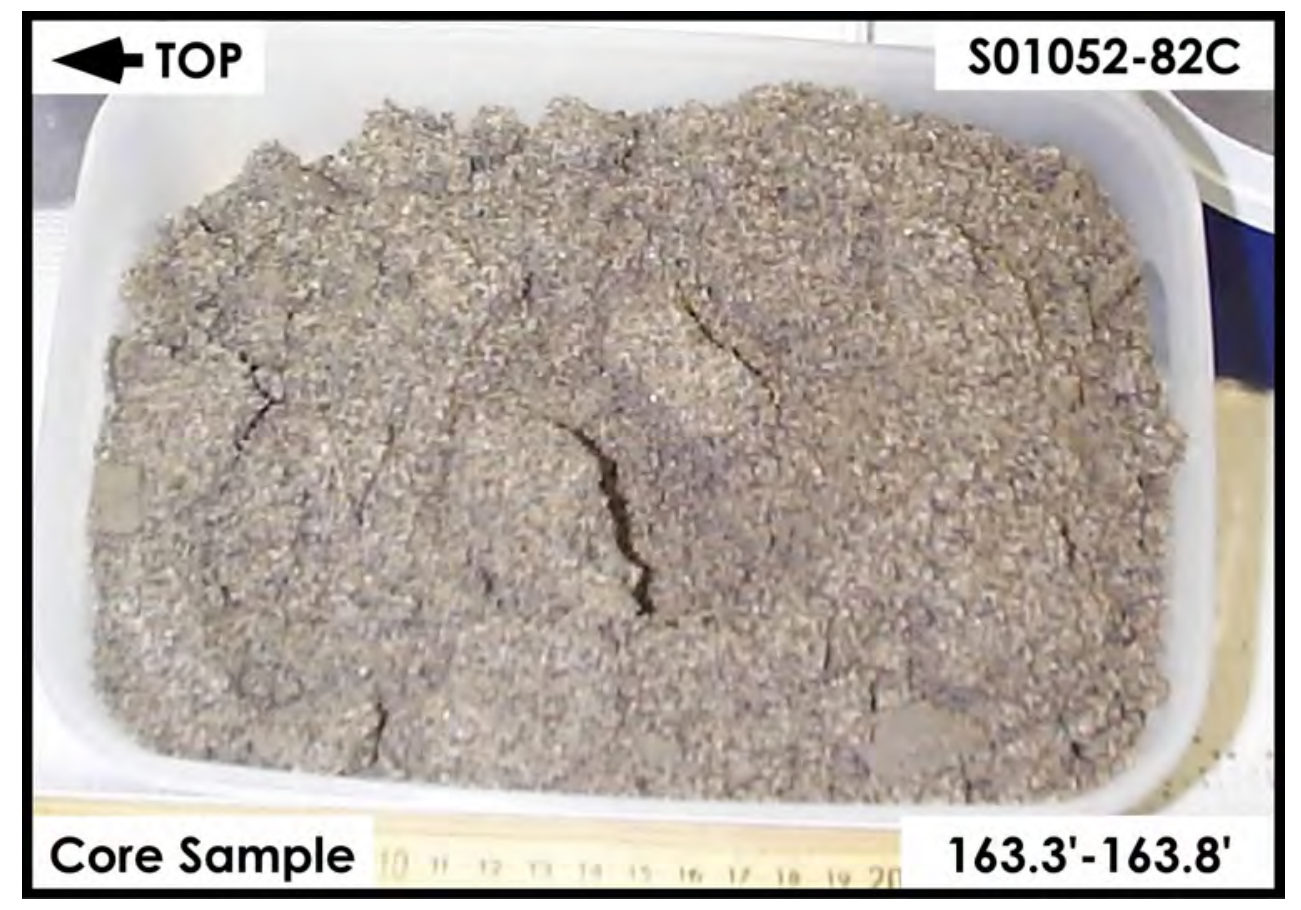

H2-Upper Sand and Gravel Sequence

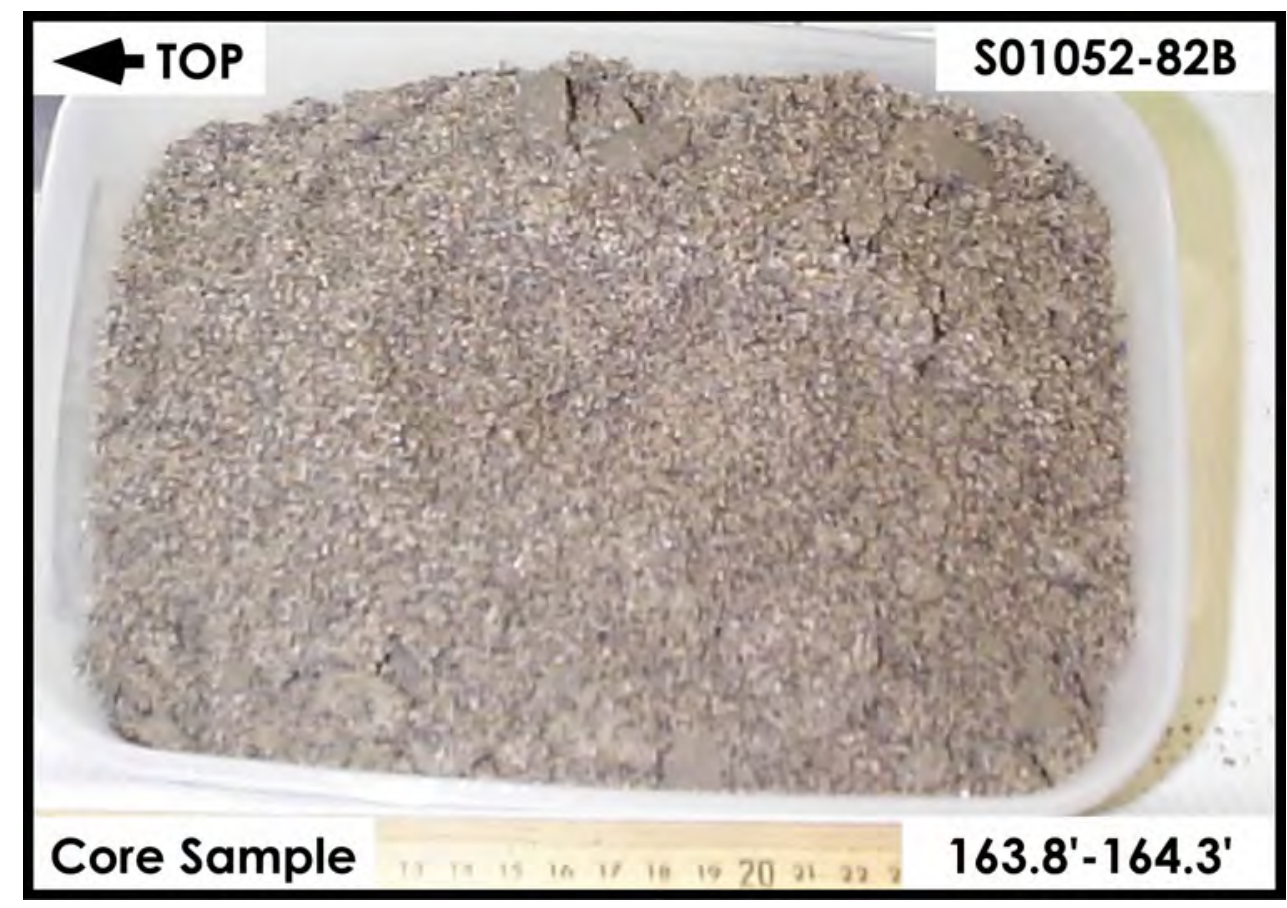

H2-Upper Sand and Gravel Sequence 


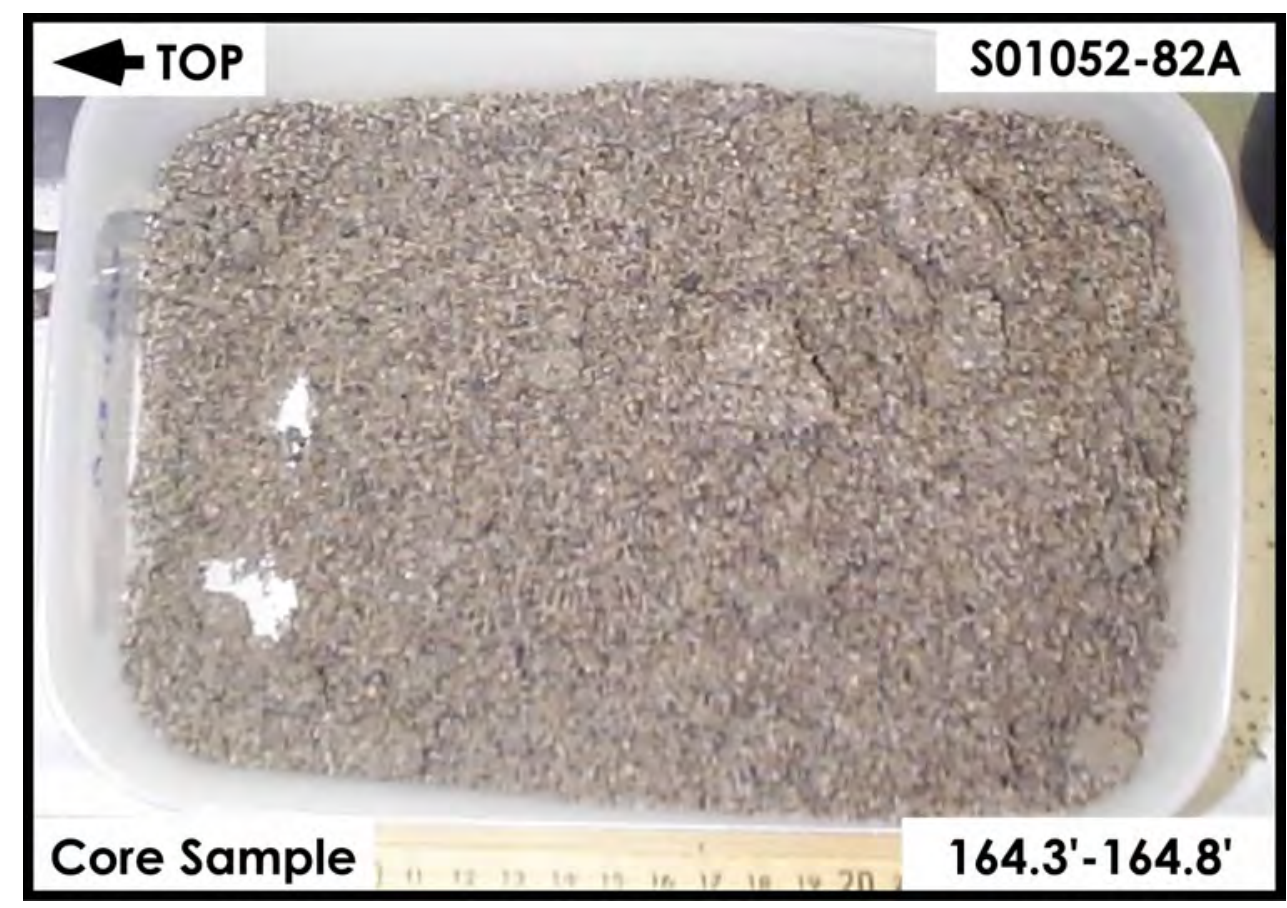

H2-Upper Sand and Gravel Sequence

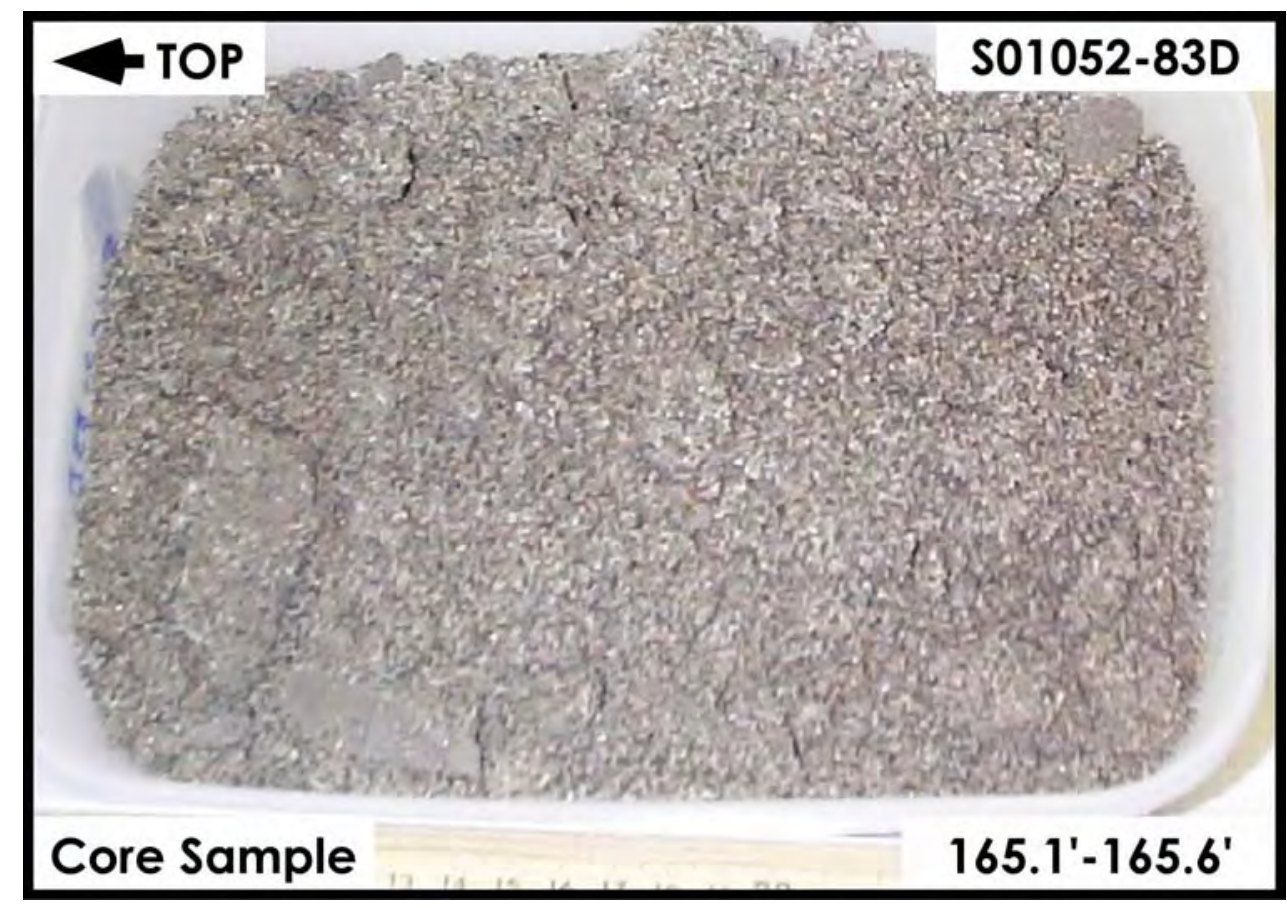

H2-Upper Sand and Gravel Sequence 


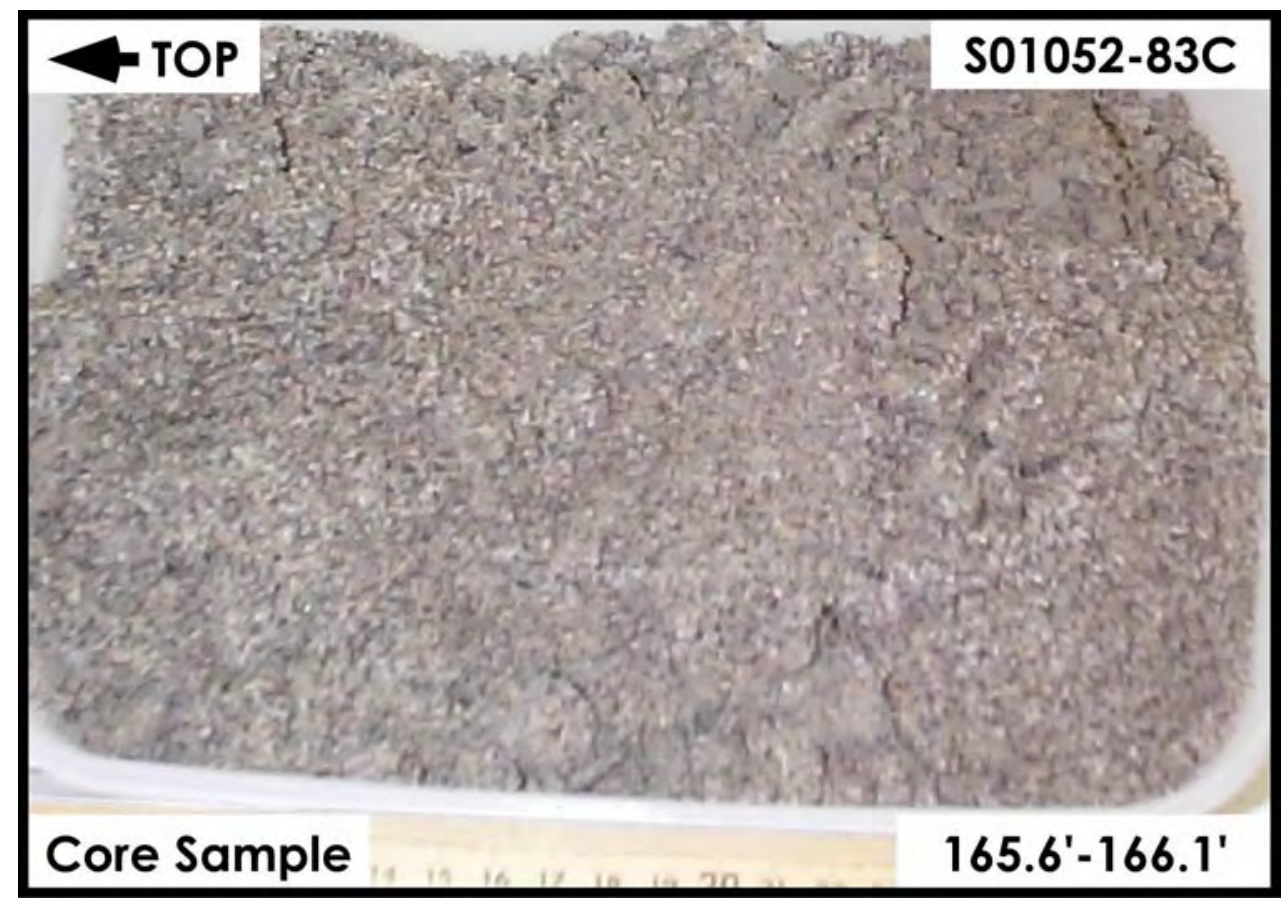

H2-Upper Sand and Gravel Sequence

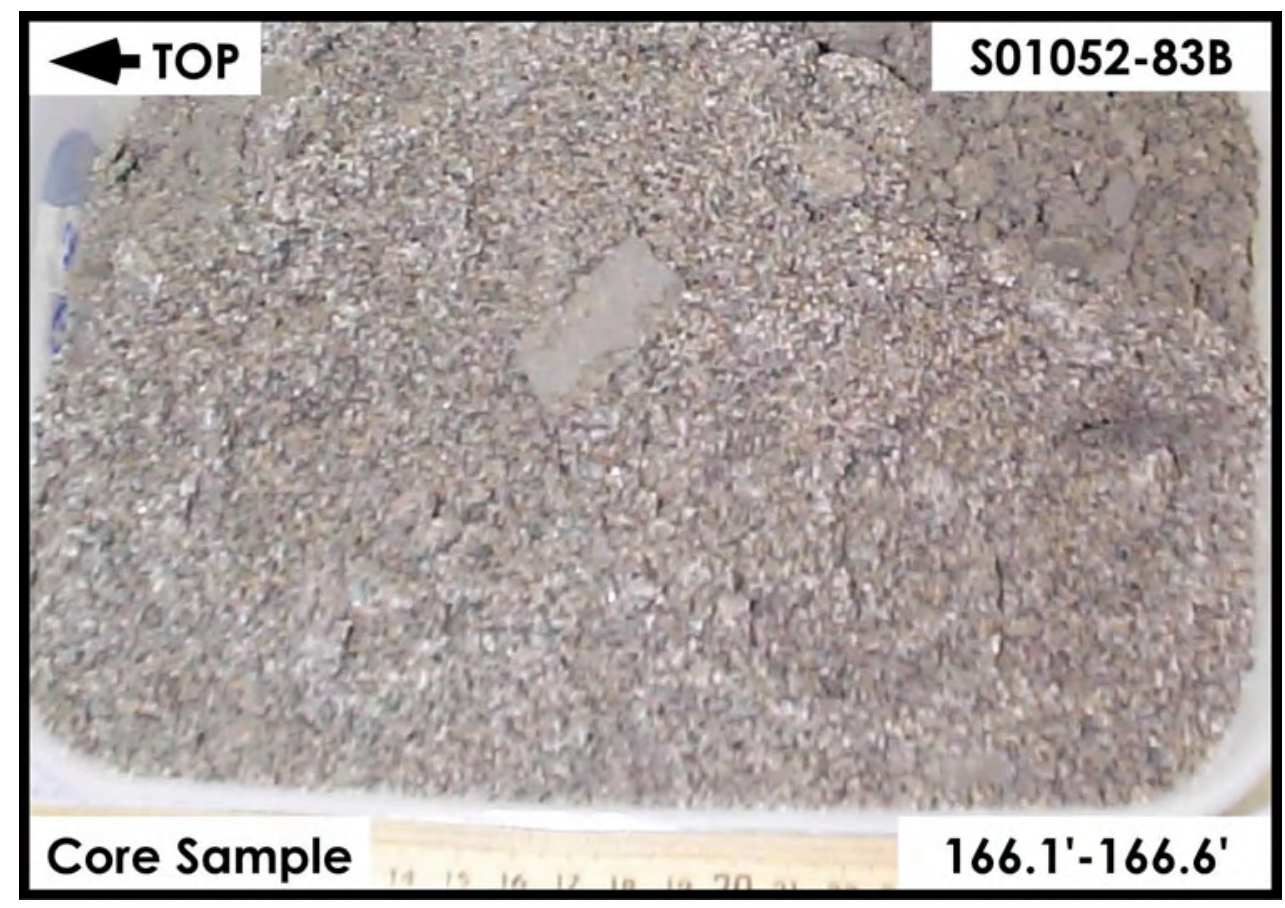

H2-Upper Sand and Gravel Sequence 


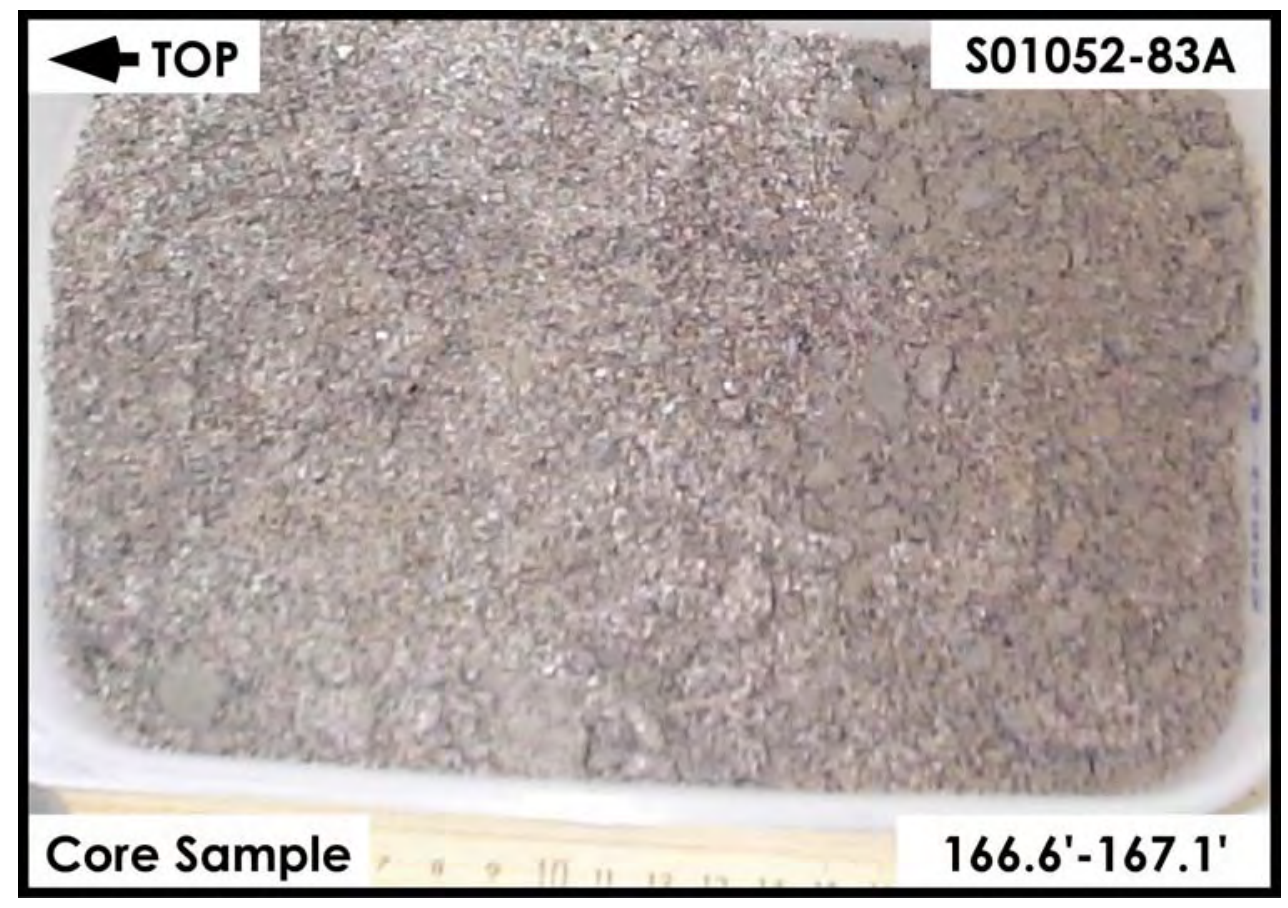

H2-Upper Sand and Gravel Sequence

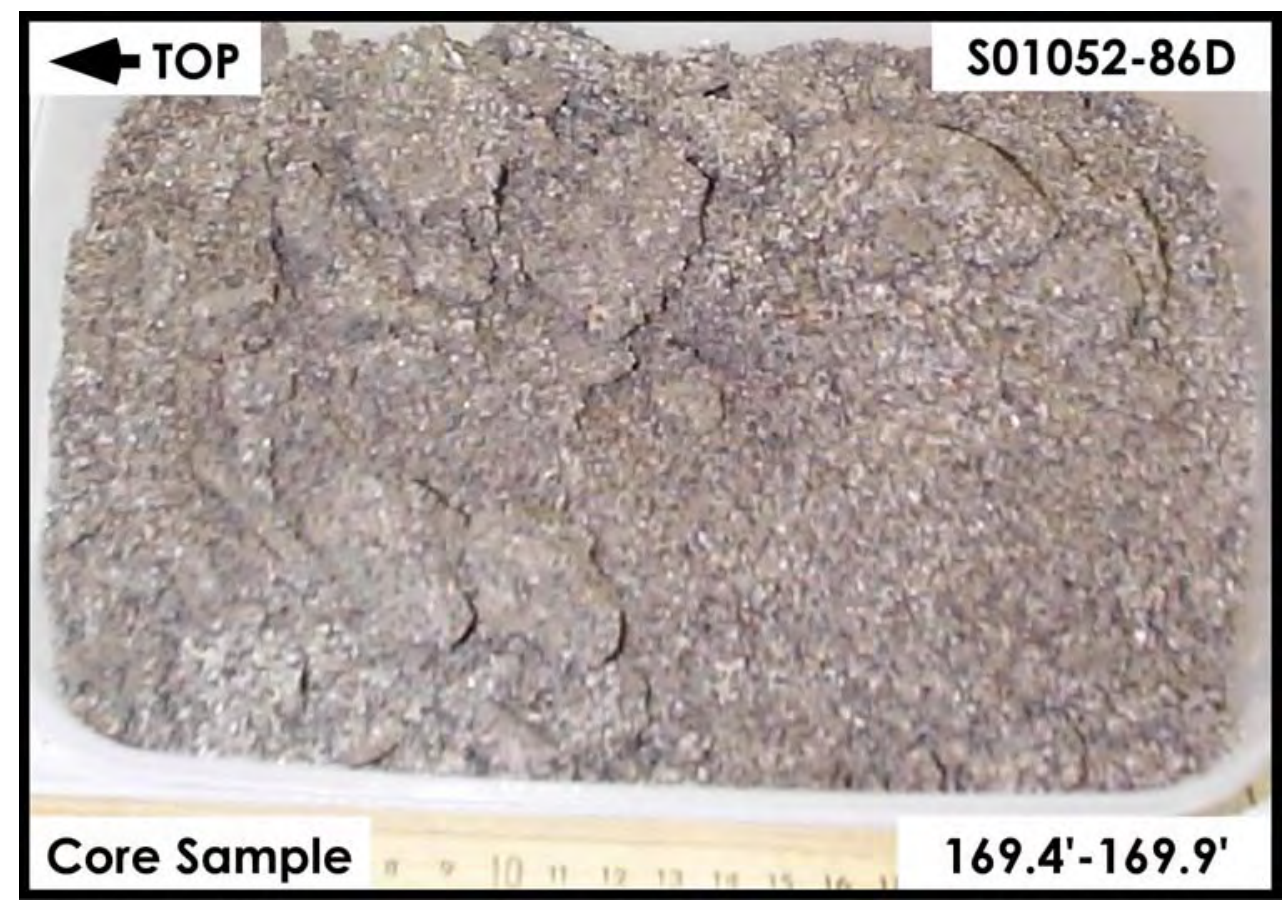

H2-Upper Sand and Gravel Sequence 


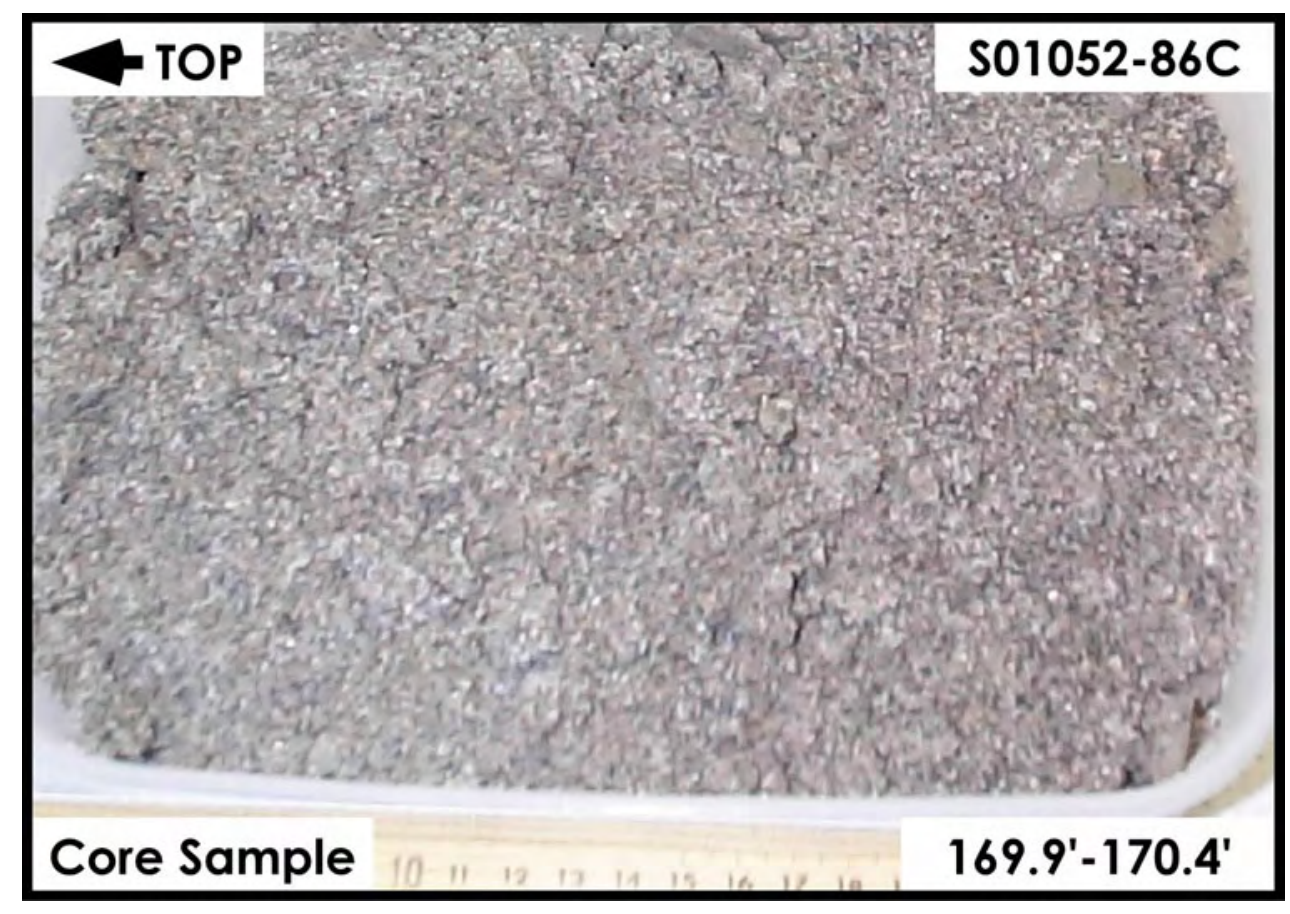

H2-Upper Sand and Gravel Sequence

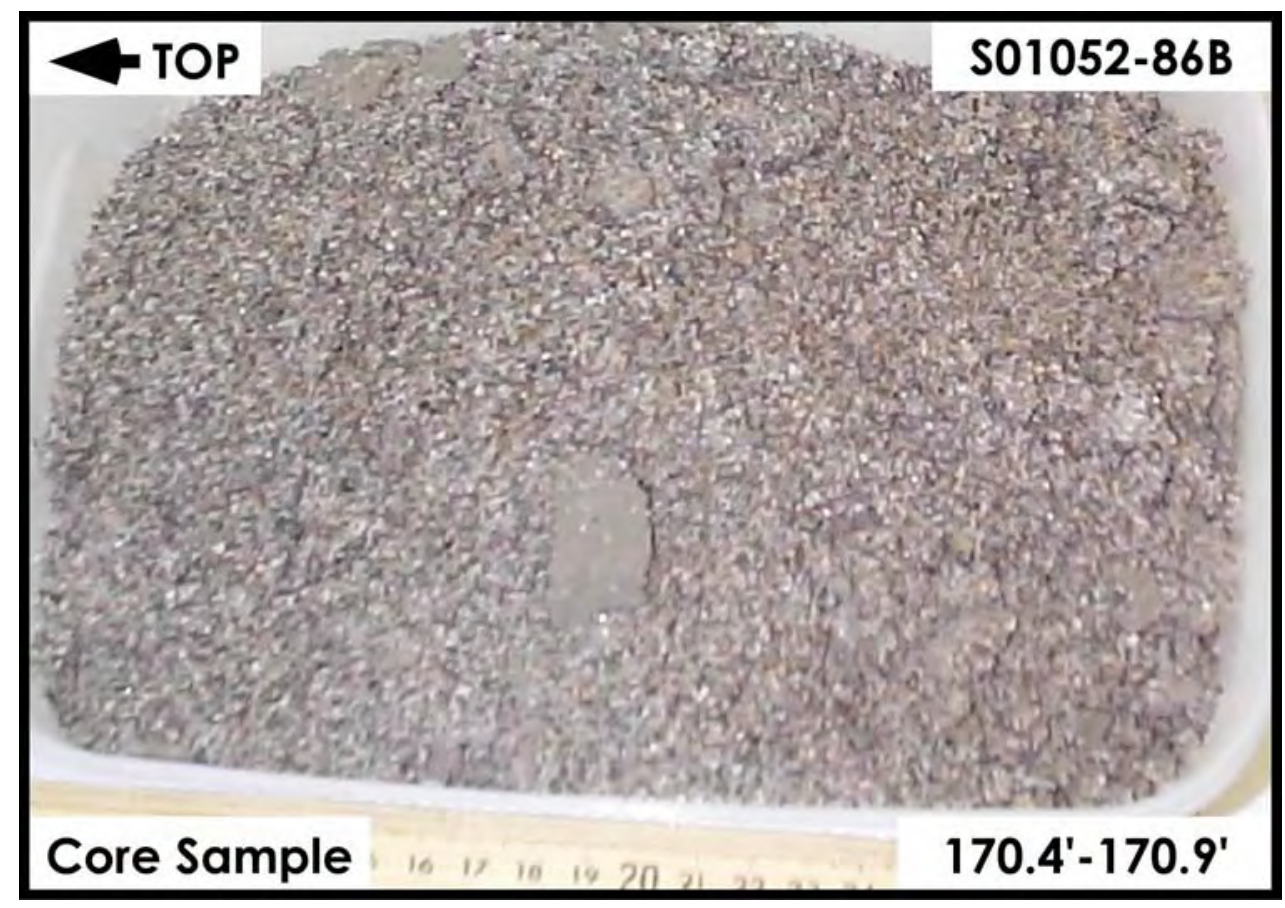

H2-Upper Sand and Gravel Sequence 


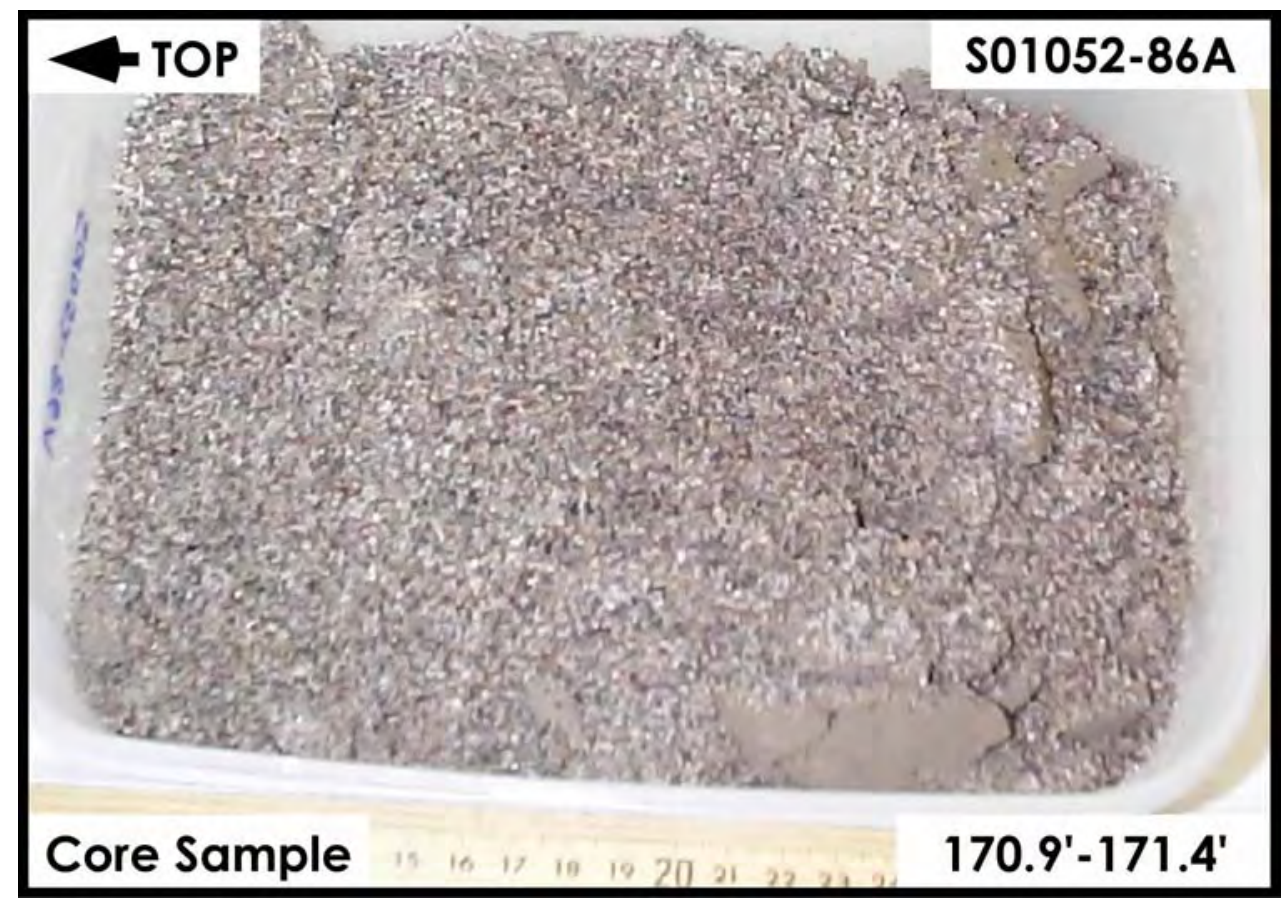

H2-Upper Sand and Gravel Sequence

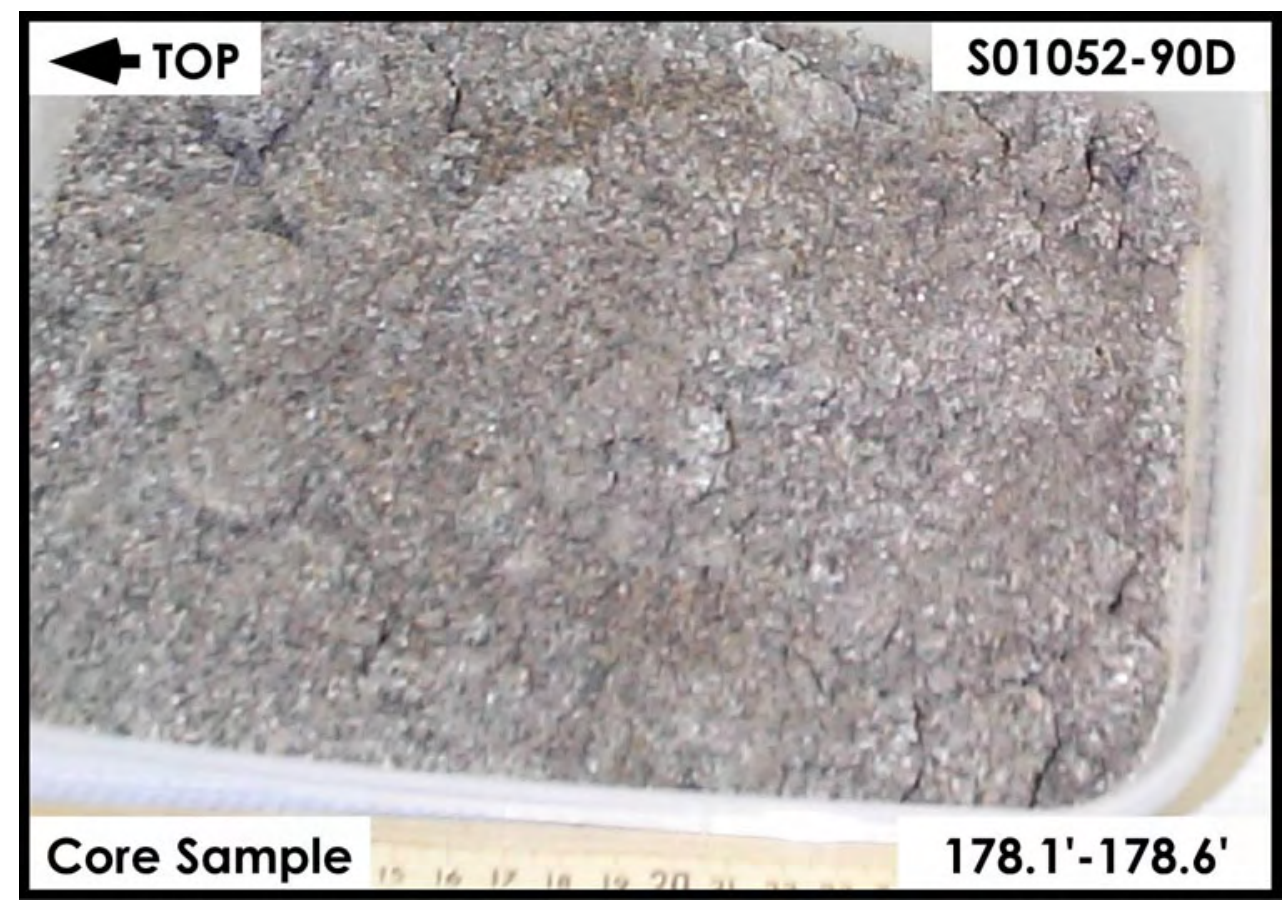

H3-Lower Sand and Gravel Sequence 


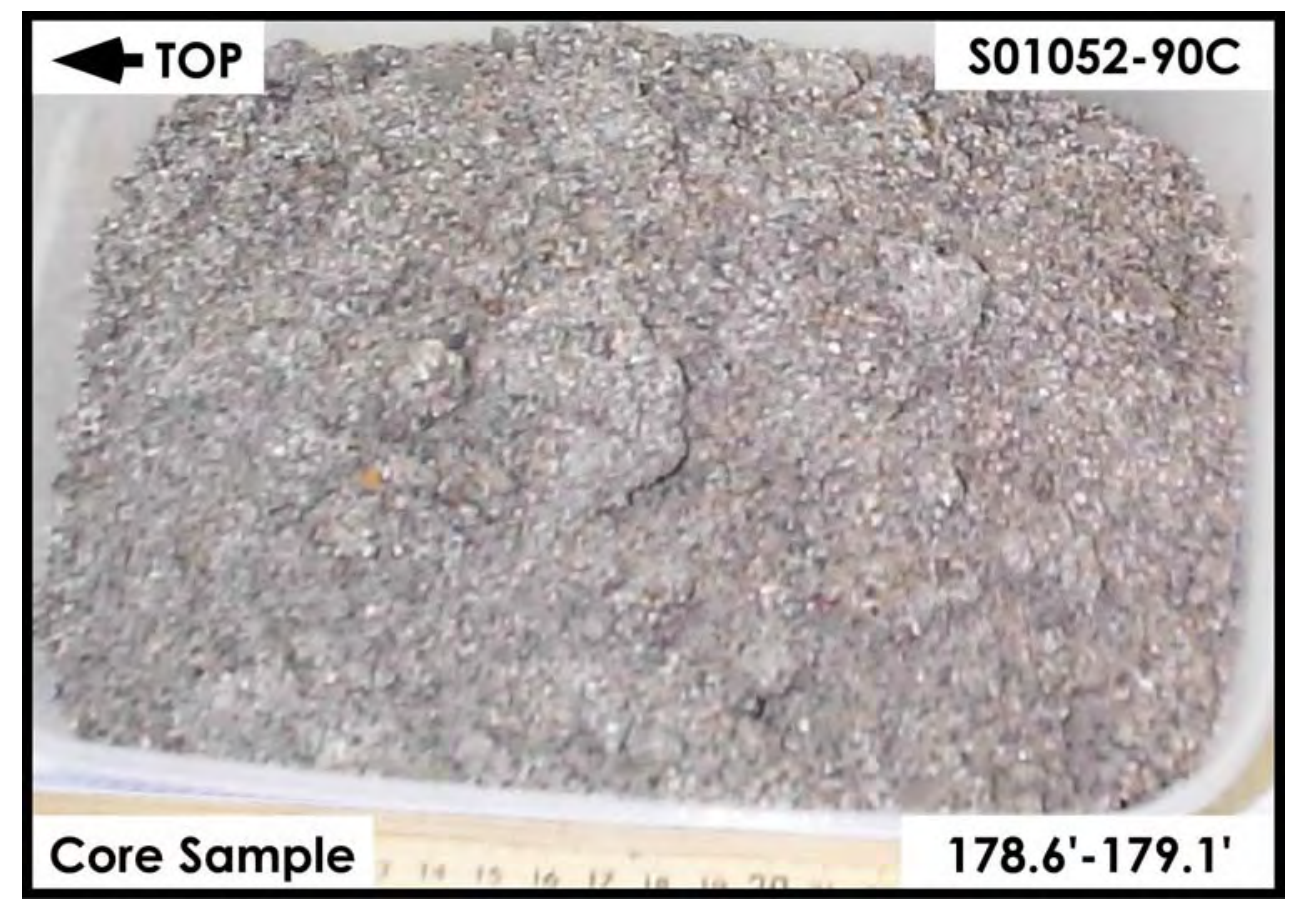

H3-Lower Sand and Gravel Sequence

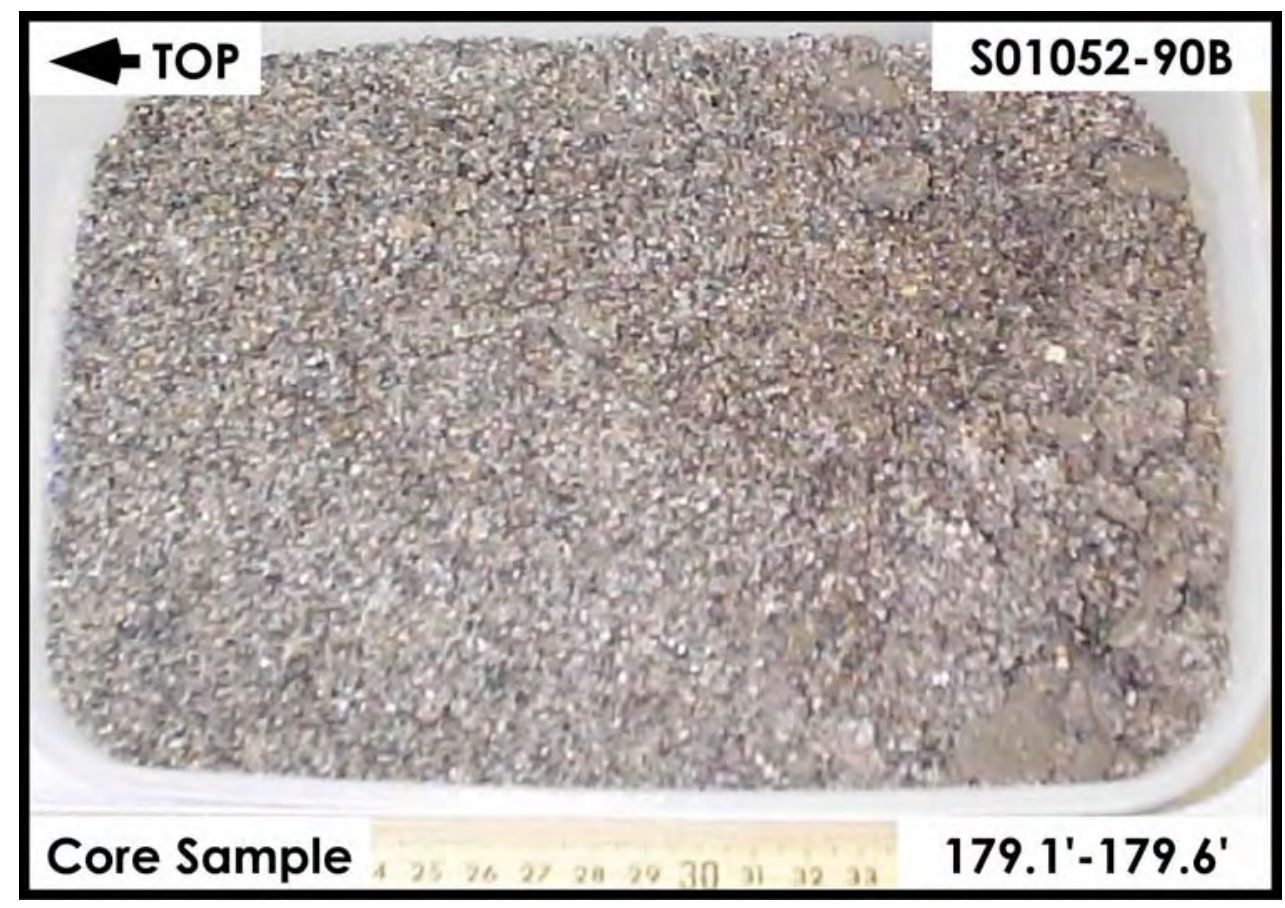

H3-Lower Sand and Gravel Sequence 


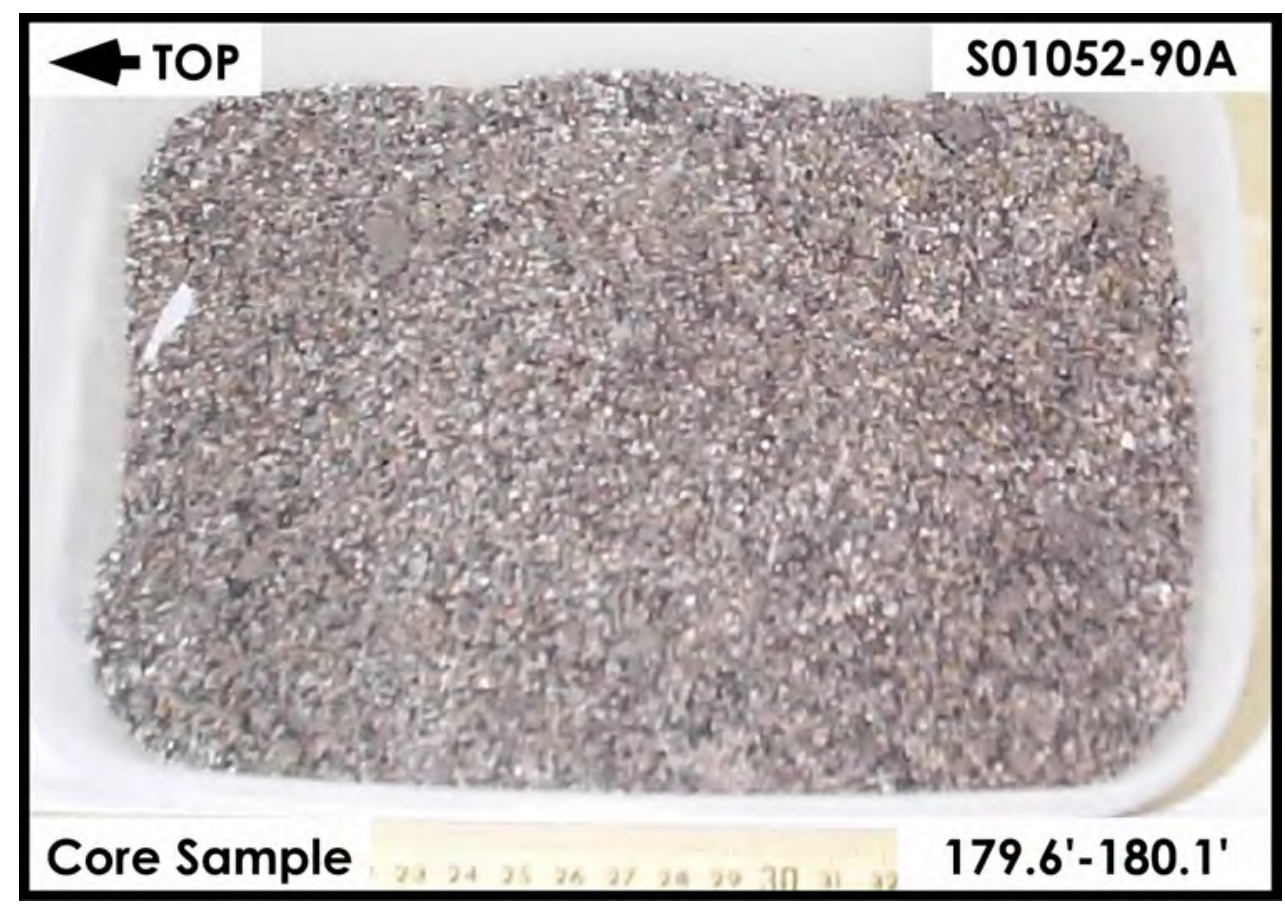

H3-Lower Sand and Gravel Sequence

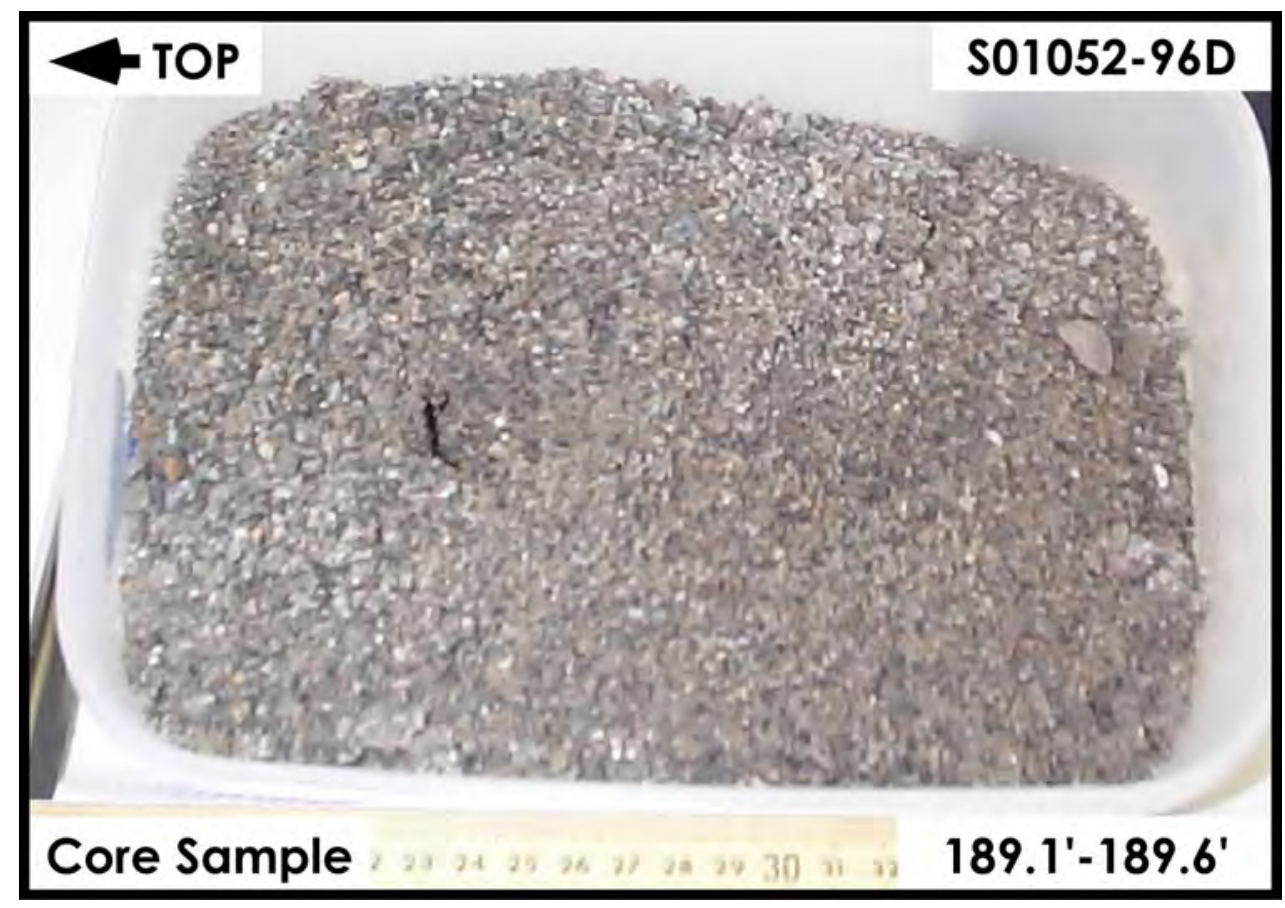

H3-Lower Sand and Gravel Sequence 


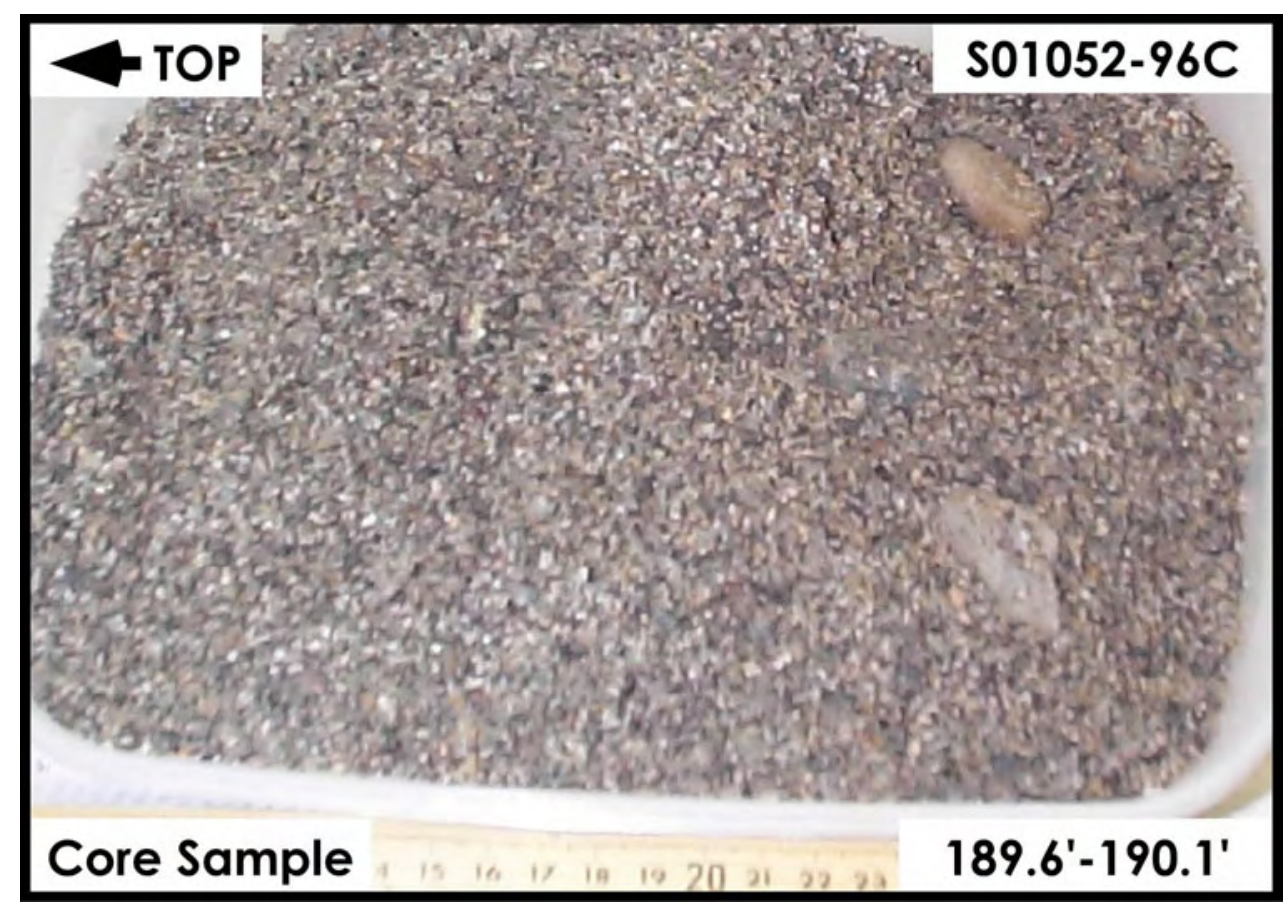

H3-Lower Sand and Gravel Sequence

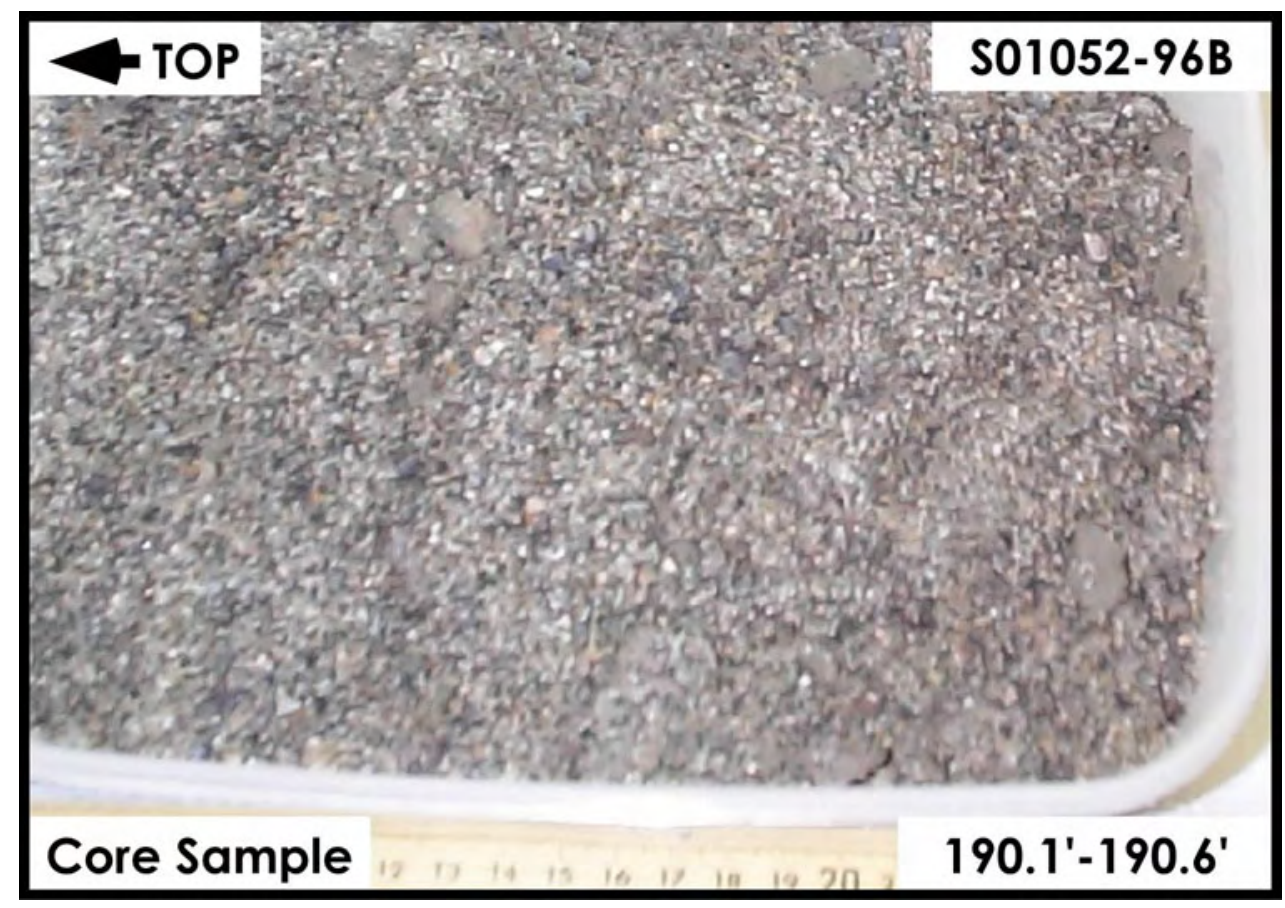

H3-Lower Sand and Gravel Sequence 


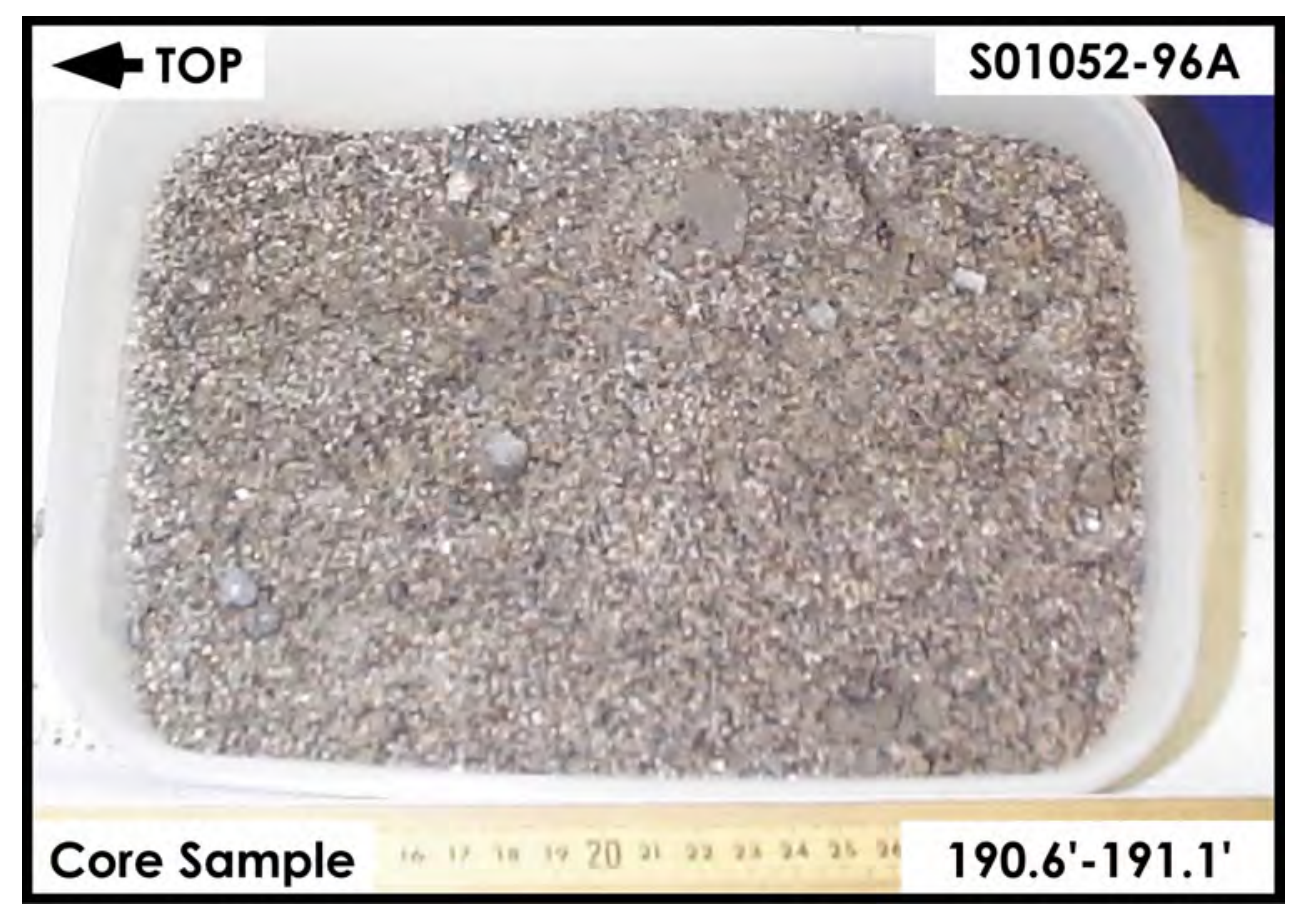

H3-Lower Sand and Gravel Sequence

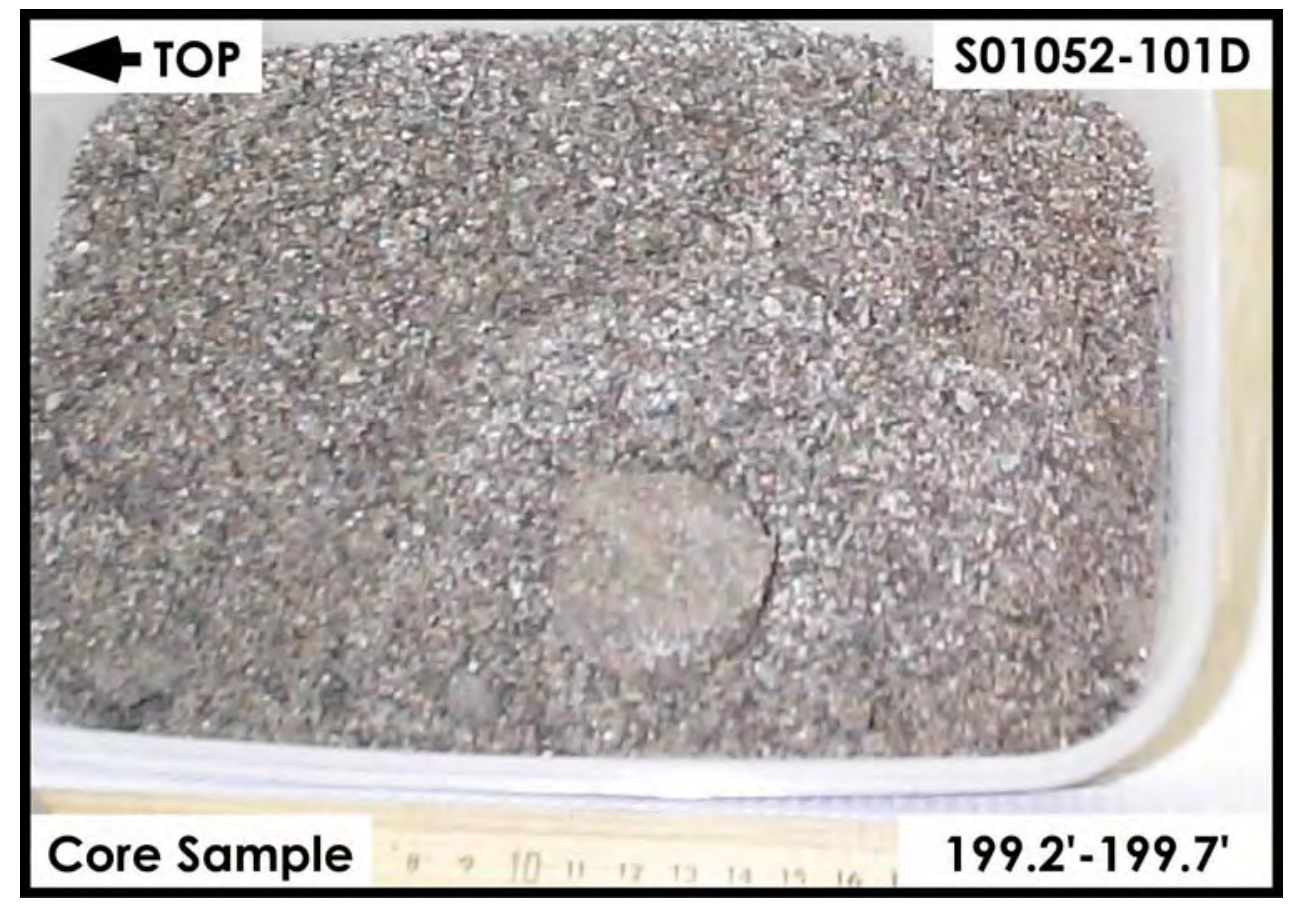

H3-Lower Sand and Gravel Sequence 


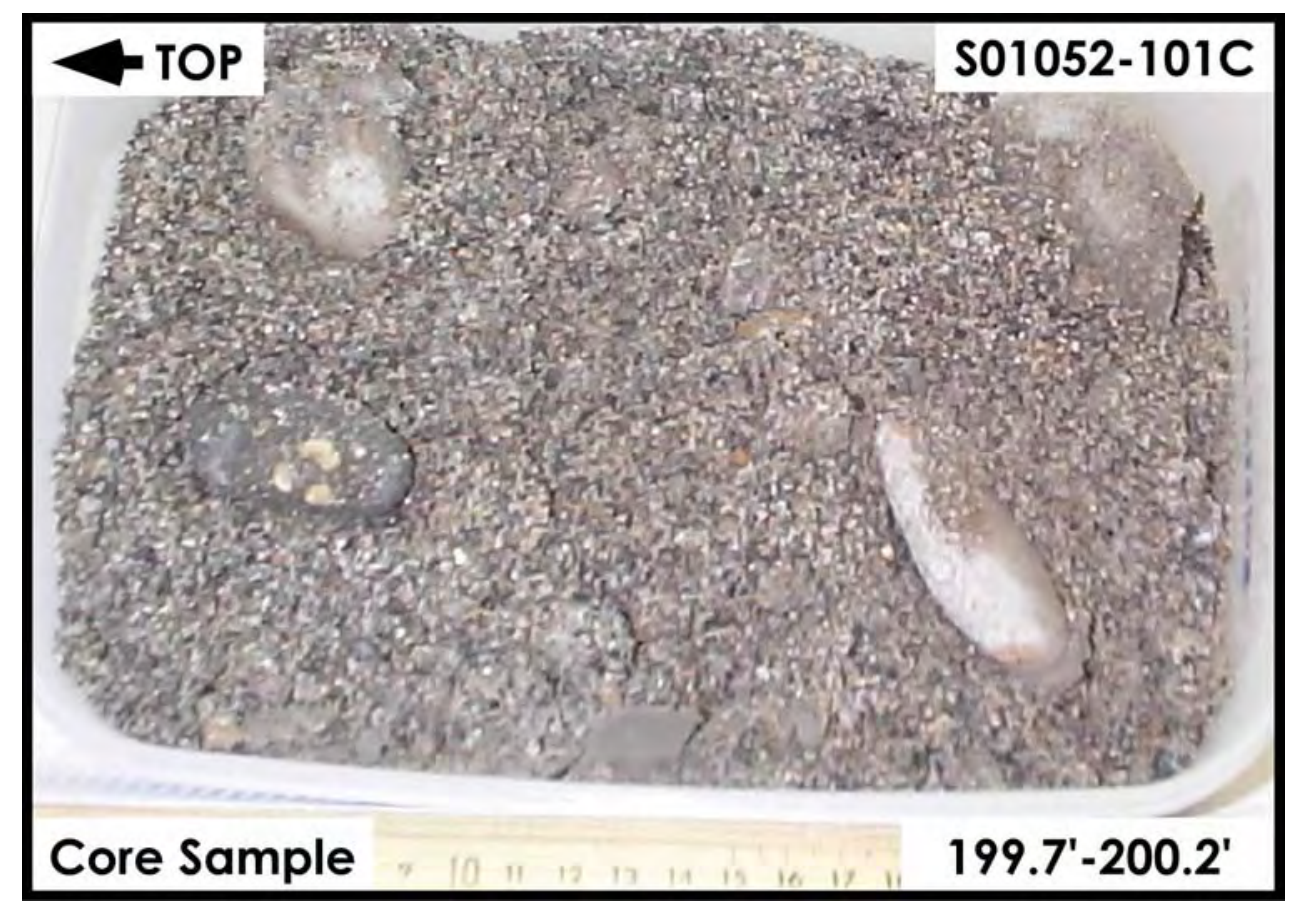

H3-Lower Sand and Gravel Sequence

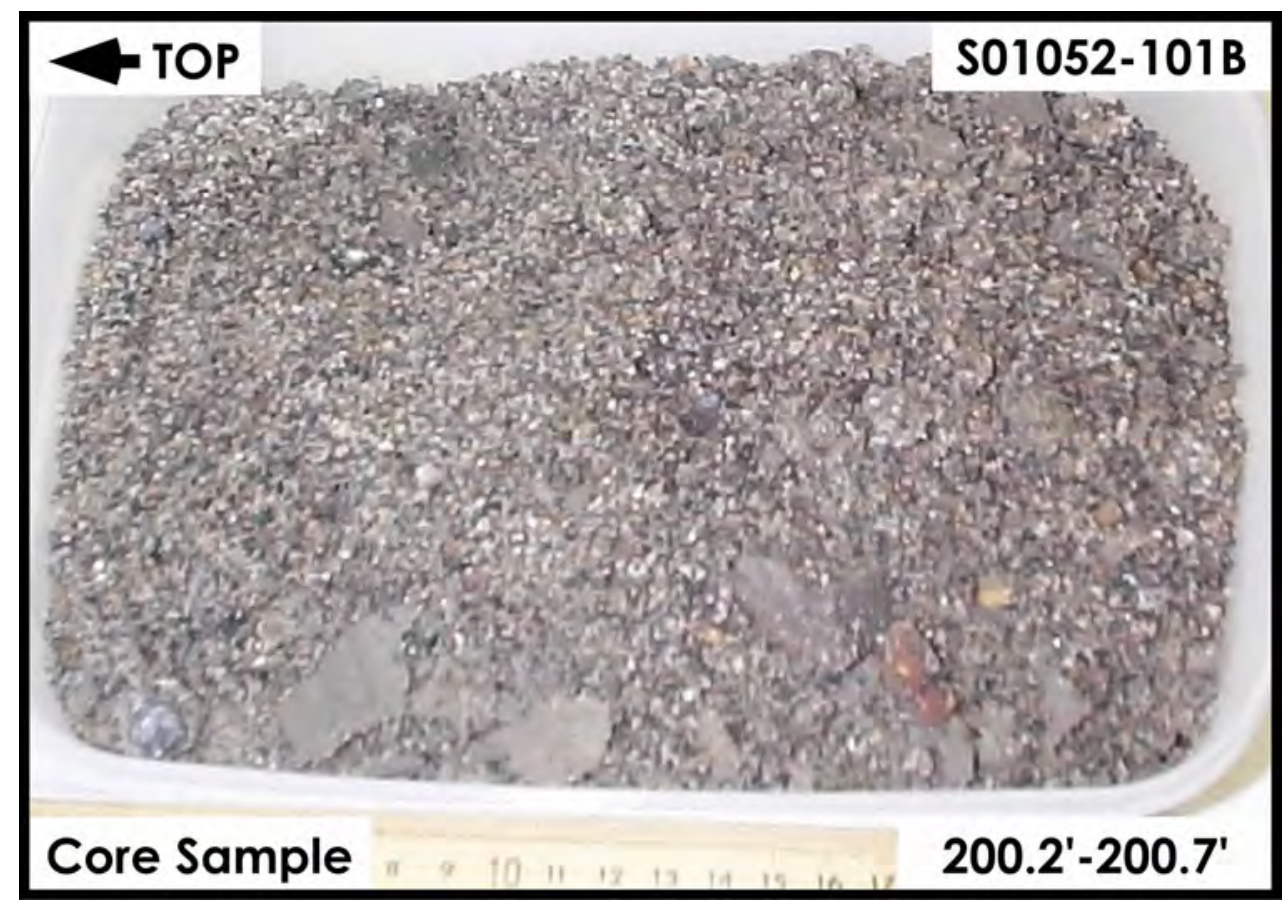

H3-Lower Sand and Gravel Sequence 


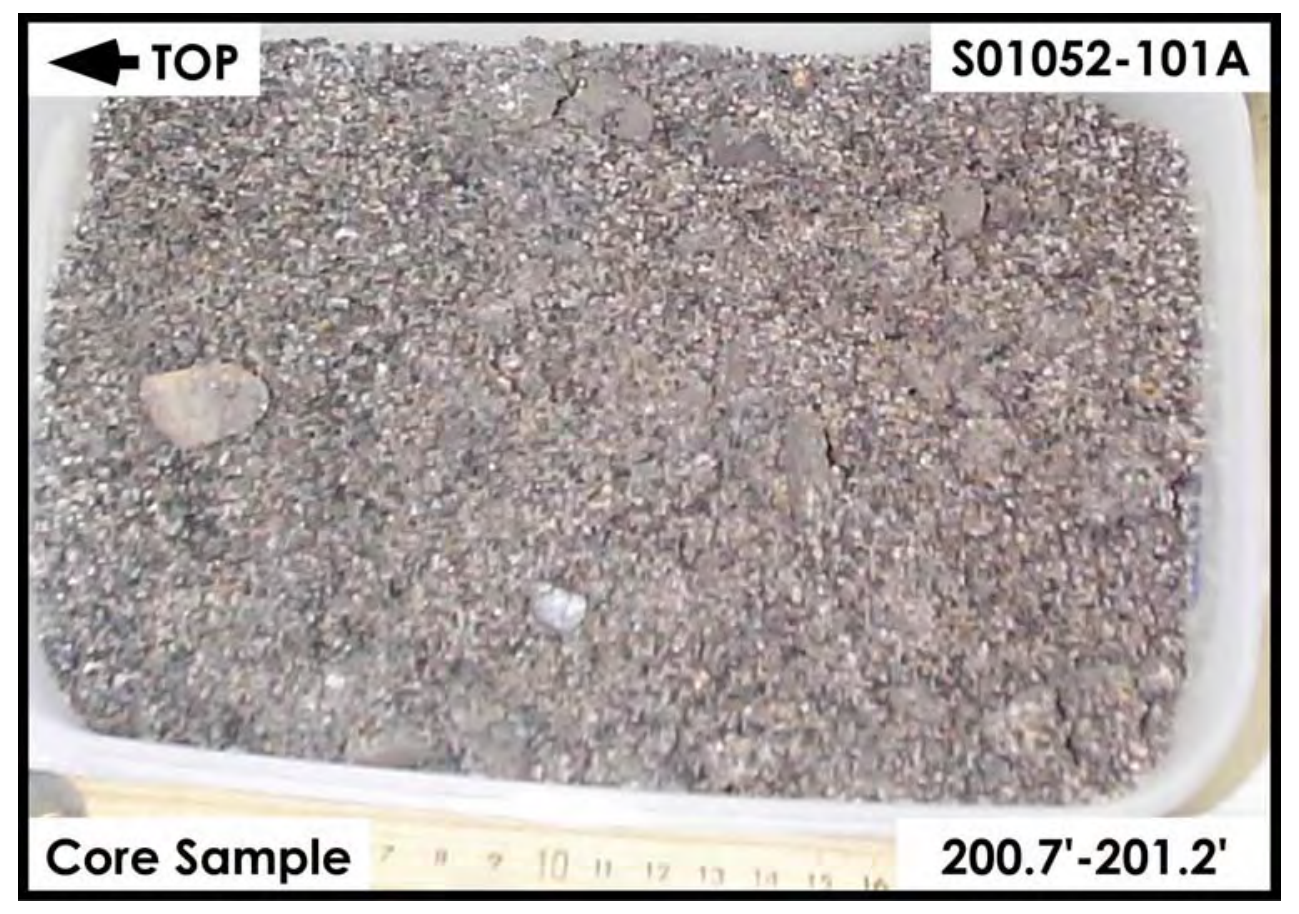

H3-Lower Sand and Gravel Sequence

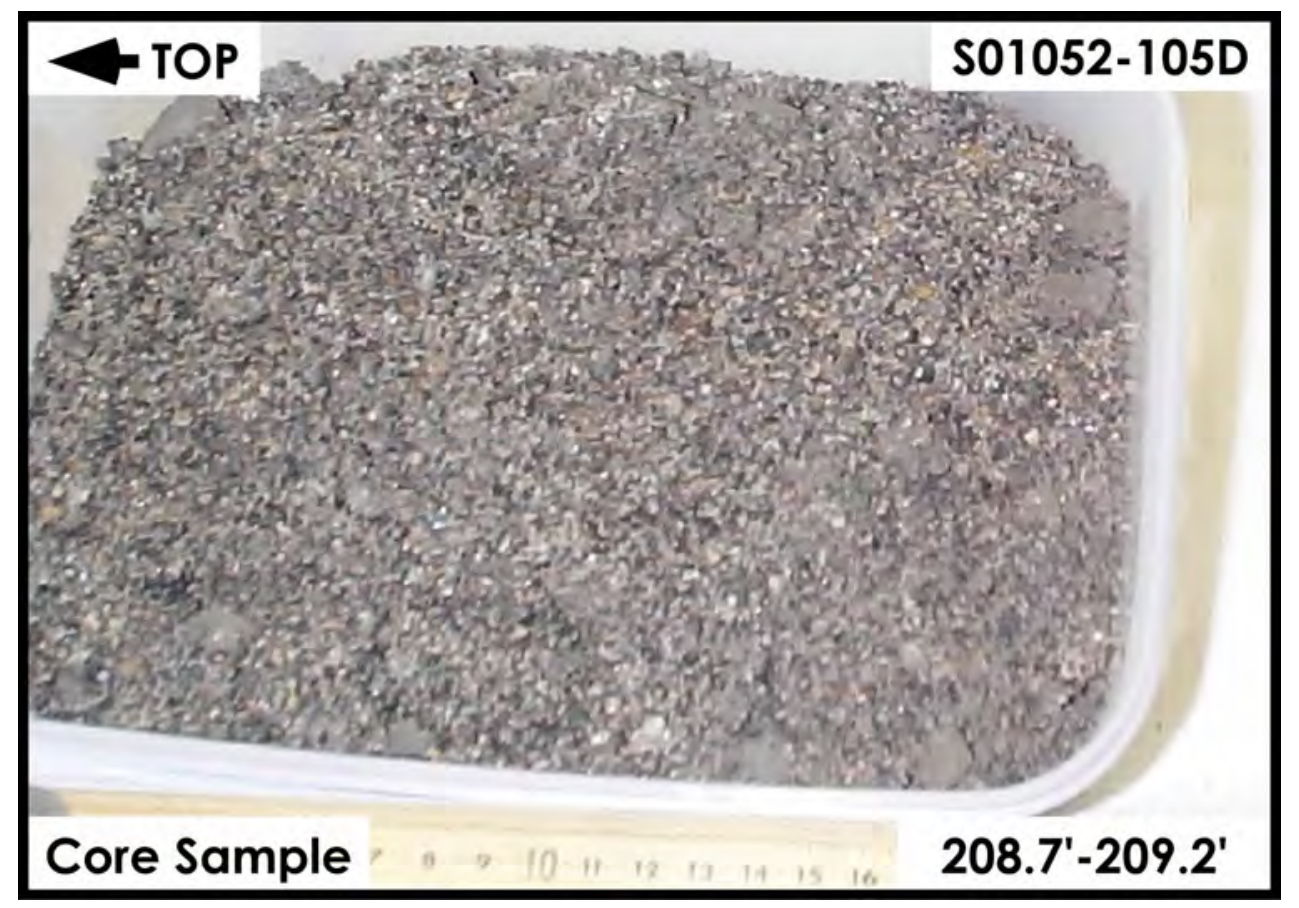

H3-Lower Sand and Gravel Sequence 


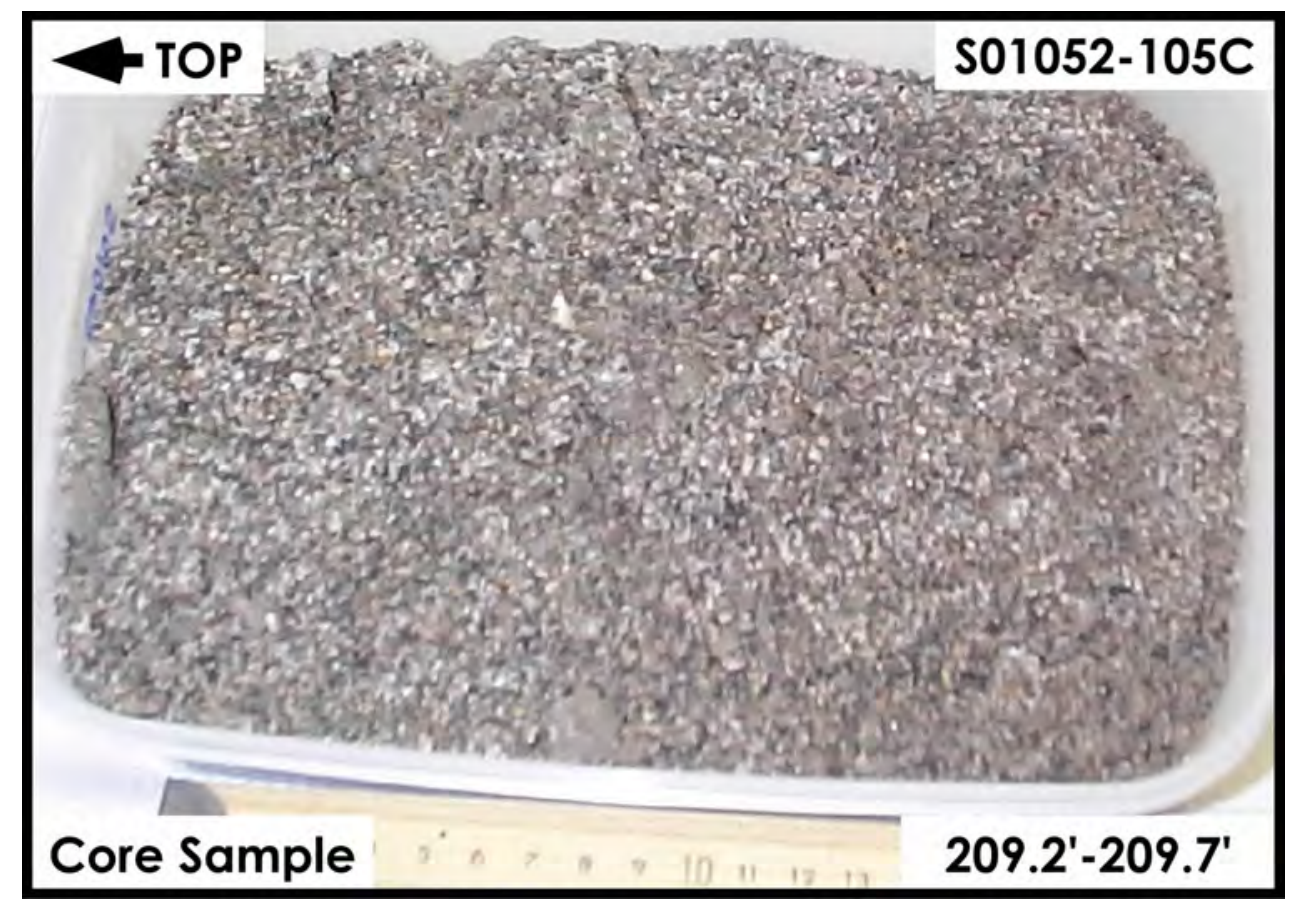

H3-Lower Sand and Gravel Sequence

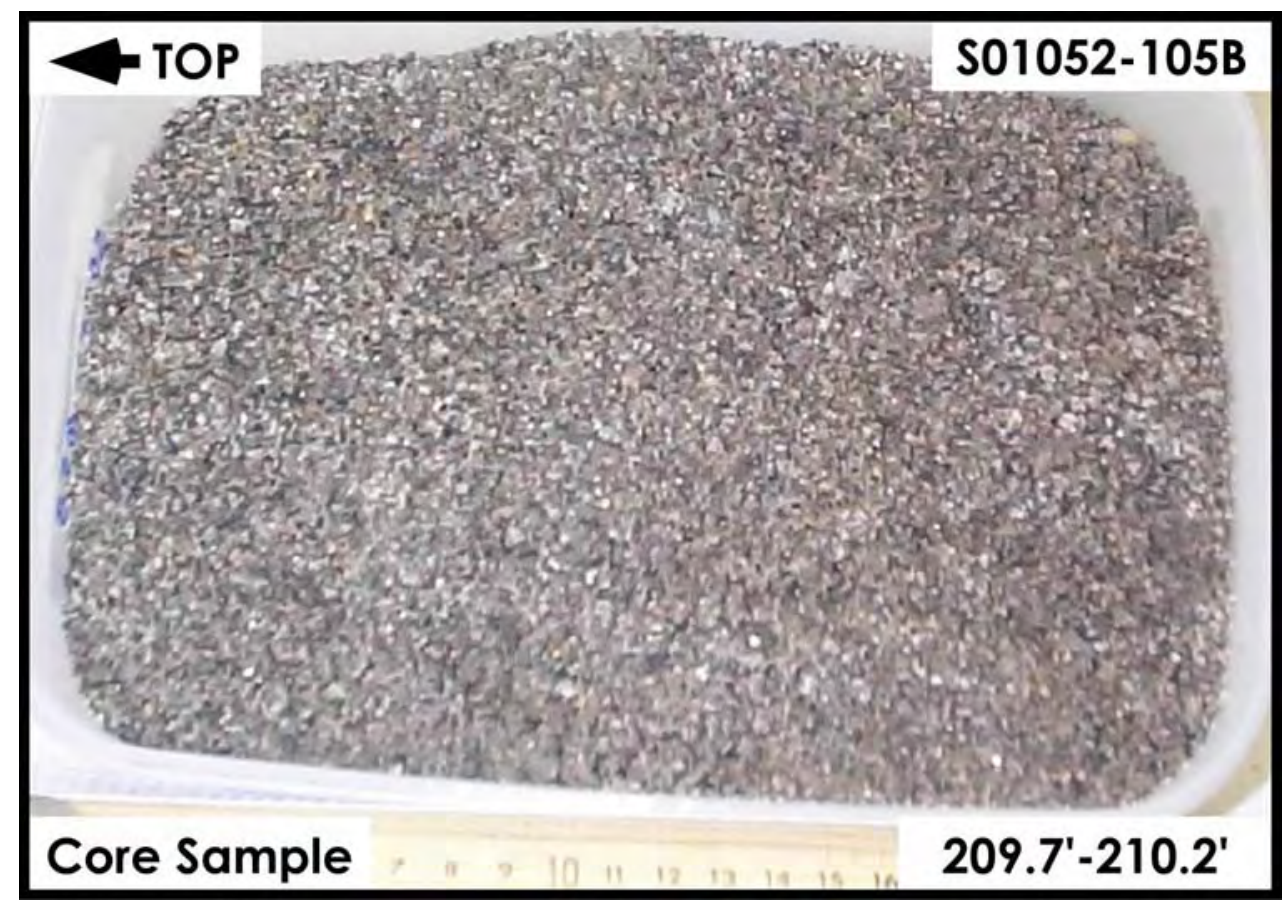

H3-Lower Sand and Gravel Sequence 


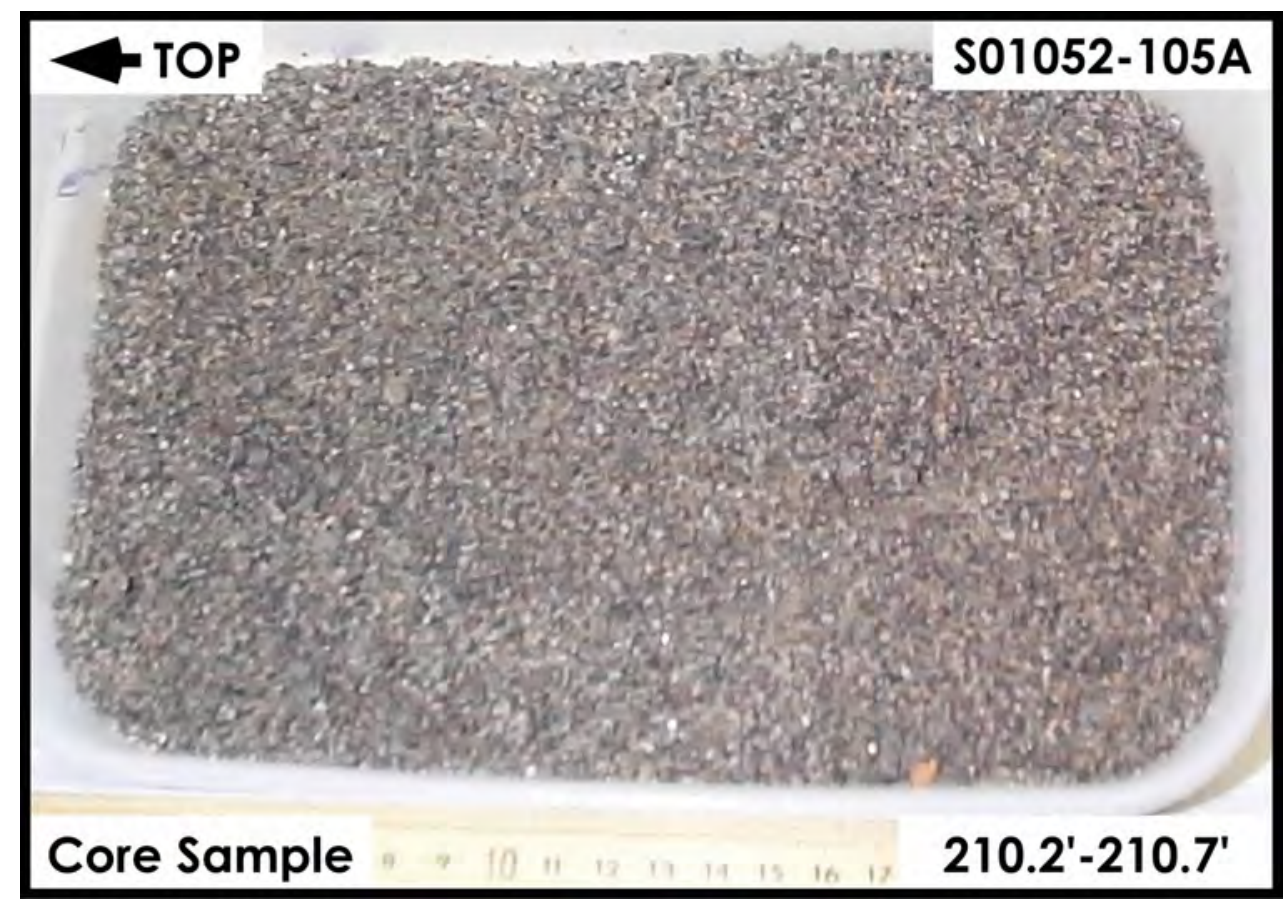

H3-Lower Sand and Gravel Sequence

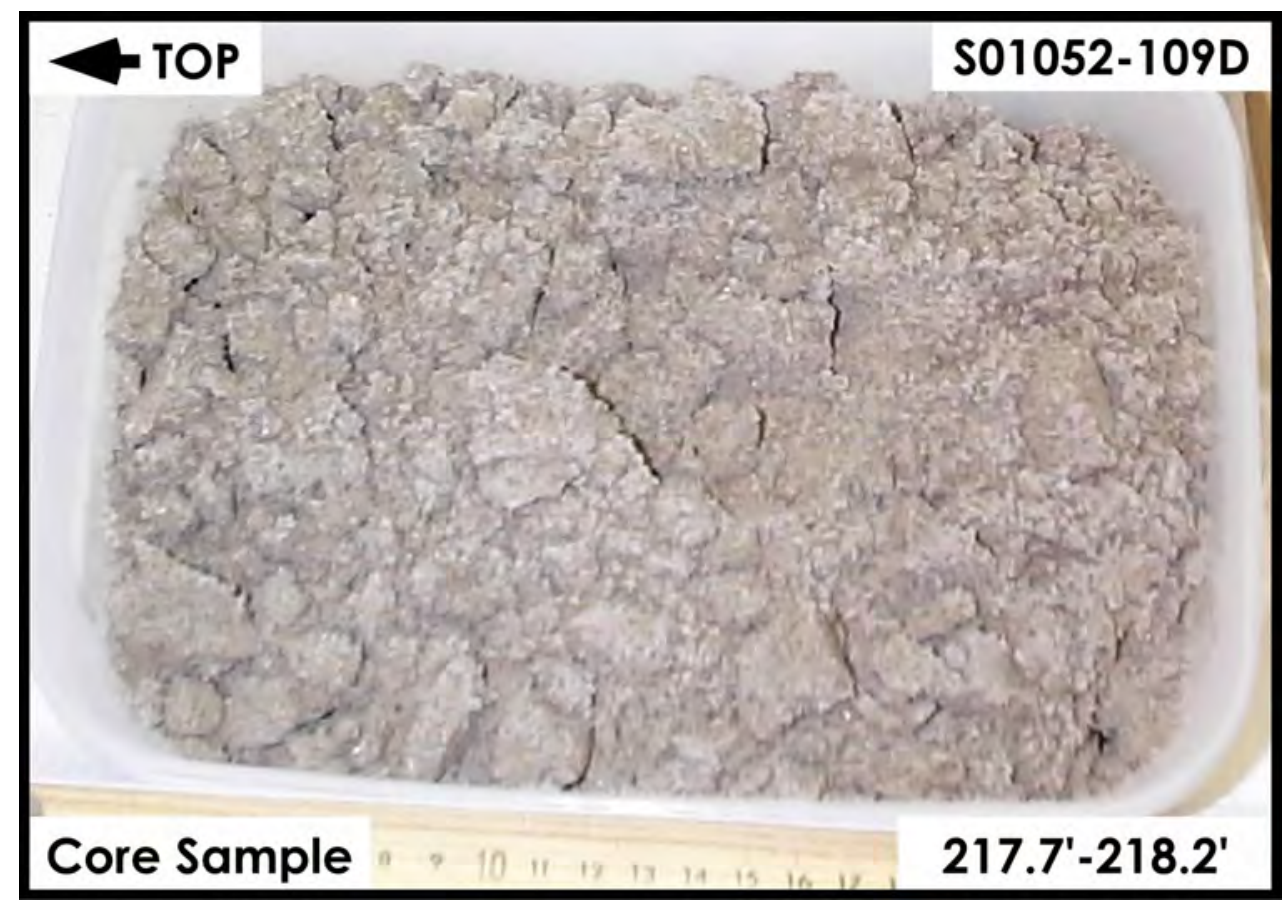

Plio-Pleistocene Silt Unit (PPlz) 


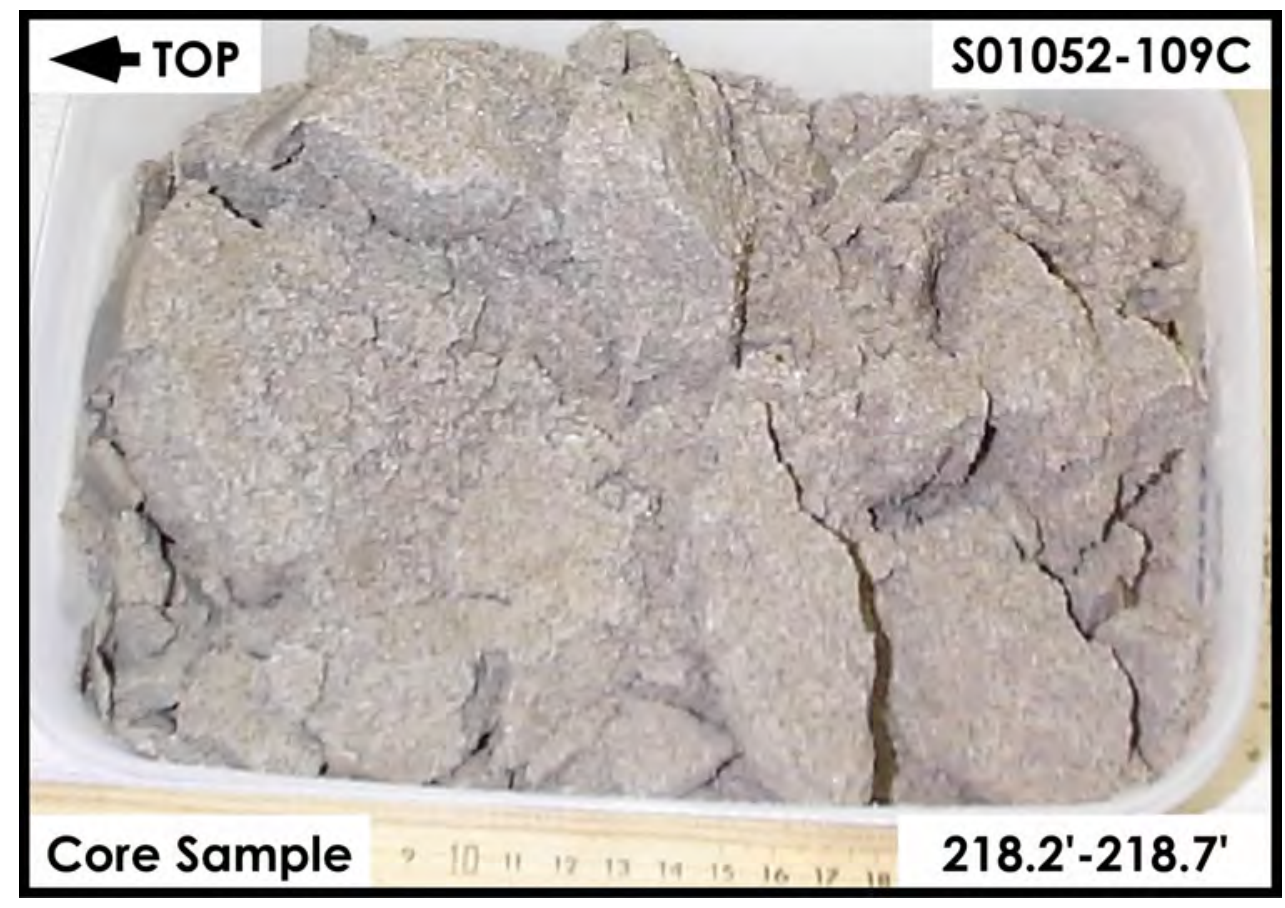

Plio-Pleistocene Silt Unit (PPlz)

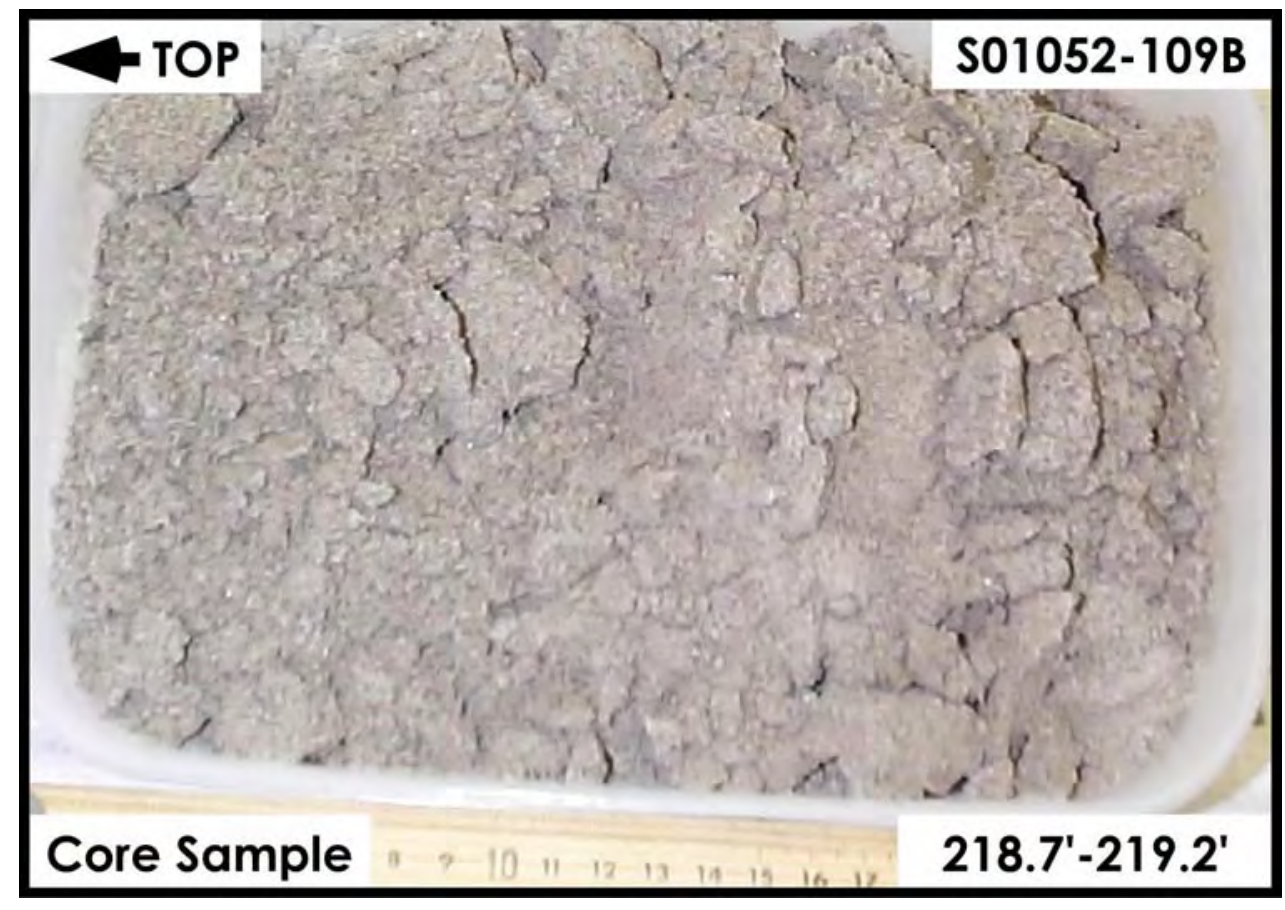

Plio-Pleistocene Silt Unit (PPlz) 


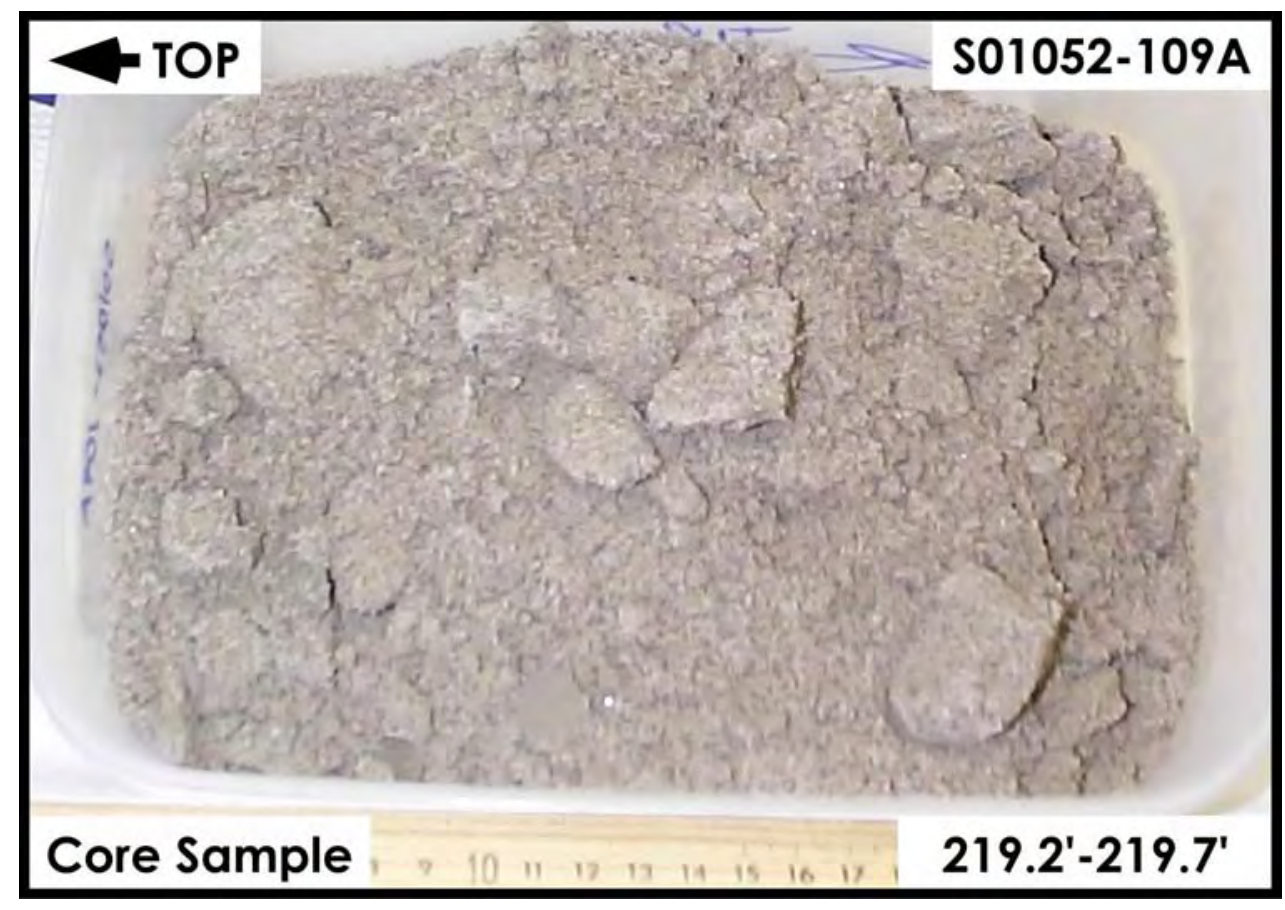

Plio-Pleistocene Silt Unit (PPlz)

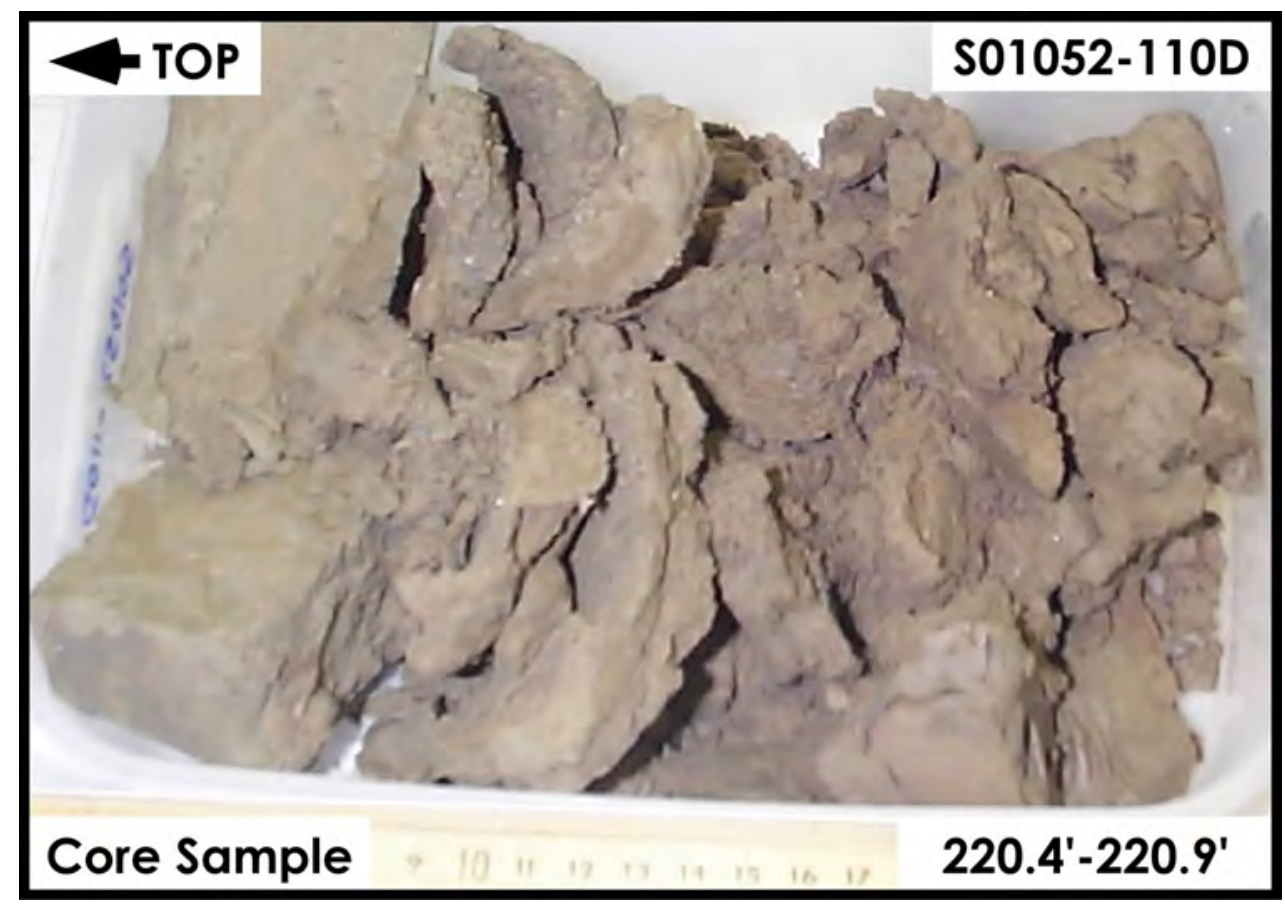

Plio-Pleistocene Silt Unit (PPlz) 


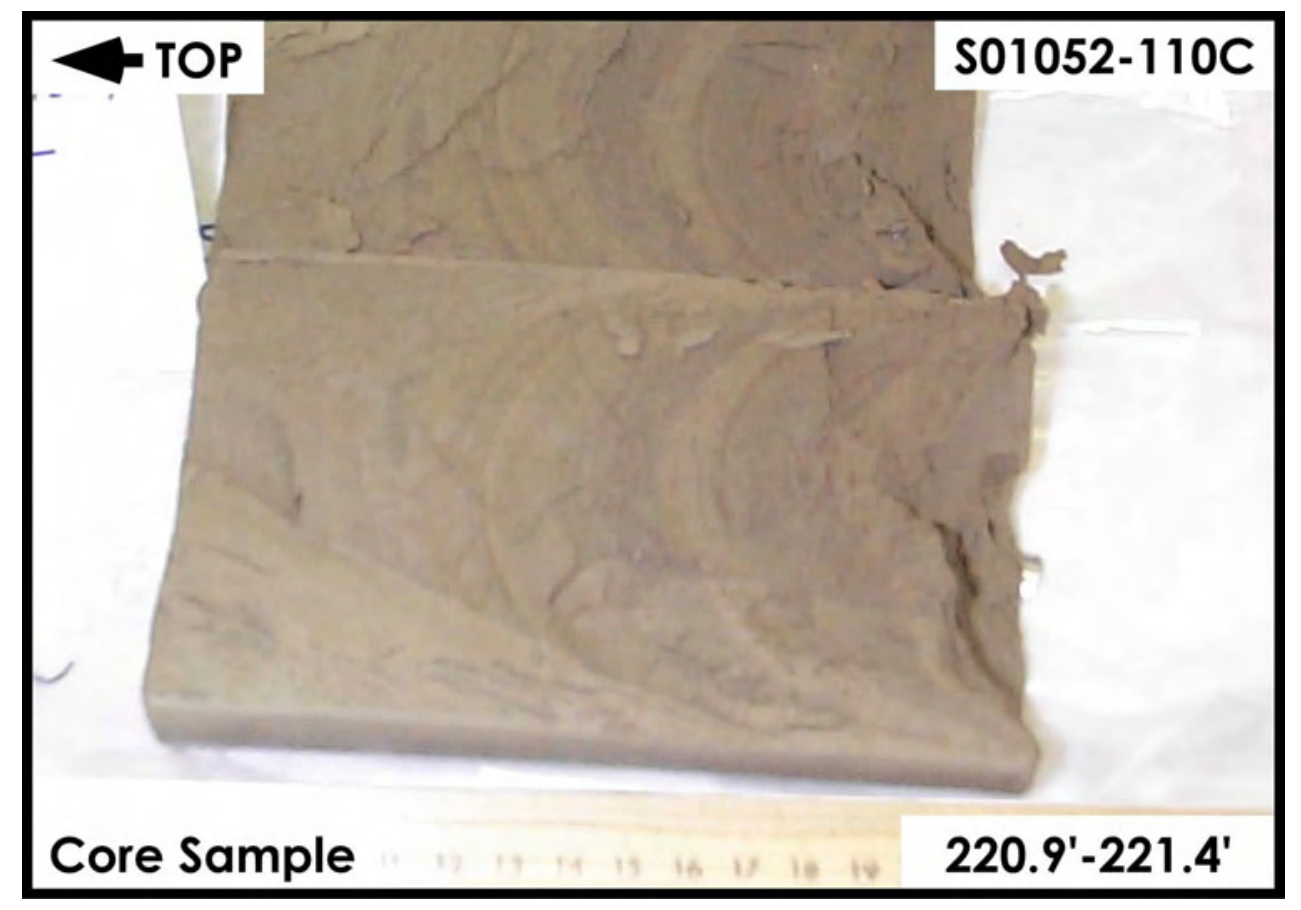

Plio-Pleistocene Silt Unit (PPlz)

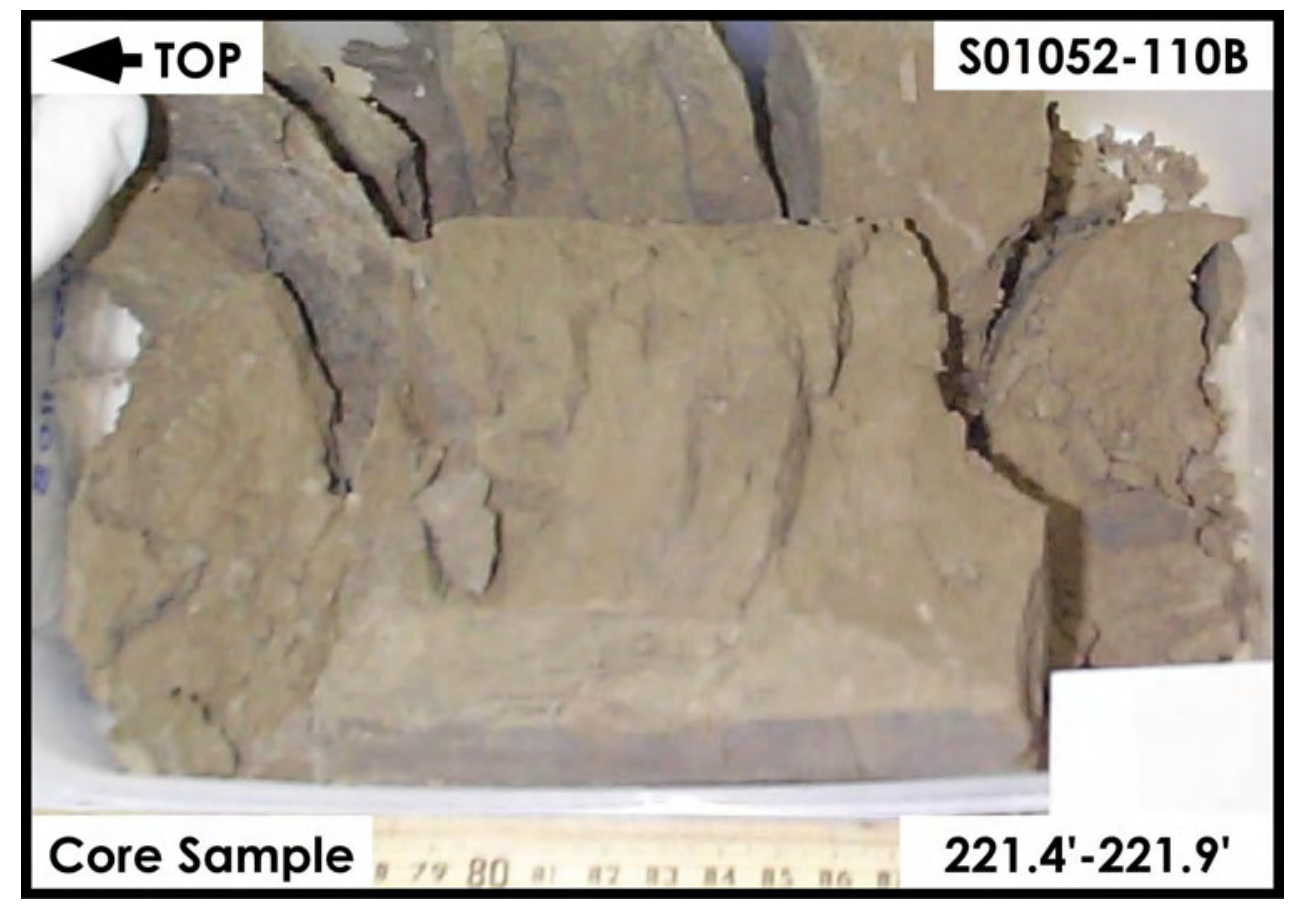

Plio-Pleistocene Silt Unit (PPlz) 


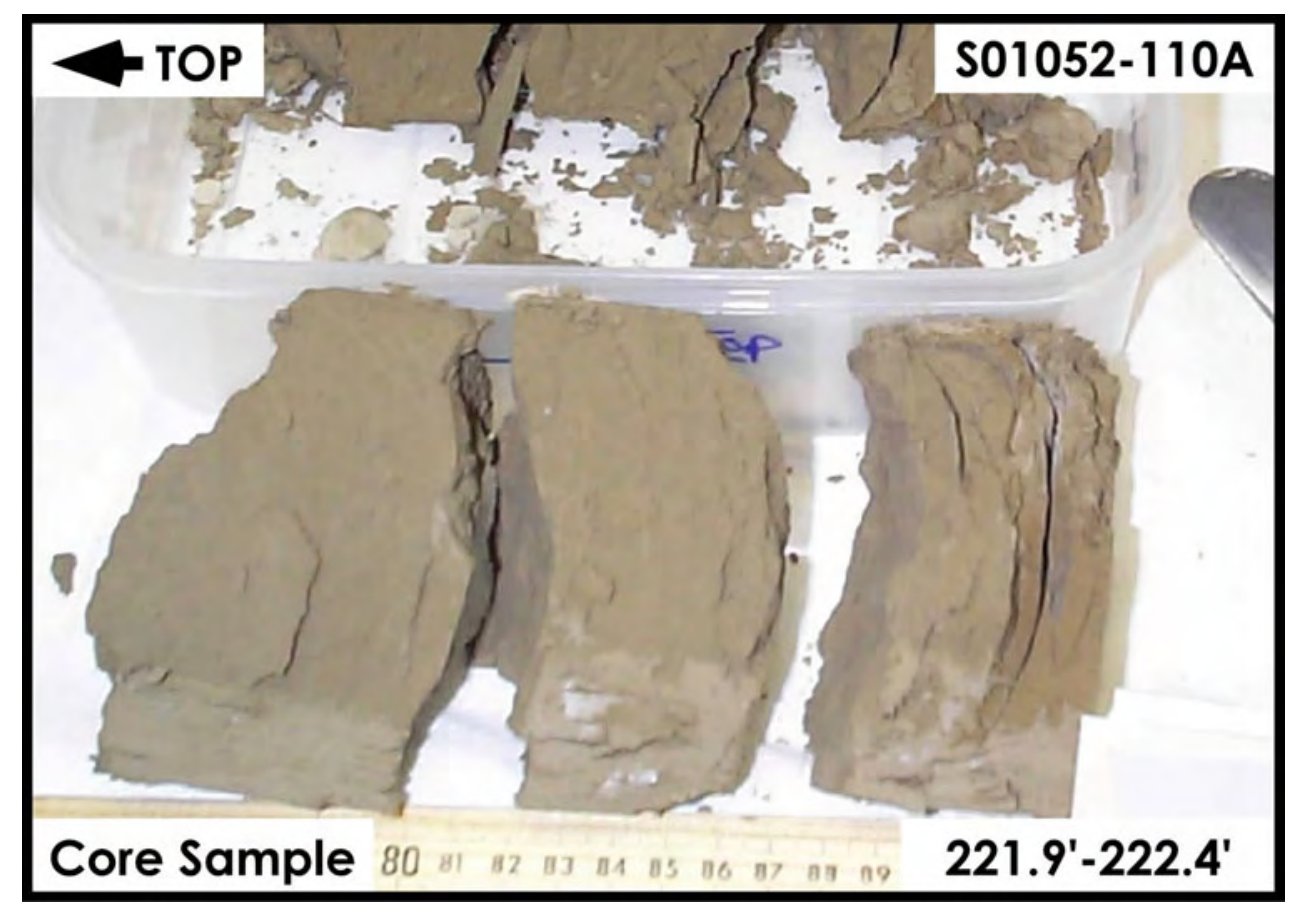

Plio-Pleistocene Silt Unit (PPlz)

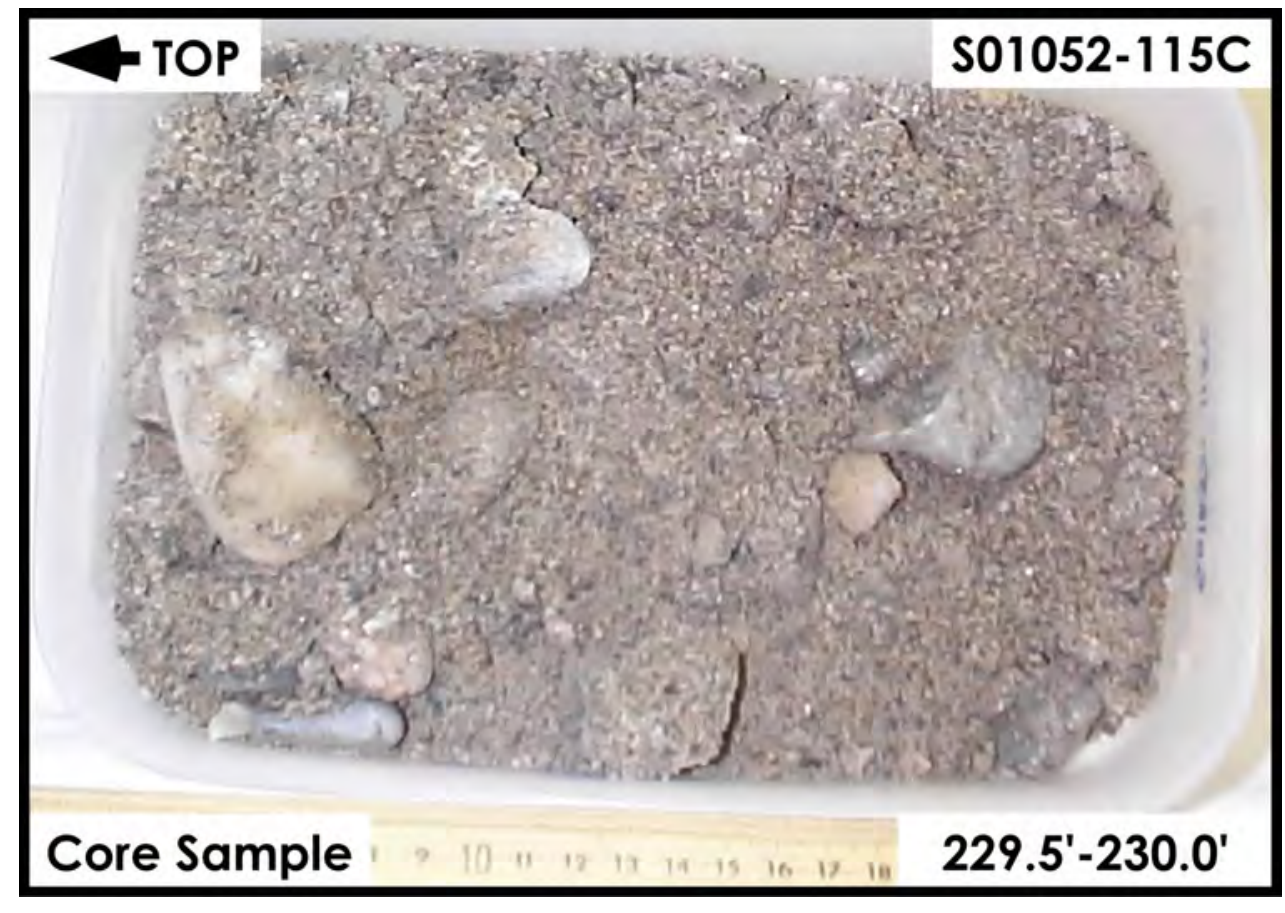

Plio-Pleistocene Gravel Unit (PPlg) 


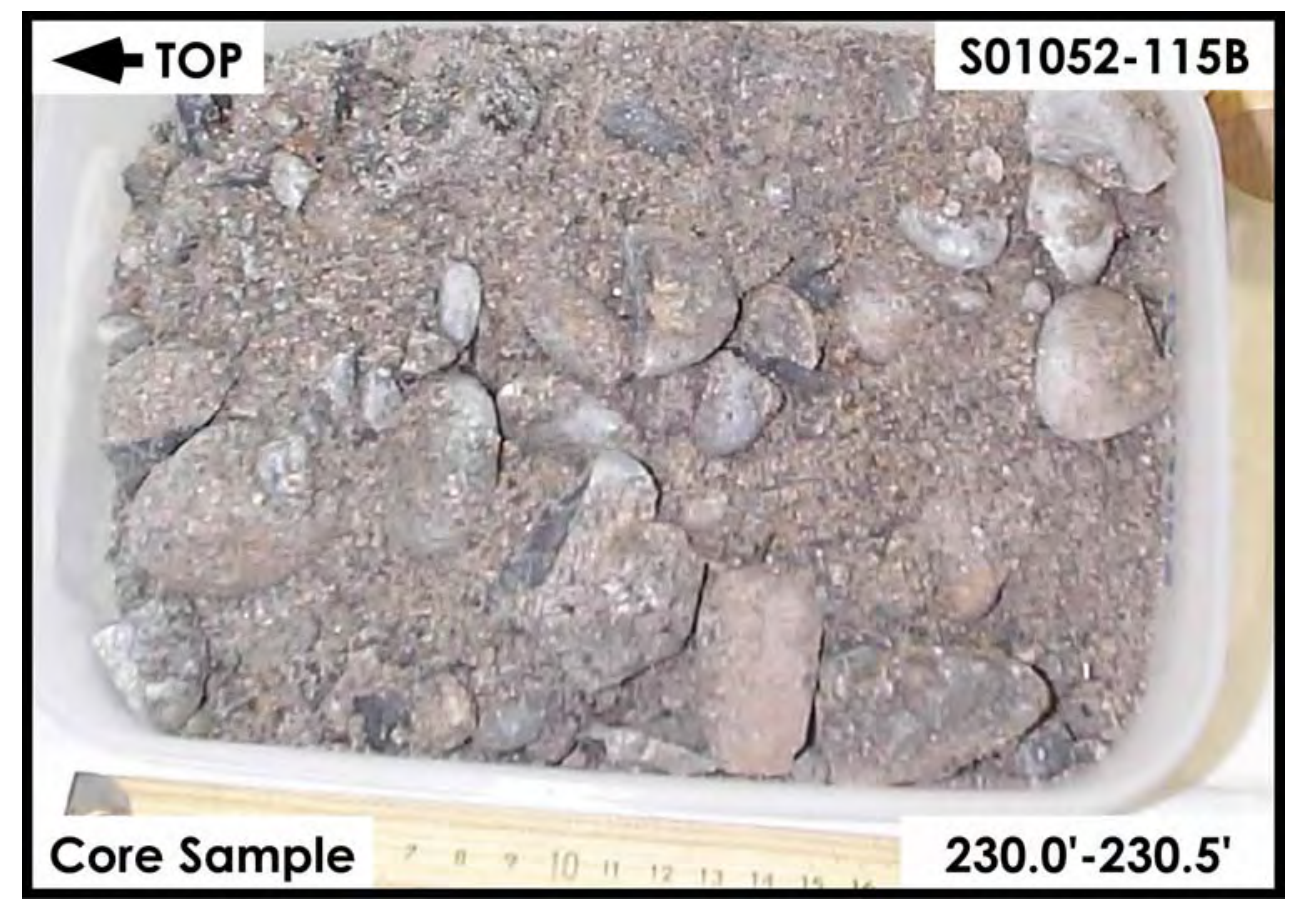

Plio-Pleistocene Gravel Unit (PPlg)

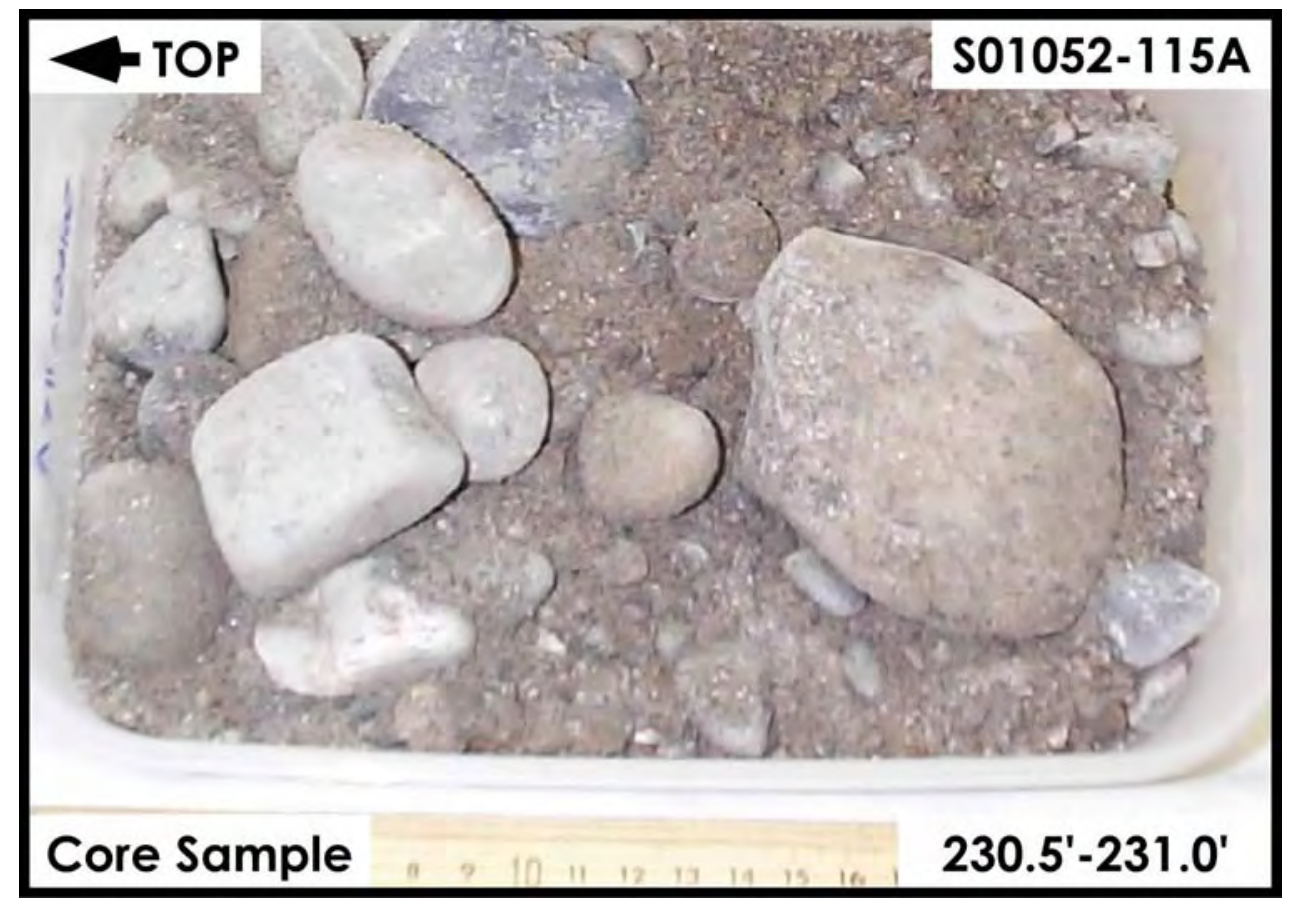

Plio-Pleistocene Gravel Unit (PPlg) 


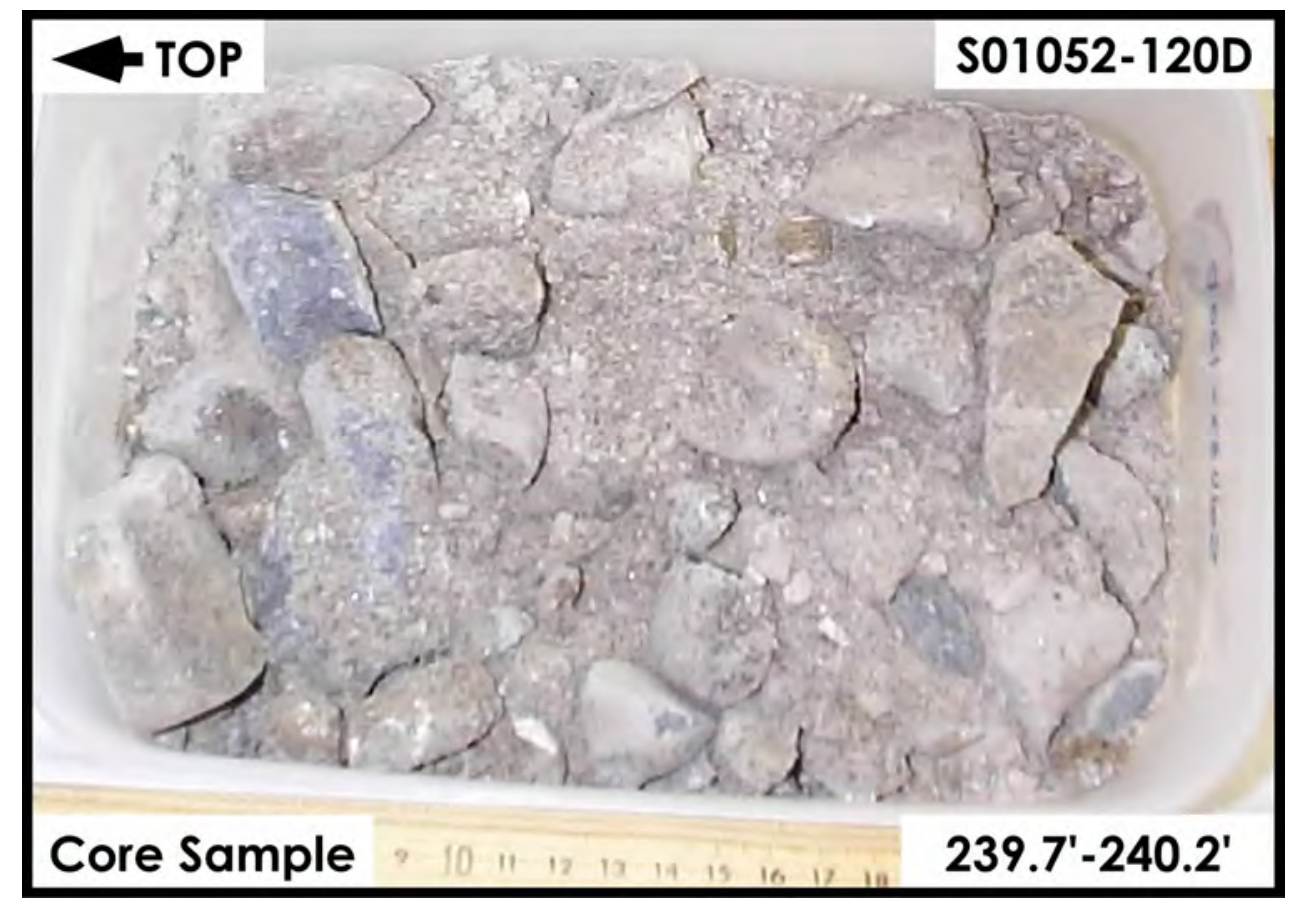

Plio-Pleistocene Gravel Unit (PPlg)

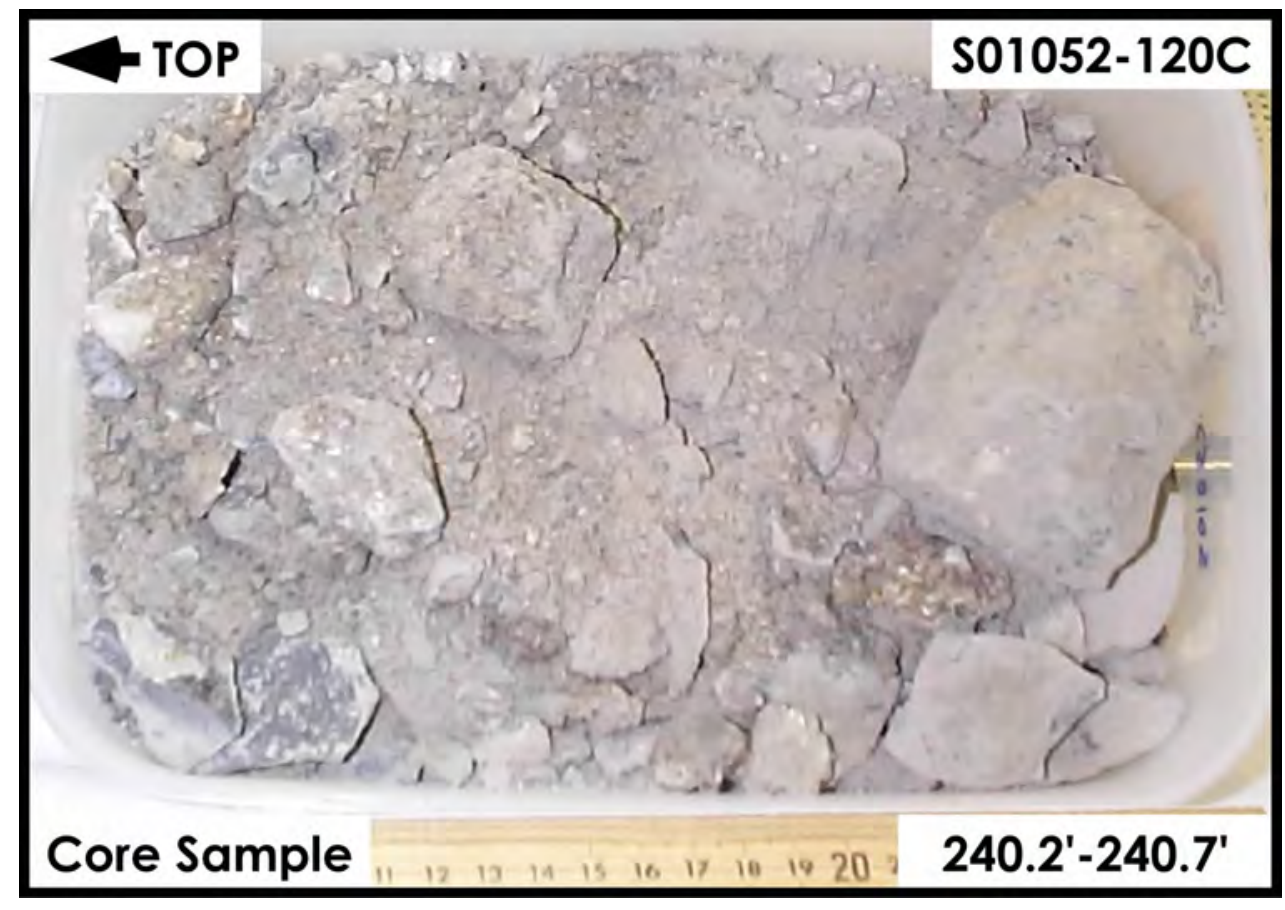

Plio-Pleistocene Gravel Unit (PPlg) 


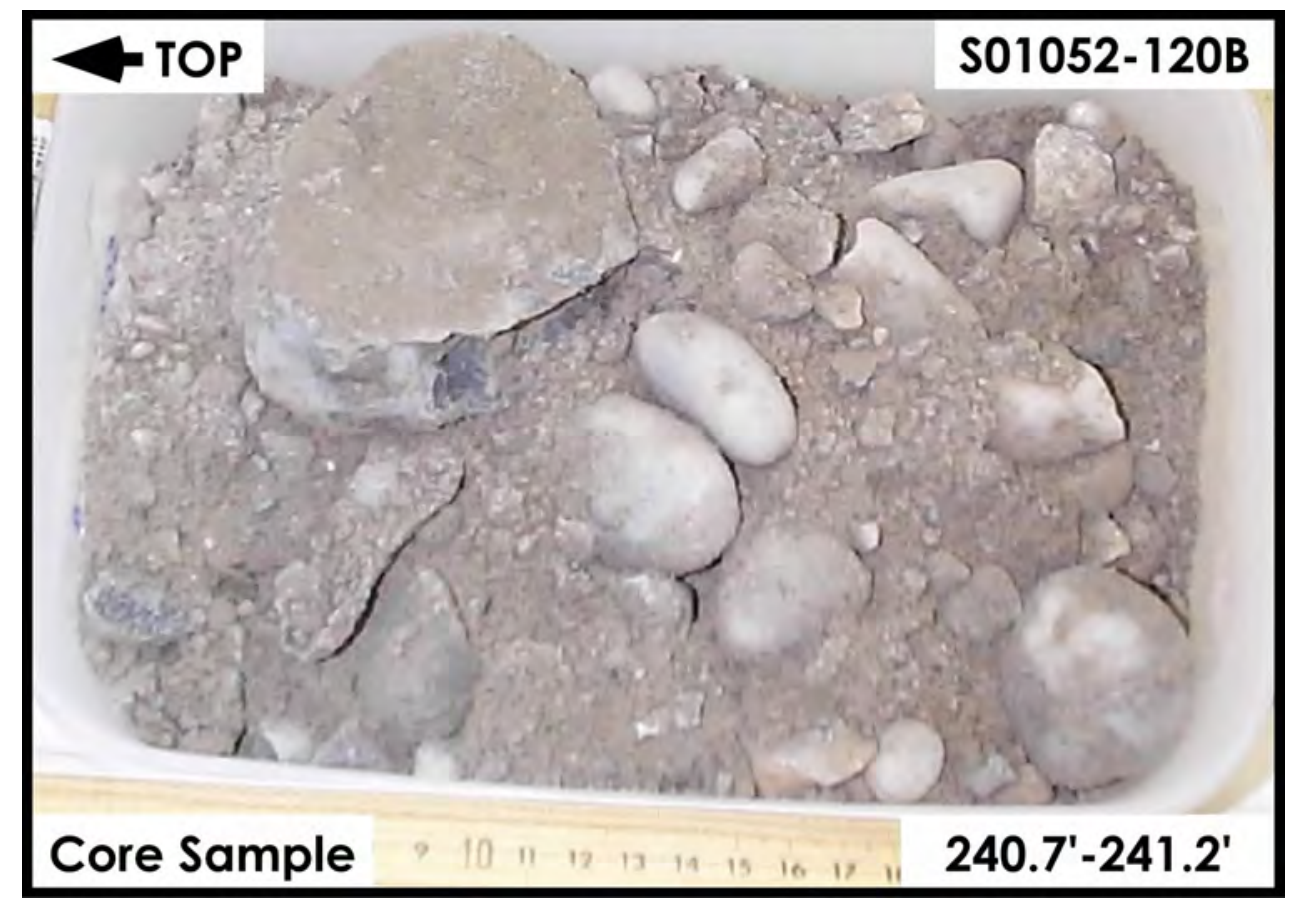

Plio-Pleistocene Gravel Unit (PPlg)

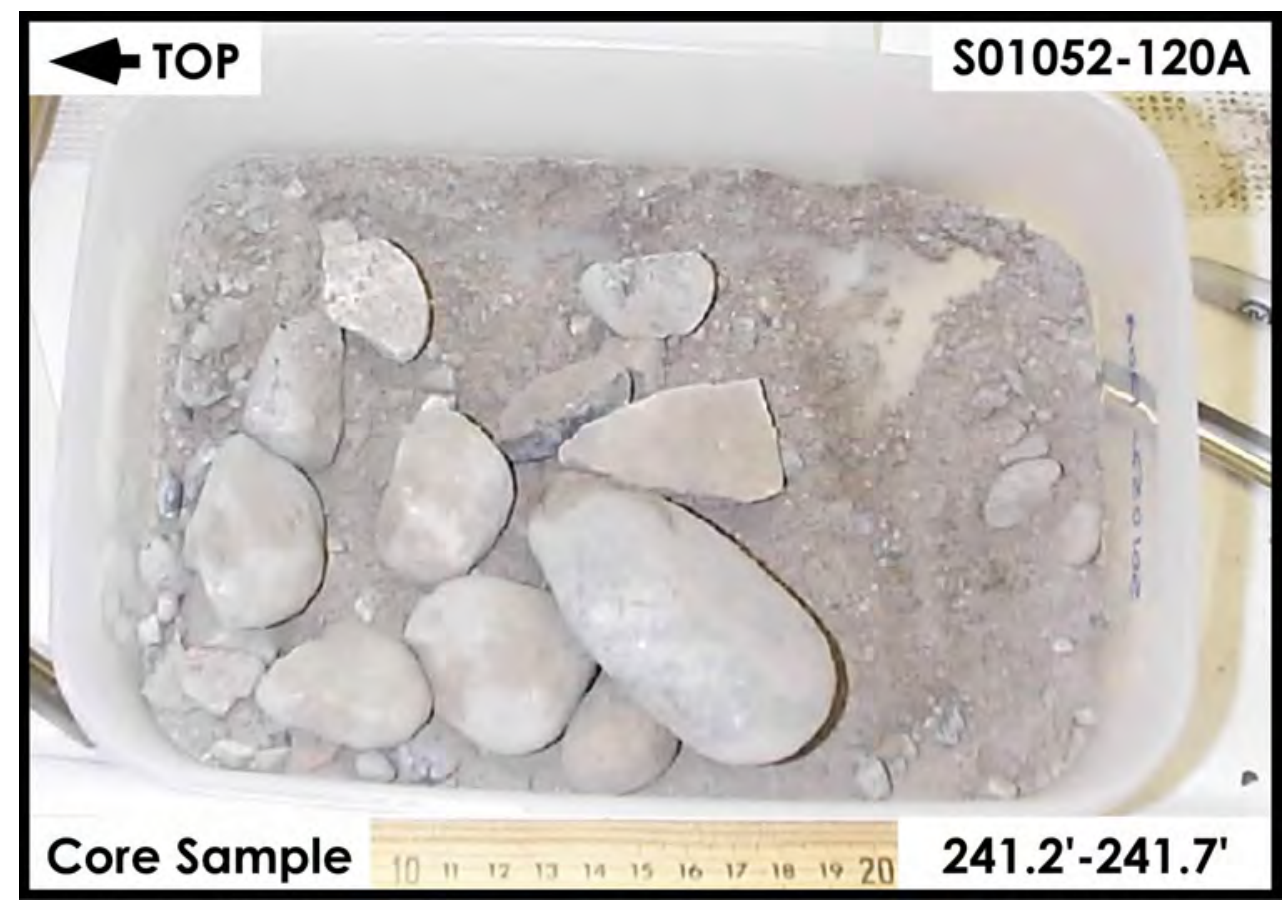

Plio-Pleistocene Gravel Unit (PPlg) 


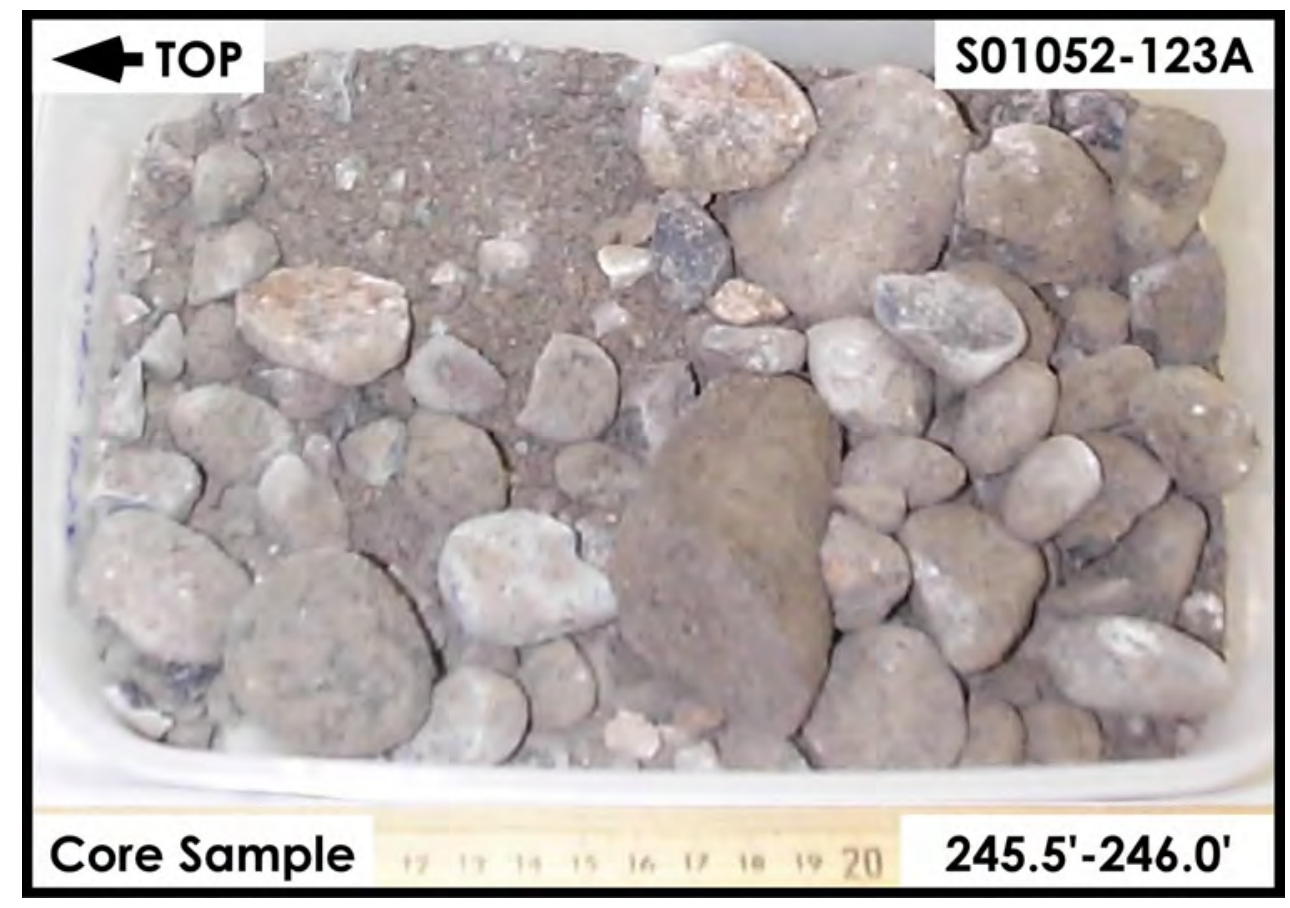

Plio-Pleistocene Gravel Unit (PPlg)

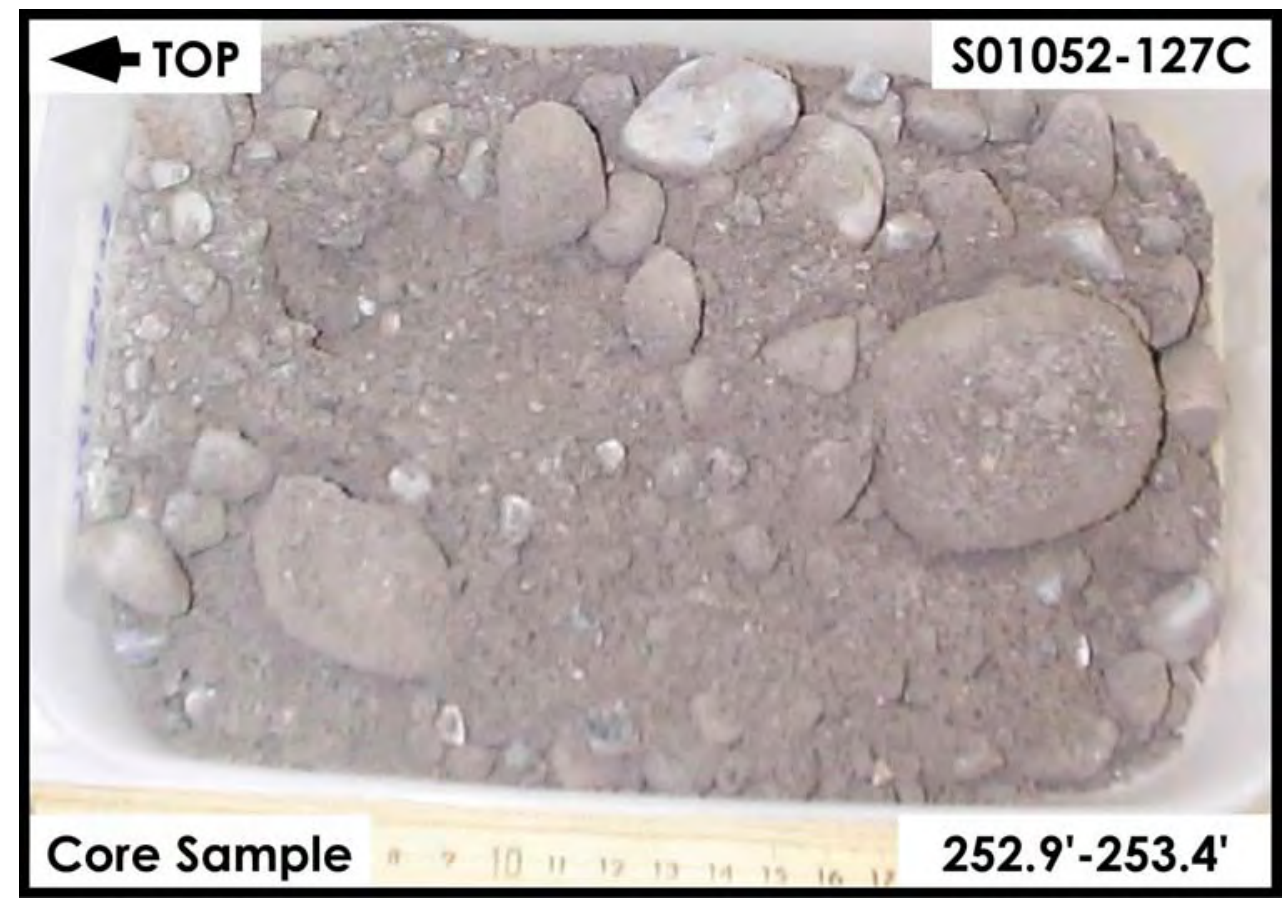

Plio-Pleistocene Gravel Unit (PPlg) 


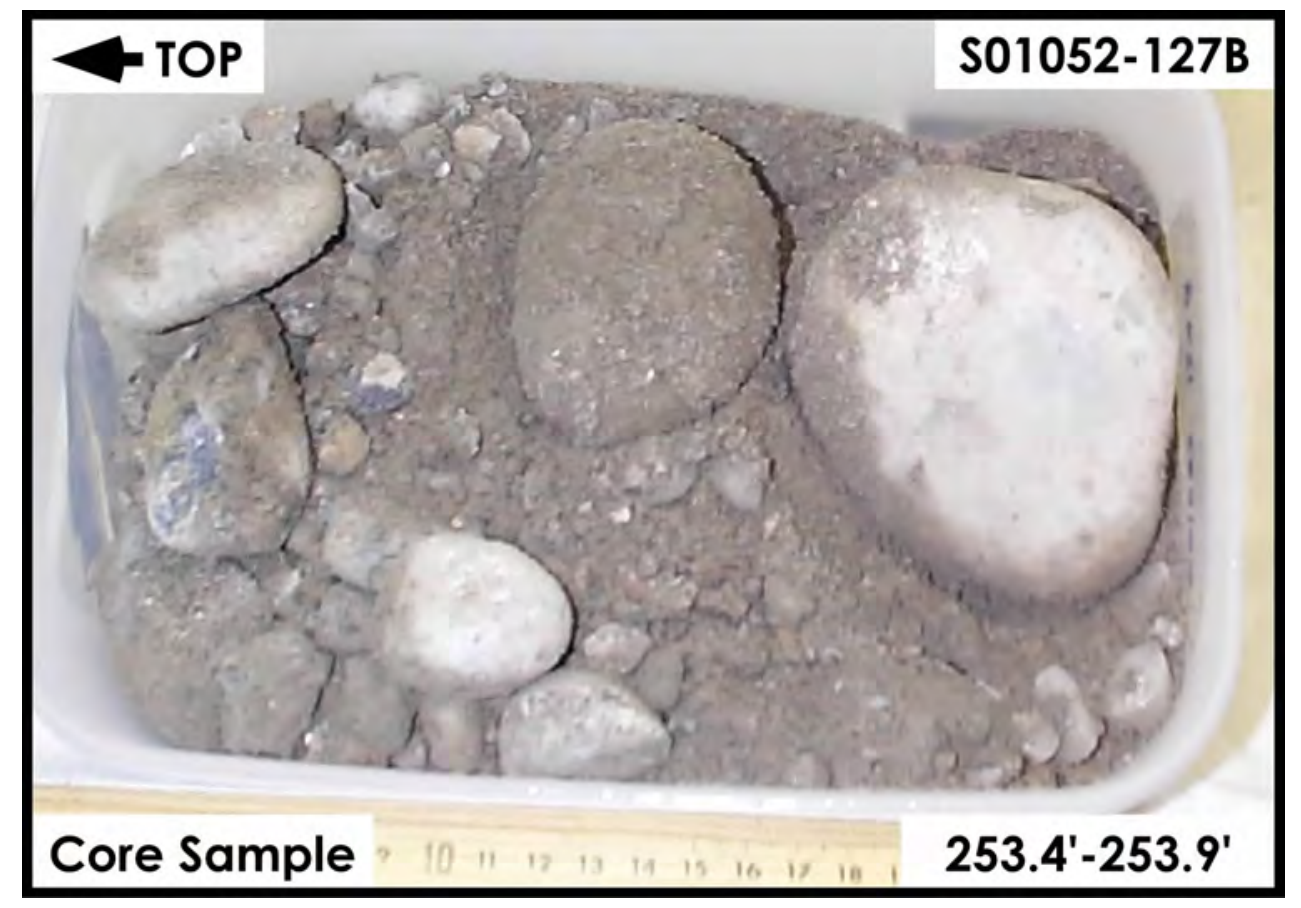

Plio-Pleistocene Gravel Unit (PPlg)

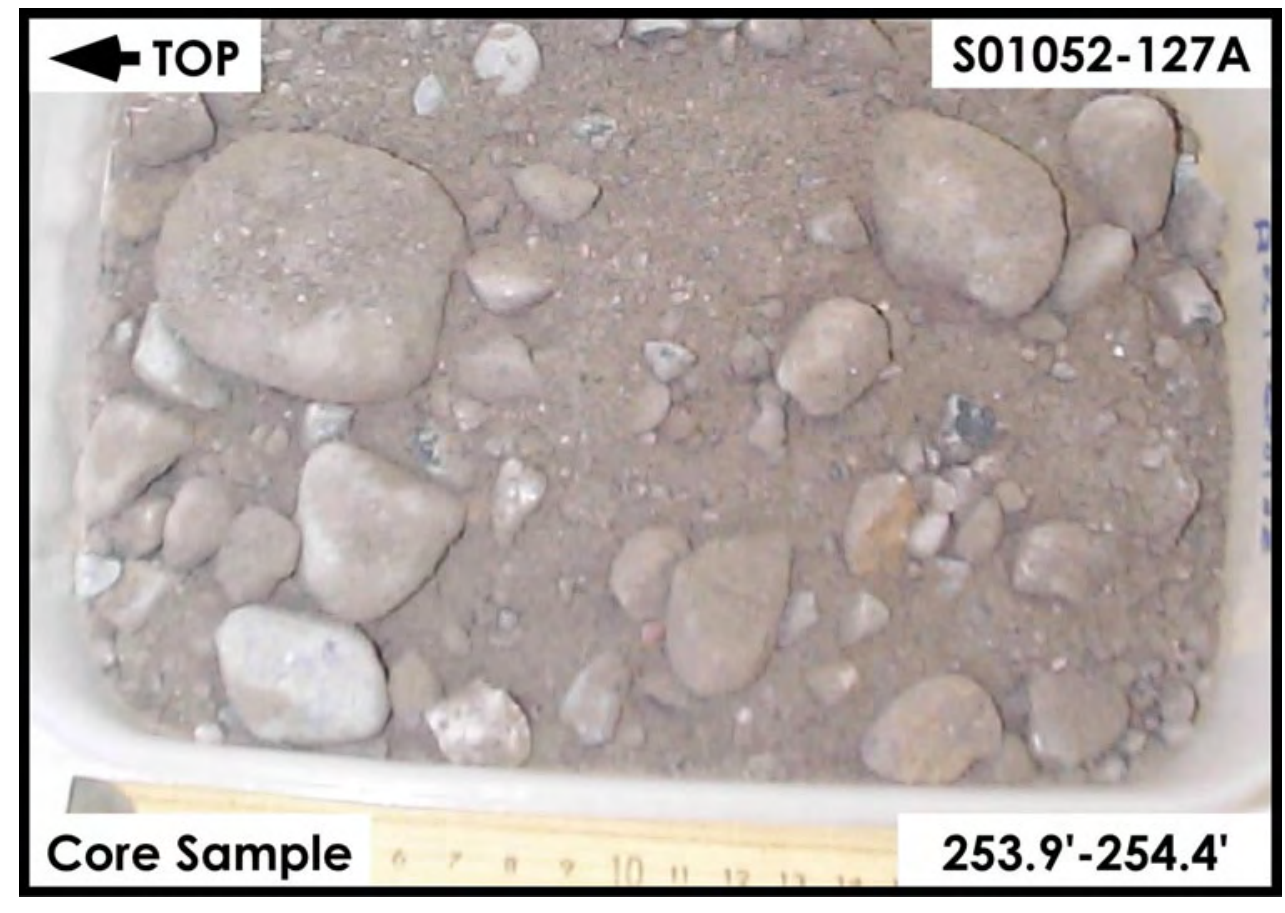

Plio-Pleistocene Gravel Unit (PPlg) 
Appendix B-2

299-E33-46

Composite Grab

and

Splitspoon Shoe

Sample Photographs 


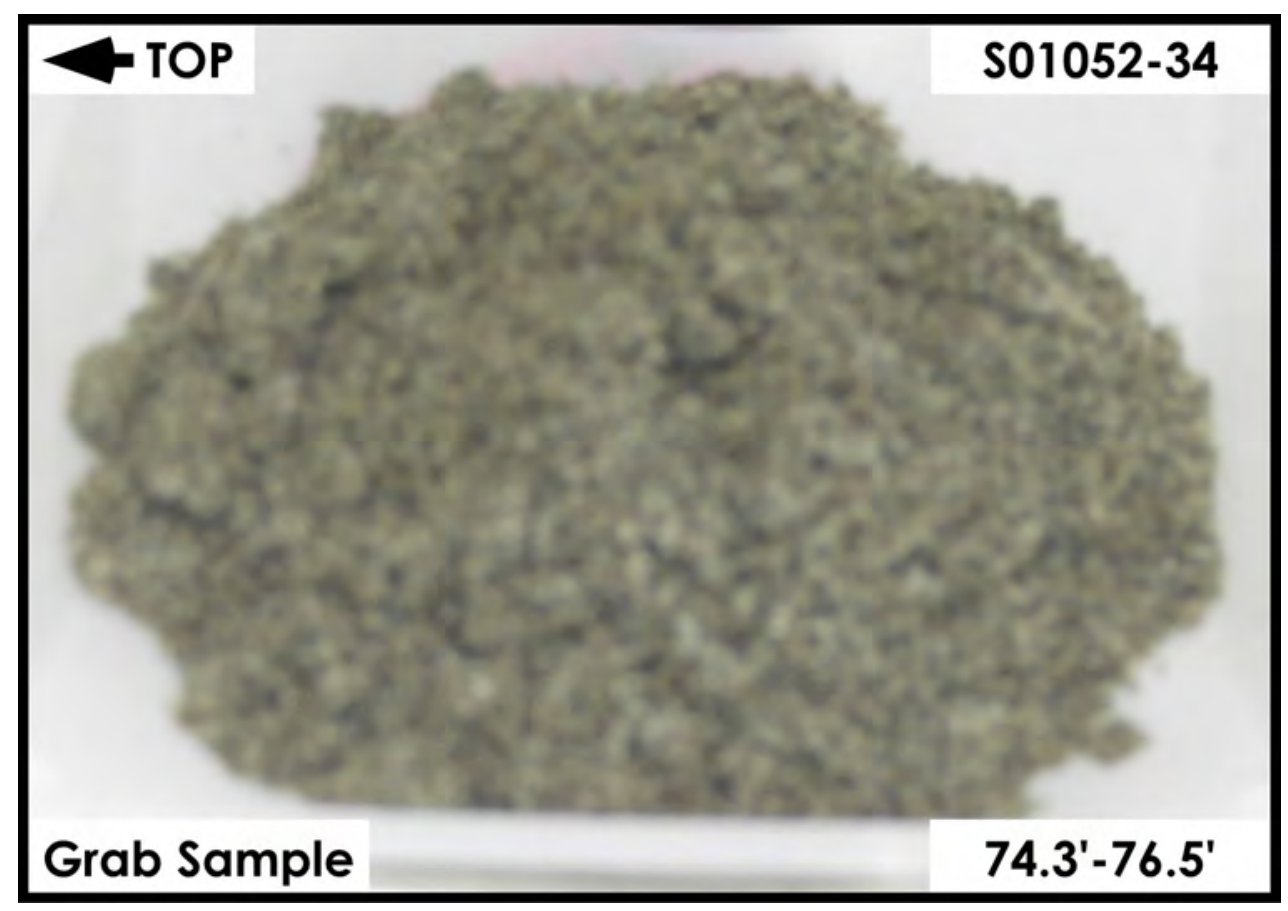

H2-Upper Sand and Gravel Sequence

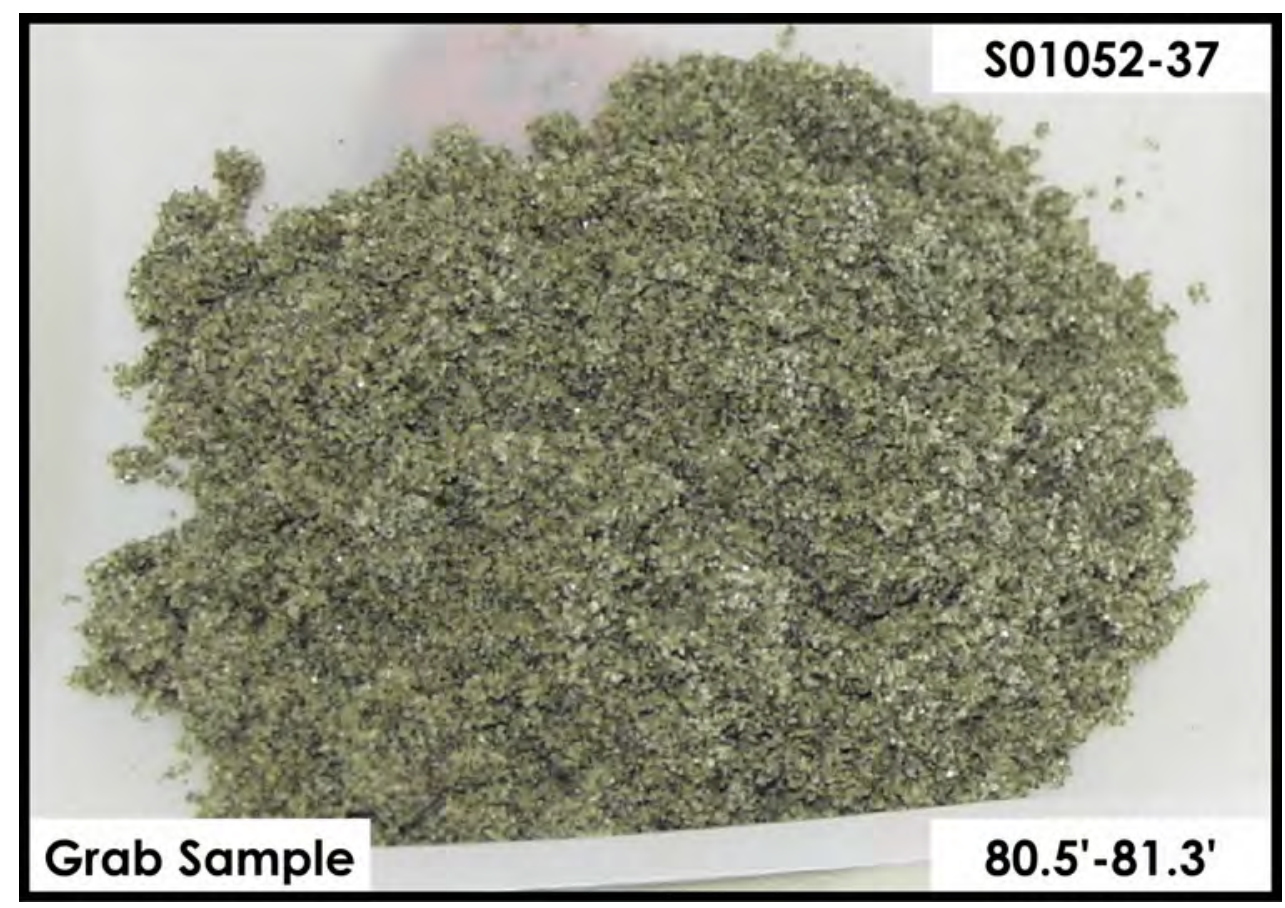

H2-Upper Sand and Gravel Sequence 


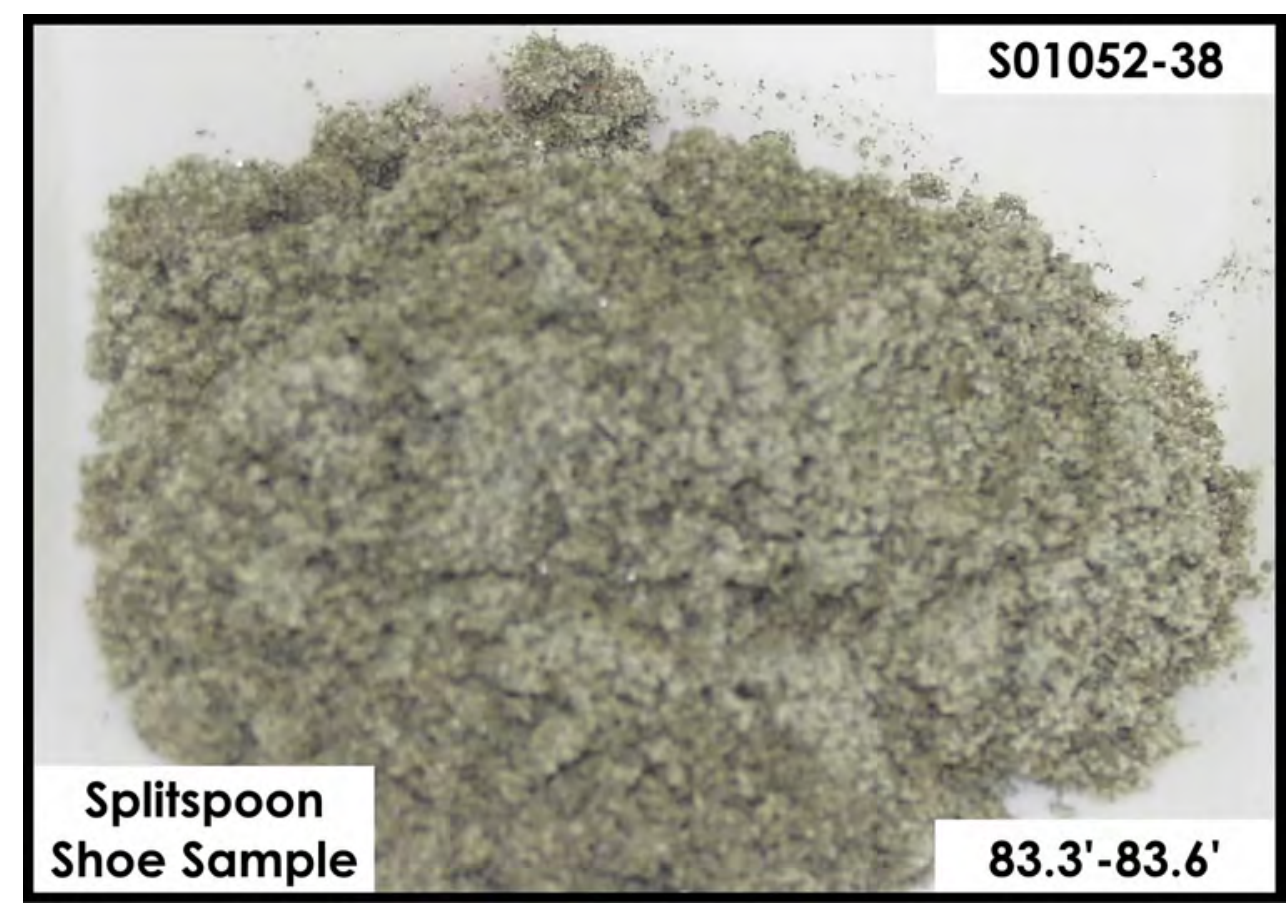

H2-Upper Sand and Gravel Sequence

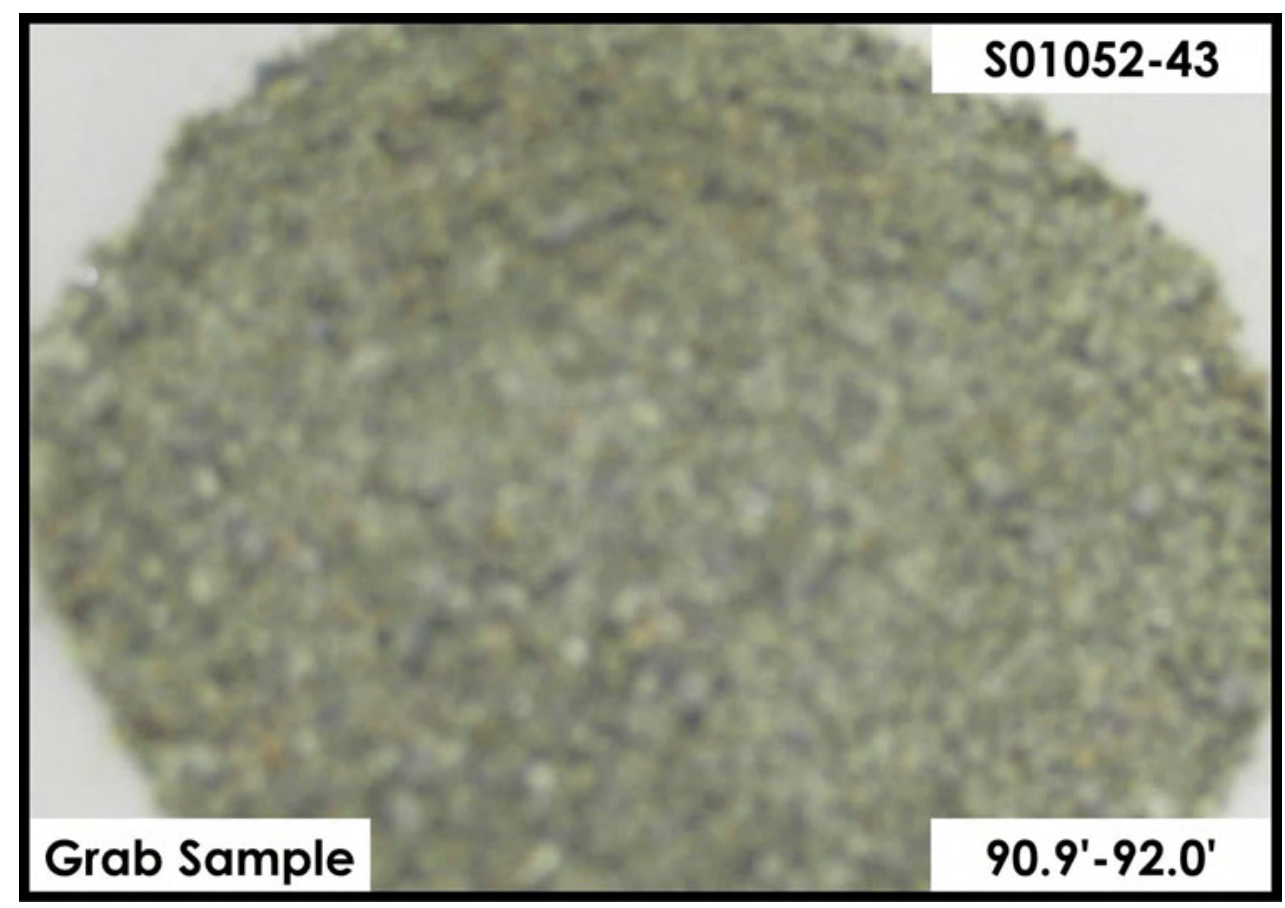

H2-Upper Sand and Gravel Sequence 


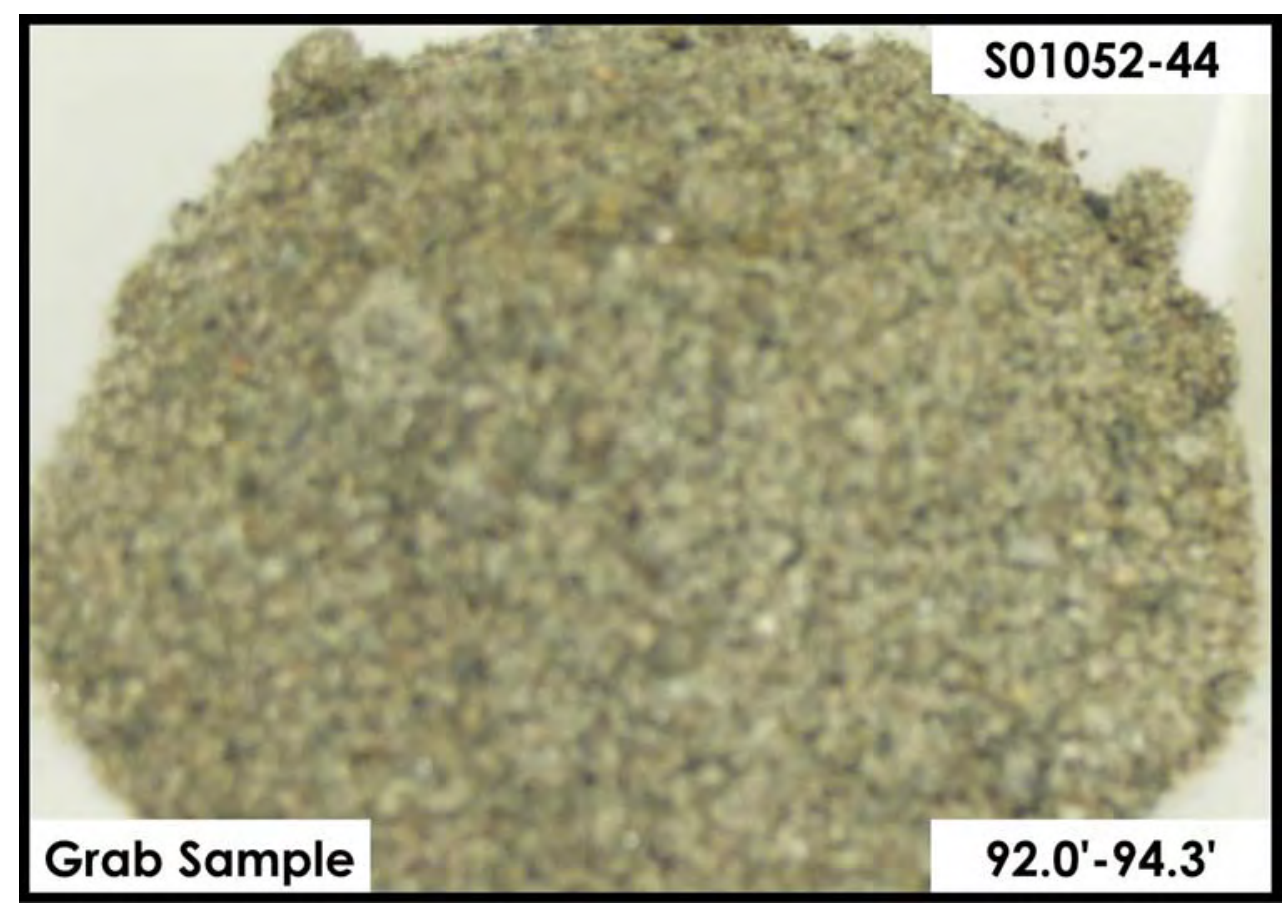

H2-Upper Sand and Gravel Sequence

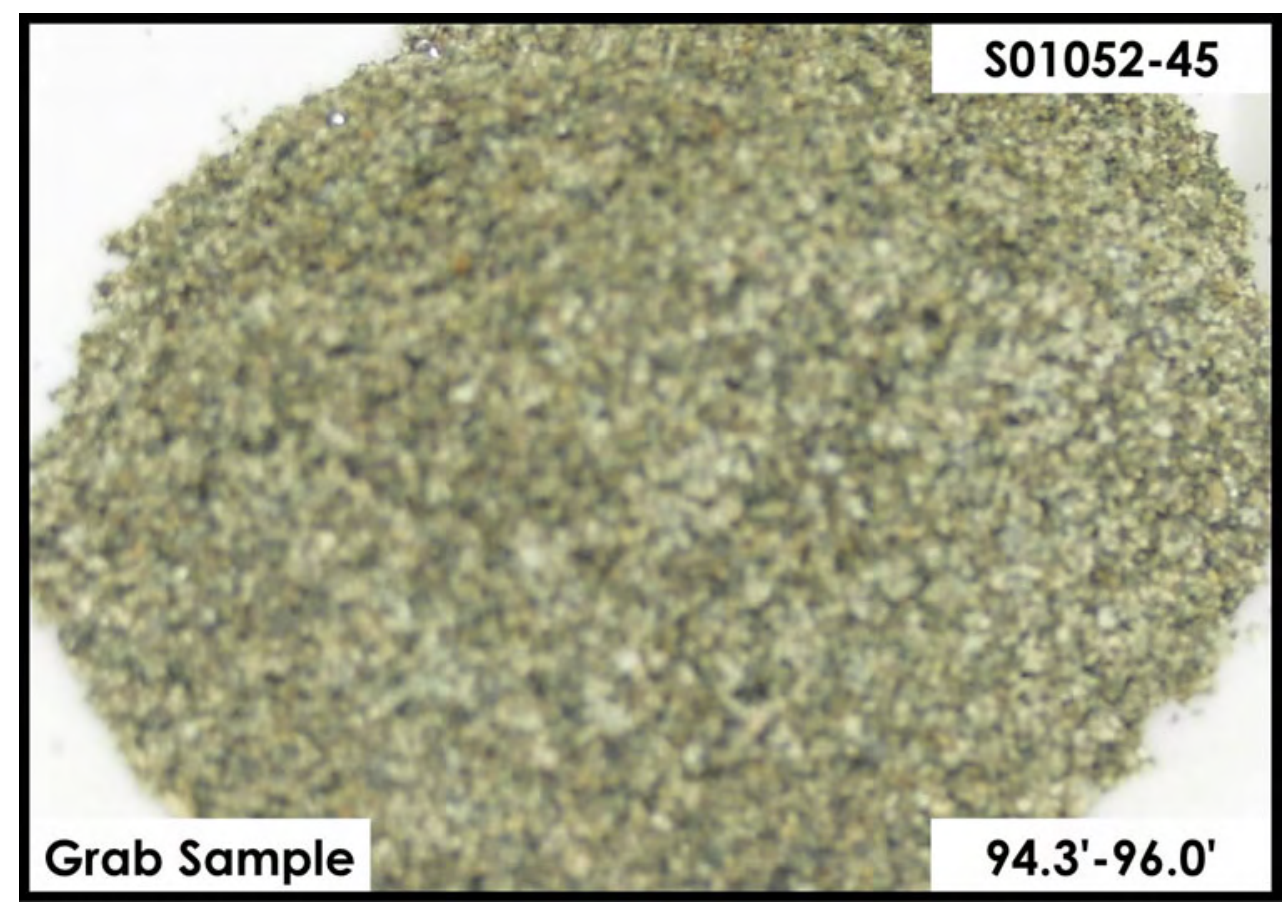

H2-Upper Sand and Gravel Sequence 


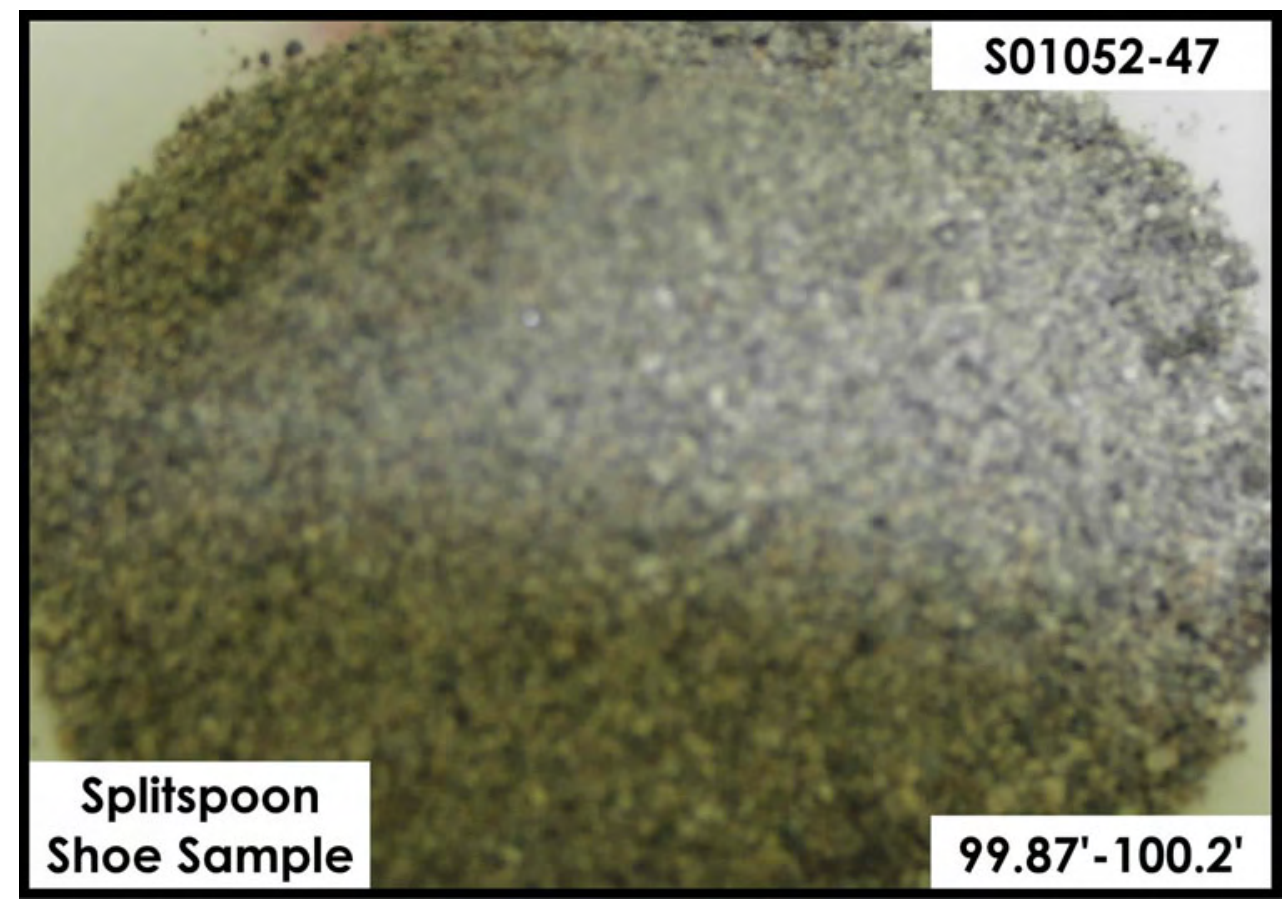

H2-Upper Sand and Gravel Sequence

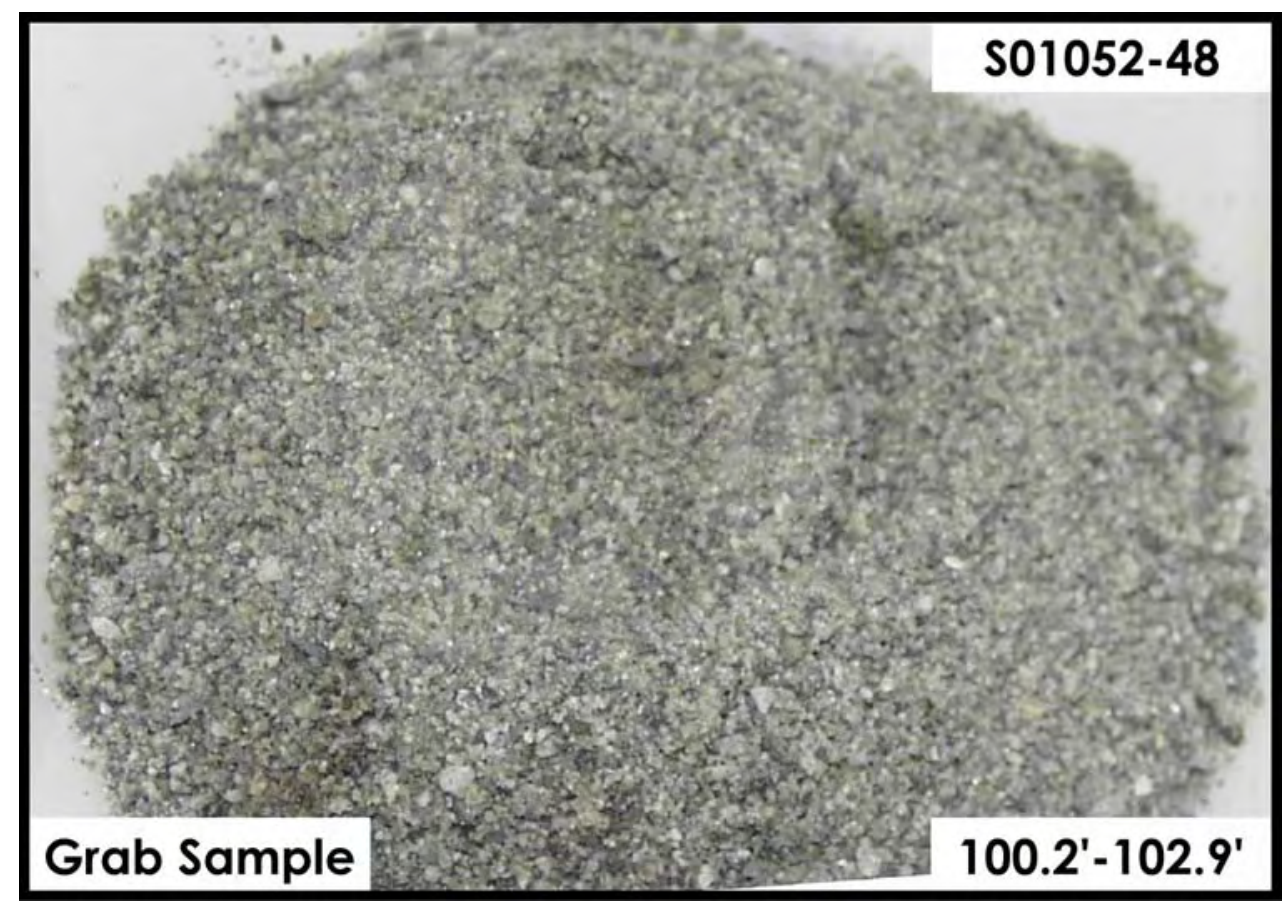

H2-Upper Sand and Gravel Sequence 


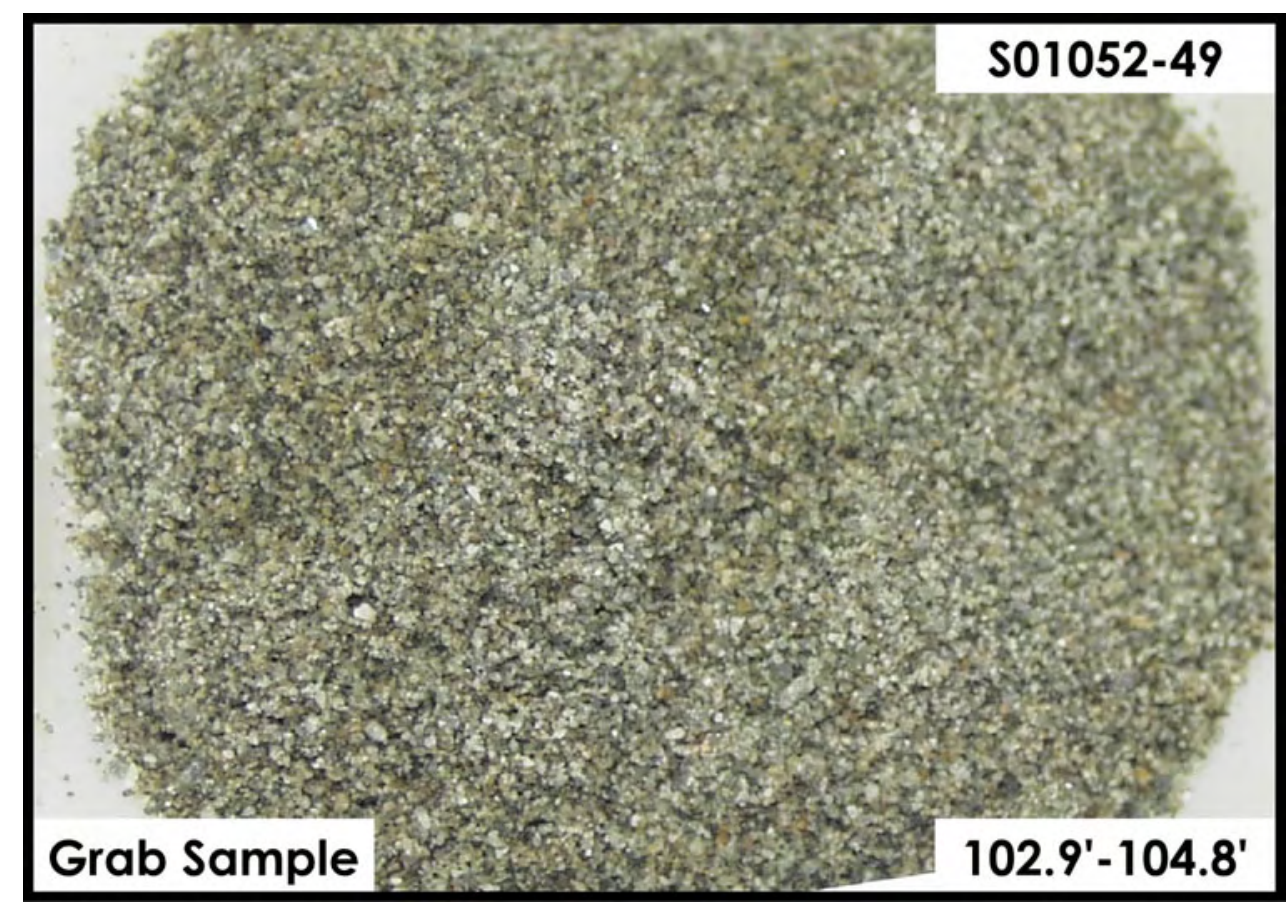

H2-Upper Sand and Gravel Sequence

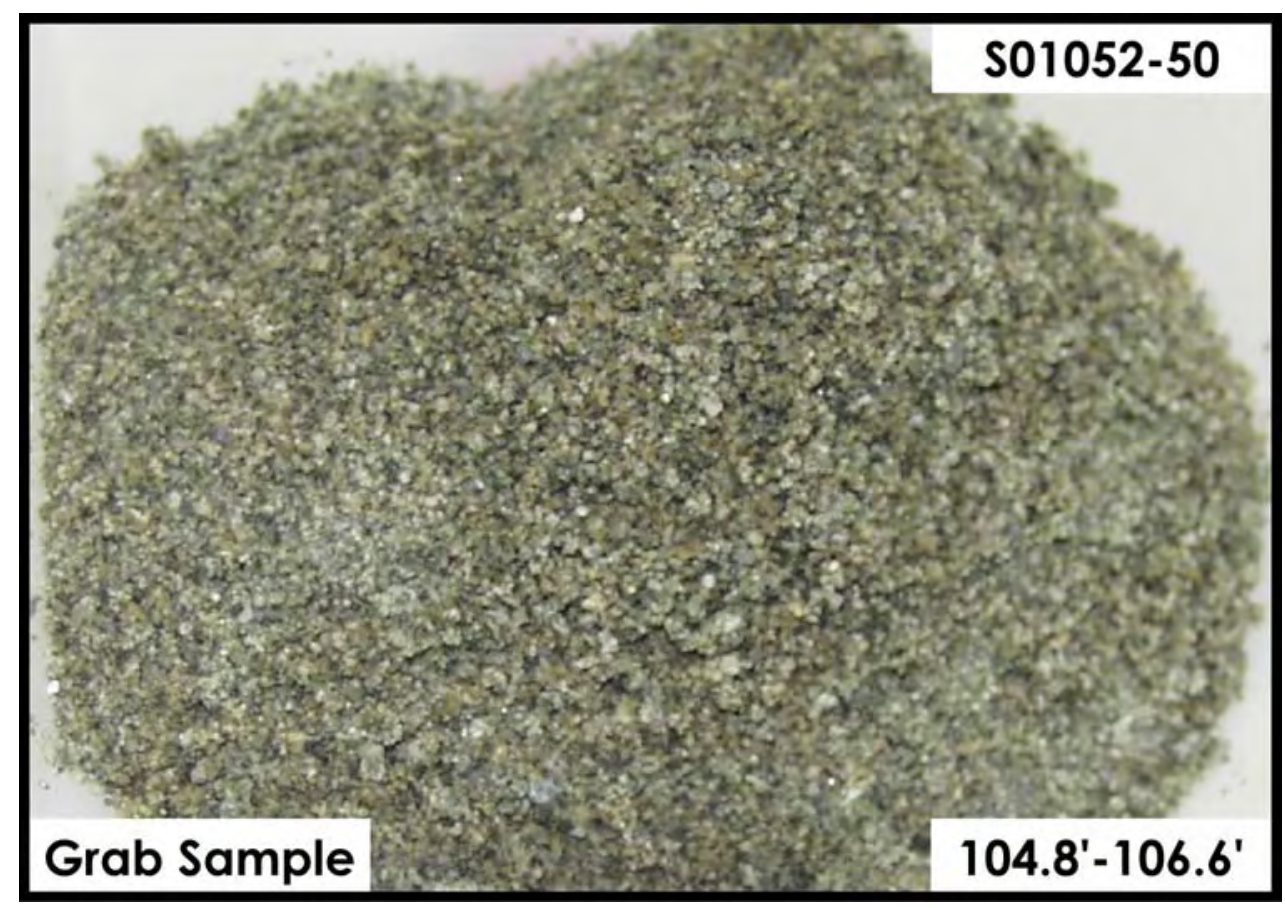

H2-Upper Sand and Gravel Sequence 


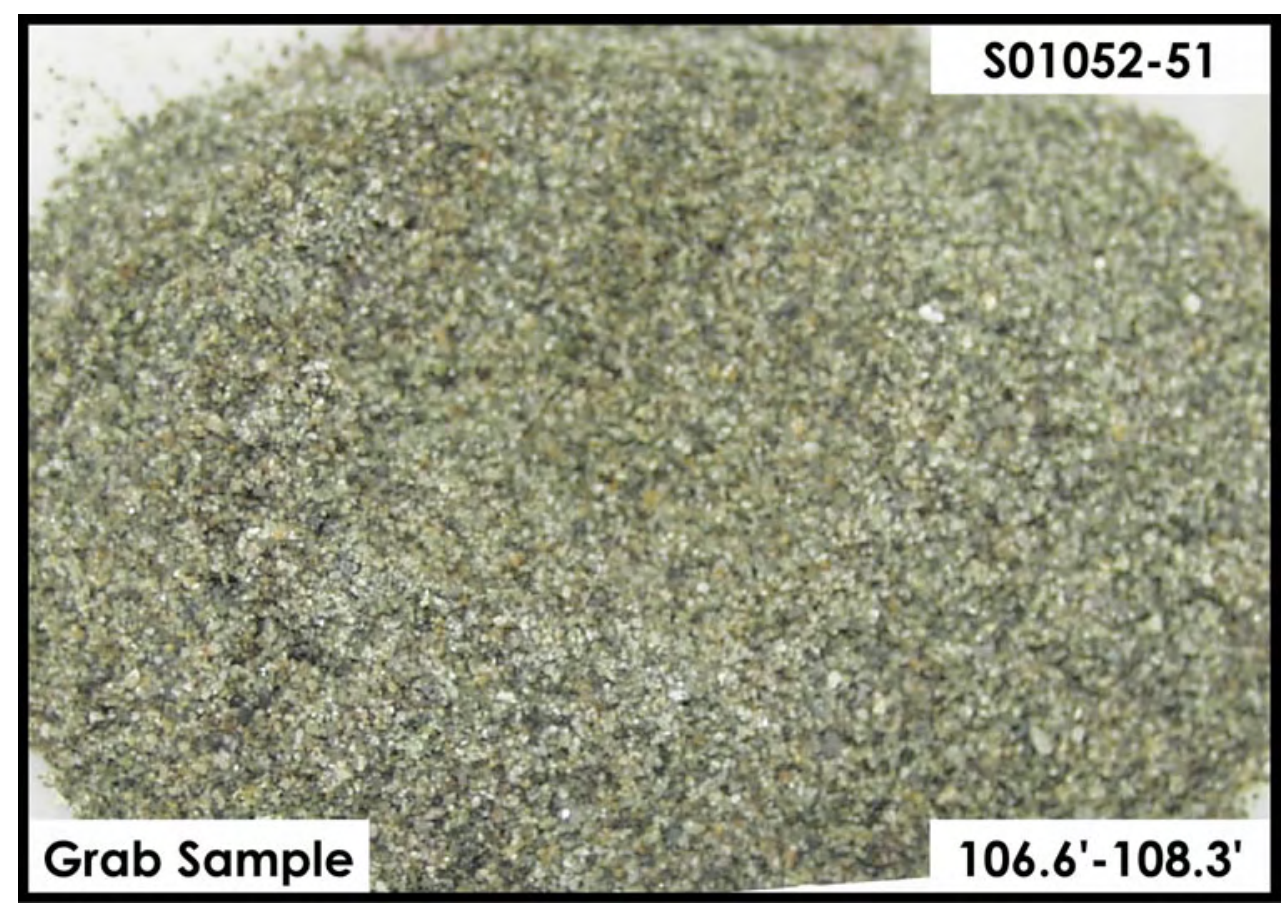

H2-Upper Sand and Gravel Sequence

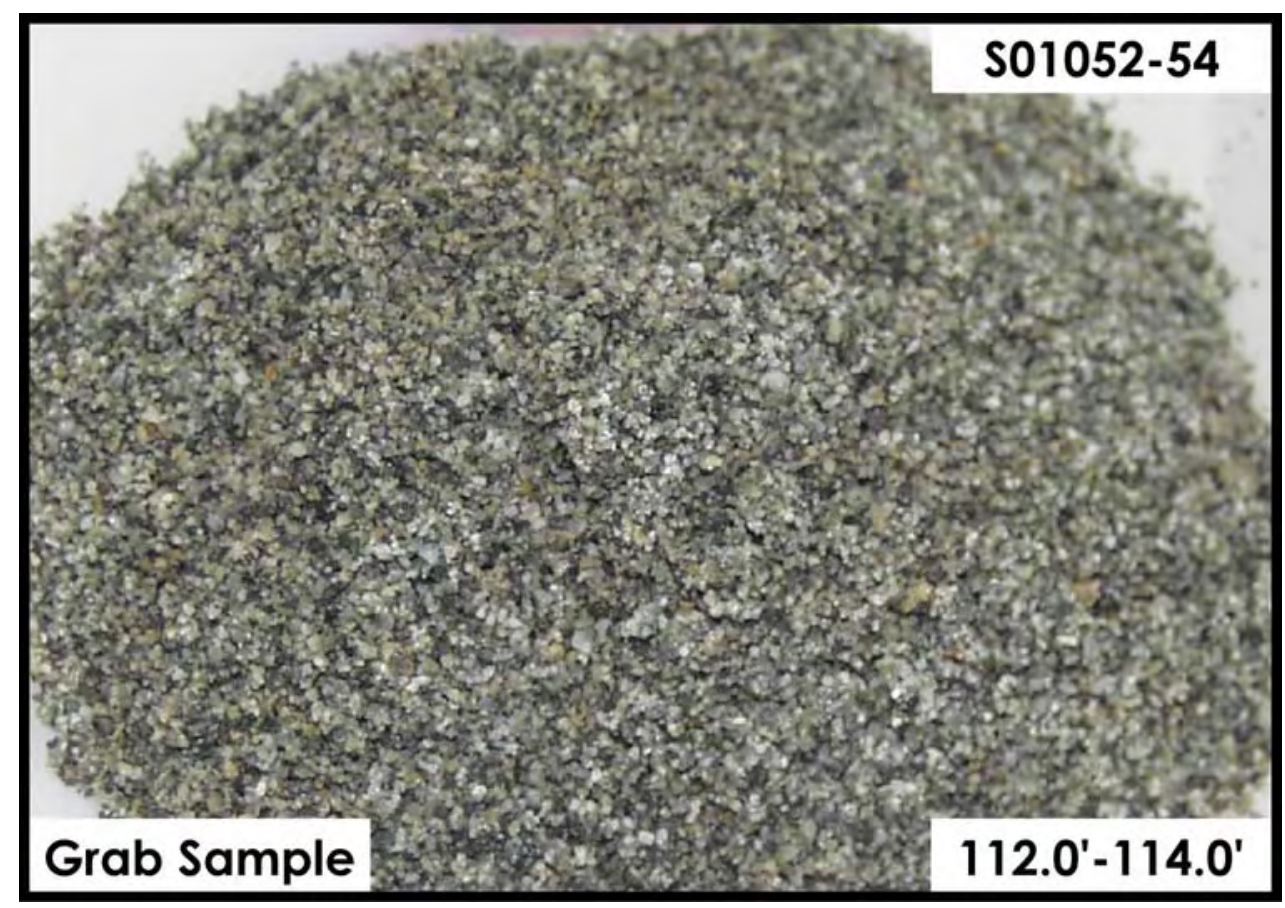

H2-Upper Sand and Gravel Sequence 


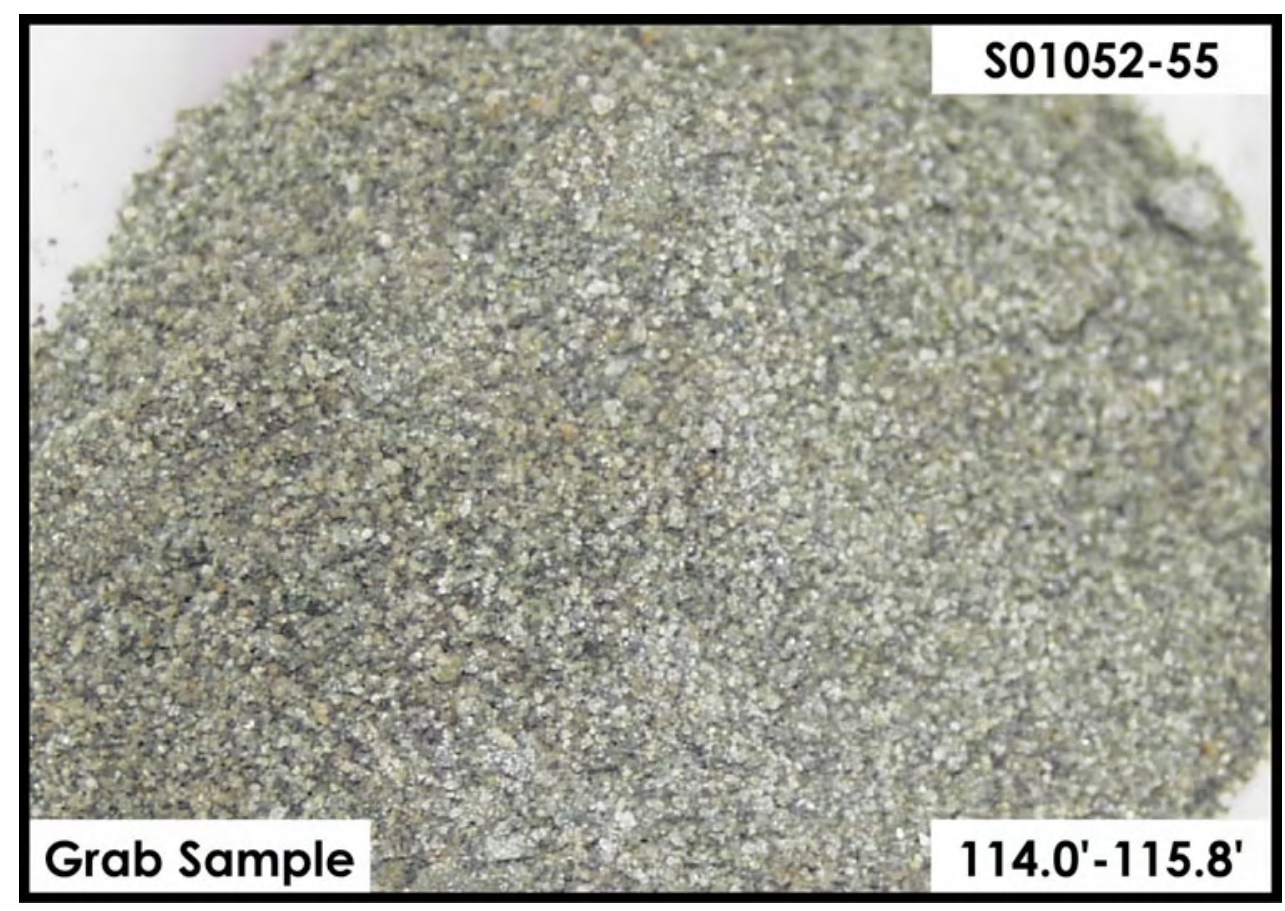

H2-Upper Sand and Gravel Sequence

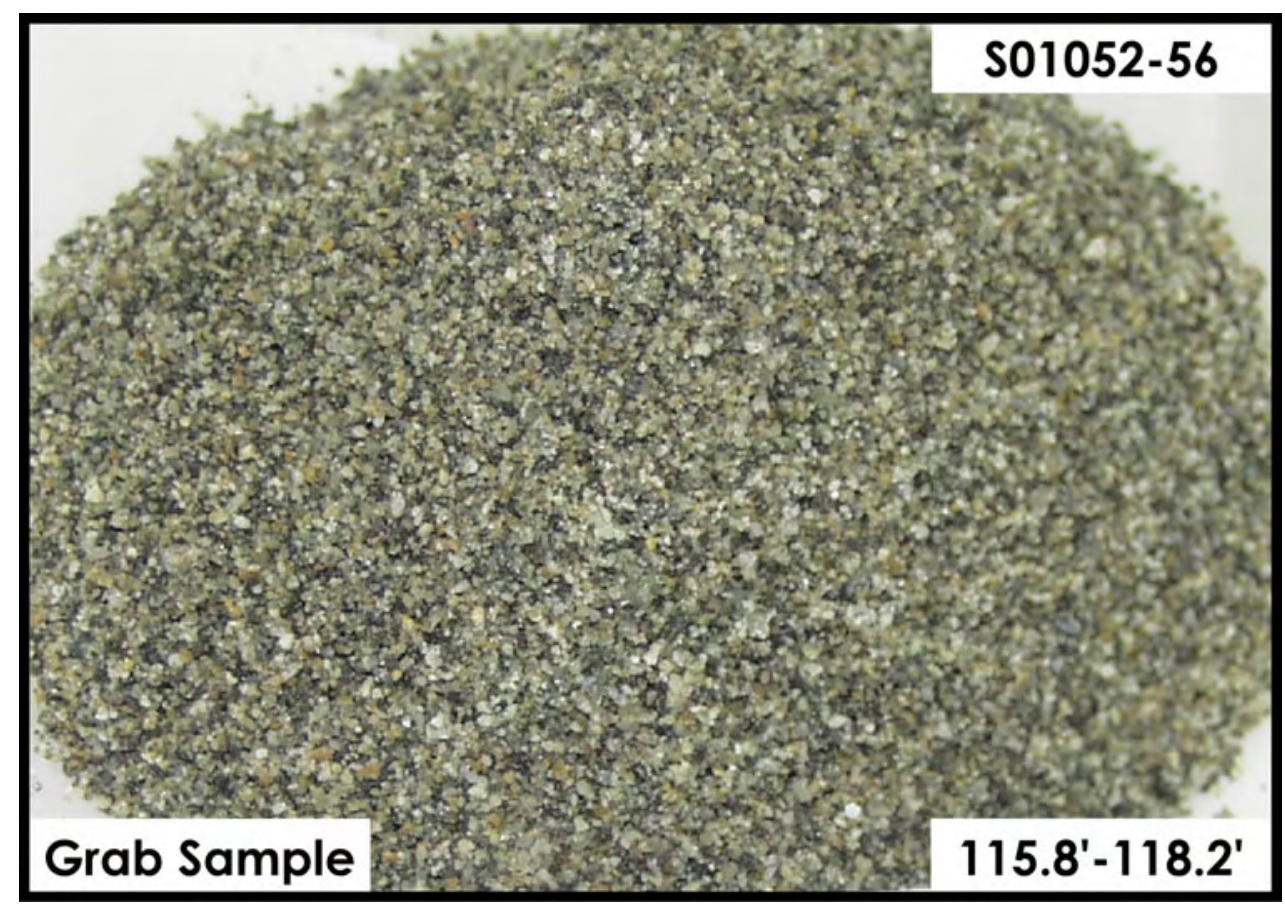

H2-Upper Sand and Gravel Sequence

B.61 


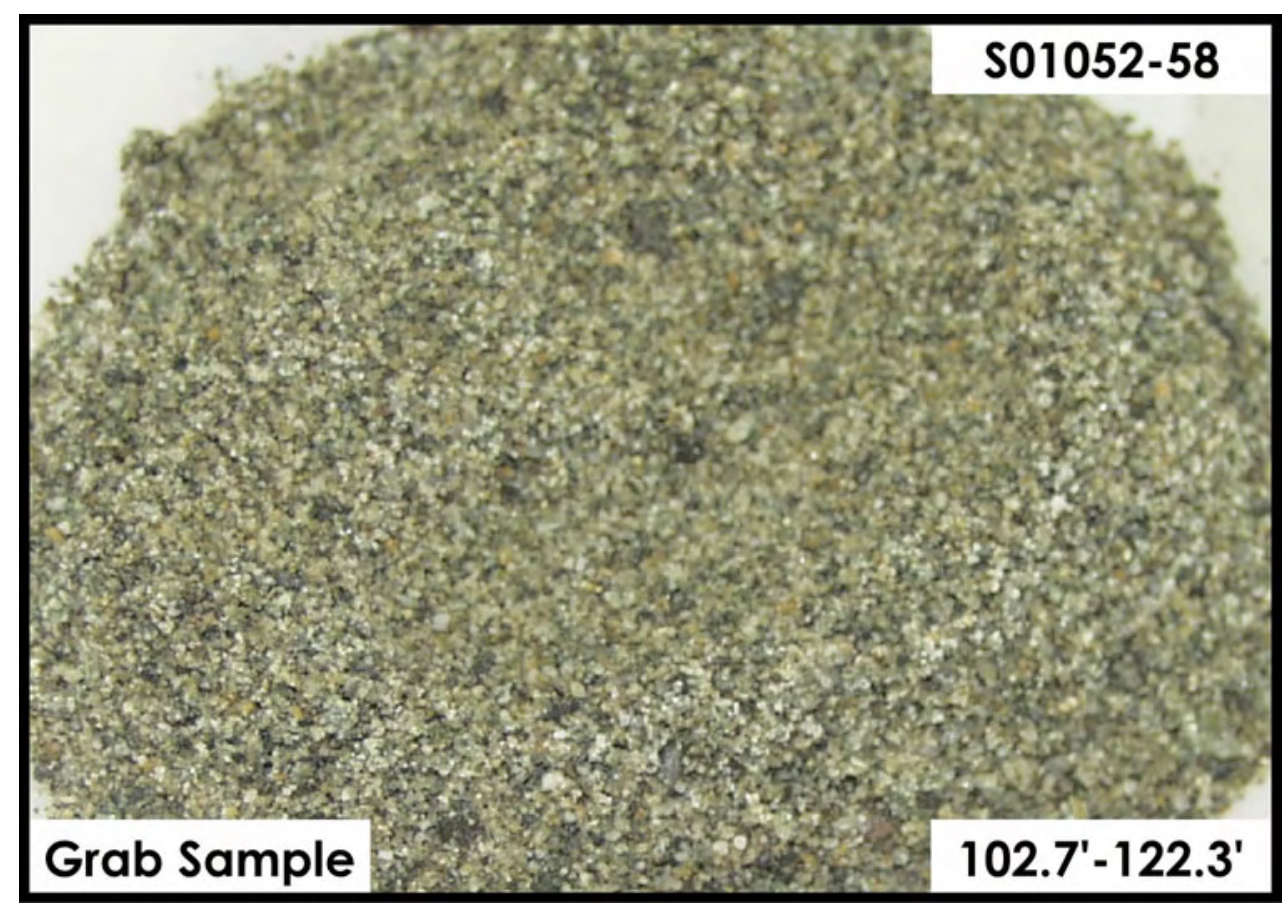

H2-Upper Sand and Gravel Sequence

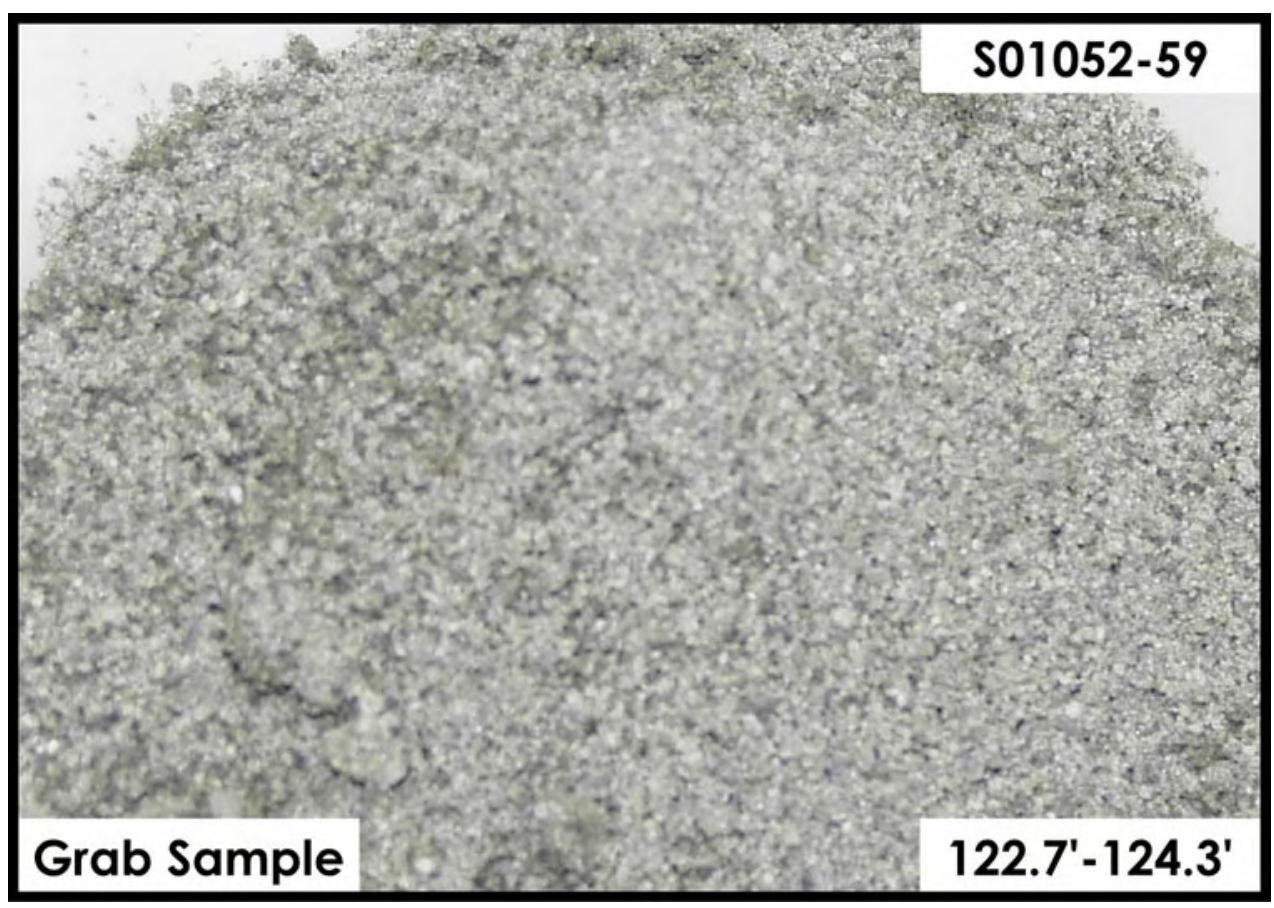

H2-Upper Sand and Gravel Sequence 


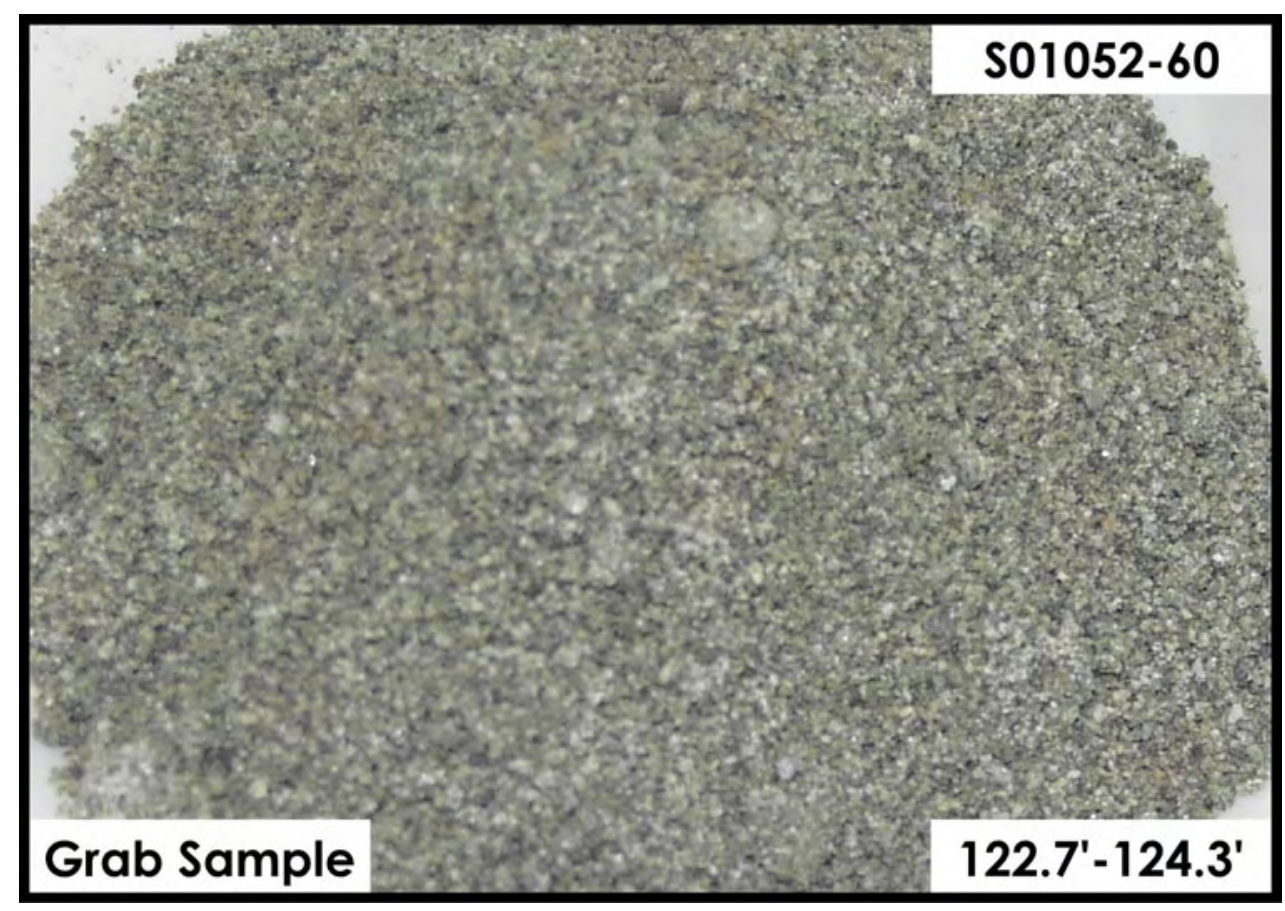

H2-Upper Sand and Gravel Sequence

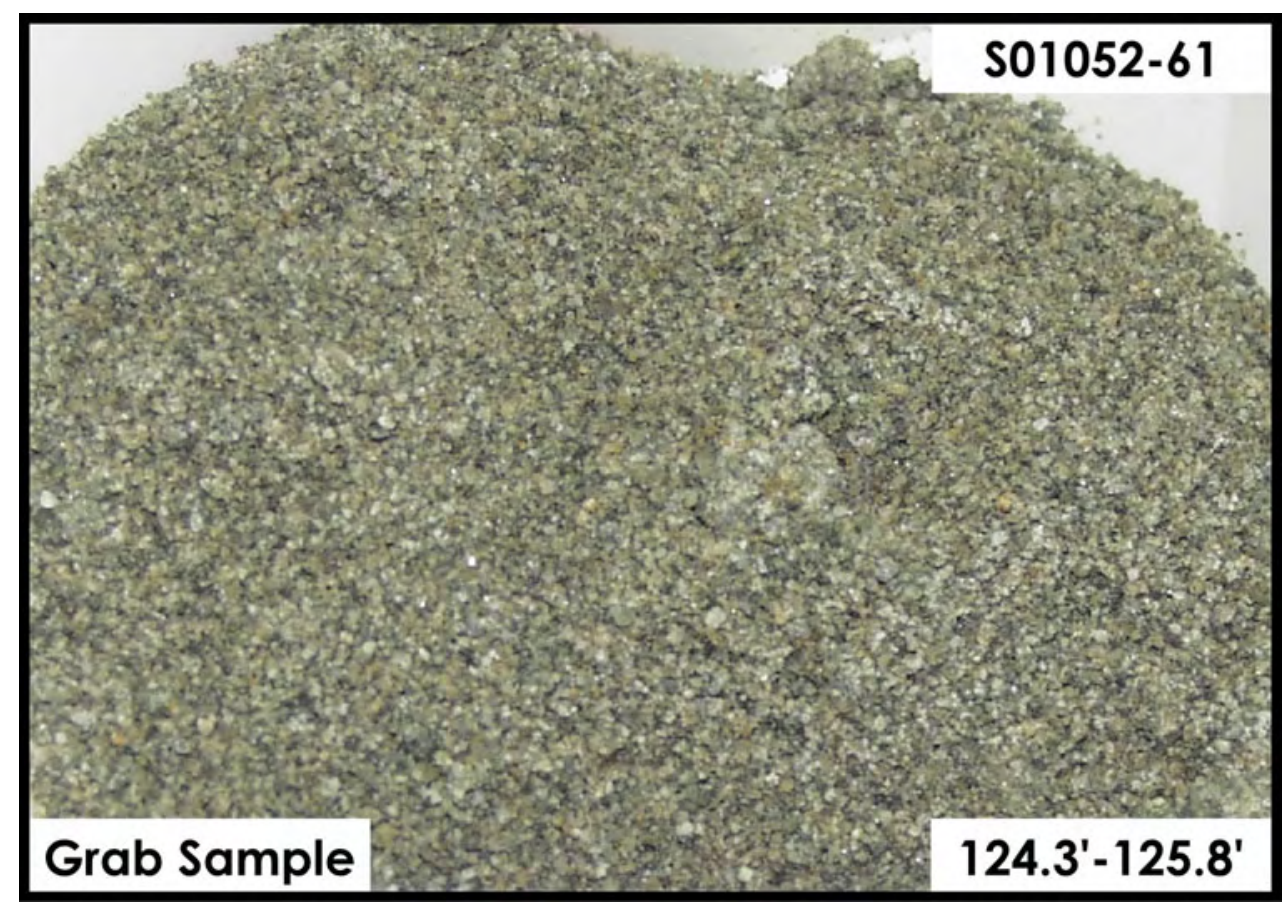

H2-Upper Sand and Gravel Sequence 


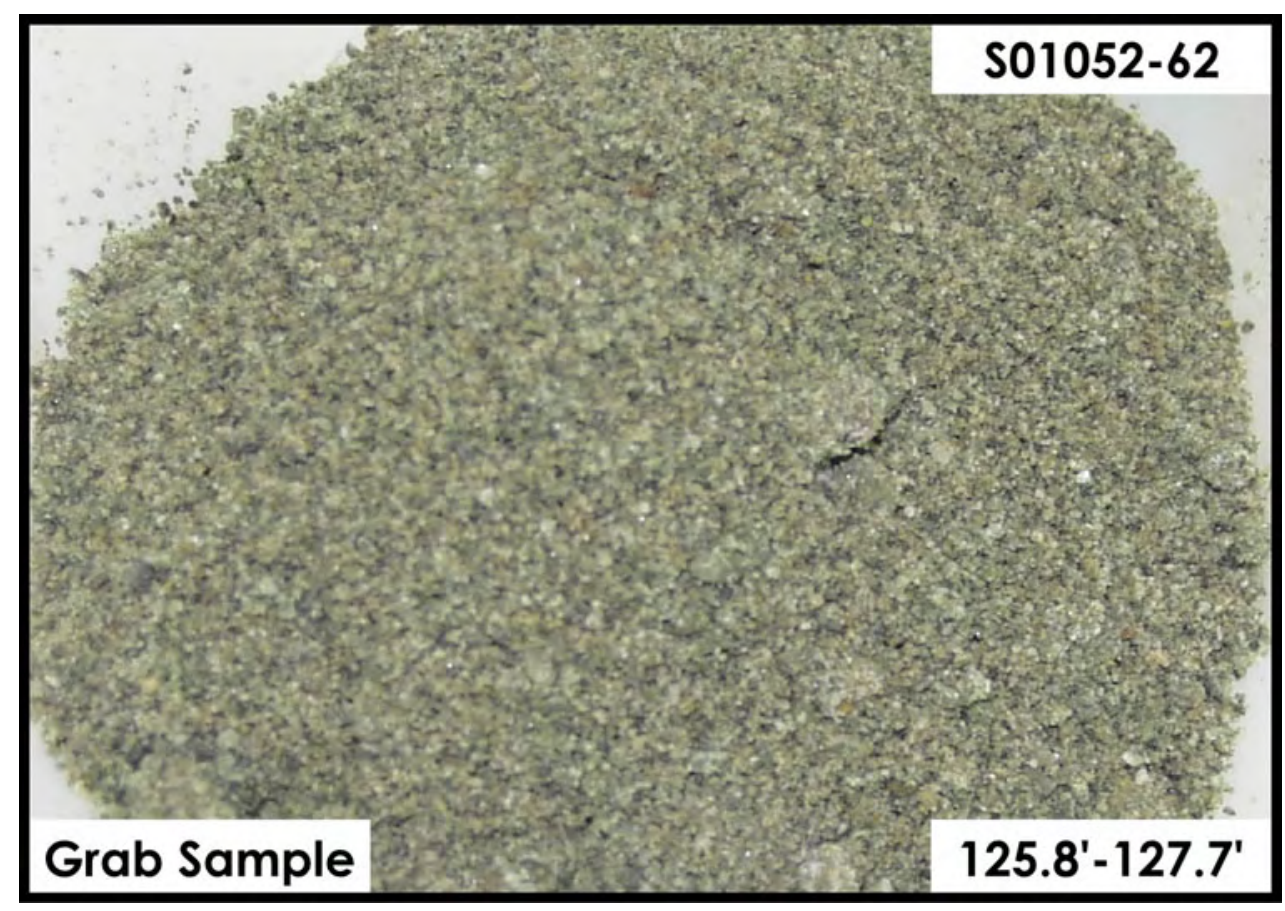

H2-Upper Sand and Gravel Sequence

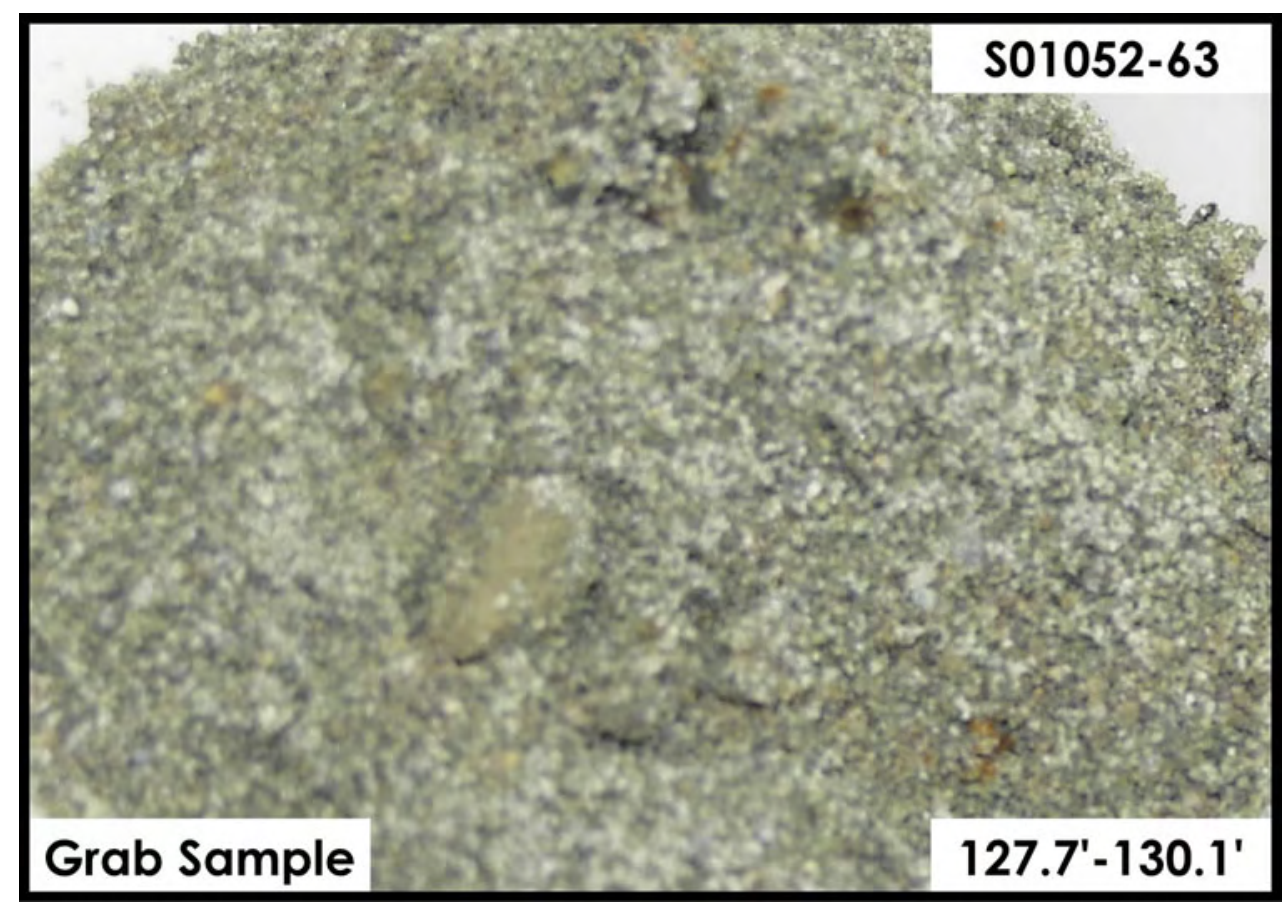

H2-Upper Sand and Gravel Sequence 


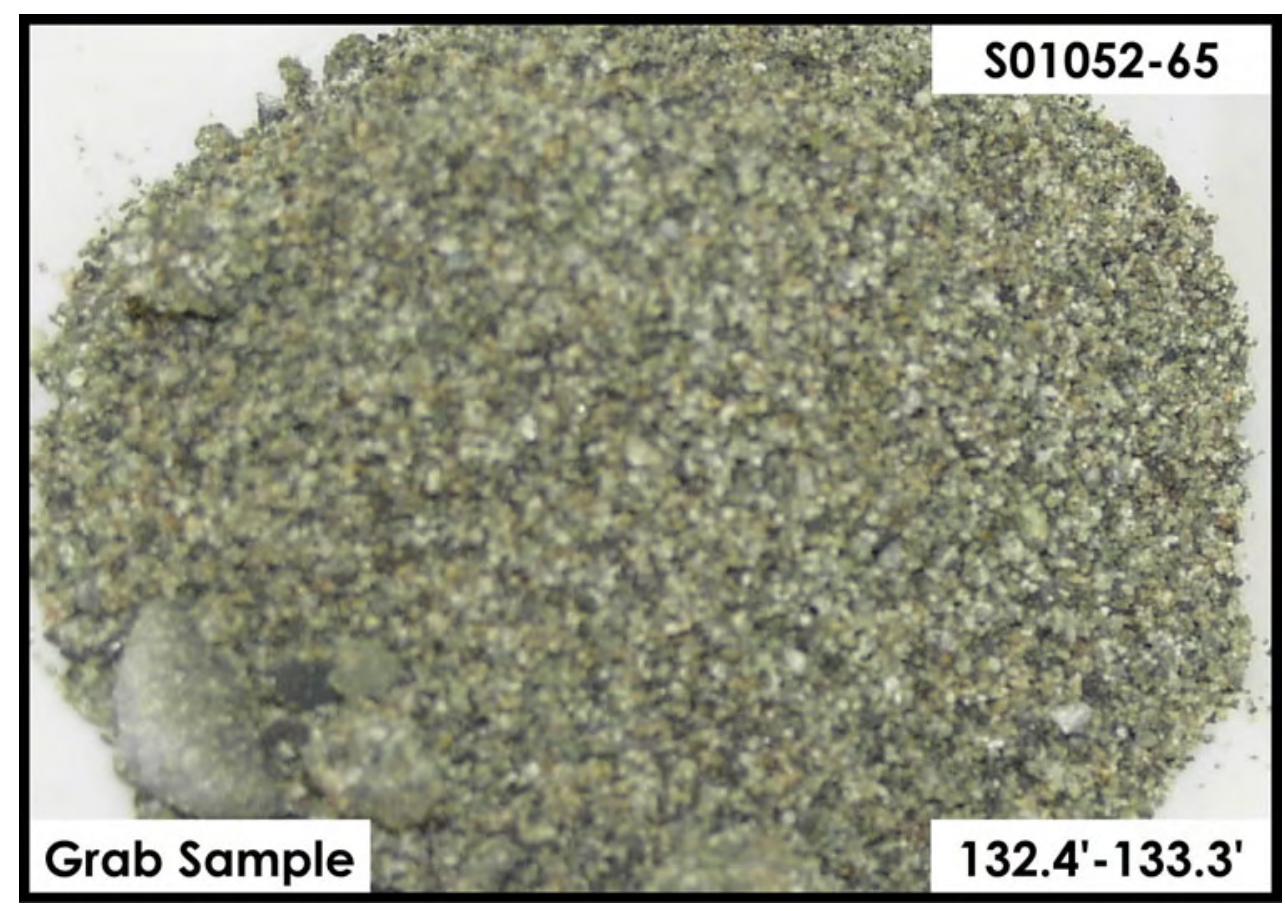

H2-Upper Sand and Gravel Sequence

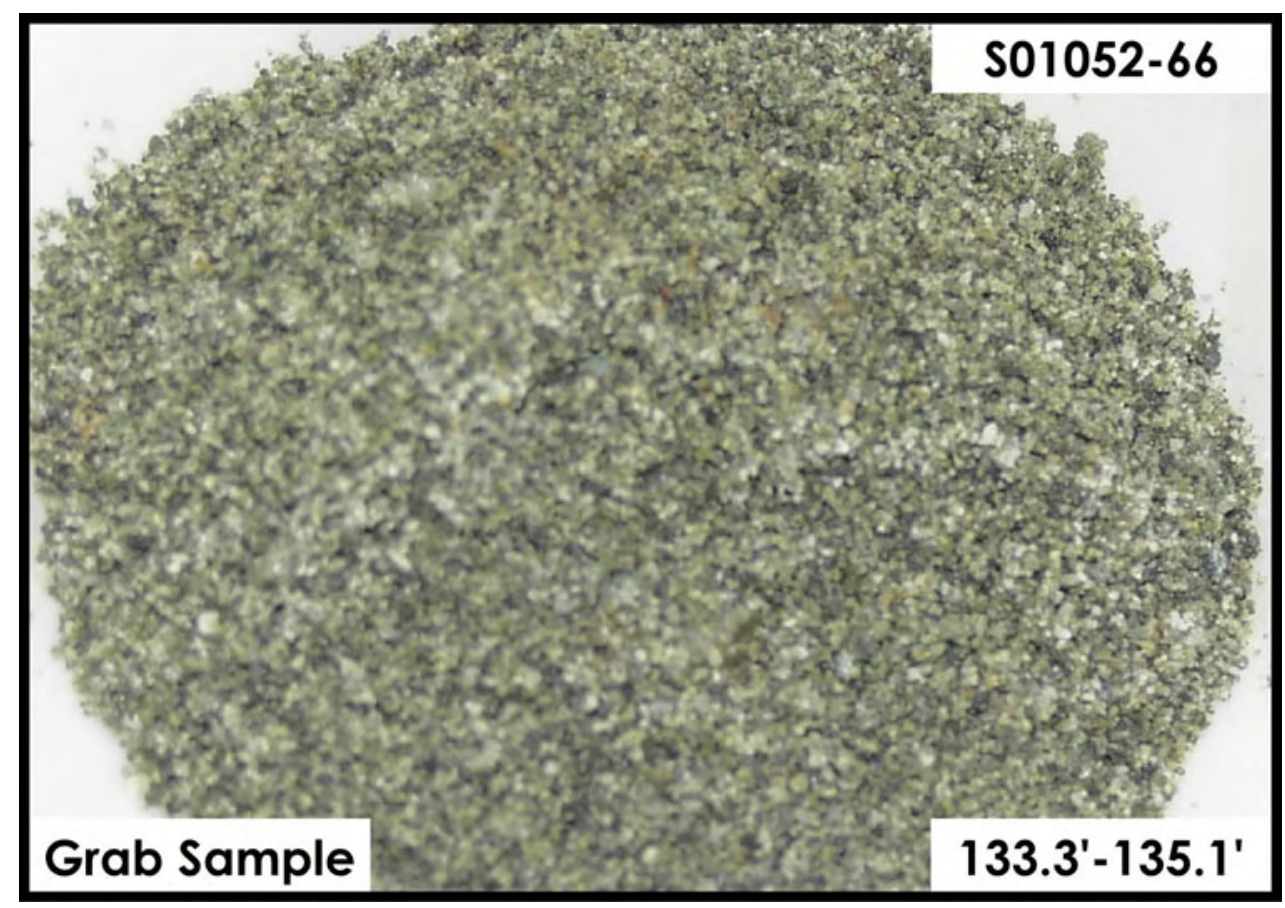

H2-Upper Sand and Gravel Sequence 


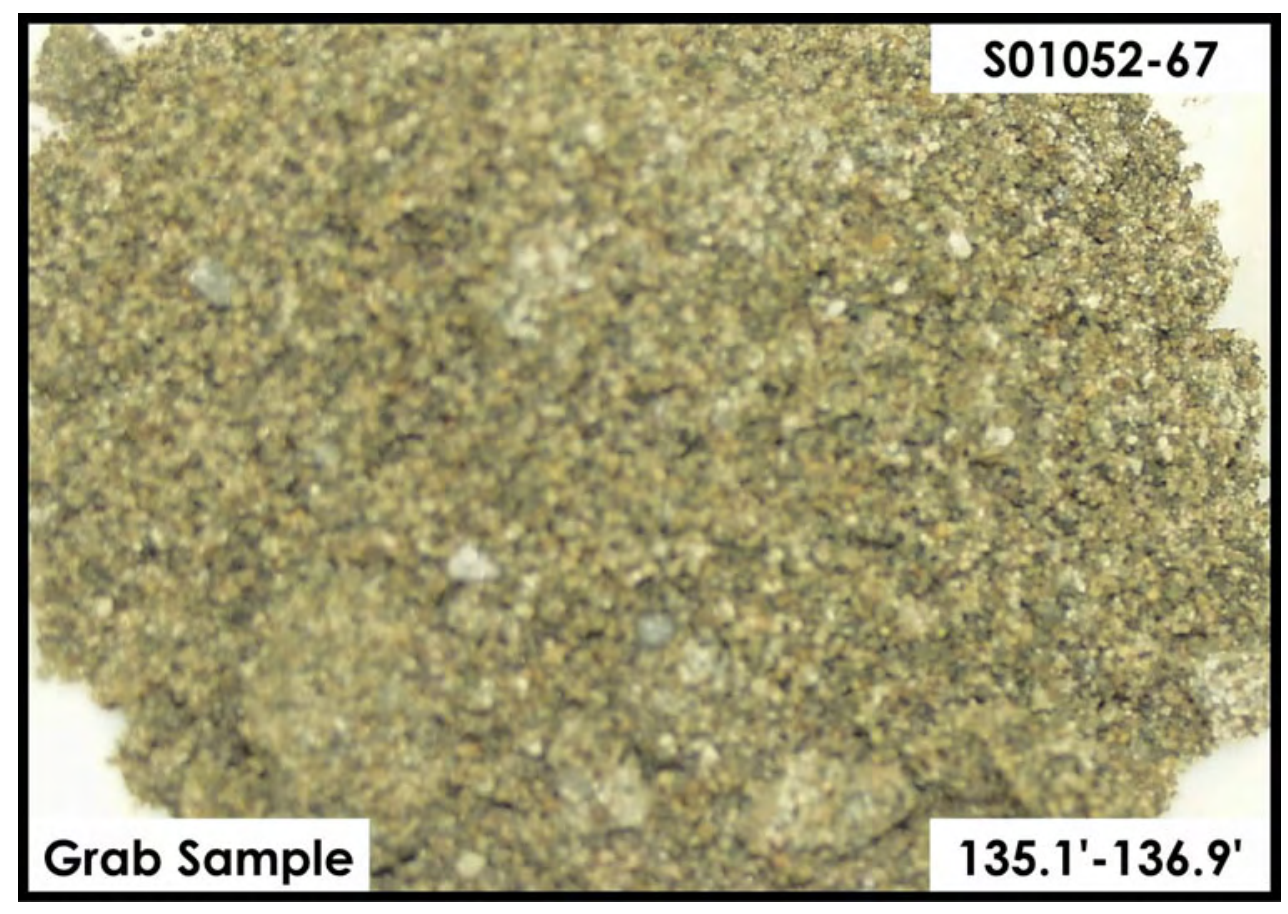

H2-Upper Sand and Gravel Sequence

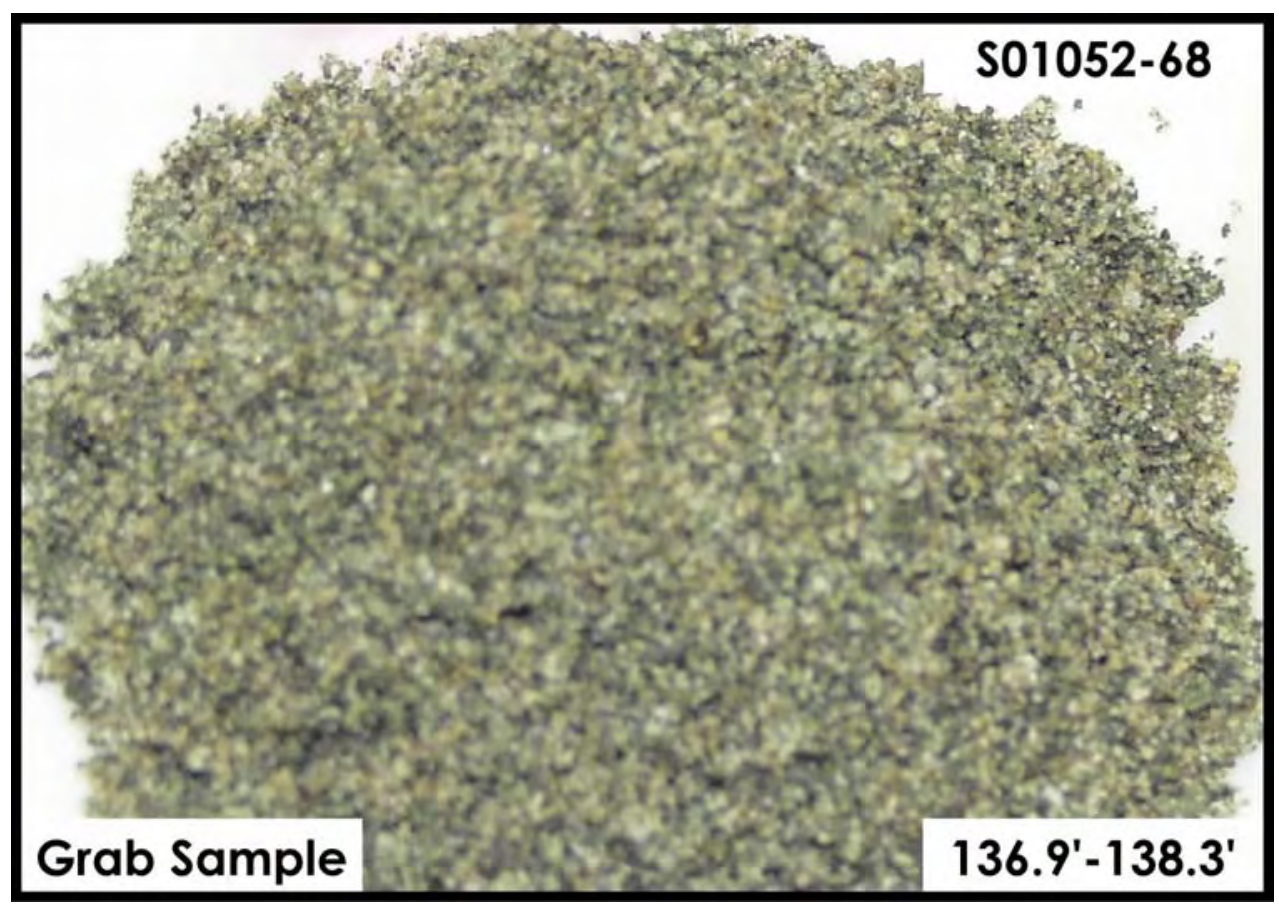

H2-Upper Sand and Gravel Sequence 


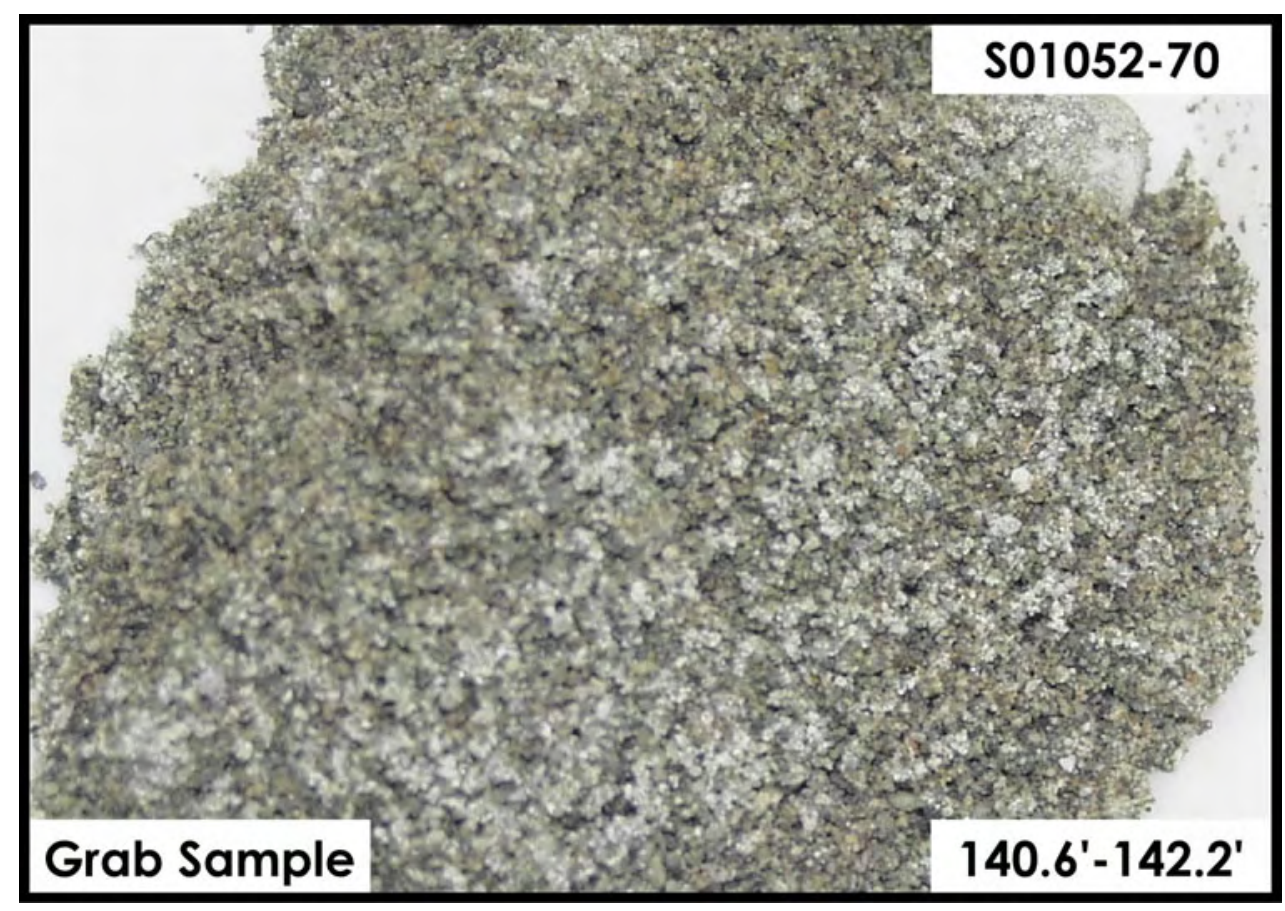

H2-Upper Sand and Gravel Sequence

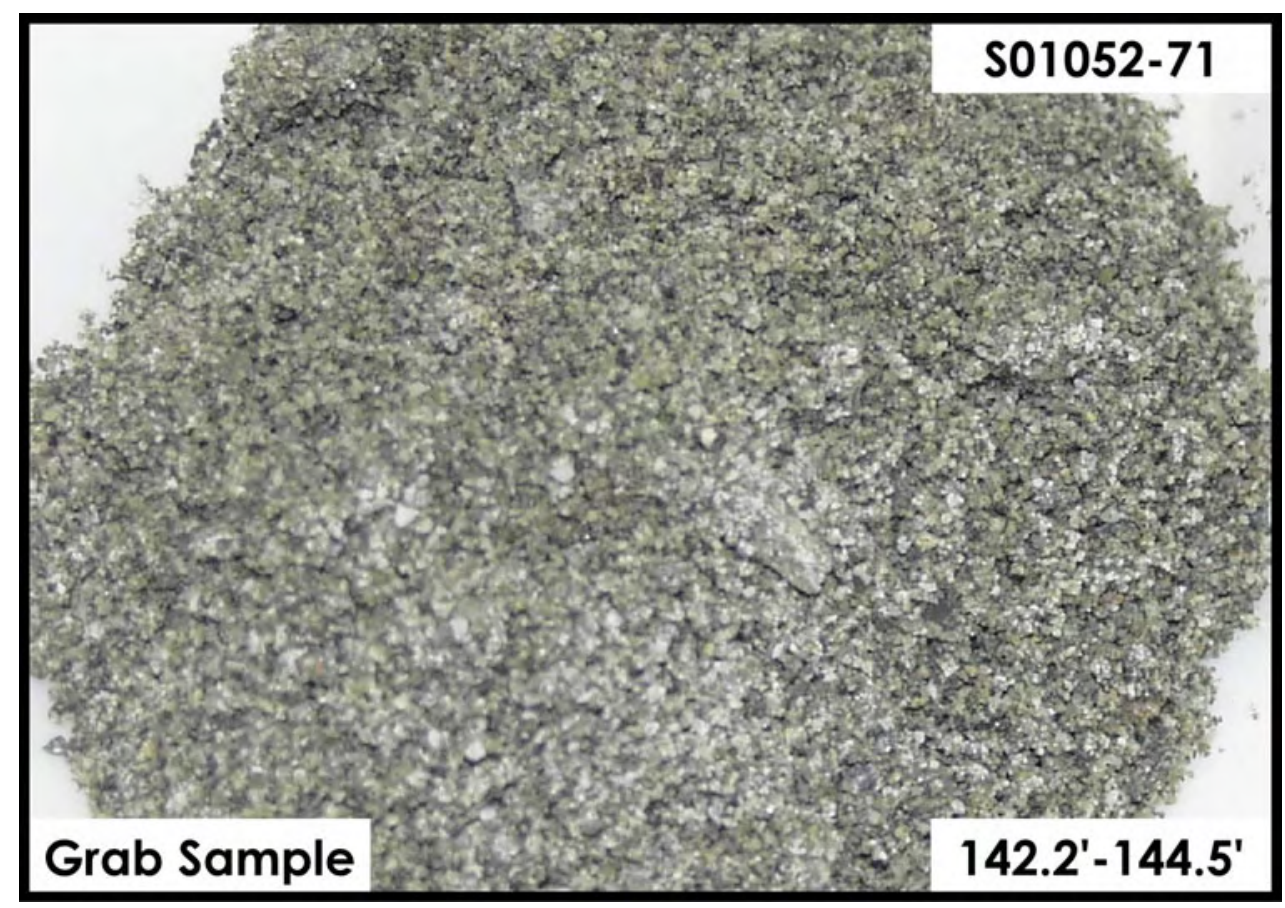

H2-Upper Sand and Gravel Sequence 


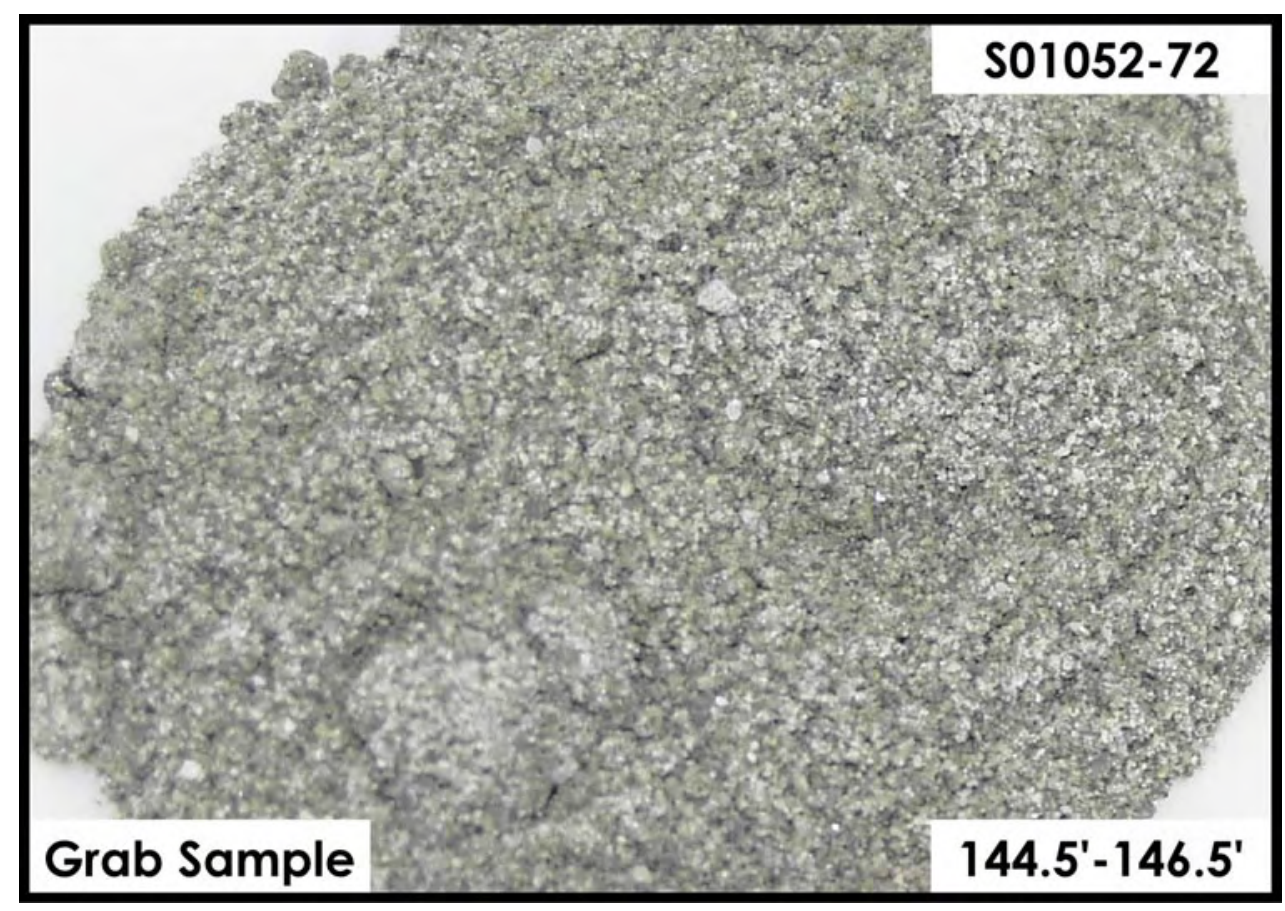

H2-Upper Sand and Gravel Sequence

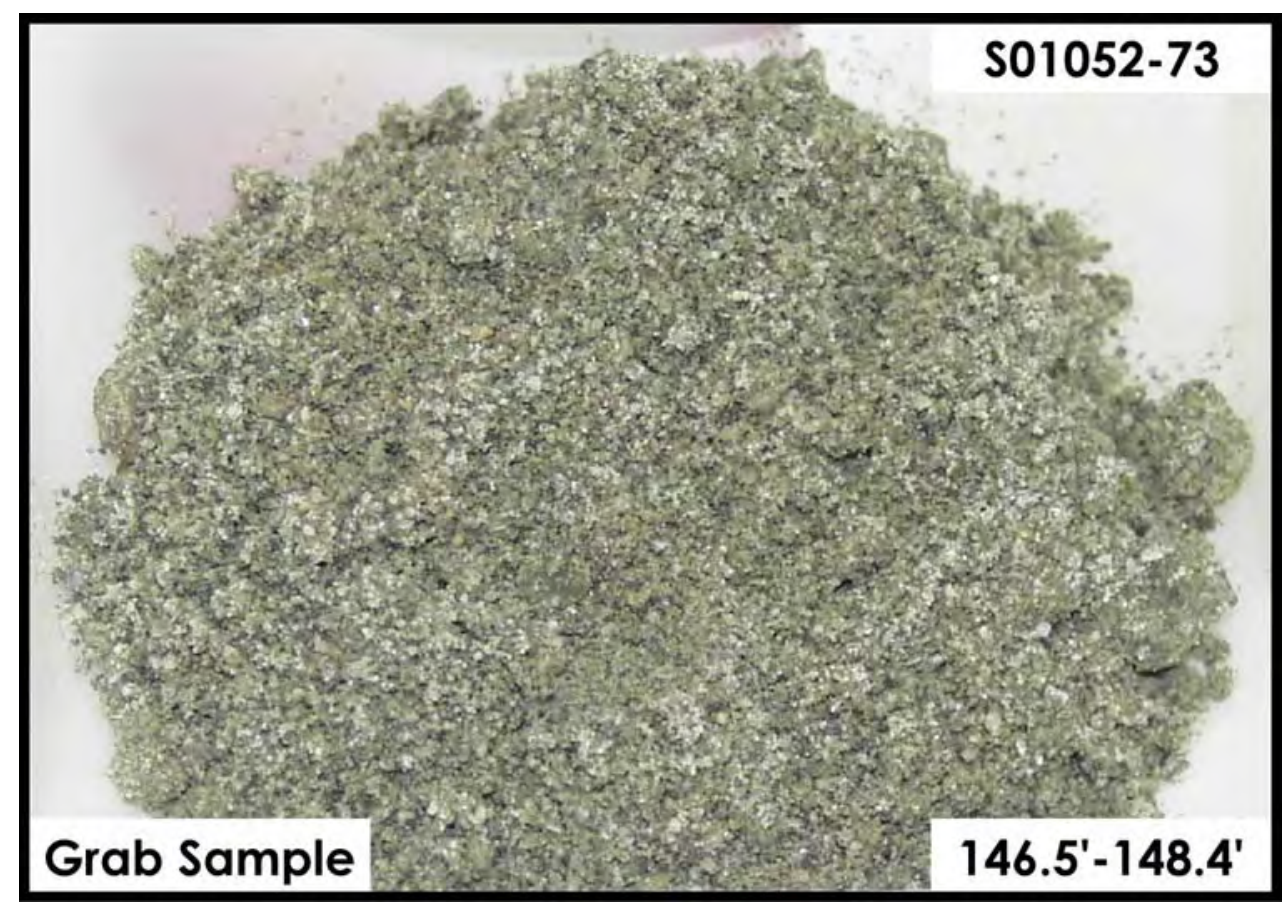

H2-Upper Sand and Gravel Sequence 


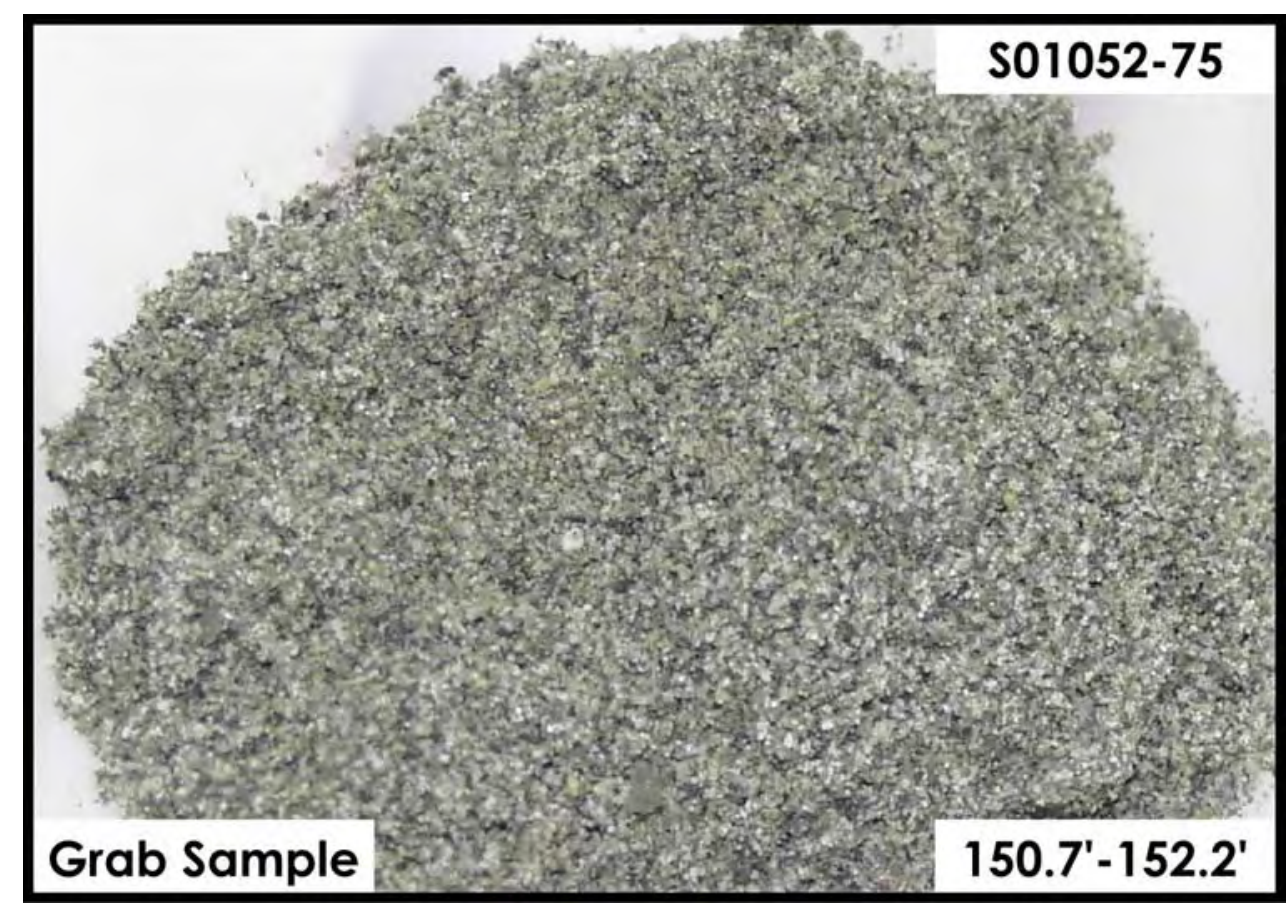

H2-Upper Sand and Gravel Sequence

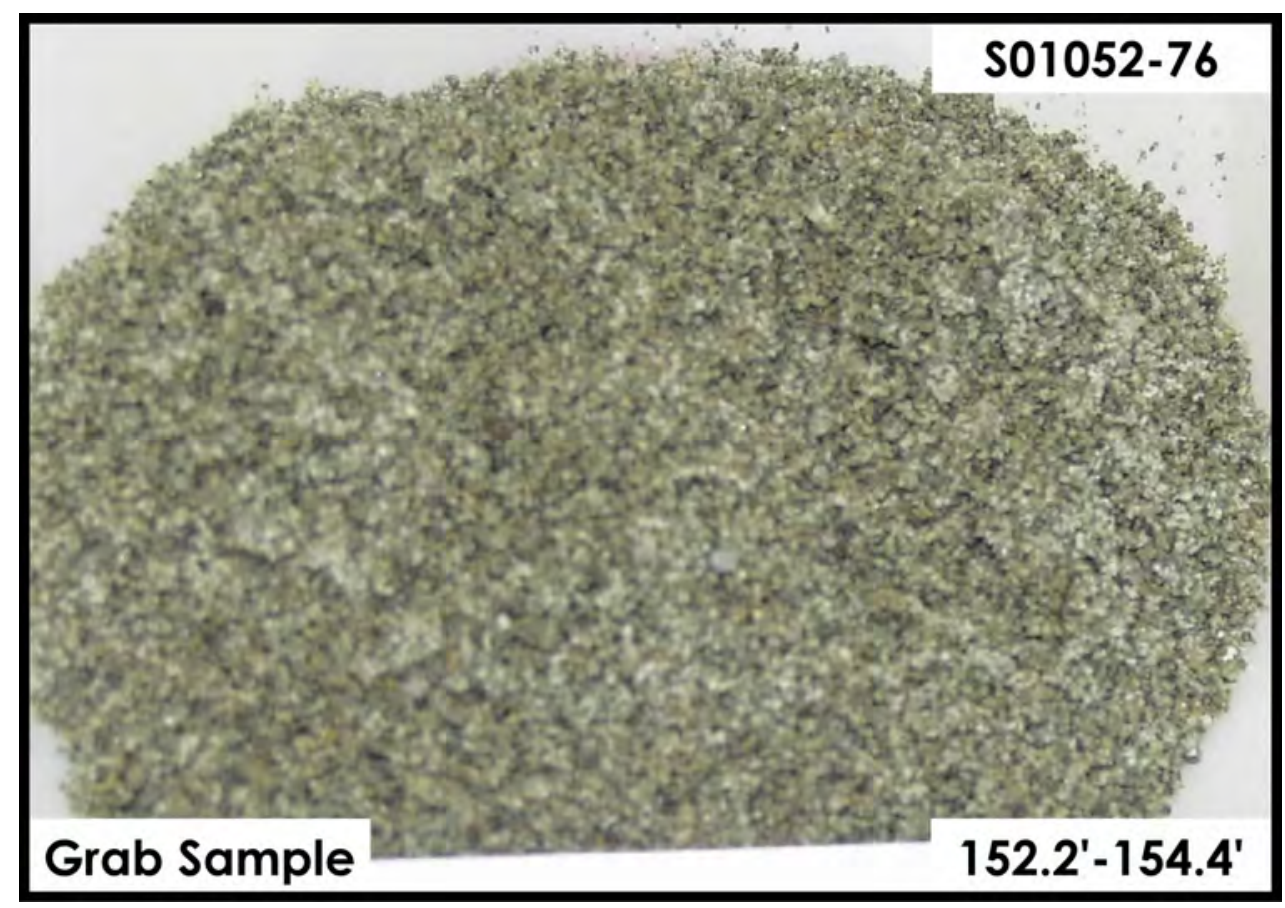

H2-Upper Sand and Gravel Sequence 


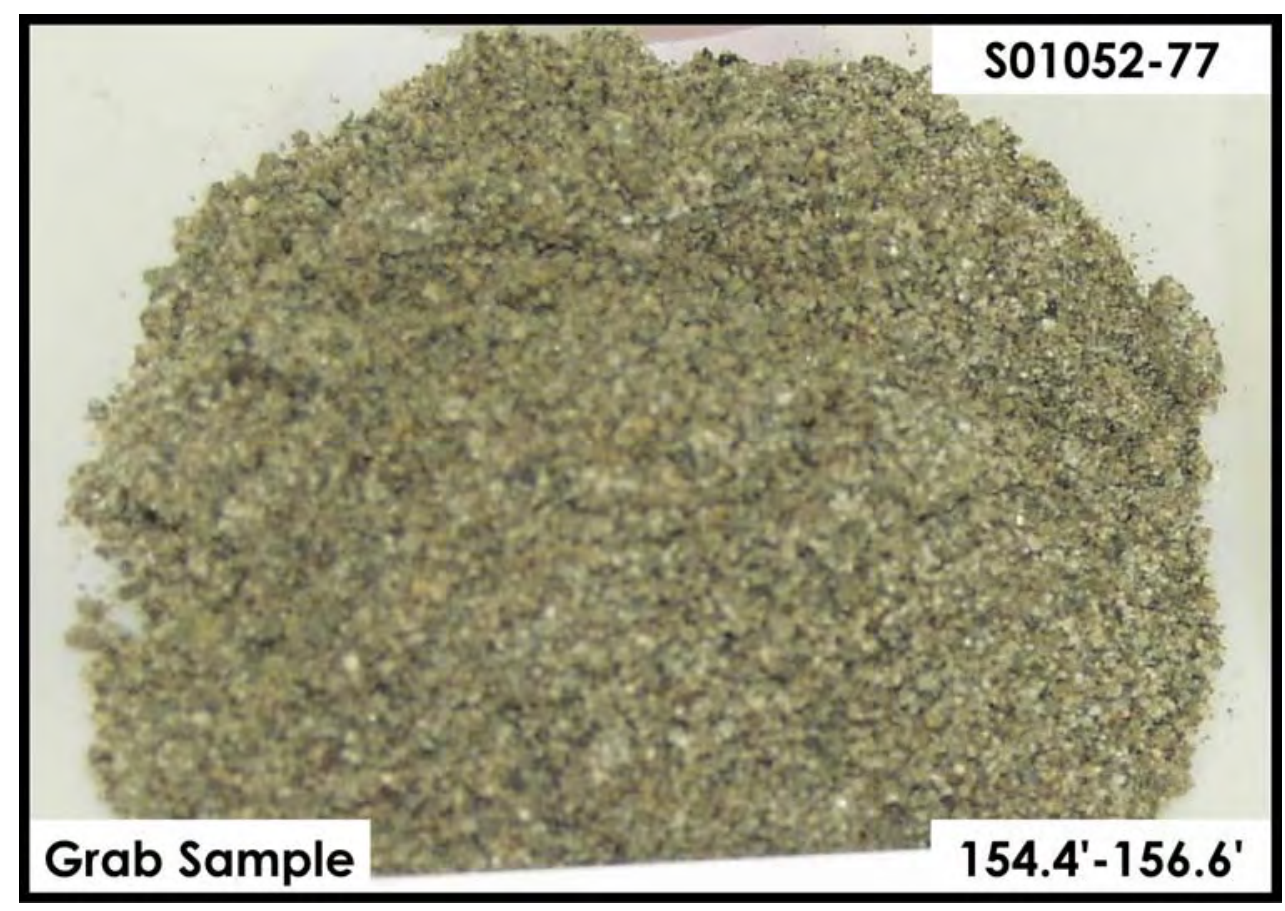

H2-Upper Sand and Gravel Sequence

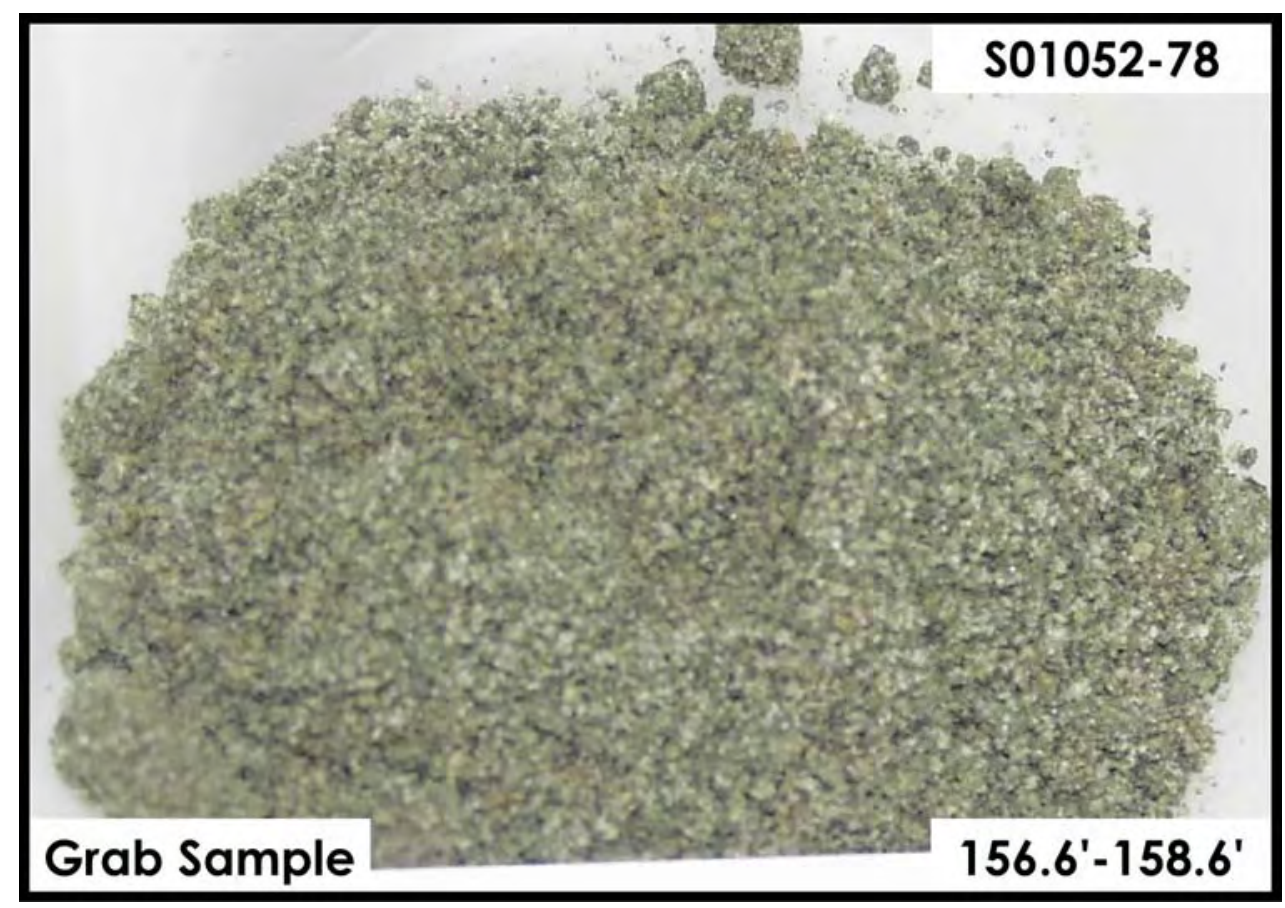

H2-Upper Sand and Gravel Sequence 


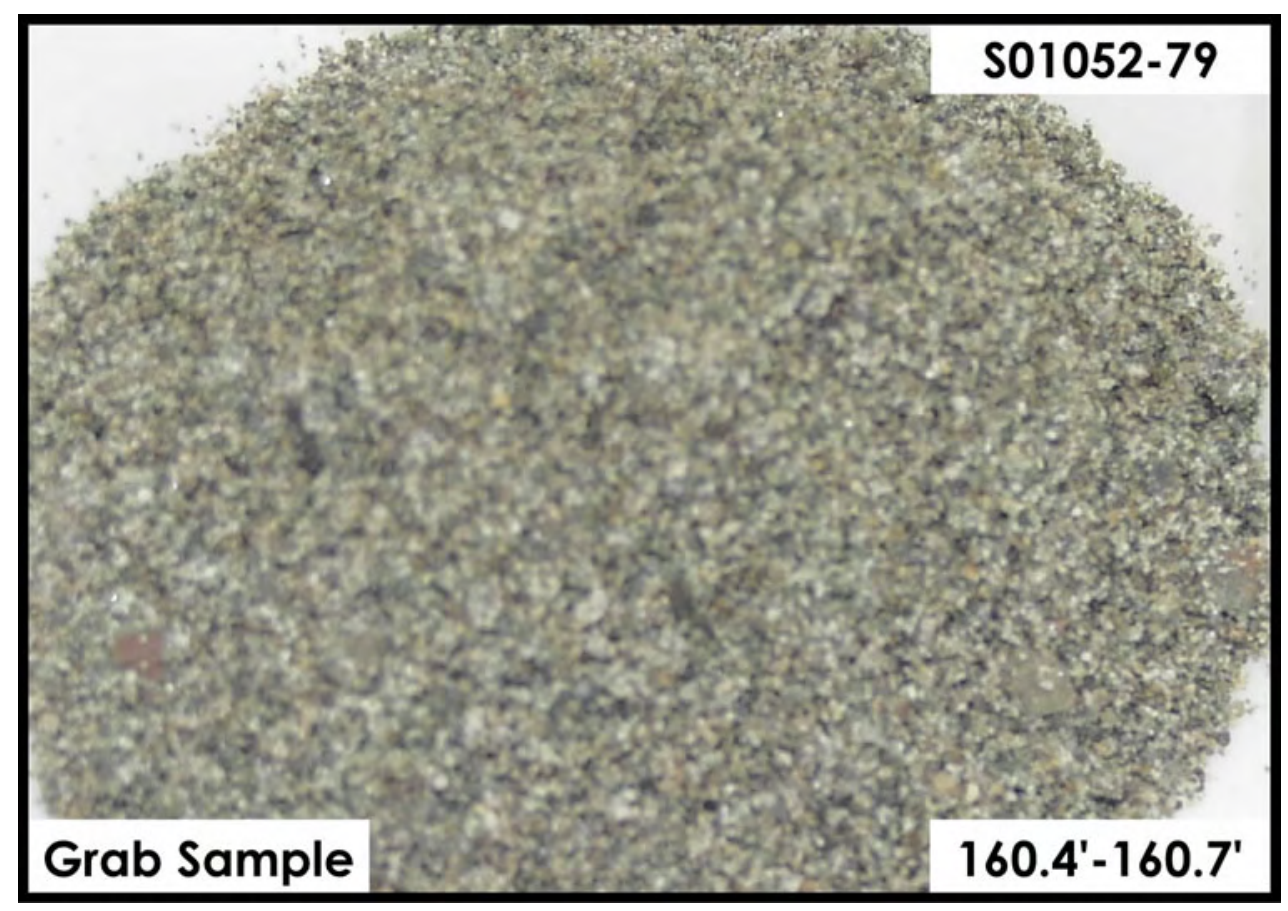

H2-Upper Sand and Gravel Sequence

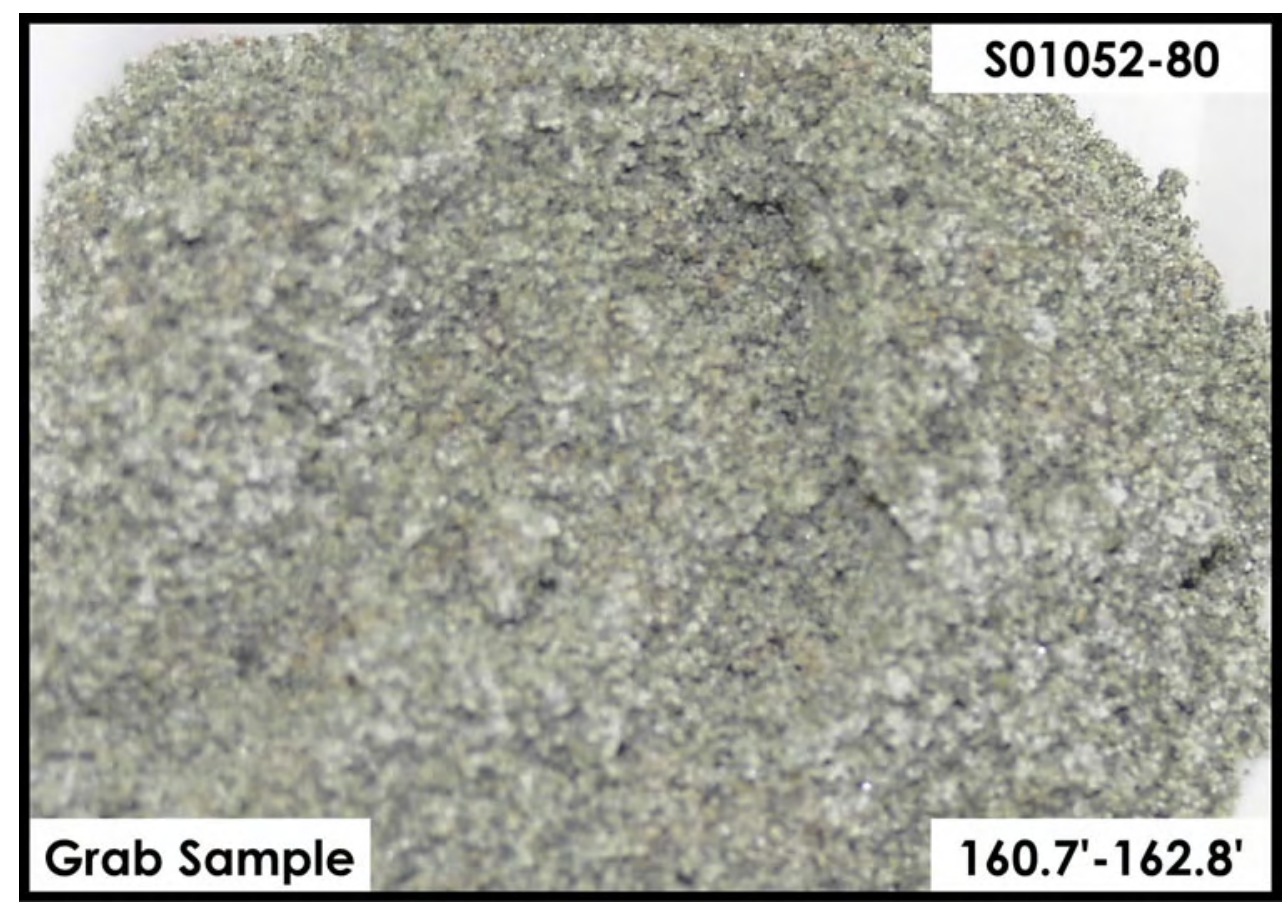

H2-Upper Sand and Gravel Sequence

B.71 


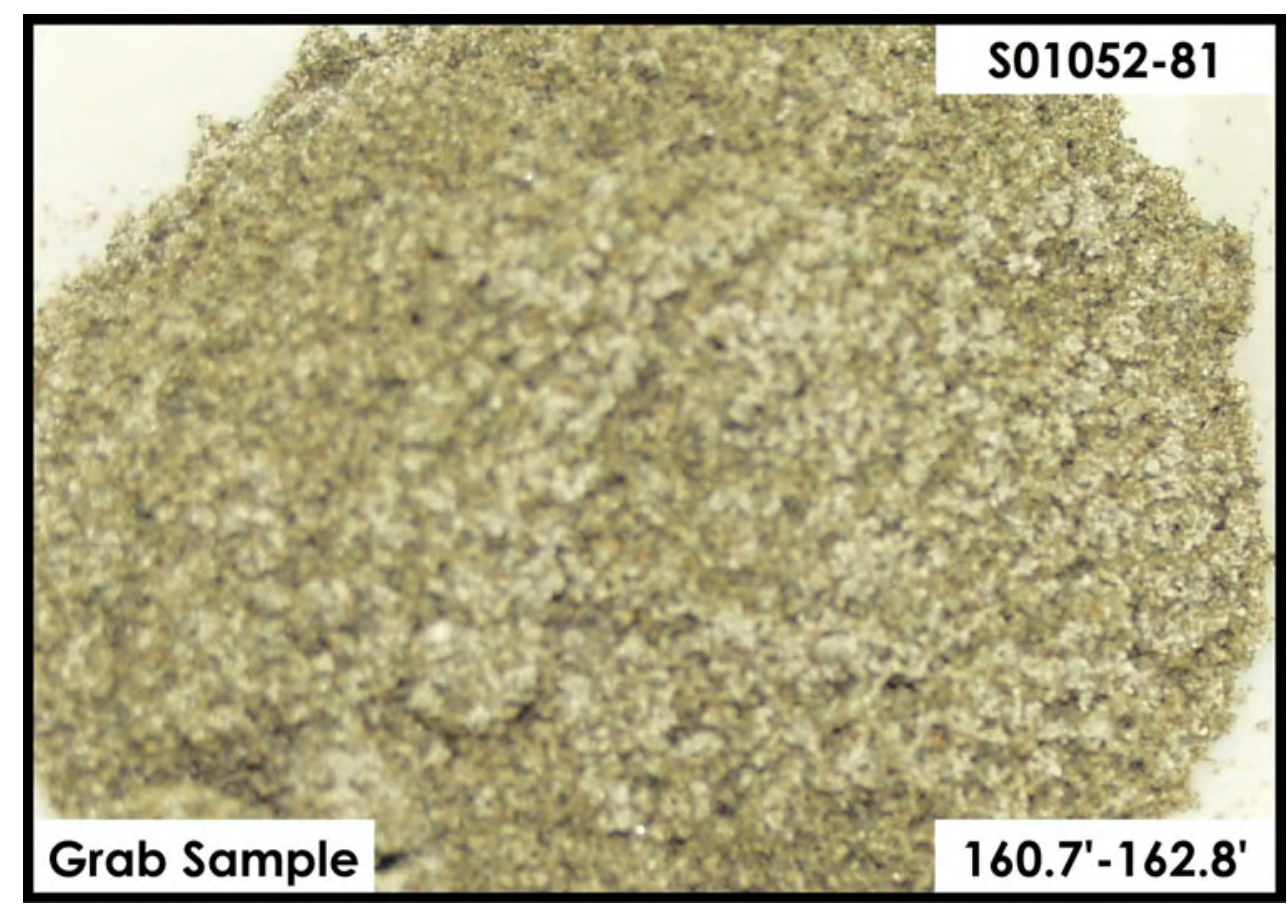

H2-Upper Sand and Gravel Sequence

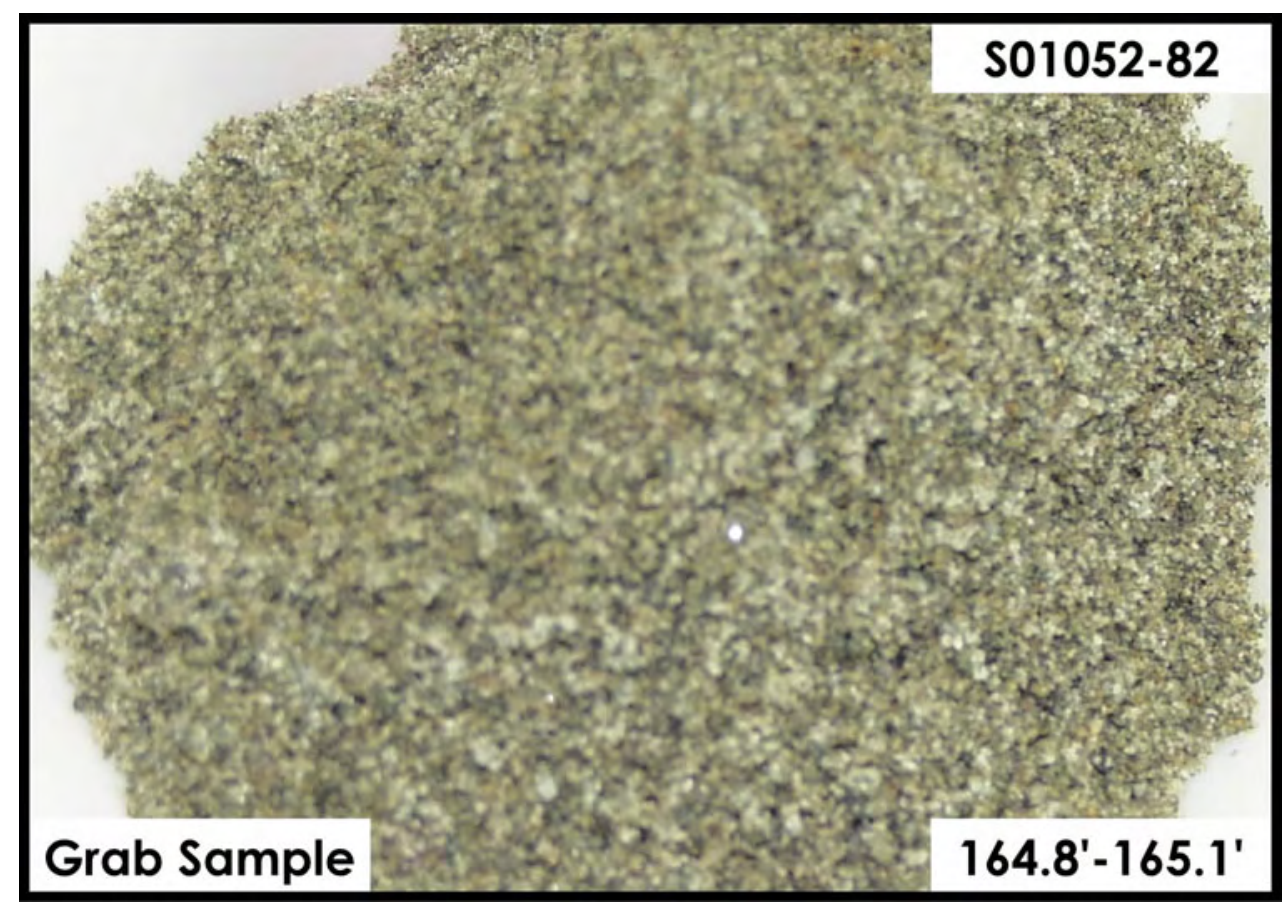

H2-Upper Sand and Gravel Sequence

B.72 


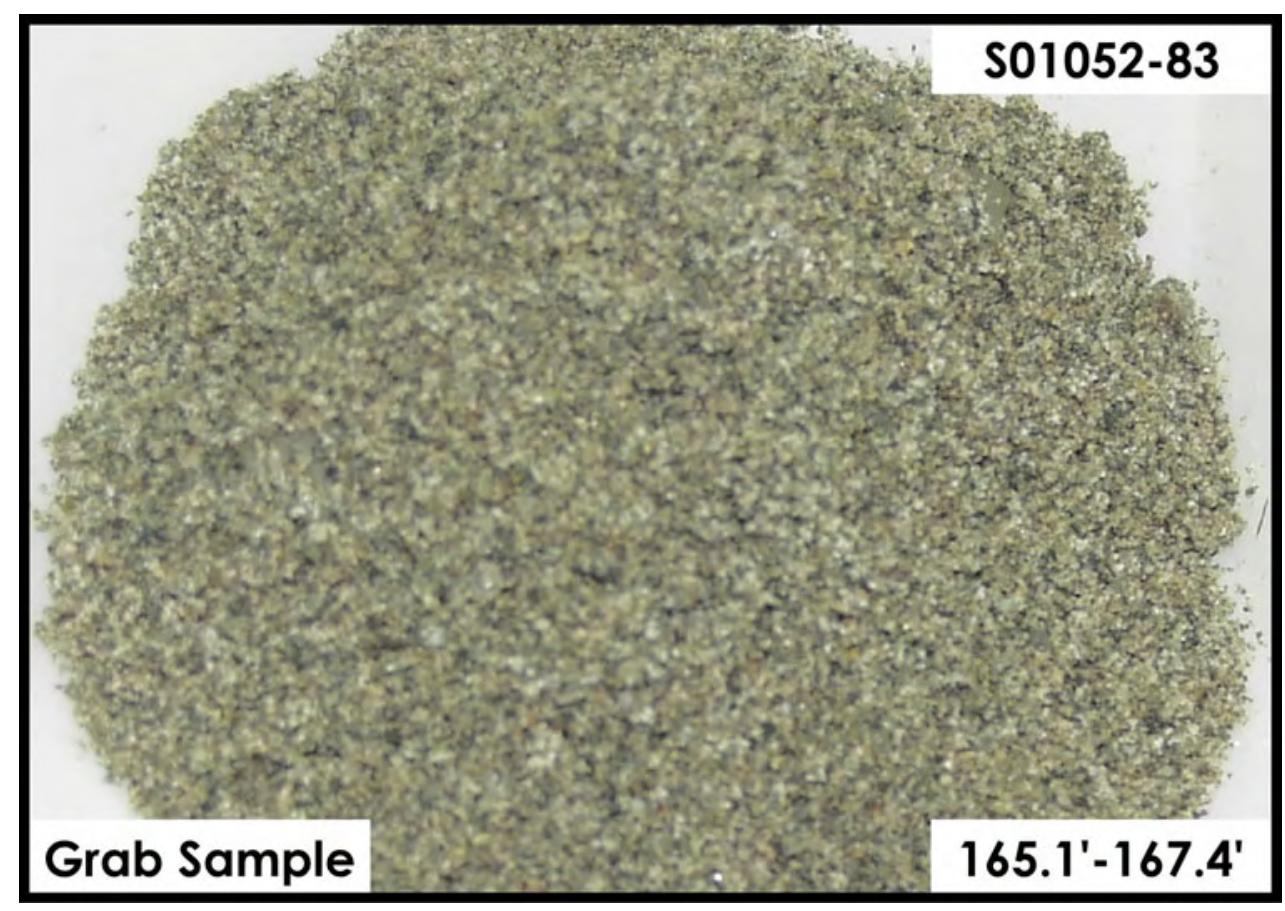

H2-Upper Sand and Gravel Sequence

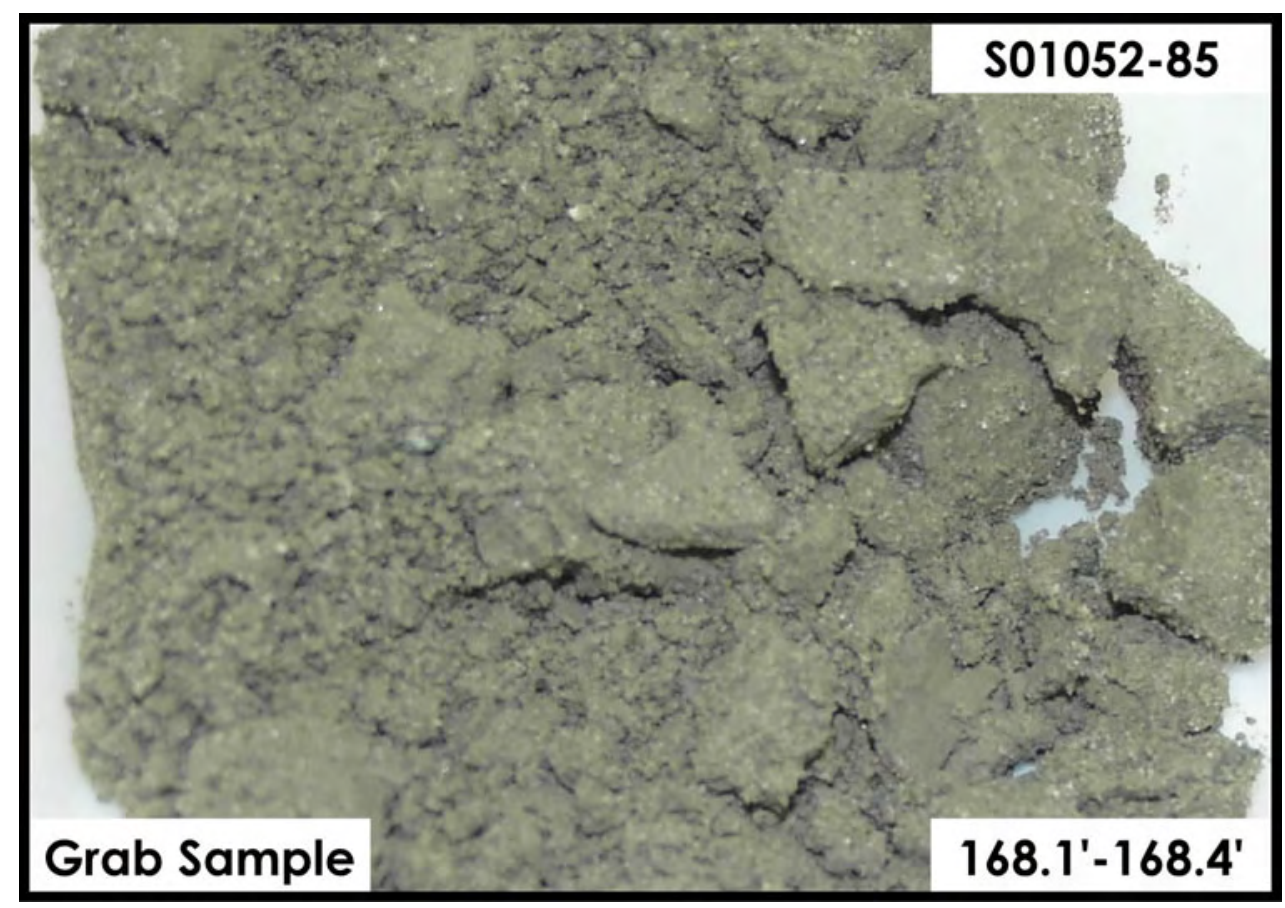

H2-Upper Sand and Gravel Sequence

B.73 


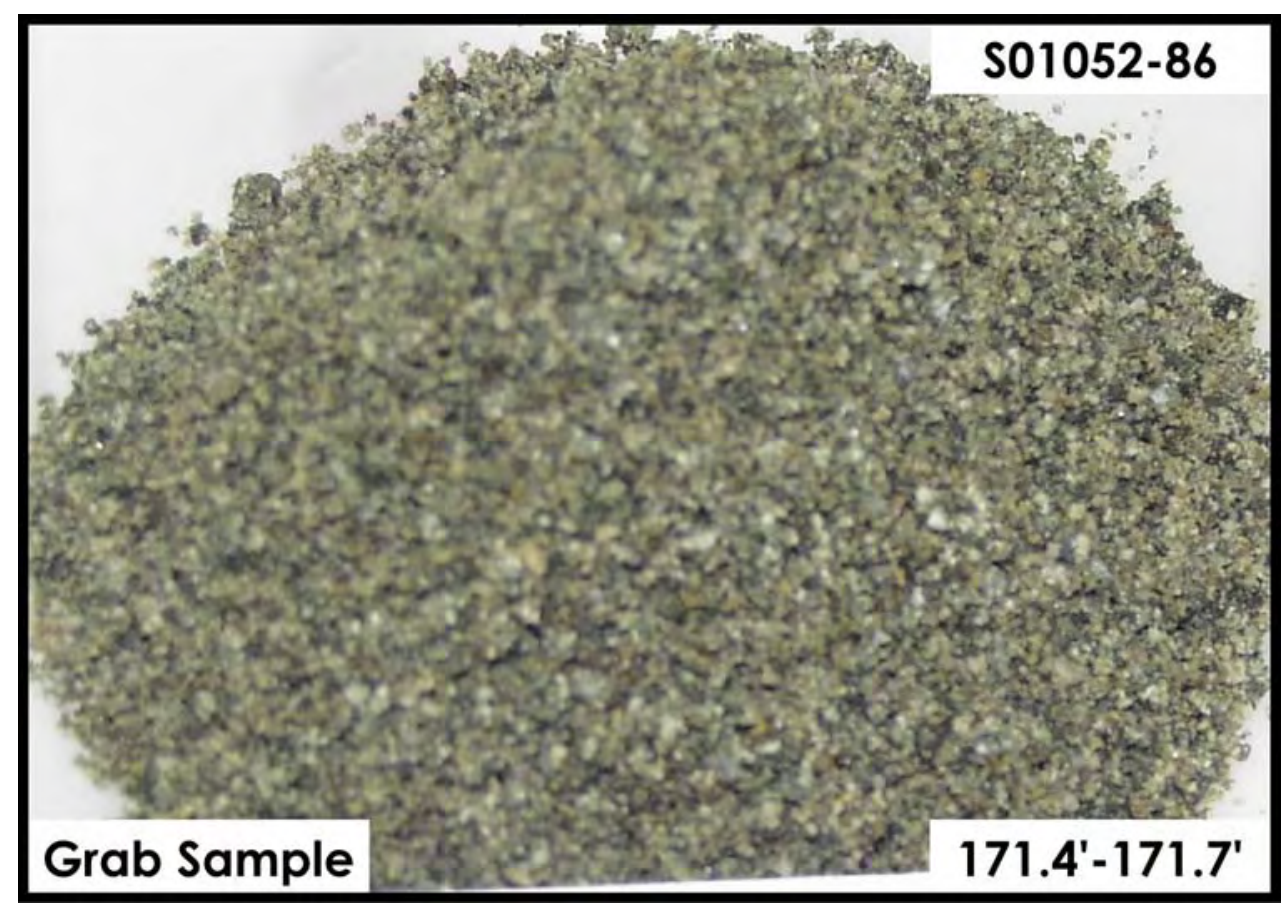

H2-Upper Sand and Gravel Sequence

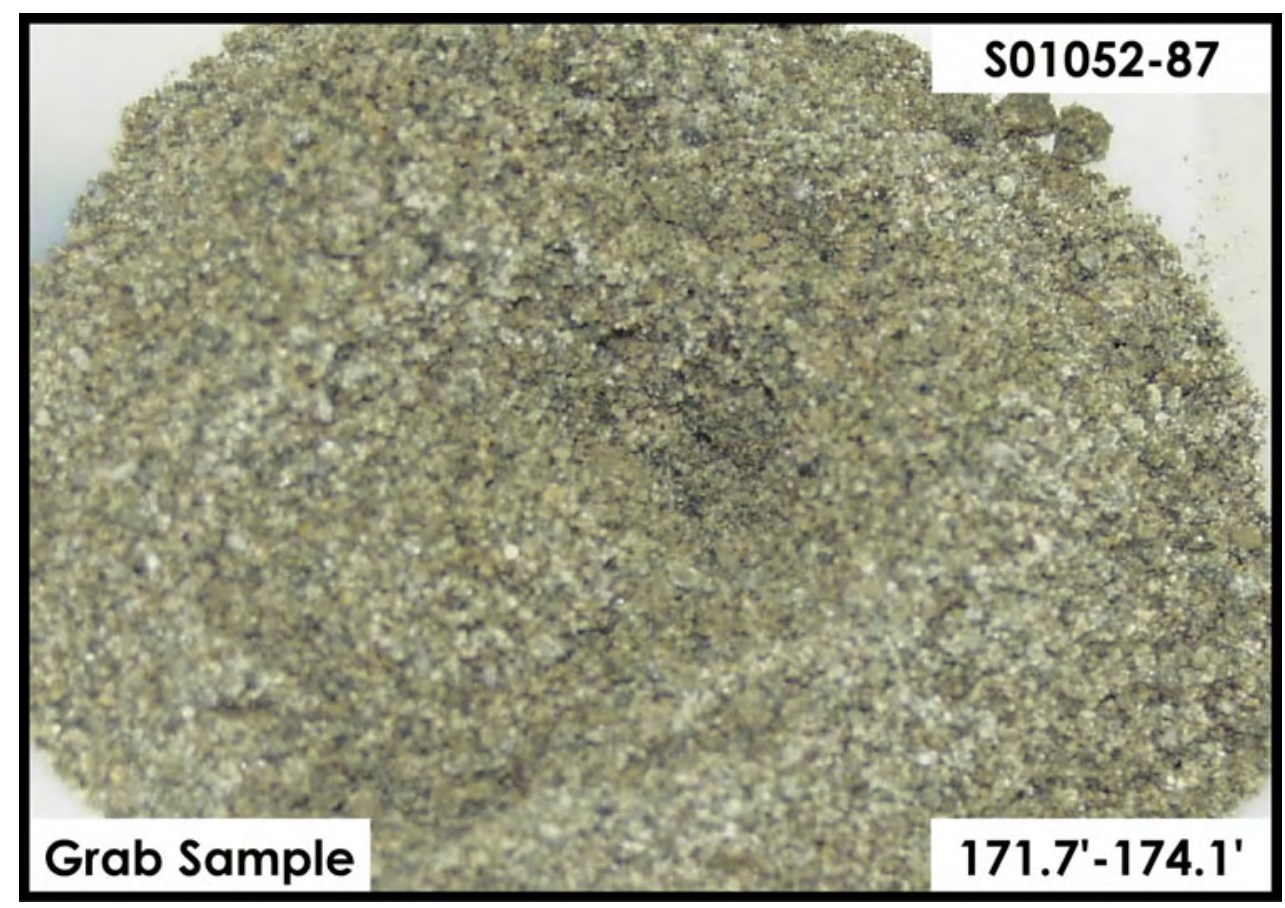

H2-Upper Sand and Gravel Sequence

B.74 


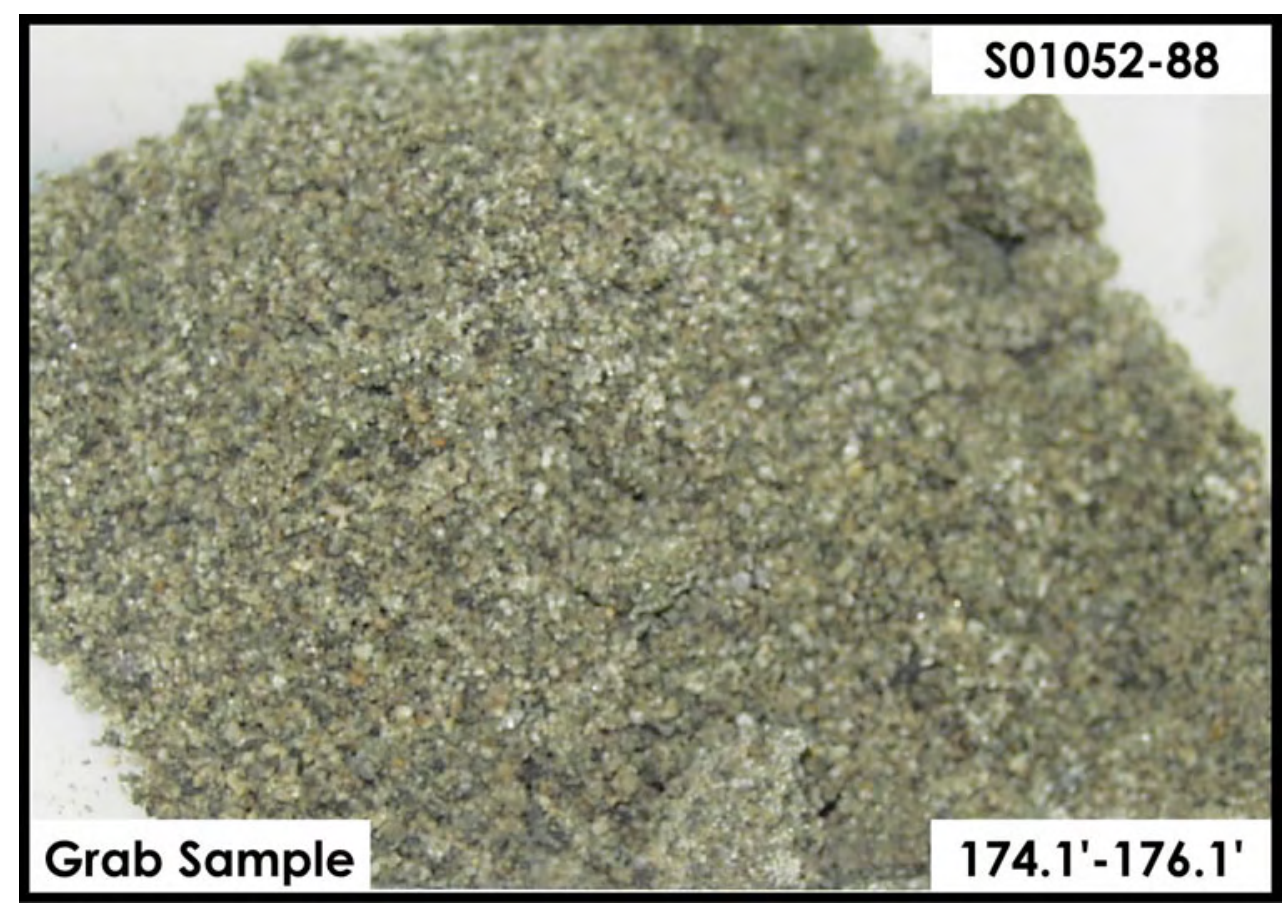

H2-Upper Sand and Gravel Sequence

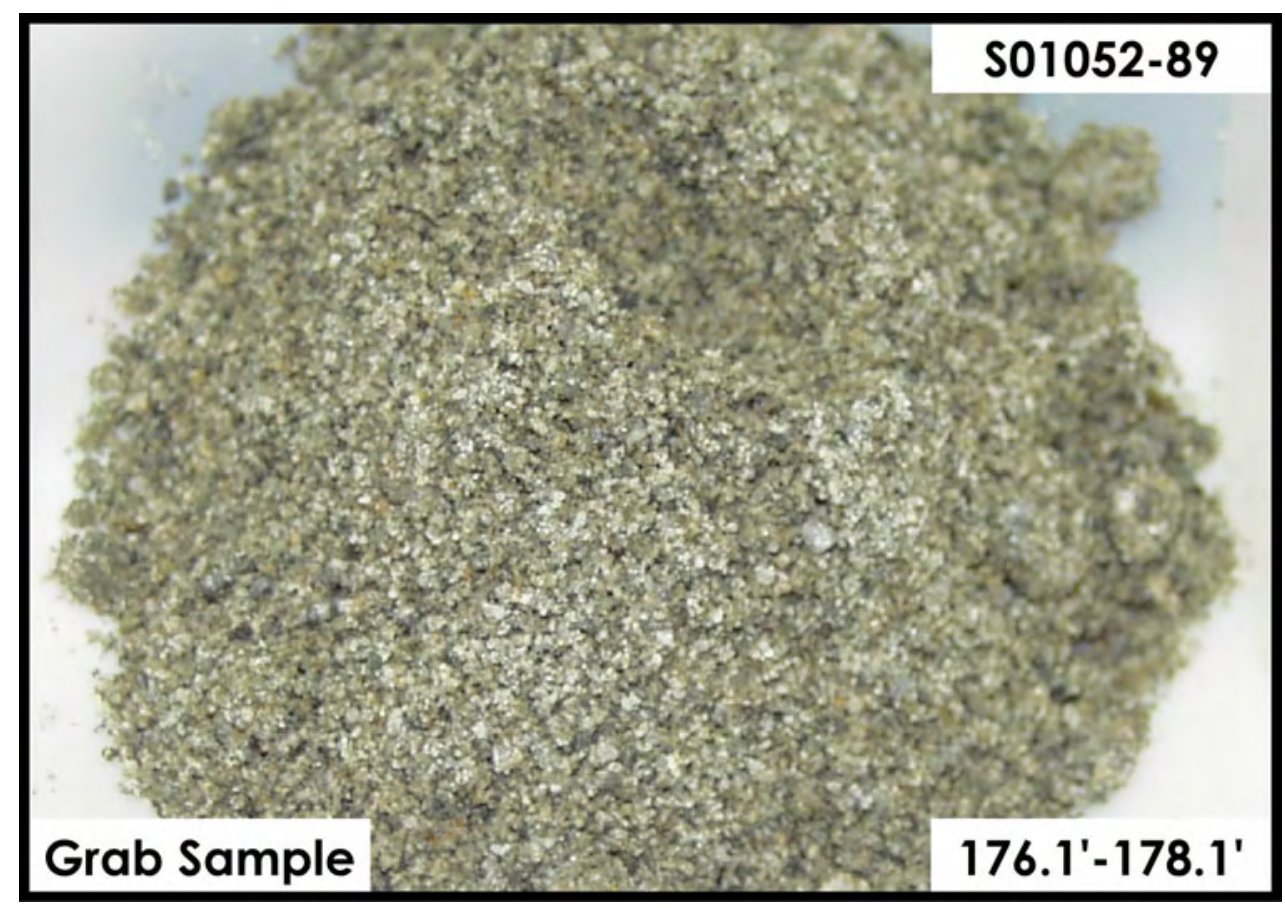

H3-Lower Sand and Gravel Sequence

B. 75 


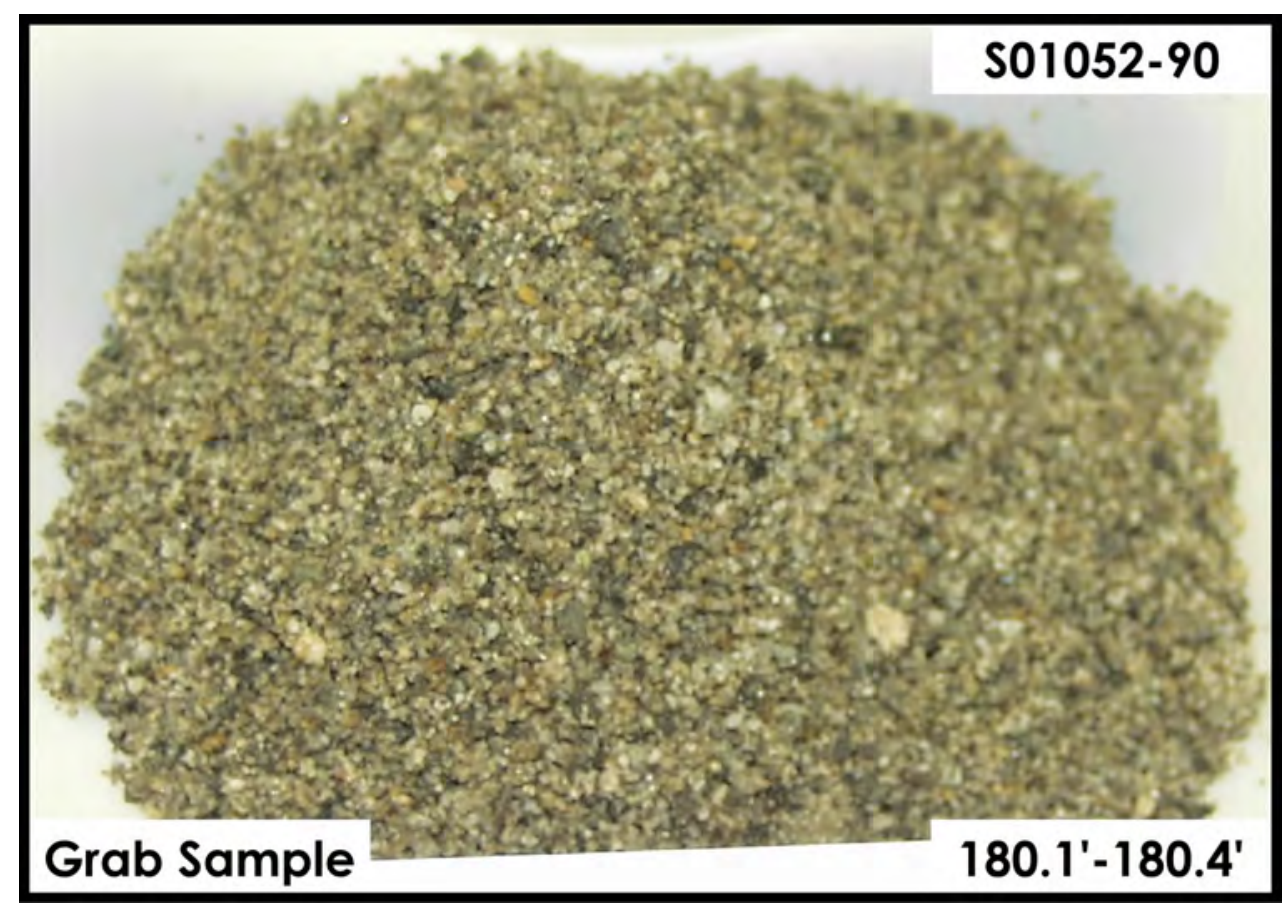

H3-Lower Sand and Gravel Sequence

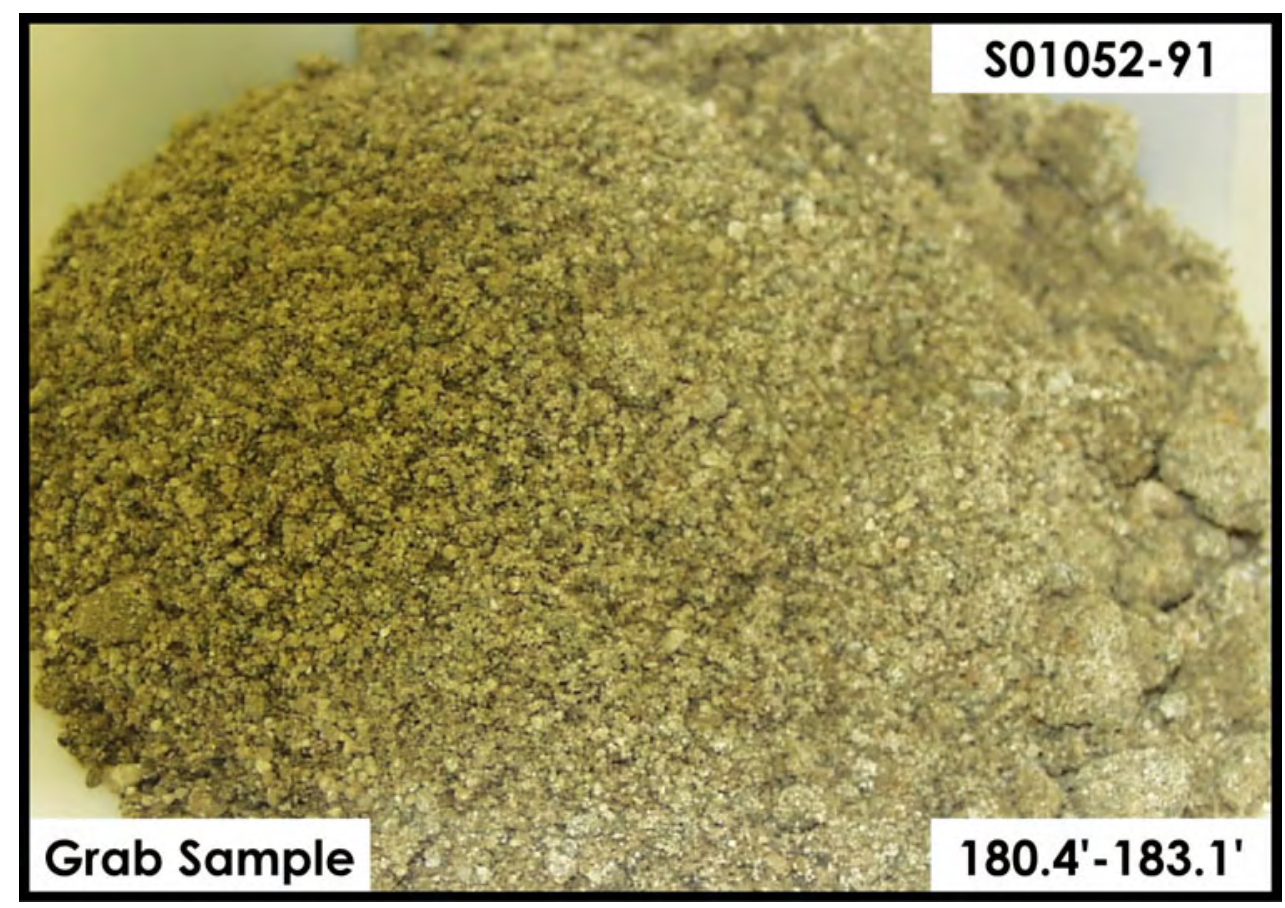

H3-Lower Sand and Gravel Sequence

B.76 


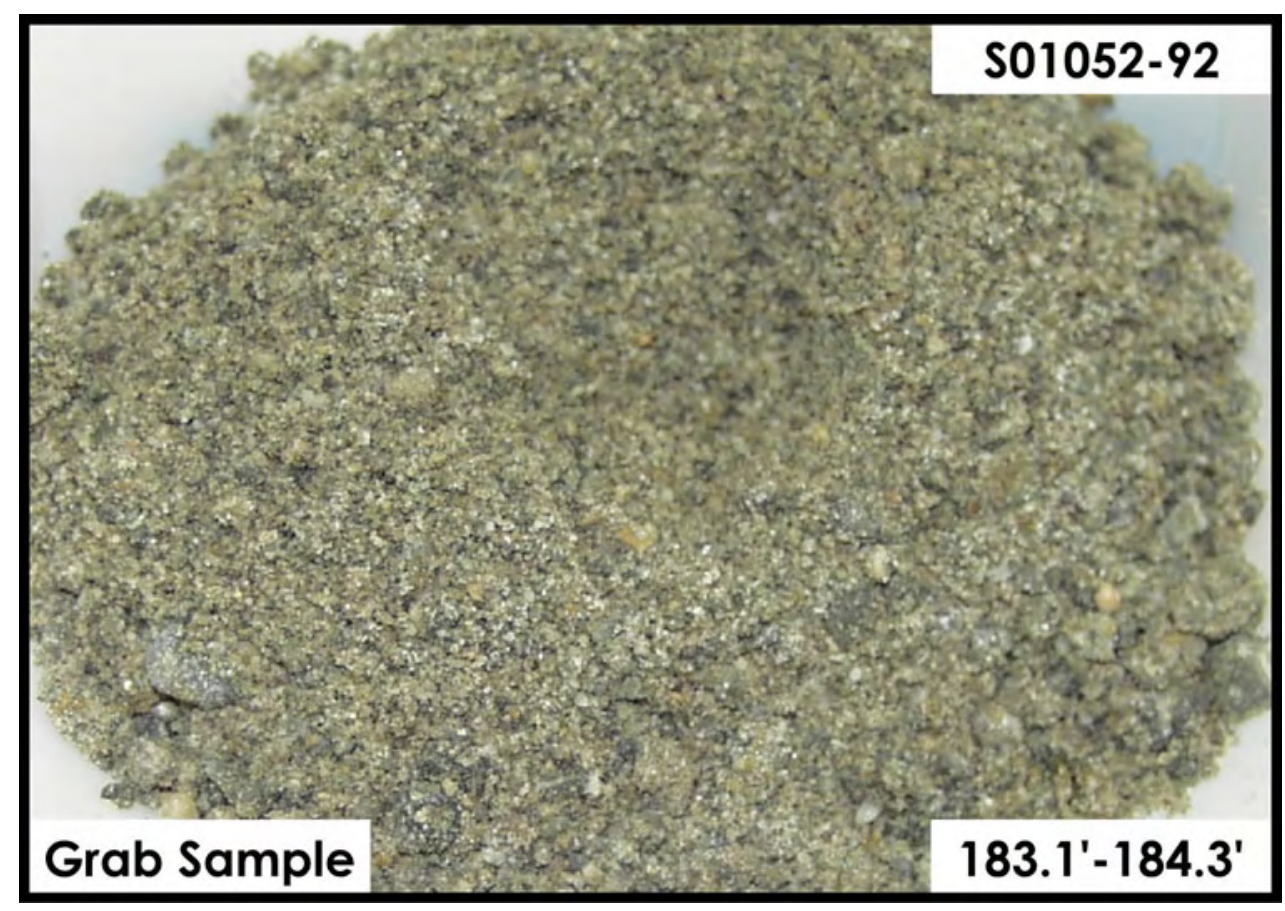

H3-Lower Sand and Gravel Sequence

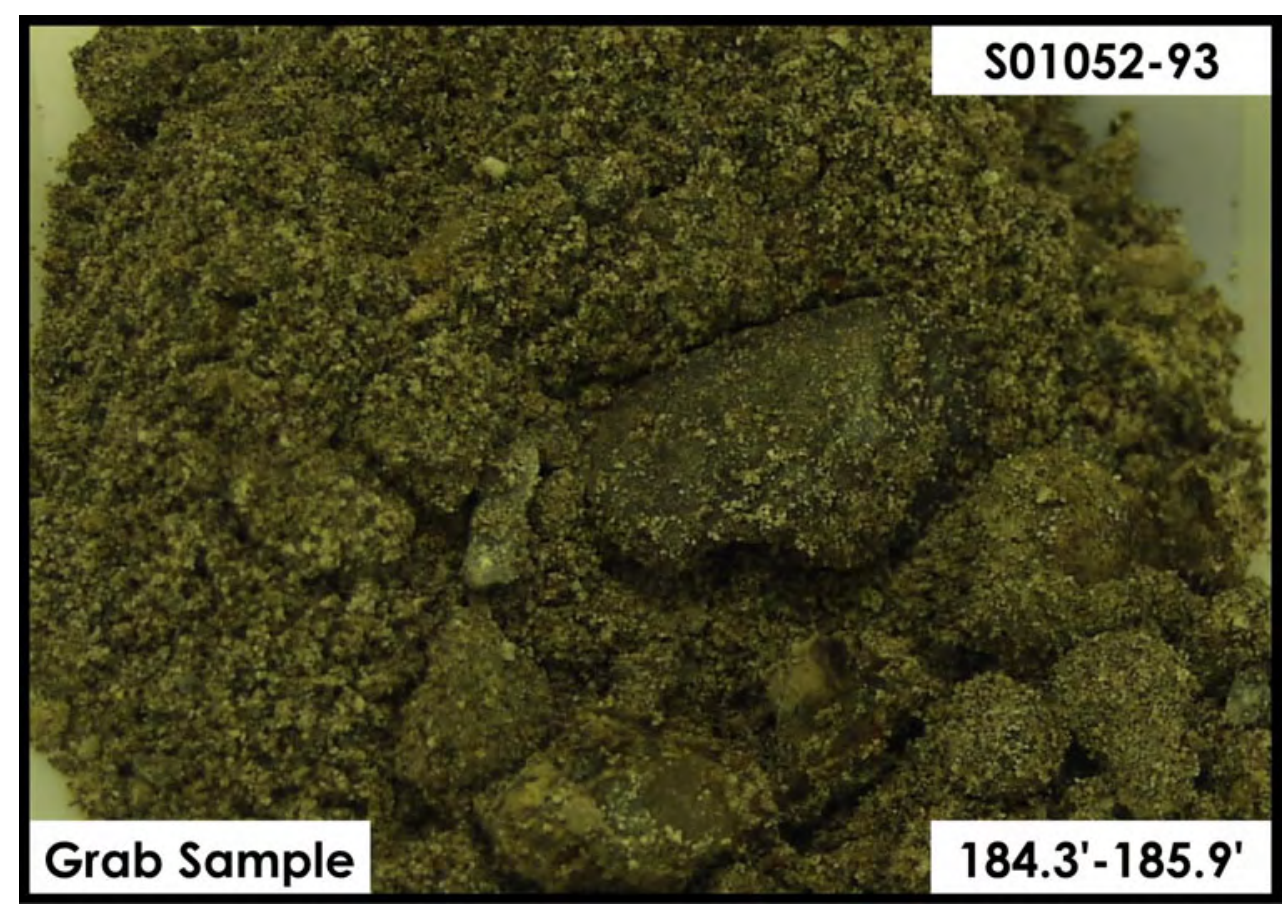

H3-Lower Sand and Gravel Sequence

B.77 


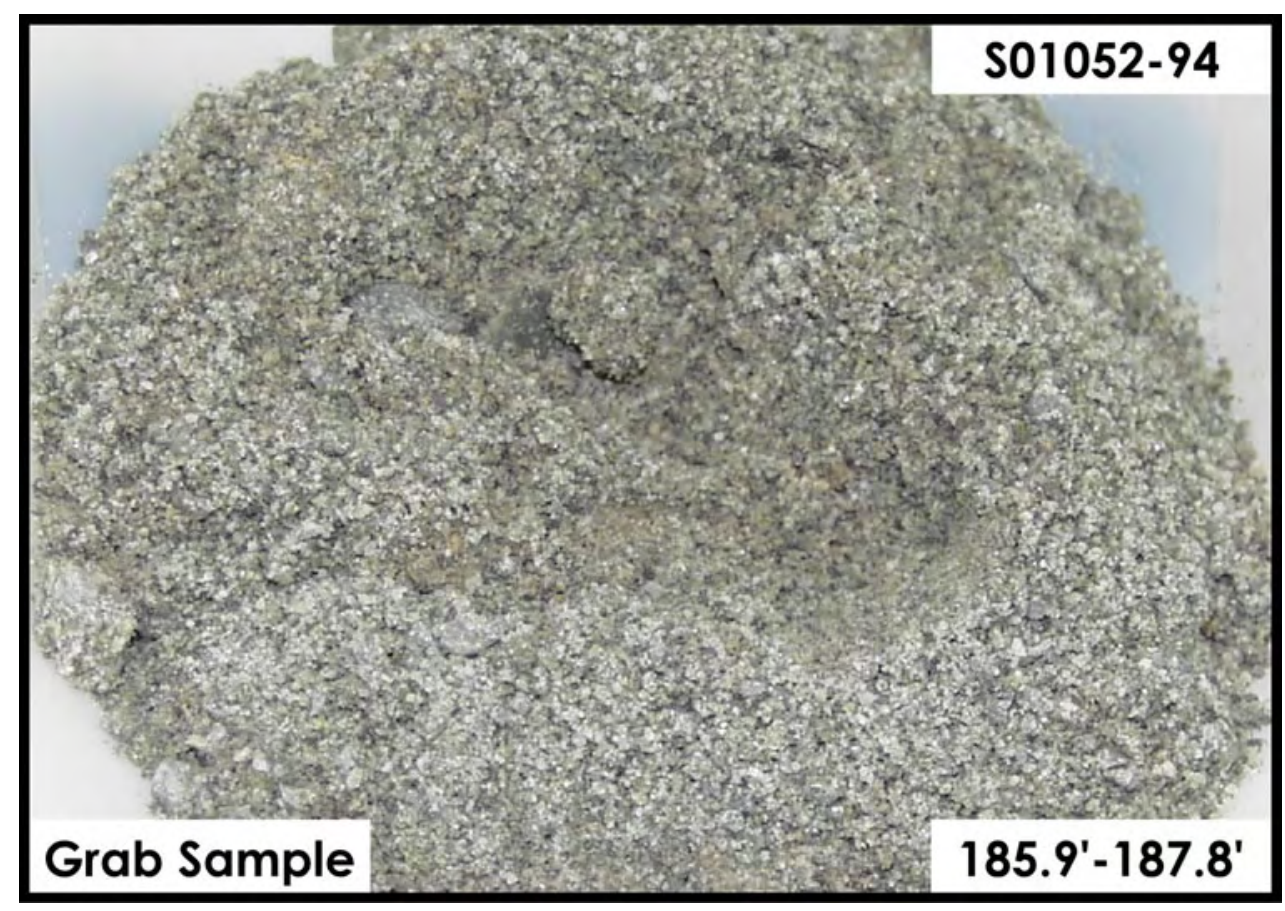

H3-Lower Sand and Gravel Sequence

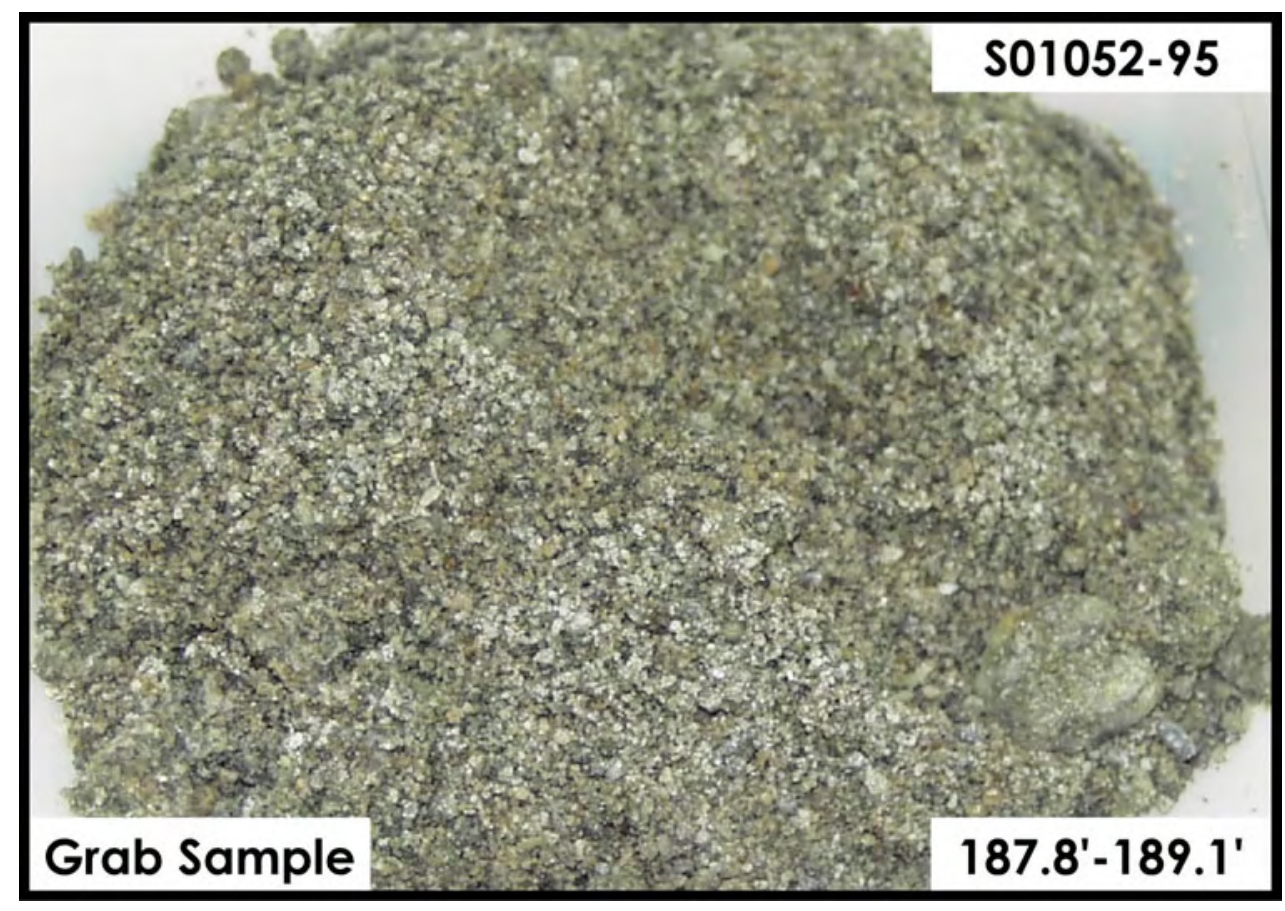

H3-Lower Sand and Gravel Sequence

B.78 


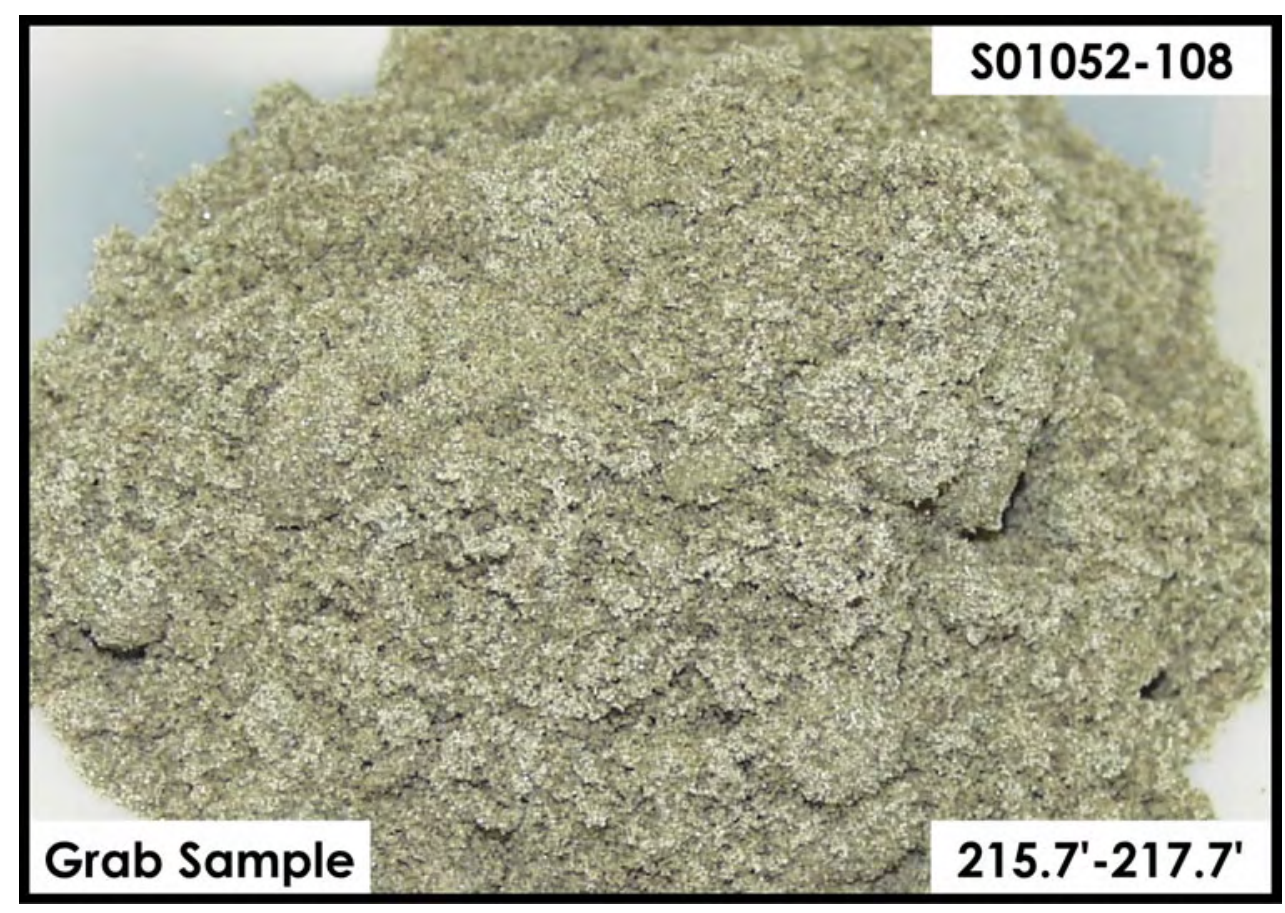

Plio-Pleistocene Silt Unit (PPlz)

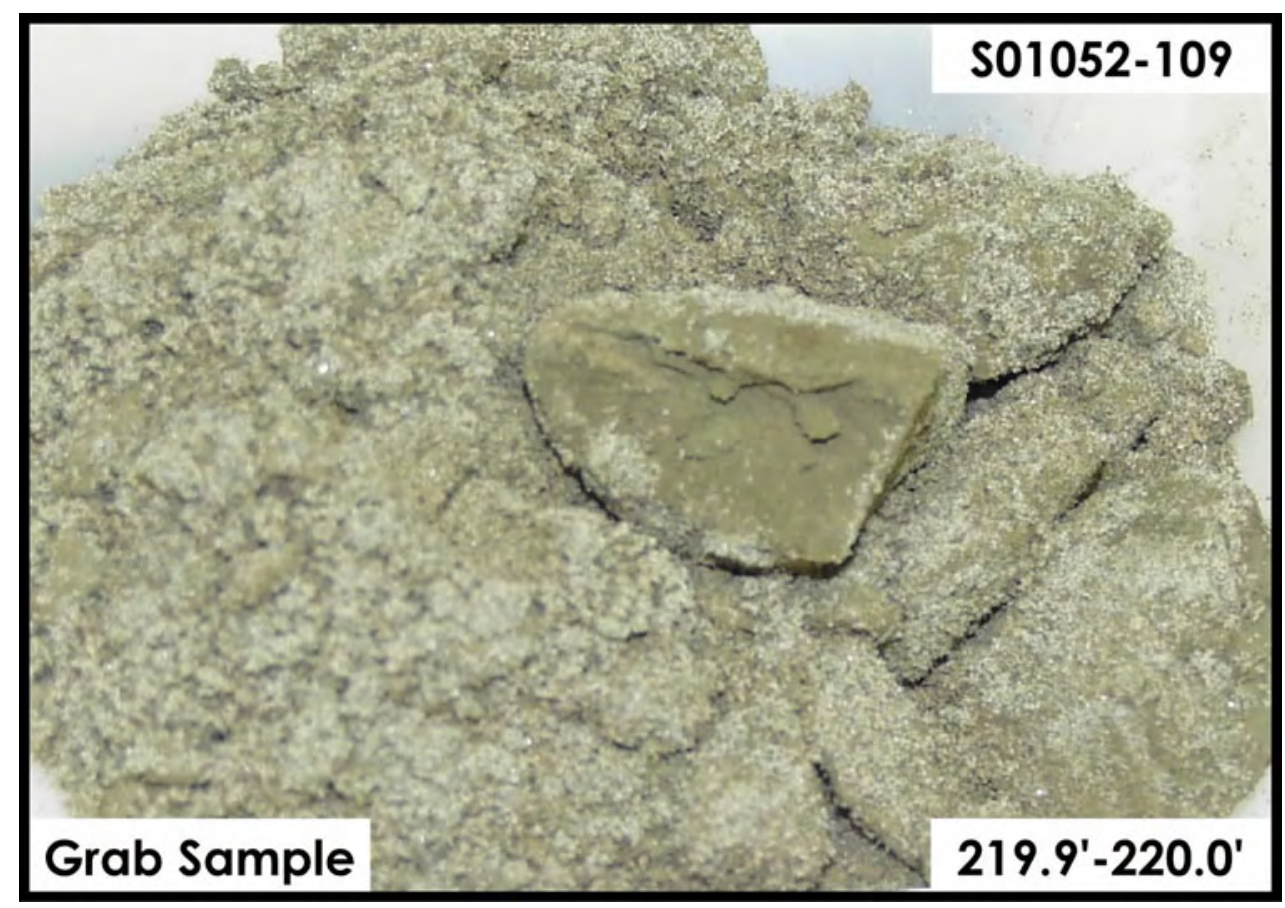

Plio-Pleistocene Silt Unit (PPlz) 


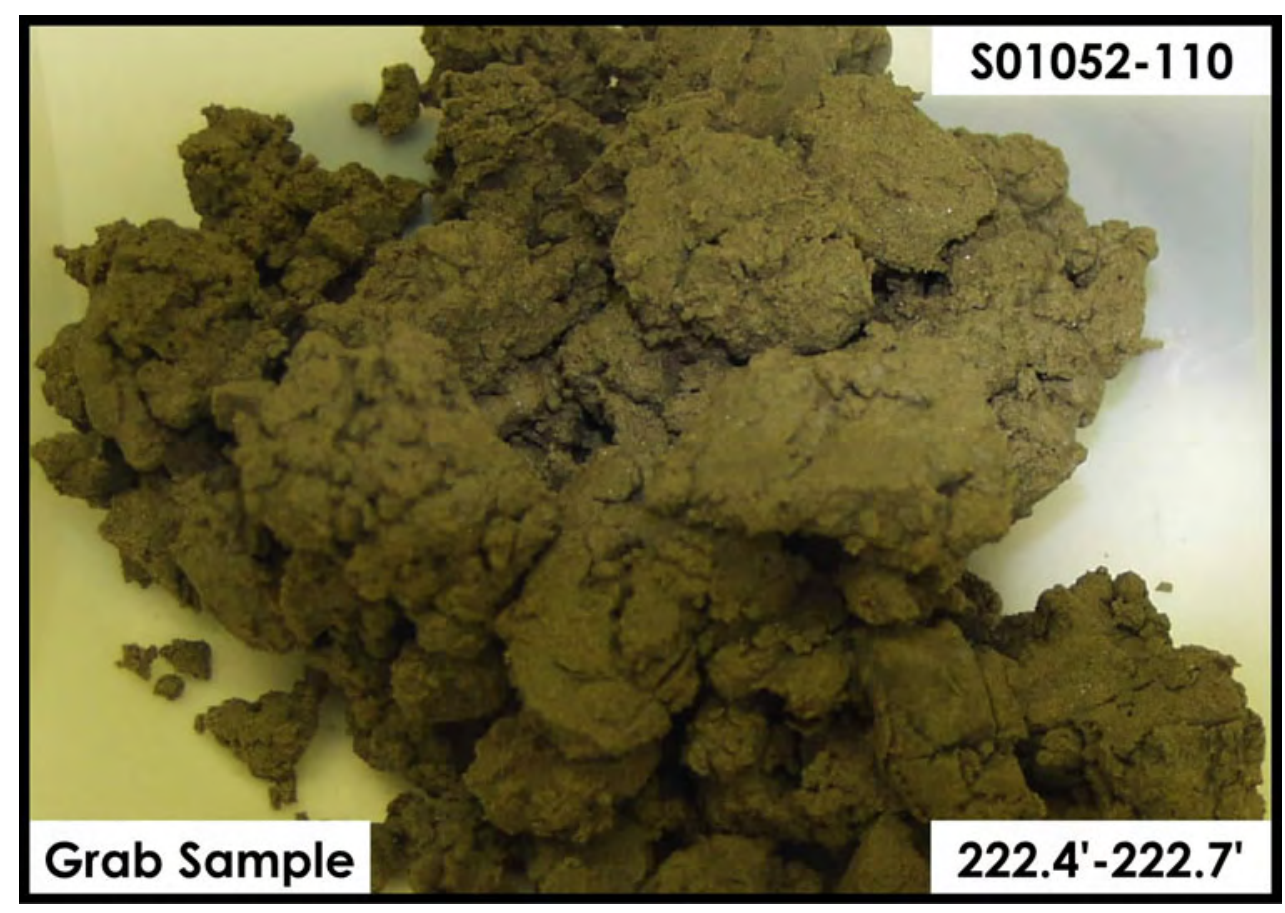

Plio-Pleistocene Silt Unit (PPlz)

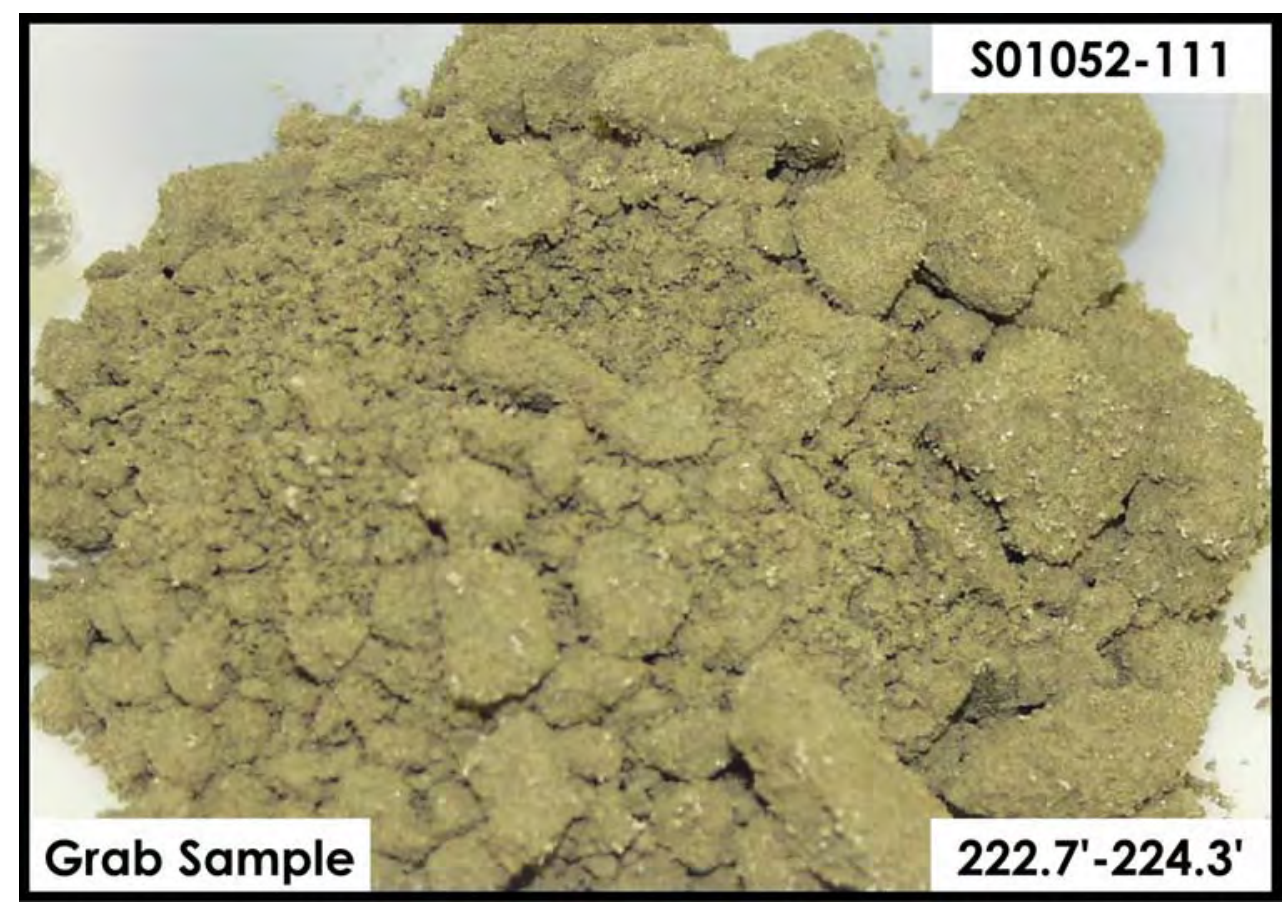

Plio-Pleistocene Silt Unit (PPlz) 


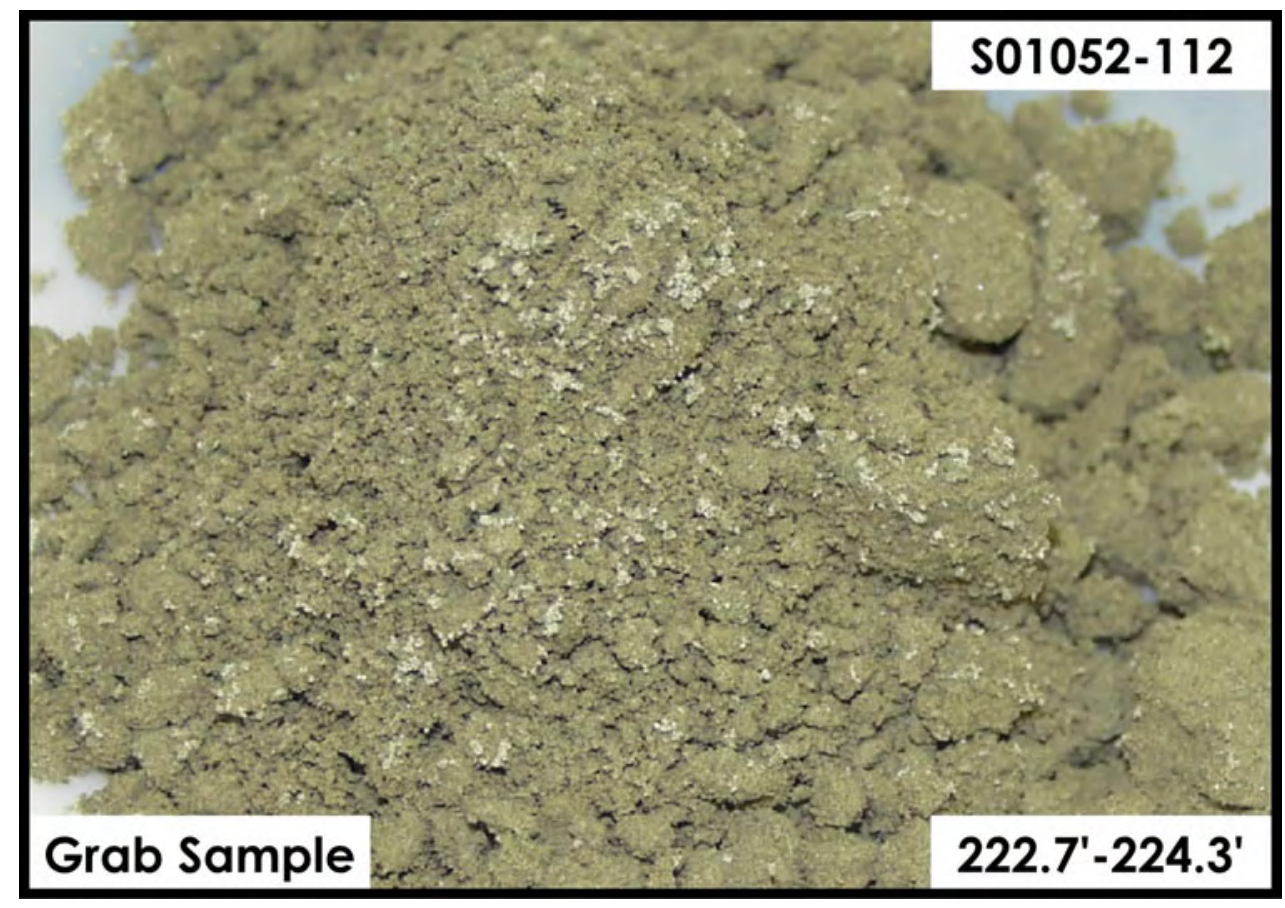

Plio-Pleistocene Silt Unit (PPlz)

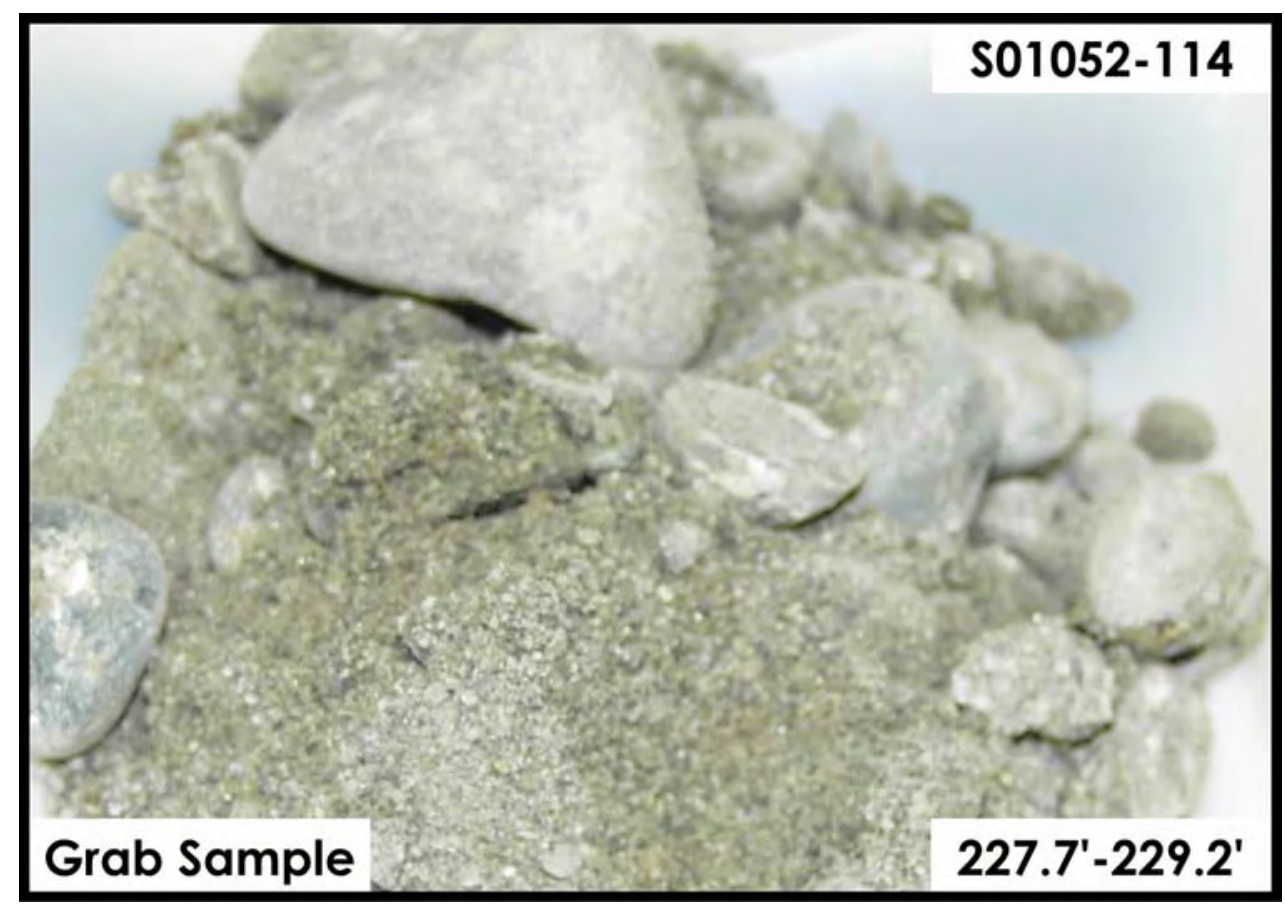

Plio-Pleistocene Gravel Unit (PPlg) 


\section{Appendix C}

Correlation Of Spectral Gamma Log Response Through Borehole Casing With ${ }^{90}$ sr Concentration In Sediments 


\title{
Appendix C
}

\section{Correlation Of Spectral Gamma Log Response and ${ }^{90}$ sr Concentration for a Steel - Cased Borehole}

\author{
RG McCain \& CJ Koizumi \\ MACTEC-ERS
}

May 31, 2002

\section{Executive Summary}

In passive gamma-ray logging, the presence of anomalous gamma activity without detectable spectral lines associated with specific radionuclides may indicate the presence of a high-energy beta-emitting radionuclide such as ${ }^{90} \mathrm{Sr}$. Brodzinski and Nielson (1980) described a means of estimating ${ }^{90} \mathrm{Sr}$ concentrations by measurement of bremsstrahlung radiation in the $60-236 \mathrm{KeV}$ range. Baseline spectral gamma logging in the 241-B tank farm detected anomalous incoherent gamma activity with no identifiable gamma lines in several boreholes north and east of tank B-110. It was suggested in the B Tank Farm Report that this activity represented a probable subsurface plume of ${ }^{90} \mathrm{Sr}$. Subsequently, laboratory analysis of soil samples from a new borehole (299-E33-46 / C3360) drilled in this region confirmed the presence of ${ }^{90} \mathrm{Sr}$. Concentrations as high as $11,000 \mathrm{pCi} / \mathrm{g}$ of dry sediment were reported. Spectral gamma log data from this borehole are compared to sediment ${ }^{90} \mathrm{Sr}$ values measured by acid extraction and liquid scintillation counting. Shape factor analysis (Wilson, 1997, 1998) is shown to be useful in identifying zones of probable ${ }^{90} \mathrm{Sr}$ and a correlation between net counts in the $60-350 \mathrm{KeV}$ range and ${ }^{90} \mathrm{Sr}$ concentration is established for the specific casing configuration. Recommendations are made for additional investigations to more fully investigate the nature of the bremsstrahlung phenomena with respect to cased boreholes, and to determine the effect of casing thickness on bremsstrahlung radiation inside the casing.

\section{Background}

During characterization logging in the 241-B Tank Farm, the SGLS detected anomalous incoherent gamma activity in boreholes northeast of tank B-110. Specifically, boreholes 20-10-02, 20-0807 and 20-07-11 exhibited intervals of anomalous gamma activity with no evidence of well-defined energy peaks that would be diagnostic of specific radionuclides. Figure C. 1 shows a combination plot for borehole 20-10-02. Note the anomalous total gamma activity between approximately 69 and $85 \mathrm{ft}$ bgs in both the SGLS total gamma log (the fifth plot) and the Tank Farms gross gamma log (the sixth plot). This anomaly does not appear to be related to either man-made radionuclides or variations in natural radionuclides. Figure C.2 illustrates two typical spectra from borehole 20-10-02. Spectrum 3A2A1076 (60 ft) is typical of an uncontaminated portion of the borehole. Spectrum 3A2A1036 (80 ft) is an example of anomalous gamma activity. Note that there are no clearly defined gamma energy peaks other than those associated with natural radionuclides. Both represent approximately the same concentrations of natural radionuclides, and yet 3A2A1036 has a gross count rate approximately 3 times that of 3A2A1076. 
Note that the bulk of the difference in counts occurs as incoherent gamma counts below approximately $600 \mathrm{KeV}$. Brodzinski and Nielson (1980) and Wilson (1997) suggest that these incoherent counts may result from bremsstrahlung associated with the interaction between high-energy beta particles from ${ }^{90} \mathrm{Sr} /{ }^{90} \mathrm{Y}$ decay and the steel casing. In the B tank farm report (DOE, 2000) it was postulated that a subsurface zone of ${ }^{90} \mathrm{Sr}$ contamination had been encountered in this borehole and others in the vicinity.

Borehole (C3360 or 299-E33-46) was drilled in May 2001 to investigate this region and collect samples for laboratory analysis. ${ }^{90} \mathrm{Sr}$ concentrations in samples at selected depths have been determined (see Table 4.10 in the main text). The depth interval from 50 to $120 \mathrm{ft}$ in borehole 299-E33-46 was logged with the SGLS, and man-made gamma-ray-emitting nuclides were determined to be absent, or present in negligible concentrations. Thus, emissions from such nuclides did not introduce significant extraneous spectral background. The photons in the borehole that were not due to natural radioactive sources were bremsstrahlung created by collisions and accelerations of the beta emissions from ${ }^{90} \mathrm{Sr} /{ }^{90} \mathrm{Y}$ decay. The borehole logging data was used test theories about the bremsstrahlung contributions to passive gammaray spectra, and the correlations of such bremsstrahlung signals to the ${ }^{90} \mathrm{Sr}$ concentrations.

The guide to the investigation was work by R.D. Wilson on spectral shape factor analysis, most of which is reported in Wilson (1997) that presents results of model studies using the MCNP radiation transport code and model experiments. Unfortunately, in relation to Wilson's work, borehole 299-E33-46 is an imperfect for this investigation, for at least two reasons:

- The borehole casing in Wilson's MCNP model was 0.313-inch-thick steel, whereas the steel casing in borehole 299-E33-46 is 0.514 inches thick. The effect of casing thickness on generation and transmission of bremsstrahlung gamma rays is unknown.

- The beta source in Wilson's MCNP model was "distributed uniformly $2 \mathrm{~cm}$ radially into the formation and extended $\pm 15.24 \mathrm{~cm}$ ( \pm 6 in.) axially" (with respect to the center of the gamma-ray detector), whereas the ${ }^{90} \mathrm{Sr}$ distribution outside borehole 299-E33-46 appears to be somewhat nonuniform. 


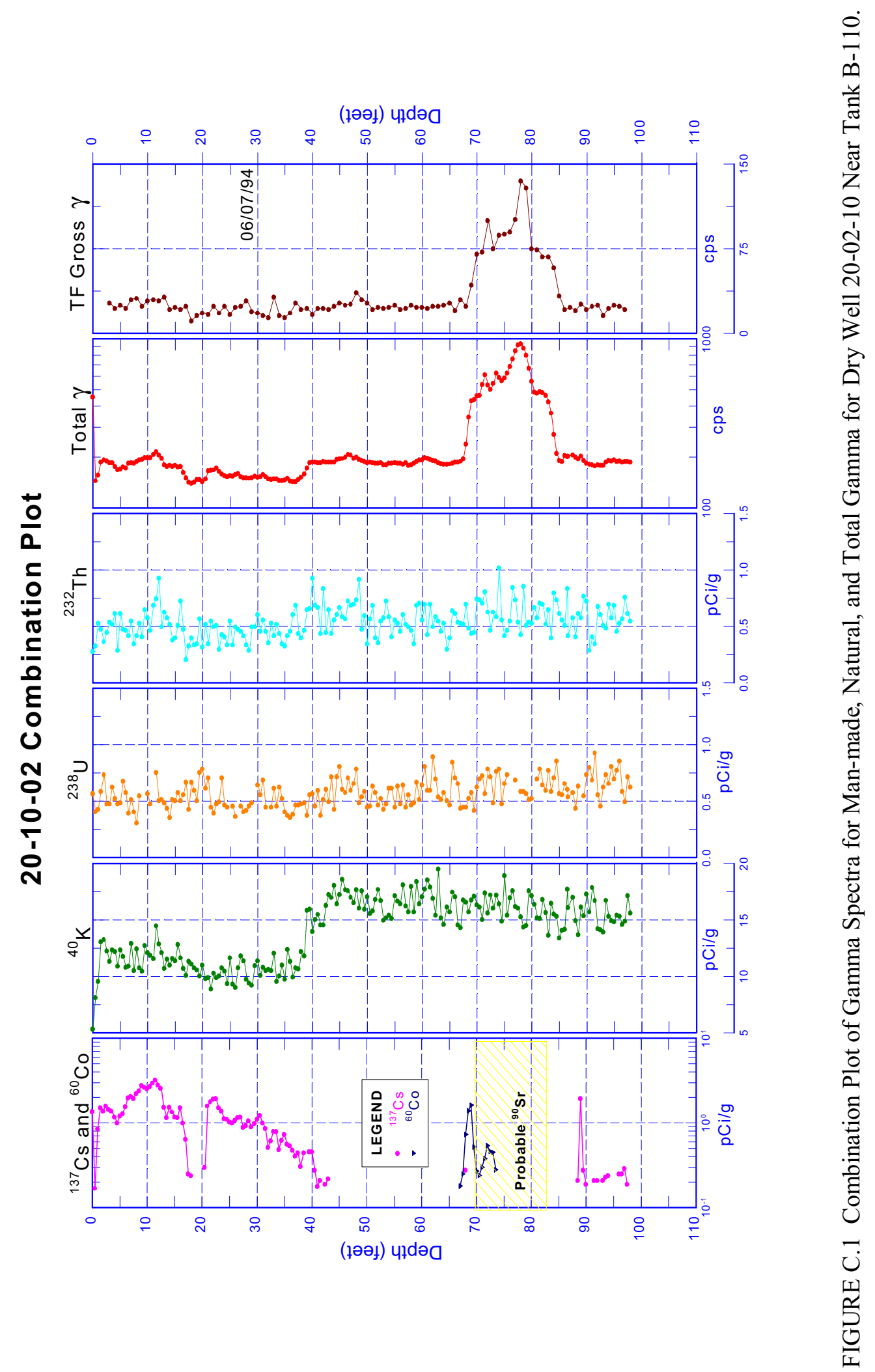

C. 3 


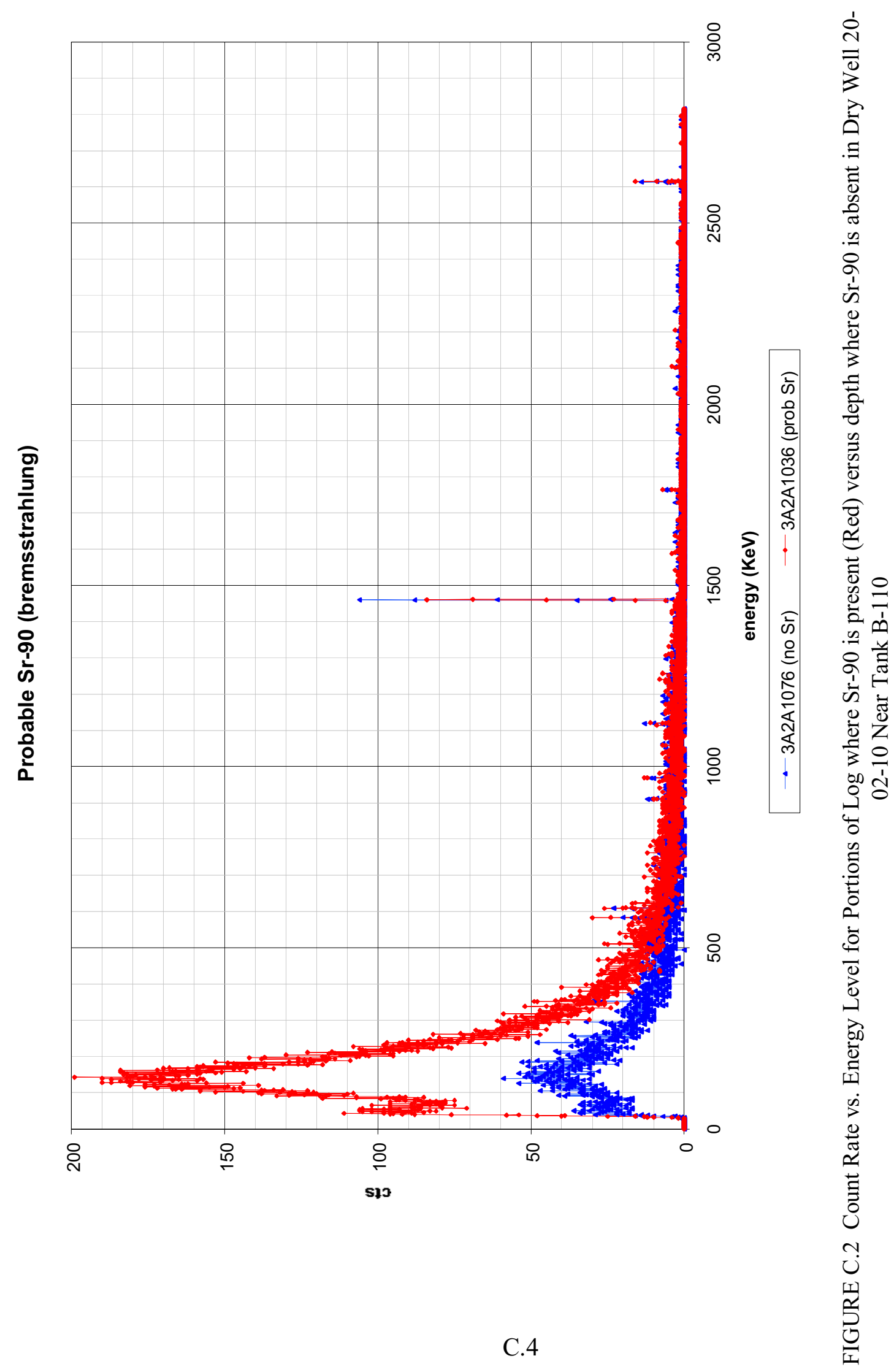




\section{Shape Factor Analysis}

The technique of shape factor analysis is described in Wilson (1997 \& 1999). This technique was developed as a means to assess the distribution of ${ }^{137} \mathrm{Cs}$ and ${ }^{60} \mathrm{Co}$ with respect to the borehole axis. For both ${ }^{137} \mathrm{Cs}$ and ${ }^{60} \mathrm{Co}$, a shape factor, SF1 was defined as the ratio between the energy peaks and the increased spectral noise due to Compton scattering. SF1 is sensitive to spectral differences for a borehole-confined source, a source uniformly distributed in the formation, and a remote source. However, it is only valid when the respective contaminant is present and has no bearing on identification of ${ }^{90} \mathrm{Sr}$. It will not be discussed further in this document. Another shape factor was defined to assess the distribution of counts in the low-energy continuum:

$$
S F 2=\frac{\text { counts }(60-350 \mathrm{KeV})}{\text { counts }(350-650 \mathrm{KeV})}
$$

(Wilson, 1997)

This factor is sensitive to differences in the scattered portions of the spectrum from gamma emitters and from bremsstrahlung sources. In particular, SF2 is capable of identifying the presence of low-energy bremsstrahlung radiation from the decay of ${ }^{90} \mathrm{Sr} /{ }^{90} \mathrm{Y}$ and is able to distinguish this spectral effect from the enhanced low-energy response obtained from remotely located ${ }^{137} \mathrm{Cs}$ and ${ }^{60} \mathrm{Co}$. Wilson's model studies indicated that "for virtually all gamma-emitting contaminants and for all possible source distributions, SF2 never exceeds a value of about 5. An SF2 value greater than 5 is evidence for the presence of a bremsstrahlung-producing energetic beta emitter, such as ${ }^{90} \mathrm{Sr}{ }^{90} Y$." (Wilson et al, 1997). Other reports (Wilson, 1997 and Wilson, 1999) have suggested that SF2 values may be as high as 20 in zones with significant ${ }^{90} \mathrm{Sr}$ concentration.

Figure C. 3 shows the shape factor log for borehole 20-10-02. Note that within the region of anomalous total gamma activity between 69 and $85 \mathrm{ft}$ bgs, SF2 attains a value of approximately 8 . In this $\log , \mathrm{SF} 2$ is calculated from counts in the two spectral windows after the contribution from naturally occurring radionuclides has been removed. This leads to the erratic behavior of SF2 in uncontaminated intervals.

\section{RESULTS FROM BOREHOLE 299-E33-46}

Figure C.4A shows a plot of total gamma count rate and count rate in the $60-350 \mathrm{KeV}$ range for the 50 to $120 \mathrm{ft}$ depth interval in borehole 299-E33-46. Figure C.4B shows laboratory measured ${ }^{90} \mathrm{Sr}$ concentrations plotted at the same depth scale. Figure C.4C shows SF2 and SF2* calculated as the ratio between counts in the $60-350 \mathrm{KeV}$ range and counts in the $350-650 \mathrm{KeV}$ range. SF2 is calculated using count rates corrected for natural radionuclides, while SF2* is calculated using gross (uncorrected) counts in the two energy windows. There appears to be a correlation between laboratory ${ }^{90} \mathrm{Sr}$ concentrations and either total gamma count rate or count rate for $60-350 \mathrm{KeV}$. Furthermore, SF2* has a value of about 3.3 to 3.6 in uncontaminated areas, rising to greater than 6 in intervals of high ${ }^{90} \mathrm{Sr}$.

Figures C.5a and 5b display two HPGE spectra from borehole 299-E33-46. Both figures show the same two spectra; counts (vertical axis) are plotted on a log scale in Figure C.5a, and on a linear scale in Figure C.5b. The upper spectrum (named FOCA1024.S0) was recorded at a depth of 62.0 feet bgs, where the ${ }^{90} \mathrm{Sr}$ concentration was $11245 \pm 363 \mathrm{pCi} / \mathrm{g}$. The lower spectrum (named FOCA1100.S0) was recorded at a depth of $100.0 \mathrm{ft} \mathrm{bgs,} \mathrm{where} \mathrm{the}{ }^{90} \mathrm{Sr}$ concentration was 
zero, or close to zero. The full energy peaks are all associated with natural background; the peak for the $1460.8-\mathrm{keV}$ gamma ray of ${ }^{40} \mathrm{~K}$, and the peak for the $2614.5-\mathrm{keV}$ gamma ray of ${ }^{208} \mathrm{Tl}$ are labeled. Because spectrum FOCA1024.S0 contains no evidence of man-made gamma-ray emitters, the offset relative to spectrum FOCA1100.S0 is presumably due to bremsstrahlung associated with ${ }^{90} \mathrm{Sr}$ beta emissions.

Spectrum FOCA1024.S0 seems generally consistent with Wilson's MCNP simulation, which indicated that most of the bremsstrahlung contribution would appear in the part of the spectrum below $500 \mathrm{keV}$ (see Figure 8 in Wilson's report).

Although the shape of spectrum FOCA1024.S0 more or less agrees with Wilson's model, the gross count rate apparently does not. Spectrum FOCA1024.S0 has a gross count rate equal to $2713.12 \mathrm{c} / \mathrm{s}$, and spectrum FOCA1100.S0 has a gross count rate of $162.82 \mathrm{c} / \mathrm{s}$. Since FOCA1024.S0 has a ${ }^{90} \mathrm{Sr}$ contribution, but FOCA1100.S0 does not, the difference of $2550.3 \mathrm{c} / \mathrm{s}$ would seem to be attributable to the ${ }^{90} \mathrm{Sr}$ contribution (assuming the potassium-uranium-thorium background is more or less uniform). The ${ }^{90} \mathrm{Sr}$ concentration corresponding to FOCA1024.S0 was $11245 \mathrm{pCi} / \mathrm{g}$, meaning that the measurement sensitivity to ${ }^{90} \mathrm{Sr}$ was about $0.23 \mathrm{c} / \mathrm{s} \mathrm{per} \mathrm{pCi} / \mathrm{g}$. This is almost an order of magnitude higher than the value of $0.028 \mathrm{c} / \mathrm{s} \mathrm{per} \mathrm{pCi} / \mathrm{g}$ that Wilson estimated.

Because the sensitivity was in substantial disagreement with Wilson's estimate, the sensitivity was recalculated using 22 spectra from ${ }^{90} \mathrm{Sr}$-contaminated depths. A background gross count rate of $159.3 \pm 13.4 \mathrm{c} / \mathrm{s}$ (uncertainty $= \pm 2 \sigma$ ) was determined by calculating the average gross count rate of the spectra from depths below 90 feet, where the ${ }^{90} \mathrm{Sr}$ concentrations were zero, or close to zero. The background was subtracted from each of the 22 spectra, then each gross count rate was divided by the associated ${ }^{90} \mathrm{Sr}$ concentration. The average of the sensitivity values was $0.26 \pm 0.18 \mathrm{c} / \mathrm{s}$ per $\mathrm{pCi} / \mathrm{g}$, which agreed with the initial finding.

SF2 for FOCA1024.S0 was calculated by subtracting counts from FOCA1100.S0 in each channel, computing the sums of the remainder over $60-350 \mathrm{KeV}$ and $350-650 \mathrm{KeV}$, and dividing the two numbers. SF2* was calculated by dividing the total counts in the same channel ranges. SF2 was found to be 6.61 and SF2* was found to be 6.34. These values are somewhat lower than those encountered in dry well 20-10-02, and considerably lower than the value of 20 suggested by Wilson's model studies. This discrepancy may be due at least in part to the greater casing thickness. The maximum range of a $2.28 \mathrm{MeV}$ beta particle from the daughter product ${ }^{90} \mathrm{Y}$ in iron is estimated to be on the order of 0.06 inches. This suggests that incident beta radiation only interacts with a relatively thin outer layer of the casing, and that the remaining casing material simply attenuates the bremsstrahlung gamma activity. Since lower-energy gamma rays are attenuated to a greater degree, this would result in a lower value of the SF2 ratio in thicker casing.

In spite of the sensitivity discrepancy, and differences between Wilson's MCNP model and the casing thickness and ${ }^{90} \mathrm{Sr}$ distribution presented by borehole 299-E33-46, values for several parameters were calculated from the SGLS spectra, and correlations between these parameter values and the ${ }^{90} \mathrm{Sr}$ concentrations were investigated. 


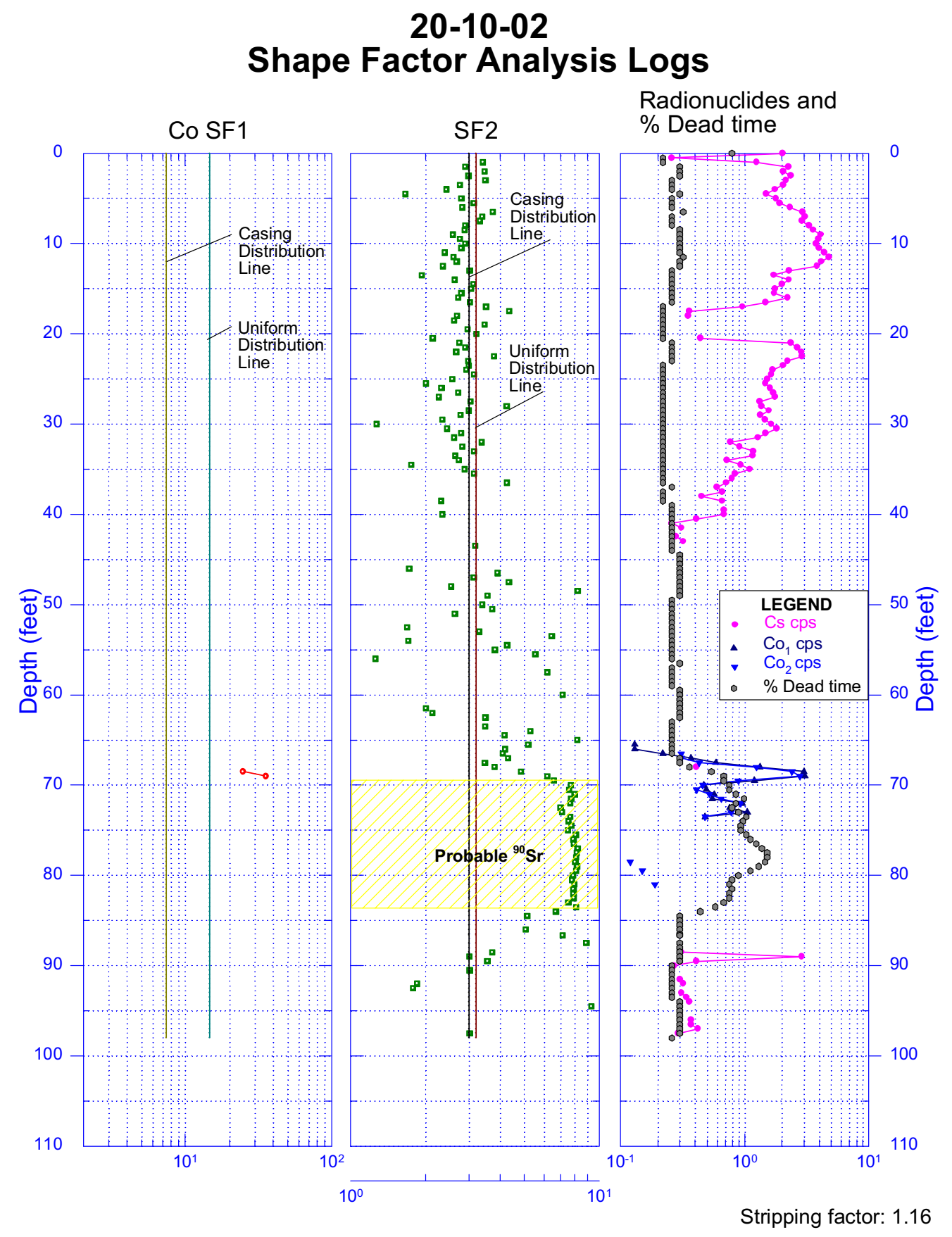

FIGURE C.3 Shape Factor Parameters versus Depth for Logging Spectra through Dry Well 20-02-10 Near Tank B-110 

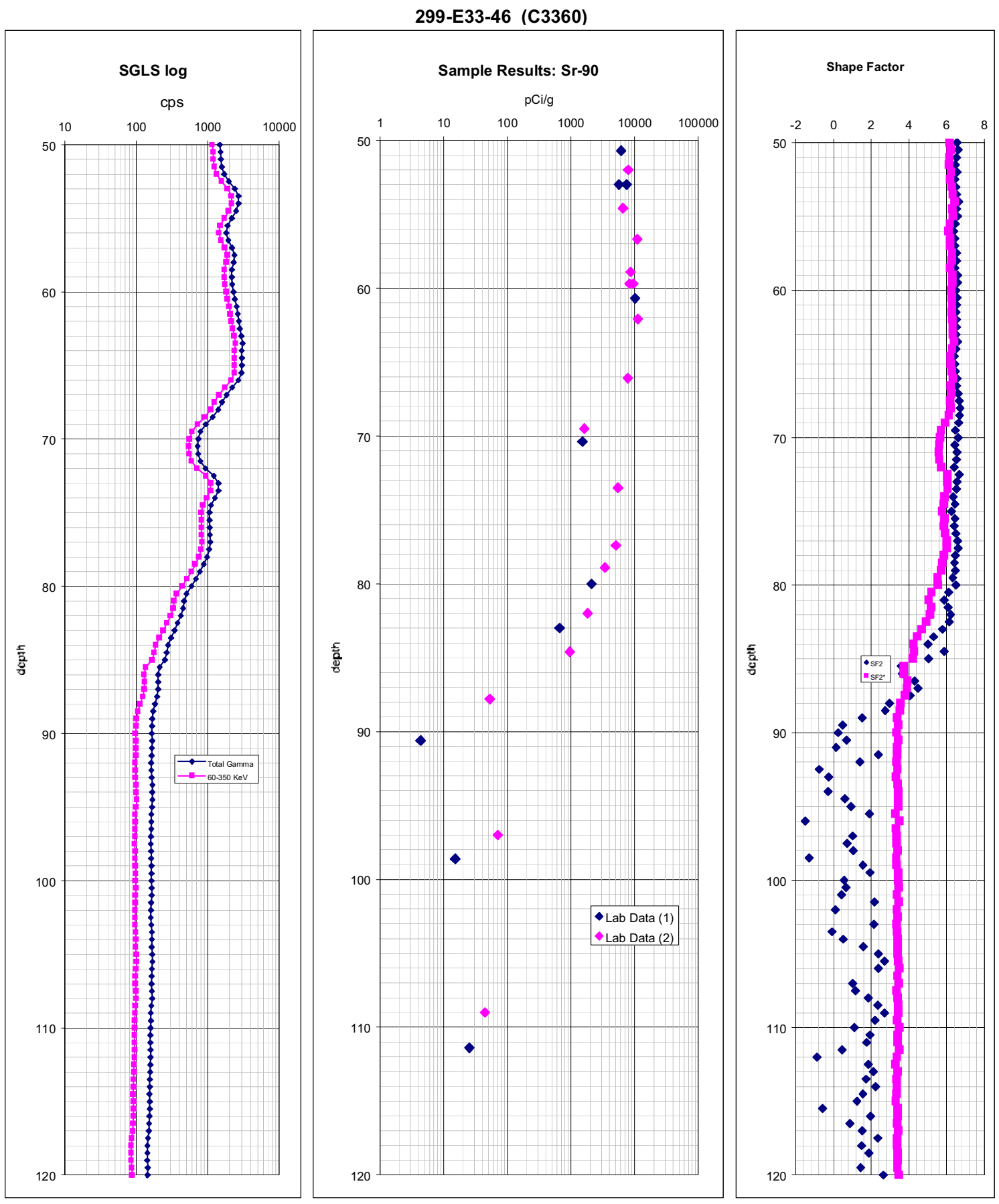

A

$\mathrm{B}$

$\mathrm{C}$

FIGURE C.4 Logging Data for Borehole 299-E33-46 versus Depth. (A.) Total Gamma;

(B.) 60 to $350 \mathrm{Kev}$ Window vs. Lab Measured Sr-90; (C.) Shape Factor Parameters 


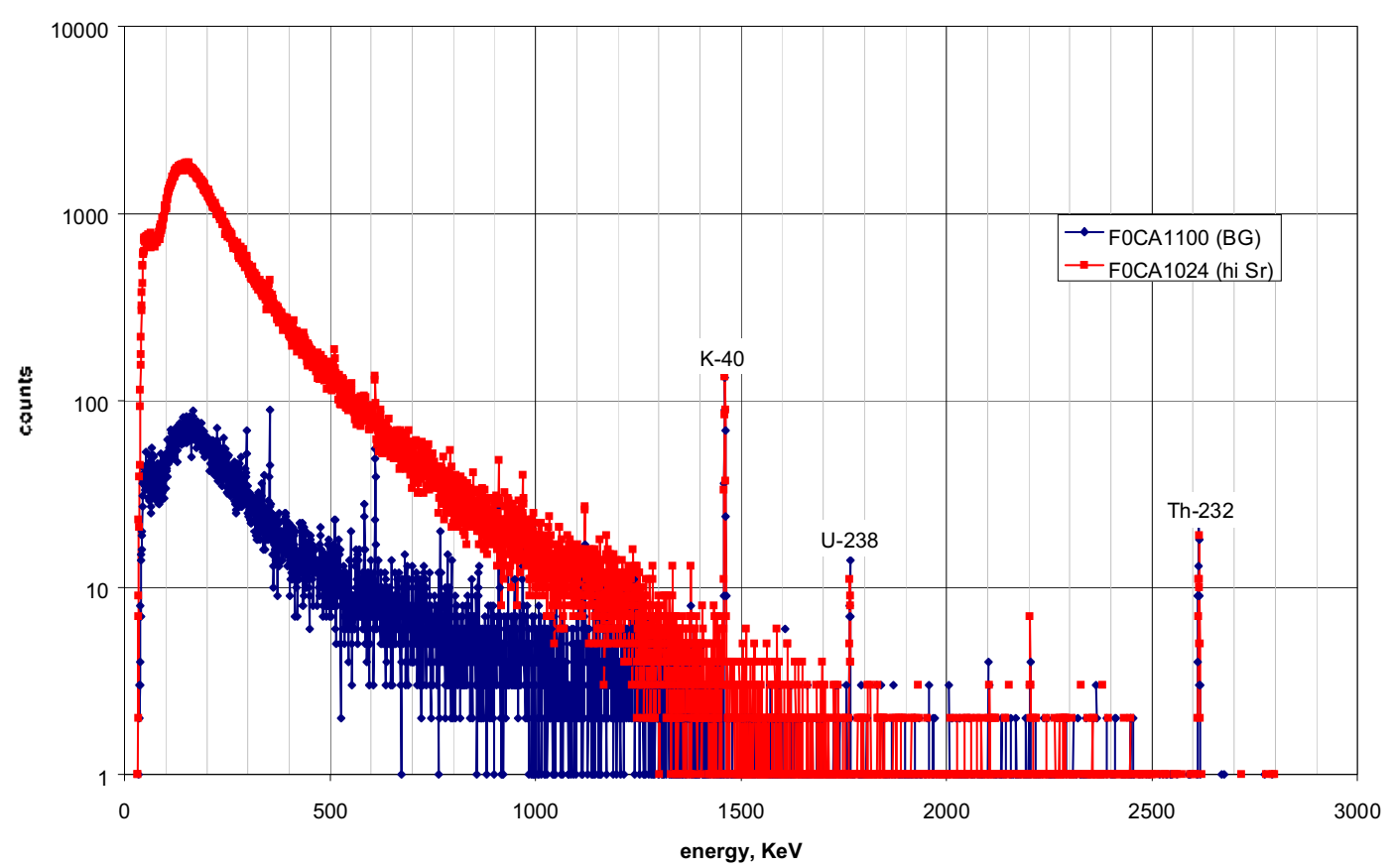

299-E33-46 Example Spectra

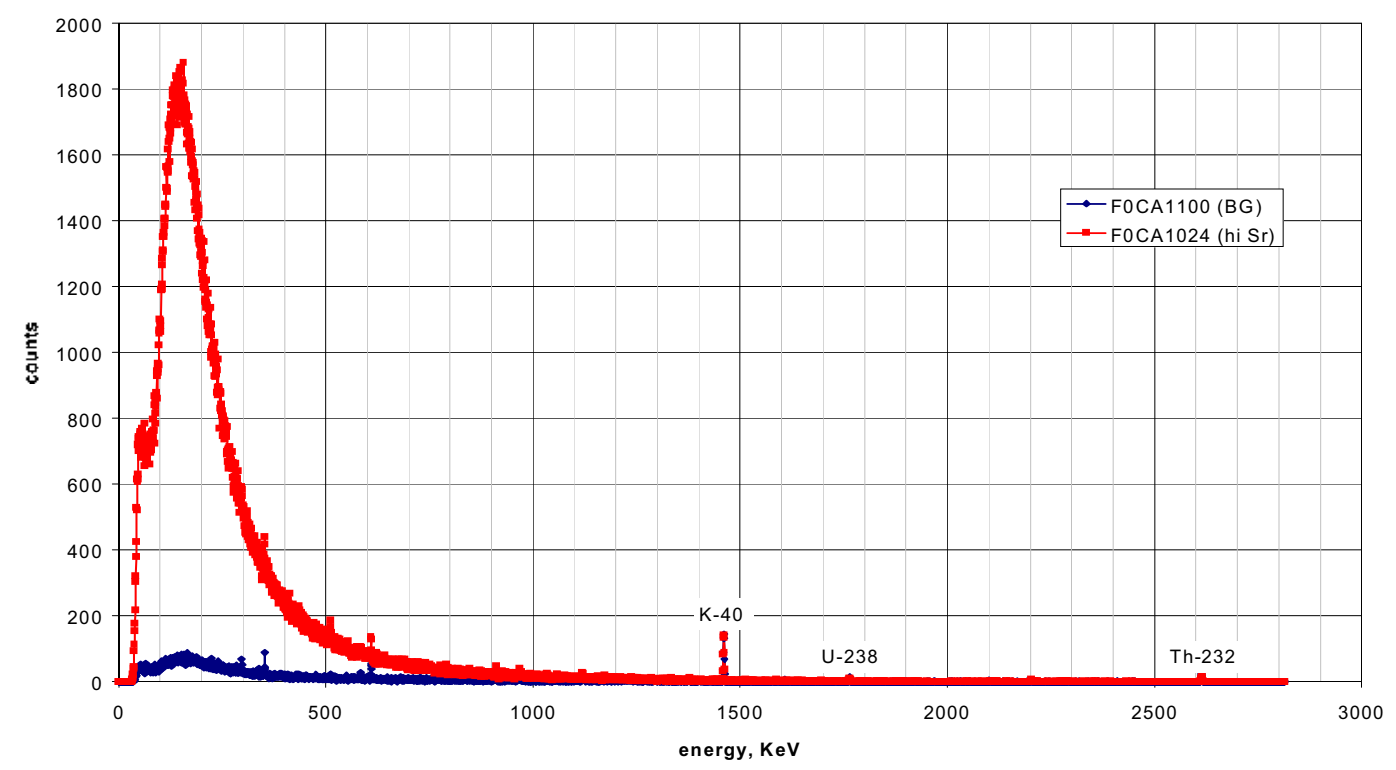

FIGURE C.5 Logging Spectra for Two Detectors vs. Energy for a Particular Depth at Borehole 299-E33-46. Top has counts on log scale and bottom has counts on linear scale. 
Spectra from various depths, mostly where ${ }^{90} \mathrm{Sr}$ was present, were analyzed as follows. Count rates for two spectral windows were calculated, $60 \mathrm{keV}$ to $350 \mathrm{keV}$ (window 1) and 350 $\mathrm{keV}$ to $650 \mathrm{keV}$ (window 2). Both windows are corrected for background using stripping factors based on the K-40, U-238 and Th-232 peaks. The ratio of the corrected rate for window 1 to the corrected rate for window 2 is Wilson's shape factor 2 (SF2). SF2 is plotted in relation to ${ }^{90} \mathrm{Sr}$ concentration in Figure C.6. Also plotted in Figure C.6 is a "modified" SF2, designated SF2*, which is the ratio of total counts in window 1 to total counts in window 2 . Note that both SF2 and SF2* increase with increasing ${ }^{90} \mathrm{Sr}$. Both are greater than 5 when ${ }^{90} \mathrm{Sr}$ concentrations are greater than $1000 \mathrm{pCi} / \mathrm{g}$, and both seem to reach a maximum value between 6 and 7 . At low ${ }^{90} \mathrm{Sr}$ concentrations, however, SF2 varies widely, while SF2* seems to have a relatively stable value between 3.3 and 3.6. From a mathematical perspective, this behavior should be expected: in intervals with no contamination, the corrected values for windows 1 and 2 should be close to zero, or even slightly negative. Division of two numbers close to zero can result in unpredictable results. At high ${ }^{90} \mathrm{Sr}$ concentrations, the counts due to bremsstrahlung dominate the spectra, and subtraction of background has little effect. In borehole 299-E33-46, one could infer that values of $\mathrm{SF} 2$ (or SF2*) greater than 5 indicate the presence of ${ }^{90} \mathrm{Sr}$, while values less than 4 indicate that ${ }^{90} \mathrm{Sr}$ concentrations are less than 500 to $1000 \mathrm{pCi} / \mathrm{g}$. For spectra where no ${ }^{90} \mathrm{Sr}$ is present, SF2* appears to be preferable, since it approaches a relatively stable value. Figure C.4C shows both $\mathrm{SF} 2$ and SF2* plotted as a function of depth. Note that SF2 is only stable where ${ }^{90} \mathrm{Sr}$ is present, while SF2* achieves stable values in both the contaminated interval and the uncontaminated interval.

Examination of Figure C.6 indicates that neither SF2 or SF2* appears to be useful as a quantitative indicator of ${ }^{90} \mathrm{Sr}$ concentration. Over the range of about 500 to $5000 \mathrm{pCi} / \mathrm{g}$, it appears that both shape factors do increase with increasing ${ }^{90} \mathrm{Sr}$ content, but above about $5000 \mathrm{pCi} / \mathrm{g}$, SF2 and SF2* values remain relatively constant. This behavior can be explained by the fact that both numbers are ratios. Below about $500 \mathrm{pCi} / \mathrm{g}$, the contribution to the gamma spectrum from bremsstrahlung associated with ${ }^{90} \mathrm{Sr} /{ }^{90} \mathrm{Y}$ decay is relatively minor. The behavior of SF2 is erratic, because counts due to background have been removed and only "noise" is left to calculate the ratio. SF2* assumes a stable value, which represents the ratio based on typical levels of natural radionuclides. Between about 500 and $5000 \mathrm{pCi} / \mathrm{g}$, the bremsstrahlung contribution becomes increasingly more important and the ratio changes. Above about $5000 \mathrm{pCi} / \mathrm{g}$, the bremsstrahlung contribution dominates the spectra; counts in both windows increase proportionately, and both $\mathrm{SF} 2$ and SF2* exhibit little or no change with increasing concentration.

Count rates are more likely to exhibit a correlation with ${ }^{90} \mathrm{Sr}$ concentration over a wider range. Figures C.7 and C.8 show total gamma count rate and count rate in the 60 to $350 \mathrm{KeV}$ energy range plotted as a function of ${ }^{90} \mathrm{Sr}$ concentration. Each figure shows both the total or gross count rate, as well as the net count rate after subtraction of background. The values plotted against ${ }^{90} \mathrm{Sr}$ concentration are based on a 3-point average of the SGLS data, centered on the midpoint depth of the sediment sample analyzed in the lab. Also shown on Figure C.7 is a line corresponding to the sensitivity of $0.26 \mathrm{cps} /(\mathrm{pCi} / \mathrm{g})$ determined above. This shows reasonable agreement with the net count values. 

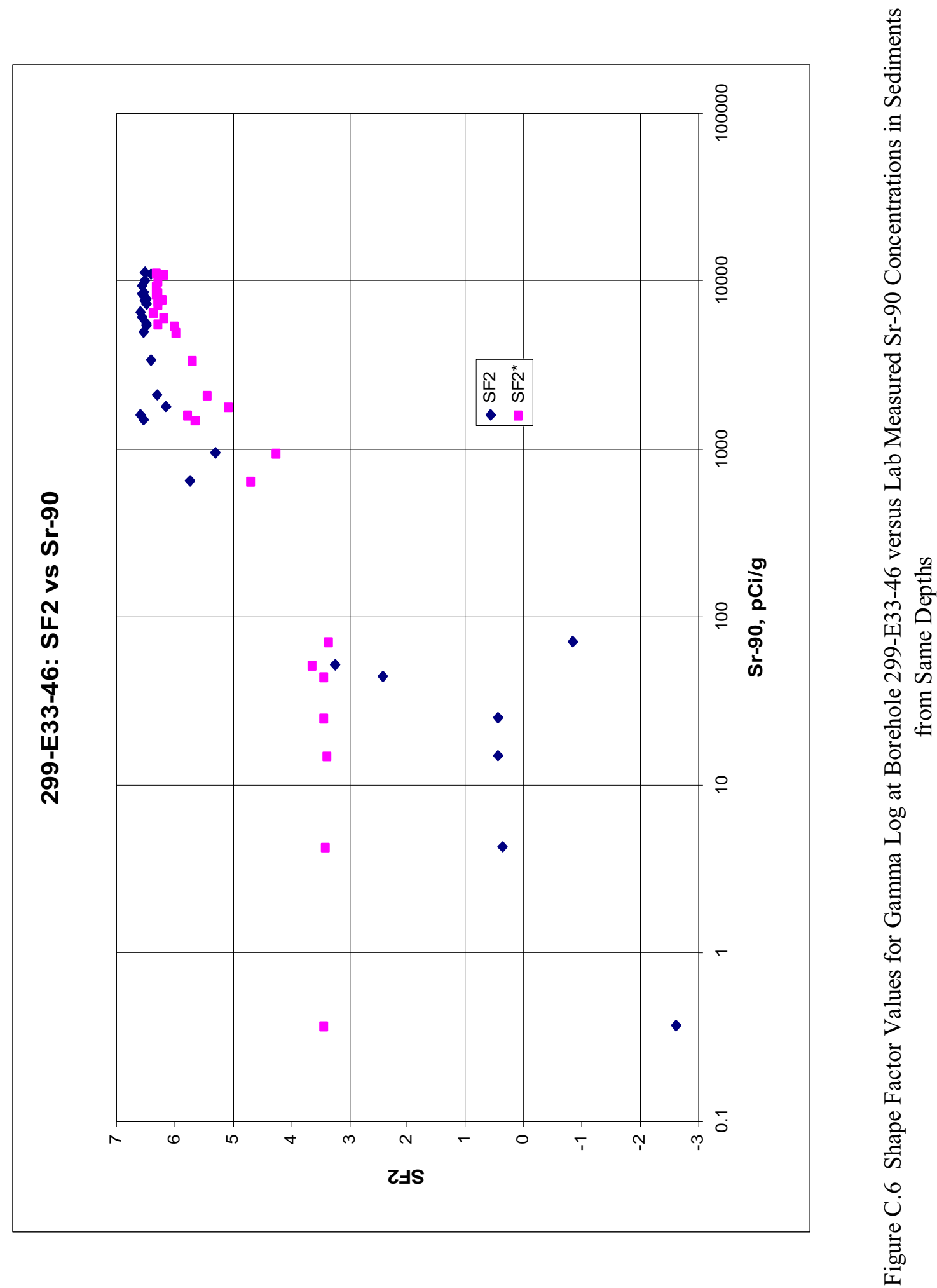

C. 11 


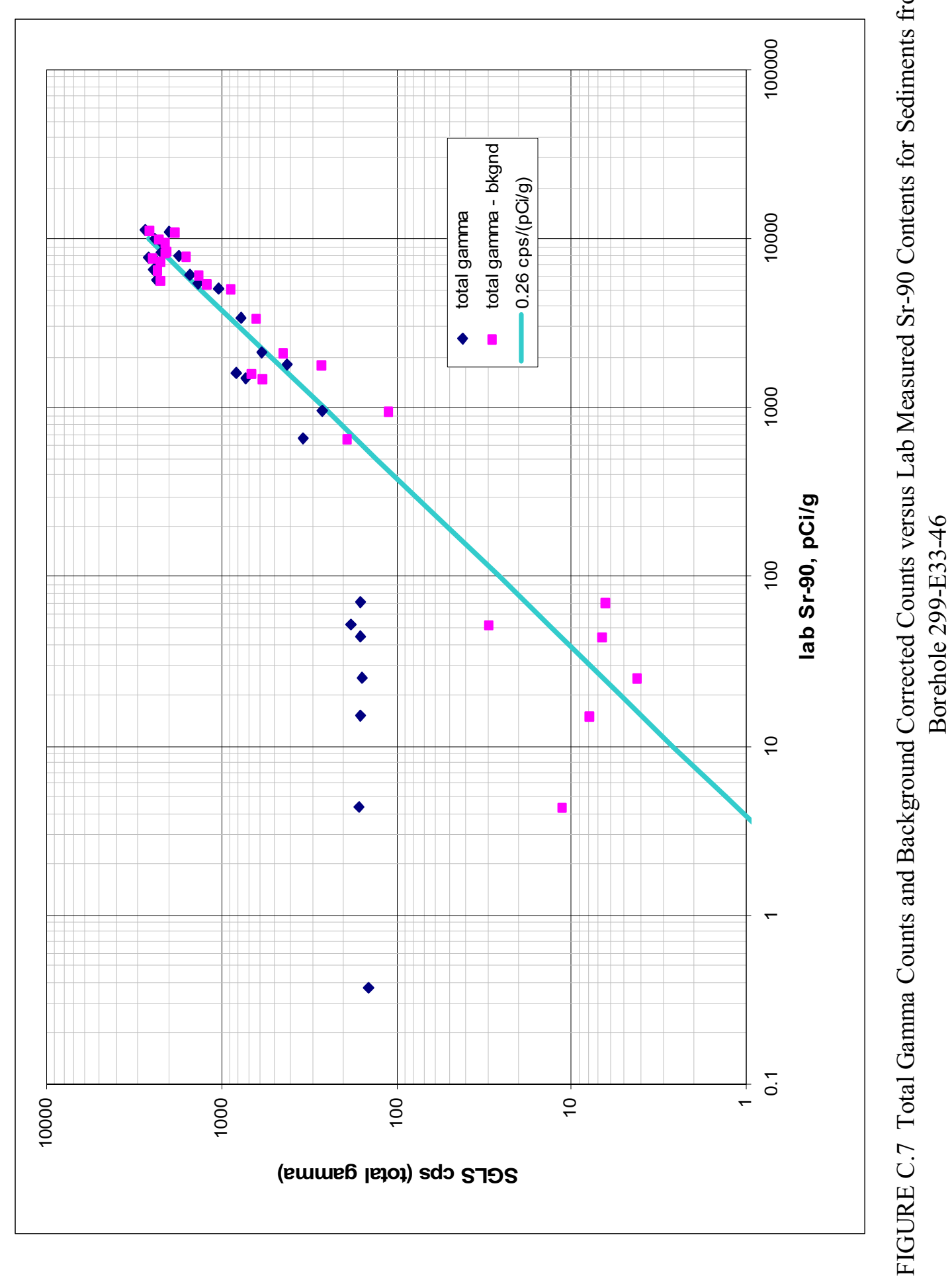

C. 12 


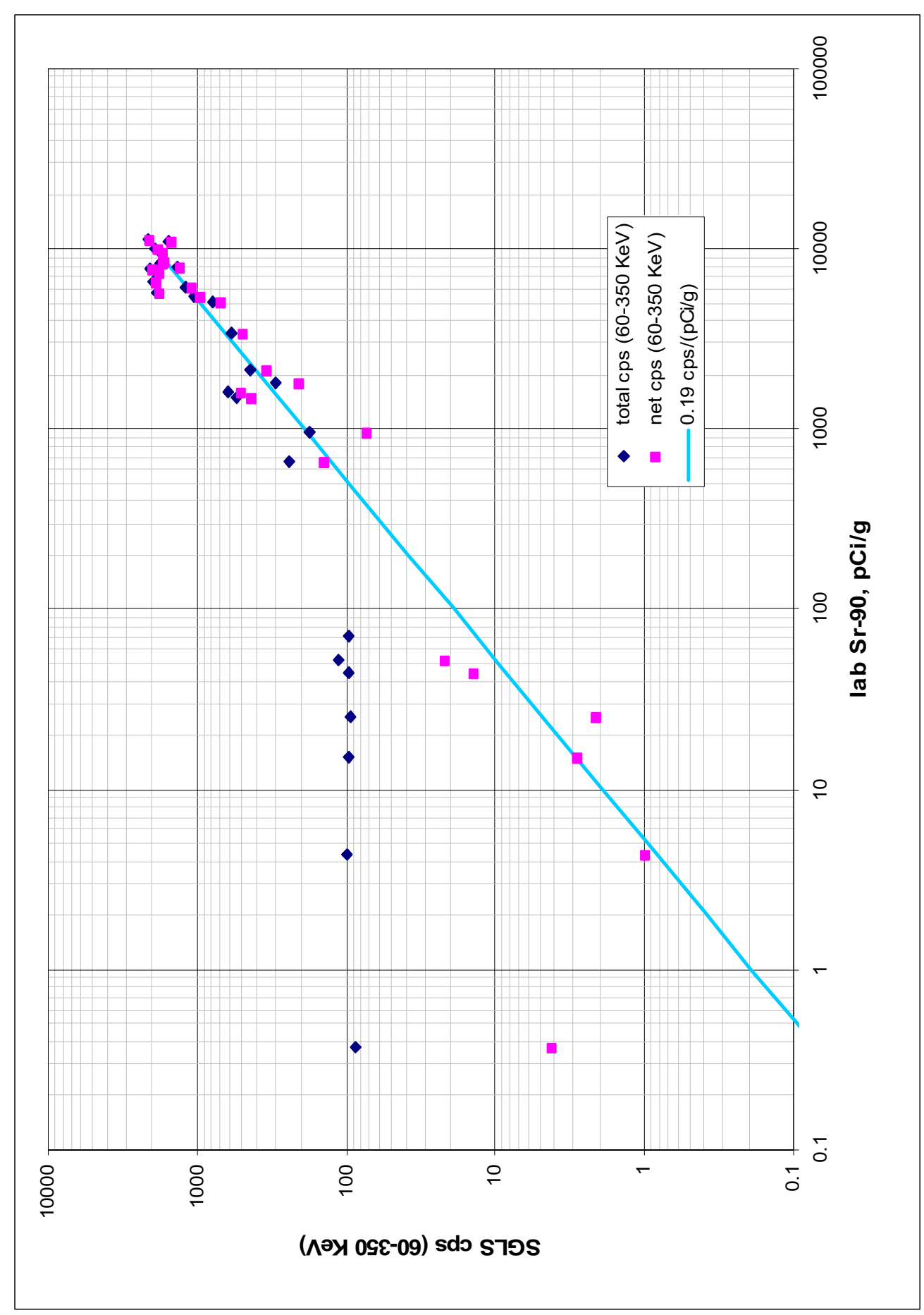

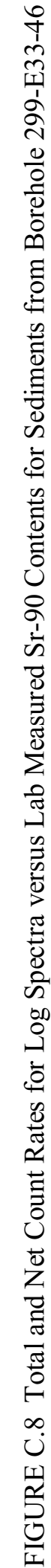

C. 13 
However, the total count rate is subject to variation associated with the presence of any manmade radionuclides or with variations in natural radionuclide concentrations.

The results of model studies (Wilson, 1977) indicated that the bulk of the gamma activity associated with bremsstrahlung occurs in the 60 to $350 \mathrm{KeV}$ window. Following Wilson's method, the net counts in this window can be determined by subtracting the background associated with the natural radionuclides ${ }^{40} \mathrm{~K},{ }^{238} \mathrm{U}$, and ${ }^{232} \mathrm{Th}$, using stripping ratios developed by Koizumi and reported by Wilson (1997). The "net cps (60-350 KeV)" plotted in Figure C.8 are determined in this manner. With one exception, this plot shows a strong linear trend. A leastsquares regression was used to estimate the sensitivity of SGLS net counts in the $60-350 \mathrm{KeV}$ energy window to ${ }^{90} \mathrm{Sr}$ concentration. It was determined that:

$$
N_{(60-350 \mathrm{KeV})}=0.19 \times C_{{ }^{90} \mathrm{Sr}} \quad\left(R^{2}=0.874\right)
$$

Where $\mathrm{N}$ is the net count rate and $\mathrm{C}$ is the ${ }^{90} \mathrm{Sr}$ concentration in $\mathrm{pCi} / \mathrm{g}$. This relationship is plotted as a line on Figure C.8. It can be re-arranged to:

$$
C_{90}=5.24 \times N_{(60-350 \mathrm{KeV})}
$$

This relationship was developed for a borehole casing thickness of $0.514 \mathrm{in}$. Since the nature of bremsstrahlung generation associated with the interaction between high energy beta particles and steel casing is poorly understood, the equation above should not be used where the casing thickness is significantly different from 0.514 in.

\section{Conclusions}

Analysis of borehole spectral gamma measurements and laboratory determination of $90 \mathrm{Sr}$ concentration in vadose zone sediment samples from borehole 299-E33-46 (C3360) has shown that relationships exist between SF2 and sediment $90 \mathrm{Sr}$ concentration and between net counts in the 60 to $350 \mathrm{KeV}$ energy window and sediment $90 \mathrm{Sr}$ concentration. Comparison of the borehole logging data and laboratory measured sediment $90 \mathrm{Sr}$ data resulted in the following findings and observations:

- The borehole casing in Wilson's MCNP model was 0.313-inch-thick steel, whereas the steel casing in borehole 299-E33-46 is 0.514 inches thick. The effect of casing thickness on generation and transmission of bremsstrahlung gamma rays is unknown.

- The beta source in Wilson's MCNP model was "distributed uniformly $2 \mathrm{~cm}$ radially into the formation and extending $\pm 15.24 \mathrm{~cm}( \pm 6$ in.) axially" (with respect to the center of the gamma-ray detector), whereas the ${ }^{90} \mathrm{Sr}$ distribution in the sediment in the formation outside of the borehole 299-E33-46 casing appears to be non-uniform axially and of undetermined radial distribution, but most certainly larger than $2 \mathrm{~cm}$.

- Only the borehole interval from 50 to $120 \mathrm{ft}$ bgs was used for the comparison studies. The entire borehole was logged, but other intervals were logged with slightly different equipment and procedures. Variations in logging system response would complicate the comparison of log data and laboratory derived sediment values.

- Comparison of gamma spectra from intervals of high ${ }^{90} \mathrm{Sr}$ concentration with spectra from low concentration intervals indicated that bremsstrahlung associated with ${ }^{90} \mathrm{Sr}$ decay 
resulted in greatly increased low energy counts, with the bulk of the activity below 350 $\mathrm{KeV}$.

- After subtracting background, total gamma counts from the logging detector were compared to ${ }^{90} \mathrm{Sr}$ concentrations in sediment from the same depths. The average sensitivity was found to be approximately $0.26 \mathrm{cps}$ per $\mathrm{pCi} / \mathrm{g}$. This is almost an order of magnitude higher than the value of $0.028 \mathrm{c} / \mathrm{s}$ per pCi/g predicted by Wilson, 1997.

- SF2 values on the order of 6 to 8 indicate the presence ${ }^{90} \mathrm{Sr}$ concentrations greater than $1000 \mathrm{pCi} / \mathrm{g}$ in the sediments interrogated by the logging tool. Wilson (1997) predicted the existence of a correlation between ${ }^{90} \mathrm{Sr}$ concentration and SF2, but the observed correlation does not fully conform to Wilson's expectations. Wilson's MCNP model predicted SF2 values greater than 20 in the presence of ${ }^{90} \mathrm{Sr}$ in the sediments outside the casing in model configurations.

- A modified shape factor, $\mathrm{SF} 2^{*}$, is defined as the ratio between total counts in the 60-350 $\mathrm{KeV}$ and $350-650 \mathrm{KeV}$ windows. Because background is not subtracted, SF2* tends to remain stable in the absence of contamination. SF2* assumes a value between 3.3 and 3.7 in uncontaminated intervals and increases to greater than 6 in intervals with high ${ }^{90} \mathrm{Sr}$ concentration. For ${ }^{90} \mathrm{Sr}$ concentrations on the order of 500 to $1000 \mathrm{pCi} / \mathrm{g}, \mathrm{SF} 2 *$ values are transitional between 3.7 and 6 .

- Cross-plots of SGLS total gamma vs ${ }^{90} \mathrm{Sr}$ concentration in the sediment show a linear trend, particularly when total counts are corrected for background. However, total counts are affected by the presence of man-made radionuclides, as well as by variations in natural radionuclides.

- Cross-plots of SGLS total counts and net counts in the 60 to $350 \mathrm{KeV}$ energy range vs ${ }^{90} \mathrm{Sr}$ concentration in the sediments also show a strong linear trend. For this energy window, background counts can be estimated from the 1461, 1764 and $2615 \mathrm{KeV}$ peaks, using stripping ratios developed by Koizumi. The net counts show a good correlation with ${ }^{90} \mathrm{Sr}$ concentration. The sensitivity is about $0.19 \mathrm{cps}$ per $\mathrm{pCi} / \mathrm{g}$. It is possible that similar corrections could be made for limited amounts of ${ }^{137} \mathrm{Cs}$ and ${ }^{60} \mathrm{Co}$, using stripping ratios estimated from modeling and shape factor experiments. This would allow ${ }^{90} \mathrm{Sr}$ concentrations to be estimated in the presence of other gamma emitting contaminants.

\section{Recommendations}

The results of this study and previous experience in B tank farm and elsewhere indicate that, at least in the absence of other gamma emitting contaminants, ${ }^{90} \mathrm{Sr}$ can be detected by spectral gamma logging in steel-cased boreholes. It also appears that quantitative ${ }^{90} \mathrm{Sr}$ concentrations can be estimated, at least to an order of magnitude accuracy. Unfortunately, there are a number of unknown factors that must be investigated before a widely applicable gamma spectra-to- ${ }^{90} \mathrm{Sr}$ in sediments relationship can be established. Specific recommendations for future work include the following:

- Conduct experiments to investigate the nature of gamma ray generation and transmission associated with bremsstrahlung. 
Discrepancies exist in the relationship between ${ }^{90} \mathrm{Sr}$ concentrations and gross gamma count rate, and in the behavior of SF2 in the presence of ${ }^{90} \mathrm{Sr}$. In both cases, the relationship observed in the field differs significantly from predictions based on radiation transport modeling. These discrepancies may be due to the difference in casing thickness, or to errors in the way bremsstrahlung is addressed in the model. A relatively simple experiment could be set up to investigate the effects of casing thickness on gamma activity from bremsstrahlung. Gamma spectra would be recorded from a detector placed a short distance from a ${ }^{90} \mathrm{Sr}$ source. Steel plates with various thicknesses between about 0.25 and 1.0 inches would be placed between the source and the detector, and the data would be evaluated to determine the effect of casing thickness on gamma detector response. This experiment would also be modeled with the radiation transport code and model results compared to measurement data.

- $\quad$ Perform additional modeling to investigate the effects of casing thickness, ${ }^{90} \mathrm{Sr}$ concentrations, and the presence of other radionuclides on spectral gamma response.

The borehole geometry with a distributed source is much more difficult to construct in a physical model, but numerical modeling can be performed to estimate response.

- $\quad$ Collect additional sample data where possible and log all boreholes in which samples containing elevated ${ }^{90} \mathrm{Sr}$ concentrations are encountered.

Comparison of borehole log data and laboratory measured sediment ${ }^{90} \mathrm{Sr}$ data in multiple boreholes will help validate the model predictions.

\section{References}

Brodzinski, R.L. and H.L. Nielson. 1980. “A Well-Logging Technique for the In-Situ Determination of ${ }^{90} \mathrm{Sr}$, ” Nuclear Instruments and Methods, 173: 299-301.

DOE. 2000. Hanford Tank Farms Vadose Zone: B Tank Farm Report, GJO-99-113-TAR, GJO-HAN-28, U.S. Department of Energy, Grand Junction Project Office, Grand Junction, Colorado.

Wilson, R. D., C. J. Koizumi, J. E. Meisner, and D. C. Stromswald. 1997. "Spectral Shape Analysis for Contaminant Logging at the Hanford Site," 1997 IEEE Nuclear Science Symposium, Albuquerque, November, 1997.

Wilson, R. D. 1997. Spectrum Shape-Analysis Techniques Applied to the Hanford Tank Farms Spectra Gamma Logs. GJO-96-13-TAR, GJO-HAN-7, prepared by MACTEC-ERS for the Grand Junction Office, Grand Junction, Colorado.

Wilson, R. D. 1998. Enhancements, Validations and Applications of Spectrum Shape-Analysis Techniques Applied to Hanford Tank Farms Spectral Gamma Logs. GJO-97-25-TAR, GJOHAN-15, prepared by MACTEC-ERS for the Grand Junction Office, Grand Junction, Colorado. 


\section{Appendix D}

X-Ray Diffractograms for Bulk and Clay Sized Sediments From Borehole 299-E33-46 


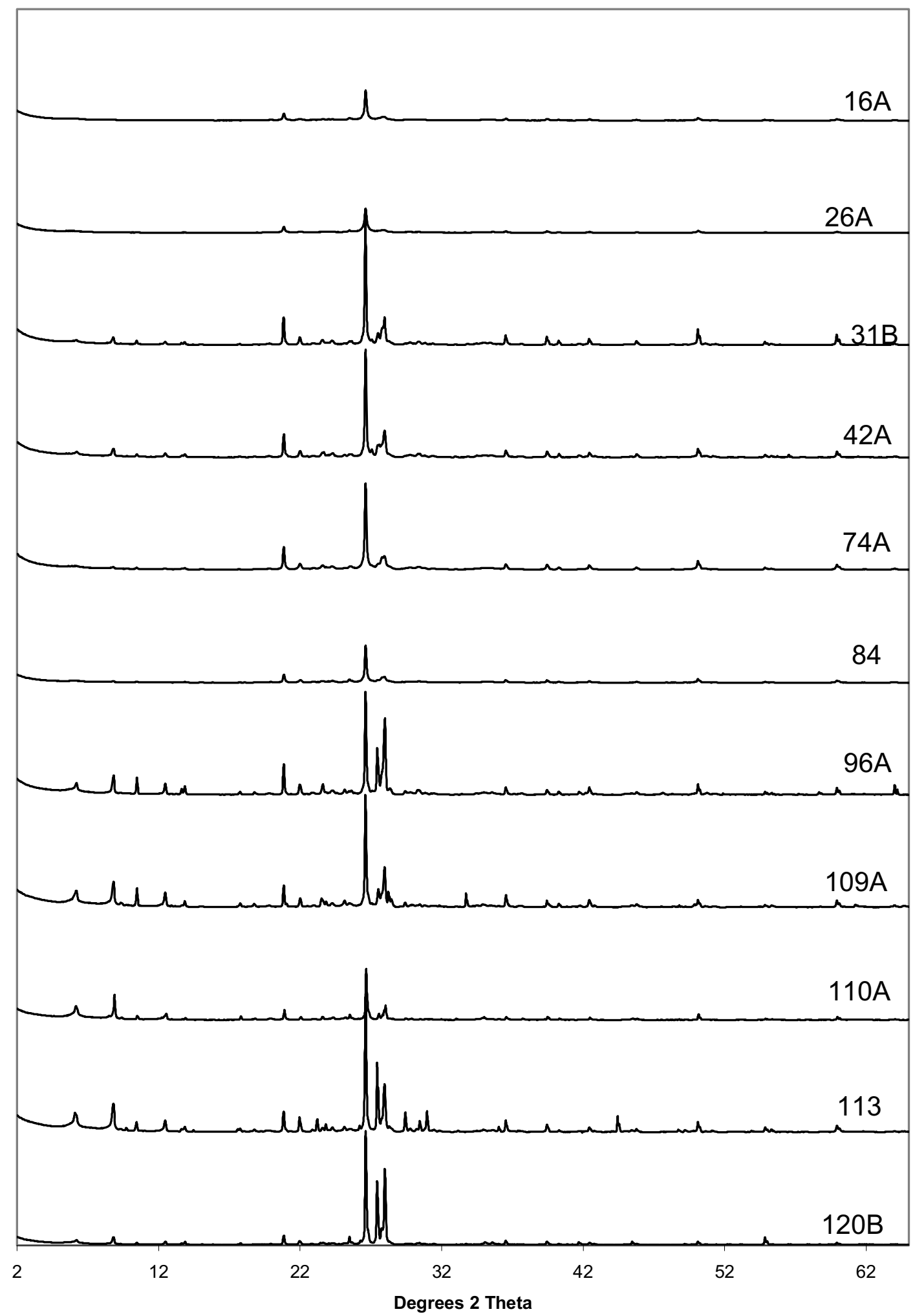

Figure D-1. Bulk Powder XRD Tracings for Sediments from Borehole 299-E33-46.

D. 1 


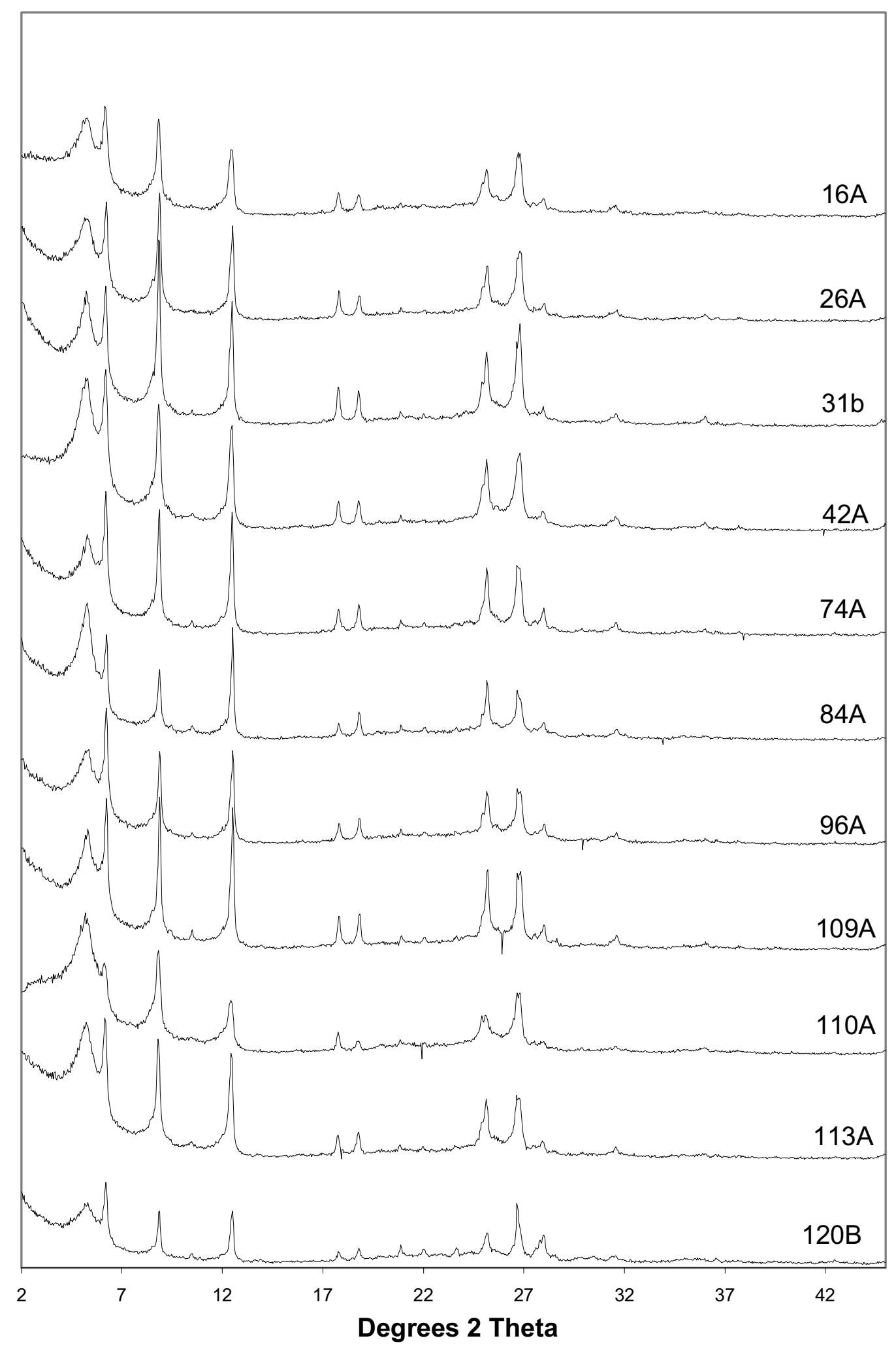

Figure D-2. Clay XRD Tracings from Sediments from 299-E33-46. 


\section{Distribution}

No. of

\section{Copies}

\section{OFFSITE}

Dr. Harry Babad

2540 Cordoba Court

Richland, WA 99352-1609

Pat Brady

Geochemistry Department, 6118

Sandia National Laboratories

P.O. Box 5800

Albuquerque, New Mexico 87185-0750

Charles R. Bryan

Sandia National Laboratories

4100 National Parks Highway

Carlsbad, N.M. 88220

Susan Carroll

Lawrence Livermore National Laboratory

Mail Stop L-219

Livermore, CA 94550

Jon Chorover

Associate Professor - Environmental

Chemistry

Department of Soil, Water and

Environmental Science

Shantz 429, Building \#38

University of Arizona

Tucson, AZ 85721-0038

Dave G. Coles

Coles Environmental Consulting

750 South Rosemont Rd

West Linn, OR 97068
No. of

\section{Copies}

Mark Conrad

Department of Earth and Planetary Sciences

University of California Berkeley

Berkeley, CA 94720

Dr. James A. Davis

U.S. Geological Survey

MS-465

345 Middlefield Rd.

Menlo Park, CA 94025

Donald J. DePaolo

Geology \& Geophysics Dept., MC4767

University of California

Berkeley, CA 94720-4767

Dirk A. Dunning

Oregon Office of Energy

625 Mariona St. N. E.

Salem, OR 97301-3742

Mark Ewanic

MSE Technology Applications, Inc.

200 Technology Way

Butte, MT 59701

Markus Flury

Department of Crop and Soil Sciences

Washington State University

Pullman, WA 99164

Amy P. Gamerdinger

2122 E. Hawthorne

Tucson, AZ 85719

Distr.1 
No. of

Copies

Jim Harsh

Department of Crop \& Soil Sciences

Washington State University

Johnson Hall - Room 249

Pullman WA 99164-6420

Dr. Cliff Johnston

Soil Chemistry and Mineralogy

1150 Lily Hall

Purdue University

West Lafayette, IN 47907-1150

Dr. Daniel I. Kaplan

Westinghouse Savannah River Company

Bldg. 774-43A, Rm 215

Aiken, SC 29808

Dr. Peter C. Lichtner

Los Alamos National Laboratory

P.O. Box 1663

Los Alamos, NM 87545

Patrick Longmire

Los Alamos National Laboratory

Mail Stop J534

P.O. Box 1663

Los Alamos, NM 87545

Kate Maher

The Center for Isotope Geochemistry

301 McCone Hall

University of California, Berkeley

Berkeley, CA 94702-4746

Melanie A. Mayes

Environmental Sciences Division

Oak Ridge National Laboratory

P.O. Box 2008

Oak Ridge,TN 37831-6038
No. of

Copies

Dr. Kathryn L. Nagy

Department of Earth and Environmental Sciences

University of Illinois at Chicago (MC-186)

845 West Taylor Street

Chicago, IL 60607-7059

Heino Nitsche

Director, Center for Advanced Environmental and Nuclear Studies

Lawrence Berkeley National Laboratory

1 Cyclotron Road

MS 70A-1150

Berkeley, CA 94720

Phil Reed

U.S. Nuclear Regulatory Commission

Office of Nuclear Regulatory Research

Division of Systems Analysis and Regulatory Effectiveness

Radiation Protection, Env. Risk and Waste Management Branch

Mail Stop: T9-F31

Washington, DC 20555-0001

Richard J. Reeder

Dept. of Geosciences

State University of New York at Stony Brook

Stony Brook, NY 11794-2100

Al Robinson

68705, E 715 PRNE

Richland WA 99352

Phil Rogers

13 Mountain Oak

Littleton, CO 80127

Distr.2 
No. of

Copies

David Shafer

Desert Research Institute

University of Nevada

P.O. Box 19040

Las Vegas, NV 89132-0040

Dawn A. Shaughnessy

Glenn T. Seaborg Center

Lawrence Berkeley National Laboratory

1 Cyclotron Road

MS 70A-1150

Berkeley, CA 94720

Doug Sherwood

Rivers Edge Environmental

1616 Riverside Drive

West Richland, WA 99353

David K. Shuh

Lawrence Berkeley National Lab

1 Cyclotron Road

Mail Stop 70A-1150

Berkeley, CA 94720

James "Buck" Sisson

Idaho National Engineering and

Environmental Laboratory

PO Box 1625, MS-2107

Idaho Falls, ID 83415-2107

Carl I. Steefel

Lawrence Livermore National Laboratory

Earth \& Environmental Sciences Directorate

Mail Stop L-204

PO Box 808

Livermore, CA 94551-9900

Dr. Samuel J. Traina, Director

Sierra Nevada Research Institute

University of California, Merced

P.O. Box 2039

Merced, CA 95344
No. of

Copies

Dr. T. T. Chuck Vandergraaf

Atomic Energy Of Canada, Limited

Whiteshell Nuclear Research Establishment

Pinawa, Manitoba ROE 1LO

Canada

Dr. Jiamin Wan

Lawrence Berkeley National Laboratory

1 Cyclotron Rd. MS 70-0127A

Berkeley, CA 94720

Mr. Ronald G. Wilhelm

Office of Radiation and Indoor Air

401 M Street, S.W.

Mail Code 6603J

Washington, D.C. 20460

W. Alexander Williams

US Department of Energy

Office of Environmental Restoration

EM-33

19901 Germantown Road

Germantown, MD 20874-1290

\section{ONSITE}

4 DOE Office of River Protection
C. A. Babel
H6-60
P. E. LaMont
H6-60
R. W. Lober
H6-60
R. B. Yasek
H6-60

\section{DOE Richland Operations Office}

$\begin{array}{ll}\text { B. L. Foley } & \text { A6-38 } \\ \text { J. P. Hanson } & \text { A5-13 } \\ \text { R. D. Hildebrand } & \text { A6-38 } \\ \text { K. A. Kapsi } & \text { A5-13 } \\ \text { J. G. Morse } & \text { A6-38 } \\ \text { K. M. Thompson } & \text { A6-38 } \\ \text { DOE Public Reading Room (2) } & \text { H2-53 }\end{array}$

Distr.3 
No. of

Copies

Bechtel Hanford, Inc.

K. R. Fecht H0-02

18 CH2M Hill Hanford Group, Inc.

J. E. Auten

E6-35

K. C. Burgard

L6-57

M. P. Connelly

E6-35

E. A. Fredenburg

H9-03

T. E. Jones (2)

E6-35

A. J. Knepp (2)

H6-60

F. M. Mann (5)

E6-35

W. J. McMahon

E6-35

C. W. Miller

H9-03

D. A. Myers (3)

E6-35

3 Duratek Federal Services, Inc., Northwest Operations

M. G. Gardner

H1-11

K. D. Reynolds

H1-11

D. E. Skoglie

H1-11

3 Environmental Protection Agency

Nick Ceto

B5-01

D. A. Faulk

B5-01

M. L. Goldstein

B5-01

2 Flour Federal Services

R. Khaleel

E6-17

R. J. Puigh

E6-17

5 Flour Hanford, Inc.

T. W. Fogwell

E6-35

B. H. Ford

E6-35

J. G. Hogan

H1-11

V. G. Johnson

E6-35

M. I. Wood

H8-44
No. of

Copies

R. W. Bryce E6-35

R. E. Clayton P7-22

W. J. Deutsch K6-81

P. E. Dresel K6-96

K. M. Geisler P7-22

M. J. Fayer K9-33

A. R. Felmy K8-96

M. D. Freshley K9-33

J. S. Fruchter K6-96

D. G. Horton K6-81

J. P. Icenhower K6-81

C. T. Kincaid E6-35

K. M. Krupka K6-81

I. V. Kutnyakov P7-22

G. V. Last (3) K6-81

V. L. LeGore P7-22

M. J. Lindberg P7-22

C. W. Lindenmeier (2) P7-22

W. J. Martin K6-81

S. V. Mattigod K6-81

B. P. McGrail K6-81

P. D. Meyer BPO

C. J. Murray K6-81

S. M. Narbutovskih K6-96

R. D. Orr K6-81

E. M. Pierce K6-81

S. P. Reidel K6-81

R. J. Serne (20) P7-22

H. T. Schaef K6-81

W. Um P7-22

M. Valenta P7-22

T. S. Vickerman P7-22

B. A. Williams K6-81

S. B. Yabusaki K9-36

J. M. Zachara K8-96

Hanford Technical Library (2) P8-55

64 Pacific Northwest National Laboratory
S. R. Baum
P7-22
B. N. Bjornstad (3)
K6-81
C. F. Brown
P7-22

Distr.4 